UNIVERSIDAD DE SALAMANCA

FACULTAD DE FILOSOFÍA

Departamento de Filosofía, Lógica y Estética

\title{
El problema ontológico del advenir en el proyecto filosófico de Martin Heidegger
}

Tesis Doctoral presentada por Dune Valle Jiménez, bajo la dirección de la Prof ${ }^{\mathrm{a}}$. Dra . María del Carmen Paredes Martín, Catedrática de Filosofía, para optar al grado de Doctor en Filosofía.

$\mathrm{V}^{\mathrm{o}} . \mathrm{B}^{\mathrm{o}}$. 


\section{ÍNDICE}

AGRADECIMIENTOS 9

ABREVIATURAS 11

MODO DE CITAR 13

INTRODUCCIÓN 15

PRIMERA PARTE 24

Capítulo I: Primer acercamiento al problema del tiempo en la obra temprana de Heidegger 24

Capítulo II: La experiencia originaria del cristianismo primitivo como suelo fértil para los primeros pasos del proyecto filosófico heideggeriano 35

a. El método fenomenológico dirigido a la experiencia fáctica de la vida 40

b. Filosofía, experiencia fáctica de la vida y fenómeno 43

c. La pregunta por el sentido de lo histórico y el tiempo; la indicación formal y su importancia en la determinación del fenómeno y de la fenomenología 49

d. La experiencia fáctica de la vida en el cristianismo primitivo 68

e. La oposición entre tiempo kairológico y cronológico 77

f. La conceptualidad griega y su influencia en San Agustín: la concepción del ser como presencia constante 85

g. La penetración de la filosofía griega en la teología: teología de la cruz como contraposición de la teología de la gloria 92

Capítulo III: La filosofía práctica de Aristóteles y la concepción de la temporalidad de la vida fáctica 97

a. Las categorías de la vida fáctica 101

b. La necesidad de una vuelta a Aristóteles 113

c. La dimensión ontológica de la phrónesis 119

d. Contraposición entre el saber práctico y teórico 124

e. La pregunta por el concepto directivo del ser en la ontología aristotélica 128

f. La determinación del ser como ser-producido 133 


\section{Capítulo IV: La ontologización de la vida fáctica como hermenéutica fenomenológica de la facticidad 138}

a. Significado e importancia de la hermenéutica de la facticidad 142

b. Hermenéutica fenomenológica de la facticidad: la formulación incipiente de la pregunta por el ser 144

c. Hermeneútica de la facticidad como ontologización de la vida fáctica 151

d. Apropiación de la situación hermenéutica y destrucción fenomenológica 159

\section{Capítulo V: La concepción del ser como presencia, el tiempo como puro presente 168}

a. El tratado y la conferencia. El concepto del tiempo 172

b. San Agustín y el problema del tiempo 175

c. Tiempo y eternidad 179

d. El reverso del tiempo de la metafísica, el advenir como carácter fundamental del tiempo 181

e. El tiempo como horizonte privilegiado de la pregunta por el ser 196

f. Aristóteles y el tiempo desde el modelo de la naturaleza 200

g. El tiempo como medición 203

h. La crítica heideggeriana a la comprensión del Dasein como Vorhandenheit 206

i. El sentido del ser como ousía y substancia 212

j. Dios como substancia perfecta, la presencia constante por antonomasia 215

k. La insuficiencia ontológica de las concepciones greco-cristianas del hombre 217

\section{Capítulo VI: Lógica filosofante, la pregunta por el ser y su vinculación con el tiempo 219}

a. Lógica de escuela y lógica filosofante 221

b. La pregunta por el lugar de la verdad: destrucción de los prejuicios 223

c. La posibilidad de la verdad y la falsedad en el enunciado 224

d. Nivelación de la estructura originaria del Als Was con el Als propio del determinar 230

e. La pregunta por la verdad y la pregunta por el ser 232 
f. Ser como presencia: el presente como horizonte fundamental de la pregunta por el ser en la tradición metafísica 235

h. Desde la interpretación del ser como simple presente, hacia la concepción del futuro como sentido de la temporalidad 239

\section{SEGUNDA PARTE 250}

Capítulo I: EI tiempo como articulador de la reformulación de la pregunta por el ser 250

Capítulo II: La determinación del ente privilegiado: el Dasein, el ente que es comprensión del ser 260

\section{Capítulo III: Ser-en-el-mundo como estructura fundamental del} Dasein 269

a. La crítica de Heidegger a la concepción del mundo como naturaleza ahí presente 271

b. El útil como ser a la mano: la relación pragmática con las cosas del mundo 274

Capítulo IV: La constitución del Dasein como estado de abierto 280

a. El cómo "le va" al Dasein en cuanto encontrarse 282

b. El comprender (Verstehen): la determinación originaria del Dasein como poder ser, como posibilidad 287

Capítulo V: La unidad estructural del Dasein 294

a. La caída, la tensión insuperable entre la propiedad e impropiedad 295

b. El quién de la cotidianidad: el uno 300

c. La angustia, encontrarse fundamental que singulariza al Dasein 303

d. El ser-en-el-mundo como ante qué y el por qué de la angustia 308

e. El cuidado como sustento ontológico de la unidad estructural del Dasein 310

Capítulo VI: La muerte y la conciencia, fenómenos fundamentales del Dasein, que le enfrentan a su más propia posibilidad de ser: su ser total y propio 317

a. La muerte la posibilidad más propia del Dasein 318

b. El Dasein como ser relativamente a la muerte y el adelantarse hasta la posibilidad de la imposibilidad 321

c. La angustia y la comprensión de un poder ser total y propio 324 
d. El testimonio de la propiedad como modo fundamental del Dasein: la voz de conciencia 326

e. El Dasein un ser que es fundamento de una nihilidad: la culpa originaria 330

f. El querer tener conciencia y el estado de resuelto 335

\section{Capítulo VII: La temporalidad originaria como sentido del ser del} Dasein 337

a. El precursor estado de resuelto como la posibilidad originaria de la propiedad del Dasein 337

b. El sentido temporal del precursor estado de resuelto. El ser del Dasein como esencialmente advenidero 344

c. Temporalidad originaria, la unidad del advenir, presente y haber sido. La estructura del cuidado a la luz de la temporalidad originaria 349

d. La primacía del advenir en la estructura de la temporalidad originaria 355

Capítulo VIII: Desde la temporalidad originaria al tiempo de la cotidianidad 358

a. El futuro de la cotidianidad como estar a la expectativa 361

b. El presente de la cotidianidad 365

c. El pasado como olvido 366

Capítulo IX: El advenir, el fundamento oculto de la historicidad 368

a. El ser del Dasein como prolongación del entre el nacimiento y la muerte 368

b. La concepción vulgar de la historia como puro pasado 373

c. Herencia, tradición y destino 377

d. El advenir como fundamento oculto de la historicidad 381

e. El ente histórico mundano y la interpretación del ser como presencia 384

f. La historiografía y su fundamento desde el advenir 390

\section{Capítulo X: El fundamento del tiempo vulgar, la concepción del tiempo} como simple presente 392

a. El contar con el tiempo y el tiempo del mundo 393

b. Tiempo del ahora, como tiempo de la ocupación de lo que hace frente en el mundo 396

c. La intratemporalidad como tiempo público 400 
d. Medición y cálculo del tiempo 404

e. Nivelación del tiempo originario 409

f. Derechos naturales de la interpretación vulgar del tiempo 413

CONCLUSIONES 417

BIBLIOGRAFÍA 431

Bibliografía Primaria: Textos de Heidegger 431

Bibliografía Crítica 433 


\section{AGRADECIMIENTOS}

Este trabajo tiene nombres propios, todas y cada una de sus páginas se han escrito gracias al enorme amor y cariño que me han dado mi padres, sin su ayuda este modesto trabajo no hubiese sido posible. A Valle y Betty, que en los momentos más duros de mi vida, cuando mi salud estuvo seriamente comprometida, nunca me dieron la espalda, siempre estuvieron a mi lado y me brindaron todo el aguante. A mi amada Catalina, a pesar que la distancia por momentos se ha vuelto insalvable, su recuerdo y la esperanza de poder recuperar ese tiempo me han dado ilusión y fuerza en los momentos difíciles. A mi querida hermana que ha compartido conmigo los buenos y malos momentos.

A los que ya no están. A mi abuela, que perdí cuando me encontraba realizando este trabajo y no pude acompañar en su último viaje. A mi querido maestro Nicolás Dragicevic, que me dejó hace algún tiempo ya, pero que siempre he llevado en el corazón, por su apoyo y dedicación, y que a pesar de ser un marxista-ortodoxo siempre me alentó a seguir con esto. Al profesor José Luis Rodríguez Molinero, con el cual di los primeros pasos de esta investigación, que sin su sabio consejo nunca hubiese partido, doy gracias por esas largas horas de conversación y discusión. Para ustedes donde estén, mí más sincero reconocimiento y agradecimiento.

A mi editor, amigo y compañero, Iago Ramos, que durante gran parte de estos años ha sido una ayuda invaluable, tanto en el plano intelectual como en aquellos otros ámbitos más propiamente humanos y de mayor importancia, solo me quedan palabras de eterna gratitud y cariño. A mi querida amiga María, que a lo largo de este tiempo me ha hecho sentir en casa, siempre con una palabra de amistad y comprensión, que son las cosas que te hacen realmente fuerte.

A los pibes de la esquina del barrio de 21, allí donde dobla el viento y se cruzan los atajos, donde se plantean las preguntas filosóficas verdaderamente fundamentales, y que gracias a la cuales he podido llevar a cabo este trabajo. A la Srta. Roa, que me brindó todo su apoyo en un momento clave.

Y por último, quiero agradecer a la Dra. Maria del Carmen Paredes Martín, por aceptar guiarme en este largo y complicado proceso, siempre con la mejor disposición para aconsejarme y ayudarme.

En fin para todos aquellos que nunca me dieron la espalda y siempre estuvieron a mi lado. ¡Gracias por todo! ¡De todo corazón! 


\section{ABREVIATURAS}

GA $1 \quad$ Frühe Schriften

GA 17 Einführung in die phänomenologische Forschung

GA $18 \quad$ Grundbegriffe der aristolischen Philosophie

GA $20 \quad$ Prolegomena zur Geschichte des Zeitsbegriffes

GA $21 \quad$ Logik. Der Frage nach der Wahrheit

GA $60 \quad$ Phänomenologie des religiösen Lebens. I.Einleitung in die Phänomenologie der Religion. II. Augustinus un der Neuplatonismus.

GA $61 \quad$ Phänomenologische Intepretationen Zu Aristoteles

GA 63 Ontologie. Hermeneutik der Faktizität

GA 64 Der Begriff der Zeit.

Otros textos

NB Natorp Bericht (Phänomenologische Intepretationen zu Aristoteles. Anzeige der hermeneutischen Situation)

KV Kasseler Vorträge. (Wilhelm Diltheys Forschungsarbeit und der Gegenwärtige Kampf um eine historische Weltanschaunnung)

ST Sery tiempo. 


\section{MODO DE CITAR}

En la primera parte de nuestro trabajo las obras de Heidegger se citan dentro del texto con la abreviatura y el numero de página correspondiente, también se incluye ahí el numero de página de la respectiva traducción española. La primera vez que se utiliza la mencionada traducción, también se cita a pie de página.

En la segunda parte, como está dedicada exclusivamente a Ser y tiempo, citamos a pie de página con las iniciales ST, teniendo en cuenta las dos traducciones españolas. 


\section{INTRODUCCIÓN}

Sin lugar a dudas la obra de Martin Heidegger ocupa un lugar de privilegio dentro de la historia de la filosofía. Para bien o para mal su interpretación de los problemas filosóficos marca un punto de inflexión en la historia del pensamiento occidental. Esto, a raíz de la peculiar forma de plantear y tratar aquellas cuestiones que desde siempre han sido consideradas como los problemas fundamentales de la filosofía. Y también por la profundidad y originalidad que han caracterizado su pensamiento, podemos decir, sin temor a equivocarnos, que ha entrado ya al selecto grupo de pensadores que han marcado y determinado la historia de la meditación filosófica, posicionándose como uno de los grandes nombres en la historia de la filosofía. Entre sus aportes se pueden contar la pregunta por la técnica, el diálogo que mantuvo con la ciencia, su interpretación de la obra de arte o su original planteamiento de la hermenéutica fenomenológica, esto, por nombrar algunas de las cuestiones tratadas por el pensador de la Selva Negra.

No obstante, hay una cuestión que sobresale y que de alguna forma es el articulador, el hilo conductor que guía la filosofía de Heidegger hasta el final, nos referimos al planteamiento de la pregunta por el ser desde el horizonte del tiempo. Ejemplo de esto es el título que da a aquella obra que le brindó el reconocimiento y el status filosófico que le acompañará por siempre. Que el nombre de su tratado de 1927 sea Ser y tiempo no es ninguna casualidad. La originalidad y radicalidad de la filosofía de Heidegger se fundamenta principalmente en la determinación del carácter temporal que se ocultaba en la interpretación del ser que desde la antigüedad filosófica había determinado la conceptualidad de la tradición metafísica. A su juicio, desde sus primeros pasos el pensamiento occidental había comprendido el ser como ousía, como substancia, en lo fundamental como aquello que es presencia y que por lo tanto tiene el carácter de ser siempre.

Los griegos interpretaron el ser como presencia constante, lo que significa que lejos de ser el tiempo un carácter de aquello que es, o de ser un criterio desde el cual se distinguen y diferencian las regiones del ente, el tiempo mantiene un vínculo esencial con la cuestión del ser. El ser mismo es concebido desde el horizonte del tiempo, concretamente desde un modo del tiempo, el presente. Cuestión que si bien tiene su punto de partida en la filosofía griega, ésta fue incapaz de ver la conexión que se ocultaba tras su interpretación, comprensión en la cual se piensa el ser desde el tiempo, lo que significa que el ser es interpretado como presencia, como puro presente. Ésta habría sido la intelección decisiva a la que Heidegger habría llegado en la estancia temprana de su pensamiento y determinaría el camino de su filosofía. 
El ser del Dasein ${ }^{1}$, la constitución originaria de la vida fáctica ha permanecido oculta, oscurecida bajo la influencia y la conceptualidad proveniente de las interpretaciones legadas por la tradición metafísica, principalmente la que tiene que ver con su concepción del ser, en la cual se fundamentan dichas exégesis. Todo ente, incluido el Dasein, se entienden desde el modelo ontológico de la naturaleza, desde lo Vorhandenheit. Atrapados bajo la influencia y designios de esta interpretación, el ser y el ente desde antaño han sido medidos según la vara de la presencia constante, que considera que aquello que es, es lo que es presencia y está presente.

El filósofo alemán en su tratado de 1927 plantea la cuestión del ser a través de una ontología fundamental, en la cual sostiene que el ente privilegiado para desarrollar y plantear la pregunta por el ser es el Dasein que en su ser es comprensión del ser. Heidegger plantea ahí su crítica a esta interpretación del ser que ha dominado sin contrapeso la historia de la filosofía. Y lo hace a través del análisis del Dasein, que tiene una constitución ontológica distinta a la de las cosas, a la de lo entes de la naturaleza; porque su ser es tiempo, su esencia es temporal y finita. En esta interpretación del Dasein, que sería el primer paso para llegar a la cuestión del ser, Heidegger plantea precisamente una idea del tiempo distinta a la que domina en la tradición metafísica, porque tal como señala en Ser y tiempo, "El fenómeno originario de la temporalidad originaria y propia es el advenir", , lo que se muestra como una clara contraposición a la idea del tiempo de la tradición filosófica, que desde la Física de Aristóteles comprende el tiempo desde el privilegio del presente, como mera secuencia de ahoras siempre presentes.

Hasta hace relativamente poco tiempo, el de la publicación de los trabajos y lecciones de Heidegger anteriores a la aparición de Ser y tiempo, este problema ontológico del advenir, como muchas otras cuestiones, se mantenía en el misterio absoluto en relación a su génesis, sus primeras formulaciones y al grado de importancia que poseía en el entramado de su filosofía temprana. Dado que esta obra por mucho tiempo pareció haber surgido así sin más, como nacida de la nada gracias al genio creativo de su autor, eso fue

\footnotetext{
Hemos preferido dejar la palabra Dasein sin traducción por ser un término técnico de la filosofía de Heidegger ampliamente reconocido, además cualquier traducción limitaría la amplitud de sentido que este término tiene. Como dice Rivera en las notas de la página 454 de su traducción de Ser y tiempo: "Dasein significa literalmente 'ser el ahi', y por consiguiente se refiere al ser humano, en tanto que el ser humano está abierto a sí mismo, al mundo y a los demás seres humanos pero Dasein alude también, indirectamente al abrirse del ser mismo, a su irrupción en el ser humano".

2 Heidegger, M., El ser y el tiempo, F.C.E, Argentina, 1991, p.357. Trad. José Gaos. En nuestra investigación utilizamos preferentemente la traducción realizada por Gaos, pero en ocasiones se recurre también a la de Jorge Rivera, quedando claramente establecido en la notas de pie de página cuando se utilice esta última. También en determinadas ocasiones introduciremos ciertas modificaciones a dichas traducciones. En la notas a pie de página se indica a qué traducción corresponde, cuando solo se alude a las siglas de ST, se refiere a la traducción de Gaos, y cuando se utilice la de Rivera, se indicará al final de la cita. En las restantes citas bibliográficas sobre Heidegger, nos atenemos a la traducción de los autores correspondientes.
} 
un impedimento para hacer una valoración más completa de la problemática abordada en su tratado de 1927, donde el problema ontológico del advenir parecía tener un rango de importancia limitado.

Sin embargo, gracias a la reciente-y no tan reciente-, publicación de los trabajos y lecciones de sus primeros años de docencia universitaria, ha sido posible realizar este trabajo, que sin ese importante aporte textual se habría podido llevar a cabo, pero no lograría dar cuenta de la importancia y radicalidad que a nuestro juicio posee esta cuestión en el proyecto filosófico de Martin Heidegger y que se podrá verificar en las múltiples y constantes alusiones que hace de ella y las distintas modulaciones que adquiere este problema en su obra temprana, lo que nos lleva a pensar que esta cuestión es clave en el camino de su pensamiento, lo que haremos será destacar lo que podríamos llamar su potencial ontológico.

Nuestro trabajo no se plantea como objetivo principal hacer una suma minuciosa de las influencias recibidas por Heidegger, ni tampoco rastrear paso a paso el desarrollo de su pensamiento. Nuestra tarea tiene otro carácter, pretende analizar y presentar la progresión explícita que la problemática del tiempo tiene en la obra temprana del pensador de la Selva Negra; reconocer sus manifestaciones en la fase primigenia de su pensamiento y cómo va tomando su forma definitiva hasta llegar a Ser y tiempo. Podremos ver de qué modo este fenómeno señalado permite replantear la pregunta por el ser, con la cual Heidegger quiere principalmente rescatar a la metafísica de la poderosa influencia de la tradición y reconducirla a su elemento originario y auténtico: la cuestión del ser.

En consecuencia, hemos de seguir al filósofo alemán en el camino de su pensamiento, reconociendo de qué modo el advenir, como éxtasis temporal privilegiado, va adquiriendo un protagonismo peculiar, lo que nos llevará a preguntarnos cuál es la relevancia de esta problemática en el interior de su pensamiento filosófico, pero sin dejar de lado la concepción del ser en la que descansa ese olvido o confusión fundamental, esa idea directiva del ser que lo concibe como presencia. También veremos de qué modo se va haciendo visible ese carácter relacional indisoluble entre la cuestión del ser y el tiempo. Podríamos decir que nuestro trabajo más que intentar llevar a cabo una interpretación genealógica del problema del tiempo o del ser, busca enfocarse en la progresión de esta cuestión, para ver en ella de qué forma se van planteando, desarrollando y precisando dichos lineamientos y cómo en el rigor del tratamiento de estas cuestiones el problema ontológico del advenir desempeña un papel destacado en cuanto que permite, por ser el reverso del tiempo de la metafísica, la articulación de la pregunta por el ser hasta llegar a su formulación más definitiva que se presenta en Ser y tiempo.

No obstante, Pöggeler hace ya algunos años, en el epílogo de la segunda edición de su obra El camino del pensar de Martin Heidegger, plantea una serie de cuestiones que adquieren para nosotros un valor inestimable, en relación a las dudas o cuestionamientos 
que surgen acerca de la relación existente entre los primeros cursos universitarios de Friburgo y Marburgo y la aparición de Ser y tiempo, principalmente en lo que tenía que ver con el estudio de la experiencia fáctica de la vida del cristianismo primitivo, que Heidegger le había permitido revisar y que, por lo demás, no quería que salieran a la luz en la edición de sus Obras completas. Según Pöggeler, Heidegger:

soñaba, por tanto, con un futuro descubrimiento de lo más bello que él pudiera elaborar). Pero nunca había llegado tan lejos como cuando dijo a Becker que Ser y tiempo no era ya el Heidegger originario, cuya ruptura con lo anterior se limitaría esa obra a reproducir de manera escolásticamente coagulada. Lo que Heidegger me sugería entonces era la convicción inversa, a saber, que era en 1923 o en 1922/1923 cuando había dado con su pregunta por ser y tiempo. Si la edición de las Obras completas no admite la inclusión de los trabajos de la época de la disertación y la habilitación más que como títulos advenedizos extraños, y en todo lo demás comienza con los curso de Mar burgo, está claro que lo que ha contado para los editores es la convicción de que es en 1923 cuando esa obra comienza ${ }^{3}$.

Sin embargo, todas estas lagunas han tendido a desaparecer luego que desde el año 1985 hasta la fecha han sido publicadas la casi totalidad de la lecciones y trabajos que Heidegger dictó y realizó en su primer periodo de Friburgo y en su estancia en Marburgo ${ }^{4}$. Incluidas en ellas los cursos de Introducción a la vida religiosa y el Informe Natorp, los cuales tienen una determinada relevancia para la problemática planteada por nosotros. El motivo por el cual estos trabajos o lecciones de Friburgo han permanecido durante mucho tiempo en la más absoluta oscuridad y que solo unos pocos especialistas hayan accedido a ellos, tiene que ver con que su edición quedó por mucho tiempo postergada. La edición de las obras completas en principio se dividía en cuatro secciones. En la primera constaban los textos publicados por Heidegger mientras estaba vivo. La segunda contenía los cursos dictados en Marburgo entre 1923-1928 y los de Friburgo de 1928-1944. La tercera se reservaba para los escritos y ensayos no publicados. Y la cuarta, también para textos no publicados $^{5}$.

Como vemos, no se alude aquí a la publicación de las lecciones de Friburgo, de las que Heidegger se mostró renuente a su publicación. Cuestión que puede ser entendida desde dos perspectivas. Se podría pensar que el filósofo alemán no se sentía

3 Pöggeler, O., El camino del pensar de Martin Heidegger, Alianza, Madrid, 1993, p. 401. Trad. Felix Duque.

4 Sin embargo, permanecía en la oscuridad el momento preciso en el cual Heidegger habría llegado a dar con la pregunta por el ser y el tiempo, aunque si bien ya teníamos una información autorizada respecto a ello, gracias a los trabajos de Pöggeler y Kisiel, no es hasta 2002 y 2004, con las respectivas publicaciones de las lecciones de Marburgo de invierno de 1924 llamado Conceptos fundamentales de la filosofía aristotélica, y el tratado El concepto del tiempo escrito en noviembre del mismo año, que es posible determinar con claridad el momento en el que Heidegger ha conseguido dar con esta intelección decisiva para su pensamiento. Esto, especialmente en el tratado, donde plantea la pregunta por el ser vinculada ya directamente a la cuestión del tiempo

5 Cf. Redondo, P., Experiencia de la vida y fenomenología en las lecciones de Friburgo de Martin Heidegger, Universidad de Salamanca, 2001, p. 19. 
completamente seguro de que la edición fuera del todo fidedigna con lo que él había planteado en dichas lecciones, pues muchos de los escritos originales con los que había dictado los cursos ya no existían, lo que obligaba a que textos de estas lecciones fueran recabados a partir de una recolección de los apuntes de los estudiantes, comparándolos para obtener finalmente un texto que fuera, si bien no igual al de las lecciones que había dictado, sí por lo menos fiable 6 . Pero por otra parte, se alude a una razón más propiamente filosófica, que tendría que ver con que Heidegger a medida que su filosofía iba avanzado y adquiriendo una forma más definida se iba mostrando más crítico con las ideas que había presentado en sus primeras lecciones. Los juicios posteriores de Heidegger, especialmente Mi camino en la fenomenología y la carta al padre Richardson, dan a impresión de que estos primeros cursos significaron una desviación, un alejamiento de un único camino que solo posteriormente logró retomar ${ }^{7}$, el de la pregunta por el ser.

Es importante hacer esta precisión, dado que en nuestro trabajo se podrá verificar que la cuestión fundamental que Heidegger plantea en sus inicios tiene que ver principalmente con la pregunta por la vida fáctica, es la pregunta por la estructura ontológica de la vida fáctica la interrogante fundamental de la filosofía, su estructura temporal que nos revelará su ser. La pregunta por el ser, que a juicio del Heideger tardío, sería la pregunta que desde siempre y por siempre motivo y guió su camino filosófico, aparece desplazada y derivada como pregunta de segundo orden en relación a la pregunta conductora, en este caso, la pregunta por vida fáctica. Todo esto tiene una importancia capital en relación con nuestra tesis, porque tal como afirmamos, el problema ontológico del advenir permite en gran parte articular la pregunta por el ser, a saber, que Heideggger en su análisis de la vida fáctica, reconoce desde un principio que el carácter temporal privilegiado de la vida fáctica es el futuro. Asunto que no tiene tan clara respecto a la interpretación dominante de tradición metafísica en términos de presencia, como simple presente.

Además, podremos verificar que estas cuestiones caminan de forma paralela en su programa filosófico anterior a Ser y tiempo y siguen así hasta el momento de su plena cristalización, que solo se materializa una vez que Heidegger da con la formulación más acabada de que el fenómeno fundamental del tiempo es el futuro. En ese momento se le hace plenamente visible que en la interpretación griega del ser como presencia se esconde un modo del tiempo, el presente. Desde ahí la filosofía de Heidegger adquiere un programa más bien definido en esta llamada primera etapa del pensar heideggeriano, en la cual la pregunta por el ser desde el tiempo permite plantear la reformulación de la pregunta por el ser, a través de la analítica del Dasein. El proyecto filosófico de Heidegger, da un giro en 1927 pues al inicio de los años 20 la cuestión filosófica fundamental era la que preguntaba por la vida fáctica, que reclamaba una comprensión originaria de su

\footnotetext{
${ }^{6}$ Cf. Ibíd., p. 20.

7 Cf. Ibíd., p. 24.
} 
estructura ontológica, lo que al mismo tiempo revelaba la insuficiencia de las categorías de la tradición metafísica para dar cuenta de este fenómeno, lo que llevaba a un cuestionamiento de la tradición filosófica y por tanto a la pregunta por el ser. Pero, en 1927 se planteaba como cuestión fundamental la pregunta por el sentido del ser, que necesariamente tenía que pasar por una analítica existenciaria como ontología fundamental, sería entonces la pregunta por el ser la interrogante verdaderamente fundamental de la filosofía.

Este camino nos permitirá ver cómo este problema ontológico del advenir está presente a lo largo de este proyecto filosófico, que entre otras cosas se pregunta por el tiempo, pero que fundamentalmente es pregunta por el ser y el tiempo, lo que se presentará con distintas figuras, con distintas modulaciones, pero en todas ellas se mostrará en su radicalidad e importancia como consideración del tiempo que precisamente es el reverso del tiempo de la metafísica.

Si el Heidegger originario está en las lecciones anteriores a 1923 como le comentó personalmente a Becker, o si por el contrario, lo realmente importante se encuentra en la obra posterior al descubrimiento de la conexión entre el ser y el tiempo, son cosas que el propio estudioso o lector de Heidegger puede concluir, pero no a través de sus escritos autobiográficos o de la lectura crítica, sino que se encuentra en los propios textos, que es lo que hemos intentado hacer en este trabajo.

La idea principal que guía este trabajo en la primera parte es destacar la importancia del problema ontológico del advenir en lo que podríamos llamar su potencial ontológico, como articulador en la reformulación de la pregunta por el ser que Heidegger plantea en la estancia temprana de su pensamiento anterior a la publicación de su obra de 1927, periodo en el cual entiende que en la interpretación del ser de origen griego, el ser es concebido como ousía, como presencia(Anwesenheit) y en ello se oculta un modo del tiempo, el presente. Y Heidegger sostiene precisamente una tesis que se opone a la anterior, la cual afirma que el fenómeno fundamental del tiempo es el futuro. En esta tesis parece manifestarse una cierta identificación entre el tiempo del Dasein y el tiempo mismo, o entre la temporalidad humana y el tiempo del ser. Heidegger afirma en un momento que el futuro es el carácter o fenómeno fundamental del tiempo mismo y no de la temporalidad originaria. Cuestión que como veremos en Ser y tiempo es precisado claramente.

En función de esto, revisaremos principalmente, pero no exclusivamente, aquellas lecciones o trabajos en los cuales el pensador de la Selva Negra trata directamente la cuestión del tiempo y la crítica a la tradición metafísica, lo que nos permitirá reconocer la progresión del problema ontológico del advenir y destacar lo que llamamos el potencial ontológico de este fenómeno en el descubrimiento que hace Heidegger de la conexión 
entre el ser y el tiempo que subyacía en la interpretación dominante del ser de la filosofía griega. Esto hasta llegar a la formulación expresa de dicha pregunta y ver las distintas perspectivas y conexiones que se abren con ella, que el joven profesor se preocupará de resaltar, puntualizando la importancia y la trascendencia que tiene esta cuestión para su proyecto filosófico.

Posterior a esto, pasaremos a exponer algunas de las consecuencias más directas que se derivan de esta interpretación del ser que ha dominado sin contrapeso la historia del pensamiento occidental. Veremos cómo esta concepción del ser determina e influencia nuestra comprensión del hombre, del tiempo y de Dios y que nos lleva a someter a todo ente al criterio ontológico que nos entrega la naturaleza. Para plantear en último término la pregunta por una lógica filosofante que nos acaba por remitir también a la pregunta por el ser y el tiempo.

En cuanto a los textos utilizados, nuestra investigación comienza con su trabajo de habilitación titulado El concepto del tiempo en la ciencia histórica, que sería uno de los primeros escritos en los que Heidegger muestra su incipiente interés por la cuestión del tiempo, donde plantea una distinción clara entre el tiempo de la ciencias naturales y el tiempo de la ciencia histórica. Este texto se encuentra publicado en tomo 1 de la Gesamtausgabe. Pasaremos luego a la Introducción a la fenomenología de la religión(semestre de invierno de 1920-1921) que Heidegger dictó desde el 29 de octubre hasta el 25 de febrero, publicado en el año 1995. La inclusión de este curso ha suscitado múltiples discusiones respecto a la pertinencia de su integración en la edición de las Obras completas, esto porque, como lo mencionábamos anteriormente, lo que allí se presenta no es más que el resultado de la recopilación de los apuntes de algunos estudiantes. Kisiel es uno de los que señala que no se debería incluir ahí dichos cursos porque solo se trata de apuntes de estudiantes y no de un trabajo del mismo Heidegger ${ }^{8}$.

También se incluyen en el segundo capitulo de nuestra investigación las lecciones del semestre de verano de 1921 publicadas en el tomo 60 de la Gesamtausgabe, el nombre de dichos cursos es Agustín y el neoplatonismo. Estas lecciones siguen dentro de la dinámica de los cursos de fenomenología de la religión. Heidegger presenta ahí su crítica a la tradición metafísica a través del estudio de San Agustín y Lutero.

Luego nos detendremos en el denominado Informe Natorp que data de octubre del año 1922 escrito por Heidegger a petición de Natorp con vistas a obtener una plaza en Marburgo. Como dice Gadamer el escrito resultó tan osado y excitante que como resultado de ello Heidegger fue llamado a Marburgo ${ }^{9}$. Este escrito permaneció perdido por muchos años y fue publicado recién en el año 1989.

8 Cf. Kisiel, T., The Genesis of Heidegger's Being and time, University of California Press, Berkeley-Los Angeles, 1993, p. 10.

9 Cf. Gadamer, H., "Los griegos” en Los caminos de Heidegger, Herder, Barcelona, 2002, p. 126. 
Además, entre los trabajos en los que Heidegger profundiza en el problema del tiempo, aparecen dos del mismo nombre El concepto del tiempo, en los cuales de alguna forma se da ese paso entre su filosofía temprana, cristalizada en sus lecciones universitarias de Friburgo y una que podríamos denominar como segunda etapa, en la que se puede ver una configuración más estructurada de su analítica del Dasein y la reformulación de la pregunta por el ser, tomando como fundamento la conexión entre ser y tiempo que se oculta en la interpretación del ser de origen griego. Una de ellas es la conferencia el concepto del tiempo que Heidegger presentó ante la Sociedad Teológica de Marburgo el día 25 de julio de 1924 y fue publicada en el año 1989 por la editorial Max Niemeyer; algo distinto es el tratado que lleva el mismo nombre y que solo fue publicado en el año 2004 en el volumen 64 de las Obras completas que había permanecido inédito hasta esa fecha. Es precisamente en este año de 1924 en cual Heidegger da definitivamente con su tesis de que la cuestión del ser está estrechamente ligada a la cuestión del tiempo, por eso también aludiremos someramente al curso de verano de 1924 llamado Conceptos fundamentales de la filosofia aristotélica donde llega a algunas de las conclusiones que le permitirán estructurar de forma precisa la problemática ontológica de la cuestión del ser y el tiempo.

También será necesario remitirnos a dos lecciones de sobra conocidas, unas son las lecciones del semestre de verano de 1925, llamadas Prolegómenos a una historia del concepto del tiempo, publicada en 1988. Las otras lecciones corresponden al curso de invierno de 1925-1926, titulada Lógica: la pregunta por la verdad, que se publicó en el año 1976. Estas lecciones están ya enmarcadas dentro del camino franco a Ser y tiempo donde lo ganado en años anteriores ya se expresa de forma concreta, como por ejemplo la crítica a la tradición metafísica y la reafirmación de la radicalidad que posee para la filosofía la reformulación de la pregunta por el ser desde el tiempo, fenómeno hacia el cual también debe ser reconducida la lógica.

En la segunda parte analizaremos la importancia y el significado del problema ontológico del advenir en la analítica del Dasein y su prioridad al interior de la temporalidad originaria. Lo que llevaremos a cabo será elucidar una interpretación de Ser y Tiempo, fijando nuestra atención en esta cuestión, esto en los distintos niveles de desarrollo de la analítica. Pero principalmente en el tratamiento de la cuestión de la temporalidad originaria que Heidegger propone, en la que esta dimensión del tiempo adquiere un lugar destacado. Recorrido que nos permitirá reconocer al Dasein como un ente que en esencia es temporal, su ser es concebido como temporal, histórico. Seguiremos muy de cerca el camino trazado por el autor, en ese giro conceptual que su pensamiento imprime en relación con la tradición filosófica. Esto, a través de una aproximación al Dasein, a sus caracteres constitutivos, a las estructuras fundamentales de la abertura que este es, teniendo en cuenta que la comprensión es el hilo conductor de la investigación 
heideggeriana, lo que permitirá determinar cuál es su posibilidad más propia para así visualizar la prioridad que adquiere el advenir en la estructura existencial. Gracias a la primacía del advenir en el fenómeno de la temporalidad originaria esbozada por Heidegger esta dimensión temporal recupera la importancia que la tradición le había negado, cuestión que en último término hace posible la superación de la interpretación del tiempo peculiar a la tradición metafísica, cuya consecuencia directa es que considera al ser y al hombre como pura substancia, como lo meramente presente. Seguiremos el camino a través del cual Heidegger en virtud de este nuevo pensamiento, da el giro a esas concepciones, que son derivadas de una comprensión original.

Debemos entender al Dasein como una unidad estructural, unidad que también se hace presente en los modos de la temporalidad, pero en esta unidad si es que hay una prioridad o primacía, esta la ostenta el advenir, asunto fundamental para entender el giro filosófico que supone la obra de Heidegger.

Mostraremos como este asunto se hace presente en grandes pasajes de su obra, en la estrecha relación entre los fenómenos fundamentales del Dasein, la comprensión, el proyecto, la posibilidad y aquella que articula a todas las anteriores, el advenir. Fenómenos determinantes en la estructura del Dasein que adquieren su pleno sentido desde el advenir, que los constituye esencialmente y les abre su plena dimensión como fenómenos constitutivos y esenciales del Dasein. Estos están primariamente fundamentados en un ente que en su ser es esencialmente advenidero. Fenómenos que adquieren toda su significación en relación a su posibilidad más propia que es la muerte. Desde el cuidado en la impropiedad hasta la temporalidad originaria, desde la temporalidad originaria al sentido temporal de la cotidianidad, la historicidad del Dasein, el tiempo vulgar que se sustenta en la comprensión temporal como puro presente. En suma, para tratar de forma cabal la cuestión del advenir en Ser y tiempo, necesariamente debemos hacer un recorrido por la problemática general que se expone en el tratado, puesto que esto se enquista en el fundamento mismo de la obra, en el movimiento mismo que se opera en ella, en tanto inversión de los conceptos tradicionales.

Sin embargo, esta importancia o prioridad del advenir que enunciamos como fundamental, de ninguna manera pretende restarle originalidad, ni peso ontológico a los demás modos temporales, ya que es un fenómeno unitario, un todo estructural con sus partes constitutivas y solo como tal puede entenderse la temporalidad y la estructura del Dasein. 


\section{PRIMERA PARTE}

\section{Capítulo I: Primer acercamiento al problema del tiempo en la obra temprana de Heidegger}

Teniendo en consideración que el tema de nuestra investigación es el problema ontológico del advenir ${ }^{10}$ en el proyecto filosófico de Martin Heidegger, resulta imperativo al comenzar el presente trabajo, investigar aquellos primeros indicios que dan cuenta de la preocupación de Heidegger por el problema del tiempo, interés que por lo demás lo acompañará en su largo camino meditativo y será un asunto del que se ocupará hasta el final de su vida. En este contexto, analizaremos su trabajo de habilitación docente del verano de 1915, llamado El concepto del tiempo en la ciencia histórica (Der Zeitbegriff in der Geschichtswissenschaft).

Este trabajo fue presentado en el marco de una prueba de habilitación docente, que Heidegger realizó el 27 de julio de 1915 en la Universidad de Friburgo a la edad de 25 años, para la obtención de la venia legendi y fue publicado en el primer volumen de sus Obras completas. La importancia que posee para nosotros es significativa, toda vez que es el primer escrito en el que Heidegger trata específicamente del concepto del tiempo, en este caso en relación con la ciencia histórica. Además, muchas de las tesis aquí presentadas seguirán estando presentes en sus obras posteriores como lo recuerda con total claridad en una nota de Ser y tiempo $^{l l}$. En este estado primitivo de su filosofía, resplandecen problemas que no dejarán de ser fundamentales para Heidegger, esto es lo que analizaremos en esta primera parte de nuestro trabajo.

Lógicamente que esas ideas primeras irán adquiriendo una forma más definitiva a medida que el pensador va estructurando su proyecto filosófico y se irán articulando en el todo de un pensamiento de mayor complejidad del que podemos apreciar en este primer momento. Sin embargo, es necesario valorar este escrito desde la perspectiva en la que surge: un Heidegger que está comenzando a forjar una carrera académica y que se enfrenta ya a las corrientes filosóficas en boga.

Es muy ilustrativo, por no decir clarificador, en cuanto a la dirección que seguirá la pregunta heideggeriana acerca del tiempo, la cita con la que comienza su escrito de 1915

${ }_{10}$ A lo largo de nuestro trabajo para traducir Zukunft utilizaremos tanto el concepto de advenir como el de futuro. Pero debemos tener en cuenta que "futuro" o "advenir" en la interpretación heideggeriana no mientan un ahora no que luego o más adelante se hará efectivo o real, por lo tanto no debe ser entendido como una dimensión del tiempo que ahora no es y luego será, sino que nombra el carácter fundamental de este ente como esencialmente futuro o advenidero en su ser. Como un futuro que ya está siendo a cada momento, siempre adviene a sí, como un constante sobrevenir de las posibilidades.

${ }^{11}$ Heidegger, M., Ser y tiempo, Universitaria, Chile, 1997, p.433. Trad. Jorge Rivera. 
El concepto del tiempo en la ciencia histórica, en la que recuerda al maestro Eckhart cuando dice que "el tiempo es lo que cambia y se diversifica, la eternidad se mantiene simple". En una primera aproximación, es posible visualizar la dirección de las perspectivas interpretativas que guiarán a Heidegger. En primer lugar la contraposición entre la movilidad y el cambio, propia del tiempo humano, y en segundo aquella simpleza que caracteriza a la concepción del tiempo como eternidad, el tiempo como lo que es siempre. En esta frase recordada por Heidegger al comenzar su escrito de habilitación, se anuncian tempranamente las coordenadas que guiarán su pensamiento filosófico, esa contraposición entre la idea de un tiempo propiamente humano y esa otra del tiempo como eternidad, infinitud. De alguna manera, ya Heidegger tiene esa idea de la diferencia entre ese tiempo que es cambio, movilidad, dinamismo, y ese otro que es simple, imperecedero, eterno. Se aprecia aquí una idea que adquirirá un protagonismo especial en la posterior analítica del Dasein, la peculiaridad del tiempo propiamente humano, de un hombre concreto, finito y la concepción del tiempo como eterno.

Sin embargo, posteriormente esa aparente contraposición que Heidegger hace notar aquí se diluirá y se considerará como un falso problema, sobre el cual la filosofía no tiene nada que decir. Pero claro, estamos en una primera aproximación y estas ideas que aquí recogemos están en una fase germinal, lógicamente irán adquiriendo un contenido distinto a medida que el filósofo alemán va madurando su pensamiento. Pero estamos sin duda ante los primeros escarceos del pensador de la selva negra con el problema del tiempo. Como habíamos señalado el valor que posee este escrito de habilitación, es que en él se adelantan ciertos problemas y tesis que luego serán retomadas y desarrolladas de forma más exhaustiva, esto principalmente en la célebre conferencia de 1924 titulada El concepto del tiempo (Der Begriff der Zeit) y en el tratado del mismo nombre, además de mencionarlo en Ser y tiempo, entre otras alusiones. Esto porque, "más allá del problema puramente epistemológico, se perfilan ya las consideraciones ontológicas sobre lo que constituye el "verdadero" tiempo, que no es el de la física y que se caracteriza por la diversidad y la heterogeneidad. Pero este es aún captado en su oposición a la eternidad, como lo atestigua la cita inicial del maestro Eckhart, del cual Heidegger había hecho el lema de su lección"12.

El contexto en el que se presenta este trabajo de habilitación, es el de la distinción entre la ciencia histórica y la ciencia natural. La metodología utilizada por Heidegger es llevar a cabo una comparación entre la ciencia natural y la ciencia histórica, reconociendo en ellas su peculiar concepto del tiempo. Lo que se pretende con dicha distinción es acuñar un nuevo concepto de tiempo que sea capaz de brindar una originaria interpretación de la historicidad de la vida y dar otro status teórico a la ciencia histórica. Esta intención heideggeriana viene a estar claramente influenciada por la obra de Dilthey, quien entendía

$\overline{{ }^{12} \text { Dastur, F., Heidegger y }}$ la cuestión del tiempo, Signos, Buenos Aires, 2006, p.26. 
que una de las tareas fundamentales de la filosofía debía ser la rescatar la importancia y el valor de la historia.

Esta idea del tiempo que quiere presentar Heidegger, no puede concebirse según los dogmas propios del concepto del tiempo de la física o de las ciencias matemáticas, entendiendo el pensador alemán, que estos conceptos serían insuficientes para dar respuesta satisfactoria a la pregunta por el hombre y su historicidad. En la física señala Heidegger, se habla del problema de la medición del tiempo, de una unidad de medida, no de una pregunta por el tiempo en sí mismo, o por el ser del tiempo. Pero vamos a ir paso a paso, siguiendo al pensador en su meditación.

Heidegger define con claridad la dirección de su investigación, no es el concepto del tiempo de la tradición o el tiempo propio de la ciencia natural lo que pretende escrutar, sino que más bien:

\begin{abstract}
se trata de mostrar el paso que conduce de esta determinación del concepto de "tiempo en general" al concepto de "tiempo histórico". Esta determinación responde al hecho de que la ciencia histórica aplica el concepto de tiempo de acuerdo con sus tareas. Así, pues, podremos reconocer la estructura del concepto del tiempo propio de la historia a partir de su función en la ciencia histórica; esta función peculiar, a su vez, deberá comprenderse a partir de la finalidad de la ciencia histórica (GA1,417/18) ${ }^{13}$.
\end{abstract}

Por lo tanto, lo esencial es delimitar la estructura del concepto del tiempo de la ciencia histórica, distinguiéndolo claramente del concepto del tiempo en general, dado que por su propio objeto, la historicidad de la existencia, nada tiene que ver con la idea del tiempo de las ciencias naturales. Este camino propuesto nos conduce en principio a determinar el objetivo inherente a la ciencia histórica y la función que le es propia para desde ahí ir hasta la estructura del concepto del tiempo. Heidegger entiende que es necesario, con base a la finalidad a la que apunta cada ciencia, establecer desde allí una distinción clara y precisa del concepto de tiempo que es propia a cada cual, ello dependiendo de su particular objeto de estudio.

Según Heidegger, no se puede presentar un concepto general o universal del tiempo, que sea uniforme y general para todas las ciencias, no podemos hablar de un único y exclusivo concepto del tiempo. Incluso para definir la historia o su concepto de tiempo, no lo podemos hacer de forma automática, sin entrar en una discusión con ella, "no presuponemos, por tanto, una determinada teoría filosófica acerca de la ciencia histórica, tampoco investigamos qué estructura del concepto del tiempo encaja con ella, sino que partimos de la ciencia histórica como un hecho, estudiamos la función real y efectiva que el concepto de tiempo cumple esta ciencia y, a partir de ahí, determinamos su estructura lógica"(GA1,418/18). Estos son los objetivos primordiales para Heidegger, preguntar por

13 Heidegger, M., El concepto del tiempo en la ciencia histórica, Trotta, Madrid, 2009, p. 18. Trad. Jesús Adrián. 
la ciencia histórica, por el tiempo histórico, por el sentido que posee el tiempo en la ciencia histórica, cuestiones que nos deberían ayudar a determinar las características generales de la estructura lógica de la historia como ciencia. Heidegger va a desarrollar esta tarea, por medio de una comparación con el tiempo en la ciencia natural, específicamente de la física. Justamente de aquella ciencia con la que se quiere tomar distancia. Quiere que quede muy clara la diferencia entre las demás ciencias y la ciencia histórica, cuya finalidad última es la objetivación del espíritu humano y del espíritu vivo, para ello es indispensable aclarar el concepto del tiempo propio e irreductible de la ciencia histórica.

Para exponer el concepto del tiempo de la ciencia natural, el pensador alemán se sirve de una cualificación de la física según su método, distinguiendo sus rasgos más importantes, que entiende son los que determinan de forma decisiva el concepto del tiempo hasta nuestros días. En este método de la física, “1) Se establece una hipótesis que hace inteligibles los fenómenos de un determinado ámbito, en este caso, los fenómenos del movimiento. 2) La hipótesis no afirma una cualidad oculta como la causa que explica los fenómenos, sino que contiene relaciones matemáticas comprensibles-es, decir, mensurables-entre los momentos idealmente concebidos del fenómeno"(GA1, 420/21). Podemos reconocer aquí dos características destacadas de la comprensión del tiempo de la ciencia natural, que son las mismas que utiliza la filosofía clásica: la mensurabilidad y el movimiento. Lo que nos está indicando, que para determinar el modo propio de comprender el tiempo de la física es clave aclarar esta relación entre movimiento y mensurabilidad. Heidegger dice que la finalidad que persigue la física como ciencia es la de unificar y reducir todos los fenómenos a las leyes del movimientos y mensurabilidad de una masa por determinar. "Recordando su semestre de estudios en matemáticas y física, se dedica a mostrar que, de Galileo a Einstein incluido, la concepción del tiempo en física no ha cambiado: su función hacer posible la medida, constituye un momento necesario de la definición de movimiento que es el objeto mismo de la ciencia física"14. Ahora podemos afirmar, que el objeto último de la física es el corpus de leyes que dirigen y miden el movimiento y que dichos movimientos pasan en el tiempo, tenemos entonces una ecuación de tiempo, movimiento y medición. Sin embargo surgen las preguntas: ¿Puede ser medido, mensurado, el tiempo del fenómeno humano? ¿Puede esta idea del tiempo dar cuenta del hombre en su esencial historicidad?

Se pregunta Heidegger: "Pero exactamente, ¿qué significa esto? El "en” del tiempo tiene un sentido espacial; sin embargo, resulta evidente que el tiempo no es nada espacial, sobre todo si tenemos en cuenta que espacio y tiempo se contraponen siempre el uno al otro. Asimismo, salta a la vista que movimiento y tiempo está relacionados de alguna manera" (GA1,421/23). Es esencial detenernos en esta relación entre movimiento y mensurabilidad, lo que nos servirá para determinar de forma precisa cómo esta ciencia

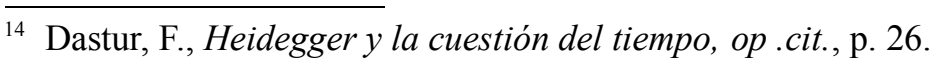


entiende el tiempo. Existe una relación entre movimiento y tiempo, relación en la cual lo primordial es la medición del movimiento realizado con la ayuda del tiempo. Es entonces una comprensión del tiempo cuantitativa, entramos por tanto en el ámbito propio de las matemáticas. Lo que nos indica, que en función de obtener una caracterización más completa del concepto de tiempo y del movimiento en la ciencia, debemos necesariamente enfocar la investigación hacia el ámbito matemático.

Esta relación entre movimiento, medición y tiempo, es tal, que "cuando queremos describir el movimiento de un punto material-dice Einstein- damos los valores de sus coordenadas en función del tiempo"(GA1,423/25). En esta órbita reflexiva propia de las ciencias naturales, el movimiento como objeto de estudio de la física se puede mesurar con la ayuda del tiempo según el lugar espacial que va ocupando el objeto de estudio en cada punto de una sucesión temporal, la principal función del tiempo sería la de posibilitar tal medición. Esto es así, hasta el extremo de que el tiempo se constituye en una instancia necesaria de la definición del movimiento, indispensable para los objetivos de la física, es indispensable para su propia fundamentación, “ahora bien, para permitir la medida, debe devenir él mismo mensurable, y no puede hacerlo si no es pensado como un transcurso uniforme, es decir, identificado con el espacio"15. Más claro aún, dice Heidegger:

el tiempo representa una serie que apunta en una dirección en la que cada punto del tiempo, medido desde el punto de partida, solo se diferencia por su posición. Precisamente porque un punto del tiempo se diferencia del punto que le precede solo por el hecho de que es el punto que le sucede, es posible medir el tiempo y, por eso, los movimientos. Tan pronto se mide el tiempo-y el tiempo solo tiene una función significativa en la física en cuanto tiempo mensurable y capaz de ser medido- determinaremos una cantidad. Esta indicación de la cantidad reúne en una unidad los puntos del tiempo transcurridos hasta ese momento. Por así decirlo, hacemos un corte en la escala temporal, con lo cual destruimos el verdadero tiempo en su fluir y lo paralizamos. El flujo se congela, se convierte en una superficie, y solo se puede medir como superficie. El tiempo se ha transformado en una ordenación homogénea de posiciones, en una escala, en un parámetro (GA1,424/26).

Entonces, a partir de la definición misma de la física y de su objeto de estudio, podemos concluir que el tiempo solo tiene valor para ella en cuanto sirve de unidad de medida y puede al mismo tiempo ser medido, es decir, el tiempo es considerado meramente como mensurable, es un tiempo cuantitativo, él permite contar la cantidad de puntos que han trascurrido hasta el momento de la medición y reúne esta suma en una unidad homogénea. Cada punto del tiempo se diferencia de otro por el determinado espacio que ocupan en la totalidad.

El tiempo es entendido como una serie homogénea de posiciones de un punto a otro en una sucesión, cada punto temporal se diferencia de otro solamente en el lugar que ocupa, lo cual es medido en referencia a un punto de partida, esto es lo que permite medir

$\overline{15}$ Dastur, F., Heidegger y la cuestión del tiempo, op. cit., p. 26. 
el tiempo y los movimientos. El movimiento es el objeto de estudio de la física y este movimiento solo se puede medir, mensurar, con la ayuda del tiempo.

En conclusión, en esta exégesis del tiempo propia de las ciencias naturales, el tiempo en entendido como mensurable, homogéneo y cuantitativo. Se podría suponer como afirma Heidegger, que la teoría de la relatividad - en pleno apogeo en la fecha de elaboración de este escrito-, abriría espacio para una interpretación novedosa y original del tiempo en virtud de sus logros y avances, sin embargo, "en la teoría de la relatividad, en tanto que teoría física, se trata del problema de la medición del tiempo, no del tiempo en sí mismo. La teoría de la relatividad no altera el concepto de tiempo; de hecho, confirma plenamente la principal característica del concepto de tiempo propio de las ciencias naturales que anteriormente pusimos de relieve, a saber, su carácter homogéneo y cuantitativamente determinable"(GA1,427/27). De modo, que esta innovadora interpretación que elabora Einstein seguiría el mismo camino interpretativo de la física clásica, por lo tanto, sigue siendo insuficiente a la hora de interpretar el tiempo de modo originario.

Es necesario tener en cuenta esta interpretación del tiempo propia de la física, porque si bien estamos en un periodo de gestación de la filosofía heideggeriana, esta interpretación del tiempo de las ciencias naturales seguirá estando presente en su filosofía, es más, a esta concepción del tiempo es a la que dirige el pensador su crítica filosófica, en ella se fundamenta la idea del tiempo como simple presente, desde esta interpretación surge la concepción vulgar del tiempo que desarrollará posteriormente.

Una vez expuesta en sus lineamientos principales la idea del tiempo propia a la física, llega el momento de describir la estructura del concepto del tiempo en la ciencia histórica. Pero "surge por de pronto la duda de de si aquí todavía cabe la posibilidad de plantear un problema nuevo. Pues para la ciencia histórica el tiempo también es en cierto modo una especie de ordenación de posiciones con respecto a la cual los acontecimientos en cuestión tienen asignados un determinado lugar en el tiempo, quedando así históricamente fijados" (GA1, 425/27). A primera vista se podría afirmar que no existe una gran diferencia entre el concepto del tiempo en la ciencia natural y en la ciencia histórica, dado que ambas tiene el status de ciencias, comparten la idea de una medición al interior de una sucesión temporal, por lo que cabría pensar que poseen una idea de tiempo similar.

Es menester para Heidegger dar el paso más allá y exponer la particularidad propia del concepto del tiempo en la ciencia histórica y ver de qué manera se distancia ésta interpretación a la de la ciencia natural. Según el filósofo alemán, lo primero que se debe hacer es determinar cuál es el papel que juega el tiempo en la ciencia histórica, esto como había dicho en un primer momento, solo se podrá descubrir si se hace entendible el objeto y la finalidad de la ciencia histórica. La estructura del concepto del tiempo en la historia 
solo se nos hará accesible, si podemos comprender cual es el objeto y el objetivo de la ciencia histórica. Heidegger comenta, que si quisiéramos obtener estos resultados de un modo fácil y sencillo no nos quedaría más que utilizar una disciplina auxiliar que se hace cargo de determinar el tiempo, nos referimos a la cronología histórica. Pero no es este el camino elegido, lo que no significa que la cronología histórica no tenga cierto grado de importancia en el concepto del tiempo de la historia, al contrario, su valor se nos revelará más adelante.

Una de las dificultades inherentes a la investigación emprendida por el joven Privatdozent, tiene que ver con el criterio o definición sobre el objetivo y el objeto de la ciencia histórica, asunto sobre el cual los historiadores nunca llegan a ponerse de acuerdo, lo que nos sitúa desde ya en una dificultad propia de la ciencia histórica.

Heidegger realiza una serie de precisiones respecto a la definición de la ciencia histórica, sus tareas, objetivos y metodología. Pero aquí no desarrollará un tratamiento acabado y completo de lo que la ciencia histórica es, solo se ciñe a caracterizar algunos conceptos y procedimientos del método científico, para ver de qué forma el concepto del tiempo se manifiesta en ella. El filósofo alemán señala: "la meta que persigue la ciencia histórica es representar el nexo de los efectos y el desarrollo de las objetivaciones de la vida humana en su unicidad y singularidad de manera que resulte comprensible en su relación con los valores culturales" (GA1,427/30) y más adelante apunta otra característica esencial del objeto histórico, "el objeto histórico, en cuanto histórico, es siempre pasado; en sentido estricto ya no existe más. Entre él y el historiador media una distancia temporal" (GA1,427/31). Se puede percibir que en la meta de la ciencia histórica existe un vínculo entre las objetivaciones de la vida humana y los valores pertinentes a cada cultura, lo que deja en evidencia la finalidad última de la ciencia histórica, que es la de establecer y aclarar esas relaciones, relaciones que siempre están en estrecha cercanía con los valores de una determinada cultura. Sale a relucir aquí algo importante en esta fase de la filosofía heideggeriana, el asunto de los valores. Toda vez, que aquí poseen para él una destacada importancia, en tanto, que de ellos dependen las señaladas fechas históricas, una fecha es histórica dependiendo de las valoraciones históricas desde donde surgen. Papel destacado el que desempeñan los valores a la hora de una comprensión original de la historia, esta importancia mencionada pronto desaparecerá en la filosofía heideggeriana, pero es clave en este periodo de su pensamiento.

Por otra parte, no se debe dejar de lado una característica esencial del objeto histórico: éste es siempre pasado, ya no existe, no está presente, razón por la cual se produciría una distancia insalvable entre el objeto histórico que es siempre pasado y el historiador que a su vez es siempre presente ${ }^{16}$. Surge entonces la pregunta de cómo puede

16 Heidegger en este escrito lleva a cabo una interpretación de la historia según los cánones clásicos, lo que es histórico es siempre pasado, que no existe más, que no está presente. Estas ideas serán claramente abandonadas por el autor en su análisis de la historicidad del Dasein. Pero llama la atención que justo sobre esta idea clásica de la historia es a la que dirigirá su crítica posterior. 
ser superada esta distancia, este abismo. Exigencia, que por lo demás, viene impuesta por la meta y el objeto de la ciencia histórica.

Es el tiempo mismo el que tiene que manifestarse para dar alguna solución a estos inconvenientes de la ciencia histórica. Heidegger sostiene, que "podremos estudiar con mayor precisión la función del tiempo implicada en la necesaria superación temporal en la que se mueve la ciencia histórica si dirigimos nuestros atención a la metodología que esta ciencia aplica a la hora de acceder al pasado y representárselo históricamente" (GA1,428/32). En primer lugar, el objetivo primordial de la ciencia histórica según Heidegger, es tener por seguro que los hechos que sean descritos por ella sean reales y efectivos. Es primordial asegurar la fiabilidad de las fuentes, ya que son las que posibilitan el acceso científico a la realidad histórica. Las fuentes deben ser fiables, verificadas en su valor de fuentes. Para ello es menester dirigir la atención a la metodología que utiliza esta ciencia.

En segundo lugar, se debe intentar llevar a cabo una exégesis correcta del contenido objetivo de las fuentes, una interpretación fidedigna de los acontecimientos, comprender su significado. Esta interpretación de las fuentes tiene que ver con una valoración de los hechos históricos, una determinación cualitativa de ellos, no es simplemente marcar una fecha en el calendario, tampoco se trata de su específica posición en una sucesión temporal, sino que conlleva una interpretación, una valoración. Dice Heidegger al respecto, "Los tiempos de la historia se distinguen cualitativamente" (GA1,431/35), afirmando de esta manera que el concepto del tiempo en la ciencia histórica difiere radicalmente del tiempo propio a la ciencia natural. Por lo tanto:

\footnotetext{
el concepto de tiempo en la ciencia histórica no guarda ninguna relación con el carácter homogéneo del concepto del tiempo de la ciencia natural. Por eso el tiempo histórico no puede expresarse matemáticamente por medio de una serie, ya que no hay ninguna ley que determine cómo suceden las épocas. En el tiempo físico, los momentos temporales se distinguen solo por su posición en la serie. Las épocas históricas también se suceden- de lo contrario no serían épocas-, pero cada una es diferente desde el punto de vista de la estructura de su contenido. El factor cualitativo del tiempo no significa otra cosa que la condensación -cristalización- de una objetivación de la vida dada en la historia. La ciencia histórica no trabaja, pues, con cantidades (GA1, 431/36).
}

Así es como va tomando cuerpo el concepto de tiempo de la ciencia histórica propuesto por el pensador de la Selva Negra. El tiempo en la historia no puede ser pensado como homogéneo, cada momento de la historia se distingue de otro desde la perspectiva de su contenido, desde su significado, es por ello que no podemos considerarlos como distintos solamente por el lugar que ocupan en la sucesión, son cualitativamente distintos. Por lo cual, "es a este tiempo homogeneizado, espacializado, devenido puro parámetro, al que se opone el tiempo histórico, caracterizado al contrario por su heterogeneidad cualitativa"117.

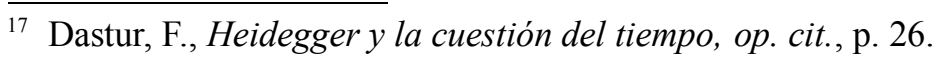


El tiempo con el que trabaja la historia es cualitativo, no cuantitativo como en la física. Esto significa que el tiempo es aquello que le hace tomar forma definitiva, que concreta la objetivación del espíritu humano que se da en la historia. Es lo que Heidegger llama la cristalización de una objetivación de la vida.

El objetivo final de la ciencia histórica es mostrar el vínculo de las vivencias y de las experiencias de la vida. El tiempo es lo que permite salvar el abismo existente entre el objeto histórico y el historiador. La ciencia histórica según su objeto, según su metodología, nos revela una estructura distinta del concepto del tiempo al reconocido en la ciencia natural. Podríamos decir que para el pensador alemán, la noción de tiempo en la ciencia histórica es dinámica, está en constante movilidad. Esta distinción del tiempo de la ciencia histórica nos muestra que sus instancias temporales se distinguen entre sí de forma cualitativa, es decir, no se puede instalar entre ellas ciertas leyes de corte científico matemático que puedan normar su sucesión, esto es completamente imposible en la ciencia histórica. Además, esta determinación cualitativa tiene una referencia directa a valoraciones e interpretaciones.

Por último, no deja de ser relevante para Heidegger preguntarse por el valor de las fechas, de los momentos históricos, de los números que son propios a la historia; la fecha de un determinado acontecimiento, un hecho histórico. Si el tiempo de la historia es cualitativo, ¿tienen algún valor estas fechas, estos números? Solo tienen importancia si se toma en cuenta el contenido histórico, su significado histórico, lo que representan dichas fechas dentro de la historia, lo que representan de acuerdo a determinadas valoraciones. Al momento de preguntar por un cuándo de algún hecho histórico, no me intereso por el número, ni por el lugar que ocupa en una determinada sucesión, sino que "estoy preguntando por su posición en un contexto histórico cualitativo y no por un cuánto"(GA1,432/37). Las fechas históricas en sí mismas no tienen ningún valor, fácilmente pueden ser cambiadas por otras fechas, por otro número en la sucesión y esto con solo cambiar el punto de inicio de la sucesión. Pero en esto radica lo importante, el hecho de comenzar a calcular el tiempo, nos demuestra que el cálculo del tiempo siempre empieza con un hecho histórico determinante.

Un ejemplo que elige Heidegger es el nacimiento de Cristo o la fundación de la ciudad de Roma. Estos ejemplos nos permiten comprender la importancia de la cronología en el concepto del tiempo de la ciencia histórica, en virtud de la cual se inicia el comienzo del cómputo del tiempo. "Esto muestra que en la ciencia histórica todo lo que tiene que ver con los números y la numeración del tiempo está determinado cualitativamente por el modo de fijar el comienzo de la numeración. Se puede decir que el principio de la formación histórica de los conceptos se manifiesta incluso en el mismo momento en que comenzamos a contar el tiempo: la relación valorativa" (GA1,433/38). Podemos concluir, que en la ciencia histórica se trabaja con coordenadas distintas a las de la física, sobretodo al momento de definir o aclarar la esencia del concepto del tiempo, toda vez que el tiempo 
en la historia tiene una determinación cualitativa, incluso al momento de fijar el comienzo de la numeración, el inicio del cómputo del tiempo depende de una valoración. El comienzo en la formación histórica de los conceptos, no es algo casual o antojadizo, por el contrario siempre depende de una relación valorativa, depende de determinadas interpretaciones que son las que fijan en último término el inicio del cómputo del tiempo, que le dan el sentido a las fechas históricas.

Como conclusión de este escrito de habilitación, nos dice Heidegger que "el reconocimiento de la significatividad fundamental que tiene el concepto del tiempo en la historia y de su radical diferencia con respecto al concepto del tiempo en la física permitirá a la teoría de la ciencia penetrar en el peculiar carácter de la ciencia histórica y fundarla teóricamente como un modo de pensar original e irreductible a otras ciencias" (GA1,433/38). Heidegger cumple así con el objetivo que se había propuesto, la tarea de distinguir con claridad la diferencia entre el objeto propio de la ciencia natural y el de la ciencia histórica, que es la vida humana, la historicidad del hombre, del espíritu vivo que menciona por estos años, cuestiones irreductibles a una ciencia de la naturaleza. Y el concepto del tiempo es el elegido para llevar a cabo esta tarea, cuestión que no es una simple casualidad, dado que es la pregunta por el tiempo el hilo conductor de la pregunta filosófica por excelencia que guía la meditación heideggeriana y que le permite reformular la pregunta por el ser.

También es menester no olvidar que estamos en una fase inicial, en un primer escarceo del pensador de la Selva Negra con el concepto del tiempo. Surgen también ciertas objeciones respecto al trabajo realizado:

\footnotetext{
cuando Heidegger intenta separar, como ya se ha señalado, ciencia natural y ciencia histórica, se hace cargo de una tentativa que ya estaba puesta en marcha por Wilhelm Wildelband y Heinrich Rickert. Queda sin embargo, irresuelta la pregunta de si la historia acontecida sea contemplada de forma suficientemente originaria por el hecho de que, en una meditación sobre el factum de la ciencia histórica, se pretenda fundamentar -como intenta aquí Heidegger- esa ciencia desde el punto de vista de la teoría de la ciencia mediante un regreso a sus conceptos fundamentales y a la formación de éstos, y por el hecho de distinguirla de la ciencia natural ${ }^{18}$.
}

Todavía tiene la intención de fundar teóricamente una ciencia histórica, su finalidad es presentar una ciencia, en este caso histórica, que sea capaz de dar cuenta de la historicidad, del acontecer histórico, pero siempre entendiendo esto como una nueva fundamentación teórica de la ciencia histórica. No obstante, sigue estando presente en su propuesta la idea de un fundamento científico, pero con otro carácter, que sea distinto al de la ciencia natural, pero al fin y al cabo, permanece considerando la investigación histórica como una exégesis de carácter científico. Pero también, está presente en principio esa distinción entre tiempo y eternidad, como un asunto que filosóficamente le preocupa, en esta preocupación por la ciencia histórica y en la delimitación de sus objetivos, se manifiesta el

18 Pöggeler, O., El camino del pensar de Martin Heidegger, op. cit., p. 36. 
interés por la existencia concreta y situada históricamente, aunque dicha preocupación se encuentre en un estado germinal.

Tenemos varios puntos importantes que destacar después de analizar este trabajo de habilitación. En primer lugar, este escrito resulta esclarecedor, puesto que, Heidegger plantea por vez primera y de forma sistemática el problema del concepto del tiempo, utilizando para ello la distinción entre ciencia histórica y ciencia natural. Pero es sintomático que ya aparezcan tratados algunos problemas que seguirán estando presentes a lo largo de la trayectoria filosófica de Heidegger. Es más, como habíamos señalado, en Ser y tiempo el autor al hacer el análisis del tiempo del que nos ocupamos, del tiempo de la naturaleza, comenta que es necesario también el análisis existenciario del conocimiento histórico y recuerda que:

como un primer intento de interpretación del tiempo cronológico y del "número en el acontecer histórico", cf. la lección para la habilitación del autor dictada en la Universidad de Friburgo (semestre de verano de 1915): "Der Zeitbegriff in der Geschichtswissenschaft" ("el concepto del tiempo en la ciencia histórica"). Fue publicada en Zeitschr.f. Philos. u. philos. Kritik, tomo 161(1916), p.173 ss. Las conexiones entre el número en el acontecer histórico, el tiempo del mundo astronómicamente calculado y la temporeidad e historicidad del Dasein requieren una investigación más a fondo ${ }^{19}$.

Todo esto muestra el valor que Heidegger le asigna a este escrito, como una primera interpretación del tiempo cronológico.

La importancia de este trabajo de habilitación no radica en la concepción de la ciencia histórica, de su objeto, de su metodología, sino que más bien, en la exigencia de un status teórico propio para fundamentar esta ciencia. Todavía considerada como ciencia por el joven Heidegger. El objeto de esta es absolutamente distinto al de las demás ciencias. Es la objetividad del espíritu humano, la historicidad del hombre, la vida concreta e individual. El concepto del tiempo es el elegido para llevar a cabo esta investigación. Esto no es una casualidad fruto de la improvisación, sino que responde a las propias motivaciones filosóficas de Heidegger, a sus propios intereses especulativos. En este escrito se prefiguran desde ya las proyecciones filosóficas que guiarán a Heidegger en su fecunda labor filosófica. Resumiendo, en este primer trabajo en el cual el pensador de Messkirch trata de forma directa el problema del tiempo:

aborda un tema llamado a jugar un gran papel en su pensamiento: la diferencia entre el concepto del tiempo en la ciencia natural y en la ciencia histórica. El primero se presenta como una línea homogénea, en la que cada punto de distingue del otro por el lugar que ocupa en el conjunto. El segundo, en cambio, no tiene la forma de una línea homogénea, sino discontinua. Los tiempos en la historia se distinguen entre sí cualitativamente, sin que quepa establecer entre ellos una ley que permita determinar su sucesión ${ }^{20}$.

${ }_{19}$ ST, p. 433. Rivera.

${ }^{20}$ Colomer,E., El pensamiento alemán. De Kant a Heidegger, Herder, Barcelona, 1990, p. 481. 


\section{Capítulo II: La experiencia originaria del cristianismo primitivo como suelo fértil para los primeros pasos del proyecto filosófico heideggeriano}

En esta fase inicial de nuestro trabajo, nos planteamos como objetivo prioritario aclarar y destacar en los trabajos de juventud de Heidegger, pertenecientes al primer periodo de Friburgo, las tempranas referencias que el autor hace del problema del tiempo y la crítica velada al concepto del ser que planteaba por aquellos años, que a su juicio dominaba la interpretación metafísica, que estaba sometida a los cánones de la tradición filosófica. Por lo tanto, hemos de tener en cuenta todas aquellas proposiciones que se relacionen con nuestro tema de investigación, el problema ontológico del advenir, que entendemos es fundamental en el proyecto filosófico de Heidegger en su intención de reformular la pregunta por el ser, con la que pretende llevar a cabo una relectura en clave metafísica de la tradición filosófica. Reinterpretación en la cual la pregunta por la vida fáctica, por el tiempo y por el ser, están llamados a cumplir un papel destacado. Como bien dice Berciano: "Heidegger quiere desde el comienzo de su pensar una renovación radical de la filosofía; y considera ésta desde la perspectiva del mundo de la vida, de un mundo que es histórico, que está en el acaecer histórico y es temporal’21.

Sin embargo, en este periodo primitivo del pensamiento de Heidegger no están definidos del todo los senderos que habrá de recorrer su andar filosófico, aclararlo es lo que nos mueve en este momento; para poder fijar de forma precisa los lineamientos fundamentales que guían su proyecto filosófico en los comienzos y que marcarán inevitablemente su filosofía, nos referimos a la pregunta por el ser y el tiempo. La filosofía de Heidegger se encuentra en una fase germinal, da sus primeros pasos y se trata de desmarcar de las principales directrices que dicta la tradición filosófica. Para ello posee un instrumento filosófico determinante, la fenomenología, no obstante, por ahora no puede aplicar sin más su método a la pregunta por el ser, tal como comenta Pöggeler: "la cuestión del ser no puede ser por ahora objeto, a causa de sus inevitables implicaciones metafísicas. En su lugar escoge Heidegger como objeto de análisis fenomenológico de la vida fáctica, la vida que en su concreta facticidad se autorrealiza, desde situaciones siempre nuevas, y se comprende por ende a sí misma como histórica. La fenomenología se convierte entonces en autointerpretación de la vida fáctica, que se coge a sí misma en el proceso de su ejecución (Vollzug)" ${ }^{22}$. En tanto la filosofía es fenomenología, y para Heidegger la fenomenología tiene como principal objetivo aclarar la vida en su ejecutividad, la pregunta e investigación acerca de la vida humana en su facticidad es la pregunta filosófica que es menester plantear con urgencia.

\footnotetext{
${ }^{21}$ Berciano, M., La revolución filosófica de Martin Heidegger, Nueva, Madrid, 2001, p. 19.

${ }^{22}$ Colomer, E., El pensamiento alemán. De Kant a Heidegger, op, cit., p. 483.
} 
Con el afán de responder a estas interrogantes, es menester determinar con claridad un asunto clave para el desarrollo del pensamiento filosófico del autor alemán que comienza a despuntar, tiene que ver con el hecho histórico, con el acontecimiento del que se sirve para desarrollar su crítica filosófica, por esto, es imperioso ir paso a paso. Justamente siguiendo esta dirección, Pöggeler se pregunta: “¿De dónde recibirá el impulso decisivo un pensar que se apresta a tomar la cuestión del ser y de la historia acontecida, si el pensar histórico de la época moderna, del que parte Dilthey, sigue siendo insuficiente y si el "hombre moderno" está, en general, apunto de que lo entierren?"23, esta es una cuestión que sin duda es determinante, ya que en su obra más representativa de 1927, no queda para nada claro de dónde recibe ese impulso decisivo, esa influencia que le permite inaugurar una reflexión que se propone poner en duda la conceptualización metafísica de la tradición filosófica. Comenta Pöggeler que la respuesta a esto se puede encontrar en sus lecciones universitarias de juventud, dado que, "los primeros cursos de Heidegger muestran que ha sido la fe del cristianismo primitivo la que enderezó el pensar heideggeriano hacia las preguntas decisivas"24. De modo que esta experiencia originaria del cristianismo primitivo no es un fenómeno más que Heidegger sometió al escrutinio de su método fenomenológico, por el contrario, es un fenómeno decisivo que le permitió echar a andar su maquinaría filosófica, que le dio el impulso decisivo para desarrollar su gigantomaquia peri tes ousias, para reformular originariamente la pregunta por el ser.

Cuestión que desarrolla en sus lecciones de fenomenología de la religión, las que se dividen en dos marcos temáticos claramente destacados. Por una parte analiza el cristianismo primitivo de San Pablo en las primeras comunidades y por otra lleva a cabo una interpretación de la experiencia religiosa de San Agustín de Hipona, que por la influencia del neoplatonismo, se sobrecarga de una conceptualización propiamente griega, que afectaría su meditación, además, dicha influencia lastraría largamente la conceptualidad de la filosofía a lo largo de su historia. Heidegger en su análisis de las epístolas paulinas lleva a cabo una exégesis originaria del tiempo propiamente humano, del tiempo propio a la facticidad de la vida y, luego, en su lectura de San Agustín, presenta una crítica abierta a la concepción del ser de procedencia griega. Mostrar ambas direcciones interrogativas es la tarea que nos proponemos desarrollar a continuación.

La problemática tratada por Heidegger en estas lecciones es aún más amplia y rica de lo brevemente reseñado, pero es la pregunta por el ser y su relación con el tiempo lo que nos interesa resaltar, ya que ellas son los pilares fundamentales que sostienen el quehacer filosófico del pensador de la Selva Negra y son los asuntos que nos interesa determinar en este trabajo. No obstante, dada la importancia que poseen estas lecciones para el desarrollo y la elaboración de su filosofía de este periodo, hay muchos otros asuntos que no podemos pasar por alto, como por ejemplo, el problema de la indicación

${ }^{23}$ Pöggeler, O., El camino del pensar de Martin Heidegger, op. cit., p.41.

${ }^{24}$ Ídem. 
formal, la triple estructura de la intencionalidad. Pero hacemos la precisión de que nos enfocaremos principalmente en sus incipientes reflexiones acerca del tiempo y del ser, pero en función del correcto acceso a ellas, es necesario hacer un largo recorrido, que se materializa en estas lecciones con un análisis de la vida humana en su experiencia fáctica, en su ejecución, esto como la tarea más propia de la filosofía.

Es menester, entonces, buscar una experiencia originaria de la vida fáctica para encontrar en ella lo esencialmente constitutivo de esa vida pero en su ejecución, en la propia situación de un yo histórico. En función de esto, Heidegger sostiene que necesariamente hemos de dirigirnos a la experiencia del cristianismo primitivo y al concepto del tiempo que se desliza en ella, lo que nos permitiría además, plantear con claridad una crítica a la tradición metafísica. Sabemos que los objetivos de la filosofía heideggeriana son diversos, especialmente en este periodo, pero esencialmente siguen siendo los mismos, reformular la pregunta por la vida humana, recuperándola en su esencial historicidad, para de esta forma llegar a la pregunta que verdaderamente le interesa, la pregunta por el ser, por su sentido, por su interna y esencial relación con el tiempo. Ahora bien, antes debemos establecer de forma concreta por qué Heidegger se sirve del cristianismo para explicar originariamente la vida fáctica, qué encuentra en el cristianismo, qué importancia tiene para su filosofía.

Prescindiendo de referencias biográficas o de la propia formación católica del joven Heidegger, nosotros pretendemos destacar la importancia que tiene para nuestra investigación esa interpretación fenomenológica de las comunidades cristianas primitivas, su forma de comprender la vida, puesto que este es un punto de referencia importante que le da el impulso necesario para comenzar a estructurar su labor filosófica, esto desde la pregunta por la temporalidad propiamente humana, por la historicidad propia de la existencia. La fenomenología no puede trabajar o desarrollarse en el vacío o de forma abstracta, necesita un fenómeno, se debe a ellos. Por eso se elige un fenómeno religioso originario, la experiencia fáctica del cristianismo primitivo. Gadamer expone esto de la siguiente forma:

la primera pregunta del primer comienzo había sido: ¿qué es el ser del ser-ahí (Dasein) humano? Sin duda no es mera coincidencia. Más, ¿qué es este ser que no dura ni vale como las estrellas eternas o las verdaderas matemáticas, sino que siempre se está desvaneciendo como toda vida que se extiende entre nacimiento y muerte, y que, sin embargo, en su finitud e historicidad, tiene un "ahí", un aquí, un ahora, presencia en el instante, no un punto vacío, sino plenitud de tiempo y reunión de todo? El ser del ser-ahí humano consiste en ser ese ahí, en el que el futuro y pasado no son momentos que se acercan y se alejan rodando, sino que son el futuro propio en cada caso y la propia historia que conforma el propio ser desde la ocasión del nacimiento. Puesto que el ser-ahí que se proyecta de esta manera al futuro se lo tiene que asumir en su finitud y se halla como 
arrojado en el ser, por eso la palabra clave para el primer planteamiento de la pregunta por el ser no es la autoconciencia, la razón o el espíritu, sino la facticidad ${ }^{25}$

Estas cuestiones son las que esencialmente le preocupan por aquellos años, la facticidad de la vida, la experiencia fáctica de la vida y la temporalidad inherente a ella.

Dentro de este contexto es en el que se manifiestan estas preocupaciones filosóficas, que se plasman en las lecciones de 1920-1921, publicadas en el año 1995 en el volumen 60 de la Gesamtausgabe titulado Fenomenología de la vida religiosa (Phänomenologie des Religiösen Lebens), que a su vez se divide en dos lecciones, una es Introducción a la fenomenología de la religión (Einleitung in die Phänomenologie der Religión) que Heidegger dictó en el semestre de invierno de 1920-1921 y otro es Agustín y el neoplatonismo (Augustinus und der Neuplatonismus) que presentó en el semestre de verano de 1921, edición que además incluye un estudio sobre mística medieval en el que no entraremos.

En estas lecciones de Friburgo Heidegger toma como punto de partida para su análisis el hecho de la religiosidad de las comunidades cristianas primitivas, pero no para llevar a cabo una exégesis teológica o interpretativa en clave religiosa, sino que tiene por finalidad presentar los indicadores formales de la historicidad y de la facticidad de la vida humana en su ejecución. Esto lo deja muy claro Heidegger en la introducción de la segunda parte de la Einleitung in die Phänomenologie der Religion, donde señala que, "en lo que sigue no tenemos la intención de ofrecer ni una interpretación dogmática o teológico-exegética ni tampoco un estudio histórico o una meditación religiosa, sino solo una introducción a la comprensión fenomenológica. Lo peculiar de la comprensión fenomenológico-religiosa es la obtención de una precomprensión para una vía originaria de acceso" (GA 60, 67/97).

Es clara la intención que guía al joven profesor. No obstante, la importancia de estas lecciones es superlativa en relación con los objetivos de nuestro trabajo, en ellas de alguna manera se abordan los dos ejes fundamentales que guían la investigación heideggeriana y que se encuentran entrelazados de forma irreductible. Nos referimos al problema de la temporalidad de la existencia y a la concepción del ser como simple presencia, pero debemos adelantar que en estos cursos dichas cuestiones solo se anuncian, se indican de forma tenue, lo que significa que no se desarrollan de forma acabada o definitiva, ni tampoco se exponen de modo concreto, no obstante, quedan ahí anunciadas estas líneas fundamentales de su pensamiento que terminan por vertebrar su filosofía en sus primeros años de docencia en Friburgo y que son parte fundamental del tema de la presente investigación, en lo que tiene que ver con la forma cómo se conectan y relacionan ambas cuestiones.

${ }^{25}$ Gadamer, H.,"Martin Heidegger en su 25 cumpleaños" en Los caminos de Heidegger, op. cit., p. 34. 
En estas lecciones Heidegger lleva a cabo una aproximación, determinación y definición del método fenomenológico, de ahí el valor añadido de estos cursos, es el lugar en el que se aprecia una elaboración concreta de su concepción de la fenomenología, además, que la idea de fenómeno y fenomenología que ahí desarrolla mantendría una gran coherencia con la forma en que entiende dichas cuestiones por aquellos años. Para desarrollar su labor fenomenológica elige a la comunidad cristiana primitiva a la cual aplica su método, cuya finalidad prioritaria es exponer fenomenológicamente aquella tarea más propia de la filosofía, la de presentar de forma originaria la experiencia fáctica de la vida, pero todo ello alejado de una reflexión teórica o gnoseológica de lo que la vida pueda ser. "Una y otra vez surge la misma pregunta: ¿cómo es posible aprehender genuinamente el fenómeno de la vida sin hacer uso del instrumental con tendencia objetivante de la tradición filosófica? La respuesta es tajante: hay que suspender la primacía de la actitud teórica y poner entre paréntesis el ideal dominante de las ciencias físicas y matemáticas que impregnan el quehacer filosófico desde Descartes hasta Husserl"26.

A Heidegger no le interesa el qué sino el cómo de la vida humana en su esencial facticidad, en su ejecución ${ }^{27}$ (Vollzug). En el mismo despliegue de la fenomenología, de la experiencia fáctica de la vida del cristianismo, se nos muestra una distinción fundamental entre dos concepciones de tiempo, una es la del tiempo cronológico y la otra la del tiempo del kairós. Esto nos permite verificar que desde sus comienzos en la obra de Heidegger se manifiesta esa preocupación por el problema del tiempo y su tratamiento en la tradición filosófica -tal como hemos visto en el primer capítulo de nuestro trabajo y que se ratifica aquí-, que él considera ha sido impotente para dar cuenta de la temporalidad propia de la existencia. Por último, en la discusión con San Agustín y con la tradición neoplatónica, Heidegger afirma que la influencia no problematizada de la conceptualidad griega tiene consecuencias nefastas para la filosofía, entre las que se cuenta, el oscurecimiento de conceptos fundamentales del cristianismo, de su vivencia originaria, lo que ha derivado en que permanezcan inexpresadas algunas experiencias originarias de la vida humana, de la historicidad de la existencia, de su temporalidad originaria. En la nombrada influencia del pensamiento griego, radicaría la interpretación tradicional del ser como presencia siempre constante, como un ser ante los ojos, siendo el ver el determinante para fijar cualquier relación de conocimiento, es lo que se llama el goce estético. Estas son las vías principales que guían nuestro análisis de los cursos del semestre de invierno de 1921-1922 de la Phänomenologie des religiösen Lebens.

Heidegger desarrolla un análisis fenomenológico del modo de vida del cristianismo primitivo, absteniéndose de investigar o sacar conclusiones acerca de las características históricas de los textos de San Pablo que ha elegido para exponer la vida fáctica del

${ }_{26}$ Adrián., J., Heidegger y la genealogía de la pregunta por el ser, Herder, Barcelona, 2011, p. 58.

27 También Vollzug puede ser traducido por "cumplimentación” o "realización". 
cristianismo primitivo, tampoco pretende revisar su aparato conceptual o normativo. Esto se motiva en que: "A juicio de Heidegger, en los inicios del cristianismo se emprendió una primera reacción en contra de la ciencia clásica y su anclaje en una metafísica objetiva, rehabilitando así el fenómeno de la vida"28.

En la primera parte del curso Einleitung in die Phänomenologie der Religión el filósofo alemán se refiere al planteamiento del método fenomenológico y en la segunda parte toma como punto de partida un fenómeno concreto, la experiencia religiosa originaria, para someterla a las pautas de la investigación fenomenológica.

\section{A. El MÉTOdo FENOMENOLÓGICO DIRIGIDO A LA EXPERIENCIA FÁCTICA DE LA VIDA}

Es importante tener en cuenta que Heidegger entiende que la filosofía es fenomenología y la fenomenología es filosofía. Por eso, la labor de la fenomenología será preguntar y precisar de qué se habla cuando se dice vida humana, qué estamos entendiendo por ello, lo importante es iluminar la experiencia fáctica de la vida humana. Esto se señala al comienzo de la exposición del método fenomenológico, que se inicia con la distinción clara entre lo propiamente filosófico y la ciencia en general. Para entender la problemática de la comprensión propia de la filosofía, dice Heidegger:

si se toma el problema radicalmente, se cae en cuenta de que la filosofía brota de la experiencia fáctica de la vida para luego volver a ella. Es fundamental el concepto de experiencia fáctica de la vida (Der Begriff der faktischen Lebenserfahrung ist fundamental). Con la designación de la filosofía como comportamiento racional y cognoscitivo no se consigue nada, sucumbiendo así al ideal de la ciencia. Así solo se emboza la dificultad principal (GA 60, 8/43).

Se puede reconocer aquí una de las primeras intenciones que guían al pensador de Messkirch: distanciarse de la compresión de la filosofía según los cánones de la ciencia, alejándose de una definición de la filosofía como construcción teórica sobre un ámbito objetual determinado. Y la mejor herramienta para desarrollar esta tarea es la fenomenología: "Heidegger entiende desde un principio la fenomenología como un nuevo modo de filosofar; como un modo apto para una filosofía devuelta a su lugar propio y originario, al mundo de la vida, y capaz también, según él, de llevar a expresión la experiencia originaria y las vivencias del mundo de la vida" ${ }^{929}$.

Todo ello representa una novedosa forma de hacer filosofía que pregunta fundamentalmente por la facticidad de la vida humana, dado que es en ella desde donde surge y se desarrolla la filosofía, desde ahí surge el filosofar mismo para luego retornar a ella misma. Se fija como tarea primordial la determinación e interrogación sobre el concepto de experiencia fáctica de la vida. Esto, Heidegger lo lleva a cabo a pesar de que "hasta ahora los filósofos venían esforzándose en despachar la experiencia fáctica de la

\footnotetext{
28 Adrián., J., Heidegger y la genealogía de la pregunta por el ser, op. cit., p. 190.

29 Berciano, M., La revolución filosófica de Martin Heidegger, op. cit., p. 13.
} 
vida como algo secundario, aun cuando de esta última surja el filosofar, y éste vuelva a ella en una inversión totalmente esencial"(GA 60,15/50). Es necesario recuperar para la filosofía la experiencia fáctica de la vida, fenómeno que la mayor de las veces ha sido considerada como derivado o secundario en relación a problemas filosóficos de mayor envergadura, situación que debe ser resuelta por vía de una investigación genuina acerca de la vida humana. Este es el suelo seguro para el desarrollo de una filosofía que se precie de tal. Por otra parte, es en esta vida fáctica donde podemos encontrar algo común a la ciencia y la filosofía, un lugar compartido, porque ambas tienen su punto de partida en la experiencia de la vida, surgen desde la misma raíz, tanto filosofía como ciencia están enraizadas en el mismo suelo. Por eso, debemos estudiarlas en su cumplimiento, en su momento ejecutivo, no tanto en su forma teórica o contemplativa, sino que en su propia ejecución. Esto lo resume Berciano de la siguiente forma: "el origen de la filosofía no son los problemas del conocimiento(...) la filosofía nace en el mundo de la vida, por el carácter problemático de la existencia propia, del mundo histórico, de lo real, en general" 30 .

Como podemos ver en una primera aproximación, en este curso en el cual se pretende investigar fenomenológicamente la religión, Heidegger parte con una reafirmación y caracterización del quehacer propiamente filosófico, como una meditación acerca de la facticidad de la vida humana, que sería la auténtica finalidad de la filosofía y no otra. Al mismo tiempo, toma distancia de la interpretación clásica de la filosofía como un comportamiento racional y cognoscitivo, comprensión que respondería al ideal propiamente científico. El pensador alemán se plantea como primer objetivo de su investigación dar con una comprensión propia y esencial de la filosofía, este es el punto de partida del curso. Sin embargo, es necesario hacer cierta precisión: no se podrá conseguir una comprensión propia de la filosofía si la consideramos desde un punto de vista exclusivamente teórico, puesto que, nos llevaría a entenderla como desligada de lo fáctico, de su misma ejecución, por el contrario, el contenido propio de la filosofía es inseparable de su ejecución, de su llevarla a cabo. Esta es una idea clave en la concepción de la filosofía tal como la entiende Heidegger. Solo podemos acceder a la filosofía a través del filosofar mismo, no por medio de teorías o elucubraciones gnoseológicas.

La filosofía no se puede desarrollar teorizando o estableciendo conexiones cognoscitivas dirigidas a una región de objetos determinados con la finalidad de establecer o determinar que pueda ser aquél objeto puesto en cuestión. La filosofía solo puede ser comprendida de modo originario si se está ejercitando, solo en el ejercicio filosófíco mismo es donde ella se desarrolla. Heidegger se pregunta:

¿Como se llega a una comprensión propia de la filosofía? Esto solo lo puede conseguir mediante el filosofar mismo y no mediante demostraciones y definiciones científicas, es decir, no insertando todo en el complejo temático general objetualmente conformado. Esto

30 Ibíd., p. 38. 
estriba en el concepto "entendimiento sobre sí mismo". Lo que la filosofía es no puede ser jamás objeto de una evidencia científica, sino que solo se puede aclarar en el filosofar mismo. No se puede definir la filosofía de la forma corriente ni tampoco caracterizarla mediante su inserción en un complejo temático, como cuando se dice que la química es una ciencia, y la pintura, un arte (GA 60, 7/43).

Se comienza así a perfilar un marco novedoso en la forma de hacer filosofía. Por una parte, ésta solo puede ser entendida, comprendida, en el ejercicio mismo del filosofar donde ella se lleva a cabo, donde se ejecuta, solo de esta forma puede ser comprendida originalmente y nada más, lo que la sitúa lejos de esas concepciones meramente teóricas. Por tanto, debe ser alejada del ámbito propiamente científico, no puede ser nunca objeto de una evidencia científica. Lo que se nos está diciendo es que la filosofía no puede estar nunca separada de su misma ejecución, de su mismo ejercicio, de su cumplimiento. Por eso se hace apremiante para Heidegger la investigación de la filosofía en su misma ejecución, por sobre la objetivación de la tarea de la filosofía. Con esto se pretende superar aquel quehacer filosófico, que se ha "limitado constantemente a la esfera teórica del conocer. La reducción a este campo teórico tiene sus motivos bien comprensibles. Es más fácil de localizarlo y disponer de él, ya que el conocer científico es más objetivo que otros; por eso sus normas parecen más seguras"31.

La tarea que Heidegger se propone es ganar una comprensión originaria de la filosofía, que permita alcanzar un nuevo marco meditativo para una pregunta esencial por ella misma, la filosofía no puede ser definida según los dogmas de la tradición ni menos aún ser entendida según la conceptualidad propiamente científica. Además, ella no puede ser caracterizada en razón de su objeto de estudio, debido a que este no es fácilmente determinable y ello principalmente por el malentendido generalizado cuyo punto de partida es la intención y pretensión de muchos filósofos que le asignan a la filosofía una categoría de científica. Heidegger entiende que para distanciarse de esta idea y alcanzar los objetivos que se propone, lo primero que debe ocurrir es, que "la filosofía debe ser liberada de su haber sido "secularizada" y convertida en una ciencia y en una doctrina científica sobre la concepciones del mundo. Hay que ofrecer una definición positiva de la relación derivativa de la ciencia respecto a la filosofía" (GA 60, 10/45). En consecuencia, en esta primera parte de las lecciones, queda claro lo que Heidegger pretende, quiere ganar una comprensión originaria y esencial del quehacer filosófico, distanciándose con claridad de las concepciones de la filosofía como ciencia o como una elaboración meramente racional y cognoscitiva. Si bien es cierto que la crítica hacía la perspectiva científico teórica es manifiesta, esto no significa que la filosofía no tenga carácter cognoscitivo."La filosofía no carecería, según Heidegger, de un comportamiento cognoscitivo ni de una toma de conciencia. Aún más, mientras se mantenga esto, bien entendido, no tendría aún el carácter de conocimiento teórico de un objeto" ${ }^{" 32}$.

\footnotetext{
${ }^{31}$ Berciano, M., La revolución filosófica de Martin Heidegger, op. cit., p. 22.

32 Ibíd., p. 20.
} 
Solo se puede aclarar la filosofía en el filosofar mismo, en su propio ejercicio. Teniendo en cuenta esto, es que Heidegger propone un nuevo marco de referencia para la meditación, apuesta por un giro, una vuelta, que permita enfrentar y comprender esta nueva modalidad filosófica que él propone. Pero esto no se puede conseguir con una simple modificación en la dirección de la mirada hacia otros objetos, como por ejemplo la vida humana. La transformación debe ser aún más profunda, debe ser una verdadera transformación radical en la forma de entender la filosofía y su finalidad. Heidegger quiere dirigirse hacia la esencia misma de la filosofía, dado que solo por este camino se nos haría comprensible lo que la filosofía pueda ser en sí misma, lo que nos conduciría a comprenderla originariamente, una filosofía que avanza retrocediendo hacia el mismo origen de los fenómenos, esencialmente el de la experiencia fáctica de la vida.

Es evidente que la tarea que Heidegger se propone no es una problemática común y corriente ni de fácil solución, por el contrario, se enfrenta a un asunto sumamente complejo, la experiencia fáctica de la vida está fuertemente lastrada y oscurecida, tanto por la interpretación de la filosofía como ciencia, como por los conceptos metafísicos de la tradición. Por eso, Heidegger considera necesario fijar un camino seguro al momento de iniciar esta transformación, este giro que propone. En razón de eso, dice que, "el camino hacia la filosofía comienza con la experiencia fáctica de la vida (die faktische Lebenserfahrung)" (GA 60, 10/45), se inicia ahí, pero en el mismo camino se retorna hacia ella, hacia la experiencia fáctica de la vida. Lo que posee una dificultad añadida, ya que, "la experiencia fáctica de la vida es algo por entero peculiar. En ella se posibilita el camino hacia la filosofía, y en ella se ejerce también el giro radical que lleva a la filosofía. Por una caracterización provisional del fenómeno de la experiencia de la vida fáctica se puede entender esta dificultad." (GA60, 11/45-6). La tarea que el filósofo alemán se propone es caracterizar de forma concreta la experiencia fáctica de la vida, porque en ella se nos hará visible una comprensión originaria de la filosofía. Aún cuando esta experiencia fáctica de la vida tiene esa particularidad de ser el punto de inicio del camino de la filosofía, la que posibilita ese caminar, es al mismo tiempo en ella en donde se lleva el giro radical que conduce a la filosofía. Es decir, la vida humana como filosofar y filosofar dentro de la vida humana. Lo que significa que se ha de determinar y caracterizar la experiencia fáctica de la vida para leer en ella las experiencias originarias que permitan allanar el camino hacia una comprensión genuina de la filosofía. El camino por el que nos lleva Heidegger en estos cursos de religión es aparentemente difuso, lo que debe ser una introducción a la fenomenología de la religión, comienza con la pregunta por la filosofía en su carácter originario, lo que permitiría llegar a su punto de partida, el lugar dónde se inicia el camino, esto es: la experiencia fáctica de la vida. 
Heidegger precisa los conceptos de experiencia fáctica, para de esta forma, evitar cualquier tipo de malentendido respecto a las intenciones que guían su interpretación. En primer término, señala que el concepto de experiencia (Erfahren) tiene dos connotaciones, una es la confirmación experiencial y lo otro es lo experienciado en la confirmación experiencial. Es necesario conservar ambos sentidos del concepto de experiencia, ya que en ellos se expresa lo esencial de la experiencia fáctica de la vida, que es un vérselas de forma directa con lo experienciado, lo cual tiene un sentido pasivo y activo. De la misma forma, el concepto de fáctico(faktisch) no tiene la connotación de ser algo efectivo al modo de la naturaleza o como una cosa, como una realidad más de las que hacen frente en el mundo. El joven Heidegger quiere dejar suficientemente claro que a estos conceptos no se les debe recargar de una connotación teórica o gnoseológica, sino que más bien, solo se harán verdaderamente comprensibles si los consideramos desde el concepto de lo histórico; lo fáctico solo puede ser comprendido desde lo histórico mismo y no desde otra perspectiva. Esto significa que es necesario determinar fenomenológicamente este concepto de lo histórico, para comprender a qué se refiere Heidegger cuando alude a lo fáctico, pero esto lo veremos más adelante, por ahora nos quedamos con aquello que no corresponde a lo fáctico.

Al iniciar la caracterización de la vida fáctica, a lo primero que hace referencia el pensador de la Selva Negra es al concepto de mundo. El mundo es aquello en lo que la vida fáctica se encuentra, aquello que experiencia, aquello que vivencia, no es un objeto sino que es un mundo de relaciones, de significatividades. Heidegger señala tres sentidos peculiares al mundo de la vida.

"Mundo" es algo dentro de lo que se puede vivir. (En una objetualidad no se puede vivir). $\mathrm{Al}$ mundo se le puede llamar formalmente mundo circundante (medio), esto es, lo que nos sale al encuentro, aquello de lo que forman parte no solo las cosas materiales sino también objetos ideales, ciencias, artes. En este mundo circundante está también el mundo compartido con los otros, es decir, los hombres según una caracterización fáctica concreta: como estudiantes, docentes, parientes, superiores etc., y no como ejemplares del género científico natural homo sapiens etc. En fin, también está en la experiencia fáctica de la vida el yo-mismo, el mundo propio (GA 60, 11/46).

La finalidad que se persigue con esta triple distinción formal del mundo, no es la de graduarlas gnoseológicamente, ni tampoco determinar en un ordenamiento valórico cuál es la de mayor importancia, ni menos aún se pretende verificar la dignidad ontológica de cada una. Lo importante es que ellas son accesibles a la experiencia fáctica de la vida, son reconocibles, en último término, son familiares. Respecto a esto, señala Heidegger: "Solo se puede caracterizar el modo, el cómo del experienciar aquellos mundos, es decir, se puede preguntar por el sentido referencial de la experiencia fáctica de la vida (Bezugssinn der faktischen Lebenserfahrung). Es cuestionable el que el cómo, la referencia, determine aquello qué es experienciado, el contenido, y cómo éste se caracterice" (GA 60, 12/46), por lo tanto, esta distinción de los diversos sentido del mundo es el punto de partida de 
Heidegger en la explicitación de algunas de las herramientas fenomenológicas que le servirán para desarrollar su investigación. El sentido referencial no puede determinar el qué es experienciado, el contenido.

También el filósofo alemán puntualiza, que esta experiencia fáctica de la vida tal como él la entiende, es algo más que una simple experiencia que se adquiere por medio de un conocimiento o una teoría, significa más bien la posición total, activa y pasiva del hombre ante el mundo. Por ello, si consideramos la experiencia fáctica de la vida solo desde la dirección del contenido experimentado en su misma ejecución, aquello que es experimentado, lo propiamente vivido se nombra como mundo y no meramente como objeto (Cf. GA 60, 11/46).

En esta primera parte de las lecciones, Heidegger realiza una serie de precisiones respecto al método fenomenológico, pero antes de esto, lo primero que desarrolla es una caracterización acabada del cómo de la vida fáctica. Siguiendo esta dinámica presenta una determinación esencial de la vida fáctica, que habla de la autosuficiencia de la experiencia fáctica de la vida. Pero, ¿A qué se refiere al hablar de la autosuficiencia de la vida fáctica? ¿Se habla de un ente autosuficiente al modo de la substancia? Desde luego que no, el pensador alemán cree que es un fallo manifiesto pensar el ser del hombre como substancia. Lo que él hace es justamente exponer una serie de características de la experiencia fáctica de la vida humana para distinguirla de cualquier otro ente de la naturaleza. Así nos encontramos con este carácter de la vida humana, su autosuficiencia, pero no al modo de la substancia autosuficiente. Lo propio de la vida fáctica es la forma en la que me pongo frente a las cosas, el modo mismo de la experiencia, lo que no está incluido en la experiencia misma. Estamos frente a una incipiente caracterización ontológica de la vida fáctica

Aquello que se ha de destacar fenomenológicamente de la vida fáctica es que ella en su cotidianidad se vuelca completamente en el contenido, más que en su propia ejecución. Día tras día en la experiencia fáctica de la cotidianidad me asaltan múltiples quehaceres, idas y venidas ocupándome de las cosas más variopintas, sin embargo, en ese estar sumido en el constante quehacer no se me hace consciente el cómo de mi enfrentar aquello diverso de que me ocupo y que muchas veces desconozco, ello simplemente me hace frente, me sale al encuentro en lo que voy experienciando. Esto indica, que:

la experiencia fáctica de la vida muestra una indiferencia con respecto a la forma de experienciar. A ella no se le ocurre la idea de que no le pueda ser algo accesible. Este experienciar fáctico parece como acometer todos los asuntos de la vida. Las diferencias y los realces obedecen al contenido mismo. Esta indiferencia fundamenta, por lo tanto, la autosuficiencia de la experiencia fáctica de la vida (Selbstgenügsamkeit der faktischen Lebenserfahrung), que se extiende a todo (GA 60,12/47).

La vida fáctica pone toda la atención en el contenido de las cosas que le salen al encuentro, pero es indiferente a la forma en que se experiencia, en que se ejecuta, la 
experiencia fáctica de la vida parece poder cumplir con todos los asuntos de de la vida, lo que alude a la indiferencia respecto a la ejecución.

En el mismo sentido, nos dice el filósofo alemán: "si atendemos, pues, a la peculiar indiferencia del experienciar fáctico (faktischen Erfahrens) hacia todo vivir fáctico (faktischen Leben), se nos hará entonces patente un determinado sentido total del mundo circundante, el mundo compartido con los otros y el mundo propio: todo lo que se experiencia en la vida fáctica de la vida lleva el carácter de significatividad (Bedeutsamkeit); todo contenido lleva en ella ese carácter" (GA 60, 13/47). Este es un rasgo fundamental para la caracterización de la experiencia fáctica de la vida, el carácter de la significatividad es clave para comprender la forma que tiene la vida fáctica de encontrarse con aquello que le hace frente en la cotidianidad, con aquello que se enfrenta día a día. Antes de sostener una relación cognoscitiva o teórica con las cosas del mundo, estas se entienden primero significativamente, con rasgos de significado. Puede ser que no sepamos muy bien que cosas o realidades se nos presentan, pero sí las comprende dentro de un contexto de significado. Como comenta Pöggeler:

Se declara la "autosuficiencia" de esta vida fáctica: solo en su propio lenguaje da la vida respuesta a sus preguntas; le pertenecen expresión, aparición y dar cuenta de sí. El "sentido" no es un mundo propio que deba ser captado como algo que, estáticamente, repose en sí; el sentido es más bien lo originariamente propio de la vida fáctica y, de acuerdo con su estructura, tiene que ser concebida a partir de la vida. Esta es, en su factualidad, conexión de significatividad ${ }^{33}$.

De tal forma, que desde la significatividad se determina el contenido del experienciar, desde ella vivo mi experiencia de la facticidad. No como teoría o reflexión respecto a ella. No mantengo primeramente una relación teórica sino una relación de significatividad con lo que me rodea. Mi experiencia de la facticidad la vivo como significatividad, lo que me aparece a lo largo de la cotidianidad se manifiesta dentro de un ámbito cubierto de significado, de sentido, de familiaridad. Esta es la forma originaria de experienciar mi propia existencia fáctica, por eso dice Heidegger:

yo mismo no me experiencio en la vida fáctica como un complejo de vivencias ni como conglomerado de actos y de procesos, ni siquiera como algo yoico-objetual cualquiera en un sentido bien delimitado, sino en aquello que yo realizo, padezco, en lo que me sale al encuentro, en mis estados de depresión y euforia etc. Yo mismo no me experiencio, ni siquiera mi yo en su estar delimitado de lo demás; por el contrario, estoy siempre sujeto al mundo circundante. Este experienciarse a sí mismo no es una "reflexión" teórica tampoco una "percepción interna" etc., sino una experiencia del mundo propio, porque este experienciar tiene un carácter mundanal, por estar volcado a la significatividad, de tal modo que el mismo mundo propio experienciado no queda resaltado de hecho frente al mundo circundante (GA 60,13/48).

33 Pöggeler, O., El camino del pensar de Martin Heidegger, op. cit., p. 32. 
Este es el punto de partida para desarrollar su fenomenología de la religión. Considera esencial exponer la experiencia fáctica de la vida como el inicio del camino filosófico, y presentar la forma en que ella se experiencia por medio de la significatividad. Esto teniendo en cuenta, que "la experiencia fáctica de la vida tiene estas características y es(...) algo anterior a la experiencia cognoscitiva en sentido más propio"34. Por lo tanto, modo de experienciar la vida fáctica no es al modo de una relación de sujeto-objeto, o como complejo de vivencias, ni contemplación teórica.

Desde dónde se inicia y hacia dónde retorna la filosofía, solo allí se puede operar el giro radical que ésta necesita para comprender la filosofía de una forma verdaderamente originaria, que sea capaz de sacar el velo del encubrimiento que la cubre a ella y a su marco conceptual. Es en el ejercicio de la propia filosofía desde donde se puede operar un giro para volver hacia las cuestiones fundamentales que se han oscurecido a lo largo de la historia de occidente. Una de estas tiene que ver con la consideración de la filosofía desde el marco de las ciencias naturales, esto es lo primero que quiere delimitar Heidegger, la distancia entre la ciencia y la filosofía. Pero además, pretende fijar las categorías, las características que le son propias a esta experiencia fundamental que es la experiencia fáctica de la vida.

Sin embargo, a pesar de la radicalidad e importancia que supone el fenómeno de la experiencia fáctica de la vida para la filosofía, en tanto es el punto de partida del mismo filosofar, subyace paradójicamente en ello un problema, porque es el punto de partida, y al mismo tiempo es lo que cierra el acceso al filosofar mismo, como dice Heidegger, "la experiencia fáctica de la vida no cesa de ocultar ella misma, merced a su insuficiencia, una incipiente tendencia filosófica: dentro de esta preocupación autosuficiente cae de continuo la experiencia de la vida fáctica en la significatividad y aspira incesantemente a vertebrarse en ciencia"(GA60,15/41). En principio puede parecer confuso y contradictoria la forma en joven profesor aborda esta experiencia fáctica de la vida, que por una parte, es el punto de inicio del filosofar, el principio del camino, pero al mismo tiempo, es lo que nos impide filosofar propiamente, es decir, nos cierra a una experiencia originaria de la filosofía como la que se pretende llevar a cabo.

No obstante, esta es una estrategia recurrente de su filosofía, presentar constantemente nuevas aporías, abrir y cerrar caminos para volver a ser abiertos de una forma aún más originaria, en un continuo ejercicio que se va problematizando a sí mismo. A juicio de Heidegger esta imposibilidad de la filosofía de comprenderse es más bien una insuficiencia de la propia vida humana, una falencia radicada en la constitución misma de la existencia. Al ir avanzando en la caracterización de este fenómeno, da alguna información al respecto, cuando dice:

la experiencia fáctica de la vida es la "preocupación actitudinal, caediza, referencialmente indiferente y autosuficiente por la significatividad" ( Faktische Lebenserfahrung ist die

${ }_{34}$ Berciano, M., La revolución filosófica de Martin Heidegger, op. cit., p. 20. 
“einstellungsmäBige, abfallende, bezugsmäBig-indifferente, selbstgenügsame Bedeutsamkeitsbekümmerung).Si atendemos primero al sentido referencial, ahí se muestra que el transcurso de este experienciar tiene un carácter por completo indiferente, y que las diferencias de lo que yo experiencio se dan en el contenido (...) La pluralidad de experiencias solo se me hace consciente en el contenido experienciado (GA 60, 16/50).

Esto quiere decir, que la diferencia respecto a como cada uno vivencia, como se siente cada uno en determinada situación, solo tiene que ver con el modo en que se experiencia en los contenidos, las distintas experiencias que puedo experienciar solo se me pueden hacer conscientes por medio del contenido de ese experienciar. Por esto, en el modo en que el yo puedo experimentar algo como estar agobiado o preocupado por lo que le rodea, por las cosas que tiene en torno, son para él de cierto modo indiferentes, dado que enfrenta todas sus quehaceres sin una mayor reflexión, solo los lleva a cabo, podríamos decir que automáticamente, por lo tanto, este modo de entender el mundo y las cosas refleja su tendencia a la caída en la significatividad, como una tendencia esencial de la existencia. Por lo tanto, "esta "vida fáctica" ya no se sostiene en ninguna instancia metafísica, cae en un vacío y se abre en el ser-ahí. No solo en el mundo, también la "vida fáctica" es la caída en sentido literal" ${ }^{\prime 35}$.

Heidegger ha hecho alusión a una deficiencia importante de la vida humana y la razón de esa deficiencia se encuentra, en "la tendencia cadente de la experiencia de la vida fáctica (Die abfallende Tendenz der faktischen Lebenserfahrung) a dirigirse de continuo hacia los complejos significativos del mundo fácticamente experienciado, como si fuese su centro de gravedad, condiciona una tendencia a una determinación actitudinal de objetualidades y a una relación objetual de la vida fácticamente vivida(des faktisch gelebten Lebens)"'(GA60,18/52). En consecuencia, en esta primera aproximación a la vida fáctica hemos dado de frente a un problema que no es menor, nos enfrentamos a una cuestión que surge desde la propia vida fáctica, que constantemente se pierde a sí misma en su tendencia caediza, se extravía en la cosas del mundo y cree que ellas son el centro de gravedad de su existencia. De esta forma, el filósofo alemán alude a una esencial deficiencia de la vida fáctica, que surge desde ella misma, por la cual, considera el mundo y su propia vida fáctica como un objeto más. Según Pöggeler:

la significatividad puede, ciertamente, ser nivelada por la tendencia humana a cosificar u “objetivar"- también en la filosofía moderna se ha presentado frecuentemente la tendencia a la objetivación como idea constructora del conocer científico en general-; sin embargo, la objetivación debe ser captada como "desvitalización” de la vida: por ella, la vida se ve privada de su "vida", de su estructura "tendencial" y de los respectos de significatividad de su mundo. La vida que, en su factualidad, queda cumplimentada en las conexiones de significatividad, consiste en "situaciones". Sentido de cumplimentación (Vollzugssinn), del contenido (Gehaltssinn) y de la respectividad (Bezugssinn) constituyen la estructura de la situación. En la vida fáctica predomina el sentido de cumplimentación: la cumplimentación de la vida misma está por encima de la orientación hacia “contenidos".

35 Safransky, R., Un maestro de Alemania, Tusquets, Barcelona, 2007, p. 141.Trad. Raul Gabás. 
La vida, tomada en su carácter de cumplimentación, crea el sentido fundamental de sí misma; pero de este modo se entiende a sí misma como vida "histórica" (acontecida en sí misma) y está en camino hacia su origen ${ }^{36}$.

Ocurre entonces que se establece una relación objetual con el mundo en virtud de la cual la vida misma es considerada solamente como algo, un algo más que aparece en esa relación de la vida humana y el mundo, se la considera como un objeto más. Todo esto nos muestra, que si queremos obtener una consideración originaria de la filosofía, es necesario profundizar aún más en la experiencia fáctica de la vida, para así poder alcanzar el punto que posibilite la inflexión que permita el giro radical que pretende llevar a cabo Heidegger, para de este modo, dar con una comprensión originaria de la experiencia fáctica de la vida. En la misma vida humana subyace una limitación fundamental que nos impide acceder a su constitución originaria, una tendencia misma de la vida, algo así como un pecado original inherente a ella misma. Debemos tener presente respecto a esta pregunta por la vida fáctica, que "Heidegger acentúa sin cesar que no se debe filosofar "sobre" la vida fáctica, sino "desde" ella"37.

Es menester tener presente, que el sentido de referencia (Bezugssinn), el sentido de ejecución (Vollzugssinn)y el sentido de contenido (Gehaltssinn), son importantes en la transformación de la fenomenología que opera en la filosofía de Heidegger, dado que conforman la triple unidad de sentido de la intencionalidad presente en la investigación fenomenológica. En esta fase inicial de su filosofía se constituyen en el núcleo del método fenomenológico. Esta temprana alusión al sentido de contenido, ejecución y referencia, deja claro desde un principio que el filósofo alemán en su interpretación va a tratar la experiencia de la vida del cristianismo primitivo como un fenómeno, lo importante para él son los comportamientos vitales que se puedan extraer de dicha experiencia ${ }^{38}$

\section{LA PREGUNTA POR EL SENTIDO DE LO HISTÓRICO Y EL TIEMPO; LA INDICACIÓN FORMAL Y SU IMPORTANCIA EN LA DETERMINACIÓN DEL FENÓMENO Y DE LA FENOMENOLOGÍA}

Heidegger con la finalidad de puntualizar el significado y sentido de la experiencia fáctica de la vida desde una perspectiva filosófica originaria, considera que necesariamente se ha de remitir al concepto de lo histórico, cuestión que ya había tratado en su trabajo de habilitación de 1915, pero al que ahora dará un nuevo impulso. Al iniciar la caracterización de lo histórico, fundamenta la validez de su elección, diciendo que este fenómeno es el nexo de sentido, es el fenómeno nuclear (Kernphänomen) que está presente en las tres palabras del título de la lección Introducción a la fenomenología de la religión. A simple vista, no parece que sea correcta dicha afirmación, dado que histórico

\footnotetext{
${ }^{36}$ Pöggeler, O., El camino del pensar de Martin Heidegger, op. cit., p. 33.

${ }^{37}$ Safransky, R., Un maestro de Alemania, op. cit., p.144.

${ }^{38}$ Cf. Redondo, P., Experiencia de la vida y fenomenología en las lecciones de Friburgo, op. cit., p. 362.
} 
no se menciona en ninguna parte del título, ni pareciera tener mayor incidencia en el enunciado. Por eso, Heidegger se pregunta, “¿En qué medida son "introducción”, “filosofía” y "religión” fenómenos históricos?" (GA 60, 31/63). Esto, es a su juicio lo que se debe aclarar imperiosamente, porque el concepto de lo histórico es en sí mismo problemático y tampoco parece ser un problema de fácil solución, dado que lo histórico tiene múltiples acepciones que dependen del marco teórico desde el que se lo interprete. Esta es la dirección que toma la investigación heideggeriana, se han de iluminar los conceptos fundamentales que han quedado ocultos bajo el manto de oscuridad del que les ha cubierto la tradición metafísica y su conceptualidad. Por todo esto, el filósofo nativo de Messkirch entiende que es de una importancia superlativa preguntar por el sentido originario de lo histórico, sentido que está lejos de esa comprensión que entiende la tarea de lo histórico y lo histórico mismo como un objeto. Por lo cual, se ha de tomar un camino distinto al que sigue aquella interpretación que considera lo histórico como una objetualidad (Objekt) y que, como consecuencia directa, lo caracteriza dentro de conceptos generales que pueden abarcarlo; se comprende lo histórico como una objetualidad más entre otras.

Es necesario aclarar el sentido originario de lo histórico, para ver el nexo de relación entre introducción, religión y filosofía. La clarificación de lo histórico permitirá allanar el camino de acceso a una comprensión propia y auténtica de la filosofía, es decir, lo histórico mismo en su sentido genuino es lo que abre la posibilidad de superar los obstáculos para lograr un camino de acceso adecuado. Este asunto del acceso es esencial, ya que en ello se hace visible la cuestión del método, como dice Heidegger, "la cuestión fenomenológica del método no es una cuestión del sistema metodológico, sino una cuestión de acceso que conduce por la senda de la experiencia de la vida" (GA 60, 34/65), es evidente entonces, que la cuestión de lo histórico nos lleva a la cuestión del método fenomenológico, dicho fenómeno es el que permite su explicación y aplicación, es un fenómeno de una importancia señalada en la totalidad de la filosofía de Heidegger, él aplica a este fenómeno su fenomenología, su método, con el objetivo último de poder acceder a los problemas fundamentales que se ocultan bajo la consideración tradicional de lo histórico y la interpretación temporal que deriva de ello, transformándose así en una cuestión primordial para el filosofar mismo.

Por eso, sostiene Heidegger: "lo que importa es extraer de la experiencia de la vida fáctica los motivos para la comprensión propia de la filosofía. Es de esta comprensión propia de donde obtenemos la tarea total de una fenomenología de la religión" (GA 60, 34/65). Por lo tanto, esta determinación de lo histórico debe llevarse a cabo prescindiendo de la clasificación de lo histórico según una división en disciplinas distintas, con sus respectivos objetos, como podría ser la historia de la filosofía o historia de la religión. La experiencia fáctica de la vida es el punto de partida de una comprensión propia de la filosofía y de sus tareas fundamentales, y desde ahí es posible plantear una fenomenología 
de la religión, pero antes es necesario interrogar a lo histórico, y de ese modo reconocer todas aquellas cuestiones que ahí se ocultan y que se vinculan directamente con la investigación heideggeriana.

Lo importante es preguntar por el sentido de lo histórico, por su sentido primigenio, para recuperar su significado originario, que dista mucho de considerarlo como un algo, como una objetualidad o una propiedad del ente, todas estas características provenientes de una exégesis que convierte a lo histórico en un simple objeto dentro de una región más amplia de objetos. Tarea para nada fácil según el joven profesor, puesto que, tradicionalmente lo histórico posee una multiplicidad de interpretaciones $\mathrm{y}$ significados, dependiendo estos del punto de vista de la mirada. Se debe aclarar fenomenológicamente el significado de lo histórico, para obtener así una comprensión originaria, que sea capaz de poner en duda esa caracterización que lo considera como propiedad de una determinada cosa o hecho, en otras palabras, que lo entiende como una objetualidad a la cual le es peculiar la propiedad de ser de forma histórica.

Heidegger pregunta por lo histórico desde la indicación formal, él entiende que lo histórico está presente en los tres conceptos del título del curso y se pregunta qué significa que esté presente en la totalidad del título de las lecciones. Teniendo esto en cuenta, presenta una definición de lo histórico que incluiría los tres conceptos del título del curso, además, sería una caracterización general de las ideas de lo histórico, de la idea común y corriente que se tiene de ello. Comenta el joven profesor que lo propio de lo histórico es su "llegar a ser, surgir, transcurrir en el tiempo; una caracterización que le conviene a la realidad. Estando uno en el estudio cognoscitivo de los complejos objetuales, toda caracterización o empleo de sentido de "histórico" está determinada siempre por este preconcepto de la objetualidad (Vorgriff auf das Objekt bestimmt). Lo objetual es histórico (Das Objekt ist historisch); tiene la propiedad de transcurrir en el tiempo, de modificarse" (GA 60,32/64). Esta definición de lo histórico que Heidegger presenta aquí es precisamente la que luego cuestionará fuertemente. Pero antes, legitima su elección dado que si atendemos a esta determinación de lo histórico como aquello que pasa en el tiempo, religión, fenomenología y vida son históricas porque pasan en el tiempo, discurren en él. En esta acepción, que por lo demás es bastante utilizada, lo histórico es lo que pasa en el tiempo y se entiende como algo general, predicable de todos los objetos que de una forma $\mathrm{u}$ otra son temporales en cuanto cumplen con el requisito de transcurrir en el tiempo.

Por lo tanto, todos los objetos tienen un algo en común y es que de algún modo u otro pasan en el tiempo. Este algo en común puede ser considerado como general y permite predicar lo histórico de todos los objetos con ese algo en común que es el pasar en el tiempo. No obstante, Heidegger no está para nada de acuerdo con esta comprensión de lo histórico que lo convierte en una propiedad, lo histórico no puede ser entendido como una característica más del objeto. El filósofo alemán no comparte la idea de que la definición y aplicación de este concepto se pueda obtener como resultado de un proceso en 
el que se eliminan poco a poco las diferencias entre los objetos, tras lo cual queda ese algo en común, que luego en un proceso de generalización puede ser aplicado a todo objeto presuntamente histórico. Si se actuara de esta forma, lo histórico sería aplicable a todos las cosas que cumplen con ese algo común. Lo que el joven profesor pretende al hacer esta distinción es establecer diferencias entre lo que es mostrar un fenómeno desde la indicación formal y lo que significa presentarlo sin ella.

Lo histórico así entendido sería una propiedad del objeto, que puede ser aplicable tanto a la vida humana como a una roca, es la característica general propia a todo fenómeno que pasa en el tiempo. Teniendo en cuenta lo anterior, podríamos preguntarnos si esta comprensión de lo histórico es una de carácter genuino, si lo histórico es una propiedad más que se pueda aplicar en general a los objetos. Heidegger se muestra completamente en desacuerdo con estas posturas y ve en ello una desfiguración de lo más genuino y propio de la historia, de aquello que es lo propiamente histórico: la vida humana. Lo histórico no puede entenderse como una propiedad más de la vida fáctica, que junto a otras propiedades conforman la estructura de este fenómeno, precisamente hacia esta idea se dirige la crítica heideggeriana. Su objetivo es clarificar el sentido genuino de lo histórico y mostrar su esencial conexión con la experiencia fáctica de la vida.

Al considerar que lo histórico es una propiedad más que la vida o la religión posean, se oculta un rasgo esencial de ellas, no se concibe la vida fáctica desde una perspectiva originaria, se le niega su primordial carácter histórico, consecuencia de esto es que se produciría una desvitalización de la vida humana y de lo histórico; la vida es una objetualidad y lo histórico es una propiedad de ella. Esta tesis crítica, vital para el análisis heideggeriano, entiende que esta idea dominante de lo histórico debe ser desmontada para leer en ella su sentido genuino y mostrar el oscurecimiento en el que se sostiene, cuestión que se podrá llevar a cabo gracias al instrumento metodológico del indicador formal, constructo fenomenológico llamado a jugar un rol determinante en estas lecciones de Friburgo.

En función de llegar a una determinación concreta del fenómeno originario de lo histórico, Heidegger se detiene en una distinción entre lo objetual (Objekt), el objeto (Gegenstand) y el fenómeno propiamente dicho. Esta distinción realizada por Heidegger entre la objetualidad y el objeto se presenta en algunos de los escritos de juventud y solo es mencionado de forma sucinta en su obra de 1927. La objetualidad (Objekt) es lo que se entiende desde la perspectiva de un sujeto frente a un objeto, es decir, lo propio a la relación sujeto-objeto, como objeto para un sujeto. Por otra parte, el término objeto (Gegenstand) hace referencia a un algo que se encuentra en frente, pero no necesariamente como objetualidad que se sitúa frente a un sujeto ${ }^{39}$. No obstante, en ocasiones se

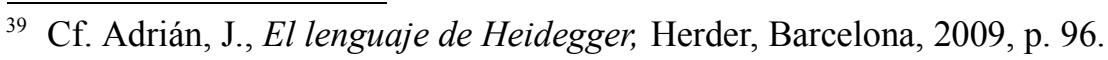


confunden ambos conceptos lo que lleva a comprenderlos equívocamente. Todas las objetualidades son objetos, pero no todos los objetos son objetualidades. Y por otra parte, Heidegger aclara que "el fenómeno no es ni objetualidad ni objeto (Ein Phänomen ist nun weder Objekt noch Gegenstand). Con todo un fenómeno es también formalmente un objeto, es decir, un algo en general" (GA 60, 35-6/67). Como puede observarse, la determinación de fenómeno no queda del todo clara, si el fenómeno puede ser objeto pero no puede ser objetual ¿cuál es la índole de fenómeno dentro de esta caracterización de lo objetual y del objeto? Para el profesor Heidegger esta es una pregunta que quedará abierta y que deberá ser aclarada al rigor de la investigación, más precisamente, en la determinación misma de fenómeno.

La cuestión problemática radica en que se sigue aplicando esta categoría de la objetualidad a lo histórico, ejemplo de esto es que "a una objetualidad le corresponde estar determinada temporalmente; con ello es histórica (...) la aplicación de lo histórico a la realidad humana será una determinación de la objetualidad "lo histórico". Incluso el hombre es su realidad está como objetualidad en el tiempo, en el llegar a ser. Ser histórico es una de sus propiedades. Esta concepción se mueve dentro de los cauces del sentido común" (GA60,36/67). Es esta interpretación de la vida humana como objetualidad a la que es necesario reconducir la crítica, para conseguir ir más allá de la concepción objetual de la historia. Y según Heidegger, esto solo será posible si retornamos al suelo seguro donde asentar los fenómenos; la experiencia fáctica de la vida. Pero, para llegar ahí, antes es necesario desarrollar y plantear la pregunta por lo histórico mismo.

Al iniciar el análisis de este fenómeno, el autor alemán reconoce dos notas distintivas de lo histórico: una en sentido positivo, la multiplicidad de formas históricas que llenan la vida y descansan dentro de la pluralidad de configuraciones históricas. Otra en sentido negativo, que hace referencia a que lo histórico es un peso para nosotros, peso con el que debemos cargar, una especie de impedimento con el que debemos convivir. Sin embargo, en ambos sentidos, "lo histórico es desasosegante; la vida pugna por afirmarse contra él y asegurarse. Pero es cuestionable si aquello contra lo que se afirma la vida es realmente lo histórico" (GA 60, 37/68). Es evidente que se pone en tela de juicio el concepto general de lo histórico, al mismo tiempo, se pone en duda si aquello puede ser considerado como lo genuinamente histórico. Una característica del ser de lo histórico es que es desasosegante (beunruhigend), intranquilizador, por lo cual la vida busca una forma de aseguramiento, un mecanismo de seguridad que le permita hacer frente a eso intranquilizador, frente a esto la vida pretende asegurarse.

Como respuesta a ese carácter desasosegante de lo histórico es necesaria la tranquilidad. A juicio de Heidegger, este sería el motivo que lleva a buscar una definición de lo histórico que implique tranquilidad, que sea capaz de anular ese efecto inquietante, 
lo que permitiría vivir en y con cierta seguridad. En función de esto se hace necesario prescindir de aquellos elementos que dificulten una comprensión de la historia. Según la consideración tradicional, se han de evitar aquellas ideas de lo histórico que dificulten el dominio y disponibilidad de ello. Heidegger reconoce principalmente tres vías de defensa frente a lo desasosegante de lo histórico, tres vías que hacen frente al poder intranquilizador de lo histórico. Uno es el camino platónico, el segundo es el representado por Spengler y el tercer camino se sustenta en las figuras de Dilthey, Rickert, Simmel y Wildelband. Dice el joven profesor que en la vía platónica "la realidad histórica no es la única, ni siquiera es la realidad fundamental, sino que solo se entiende remitiendo al mundo de la ideas, se conciba como se conciba en concreto: como mundo de substancias, valores, normas o principios racionales" (GA60,39/70). Lo histórico, lo que pasa en el tiempo, es derivado y secundario en relación al mundo supratemporal de las ideas. El mundo sensible en el cual se desarrolla lo histórico es derivado en relación a un orden supratemporal desde donde obtiene su sentido.

Por otra parte, la segunda vía es una radicalización completa en el sentido opuesto, "la tendencia de Spengler es la de asegurar la ciencia de la historia en cuanto tal(...)la ciencia de la historia debe hacerse independiente del condicionamiento histórico del presente (...)a la historia no se le contrapone ninguna realidad supratemporal, sino que el aseguramiento del presente contra la historia se consigue haciendo que el presente mismo sea visto históricamente" (GA 60, 43/73-4), según esta consideración, que en apariencia es la opuesto al camino platónico, no se relativiza la historia ni se entiende lo histórico como algo secundario, sino que más bien, se propone una absolutización de la historia como tal, entregándose por completo a lo histórico y no dejando de considerar ninguna de sus manifestaciones. Como comenta Berciano, "la realidad y la falta de seguridad del presente se vive de tal manera que este mismo es llevado al proceso objetivo del devenir histórico" $"$.

Heidegger entiende que Spengler sigue la misma vía de Platón, porque a pesar de que su escepticismo sea opuesto a la validez del platonismo, la forma de aseguramiento es para ambos la misma, ya que, en esta vía el mundo histórico es lo decisivo, la única realidad. Sin embargo, afirmar el mundo histórico como realidad suprema, conlleva un problema: no se explica ni comprende de forma suficiente lo histórico mismo. Por lo tanto, aunque a simple vista esta posición parezca como absolutamente contraria a la anterior, seguiría dominada por el esquema platónico, pero intercambiando el centro de gravedad. Y por último, la tercera vía vendría a constituirse como una síntesis de las anteriores, dado que: "intenta unir las dos primeras. Ambas se combaten entre sí encarnizadamente, como muestra la reacción contra el escepticismo de Spengler, que se dirige contra la posición extrema de la segunda vía, en cuya fundamentación gnoseológica se basa. Pues la conformación de la historia como objetualidad dada en el conocimiento tiene como norma

$\overline{40}$ Berciano, M., La revolución filosófica de Martin Heidegger, op. cit., p. 122. 
el valor de la verdad. La historia es una realización continua de valores, que, no obstante, nunca se realizan plenamente"(GA 60,44/74). En esta tercera vía la historia es considerada principalmente como una realización continua de valores, que por lo demás, nunca se desarrolla por completo, es una realización de valores en el tiempo, lo que significa que los valores se dan en lo histórico de forma relativa. Todo esto significa que desde una reflexión sobre el pasado es posible conseguir una orientación hacia el futuro como en un proceso de realización ${ }^{41}$.

Lo determinante en la exégesis de Heidegger es que considera que estas tres vías, aparentemente distintas, no son en realidad diferentes. La vía platónica sería la que ejerce el dominio sobre las tres interpretaciones. Respecto a esto, el filósofo alemán sostiene, que este modo de comprender lo histórico es pobre, insuficiente y sesgado, lo que termina por oscurecer el sentido originario de lo histórico. "La realidad histórica está puesta en las tres vías como un ser objetual (objektives Sein). La vía es la del conocimiento, la del estudio temático. Literalmente se desenvuelve una tendencia a la tipificación, a la comprensión tipificadora. Esta tendencia es importante por designar el carácter fundamental de la actitud teórica que se refiere a la historia. Aquí se hace patente el carácter actitudinal de la referencia a la historia" (GA60,48/78). En consecuencia, este ser objetual es visto como la realidad determinante y única, lo que significa que en estas tres interpretaciones se entiende lo histórico como cosa, como un objeto que puede ser conceptualizada por medio de una ciencia histórica.

A juicio de Heidegger, estas vías se revelan como deficientes a la hora de determinar esencialmente lo histórico. En las tres resplandece la forma platónica de pensar. La primera vía está fundamentada en la consideración de la idea como realidad suprema, lo determinante de lo real es la idea, el mundo suprasensible, la idea coge un carácter de absoluto, como el modo eminente de ser, para esta interpretación lo histórico es solo un añadido de ella, que posee un valor que solo obtiene en referencia al mundo ideal, que es el verdaderamente real. En la segunda, ocurre lo contrario, aquí lo absoluto es lo histórico, por lo cual se pretende prescindir completamente de lo ideal, pero de igual modo, lo histórico se termina convirtiendo en absoluto. $Y$ en la tercera vía, que es una postura que incluye a las anteriores, en razón de su compromiso con los valores, se concibe lo histórico como realización (temporal) de valores en el tiempo, por lo tanto el problema de lo histórico y su nexo con lo intemporal sigue estando presente en estos caminos que presenta Heidegger. Todo esto significa, que:

\footnotetext{
lo histórico, la historicidad genera desasosiego y el pensamiento ha intentando siempre asegurarse frente a esta inquietud de diversas maneras: Platón y Spengler constituirían los dos extremos frente a los cuales se ha buscado también un camino intermedio; pero a través de éste no se capta el sentido de lo histórico que se revela en el mismo fenómeno de la inquietud (Bekummerung). En definitiva, es preciso desvelar cuál es la relación que el
}

${ }^{41}$ Cf. Ídem. 
Dasein mantiene con lo histórico y, por tanto, con la temporalidad. Más aún, es preciso determinar a qué tiempo nos referimos ${ }^{42}$.

Por consiguiente, en las tres vías que Heidegger presenta de forma sucinta, se considera lo histórico como objetualidad, como algo disponible y ahí presente para un aseguramiento. Estas vías de aseguramiento frente a lo histórico, que según él, aún hoy poseen plena vigencia, traen consecuencias nefastas, entendiendo que no dejan lugar a una meditación auténtica de la vida humana en su facticidad, en su ejecución. Lo propiamente histórico de la vida queda anulado en ellas, por lo tanto se desvitaliza, cerrándose el acceso a una investigación genuina de la vida humana, en suma, una meditación originaria acerca de la experiencia fáctica de la vida queda coartada de raíz. Se presenta aquí un primer análisis de lo histórico y una crítica a la noción de lo temporal como aquello que pasa en el tiempo. En resumen, Heidegger considera que en estas tres interpretaciones está presente una necesidad de aseguramiento de lo histórico. " En el primer caso se hace elaborando una teoría de lo temporal; en el segundo (...) se da también dicha tendencia, ya que el mundo histórico es visto como la única realidad; el tercer caso es un compromiso entre las anteriores. Por un lado está la historia y por otro permanece relacionado con las ideas ${ }^{\Re / 3}$.

En las tres vías lo histórico es comprendido exclusivamente desde un determinado punto de vista, lo que imposibilita un análisis originario de la vida humana es su facticidad. En palabras de Heidegger:

en la tres vías estudiadas queda considerado el estar ahí preocupado como una objetualidad dentro de la historia misma. Así desaparece lo que de verdad (originariamente) desasosiega, y la solución propuesta sería así muy sencilla. Pero preguntamos: ¿qué se quiere realmente asegurar contra la historia? En las tres vías se va destacando la vida, la realidad histórica, como aquello que tiene un sentido. En la filosofía hodierna esta esfera no se convierte en problema, o al menos solo se lo toma dentro del esquema conceptual de la filosofía respectiva. No se plantea la pregunta de si quizá sea imposible aprehender el sentido del estar-ahí fáctico con los medios filosóficos hodiernos (GA 60, 54/83).

Heidegger no quiere decir con esto que la filosofía no se haya hecho cuestión de lo histórico o de la vida humana, sino que no lo ha hecho de una forma tal que revele el carácter genuino de este fenómeno. La vida no ha sido cuestionada de manera suficiente. Se la considera como una objetualidad, una cosa importante, pero una más entre otras muchas.

La filosofía, según la interpretación del filósofo alemán, no ha estado a la altura de las circunstancias, no está lo suficientemente preparada para llevar a cabo una tarea tan exigente como esta, es más, ni siquiera ha pretendido llevarla a cabo ni se ha problematizado dicha cuestión originariamente, o si lo ha hecho, ha sido de forma muy limitada, unilateral, dependiendo siempre de la perspectiva interpretativa desde la cual se

42 Segura, C., Hermenéutica de la vida humana, Trotta, Madrid, 1999, p. 23.

43 Berciano, M., La revolución filosófica de Martin Heidegger, op. cit., p. 122. 
lleva a cabo. Heidegger sostiene que en esto se sustenta un olvido fundamental en relación a la vida humana, "no se pregunta cómo se puede explicitar originariamente el estar ahí, es decir, como se lo puede explicitar filosóficamente. Parece que hay que colmar una laguna en el sistema categorial filosófico. Se mostrará también que mediante la explicación del estar ahí fáctico saltará en pedazos el entero sistema categorial filosófico: tan radicalmente nuevas serán las categorías del estar ahi fáctico" (GA 61, 54/83). Estas palabras parecen una declaración de principios, una hoja de ruta, que indica el camino que debe tomar la investigación, esto a modo de conclusión en esta discusión respecto a lo histórico.

Heidegger recoge aquí tres importantes cuestiones. La primera hace referencia a un fallo, a un olvido de la investigación filosófica, que al no hacerse cuestión de la vida humana correctamente, no le ha sido posible preguntarse por cómo se puede explicitar filosóficamente la vida humana en su constitución esencial. Con esto, el filósofo de la Selva Negra no quiere decir que las filosofías anteriores lo hayan olvidado del todo, sino que no lo han hecho esencialmente. Por eso dice: "El punto de partida y meta de la filosofía es la experiencia fáctica de la vida (Ausgang sowohl wie Ziel der Philosophie ist die faktische Lebenserfahrung)" (GA 15/50). Además, sostiene que es necesario llenar un vacío en la conceptualidad filosófica, para que ésta sea capaz de expresar la constitución originaria de la vida humana, de explicarla filosóficamente de un modo auténtico y sin encubrimientos. Y por otra parte, está el proyecto de más largo alcance, que en la dinámica de su propio desarrollo será capaz de abrir un nuevo camino de interpretación de la vida fáctica, que llevará a cabo una verdadera revolución filosófica, que en virtud de sus alcances y logros, destruirá, hará saltar en pedazos el entero sistema categorial filosófico en el que se sustenta la tradición filosófica.

La tarea que se propone Heidegger es a largo plazo, pero desde ya fija las coordenadas para su despliegue, son las primeras batallas de ese largo enfrentamiento que mantendrá con la tradición metafísica. Enfrentamiento que tiene como finalidad derribar las categorías filosóficas que han dominado la historia del pensamiento occidental, pero que se han mostrado como insuficientes en la determinación del hombre en su originaria constitución, en la aclaración de esa experiencia fáctica de la vida. Se verifica en este cuestionamiento un importante atisbo de esa fuerte discusión que Heidegger mantiene y mantendrá con la tradición, fundamentalmente con esa interpretación del ser como simple presencia y como substancia, desde el que nace la concepción unilateral del tiempo como puro presente. En estas lecciones universitarias se presentan estas directrices de su pensamiento, de ahí la importancia decisiva de estas, es posible reconocer ya las dos vertientes fundamentales de su labor filosófica, pero estas solo se reconocen en su latencia, no se hacen del todo explícitas, pero anuncian ya la dirección de su pensamiento.

Heidegger en esta meditación por el sentido de lo histórico, va realizando importantes precisiones metodológicas, siendo la más importante la presentación de la 
indicación formal. Dice, "en la metodología llamamos "anuncio formal”44 al empleo de un sentido que guía la explicación fenomenológica. Lo que el sentido formalmente anunciado lleva en sí constituye el horizonte en el que los fenómenos serán avistados. En la consideración metodológica será inteligible cómo es que el anuncio formal, si bien guíe la consideración, no introduce ninguna opinión prejuzgadora en el problema" (GA 60,55/85), luego dirá que el indicador formal es propio de la teoría misma del método fenomenológico, de los actos teóricos, del fenómeno del distinguir; pero luego de esta caracterización parcial, deja la definición hasta ahí, no va más allá. En estos cursos es en donde Heidegger presenta de forma relativamente precisa la definición de la indicación formal, cuya importancia y relevancia para su método fenomenológico en este periodo es destacada.

No obstante, la explicación no deja de ser algo confusa y despierta múltiples dudas e interrogantes que se mantendrán hasta el final de estos cursos. Las principales preguntas respecto a esto son: ¿por qué no avanzó en el desarrollo de esta indicación formal? ¿Por qué no explico con mayor profundidad? La razón de esto sería que:

\begin{abstract}
en consonancia con lo expuesto sobre la indicación formal, Heidegger quiere proporcionar tan solo una comprensión previa de ella, puesto que la comprensión última del fenómeno solo se puede alcanzar en y desde la experiencia de la vida religiosa. En cualquier caso, la comprensión fenomenológica se ha determinar desde la realización (Vollzug) de quien lleva a cabo la explicación. Por lo tanto, se ha de preguntar por el cómo, por el sentido del desarrollo y, además, hacer propia la situación, en este caso la de Pablo ${ }^{45}$.
\end{abstract}

Como recordaremos, las interpretaciones dominantes de lo histórico que se aplican a la vida humana resultan ser insuficientes en cuanto a su legitimidad en su intento de dar cuenta de lo histórico de forma originaria, en efecto, esas posturas parecen ahora tambalear, ya no se sostienen con la seguridad que poseían en principio. La aplicación general de esta idea de lo histórico no hace ninguna diferenciación, asignar esta propiedad a la vida humana es lo mismo que hacerlo a una piedra o a un árbol. No se hace ninguna distinción de un objeto a otro, todos ellos pasan en el tiempo. Lo que se discute de la definición general de lo histórico, es que no dice nada del ámbito de realidad a la cual se circunscribe dicha idea general. La vida humana en su facticidad pertenece a una dimensión específica de la realidad, mientras que ésta definición de lo histórico no dice nada en relación a la dimensión de realidad particular a la que pertenece aquel fenómeno. Por eso, dice Heidegger:

el sentido corriente de lo histórico quiere decir que es lo que temporalmente llega a ser y que como tal es pasado. La experiencia fáctica de la vida será examinada para saber en qué medida se da en ella algo temporal, en qué medida en ella se dan algo que llega a ser

${ }^{44}$ En la traducción que estamos utilizando formale Anzeige se traduce como "anuncio formal", en nuestro trabajo optaremos por "indicador formal".

45 Segura, C., Hermenéutica de la vida humana, op. cit., p. 25. 
y algo consciente en cuanto pasado. Este sentido de "histórico" es tan general (o al menos así lo parece) que nada obsta a que se aplique sin más a la experiencia fáctica de la vida, ya que naturalmente ésta es un determinado segmento de la realidad; lo histórico, como lo que llega a ser en general, no se limita a algo semejante (GA 60,55/85).

De esta forma resume el joven profesor lo que considera problemático de esta generalización de lo histórico y de su posterior aplicación a la experiencia fáctica de la vida. Asunto que será rigurosamente cuestionado en su legitimidad como acepción dominante, a raíz de ello se pregunta si en la vida fáctica se da algo así como lo temporal, en el sentido de algo que pasa en el tiempo, que llega a ser y deja de ser. Y al mismo tiempo se pregunta hasta dónde llega el ámbito de dominio de esta idea general de lo histórico y si esta interpretación puede ser filosóficamente originaria. Son varías las interrogantes que aquí se conjuntan, no obstante la pregunta es solo una; la pregunta por el sentido originario de lo histórico.

El filósofo nativo de Messkirch entiende que hay dos cuestiones que se deben aclarar de forma urgente. La primera tiene que ver con determinar si puede ser considerado filosóficamente originario el sentido general de lo histórico y, por otra parte, se ha de preguntar si el sentido general de lo histórico prejuzga y determina de alguna forma la búsqueda de una consideración filosófica genuina. Heidegger detecta aquí un problema que viene acompañando a la filosofía desde hace largo tiempo, que debe ser resuelto de una vez por todas y tiene que ver con que desde hace siglos se considera la generalidad por parte del objeto como la nota característica de la objetualidad de la filosofía. Esto significa, que este problema no es algo adyacente o derivado, sino que esta generalidad del objeto de la que habla Heidegger, es la nota distintiva de la concepción filosófica de sujeto-objeto.

Para aclarar esto, retoma una consideración que había desarrollado anteriormente y de la cual es deudor de Husserl: la distinción entre generificación(Generalisierung) y formalización (Formalisierung), que es clave para exponer el sentido de la indicación formal. Para Heidegger, es importante profundizar en esta distinción, dado que llevaría a un perfeccionamiento del sentido de la indicación formal. Entrando en materia, Heidegger sostiene que:

la "generificación" quiere decir generalización genérica. Por el ejemplo, el rojo es un color, el color es una cualidad sensible; o la alegría es un afecto, el afecto es una vivencia. Se puede, al parecer, continuar: las cualidades en general, la vivencia, el género, la especie, la esencia son objetos. Pero en seguida se suscita la cuestión: ¿es el tránsito generalizante (verallgemeinernde) de "rojo" a "color" o de "color" a "cualidad sensible" el mismo que va de "cualidad sensible" a "esencia" y el que va de "esencia" a "objeto"? (GA 60, 58/87)

De ningún modo el movimiento de una cosa a la otra es igual, dado que ambas generalizaciones son por completo distintas. En el ejemplo expuesto, se sostiene que la cualidad sensible no se puede utilizar en cualquier situación, sino solamente cuando venga 
al caso y corresponda. Por otra parte, en la determinación de objeto (Gegenstand), el algo va más lejos del lugar que se le ha asignado en principio en la serie del proceso de generalización.

Objeto se puede predicar de todos los momentos sin que por ello deje de ser correcto o que no sea legítimamente aplicable. Por esta razón, Heidegger dice que los fenómenos son formalmente objetos. De forma tal, que no es completamente indispensable hacer todo el recorrido de una serie cada vez para llegar a aquello que se logra con la formalización, en cambio la generificación en cada momento de la serie, debe necesariamente, tener el punto de apoyo en el momento anterior. Cada nivel de la serie debe apoyarse en el nivel anterior, lo que de no ocurrir, nos sitúa ante una serie incompleta, inacabada. Por ello dice que "la generificación está ligada, es su ejercicio, a un sector temático preciso. La secuencia de grados de lo "genérico" (géneros y especies) está determinada temáticamente. La atinencia al complejo temático es básica" (GA60, 58/88). La generificación considera principalmente un determinado ámbito de cosas, se dirige hacia lo cósico que las constituye, la mirada se dirige al qué, a cual se va a generalizar. La generificación vendría a ser la determinación de un objeto en virtud de su coseidad, pero también tiene que ver con un orden, ordena ese qué en una determinada dirección, un ordenamiento de generalidades, que se realiza a partir de géneros y especies, sería entonces un modo de ordenar. Que a través del reconocer los caracteres se lleva a cabo un ordenamiento generalizador. En la generalización se lleva a cabo un destacar y ordenar directamente los caracteres de la cosa, de qué del objeto ${ }^{46}$.

Heidegger ejemplifica esto diciendo que las series son disimiles entre sí y que los grados, los estadios que los relacionan, difieren de forma importante entre ellos porque las relaciones que los unen no son siempre iguales. Un caso de ello es que el paso de color a cualidad sensible difiere notablemente del que se da entre cualidad sensible a esencia. Los caracteres de la cosa ( como bolígrafo, utensilio, herramienta) también se subordinan a los títulos categoriales de esencia u objeto, pero el ordenamiento de estos últimos no ocurre de modo generalizador, porque no son especies con contenido cósico. Dado que esencia u objeto, no hacen referencia al contenido de los objetos, sino a su forma, por lo tanto, este es un ordenamiento distinto llamado formalización. La formalización contiene categorías formales, las cuales no están unidas al contenido cósico, al qué. En este sentido las categorías formales "esencia en general" u "objeto en general" se refieren al "de lo qué" de la referencia de la actitud teórica ${ }^{47}$.

Por lo tanto, en la generalización de color a cualidad sensible existe una dependencia de un nivel hacia otro al interior de la serie y en la formalización existe cierta libertad entre los distintos grados en la serie. Heidegger profundizando, sostiene que la

${ }^{46}$ Cf. Xolocotzi, A., Fenomenología de la vida fáctica, Universidad Iberoamericana, México, 2004, p. 117.

${ }^{47}$ Ibíd, p. 118. 
predicación formal -que es decir por ejemplo que una piedra es un objeto- no está ligada materialmente a una secuencia ni un orden determinado (se habría podido decir esto de una característica de la piedra, de su dureza, que también es un objeto en este sentido), sin embargo, no puede ser esta una operación arbitraria y completamente anárquica. La libertad de la formalización no puede llevarla a operar en el aire o de forma abstracta. En palabras de Heidegger, "tiene que estar motivada de alguna manera (GA 60, 58/88). La propuesta ante la necesidad de la motivación se transforma en la clave para entender el sentido de lo formal en este momento ${ }^{48}$.

Si la libertad de la formalización tiene sus limitaciones, qué le impide actuar arbitraria y desordenadamente, ¿Cuáles son los parámetros que permiten y posibilitan su aplicación? El joven profesor sostiene que la formalización tiene que estar de alguna manera motivada. Lo cual nos lleva hacia algo que solo había sido mencionado superficialmente, nos referimos a la estructura triple de la intencionalidad, que está constituida por el sentido de referencia (Bezugssinn), el sentido de ejecución(Vollzugssinn) y el sentido de contenido (Gehaltssinn). Es preciso develar de qué forma se vinculan estos sentidos, y cómo se estructura aquel estar motivado de alguna forma, que se muestra en la triple estructura de la intencionalidad. La formalización está motivada por "el sentido de referencia actitudinal misma" (Sie entspringt dem Sinn des Einstellungsbezugs selbst)"(GA60, 58/88), por lo tanto, lo que se gana con el sentido de referencia (Bezugssinn), por ser la forma en la cual se experiencia un fenómeno, es que gracias a ese sentido, no se interpretan los objetos únicamente desde su contenido, desde su qué, por el contrario, solo se capta el objeto en su simple estar dado, lo que permite una captación originaria. Se vislumbra un giro en el análisis de la atención que se da a los objetos, lo principal para la fenomenología no es el contenido o el qué de lo fenómenos, sino el sentido de referencia y el modo del ejercicio de dicha referencia. Si el contenido se mantiene indeterminado, se dirige toda la atención sobre la referencia y el forma de ejecutar dicha referencia, con lo cual se logra evitar que la referencia teórica sea la privilegiada y determine la referencia y la ejecución.

La formalización no está vinculada a ese qué, al contenido del objeto que ha de determinar, sino que al sentido de referencia, a la misma forma de la experiencia. En el sentido de referencia el objeto no es determinado como un qué, solamente se señala que dicho objeto se ha captado, que ha sido percibido y que está dado, que es un algo. Por lo tanto, se hace la referencia en virtud de la formalización, pero sin incluir en ella ni antes ni después ningún compromiso, el contenido se mantiene indeterminado, no se alude a ello en términos objetuales. El origen de lo formal está en el sentido de referencia. Una referencia libre de cargas teóricas. La finalidad principal que persigue Heidegger con la elaboración de la indicación formal, es que es una forma de tomar distancia de la tradición

${ }^{48}$ Cf. Redondo, P., Experiencia de la vida y fenomenología en las lecciones de Friburgo de Martin Heidegger, Universidad de Salamanca, 2001, p. 278. 
de la filosofía que considera que el modo prioritario de dirigirse a los objetos es fijándose exclusivamente en su contenido, en esto radica el fallo en esta forma de hacer filosofía, y, de alguna forma, es el origen de su debilidad en su interpretación de la vida fáctica y de lo histórico; fenómenos a los que Heidegger ha dirigido su atención en el contexto de estas lecciones, cuestiones que seguirán siendo interrogantes fundamentales en su proyecto filosófico, especialmente en esta estancia temprana de su pensamiento. "Con "indicación" Heidegger quiere enfatizar el carácter referencial de los conceptos filosóficos, que se expresarán como "indicaciones formales"”,49, en efecto, con la elección de este concepto quiere hacer frente a la actitud primordialmente teórica, que al poner toda la atención sobre el contenido del objeto, al fijar la vista unilateralmente en ello, se determina con anterioridad tanto el contenido como la forma de relacionarse con ellos y el modo como esto se ejecuta.

Lo único que se toma en cuenta del objeto es el qué, el contenido, negando así la importancia o el significado que puedan tener para la investigación otras características del fenómeno, igual de esenciales e importantes, pero que no son parte del contenido. De este modo, la investigación filosófica se niega el acceso a una exégesis amplia y esencial de los fenómenos, que sea capaz de referirse a ellos originariamente, que permita analizarlos plenamente y no unilateralmente, cuestión que ha sido el signo distintivo de las investigaciones filosóficas. Si nos dirigimos exclusivamente al sentido de contenido, el sentido de referencia está predeterminado desde el comienzo y el sentido de ejecución desaparece. Esta perspectiva de interpretación que se sustenta en privilegiar el contenido, el qué, es perjudicial para la filosofía, porque la modalidad que utiliza para acceder a los objetos estaría más cerca de una conceptualidad propiamente científica, que una propiamente filosófica.

Heidegger considera que el método de las ciencias naturales ofrece una perspectiva de la realidad que queda sesgada desde un principio, producto de la forma de dirigirse a los objetos, en virtud de que se conduce unidireccionalmente hacia el contenido de los fenómenos, lo que genera prejuicios y malentendidos en el tratamiento cognoscitivo de los objetos. Frente a esta perspectiva y visión unilateral dirigida al qué, Heidegger utiliza como clave la indicación formal, que tiene como principal objetivo prescindir de los prejuicios e impedir que la referencia y la ejecutividad del fenómeno sea determinado con anterioridad, advirtiendo además, de la equivocación de considerar que el sentido de referencia originario es el teórico. El anuncio formal es el instrumento que cumple dicha función preventiva frente a estos posibles prejuicios, este pertenece como instancia teórica a la explicación fenomenológica misma, por esto Heidegger dice:

se llama formal, porque "lo formal es algo relativo a la referencia. El anuncio tiene que anunciar anticipando la referencia del fenómeno, pero en un sentido negativo, ¡Como si de una advertencia se tratase! Un fenómeno tiene que estar previamente dado de tal modo

$\overline{49}$ Xolocotzi, A., Fenomenología de la vida fáctica, op, cit., p. 120. 
que su sentido referencial quede flotando. Hay que guardarse de admitir que el sentido referencial sea originariamente teórico. La referencia y el ejercicio del fenómeno no se determinan de antemano, sino que están en suspensión (a la espera de concretarse). Esto es una posición que se opone formalmente a la ciencia) (GA 60, 64).

El joven profesor explicita de este modo los objetivos que persigue al introducir la indicación formal en el método fenomenológico, debe indicar el sentido de relación de los fenómenos. Esta indicación abre una perspectiva, una dirección, señala la referencia del fenómeno, nada más, no pretende determinarlo solo dice que está ahí. Indica en dirección al fenómeno, llama la atención sobre él, y de este modo, lograr impedir los prejuicios, las predeterminaciones.

Se deben tomar todas las precauciones posibles, para evitar que una forma predeterminada y unilateral de ver los fenómenos se imponga como la correcta o verdadera, lo que supone una contraposición evidente a la forma de pensar de la ciencia. Respecto a esto Heidegger se expresa en los siguientes términos: "El anuncio formal es un rechazo, un aseguramiento previo de modo que el carácter ejecutivo aún queda libre. La necesidad de esta medida de precaución procede de la vida fáctica que amenaza constantemente con deslizarse extraviándose en lo objetual y de la cual tenemos, en cambio que resaltar los fenómenos entresacándolos" (GA 60, 64/93). Y más adelante, dice también, que la indicación formal tiene el significado de la aplicación de la explicación fenomenológica. El joven profesor define de este modo el objetivo y el papel decisivo que cumple la indicación formal al interior del método fenomenológico, cuya utilidad señalada tiene que ver principalmente con la posibilidad de superar las limitaciones que le son propias al modo exclusivamente teórico de dirigirse a los fenómenos. Se advierte al mismo tiempo, de la equivocación que supone considerar que el sentido de referencia originario es el teórico. La indicación formal no se deja guiar por el contenido sino por lo ejecutante, por ello, si la fenomenología hermenéutica pretende tratar la vida desde una vertiente originaria y no solo en relación al contenido, a lo que debe dirigir su atención es hacia sus tres direcciones de sentido (referencia, contenido y ejecución). Desde esta perspectiva la indicación formal debe entenderse como conceptualización ejecutiva que puede llevar a cabo un despliegue temático del fenómeno de la vida humana y desde ahí es desde donde se puede ver el indicado carácter referencial de la indicación formal ${ }^{50}$.

Todo esto nos muestra que Heidegger considera que puede haber otro camino, otra vía capaz de superar esas limitaciones y sesgos que produce la forma exclusivamente teórica de ver los objetos, esto gracias a la referencia que se ejecuta, que se realiza en la misma ejecución de la vida fáctica. El sentido de referencia y el de ejecución son recuperados en su carácter originario, como determinaciones fundamentales de los fenómenos, son rehabilitados como cuestiones esenciales para el quehacer filosófico, para la investigación fenomenológica. La indicación formal hace posible atender la inmediatez

${ }_{50}$ Cf. Xocolotzi, A., Fenomenología de la vida fáctica, op, cit., p. 123. 
de los fenómenos, dejando abierta la posibilidad a una vía de acceso distinta, que permita que ésta inmediatez pueda ser atendida. Todo esto indica que para el resultado de la investigación no es beneficioso que una actitud predeterminada sea la dominante al momento de captar el fenómeno en su simple aparecer.

La indicación formal tiene que ver con planteamiento mismo de la explicación fenomenológica, he aquí el rol fundamental que posee al interior del método fenomenológico, liberar la investigación de prejuicios e imposiciones. Como comenta Heidegger:

El anuncio formal solo tiene sentido en relación con la explicación fenomenológica. Se trata de la cuestión de si la tarea propuesta de la filosofía se puede mantener por principio como determinación general de lo objetivo, de si el planteamiento de la tarea brota del motivo originario del filosofar (...) tenemos que tener muy clara la mente acerca de la forma de la contemplación fenomenológica. Esto es lo que justo logra el anuncio formal. Este tiene el sentido de la puesta de la explicación fenomenológica (Ansetzens der phänomenologischen Explikation)(GA60,64/93).

La indicación formal es la construcción heideggeriana, utilizada para dirigir la investigación de un modo originario, libre de prejuicios y de predeterminaciones, que no hacen más que oscurecer los fenómenos en vez de iluminarlos en su sentido primigenio, es una puesta en marcha de la investigación fenomenológica misma. Dejando una vía libre para el acceso a los fenómenos. Mostrando sus reticencias con la modalidad exclusivamente teórica de ver los fenómenos y las consecuencias que ello conlleva, por ser una forma de pensar limitada y sesgada en su comprensión de los fenómenos.

Heidegger rechaza de plano que sea una determinada actitud la que domine y determine el momento de la manifestabilidad de los fenómenos, sino que deber ser entendida desde su triple dirección de sentido, el estudio de la indicación formal ha derivado necesariamente en una caracterización del método fenomenológico, esto porque en la investigación del filósofo de la Selva Negra está presupuesta la tesis de que la filosofía no es ni puede ser considerada una ciencia teórico cognoscitiva.

En el marco de esta discusión Heidegger estima necesario precisar con contornos más definidos qué entiende por fenomenología y por fenómeno.

Toda experiencia en cuanto experienciar y como experienciado "puede ser puesta en el fenómeno", esto es, se puede preguntar: 1) por el "qué" originario que es experienciado en él (contenido) 2) por el originario “cómo” en que es experienciado ( referencia) 3) por el originario "cómo" en que el sentido referencial es ejercido (ejercicio)". Más adelante, precisa aún más, y dice que "estas tres direcciones de sentido ( sentido de contenido, de referencia y de ejercicio) no están colocadas sencillamente las unas junto a las otras. "Fenómeno" es una totalidad de sentido según estas tres direcciones. La fenomenología es la explicación de esta totalidad de sentido, da el "logos" de los fenómenos (GA60,63/92). 
El filósofo alemán presenta una definición precisa de cómo entiende el concepto de fenómeno por estos años, lo concibe como una unidad de las tres direcciones de sentido que no están simplemente amontonadas como conjunto sino como una totalidad dotada de un sentido. Precisamente la fenomenología en cuanto tal, sería la explicación de esa totalidad de sentido. El fenómeno es concebido como totalidad de sentido en tres direcciones de una experiencia tal, que entendida desde esta unidad de su contenido, ejecución y referencia, se puede ser hacer cuestionable. Es a lo Heidegger alude con que puede ser puesta en cuestión y, justamente, la fenomenología consistiría en la explicación de esta totalidad de sentido que se hace presente en el fenómeno así entendido. Desde esta perspectiva el concepto de fenómeno alude en primer término a la forma en que la vida fáctica se manifiesta, en el modo en que se da la vida humana, lo que es determinante para la investigación fenomenológica.

De forma tal, que "el concepto de fenómeno es entonces el todo significativo, la trama de sentido en que se anudan, esas tres direcciones: referencia, objetividad, ejecución. Es esta plena intencionalidad lo que constituye el fenómeno, que como tal encuentra entonces su campo propio de aplicación de la experiencia fáctica de la vida y solo ella"51. Entonces la fenomenología ha de interpretar un fenómeno en esas tres direcciones de sentido y ese fenómeno es la experiencia fáctica de la vida, en ese mismo experienciar, se da una explicación categorial de esa experiencia fáctica de la vida.

Es hacia estas tres direcciones de sentido hacia las que se ha de volcar la fenomenología si quiere ser una ciencia preteórica de la vida se tiene que dar una prioridad señalada a aquello que significa el cómo por sobre los que significan el qué, en otras palabras, a aquellos que indicar la ejecución por sobre el contenido mismo del fenómeno. Como resume Rodríguez:

Lo decisivo para comprender la vida tal como efectivamente acontece es establecer las modalidades de referencia (el ocuparse-de) y cómo son ejercidas, más que cuales son los caracteres objetivos de la esfera de las cosas de que se ocupa. Esta primacía de los sentidos de referencia y ejecución no es una opción arbitraria del fenomenólogo, sino algo que viene propuesto por la propia facticidad: su carácter preteórico significa justamente precaverse contra la tendencia objetivante a determinar el sentido del fenómeno a partir del sentido objetivo, que es lo directamente experimentable, aquello a lo que la acción se vuelca $^{52}$.

Con esta interpretación de fenómeno, de fenomenología, Heidegger cumple con aquella intención primera que guía su meditación filosófica, desmarcarse de la prioridad propia a la actitud teórico cognoscitiva que guía a las ciencia naturales y que él tanto ha criticado, en cuanto a que no pueden dar cuenta de forma originaria de ese ente llamado vida fáctica, puede de esta forma, capitalizar su crítica a la actitud científica de acercarse al Dasein. "La posibilidad de la filosofía como fenomenología se juega en que la indicación formal logre

51 Rodríguez, R., Heidegger y la crisis de la época moderna, Síntesis, Madrid, 2006, p. 191.

52 Ídem 191. 
su cometido metódico y deje espacio para cuestionarse por el modo particular de ser referido y en que dicha referencia deber ser ejecutada" ${ }^{33}$.

Por lo tanto, la fenomenología así entendida es un método que no pretende establecer una relación teórico-cognoscitiva con su objeto que es la vida fáctica. Por el contrario, es una modalidad de la investigación cuyo carácter fundamental es el de ser preteorética, lo que permite que el fenómeno-la vida fáctica- se pueda mostrar de forma originaria para la investigación y no sea considerada como un objeto simplemente presente para un sujeto que lo contempla y que lo pueda determinar sin tener en cuenta su esencial carácter histórico y temporal. La referencia al mundo no queda marcada por una distancia insalvable que solo podría romperse si accedemos a ella a través de un puente, por una relación de sujeto objeto. Sino que por el contrario, la forma misma de ejecutar esa referencia determina el sentido de la misma. "El sentido de la vida fáctica reposa esencialmente sobre el cómo inobjetivo en que se realiza, sobre la forma como nos acercamos a las cosas, cumplimos nuestras tareas, tratamos con otros. Esa forma no es marcada o impuesta por el sentido objetivo, sino que un dato originario de la facticidad" ${ }^{54}$.

Después de esta sugerente reflexión acerca de la legitimidad de lo histórico, que entendido en sentido general significa aquello que pasa en el tiempo, y con la posterior clarificación del método fenomenológico, de su instrumento destacado -el indicador formal-, Heidegger ha llegado a concluir que la aparente legitimidad de aquella definición es cuestionable, principalmente por los prejuicios y las perspectivas unilaterales de interpretación que han guiado las investigaciones filosóficas respecto a lo histórico. Si se aplica el método fenomenológico a lo histórico, si se considera lo histórico como lo anunciado formalmente, no se puede concluir: "que la nota más general de lo "histórico" en cuanto "algo que llega ser en el tiempo" prefigura un sentido último, esta determinación formalmente anunciante del sentido histórico no es designable como una tal que determine el mundo histórico objetual en su carácter histórico estructural ni tampoco como una tal que prefigure el sentido más general de lo histórico mismo" (GA 60, 645/93), en consecuencia, después de este largo rodeo en torno al concepto general de lo histórico y de la irrupción de la indicación formal, Heidegger considera que lo histórico entendido como aquello que llega a ser en el tiempo, se muestra insuficiente y sesgado a la hora de obtener una interpretación que de cuenta de este fenómeno originariamente. En este sentido, lo histórico ha sido en principio indicado formalmente y no se le determina plenamente, lo que se dice de él es algo bastante general. Esto significa:

así "temporal" es tomado provisionalmente en un sentido bastante indeterminado y, en la medida en que permanezca indeterminado, no prejuzga. Es preciso que la filosofía, la

${ }^{53}$ Lara, F., "El concepto de fenómeno en el joven Heidegger" en Eidos: Revista de Filosofía de la Universidad del Norte, mayo, $\mathrm{n}^{\circ}$ 8, Barranquilla, 2008, p. 238.

${ }^{54}$ Rodríguez, R., Heidegger y la crisis de la época moderna, op. cit., p. 192. 
fenomenología parta de la vida fáctica y que desde ella se alcance el sentido, en este caso, del tiempo. En definitiva, el problema del tiempo se ha de captar atendiendo a la experiencia fáctica de la temporalidad, lejos de la pura conciencia y de la pura idea de tiempo. Se ha de seguir, por tanto, la dirección contraria a la de la filosofía tradiciona ${ }^{55}$.

Las interpretaciones revisadas por Heidegger ejemplifican con claridad dicha insuficiencia. Parten desde una perspectiva predeterminada y se dejan seducir por la noción de idea que subyace en ellas. Tal como se ha visto, esa nota señalada de lo histórico no está habilitada para revelar el sentido último de lo histórico. Ni siquiera se sabe muy bien con qué concepto de tiempo trabajan, ni qué idea del tiempo está supuesta en dichas interpretaciones. Solo se puede decir que esta idea general del tiempo no cumple ningún papel de fundamentación, es más, oculta una interpretación originaria del tiempo, es una falsificación del tiempo originario.

Hemos llegado a una instancia clave en las lecciones universitarias de Friburgo, momento determinante para nuestra investigación. Heidegger pregunta por el sentido originario del tiempo y su íntima conexión con la experiencia fáctica de la vida. Toda esta vuelta, el cercar el problema de lo histórico, exponiendo la forma dominante de entender lo histórico como una propiedad más de la vida humana y de considerar esa vida objetualmente, nos ha mostrado la insuficiencia y debilidad que le son propias a estas interpretaciones, incluso el profesor de Friburgo comenta que se está frente a una, "falsificación del problema del tiempo; pues se prefigura con ello a partir de lo teórico un marco del fenómeno del tiempo" (GA60,65/94), generándose así perspectivas completamente sesgadas y acotadas en la forma de orientarse al fenómeno y en su forma de dar cuenta de él. Ahora en adelante, la tarea que el pensador de la Selva Negra acometerá es la de aclarar el sentido genuino del tiempo, por eso:

tiene que ser tomado el problema del tiempo de la vida de la misma forma que nosotros experienciamos originariamente la temporalidad en el experienciar fáctico, con independencia de toda conciencia pura y de todo tiempo puro. La vía es entonces a la inversa. Tenemos que preguntar, antes bien: ¿qué es originariamente la temporalidad en la experiencia fáctica? ¿Qué quiere decir pasado, presente y futuro en la experiencia fáctica? Nuestra vía parte de la vida fáctica, de la que se obtiene el sentido del tiempo. Así está caracterizado el problema de lo histórico (GA 60, 65/94).

Es evidente entonces, que estas preguntas son las que desde un principio han determinado el camino del pensar de Heidegger, son las preguntas esenciales que han guiado su filosofía en este periodo de su pensamiento; la pregunta por la temporalidad de la vida fáctica. La pregunta por el significado genuino del presente, el pasado y el futuro en esa experiencia fáctica de la vida, en último término, es la pregunta por el sentido genuino del tiempo. Después de un largo rodeo, que ha pasado por la pregunta de lo histórico y por la determinación de su método fenomenológico hemos llegado a las preguntas rectoras de su pensamiento.

\footnotetext{
${ }_{55}$ Segura, C., Hermenéutica de la vida humana, op. cit., p. 24.
} 
Es entonces, a partir de la experiencia fáctica de la vida, que como sabemos es el punto de partida y la meta del filosofar mismo, desde dónde debemos preguntar por el sentido originario del tiempo, de sus dimensiones temporales. Cómo se vive el tiempo en la vida fáctica, este es el libro donde debemos leer las indicaciones que nos iluminen respecto a la pregunta por el tiempo. Y esto se debe acometer, sin prejuicios e ideas predeterminadas respecto a la vida humana y a la historia.

\section{LA EXPERIENCIA FÁCTICA DE LA VIDA EN EL CRISTIANISMO PRIMITIVO}

La fenomenología no puede actuar en el vacío o por medio de abstracciones, siempre tiene que estar dirigida a los fenómenos. Si en este caso el curso trata la vida religiosa, no será difícil descubrir cual será la experiencia elegida para delimitar y fijar el método propiamente fenomenológico. Heidegger entiende que si se pretende investigar cuál es el objeto de la religión, es necesario al mismo tiempo, determinar cuál es la experiencia religiosa originaria y cuál es la forma correcta de acceder a ella. En la experiencia fáctica de la vida del cristianismo primitivo, el joven profesor detecta un lugar privilegiado para desarrollar su método fenomenológico. En el cristianismo de las primeras comunidades reconoce una forma de vivir la vida según una experiencia originaria, desde la cual esa vida adquiere el sentido de su ejecución. Encuentra en este acontecimiento histórico un suelo seguro en el cual la vida humana se comprende a sí misma de forma originaria, esto desde las circunstancias especiales que le toca enfrentar.

Esta explicitación del método fenomenológico se materializa a través de la interpretación de un hecho histórico singular, la experiencia de la vida fáctica de las primeras comunidades cristianas, no en vano el nombre del curso es Introducción a la fenomenología de la religión. Al comenzar la segunda parte del curso, el joven profesor fija con claridad los alcances y las limitaciones de estas lecciones, lo que expone de la siguiente forma: "en lo que sigue no tenemos la intención de ofrecer ni una interpretación dogmática o teológica-exegética ni tampoco un estudio histórico o una meditación religiosa, sino solo una introducción a la comprensión fenomenológica. Lo peculiar de la comprensión fenomenológico-religiosa es la obtención de una precomprensión para una vía originaría de acceso" (GA 60,67/97). Por lo tanto, lo que se llevará a cabo no es una reconstrucción histórica ni tampoco una verificación de las fuentes documentales, menos aún se plantea una exégesis teológica del cristianismo. Lo importante es realizar un análisis fenomenológico de la vida humana en el cristianismo primitivo, presentándola como una experiencia originaria de la vida misma, donde será posible leer los rasgos fundamentales de este fenómeno, no obstante, debe ser un análisis integral de esta experiencia, no solo referida a un qué, sino dirigida a todas las esferas posibles que permitan recabar información importante de esta singular experiencia, esto gracias al método fenomenológico presentado en la primera parte de la lección. 
Heidegger afirma, que "por de pronto, hay que buscar una comprensión general de la epístola a los gálatas para poder adentrarse de su mano en los fenómenos fundamentales de la vida cristiana primitiva" (GA 60,68/98). En principio hay que determinar y presentar aquellas modulaciones fundamentales de la vida en el cristianismo primitivo, para destacar allí los comportamientos esenciales de la experiencia del cristianismo, en este caso de San Pablo y la historia de su conversión.

La tarea es presentar e interpretar, "la experiencia religiosa fundamental y, perseverando en esta experiencia fundamental, tratar de comprender la conexión de todos los fenómenos religiosos originarios con aquella" (GA 60, 73/102). En la actitud fundamental (Grundhaltung) o talante de fondo de San Pablo, es dónde se puede apreciar la experiencia originaria del cristianismo primitivo. Heidegger ha elegido esta experiencia, ya que ella se origina de una forma singular, desde una vivencia excepcional y no desde la sumisión ciega a los dictados de la tradición o al cumplimiento de un conjunto de leyes. Gracias a este origen peculiar, esta experiencia no cargaría con el peso desvitalizador del que generalmente se sobrecargan la experiencias originadas desde el seguimiento de leyes o normas. Se obtiene así una experiencia originaria de la vida, que cumple con el requisito de no ser una experiencia desvitalizada, u originada desde una perspectiva teórica.

Desde este talante de fondo, del modo cómo se comporta San Pablo, se ha de determinar la dirección fenomenológica que guía este comportamiento, lo que abre la posibilidad de acceder a una experiencia fundamental que no se ha oscurecido por un sobrepeso teórico que ha caído sobre ella, sino que más bien se sustenta en una experiencia, en un acontecimiento concreto. En otras palabras, la comprensión y la explicitación de la forma en que San Pablo se comporta en su vida en último término se sustenta en una experiencia originaria de la vida y no en una perspectiva teórica $o$ gnoseológica de ella. En resumen, lo que Heidegger pretende es un retorno a la experiencia originaria y la comprensión del problema de la explicación religiosa, camino que nos conduciría hacia un fundamento último basado en la experiencia misma de la vida humana.

Gracias a esta base existencial que Heidegger propone, que sirve de sustento a su introducción a la fenomenología de la religión, puede entrar ya directamente en materia y señala que en esta investigación, "no se trata de interpretar basándose en un complejo de índole histórica en el que está inscrita la epístola a los gálatas, queremos al contrario, explicitar su sentido propio. Ya la nota fundamental de la religiosidad primitiva es decisiva" (GA 60, 78/108). Según Heidegger, las notas fundamentales del cristianismo primitivo mediante las que se pretende definir la religiosidad cristiana señalan que:

1) La religiosidad cristiana primitiva está en la experiencia fáctica de la vida (Urchristliche Religiosität ist in der faktischen Lebenserfahrung). Frase final: es en realidad ella una tal (Sie ist eigentlich solche selbst). 
2) La experiencia fáctica de la vida es histórica (Die faktische Lebenserfahrung ist historisch). Frase final: la experiencia cristiana vive el tiempo mismo (Die christliche Erfahrung lebt die Zeit Selbst)

No pueden demostrarse estas "tesis" sino que deben verificarse en la experiencia fenomenológica, que es algo distinto de la experiencia empírica (GA 60, 82/112)

A simple vista, podemos ver que estas notas presentadas por Heidegger, son por decirlo menos problemáticas, y proponen en principio a una serie de interrogantes. ¿Seguirá Heidegger trabajando con el concepto de lo histórico que tanto ha criticado? ¿Qué significado tiene para nosotros que la religiosidad cristiana viva el tiempo como tal? ¿Cuál es el concepto de la temporalidad que presupone Heidegger?

Estas dos notas características de la religiosidad del cristianismo primitivo marcarán la pauta de la investigación en lo que viene, en principio se mostrará su carácter esencialmente problemático, para luego ir haciendo transparente su verdadero significado. En la primera nota, Heidegger no deja suficientemente claro por qué la religiosidad cristiana se encuentra localizada plenamente en la experiencia fáctica del cristianismo y no en las leyes o dogmas establecidos anteriormente en la historia del cristianismo, la experiencia fáctica del cristianismo es el lugar privilegiado donde podemos encontrar la religiosidad propiamente tal.

En la segunda, señala que la experiencia de la vida es histórica, sin embargo, esto de lo histórico mantiene aún su problematicidad, ya que aún no se ha develado en su sentido originario ni se ha definido con claridad. Y por último, su apuesta más arriesgada, dice que la religiosidad cristiana vive la temporalidad como tal. Es pradigmático que en estas dos proposiciones que se refieren a la religiosidad cristiana primitiva, se presenten las dos tareas que Heidegger dejaba abiertas al finalizar la primera parte de estos cursos. Por una parte, determinar lo histórico en su sentido genuino y por otra, la pregunta por la temporalidad en la experiencia fáctica de la vida. Podemos ver que esta experiencia religiosa le sirve para explicar cuestiones filosóficas que le vienen apremiando desde hace tiempo.

Heidegger dice que estas son solo proposiciones, hipótesis, por lo que quedan abiertas a una posterior reinterpretación. Estas tesis no pueden ser probadas o demostradas, deben verificarse por medio de la experiencia fenomenológica, por el rigor propiamente fenomenológico y no a través de una comprobación empírica. La forma de explicar el fenómeno no se refiere a un qué determinado o por determinar de la vida fáctica, sino que esta referido a la ejecución misma, dado que, "en el ejercicio y por medio del ejercicio el fenómeno es explicado. "La proclamación apostólica" es aún una característica demasiado amplia del fenómeno. En cuanto el "cómo" y el sentido ejecutivo de la proclamación apostólica estén determinados, ésta estará esclarecida en lo esencial. Este planteamiento de la cuestión por el "cómo" es pues, decisivo" (GA 60, 83/112), no es 
difícil concluir la importancia y prioridad que para Heidegger tiene el sentido de ejecución (Volzugssinn), cuestión que se puede verificar a simple vista si tomamos en cuenta las dos notas que recoge del cristianismo primitivo. Solamente es posible encontrar la religiosidad del cristianismo, en la forma en que ejecuta su vida la comunidad cristiana, en la propia ejecución de la existencia, en la propia facticidad que le es inherente. En ningún caso, la podemos ver en un conjunto de dogmas o tradiciones heredadas por una comunidad determinada.

Según esto, en el esquema de la intencionalidad si algún sentido posee cierta prioridad, no es el sentido de contenido, sino el de ejecución, tal como dice Pöggeler:

la historia acontecida puede, ciertamente, ser descrita también a partir de su contenido intrínseco: como historia acontecida de los contenidos, ideas, estilos, etc., o sea, como historia acontecida del "espíritu objetivo". (Hegel ha intentado comprender incluso la aparición de Cristo a partir de su sentido intrínseco como revelación de la profundidad de la sustancia o idea). Pero, según Heidegger, la experiencia de la vida del cristianismo primitivo es justamente fáctica e histórica, es una experiencia de la vida en su facultad porque ve la estructura dominante de la vida justamente en el sentido de su cumplimiento, no en el de su contenido intrínseco ${ }^{56}$.

El fenómeno fundamental en el que se hace visible la forma en que San Pablo y las comunidades primitivas viven su vida, es el de la proclamación (Verkündigung) o anunciación. Este es el acontecimiento decisivo en que se hace aprehensible la referencia vital de San Pablo, "aquí hay un determinado complejo del que se puede extraer una cosa; aquí realzamos el cómo de la ejecución. El ejercicio de la vida es decisivo. El complejo ejecutivo se experiencia también con la vida. De ahí que sea comprensible que el cómo del ejercicio tenga sentido básico"(GA60,80/110). Heidegger reafirma así la importancia de la ejecución misma de la vida, al hacer referencia a la importancia de la proclamación como el acontecimiento que determina la forma en que las comunidades cristianas primitivas conducen su vida no se está solamente preguntando qué es esta proclamación o qué dice ella. No se la define de una manera u otra, sino que se hace alusión al cómo de esta proclamación, dando al mismo tiempo, el sentido al cómo de la ejecutividad de la vida en virtud de esa proclamación, la respuesta de esta comunidad a dicha proclamación. Pero no solo a este cómo se dirige la investigación, sino que también ha de preocuparse de ver este fenómeno en todas su direcciones de sentido fenomenológico, pero siempre teniendo en cuenta, que para Heidegger lo prioritario es el sentido de ejecución.

Con el afán de comprender el sentido de la proclamación, es menester atender a qué es lo que se indica en ella, qué es lo que ella anuncia, cómo cambia su vida aquel que recibe este anuncio, ya que a este le cambia la vida, por eso es acuciante saber qué significa para la vida de aquel que recibe esta proclamación. Se debe prestar atención a qué es lo que anuncia, cómo se experiencia esa referencia, qué clase de referencia establece aquel que recibe el anuncio con aquello desde dónde viene este mensaje y cuál

\footnotetext{
56 Pöggeler, O., El camino del pensar de Martin Heidegger, op. cit., p. 44.
} 
es la forma en que ejecuta esa relación. Lo que se anuncia, el qué proclamado es el sentido de contenido; la referencia que establece aquel que recibe la proclamación con desde dónde viene, eso corresponde al sentido de referencia; y la forma de ejecutar esa relación establecida es el sentido de ejecución ${ }^{57}$. En otras palabras, se cubre la triple estructura de la intencionalidad aplicada al fenómeno de la anunciación. Por lo tanto, aquí no entra en juego solo el contenido de la anunciación, sino que también el hecho de que esta anunciación afecta a la comunidad cristiana primitiva, el hecho de que San Pablo se convierta en un seguidor de Cristo tiene una influencia directa en la comunidad con la que convive. Podemos apreciar de qué forma en el acontecimiento mismo de la anunciación se reflejan las tres instancias del mundo presentadas por Heidegger anteriormente, pero principalmente la del mundo propio, pero también el mundo compartido y el mundo en torno. De modo, que esta anunciación y posterior conversión de San Pablo, no solamente influye en su mundo propio, sino que también se refleja en la relación con aquellos que viven en su comunidad, pero también aquellos que viven en su comunidad influyen en él.

Heidegger considera que la inseguridad e inestabilidad son algunos de los rasgos que caracterizan la experiencia fáctica de la vida en el cristianismo primitivo, es una vida que rehúsa la seguridad y comodidad, por el contrario se vuelca en la espera incierta de la segunda venida del Mesías. "La expectativa (Erwartung) de la parousía del señor es decisiva. (...) el experienciar es una tribulación absoluta que forma parte de los cristianos. El aceptar en un colocarse en la necesidad. La tribulación (Bedrängnis) es una característica básica, una absoluta preocupación (Bekümmerung) de la parousía, de la venida del final de los tiempos" (GA 60, 97-8/126-7) Así expresa Heidegger los rasgos determinantes de la experiencia fáctica del cristianismo. Esta expectativa, esta espera, trae consigo la inseguridad, la tribulación constante acerca del cuándo de la parousía, del cuándo de la venida. Tribulación que se fundamenta en el no saber el momento preciso de la venida. La vida de San Pablo y de la comunidad cristiana, en tanto conversos, se modifica a partir de una experiencia originaria, se transforma a partir de la experiencia de la conversión, que les conduce a una nueva situación y frente a acontecimientos que antes no tenían ningún significado para ellos. Desde ahí que en su vida se enfrente a un cambio de la conducta. La expectativa de la parousía nos revela un concepto de tiempo propio de la vida fáctica. En el cristianismo primitivo no se espera la llegada de la parousía en un momento determinado, esta incertidumbre respecto al cuándo de la parousía es la que define esa espera como tribulación.

El filósofo alemán hace referencia a un pasaje de la segunda epístola a los Corintios (12,1-10), que Pöggeler comenta de la siguiente forma:

\footnotetext{
57 Cf. Redondo, P., Experiencia de la vida y fenomenología en las lecciones de Friburgo de Martin
} Heidegger, op. cit., p. 364. 
se trata pues del tema de la "astilla de la carne"(...)San Pablo dice en este pasaje que él no se gloria como podría hacerlo un místico que hubiera sido transportado al tercer cielo, hasta el paraíso. Si se hubiera gloriado, ciertamente no hubiera dicho sino la verdad pero, para que no se envaneciera al recibir revelaciones más altas, le ha sido dada sin embargo una astilla, una espina en la carne. Sigue diciendo que un "ángel satánico” lo ha sometido y golpeado, y que este ángel satánico se apartó de él gracias a haberle rezado por tres veces al señor. Mas el señor habría dicho: "conténtate en mi gracia, pues mi fuerza es poderosa en los débiles." Por ello, el Apóstol se gloriará, si acaso, más por su debilidad que por sus revelaciones y visiones. A partir de estas palabras del Apóstol, Heidegger pone de manifiesto cómo la orientación hacia la facticidad de la vida consiste justamente en la renuncia a visiones y revelaciones caracterizadas por su contenido intrínseco, en el rechazo de la vanagloria por haber logrado una gracia de tipo particular, y en el tomar sobre sí la debilidad"58.

Es evidente entonces que para la experiencia de vida del cristianismo primitivo lo primordial no es conocer el cuándo de la venida, ni saber si eso ocurrirá más tarde o más temprano, no es una expectativa inmóvil, o un mero esperar algo que sobreviene sin nuestra participación y que conduciría nuestra existencia como si esa venida no tuviera ninguna importancia ni trascendencia para nuestra vida. Por el contrario, para el cristiano que ha entendido el mensaje de la anunciación, su vida ha sido modificada y vive en la espera tensa, en la constante expectativa de la segunda venida del Mesías. Pero no es una espera impasible, la vida no adquiere su sentido desde ese acontecimiento que tendrá que venir, sino que la obtiene desde su propia existencia aquí y ahora, teniendo presente eso sí la tribulación de la espera.

En el tiempo peculiar a la experiencia fáctica de la vida en las primeras comunidades se manifiestan dos formas distintas de vivir el tiempo. Para aquellos que no han atendido ni entendido el mensaje de forma genuina, que no se han convertido, el sentido de referencia de su vida y el modo de comportarse en su vida es la tranquilidad, la seguridad. Lo que buscan en su vida es la seguridad, una vida ajena a las preocupaciones, quieren una relación con aquello que le rodea, que no les cause ningún tipo de intranquilidad. Los que dicen, "paz y tranquilidad se entregan a lo que la vida les da, se ocupan de cualquier tarea de la vida, se dejan absorber por aquello que la vida les da; están en tinieblas en lo que hace al saber sobre ellos mismos. Los creyentes, por el contrario, son hijos del día y de la luz" (GA 60, 105/134). Están aquellos que no quieren tener mayores preocupaciones que las que les puedan surgir en el trato con las cosas del mundo. Ellos viven en tinieblas, en oscuridad, se absorben en su trato con las cosas, con aquello que el mundo les entrega.

Pero aquellos que ha entendido el mensaje, que se han convertido en virtud de una experiencia fundamental -la anunciación, la proclamación-, viven su vida como una tribulación constante, viven su vida en la inseguridad, con la constante preocupación de la segunda venida del Mesías. No intentan determinar el cuándo de la venida de la parousía,

\footnotetext{
58 Pöggeler, O., El camino del pensar de Martin Heidegger, op. cit., p. 45.
} 
porque si quisiéramos determinar el cuándo consideraríamos el tiempo como actitudinalmente objetual. Por el contrario, "no hay seguridad alguna para la vida cristiana; la continua inseguridad es también lo que caracteriza las significatividades básicas de la vida fáctica. Lo inseguro no es casual sino necesario. Esta necesidad no es lógica ni natural. Para ver con claridad hay que reflexionar sobre la vida en su propio ejercicio"(GA $60,105 / 133)$. Heidegger establece con claridad las diferencias entre la forma de vida del converso y la de aquellos que optan por la seguridad aparente, por la tranquilidad que le brindan las cosas cotidianas, viven completamente sumergidos en su quehaceres mundanos.

Para el converso no tiene mayor relevancia fechar en el tiempo la venida del Señor, subordinándola así a una sucesión temporal, por eso aquellos que se preguntan y se preocupan constantemente por el cuándo, lo que hacen es preguntarse por el contenido, por el qué, están objetualizando esa venida, realizan una determinación objetual de la parousía, en otras palabras, no es un interés verdadero y propiamente personal lo que les motiva, sino que "están presos de lo mundano"(GA60,105/134), presos de aquello que el mundo inmediato les entrega y se sumergen en él, consideran la venida como objetualmente disponible.

El comportamiento que se exige a los cristianos de las primeras comunidades es el de mantenerse atentos, en vigilia permanente, también se les exige mantenerse sobrios, esta es la conducta que deben observar aquellos cristianos conversos; estar en alerta constante ante la segunda venida del Mesías. Es una expectativa preocupada, que implica saber de la inseguridad y de la dificultad, lo que hace de este momento una instancia única e irrepetible, por lo tanto, la comprensión del tiempo peculiar al cristianismo primitivo, no se entiende como una mera sucesión de ahoras ni como tiempo calculable, estas acepciones parecen no cuajar en la vivencia del tiempo propia del cristianismo primitivo. La vivencia, la preocupación, la inseguridad, la tribulación, hacen patente una vivificación intensa de ese instante, de ese momento, cuestión que aquellos que no se convierten no pueden vivenciar, no pueden experienciar, dado que se sostienen en la aparente seguridad y bienestar que les entrega el mundo y las cosas que tiene alrededor.

Es evidente que Heidegger considera como tarea indispensable dejar ver los fenómenos en su originariedad, que se den en su sentido genuino, y es lo que él cree lograr con esta explicitación de la experiencia fáctica del cristianismo primitivo y de su peculiar vivencia de la temporalidad. Sin profundizar mayormente en esto, hemos de destacar que ya aparecen aquí fenómenos que luego adquirirán un protagonismo especial en su filosofía ; el tiempo, la caída, la autenticidad y la preocupación. Estos son fenómenos de una importancia señalada en la filosofía de Heidegger, es en estas lecciones donde se dibujan sus primeros esbozos y que más tarde en su filosofía serán desarrolladas largamente. Es importante tener en cuenta, que "este vuelco sobre el ser humano individual y creyente, a saber, sobre la vida en cada caso mía, va acompañado de una serie de caracterizaciones 
propias de su existencia: “cuidado", “disposición”, “comprender", “angustia”, “muerte”, "caída" y "conciencia" son algunas de las más relevantes y de las que más tarde ocuparán un lugar central en la analítica existenciaria de Ser y tiempo ${ }^{59}$.

Todo esto volverá a ser tratado por Heidegger en relación a la segunda carta a los tesalonicenses, no obstante, no se deben considerar las cartas como asuntos aislados o distintos, por el contrario, entre ellas se puede verificar una estrecha conexión. La segunda epístola es menester comprenderla desde el significado que posee la primera para aquellos que la han entendido y por ende han comprendido el mensaje, lo han hecho suyo, en otras palabras, que se han convertido. La pregunta principal de la segunda epístola tiene que ver con la expectativa de la parousía, San Pablo señala ahí que no se debe preguntar por el cuándo de la parousía, lo que se exige es una conducta particular frente a ella; que se permanezca atento, vigilante y sobrio ante la expectativa de su llegada. No se señala un fecha determinada, ni se fija un cuándo ésta ha de venir, "este no piensa ni por un momento en responder a la cuestión del cuándo de la parousía. El cuándo está determinado por el cómo del comportarse, que, a su vez, es determinado por el ejercicio de la experiencia fáctica de la vida en cada uno de sus momentos" (GA 60, 106/135). Según Heidegger, en esta carta San Pablo no ha considerado en ningún momento dar alguna luz respecto al cuándo de la segunda venida del Mesías, ni menos pretende señalar el cuándo de esta. Dicha decisión busca de alguna forma profundizar esa inseguridad y tribulación, no puede ser un cuándo disponible ni menos verificable. El saber de la parousía tiene un carácter especial, que remite a los tesalonicenses a ellos mismos y a lo que saben, en cuanto han llegado a ser, el modo de responder a la pregunta depende de una decisión, depende de su propia vida

Todo esto significa que la inseguridad y preocupación propia de la vida en su experiencia fáctica, se solventa en un trato peculiar con la venida del Señor, en esta tribulación y preocupación de la vida cristiana se sustenta una relación originaria con la segunda venida del Mesías. Y esto, en cada uno de los momentos del ejercicio de la experiencia fáctica de la vida del cristianismo primitivo, no en unos momentos sí y en otros no, sino que en cada uno de ellos, en la forma cómo vivo mi religiosidad, en el día a día de la vida en su facticidad. Por ello:

Si la parousía depende de cómo vivo, entonces no estoy en condiciones de conllevar hasta el final la fe y el amor que se me exigen, y entonces me veo llevado al borde de la desesperación (der Verzweiflung). Los que así piensan se angustian en sentido auténtico, bajo el signo de la verdadera preocupación (der Wahren Bekümmerung) de si podrán llevar a cabo las obras de la fe y el amor y si aguantarán hasta el día decisivo. Pero San Pablo no les ayuda, sino que les acrecienta aún más su necesidad (GA 60, 107/136).

En esta reafirmación de la tribulación, de la inseguridad propia de la vida del cristiano, San Pablo quiere impedir que la vida olvide esa preocupación, esa inseguridad, ya que el

$\overline{59}$ Adrián, J., Heidegger y la genealogía de la pregunta por el ser, op. cit., p. 197. 
instante mismo en que la aparten de su comportamiento vital, en el momento en que la preocupación no sea su sentido de referencia, se abandonaría ese estado de vigilia permanente, lo que traería como consecuencia que la vida se perdería en los quehaceres mundanos, huiría de sí misma hacia una tranquilidad aparente, hacia una seguridad que les brindan las cosas del mundo.

Por eso, esta posición de San Pablo en la segunda carta a los tesalonicenses, que aumenta la tribulación y la necesidad, está dirigida a aquellos que creyeron que la primera carta les entregaba una promesa futura de seguridad y tranquilidad. Ellos han malentendido el mensaje, han abandonado el comportamiento auténtico de la vida cristiana y se han refugiado en esa aparente seguridad que le entregan las cosas del mundo. Lo que San Pablo hace, es dar una voz de alerta, un llamado de atención a su comunidad para no caer presa en los quehaceres mundanos, en la seguridad que le ofrecen las cosas del mundo. Los llama a mantenerse en la tensión, aumenta su preocupación e inseguridad y los insta a mantenerse vigilantes; aquí "no hay una disminución, sino un incremento de la tensión en cada una de las expresiones, toda la carta urge más que la otra: no se revoca nada, sino que se acrecienta la tensión" (GA 60, 108/137). Es un llamado a la comunidad cristiana a mantenerse alerta y vigilante, a no malinterpretar el mensaje, este llamado hace más fuerte la tensión y la tribulación. Por lo tanto, en ningún caso Pablo quiere tranquilizar a su comunidad ni tampoco los llama al sosiego, lo que pretende es incrementar, aumentar la tensión y la preocupación de la comunidad cristiana, para conseguir que se mantengan atentos y no bajen la guardia.

Es menester no malinterpretar el significado que tiene en la experiencia de vida del cristianismo primitivo ese cambio de comportamiento que se produce en virtud de la experiencia originaria. Siguiendo los cánones del rigor fenomenológico, que no privilegia el contenido, el qué de la vida cristiana; lo relevante de esto es que posterior a la aceptación del mensaje y de su respuesta a él, lo que se modifica no es el qué o el contenido de la vida cristiana, el contenido permanece invariable. Teniendo en cuenta esto, Heidegger recuerda la cita de San Pablo: “¿Que cada uno permanezca en el estado mismo a que fue llamado! Se trata solo de conseguir un nuevo comportamiento básico con respecto a esto, que tiene que ser mostrado en su estructura ejecutiva. Las significatividades existententes de la vida real se viven (...) como si no"(GA60,119/146). En consecuencia, no son los contenidos de la vida los que se transforman, pueden permanecer de la misma forma, pero lo que ha cambiado es la forma de verlos, la forma de relacionarse con ellos, es decir, se modifica el modo cómo se ejecuta esa relación. Y esto ha de hacerse patente en la ejecución misma de la vida del cristiano de las primeras comunidades. Por lo tanto, siguen manteniendo las mismas creencias, siguen atendiendo el mensaje, lo que cambia es la forma en que ejecutan su vida en relación con ello, la forma de relacionarse con el mensaje. 
Lo que varía en la experiencia fáctica de la vida del cristianismo primitivo no es la mundanidad o no de dichos contenidos, sino que el cristiano vive todo su contenido y ocuparse con estos como una ejecución, es decir, centrado en el mundo del sí-mismo. Puntualmente lo vive como una ejecución temporal, definida por la constitución temporal de su existencia. Como dice Heidegger, a través de la conversión, por el haber llegado a ser, "las significatividades del mundo circundante se convertirán, por el haber llegado a ser, en bienes temporales. El sentido de la facticidad en esa dirección se define como temporalidad" (GA60,119/148). El cristiano vive en el todavía, en el tiempo que queda para el final de los tiempos. Esta experiencia del tiempo del cristianismo primitivo hace manifiesta la facticidad de la vida como temporalidad, que se comprende como fundamentalmente abierta hacia el futuro, revelando así su carácter temporal prioritario. La vida fáctica, la historia, no son objetos ni pasan en el tiempo, el pensador alemán entiende que esta experiencia fáctica de la vida del cristianismo primitivo muestra una forma de ser que no se pierde absolutamente en los contenidos del mundo, sino que se realiza como temporalidad en la expectativa de la parousía, que ejecuta su propia vida por sí mismo y desde una comprensión propia.

Se cumple así con la prioridad que tiene para Heidegger el sentido ejecutivo en la estructura de la intencionalidad del método fenomenológico, que se presenta como el sentido primordial y explica cómo en la experiencia fáctica del cristianismo primitivo opera un cambio en la forma de relacionarse con el mundo, que no es una transformación de los contenidos de su existencia. Heidegger resume lo anterior, diciendo que, "la experiencia cristiana de la vida se modifica por el mismo haber llegado a ser (Gewordensein). El sentido de referencial de la vida cristiana es distinto del sentido del mundo circundante. Si el sentido referencial del mundo circundante estuviese autónomamente en la experiencia de la vida cristiana, algunos pasajes de la obra de San Pablo serían incomprensibles. El volcarse a la vida cristiana concierne al ejercicio" (GA $60,121 / 150)$.

\section{E. LA OPOSICIÓN ENTRE TIEMPO KAIROLÓGICO Y CRONOLÓGICO}

En la exposición de la experiencia fáctica de la vida del cristianismo primitivo, Heidegger hace referencia a una cuestión que tiene una importancia capital para su proyecto filosófico, nos referimos al problema del tiempo, adquiriendo en estas lecciones universitarias un rango protagónico como pregunta fundamental de su filosofía. En primer lugar, -aunque esto se ha tratado indirectamente-, en la pregunta acerca de lo histórico se ha dejado abierta la inquietud respecto del sentido genuino del tiempo, asunto que queda oculto en virtud de la interpretación dominante acerca de lo histórico. La pregunta por el sentido auténtico del tiempo es la tarea pendiente para el método fenomenológico, así lo 
hace saber Heidegger al finalizar su estudio preliminar de lo histórico, cuando dice que, "tenemos que preguntar, antes bien: ¿qué es originariamente la temporalidad en la experiencia fáctica?, ¿qué quiere decir pasado, presente y futuro en la experiencia fáctica? Nuestra vía parte de la vida fáctica, de la que se obtiene el sentido del tiempo. Así está caracterizado el sentido del tiempo" (GA 60, 65/94). En efecto, la mayor parte de las preguntas surgidas a lo largo de los cursos nos remiten en último término al problema del tiempo y la primera pregunta que es menester resolver tiene que ver con el esclarecimiento del carácter originario del tiempo peculiar a la experiencia fáctica de la vida del cristianismo primitivo, pareciera que todos los caminos conducen hacia allí, hacia la pregunta por la temporalidad originaria de la vida humana. Si bien, el tratamiento de la temporalidad en estas lecciones es provisional y se encuentra en una fase germinal, encontramos ya ciertas ideas que son esenciales para Heidegger al momento de estructurar definitivamente el concepto del tiempo propiamente humano y que de algún modo también nos dan los primeros indicios, que posibilitan articular nuestra investigación, en cuanto sirven de fundamento a la tesis que subyace en ella.

Podemos decir, que encontramos aquí las raíces de su concepción originaria del tiempo, aunque ahora sean simples esbozos. Esta es la razón, de que estas lecciones universitarias del invierno de 1920/1921 sean una instancia clave para nuestra investigación y se entiendan como un punto de partida del proyecto filosófico de Martín Heidegger que desembocará en Ser y tiempo, esto en cuanto aquí se presentan ya con contornos más precisos los problemas filosóficos que conducirán su filosofía. Desde sus primeros escritos (El concepto del tiempo en la ciencia histórica) y lecciones universitarias, el filósofo presenta una crítica abierta a la concepción del tiempo dominante en la tradición metafísica, el tiempo como mera sucesión de ahoras siempre presentes, la medición del tiempo, en otras palabras el tiempo que mide el reloj, todas ellas interpretaciones que a juicio de Heidegger no hacen justicia con el tiempo propiamente humano, por lo que malamente se puede predicar genuinamente lo histórico de la vida fáctica. Esta experiencia fáctica de la vida en el cristianismo primitivo parece ser el lugar ideal para cuestionar estas nociones, y si bien no presenta aquí un concepto del tiempo claramente delimitado y definitivo, sí propone una interpretación del tiempo distinta a la tradicional, que se contrapone al tiempo cronológico, nos referimos al tiempo kairológico, en el cual se desplaza el protagonismo incuestionable que ostenta el presente en su estructura, hacia una tenue pero importante prioridad del futuro, asunto que será fundamental para el desarrollo posterior de este problema y que de alguna manera define su concepción temporal. Reverberan aquí las raíces desde las que edificará su construcción filosófica.

En la exégesis de la experiencia fáctica del cristianismo primitivo, se presenta como experiencia originaria la auténtica conversión, que se tornaba esencial en la expectativa (Erwartung) atenta de la segunda venida del Mesías, la espera de la parousía, 
que es un acontecimiento futuro que ha de sobrevenir a la comunidad cristiana conducida por San Pablo, que modificará su propia experiencia vital.

La expectativa de la parousía del señor es decisiva. No en un sentido humano son para él los tesalonicenses esperanza, sino en el sentido de la experiencia de la parousía. El experienciar es una tribulación absoluta (Das Erfahren ist eine absolute Bedrängnis) que forma parte de la vida de los cristianos. El aceptar es un colocarse en la necesidad. La tribulación es una característica básica, una absoluta preocupación en el horizonte de la parousía, de la venida del final de los tiempos. Con esto nos hemos introducido en el mundo propio de San Pablo (GA 60, 97-8/126-7).

Heidegger plantea aquí la instancia decisiva que define la temporalidad de las comunidades cristianas primitivas: la expectativa de la parousía, la espera de la segunda venida del Mesías. Este es el acontecimiento que define y determina la experiencia originaria del tiempo en cristianismo primitivo. $Y$ es una expectativa de la venida, que no puede ser un simple esperar, por decirlo así, inmóvil, quieto, no es un simple esperar de brazos cruzados a que llegue un acontecimiento que vendrá en el futuro, que aún no es pero luego se hará efectivo. Por el contrario, ha de ser una espera vigilante y tensa, que se lleva a sí misma como tribulación, expectativa preocupada de la venida del Mesías.

Incluso esta misma expectativa atribulada y preocupada, remite a los tesalonicenses hacia sí mismos, ejemplo de esto es cuando Heidegger recuerda que San Pablo "No dice: en ese momento viene el Señor"; tampoco dice: "no sé cuándo vuelve", sino: "vosotros sabéis muy bien...". Ese saber tiene que ser muy peculiar, pues San Pablo remite a los tesalonicenses a ellos mismos y al saber que poseen en cuanto han llegado a ser lo que son. De ese modo de contestar se sigue el que la decisión de la "pregunta" dependa de su propia vida" (GA 60, 102-3/131). En esta expectativa de la parousía se manifiesta una idea de tiempo que sería la propia de la vida humana en su experiencia fáctica, pero no para cualquiera, porque es esencial entender el mensaje y atender la experiencia originaria. En primer lugar, el cuándo de la venida no puede ser una fecha disponible u objetivable, los cristianos no esperan sabiendo con certeza el momento en que se producirá la llegada del Mesías, ni tampoco quieren saberlo. Para San Pablo no es una pregunta de conocimiento o algo así. Es una seña característica de su temporalidad, la indisponibilidad del cuándo, este cuándo no es importante para ellos, saber si la segunda venida se concretará más temprano o más tarde no significa nada para ellos, no tiene mayor importancia.

La expectativa de la parousía no supone una espera sumida en el quietismo, sino que tiene que ver con la ejecución y movilidad constante propia de la vida humana. Por eso, esta expectativa no está caracterizada como un esperar si más a que algo en el futuro sobrevenga, sino que la vida fáctica ha de participar de forma activa en esa venida de la parousía - pero no haciéndola disponible o cosificándola-, si se la comprende como decisiva debe ser una expectativa activa, se debe participar de ella. Por lo tanto, es una expectativa que no se caracteriza por una espera quieta de un acontecimiento que viene 
desde el futuro y frente al cual no cabe hacer nada, si así lo entendiéramos, creeríamos que la temporalidad de la vida humana de la que Heidegger nos habla, adquiere su sentido desde un acontecimiento que luego llegará y se hará presente, dicho de otra forma, que obtiene su significado desde un hecho que aún no es, pero luego será. La vida se ejecuta aquí y ahora, su carácter temporal se manifiesta en la ejecución, en su ejercicio aquí y ahora, en su experiencia fáctica de la vida, eso sí determinada por la seguridad de la segunda venida, que se sustenta en una relación peculiar con Dios. Por una parte, seguridad en la venida, pero por otra, indisponible y sin posibilidad de objetivación alguna, por ello dice el autor de Ser y tiempo, que "de aquella conexión ejecutiva con Dios nace algo así como la temporalidad" (GA 60, 114/143), en esa relación que mantenga el cristiano converso con Dios se juega la posibilidad de una expectativa auténtica de la parousía y surge la temporalidad genuina de la vida fáctica.

Esta idea de la temporalidad surgida desde el seno del cristianismo primitivo, muestra dos formas de entenderla, dos forma de vivir la temporalidad. Para aquellos cristianos cuyo sentido de referencia de su vida es la seguridad y la tranquilidad, que no se han convertido y creen encontrar la seguridad en las cosas del mundo, objetivando y haciendo disponible el tiempo, lo que insinúa una primera indicación sobre la propiedad e impropiedad de la vida, Heidegger comenta en relación a aquellos que no se han convertido, que no han comprendido el mensaje, que:

una calamidad repentina cae sobre ellos. (...) Se verán sorprendidos por ella, pues no la esperan. $\mathrm{O}$ antes bien: están justamente en la espera actitudinal; su esperar expectante se absorbe en lo que la vida les procura. Ya que viven en esa expectativa, les afecta la calamidad de tal forma que no pueden escapar a ella. No pueden salvarse a sí mismos, porque no se tienen a sí mismos, porque han olvidado su propia mismidad (Selbst); porque no se tienen a sí mismos con la claridad del auténtico saber (GA 60,103/132).

Nos encontramos aquí ya con una primera idea de la propiedad e impropiedad como fenómenos que ya interesan al joven profesor.

Pero aquellos que se han convertido en virtud de una experiencia original, no intentan objetivar el tiempo ni hacer disponible el momento de la segunda venida del Mesías, el tiempo se relaciona principalmente con la inseguridad, con la tribulación, haciendo cada instante como propio, intensificando la vivencia de cada momento. No es un tiempo lineal, calculable o disponible, por eso cuando San Pablo dice, ““"estemos vigilantes", vemos que la cuestión del "cuándo se retrotrae a mi comportamiento. Como la parousía está en mi vida, ésta remite al ejercicio de la vida misma. El sentido del "cuándo", del tiempo en que cristo vive, tiene un carácter especial. Antes hemos caracterizado formalmente: "la religión cristiana vive la temporalidad". Es un tiempo sin orden propio, sin lugares fijos etc. Mediante un concepto objetual del tiempo es imposible acertar es esa temporalidad. De ningún modo el cuándo es objetualmente aprehensible" (GA 60, 104/132), lo que Heidegger hace aquí, es proponer otra idea de tiempo, la de un 
tiempo que no puede ser objetivado, ni calculado, en tanto que la experiencia temporal considerada de esta manera queda muy corta a la hora de comprender el tiempo de la experiencia fáctica de la vida del cristianismo primitivo. Esta temporalidad no tiene lugares fijos, nunca un momento es igual a otro ni un instante es repetible. El tiempo no es aprehensible al modo como se aprehende un objeto. Querer determinar el cuándo de la parousía presupone una malcomprensión de su carácter indisponible, inobjetivable, lo que no significa que a ella le sea propio una carácter supratemporal o ajeno al tiempo. Al intentar fijar, determinar u objetivar la parousía en su cuándo, se está eligiendo el camino equivocado para poder comprenderla genuinamente. Le pertenece a ella una dimensión temporal que se está por develar.

Heidegger reconoce dos formas de vida en el cristianismo primitivo: en uno se vive la venida del Señor como aquello que le entrega una cierta seguridad en cuanto venida disponible, viven una aparente tranquilidad en sus vidas, aunque no sepan el cuándo de esa venida. En cambio, los cristianos que han atendido y comprendido de modo auténtico el mensaje, viven su vida como constante vigilia, como un constante mantenerse despiertos y atentos en la expectativa de esa llegada del Señor. No pretenden determinar el cuándo, sino que desean vivir en plenitud esa expectativa, vivir en la tribulación e inseguridad del momento, es decir, intensificándolo. Heidegger reconoce en estas dos modos de vivir la vida dos formas de tiempo distintas. Una que intenta objetivarlo y hacerlo disponible y otra que establece el modo de vivir según la relación que se mantenga con Dios, con la experiencia originaria de la segunda venida del Mesías. A partir de la experiencia originaria y de la relación que se guarde con ellas se adquiere el sentido originario del tiempo. En esta estancia de su pensamiento ese papel lo juega la venida de la parousía, pero posteriormente será la muerte el fenómeno que tenga ese rol en el interior de la analítica, pero siempre se trata de una experiencia originaria, donde adquiere sentido la vida humana en su ejecutividad. Pero también en razón de la relación que se establezca con esa experiencia originaria, por ello se indica que el cristiano es de modo propio, que se ha convertido, porque ha entendido el mensaje.

Esta idea de la temporalidad en el cristianismo primitivo, nos ofrece la perspectiva de un tiempo que no está sometido a la cronología, a la disponibilidad, ni a un cómputo del tiempo que nos pueda indicar el cuándo de la parousía, sino que nos remite hacia sí mismos, hacia lo más propio de cada cual. Dice San Pablo, "No hay necesidad amados hermanos, de que os escriba por lo que hace al tiempo o la hora, pues vosotros mismos sabéis con certeza que el día del señor llegará como un ladrón en la noche" (Tes, 5:1-2). Con estas palabras del Apóstol, se reafirma y sustenta lo anterior, la idea de tiempo en la experiencia fáctica del cristianismo primitivo alude a un tiempo que no es verificable, ni computable, es un tiempo que no se encuentra en la cosas de la naturaleza o del mundo, es un tiempo que pertenece a nosotros mismos, en virtud de cual, somos remitidos a nosotros 
mismos, a nuestro propio ser, a nuestro ser sí mismos. Desde ahí obtenemos la certeza, la seguridad de la indisponibilidad del tiempo, la inseguridad del cuándo de la venida.

Es un tiempo propiamente humano, que no obtiene a partir de las cosas del mundo o de la naturaleza, sino que su sentido esencial viene dado desde la experiencia originaria que adviene sin fijar o determinar su cuándo. Es más sin ni siquiera preguntar por ese cuándo, sino que debe mantenerse como indisponible, ese es su carácter esencial. Esta indisponibilidad e inseguridad, interpela a la comunidad cristiana a mantenerse alerta, situación que intensifica su preocupación y tribulación. En ella, en la aceptación de esa necesidad vive el tiempo originariamente, sabiendo que la venida de la parousía, no puede llegar en tal o cual día, sino que es indeterminada, no puede ser objetivada, sino que ese día llegará como un ladrón por la noche.

En consecuencia, Heidegger nos sitúa frente a dos actitudes de experienciar el tiempo, dos formas de vivir el tiempo: uno es el carácter propiamente cronológico y el otro es el kairológico. A juicio de San Pablo, la experiencia en la que se fundamenta el cristianismo primitivo, es la expectativa de la segunda venida del Mesías.

\footnotetext{
San Pablo, señala Heidegger, no hace ninguna indicación temporal de la segunda venida e incluso rehúsa expresamente darla. Por ejemplo, la segunda venida no es fijada en el milenio de los seguidores del quiliasmo; San Pablo habla solo de su "subitaneidad". No de características "cronológicas", sino "kairológicas". El kairós está en el filo de la navaja, en la decisión. Las características kairológicas no computan ni domina el tiempo, sino que se emplazan más bien en la amenaza producida por el advenir. Pertenecen a la historia acontecida de la cumplimentación de la vida, historia que no puede ser objetivada ${ }^{60}$.
}

Pöggeler distingue de este modo, las dos formas de vivir el tiempo que Heidegger ha reconocido en la experiencia fáctica del cristianismo primitivo. Una concepción originaria del tiempo, que enfrenta al cristiano con la segunda venida del Señor, una experiencia originaria, cuyo punto de referencia es un acontecimiento futuro que de algún modo le abre la posibilidad de ser cristiano de modo propio, si ha comprendido el mensaje, y está en constante alerta a la segunda venida. Está a la expectativa de ese acontecimiento futuro, lo que exige una decisión en un aquí y ahora. No es una expectativa quieta, sino decidida, un futuro que ya se vive en el presente, pero no como presente. Sino como una posibilidad, aunque Heidegger no hable precisamente de posibilidad en estos cursos, podríamos entenderlo así. En tal sentido, "Heidegger descubre la originaria experiencia cristiana del tiempo como kairós : una comprensión de la temporalidad que permite experimentar la vida fáctica en sus rasgos esenciales. Así como el cristiano experimenta la vida fáctica en su historicidad puesto que el tiempo no es entendido como medida sino que, por el contrario, es vivido" ${ }^{\prime \prime}$.

\footnotetext{
${ }^{60}$ Pöggeler, O., El camino del pensar de Martin Heidegger, op. cit., p. 44.

${ }^{61}$ Segura, C., Hermenéutica de la vida humana, op. cit., p. 25.
} 
Hay que señalar que Heidegger si bien cita el tiempo propiamente kairológico, no desarrolla de forma más extensa este concepto, apenas lo menciona un par de veces más en estas lecciones, pero sin llegar a profundizar en él. Pero creemos que lo utiliza porque es una forma de presentar otro concepto del tiempo, una alternativa a la forma tradicional de entenderlo, que sea capaz hacer frente al tiempo cronológico como perspectiva omnipresente a lo largo de la historia de la filosofía. Creemos que esta sería la principal razón de su utilización en este contexto, en tanto que el filósofo alemán no se preocupa mayormente en desarrollar de forma más acabada este concepto, sino que solo lo enuncia como contraparte al tiempo cronológico. Como sostiene Berciano,

\begin{abstract}
El término kairós se refiere en todo momento se refiere en todo este contexto al momento de parusía (...) Heidegger repite una y otra vez que este kairós no se rige por el tiempo objetivo, no tiene una fecha; depende solo de Dios y vendrá como el ladrón por la noche, sin poder ser calculado o predicho de antemano. No es un chronos que se puede regir por el movimiento de los astros o el calendario, pero sí es temporal: no es eternidad atemporal ni posesión definitiva. Estos caracteres determinan la situación de la existencia cristiana. Heidegger dice que es una existencia que vive la temporalidad y no solo el tiempo. y vivir la temporalidad significa aquí vivir en constante vigilancia, porque el momento es incierto; vivir en la incertidumbre, ya que mientras se está en el tiempo nada es definitivo; vivir sin paz y sin seguridad definitiva, sino más bien en la tribulación. Pero al mismo tiempo vivir en la esperanza (...) Todo esto implica la vivir la temporalidad en el cristianismo primitivo $^{62}$.
\end{abstract}

El vivir vigilante y despierto, se contrapone a una objetivación de ese futuro, de esa segunda venida, y no la calcula como algo disponible. Esta caracterización del tiempo como imprevisto e incalculable nos acerca a esa idea del tiempo propiamente humano, distanciándose del llamado tiempo de la naturaleza, del mundo, de forma tal, que la vivencia de la temporalidad del cristianismo primitivo, que está dirigida primordialmente hacia el advenir, hacia la segunda venida del Mesías, abre una nueva y original vía de interpretación del tiempo. En este sentido referencial de la vida cristiana, entendido como la expectativa de la segunda venida de Cristo, es donde surge el nexo con Dios y propiamente la temporalidad. Dios no se manifiesta como algo eterno, sino que por el contrario, se nos hace patente en la expectativa atenta de un acontecimiento futuro, en el que se define la autenticidad de la experiencia religiosa. Respecto a esto Heidegger comenta que viven la vida como un aún no, como un estar primariamente abiertos hacia el advenir de la parousía, vueltos hacia un futuro inobjetivable, que no puede ser objetivado y determinado en términos cronológicos.

la fe del cristianismo primitivo experiencia la vida en su factualidad; como dice el joven Heidegger, esa fe se da en la experiencia fáctica de la vida, es esa experiencia vital misma. Pero la experiencia fáctica de la vida es "histórica"; entiende la vida históricamente o, como diríamos hoy, "como acontecer histórico". No solo vive en el tiempo, sino que vive el tiempo mismo. Gracias a la meditación sobre la religiosidad del cristianismo primitivo

62 Berciano, M., "Filosofía heideggeriana y kairós" en Las razones del corazón, (Eds.) M. Pena, Castillo Caballero, Naturaleza y Gracia, Salamanca, 2007, p. 121-122. 
como modelo de la experiencia fáctica de la vida adquiere Heidegger los conceptos rectores que ponen de relieve la estructura de vida fáctica $\mathrm{o}$, como dirá más tarde, de la "existencia fáctica" ${ }^{3}$.

Por lo tanto, es un tiempo que está fuera de todo cálculo o medida, que tampoco puede ser objetivado.

La experiencia fáctica del cristianismo primitivo muestra su sentido temporal como primordialmente futuro, gracias a la expectativa del advenimiento de la parousía. Esta sería para Heidegger una experiencia originaria del tiempo, cuestión que además abre una original vía de cuestionamiento filosófico, poniendo en duda principalmente el concepto del tiempo como simple presente, o como sucesión de ahoras siempre presentes (la objetivación del tiempo, el cálculo del tiempo, el tiempo cronológico, el tiempo como medida). Además:

si el hombre intenta fijar mediante cómputos cronológicos o por caracterizaciones medidas según su contenido intrínseco el acaecimiento propicio, indisponible y sobre el que se asienta su vida, empieza entonces, como si se tratase de algo asegurado, disponible, aquello que en cuanto indisponible, debe determinar-y-destinar su vida. Pero de esta manera se engaña sobre el carácter factual de la vida: "Pues", escribe San Pablo, "cuando digan: hay paz, no hay ningún peligro, les sorprenderá entonces con prontitud la perdición. A la manera en que llega el dolor a la mujer encinta, y no escaparán". El pensar de Heidegger está sostenido, y sigue estándolo, por la sospecha de que el pensar que desplaza-y-desfigura la referencia del advenimiento indisponible y calcula el tiempo volviéndose hacia contenidos disponibles, "objetivos", no escapará a la perdición ${ }^{64}$.

Según Pöggeler, Heidegger está haciendo referencia a un asunto que ya había planteado en el escrito de habilitación El concepto del tiempo en la ciencia histórica, está criticando la formulación clásica del concepto del tiempo, como tiempo objetivo y calculable, como tiempo de la naturaleza, interpretaciones que desfiguran una comprensión propia del tiempo y de lo histórico, esto último largamente tratado en estos cursos de fenomenología de la religión. No se puede entender el tiempo propiamente humano como tiempo objetivable o como tiempo de la naturaleza, no se le puede asignar aquella generalidad que se aplica a los objetos que pasan en el tiempo.

Heidegger exige para la vida humana un nuevo y genuino status temporal, que sea capaz de dar cuenta de su esencial constitución temporal. Esta primigenia formulación de la temporalidad propiamente humana es lo que hace de estas lecciones universitarias un momento clave para nuestro trabajo. Lo dice claramente Colomer, cuando comenta que, "la fe cristiana originaria experimenta, pues, la vida en su facticidad. Es, en expresión del joven Heidegger, en la experiencia de la vida fáctica esta misma experiencia de la vida, no necesita ser "interpretada", sino solo "explicitada". El tiempo "calculable" de la ontología griega, el tiempo del reloj que domina la filosofía, la ciencia, incluso la vida del hombre

${ }_{63}$ Pöggeler, O., El camino del pensar de Martin Heidegger, op. cit., p. 45.

${ }^{64}$ Ibíd., p. 44. 
moderno, fracasa ante esta experiencia del cristianismo originaria" ${ }^{65}$. Esta misma experiencia originaria que le permite a Heidegger desarrollar su concepción de la temporalidad y de la historicidad, se pueden leer en ellas las claves que permitirán moldear su constructo filosófico, que será modificado, perfeccionado, pero sin lugar a dudas, estamos aquí frente a una primera formulación de su idea de la temporalidad propiamente humana y la dirección que apunta su meditación se mantendrá inalterable, nos referimos a la temporalidad propia de la existencia cuyo carácter fundamental es el de ser advenidera, el ser futuro como sentido del tiempo, qué es lo que la constituye de modo originaria, pero también en estas lecciones se puede verificar aquel interés que se mantendrá inalterable con el paso de los años y a lo largo de su labor filosófica, nos referimos a la pregunta por el ser.

Todo lo anterior lo resume Gadamer magistralmente, comentando que, "la experiencia del tiempo que Heidegger había encontrado en Pablo era la del retorno de Cristo, que no es un retorno que se pueda esperar, y que significa una parusía, es decir, un advenir y no una presencia" ${ }^{66}$.

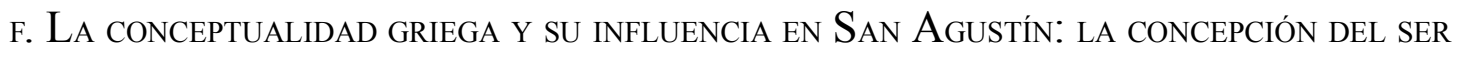 COMO PRESENCIA CONSTANTE}

La experiencia fáctica del cristianismo primitivo se ha mostrado como un terreno fértil, del cual Heidegger se ha servido para poder exponer la comprensión de la vida que considera como una experiencia de carácter originario, pero que según él, a lo largo del tiempo dicha originariedad ha ido decayendo paulatinamente. Esta experiencia fáctica de la vida ha permitido exponer una vivencia del tiempo considerada como experiencia genuina. Como sabemos, para Heidegger la crítica al concepto del tiempo en la ontología clásica es una de las instancias decisivas dentro del proyecto destructivo de su filosofía. La crítica y el desarrollo de un planteamiento originario del tiempo, se convertirá más adelante en el sustento de su quehacer filosófico, convirtiéndose en una de las vertientes de las que se alimenta su filosofía, que le permitirá plantear la reformulación de la pregunta por el ser, gracias a su conexión con la cuestión del tiempo.

Esta mal comprensión del tiempo, de lo histórico, de la temporalidad propiamente humana, que Heidegger ha denunciado tiene como punto de partida una interpretación cuyo origen está en la filosofía griega, es la consideración del ser como Anwesenheit, como presente constante-asunto que si bien Heidegger no presenta aquí de forma clara, podemos decir que se hace manifiesto de una forma tangencial-. Colomer comenta respecto a esto:

\footnotetext{
${ }^{65}$ Colomer, E., El pensamiento alemán. De Kant a Heidegger, op. cit., p. 485.

${ }^{66}$ Gadamer, H., "La dimensión religiosa" en Los caminos de Heidegger, op. cit., p. 158.
} 
que la teología cristiana tradicional, montada sobre el aparato conceptual griego, soterró bajo sus objetivaciones aquella experiencia originaria de la primera comunidad. Por ello, para recuperar esta experiencia soterrada hay que "destruir" la teología tradicional, en el sentido que Heidegger da a la palabra destrucción, que significa socavar y poner en cuestión para dar así el verdadero fundamento. Ahora bien, Heidegger se da cuenta de que la destrucción no se refiere primariamente a la teología cristiana, sino a la metafísica griega de la que aquella depende ${ }^{67}$.

De esta forma, se presentan sintéticamente los objetivos y la intenciones últimas de este segundo periodo de lecciones universitarias del verano de 1921, titulado Agustín y el Neoplatonismo (Augustinus und der Neuplatonismus).

En estas lecciones sobre San Agustín, Heidegger trabaja largamente el libro X de las Confesiones; lo hace de la misma forma en la que había tratado los textos de San Pablo. Este es el terreno seguro desde donde Heidegger ha recogido las experiencias fundamentales, que le han servido para exponer la experiencia fáctica de la vida de las primeras comunidades, pero ahora, será San Agustín el interlocutor elegido para exponer la forma en que la conceptualidad griega ha influenciado y oscurecido la experiencia religiosa cristiana. Por eso, Heidegger señala:

en la figura objetiva de la metafísica y de las cosmología griegas radica el problema del sentido de la ciencia teórico-objetiva, y la pregunta por la experiencia interior y la esencia del nexo facticio oculta (fáctico) (des faktischen Zusammenhangs birgt) un fenómeno de radicalidad mucho mayor-simplemente como título demarcador: "vida fáctica" (faktisches Leben)-, y la relación entre uno y otro es algo diferente a una inserción del uno en el otro y de este último en aquél, o lo que es igual, a una fundamentación teórico-cognitiva (constitución) de aquél en y a partir de éste(GA 60, 172/38)

El joven profesor reafirma de este modo, lo que había señalado en el curso anterior; que la filosofía, la metafísica y su conceptualidad griega han sido impotentes a la hora de preguntar por esa realidad radical llamada vida fáctica, además de dejar claro que ella no puede ser entendida bajo el prisma exclusivamente teórico. Vuelve una vez más sobre la crítica al privilegio que se le da a la objetivación y al sentido de referencia teórico, por sobre el del sentido ejecutivo. Pero lo más importante, es que aquí también resuena un cuestionamiento profundo de las consecuencias que tiene para la cultura occidental la influencia de la filosofía griega y su conceptualidad, la que perduraría hasta nuestros días. Cuestión que reflejaría de forma indiscutible el poder y alcance de dicha filosofía, que en virtud de esta penetración conceptual no problematizada, ha logrado extender su poder e influencia hacia vastos horizontes, llegando a oscurecer la experiencia originaria del cristianismo, que es en último término lo que motivaría la crítica heideggeriana.

Para Heidegger, este estudio no tiene como objetivo analizar en profundidad la obra de San Agustín, ni discutir sus tesis filosóficas tampoco discurrir sobre algún punto

${ }^{67}$ Colomer, E., El pensamiento alemán. De Kant a Heidegger, op. cit., p. 485.

68 Heidegger, M., "Agustín y el Neoplatonismo" en Estudios sobre mística medieval, Siruela, Madrid, 1997, p. 37. Trad. Jacobo Muñoz. 
en particular de ellas. Se le ha elegido por la utilidad que posee para poder hablar del presente, de la situación del hombre en la actualidad, del momento de la cultura en aquel tiempo. No es una elección antojadiza. Por eso dice Heidegger: "el Neoplatonismo y Agustín no son asumidos como una muestra discrecional del caso, sino que en la consideración ha de alzarse su historicidad hasta lo genuino, en cuya dimensión efectual estamos todavía nosotros mismos. La historia nos afecta, y nosotros somos ella misma" (GA 60, 173/39). He aquí la razón de que se elija a San Agustín, hemos de buscar en su filosofía aquello que nos lleve hasta su historicidad auténtica, para ver de qué modo muchas de las cosas que encontramos en la filosofía de Agustín siguen estando presentes en la historia y siguen influenciando el pensamiento y la filosofía actual. El filósofo alemán quiere descubrir en sus textos la presencia de determinados ideales griegos cuya presencia permanece activa y provoca que permanezcan en la oscuridad los fenómenos originarios, y esto porque dicha influencia persiste hasta nuestros días y sigue siendo decisiva en importantes ámbitos del pensamiento. "En el caso de San Agustín, la experiencia fáctica de la vida está falseada por la manera neoplatónica de pensar. Por tanto, no cabe limitarse a explicitar a San Agustín, sino que éste tiene también que ser destruido (destruiert). La interpretación tiene que captar, a través de la manera tradicional de pensar y por medio de ella, la experiencia que yace propiamente en su fondo (Grunde); esta experiencia tiene que ser liberada de la inadecuada forma de pensar en que ella se formula" $"$.

San Agustín en las Confesiones trata fundamentalmente de su vida, de su forma de enfrentarla, deja de ocuparse de su pasado para ocuparse de lo que él es ahora. El libro X de las Confesiones se inicia con una invocación a Dios, San Agustín quiere saber qué significado puede tener una confesión ante Dios, el libro se puede entender precisamente como eso: una confesión ante Dios, al que nada le queda oculto. Pero además de ser una confesión ante Dios, es una confesión ante los semejantes. En tanto confesión, San Agustín pretende comunicarle algo a Dios y al prójimo, se propone hablar de sí mismo y de sus actos. En esta confesión hay un cierto saber de sí mismo, no obstante, este saber de sí mismo es incompleto y esto también lo quiere dejar claro. No presume de un conocimiento acabado de sí mismo, pero si hay algo de lo que está seguro, su sabiduría más cierta es que ama a Dios. Al mismo tiempo, se pregunta San Agustín por la naturaleza peculiar de este amor a Dios, para Agustín es importante descubrir el carácter propio de ese amor a Dios, por ello se pregunta, “¿Qué amo cuando te amo? Agustín intenta obtener una respuesta para esta pregunta investigando qué hay digno de ser amado y si entre ello figura algo que es el propio Dios o lo que es igual, algo que vive en el amor de Dios le llene de felicidad o plenitud, le otorgue "la visión capaz de colmarle", aquello, en fin, a lo que tiende en su amor a Dios" (GA 60, 179/46). Según Heidegger, en esta pregunta queda manifiesto que para poder preguntar a Dios es necesario tenerlo de algún modo.

69 Pöggeler, O., El camino del pensar de Martin Heidegger, op. cit., p. 46. 
Hay que tener a Dios para poder dirigirnos a él, para poder amarle. Es lo que quiere decir San Agustín cuando se pregunta, “y ¿Cómo puedo buscarte si no te poseo de algún modo, si no sé de ti? (no puedo, pues, decir en absoluto que no tengo algo, ¿tengo pues también de alguna manera a Dios?)¿Qué quiere decir en tal caso buscar? (GA 60, 190). Heidegger destaca con estas palabras, que preguntar por Dios significa tenerlo de alguna forma, por lo cual se tiene eso mismo buscado. Pero qué quiere decir ese buscar, qué es lo que se busca realmente. Esta indagación es una de carácter tal, que está llena de dificultades, es un camino duro y pedregoso, compromete al hombre en la misma pregunta, motivo por el cual, éste pasa a ser algo distinto, no es solamente el interpelador, sino que también es el interpelado, "No solo soy aquel del que parte la búsqueda y se mueve hacia algún lugar, o en el que ocurre la búsqueda, sino que la propia ejecución de la búsqueda es algo de él mismo" ( GA 60, 192/63).

Siguiendo este camino trazado por San Agustín, la pregunta por el modo cómo se busca a Dios, se convierte en la pregunta por la forma en que se busca la vida bienaventurada. La pregunta que se hace San Agustín, es por aquello que se ama, y esto lo pregunta así: “¿pues acaso no es la vida bienaventurada la que todos apetecen, sin que haya ninguno que no la desee? (Querer la vida"-vita beata. Es algo que todos quieren sin que haya nadie que no la quiera)" (GA 60,193/66). Según Heidegger, en este planteamiento del obispo de Hipona, se lleva a cabo una identificación entre el anhelo de la beata vita y el correspondiente amor a Dios. La vida bienaventurada a la que todos aspiran, no puede ser considerada únicamente un goce, como si el deseo de disfrutar tuviese siempre como fin la vida bienaventurada. Pero la beata vita es un goce, pero no un disfrute circunscrito a los gustos personales de cada uno o sometida al interés de cada persona, no cualquier alegría se puede identificar con la vida bienaventurada. La beata vita es para Agustín el disfrute de Dios, consiste en gozar de él, cosa que no es comprendida por muchos hombres, que no son capaces de identificar este modo de vida con Dios, por lo tanto, hay algunos que viven su existencia de tal forma que fijan como finalidad de su vida un disfrute que no es el verdadero, un goce de la vida que no es el auténtico y genuino disfrute de ella. Dice Pöggeler en relación a esto, "la vida bienaventurada no es captada por San Agustín a partir de su contenido intrínseco, sino a partir de su carácter de cumplimentación (ejecución). La cuestión decisiva es saber cómo la vida bienaventurada es acogida por parte de la voluntad"70.

El disfrute de la vida bienaventurada se caracteriza por la estrecha relación que se establece entre ella y el goce de Dios. Pero también, el concepto de verdad entra en este contexto meditativo de Agustín. Según él, los hombres desean-por naturaleza- tener una vida de goce, de la misma forma, prefieren tener una relación con la verdad en vez de tenerla con el error. La vida bienaventurada es al mismo tiempo el goce de la verdad. San

70 Ídem. 
Agustín ha expuesto un modo de vida, que se entiende como un disfrute, pero no cualquiera, sino el más importante: el disfrute de la verdad. La vida feliz, bienaventurada, se entiende como un disfrute de Dios, que es la verdad, en tanto verdad. Por lo mismo, solamente el disfrute de Dios es el pleno y absoluto. Heidegger destaca con esto dos actitudes, que dependen de las distintas posiciones que se tenga respecto de la verdad. En algunas ocasiones puede la verdad ser detestada y rechazada, debido a que molesta, hace daño, lo que termina por enfrentar al hombre contra su propio ser. Pero, en otras ocasiones, se vive un goce estético de ella, un disfrute en la contemplación de la verdad. "La verdad, sin embargo, se le encubre al hombre que, en su indolencia, desearía quedar oculto a la vez que todo le fuera revelado. En estas interpretaciones de la vida bienaventurada y de la verdad se ve claramente y por doquier que la tendencia agustiniana está regida por la idea de cumplimentación y que la experiencia fáctica de la vida está aquí caracterizada por el predominio de la tendencia a la cumplimentación, y no por el de la orientación hacia contenidos"

Sin embargo, Heidegger también ve en esto una profunda penetración griega en el discurso agustiniano, en virtud de la importancia superlativa que éste último le concede a la verdad al interior de su interpretación. Lo que tendría como consecuencia, que esa influencia se extendería hasta el mismo discurso sobre Dios, la presencia de esa influencia marcaría indefectiblemente el modo en que se puede establecer el vínculo entre el hombre y la divinidad. Según el filósofo de la Selva Negra, donde se pueden ver con claridad las señas de esta influencia y el consecuente oscurecimiento de la experiencia originaria del cristianismo primitivo, es en la constante alusión que hace Agustín del goce y del disfrute, aquí localiza Heidegger un sentido estético que se tornaría como clave en la interpretación agustiniana. "Feliz es ciertamente quien goza del sumo bien. Viene incluido aquí un determinado sentido estético fundamental; se observa la influencia neoplatónica: lo bello pertenece a la esencia del ser" (GA 60, 271/173). Pero, además de reconocer en esto un sentido estético fundamental, se representa con claridad la influencia neoplatónica en esta idea agustiniana. Según Heidegger, cuando San Agustín dice que aquello de lo que se debe disfrutar es lo suprasensible, que sería el goce de Dios en cuanto es su presencia verdadera, esto significaría que el filósofo africano escribía sus textos desde un sentido de referencia determinado.

Los actos, las vivencias, los hechos desde los que el hombre interpreta su vida y su relación con Dios, están determinados prioritariamente por una perspectiva estética, contemplativa y visual. Como dice Heidegger: "el frui es, pues, el rasgo característico esencial de la actitud fundamental de Agustín frente a la vida misma. Su correlato es la pulchritudo; viene ahí, pues, entrañando un momento estético. Igualmente en el summum bonum. Con ello queda caracterizado una dimensión fundamental del objeto de la teología medieval (y de la historia del espíritu en general): se trata de la concepción

71 Ídem. 
específicamente griega. La fruitio $\mathrm{Dei}$ es un concepto fundamental de la teología medieval" (GA 60, 272/174). La intención de Heidegger es explicitar con claridad de qué forma la filosofía griega ha penetrado en el cristianismo. El origen de este privilegio de lo estético, fundamentado en la consideración de lo visual como la forma preeminente de acceder a Dios o a la vida humana, es de influencia propiamente griega y se transforma en el concepto fundamental de la filosofía medieval, la fruitio Dei. Dios mismo se ha convertido en un objeto de goce, puesto que la forma de llegar a él queda determinada por la dimensión propiamente estética (la instancia estética). Pero acontece lo mismo en relación con la vida humana. Hay una transformación, se contempla la verdad y se disfruta de ella, pero esto significa, que la vida humana no es considerada en su constitución originaria, en su misma ejecución. Esto lo resume Pöggeler del siguiente modo:

Del neoplatonismo toma San Agustín el pensamiento de que lo bueno y lo bello corresponden al ser, del que es posible "disfrutar". En la fruitio Dei se disfruta de Dios en tanto que El es el summum bonum, y solo de El cabe disfrutar. Como en el platonismo, hay que distinguir entre cosas visibles y cosas invisibles; las cosas visibles hay que utilizarlas (uti) únicamente en vista de otros fines; solo de las cosas invisibles cabe disfrutar (frui). La perversio, la "subversión de los valores" consiste en disfrutar de aquello que es solo de utilidad o de uso, y en usar para otros fines de aquello que de lo que debiera disfrutarse. Sin embargo, Heidegger ve que lo que hay que destruir es el hecho mismo de establecer en general un orden de valores, de apreciar en general a Dios como bonum, de compararlo en cuanto summum con lo otro. Al valor y a la apreciación se une un quietismo que escapa de la vida fáctica y busca a Dios como "sosiego" (según las palabras agustinianas: "Inquietum est cor nostrum, donec requiescat in te"). Es verdad que Sn Agustín vive y piensa a partir del desasosiego de la vida fáctica, pero en el quietismo de la fruitio Dei, cuyo origen corresponde al neoplatonismo, echa a perder la experiencia fáctica de la vida del cristianismo primitivo y se hace infiel a sus propios planteamientos" $"$.

Heidegger sostiene que esta conceptualidad griega se manifiesta en la filosofía del obispo de Hipona sin mayores reparos, sin un filtro que las pudiera depurar, por lo que determinan en gran medida su filosofía y al mismo tiempo oscurecen una interpretación genuina de la vida, sería una influencia incuestionada. San Agustín considera como categoría fundamental de la vida humana, como finalidad de ella, el descanso, el sosiego y la quietud que la contemplación de Dios les entrega, "para Agustín la meta de la vida es la quies (sosiego). Vida presente: en la realidad de los trabajos. Pero en la espera del reposo" (GA 60, 272/175). El filósofo alemán presenta una contraposición entre la búsqueda del sosiego que se encuentra al amparo de la quietud que Dios de la que habla Agustín; y la preocupación, tribulación, sufrimiento constante que se han revelado como fenómenos originarios a la luz del análisis de las epístolas paulinas.

72 Ibíd., p. 47. 
San Agustín, según esta interpretación heideggeriana, terminaría por restarle importancia a la ejecución, a la instancia propiamente ejecutiva de la vida humana, a su ejercicio, asunto que tanta relevancia había adquirido en el análisis de San Pablo. Convertirse en un espectador de la verdad y deleitarse en ello, no es más que perder la vista de lo esencial de la constitución de la vida humana. Por una parte, Heidegger destaca la dimensión temporal e histórica de la vida humana, esto en la revisión de las epístolas paulinas, y por otra, vemos en su destrucción de San Agustín, su crítica al privilegio de la contemplación, de la perspectiva estética como la prioritaria para acceder a las cosas, a la vida humana y a Dios; lo determinante es lo que está ante los ojos de un espectador que contempla, en otras palabras; la crítica a la percepción visual como modo privilegiado de conocimiento. Se crítica esta prioridad que se asigna a la contemplación, al ver, al sentido de la visión, dado que si se entiende que aquello es lo fundamental y lo primero en el modo de dirigirse a los objetos y a Dios, se privilegia una señalada comprensión del ser enquistada desde antaño en la filosofía, que lo entiende como lo presente ante los ojos, ante una mirada que lo contempla. Se entiende la realidad, el ser, como lo simplemente presente. Estaríamos ante un primer esbozo de su crítica a la tradición metafísica, las primeras formulaciones de su discusión con la filosofía griega en vías de reformular la pregunta por el ser.

En el análisis de la beata vita y de sus alcances, Heidegger localiza el punto álgido de la influencia de la filosofía griega en Agustín y en el cristianismo primitivo, en su discurso sobre los modos de vida y sobre la relación con Dios se establece y reconoce desde un principio una jerarquía en el orden de los valores. Pero además, este ordenamiento jerárquico de valores sería equivalente a una mirada exclusivamente teórica de contemplación de la realidad. Heidegger comenta con respecto al origen de esta nivelación, que la "axiologización que en última instancia, está al mismo nivel que "teorización". Esta ordenación de valores es de origen griego. (En el sentido global de la conceptualización se retrotrae finalmente a Platón)" (GA 60,277/181). A juicio de Heidegger, por vía de la axiologización la filosofía griega se introduce también en el pensamiento de San Agustín. Y esta axiologización que él reconoce, tiene un nivel de influencia tal, que afecta a casi la totalidad de los fenómenos tratados en las Confesiones. Razón por la cual, estos fenómenos en gran medida son producto de la axiologización de influencia griega, de la cual estas Confesiones serían deudoras en gran parte. Esto se puede verificar, por ejemplo, cuando se refiere al hombre, a Dios, a la relación entre ambos, al hablar de la realidad, todos estos son fenómenos que en el tratamiento que Agustín les da, quedan a merced de este proceso de axiologización.

Advierte Heidegger, que la interiorización de la filosofía griega en San Agustín es problemática. Además, "Esta axiología está ya en un nivel avanzado de formulación; pero se la malentiende si se la aísla y se renuncia a percibirla en su contexto. Surge entonces el problema de si un orden jerárquico de valores de este tipo es un orden necesario en cuanto 
a su sentido o si no se deberá más bien exclusivamente a la presencia activa de la filosofía griega en el pensamiento de San Agustín" (GA,279/184). Esto es lo que le parece verdaderamente problemático a Heidegger, esta clasificación jerárquica de valores. Por una parte, permite fijar los criterios para juzgar lo bueno o malo de un determinado acto, pero al mismo tiempo, es una gradación que lleva o conduce al bien supremo, al summum bonum. Es una escala de valores que lleva a Dios como último peldaño, considerado como el máximo bien.

\section{G. LA PENETRACIÓN DE LA FILOSOFÍA GRIEGA EN LA TEOLOGÍA: TEOLOGÍA DE LA CRUZ COMO} CONTRAPOSICIÓN DE LA TEOLOGÍA DE LA GLORIA

A juicio de Heidegger, Lutero fue el que permitió una recuperación de la experiencia originaria del cristianismo primitivo, el teólogo tenía importantes reparos con la filosofía griega, especialmente con Aristóteles. Heidegger incluso llega a decir que era odio lo que sentía Lutero por Aristóteles (Cf. GA63, 5/22). Empero, Heidegger se sirve del pensamiento de Lutero para plantear su crítica a la tradición filosófica, en este caso a la filosofía griega y su presencia no problematizada en el pensamiento del obispo de Hipona. Heidegger articula esta crítica analizando algunas de las tesis de la Disputatio de Heidelberg de 1518. En la tesis 19, con la que comienza el análisis heideggeriano, Lutero critica enérgicamente que algunos teólogos consideren que su tarea sea la de encontrar a Dios a través de las cosas creadas por él. No es factible llegar a Dios por medio de una contemplación metafísica o a través de una investigación de las creaciones divinas. "No merece el nombre de teólogo el que vislumbra lo invisible de Dios a través de lo que ha creado. El objeto de la teología no ha de buscarse por la vía de una consideración metafísica del mundo" (GA 60, 281/187).

En la tesis 21, Lutero establece una distinción entre dos tipos de teólogos, el teólogo de la gloria (Theologus gloriae) y el teólogo de la cruz (Theologus crucis). En esta distinción entre el teólogo de la gloria y de la cruz, Lutero ve una contraposición entre la teología con claras influencias de la filosofía griega y el lenguaje de la cruz, del cristo crucificado, "para el Theologus gloriae que se complace estéticamente en las maravillas del mundo, lo sensible nombra a Dios. El teólogo de la cruz dice como son las cosas" (GA 60, 282/188). Para el teólogo de la gloria, es posible acceder a Dios a través de la simple contemplación estética, lo que nos indica que por medio de lo sensible encontramos a Dios. Y en la última tesis, la 22, dice Lutero, "vuestra sabiduría, que vislumbra lo invisible de Dios en las obras hincha, ciega y endurece" (GA 60, 282/188). Como podemos ver, aquí Lutero reafirma su crítica a la contemplación estética y Heidegger al recogerlo, asume como propia la crítica de aquel a la influencia que la sabiduría griega ejerce sobre el cristianismo. 
Esta crítica a la contemplación estética, que vislumbra a Dios por medio de sus obras, tiene como consecuencia el endurecimiento y la ceguera. Esto es justamente lo que evita el teólogo de la cruz que según Lutero, solo dice cómo son las cosas, asunto que Heidegger entiende en el sentido de que no quiere apaciguarlas o trocarlas por otras más simples o menos problemáticas, pretende que aparezcan sin ocultamientos, que se muestren en su carácter de esencial problematicidad y no que terminen por disfrazarse. En efecto, el joven profesor, sigue en la misma línea de interpretación de las epístolas paulinas.

En estas tesis que Lutero presenta en las Disputatio de Heidelberg, Heidegger reconoce una crítica abierta a la conceptualidad de la filosofía griega, que ha penetrado profundamente en el cristianismo. Esta influencia no problematizada de la filosofía griega tiene como consecuencia, que todo se transforma en una gloritatio estética de lo suprasensible, una contemplación metafísica, que prescinde de las particularidades inherentes a la vida en su esencial facticidad. Este privilegio de la contemplación estética, del goce del espectáculo, se considera como una caída, un distanciamiento del dolor, de la tribulación, es alejarse del sentimiento de Cristo en la cruz, lo que habla de un oscurecimiento de la experiencia originaria del cristianismo, que tiene su raíz en la influencia griega que se ha impregnado en el cristianismo. Cuando esta perspectiva que en lo fundamental privilegia la visión y la contemplación estética comenzó a instalarse en el cristianismo, se modificó al mismo tiempo la relación del cristiano con Dios. El creyente evitaba enfrentarse a su padecimiento, quería esquivar su situación en el mundo, se olvidaba de su propia facticidad como cristiano, caracterizada por la preocupación y la tribulación, todo esto, con la finalidad última de evitar enfrentarse a su vida como padecimiento, como tribulación, ocultando esta preocupación constante, refugiándose en una realidad suprasensible, en un reino más allá que le brinda la seguridad anhelada.

La especulación metafísico-teológica quiere ser por esencia teodicea, justificación de Dios, apartando la vista precisamente de allí donde Dios ha actuado fácticamente: la pasión y la cruz. Por eso dice Lutero que la sabiduría que debe hacer ver la esencia invisible de Dios en sus obras se ensoberbece y se hace enteramente ciega y obstinada. Así pues, Lutero vuelve a buscar en su "teología de la cruz" la "experiencia fáctica de la vida" del cristianismo primitivo, que renuncia a todas las visiones y Apocalipsis, pero también y sobre todo, a las visiones de la metafísica; y es en el hecho de tomar debilidad sobre sí donde esta experiencia llega a penetrar en la profundidad de la vida fáctica, es decir, de la vida esencialmente "histórica". El puro estar de Lutero a la escucha de la palabra salvífica, su teología de la cruz y su doctrina de justificación a partir únicamente de la $\mathrm{fe}^{73}$.

Lo que Lutero propone, es una recuperación de la experiencia originaria del cristianismo, retomando lo más propio de esa vida cristiana, que se caracteriza esencialmente por la tribulación, la inseguridad, la preocupación angustiada ante la muerte.

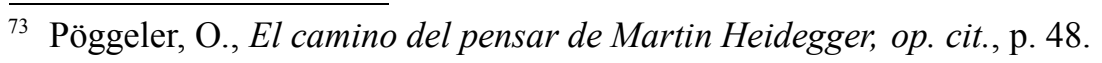


Esta herencia griega asentada profundamente en el cristianismo, debe ser depurada, el cristianismo ha de despercudirse de dicha influencia, para de esta forma volverse hacia el misterio de ese Cristo de la cruz, de volverse al sufrimiento inherente a ello. En la relación con Dios no hay nada disponible al modo de un objeto ni nada ante los ojos sobre lo cual se pueda cavilar, dado que la única experiencia que podemos tener de Dios es comprenderlo como algo inefable que muestra su ser en el propio padecimiento. Por lo tanto, se pasa de la teología de la gloria, con claras influencias de la tradición griega, a una teología de la cruz que recupera la experiencia originaria de las primeras comunidades.

\begin{abstract}
El paralelismo con los propósitos de Heidegger es claro, ya que éste interpreta el paso de la teología de la gloria al de la cruz como una destrucción, en el sentido de que hay que hacer una reducción de las alturas de la especulación a la facticidad, de lo teorético a lo fáctico. Uno de los valores de Lutero en los que más incide es precisamente haber luchado contra el establecimiento de objetividades en sí, haber denunciado que en la explicación de la relaciones del creyente con Dios no se puede apelar a elementos fijos a los que se accede contemplativamente y que dejan de lado el carácter histórico y ejecutivo de la vida del individuo ${ }^{74}$.
\end{abstract}

No es difícil deducir que esta distinción entre el teólogo de la cruz y el de la gloria es una de las influencias más importantes que ha recibido Heidegger de Lutero y es un punto de referencia señalado para el desarrollo de su crítica a la tradición metafísica que en estos cursos de verano resplandece, como un rayo de luz tenue pero persistente. Hablamos de un incipiente proyecto destructivo de la tradición. Se puede ver en estas lecciones la fuerza y la dirección de su crítica a la tradición, "el intento heideggeriano de renovar el pensar metafísico se ha hecho a través de la oposición más extrema a la metafísica y del ataque más penetrante contra ella. Según la concepción del joven Heidegger, es desde luego solamente el joven Lutero el que frente a todos los encubrimientos de la tradición, vuelve a entender la fe cristiana según su naturaleza originaria"75.

Esta contraposición entre el teólogo de la cruz y el de la gloria Heidegger lo interpreta como la contraposición entre el dominio de una perspectiva de sentido por sobre otra. En la primera, se privilegia el sentido de ejecución de la experiencia originaria del cristianismo, basado en el padecimiento que la caracteriza. Cuando se privilegia la actitud estética, la contemplación, en la que el conocimiento de Dios consiste en el goce estético, en la visión, lo mismo acabará por ocurrir en relación con la vida y el mundo. En la primacía de la contemplación y en el goce de la presencia del summum bonum, de la verdad de Dios, Heidegger considera que el sentido de referencia teórico es privilegiado de forma notable. Esta perspectiva interpretativa, en la que se manifiesta la supremacía sin contrapeso del goce estético, se ha mostrado como la (dominante) al momento de entender el conocimiento, así lo hace saber San Agustín cuando dice, que "los ojos ocupan el

${ }^{74}$ Redondo, P., Experiencia de la vida y fenomenología en las lecciones de Friburgo de Martin Heidegger, op. cit., p. 391.

${ }^{75}$ Pöggeler, O., El camino del pensar de Martin Heidegger, op. cit., p.49. 
primer lugar entre los sentidos en relación con el conocimiento (...) lo propio de los ojos es el ver (...) ver quiere decir poner delante un objeto como objeto" (GA 60, 224-5/110). Esta forma de concebir el conocimiento y el modo de acceder a los fenómenos es el que ha gobernado sin contrapeso a lo largo de la historia de la filosofía, ejemplo de ello, es lo que acontece con la vida humana, se cree que para hablar de ella, para interpretarla, lo primordial es tenerla presente ante la mirada, ante los ojos que la puedan objetivar. Esta ha sido una modalidad exegética que tiene ya una larga data en la historia del pensamiento, para la cual el ver, la simple mirada, es considerada como el medio privilegiado de conocimiento. "Este conocimiento puro, carente de toda emoción y sentimiento religioso característico de la relación teórico-contemplativa de lo divino, adopta la forma de un constante ser en acto, de una pura presencia a la mano. A través de la adopción de este repertorio conceptual griego, Agustín y otros pensadores patrísticos abre el camino a la implantación del neoplatonismo y aristotelismo que se consolida después con la patrística"76. Todo ello ha terminado por oscurecer las experiencias y fenómenos originarios, especialmente la pregunta por el ser y por la vida humana. Esta última, en función del privilegio de la contemplación, de lo teórico, ha dejado de ser considerada en su momento ejecutivo, en su propia facticidad. He aquí un punto clave en el enfrentamiento que Heidegger mantiene con la tradición, para él la filosofía griega es el origen de la supremacía de lo teórico contemplativo.

Como sostiene Berciano en su interpretación, el filósofo alemán consideró que en el cristianismo primitivo se produce un movimiento del centro de gravedad, que va desde el mundo de la vida al mundo propio, y éste entra en la vida, por ello, "el cristianismo es la gran revolución contra la antigua ciencia. Sobre todo contra la ciencia de Aristóteles, quien por contrastes de la historia había de convertirse más tarde en filósofo oficial del cristianismo. Oponerse a este proceso histórico occidental, en el que Aristóteles ha tenido una preponderancia, es una de las tareas de la fenomenología" ${ }^{77}$, por lo tanto una de las tareas fundamentales que el mismo Heidegger se plantea como decisiva de su andar filosófico.

Otra cosa que no deja de ser importante, tiene que ver con que bajo la autoridad absoluta de la actitud teórica, el conocimiento queda determinado meramente como relación de sujeto-objeto, si el ver es la actitud dominante para conocer, aquello hacia lo que se dirige el conocimiento a través de la visión deviene en objeto presente ante los ojos. Incluso la misma vida humana, bajo la influencia de esta actitud estético-contemplativa, queda reducida a cumplir el papel de un simple objeto a disposición de un espectador. Y ello, se extiende también al análisis de los distintos actos y comportamientos de la vida humana, desde los más simples a los más complejos. Heidegger expresa esto, señalando que "el sentido relacional como tal es tenaz, y tenaz y primario es el sentido pleno del

$\overline{{ }^{6}}$ Adrián, J., Heidegger y la genealogía de la pregunta por el ser, op. cit., p. 189.

${ }^{77}$ Berciano, M., La revolución filosófica de Martin Heidegger, op. cit., p. 52. 
videre, determina todas las experiencias fácticas, hasta las más decisivas y últimas. (E1 tenaz sentido relacional se aparta de la interpretación inmanente egocéntrica de la ejecución de su relevancia existencial)" (GA 60, 226/112). Significa entonces, que la visión como forma exclusiva de acceder al conocimiento, transforma aquello hacia lo que se dirige en objeto, determina la vida fáctica y todos los actos de la vida humana. De modo, que dicha actitud estética expande su influencia de forma superlativa, alcanzando incluso a la vida humana en sus mas recónditos escondrijos. Contra esta objetivación, dice Heidegger, que "el concepto genuino de "facticidad" no resulta determinable a partir de una objetividad antepuesta y asumida posicionalmente, sino en la interpretación existencialmente ejecutada de un cómo del "ser" de los conceptos existencialmente experimentados" (GA 60, 255/151).

Desde esta exposición de Heidegger, que pretende operar la destrucción, surgen diversas perspectivas de crítica, de destrucción a la tradición metafísica, siendo una de las principales, la dirigida hacia la interpretación axiológica, valorativa, como forma señalada de acceso a Dios. No encontraríamos frente a una axiologización de lo teológico, asunto al que Heidegger se opone con tenacidad y considera sumamente peligroso, así lo advierte cuando señala que, "el peligro de la axiologización de los nexos de los fenómenos es tan funesto como la conformación teórica en ámbitos regionales; ambos movimientos van juntos" (GA 60, 256/152). Heidegger localiza aquí una doble problemática, por un lado se habla de las formas o de los mecanismos de acceder a Dios o de referirse a su existencia, cuestión que a su juicio sería completamente erróneo si se pretendiera fundamentarlo axiológicamente. La otra cuestión que es igual de funesta, es intentar hacer esto desde una perspectiva meramente teórica.

Esta determinada ordenación jerárquica de valores descansa en una axiologización que Heidegger sitúa al mismo nivel que la teorización. Además, para San Agustín la consideración axiológica no es un añadido accidental, sino que recorre y domina toda la meditación. Más adelante, Heidegger insiste en el carácter funesto de la ordenación jerárquica de valores, dice la "axiologización dirigida de un modo determinado (inconmmutabile y summum bonum; y a partir de aquel orden jerárquico entero), que aún puede resultar más funesto, precisamente por haber tenido en cuenta los fenómenos de los que se trata en una perspectiva determinada" (GA 60, 261/159). Esta axiologización, este orden jerárquico de valores, puede ser más perjudicial aún, por cuanto su modo de dirigirse a los fenómenos viene predeterminado de antemano (por una perspectiva teórica y contemplativa) lo que oscurece una experiencia originaria del cristianismo, especialmente en su relación con Dios. El vínculo con Dios queda predeterminado antes de que pueda vivenciar íntimamente esta relación, esto, porque Dios le viene determinado objetualmente y con un contenido fijado de antemano.

Si se interpreta, por ejemplo, el tener experiencia de Dios como fruitio Dei, si se "disfruta" de Dios como "sosiego" del corazón, entonces Dios quedará al margen del 
desasosiego de la vida fáctico-histórica y será desplazado y acallado en su más propia intimidad vital. En verdad, no solo queda convertido así en un Dios solamente representado, muerto, sino que la adopción de la manera metafísica de pensar lleva e incluso obliga a llegar a este punto muerto ${ }^{78}$.

Para Heidegger, la única forma de salir de lo impropio e inadecuado de la axiologización, es la comprensión originaria de la facticidad, de su carácter problemático y su propia ejecución. Por eso, "lo que importa es precisamente confrontarse de modo radical constante con lo fáctico, y no huir. Tengo precisamente que tenerlo para acceder a la existencia (...) Pero ese tener quiere decir precisamente vivir-ahi (darin leben)" (GA 60, 265/164). El filósofo nativo de Messkirch hace una especie de llamado a apropiarse de la vida en su facticidad, en el carácter problemático que la caracteriza, es un llamado a apropiarse de esa ejecución misma de la vida en su facticidad. Es una vocación a comprender esa facticidad que constituye de modo invariable la existencia, viviendo la vida, ejecutándola históricamente y no considerándola desde una perspectiva teórica y contemplativa. Viviendo en esa tribulación que es esencial a la existencia y no desplazándola hacia paraísos transmundanos. De modo que la tradición filosófica,

el pensar metafísico, desde sus más tempranos comienzos esta orientado hacia el ver. Por ejemplo, ver significa para San Agustín un constante estar-ante los ojos, por lo tanto, un estar presente o un constante asistir. En la fruitio dei como beatitudo hominis el frui significa en praesto habere (Hw 338: tr 302s); por tanto, el ser de Dios viene también pensado como constante estar-ante-los-ojos, solo que aquí se mienta al ojo interno del corazón y no a aquellos ojos que se complacen en la variedad del "afuera" que distrae y dispersa $^{79}$.

\section{Capítulo III: La filosofía práctica de Aristóteles y la concepción de la temporalidad de la vida fáctica}

Dentro del extenso diálogo que Heidegger mantiene con la tradición metafísica, aparece una figura destacada, Aristóteles no es para él un interlocutor más, sino que uno de carácter privilegiado, es especial en la discusión y elaboración de su concepción de la temporalidad de la vida fáctica. Las interpretaciones de Aristóteles se convierten en una constante en los cursos universitarios de principios de los años veinte, en lo cuales sostiene un dialogo abierto con distintos escritos aristotélicos, que van desde la Metafísica hasta la Retórica pasando por la Física, hasta la Ética a Nicómaco. Extrañamente solo había sido nombrado de forma tangencial y no había adquirido un protagonismo particular.

No obstante, es a Aristóteles a quién de forma especial dirige su crítica en su enfrentamiento con la tradición metafísica, él fue el primer pensador capaz de pensar y elaborar una interpretación del tiempo que aún hoy sigue vigente y que permanece siendo

\footnotetext{
${ }_{78}$ Pöggeler, O., El camino del pensar de Martin Heidegger, op. cit., p. 49.

79 Ibíd., p. 50.
} 
la exégesis que determina cualquier consideración al momento de hablar de la cuestión del tiempo.

Heidegger recoge también múltiples elementos de la filosofía aristotélica que le sirven para desarrollar su propia filosofía, hace hablar a Aristóteles y de alguna manera le hace decir cosas que él mismo quiere escuchar. Sin embargo, se ha de hacer una prevención sobre la validez histórico filosófica de la interpretación, o de las interpretaciones que lleva a cabo el pensador alemán en su interlocución con la historia de la filosofía, fundamentalmente en el diálogo que emprende con la Grecia clásica. Esto a raíz de que no pretendemos afirmar o negar la validez de su interpretación ni su valor filológico, asuntos que no dejan de ser cuestionados continuamente por parte de sus críticos, en cuanto a si cuando Heidegger interpreta a un autor lo hace de forma correcta, si se ajusta o no a lo que determinado pensador quiere decir, y con sus traducciones de los textos griegos pasa algo similar. Por eso dice Volpi, "que si dejamos de lado de manera provisional la verdad histórica y en lugar de eso atendemos a la manera en que Heidegger se alimenta sin prejuicios de la filosofía griega como el primero y único repertorio del filosofar, podremos comprender mejor el sentido de su confrontación con los griegos y en particular con Aristóteles" $"$.

Son múltiples las referencias que Heidegger a lo largo de su trayectoria filosófica hace de Aristóteles, pero en este periodo de su pensamiento a principios de los años veinte, esta preocupación heideggeriana por la filosofía del Estagirita se intensifica, lo que se puede verificar en las constantes alusiones y estudios sobre Aristóteles que lleva a cabo por esos años ${ }^{81}$, lo que hace aún más evidente su papel como interlocutor privilegiado del filósofo de la Selva Negra, por eso en este capítulo vamos a revisar una de aquellas discusiones que resultan ser de las más fructíferas y que permitirán estructurar la filosofía heideggeriana en esta fase temprana de su pensamiento que por lo demás, se vinculan de forma directa con nuestra investigación, valga hacer esta aclaración, ya que la discusión con Aristóteles es aún más amplia de lo que tratamos aquí.

Justamente en este periodo va adquiriendo forma el pensamiento filosófico de Heidegger, siendo la elaboración de una interpretación de la temporalidad peculiar a la vida fáctica y la crítica a la concepción del ser como presencia-aunque esto último aparezca todavía de forma soterrada-, los lineamientos que despuntan en su filosofía temprana. Precisamente, en el ámbito de estas motivaciones que guían su pensamiento, aparece Aristóteles como el filósofo que le entrega importante material conceptual que le permitirá estructurar su analítica existenciaria, tal como lo sostiene Volpi. Según este, el filósofo alemán no se pregunta por "cómo se hallan las cosas desde un punto de vista

${ }_{80}$ Volpi, F., "Ser y tiempo; Semejanzas con la Ética a Nicomaco", en Signos filosóficos, vol III, núm.16, UAM, Iztapalapa, 2006, p. 128.

${ }^{81}$ GA 61 Phänomenologische Interpretationen zu Aristoteles. Einführung in die phänomenologische Forschung (WS 1921-1922); Natorp Bericht (1922); Phänomenologische Interpretation ausgewählter Abhandlung des Aristoteles zu Ontologie und Logik (SS 1922) 
histórico; Heidegger quiere más bien, y eso nos mienta a nosotros y al siglo, apropiarse y hacer justicia a las preguntas fundamentales que fueron pensadas por primera vez por los griegos y en particular por Aristóteles" $"$.

Pero además, este le servirá para llevar a cabo su destrucción crítica de la tradición, dado que ve en la filosofía griega los motivos y las interpretaciones desde las que parte la comprensión e interpretación del ser que ha dominado la historia del pensamiento occidental, siendo Aristóteles uno de sus exponentes más sobresalientes.

Un primer momento de esta larga discusión con la tradición metafísica se encuentra en los cursos de Fenomenología de la vida religiosa, allí Heidegger se enfrenta de manera indirecta al Estagirita, esto a través de Lutero, el que según Heidegger odiaba a Aristóteles. Lo que ahí se crítica es la profunda penetración de la conceptualidad griega en el cristianismo, en la cual se habría hecho presente la crítica de Heidegger al concepto del ser como presencia, que se da en el privilegio de la contemplación y del goce estético. Según Gadamer,

desde es el principio, las preguntas que le asediaron eran de tipo teológico. Lo prueba el manuscrito que Heidegger envío en 1922 a Natorp y que yo pude leer entonces. Fue una introducción que establecía los principios de las interpretaciones de Aristóteles que Heidegger había preparado y que hablaba sobre todo de Lutero, Gabriel Biel y Agustín. Seguramente, Heidegger lo habría llamado entonces una elaboración de la situación hermenéutica, es decir, se trataba de hacer conscientes las preguntas y la voluntad espiritual de oposición con las que nos enfrentamos a Aristóteles, el maestro de la tradición. Hoy nadie dudaría de que la intención básica que guiaba a Heidegger era de índole crítico destructiva. Pero en aquel momento eso no estaba tan claro ${ }^{83}$.

Pero esta crítica es aún tenue, Heidegger está dando los primeros pasos de su carrera académica, su proyecto filosófico se encuentra en una fase incipiente, sin embargo, ya en los primeros capítulos de nuestro trabajo hemos podido detectar cuales son sus coordenadas meditativas, hacia dónde va su meditación, que como hemos dicho irá adquiriendo rasgos más definitivos a medida que avanza su labor intelectual, pero hemos de señalar que sus intereses filosóficos, sus motivaciones, le acompañan desde un comienzo, aunque esto no sea fácilmente reconocible desde el principio, y se presente de forma más bien difusa. Un andar filosófico que tiene dos líneas temáticas fundamentales e inseparables, que se acoplarán de forma irreductible en la cristalización de su analítica existenciaria (existenzial); la pregunta por el ser y la pregunta por el tiempo. Estos dos ámbitos de especulación, que en un comienzo aparecen como dos líneas temáticas distintas y aparentemente independientes, a medida que se va estructurando la filosofía heideggeriana y las piezas van encajando, se articulan como problemas inseparables y con

${ }_{82}$ Volpi, F., "Ser y tiempo : Semejanzas con la Ética a Nicómaco", en Signos filosóficos, op. cit., p. 128.

83 Gadamer, H., "La teología de Marburgo" en Los caminos de Heidegger, op. cit., p. 41. 
una interna vinculación, cosa que de alguna forma se presenta en el escrito de Heidegger que pasaremos a analizar.

Dentro de este marco temático, nos aparece un trabajo que tiene mucha importancia, cuya elaboración data del año 1922, llamado Interpretaciones fenomenológicas sobre Aristóteles. Indicación de la situación hermenéutica, más conocido como Informe Natorp, en razón de que fue escrito para hacerlo llegar a Paul Natorp, con la intención de obtener una plaza de profesor titular en Gotinga. Este trabajo fue publicado en el Dilthey Jahrbuch, recién en el año 1989, Heidegger presenta aquí elementos que él considera constitutivos de la vida fáctica, es un primer paso en la construcción de la analítica existenciaria, podríamos decir, siguiendo a Kisiel ${ }^{84}$, que es un primer borrador de Ser y tiempo, escrito cinco años antes de la publicación de su obra maestra. Aquí, trataremos de forma sucinta aquellos conceptos elaborados por Heidegger en este trabajo, que adelantan la analítica existenciaría y que luego incorporará y precisará en el escrito de 1927. Esto en virtud de que volveremos más tarde sobre ellos y profundizaremos sobre su elaboración más definitiva. Por lo demás, esto se reafirma con una tesis que ha adquirido fuerza y está bastante extendida que "a lo largo de los últimos años se ha llegado a la conclusión de que Sein und Zeit es, al menos en buena medida, una transposición ontológica de la Ética a Nicómaco" ${ }^{\$ 5}$,cuyo principal exponente sería Volpi, un ejemplo de ello lo podemos verificar cuando en sus interpretaciones señala que "el surgimiento de la terminología de Ser y tiempo puede ser explicado mediante una ávida apropiación de la filosofía práctica de Aristóteles" ${ }^{\$ 6}$. Esto solo lo enunciamos a modo de ejemplo de las interpretaciones que han adquirido mayor fuerza en lo últimos años con la aparición de los escritos de juventud de Heidegger.

Este escrito se caracteriza por su brevedad y al mismo tiempo por su dificultad. En sus páginas se desarrollan y condensan múltiples temas y problemas que interesaban al joven Heidegger, además de ser muy revelador en torno al nivel de desarrollo de la discusión que mantenía con Aristóteles por aquellos años, además muestra de forma clara cuales son los lineamientos fundamentales que guiaban su interés interpretativo y que obtenía de su discusión con el Estagirita. Es posible vislumbrar en ese informe las primeras notas de un proyecto filosófico que ya está en marcha, como ontología fenomenológica y como destrucción de la historia de la metafísica.

Comenta Gadamer respecto a este escrito, que "el manuscrito, tan osado como excitante, se convirtió en la razón por la cual Heidegger fuera llamado a Marburgo, y éste, a su vez, fue el motivo por el que se suprimió del todo la publicación prevista"87, no es difícil concluir según esto, que este informe posee una importancia capital para poder

\footnotetext{
${ }^{84}$ Kisiel, Th., The Genesis of Heidegger's Being and Time, op. cit., p. 250.

${ }^{85}$ Segura, C., Hermenéutica de la vida humana, op. cit., p. 33.

${ }^{86}$ Volpi , F., "Ser y tiempo : Semejanzas con la Ética a Nicómaco", op. cit., p. 129.

${ }^{87}$ Gadamer, H., "Los griegos", en Los caminos de Heidegger, op. cit., p. 126.
} 
desentrañar las motivaciones y la dirección que sigue el pensamiento heideggeriano en esta etapa tan importante de su filosofía, en virtud de que podemos encontrar ahí los problemas filosóficos que ocupan a Heidegger en estos años y que marcarán su camino meditativo.

Es necesario decir al mismo tiempo, que este es un trabajo en el que se adelantan ya lo ejes fundamentales que conducirán la filosofía de Heidegger que desembocará en Ser y tiempo. En primer lugar, que es una tarea primordial de la filosofía plantear la pregunta por el sentido del ser, que aquí es tratada como sentido directivo del ser y esto pasa necesariamente por un análisis de las estructuras ontológicas de la vida fáctica, del Dasein humano. Como ejemplo de ello podemos referirnos al tratamiento que se da al fenómeno de la muerte, que adquiere aquí por vez primera un sentido ontológico decisivo, como contramovimiento de la caída. Heidegger deja de lado el modelo de la filosofía de la conciencia y del método exclusivamente teórico que ordena y clasifica a los entes con la finalidad de fijar y determinar su contenido objetivo. Su intención primera es conseguir una apropiación originaria de la vida en su esencial facticidad, interpretación que no esté oscurecida por la mirada exclusivamente teórica ni que tampoco sea lastrada por las interpretaciones propias de la tradición metafísica, cuyo ejemplo destacado sería la consideración del hombre como animal racional.

Pero una de las propuestas más novedosas que aparecen en este informe tiene que ver con la reinterpretación ontológica de la filosofía práctica de Aristóteles en relación con las virtudes dianoéticas. Veremos de qué forma en el tratamiento de ésta problemática se avanza sustancialmente en la cristalización del proyecto filosófico heideggeriano.

Aristóteles le sirve a Heidegger porque le brinda las herramientas que le permitirán dar un giro en la filosofía, con el que pretende reemplazar esa prioridad, que a lo largo de la historia del pensamiento, se le ha dado a la perspectiva teórica de contemplación de la realidad, trocándolo por una señalada primacía del sentido práctico-ejecutivo. En el ámbito de esta discusión, el joven profesor reconoce en el análisis aristotélico de la phrónesis, un modo privilegiado para desarrollar sus propios planteamientos, de esta forma la crítica deviene en destrucción. Lo que se pretende principalmente, es "mostrar que la teoría tiene su origen en la facticidad y que, en consecuencia, la radical actitud descubridora del Dasein no es la propia de la teoría sino de la práxis" ${ }^{98}$.

\section{A. LAS CATEGORÍAS DE LA VIDA FÁCTICA}

El Informe Natorp es uno de los primeros escritos en los que Heidegger fija con claridad un determinado proyecto de trabajo a largo plazo como un marco programático de su filosofía según el que se conducirá en esta etapa de su pensamiento, cuyas directrices fundamentales son la pregunta por el ser y por la temporalidad peculiar a la vida fáctica,

${ }_{88}$ Segura,C., Hermenéutica de la vida humana, op. cit., p. 34. 
esto mediante una interpretación ontológico-fenomenológica de la vida humana. La vida fáctica tiene que ser explicitada en su genuino sentido ontológico para revelarse en su estructura ontológica original y de esta forma lograr comprender su dinamismo, su movilidad fundamental. La temporalidad peculiar a la vida fáctica ha de someterse a una interpretación originaria para que de modo se nos haga accesible su ser. Esta interpretación ha de expresar el carácter eminentemente temporal e histórico de la vida humana, cuya constitución ontológica no tiene nada que ver con la de los entes de la naturaleza.

Pero al mismo tiempo, Heidegger se cuestiona acerca del carácter mismo de la propia filosofía, prueba de ello es, que:

las primeras discusiones con la obra aristotélica se mueven en el contexto de la pregunta acerca de qué es la filosofía. La investigación filosófica no puede ignorar el proceso de gestación de la vida humana. Esto significa que la actividad filosófica arranca siempre de una situación hermenéutica previamente dada y comprendida siempre desde el trato cotidiano que mantenemos con las personas, las cosas y las situaciones que nos rodean. La aprehensión y determinación de las cosas no son neutras, sino que se enmarcan en el horizonte de una familiaridad con un mundo previamente comprendido ${ }^{89}$.

El objeto de la filosofía es la vida fáctica, interrogada en su ser, en su carácter ontológico, y para alcanzar este objetivo, para aprehenderla de modo originario es necesaria una interpretación dirigida a una apropiación originaria del pasado. Razón por la cual es necesaria una tarea de destrucción y desmontaje de la tradición, tradición que oscurece el sentido originario de este fenómeno, qué es el objeto mismo de la filosofía. Por ello es necesario una vuelta a Aristóteles. Pero antes que nada, debemos tener claro que una apropiación como la que propone Heidegger, significa, "comprender radicalmente lo que en cada momento una determinada investigación filosófica del pasado colocó en $s u$ situación y de la inquietud de fondo que mostró por esa situación; comprender no significa aceptar sin más el conocimiento establecido, sino repetir originariamente lo que es comprendido en términos de la situación más propia y desde el prisma de esta situación" (NB, 4/33). Esta es precisamente la tarea que se propone el joven profesor, pues, la fenomenología se encuentra siempre ya en una determinada situación hermenéutica, la que debe ser reconocida y apropiada críticamente, hasta llegar al origen de los presupuestos que determinan el pensamiento y la situación en la que ya siempre nos encontramos.

Por eso, la concreción del problema fundamental de la filosofía debe tener como punto de partida la determinación, la caracterización ontológica de su objeto, que es la vida humana en su facticidad, por ello, el pensador de la Selva Negra dice claramente:

el Dasein humano (das menschliche Dasein) en tanto que se le interroga acerca de la su carácter ontológico. Esta dirección fundamental de la investigación filosófica no se impone desde fuera ni se atornilla al objeto interrogado, a la vida fáctica (dem faktischen Leben), sino que se ha de comprender como la aprehensión explícita de una actividad fundamental de la vida humana (Grundbewegtheit des fakstischen Lebens) Una vida

$\overline{89}$ Adrián, J., El programa filosófico del joven Heidegger, Herder, Barcelona, 2008, p. 20. 
fáctica que se comporta de tal modo que, en la temporización concreta de su ser, se preocupa por su ser, incluso en los casos en que evita el encuentro consigo misma. La vida fáctica se caracteriza ontológicamente por la dificultad con que se hace cargo de sí misma (NB, 3/31-2).

Nos encontramos frente a una primera caracterización ontológica de la vida fáctica en términos de Dasein humano, este concepto comienza a adquirir aquí ese peculiar carácter técnico, y que luego adquirirá una relevancia señalada, constituyéndose en un concepto clave en la filosofía heideggeriana. La acuñación de este concepto técnico le permite hacer frente a múltiples denominaciones que nombran la vida humana, tales como hombre, animal racional, y que a su juicio no hacen más que oscurecer el sentido originario de este fenómeno.

Desde un principio Heidegger sostiene que el objeto, el tema de la filosofía, no puede ser otro que la misma vida humana, pero no pretende desarrollar una interpretación de la vida humana cualquiera, sino que es necesaria una investigación que revele el carácter ontológico de este ente. Esta es la meta de la filosofía, revelar la estructura ontológica de este ente; la vida fáctica. Para ello, no sirven las consideraciones de la vida humana obtenidas desde una relación sujeto-objeto, sino que se propone una especie de autointerpretación, en la que la vida se comprende a sí misma en su actividad fundamental, en su esencial facticidad, en su ejecución. Y en esta misma actividad fundamental, en la temporización de su ser, en la ejecución de su facticidad se revela esta como un ente que es preocupación por su propio ser, se preocupa por su ser, esto es de tal forma, que incluso en aquellas oportunidades en las que la vida intenta desviarse del encuentro consigo misma también le es inherente esa preocupación por su ser.

Pero esta preocupación, esta inquietud de la que habla Heidegger, está íntimamente vinculada con lo histórico, con el sentido histórico, y por ello "es preciso develar cuál es la relación que el Dasein mantiene con lo histórico y, por tanto, con la temporalidad. Más aún, es preciso determinar a qué tiempo nos referimos" $"$, por lo tanto, se ha de comprender el sentido de lo histórico que se manifiesta precisamente en la preocupación (Bekümmerung). En efecto, aquello que caracteriza ontológicamente a la vida fáctica es su carácter problemático, dado que siempre le es difícil y complicado hacerse cargo de esa responsabilidad, de esa carga que significa tomar sobre sí la propia existencia, cargar con su propia vida fáctica, y en esta preocupación o inquietud se hace manifiesto el sentido mismo de lo histórico. Cuestión que se hace patente en la tendencia de la vida a simplificar las cosas, a evadirse de la responsabilidad y de la dificultad que conlleva cargar con la propia vida, no obstante, reconocer esto, es la forma correcta de acceder a ella y de mantener el camino abierto hacia la vida fáctica en su facticidad. Estamos ante un primer boceto o esbozo de un estudio de los caracteres ontológicos fundamentales de la vida fáctica.

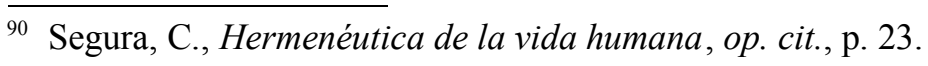


La necesidad del estudio de la vida fáctica en cuanto es objeto principal de la investigación filosófica, se fundamenta en que desde ella es desde donde debe partir una consideración filosófica que se precie de tal, "Pero no únicamente por el hecho de que la vida fáctica sea el objeto de la investigación filosófica, sino porque la investigación constituye un determinado cómo, una determinada modalidad de la vida fáctica, y como tal, contribuye en su realización (y no tan solo en el "uso" que posteriormente se pueda hacer de los resultados de la investigación) a la contraposición del ser en cada caso concreto de la vida en sí misma"(NB, 5/34), en consecuencia, esta determinación de la vida fáctica, la posibilidad de la cotemporización del ser concreto de la vida humana en su facticidad, parte del hecho primordial, de que dicha investigación es una modalidad fundamental de realización efectiva de la vida fáctica, en la que esta se mantiene de modo invariable, es una forma de concreción de la vida en sí misma, por lo tanto, es una actividad esencial de ella misma en su misma ejecución.

Heidegger entiende que para llevar a cabo esta tarea de forma exitosa, es necesario plantear una indicación de la situación hermenéutica, especificando cuál es el carácter de esta indicación, dice que, "en esta indicación de la situación hermenéutica no se trata de definir en detalle la estructuras del objeto "vida fáctica"; ni de aprehenderlas en sus articulaciones constitutivas; más bien, la simple enumeración de los elementos constitutivos más importantes de la facticidad permitirá fijar la mirada sobre lo que se pretende dar a entender con este término y convertirlo así en un presupuesto de la investigación concreta"( $\mathrm{NB}, 5 / 34)$. Heidegger va dando así sus primeros pasos en la elaboración de una ontología fundamental, toda vez, que la filosofía ha de tratar el problema del ser de la vida fáctica lo que la constituye es ontología fundamental. Esta tarea se llevará a cabo, por medio de una hermenéutica fenomenológica de la facticidad que es como define su trabajo en esta etapa de su pensamiento. La investigación tiene una doble dirección: por una parte es una destrucción o desmontaje de la tradición metafísica y por otra se plantea el desarrollo de una ontología fundamental, cuyo objeto es la vida fáctica.

Sin embargo, a juicio del filósofo de la Selva Negra, la pregunta por la vida fáctica es profundamente problemática, en virtud de la multiplicidad de definiciones con las que se intenta dar cuenta de este fenómeno, pero que en realidad no le hacen justicia, y comúnmente fracasan, y no hacen más que generar malentendidos que ocultan su sentido primigenio. Por ello, recuerda su procedencia desde el Zoé, vita, que como señala, "designa un fenómeno fundamental en torno al cual gira la interpretación griega, veterotestamentaria, neo testamentaria-cristiana y greco-cristiana de la existencia humana" (NB,6/34). Es justamente, esa multiplicidad de significados de vida y de las distintas interpretaciones que se hacen de ella, la razón, la necesidad, de que una investigación como la que emprende Heidegger sea capaz de apropiarse originariamente de ese fenómeno y lo haga completamente transparente. De este modo, también se podrá acceder 
al origen desde donde parten los distintos significados de la palabra vida, significados que tienen todos un hondo calado en la cultura occidental.

Como se observa claramente, Heidegger se propone una tarea ambiciosa, que tendrá como resultado la construcción de conceptos, que con el tiempo se transformarán en determinantes para su proyecto filosófico, que en esta etapa de su pensamiento se está en una fase germinal. Nos referimos a fenómenos como la caída, la curiosidad, la publicidad, el estado de interpretado, el uno, fenómenos que se contraponen con una vida en la propiedad, con una vivencia originaria de la muerte, que es en último término lo que nos acerca a la temporalidad propia del Dasein humano.

Según esto, la tarea primordial que Heidegger se propone para lo que viene, es destacar estos elementos constitutivos de la facticidad, lo que nos da la posibilidad de fijar la mirada sobre el sentido de la vida fáctica y su estructura ontológica, para de esta forma poder convertirla en el presupuesto de la investigación, lo que al mismo tiempo nos permite reconocer el nivel de desarrollo que la filosofía de Heidegger ha alcanzado por entonces. Dice Heidegger, que "el sentido fundamental de la actividad fáctica es el cuidado(Der Grundsinn der faktischen Lebensbewegtheit ist das Sorgen) (curare).(...) El significado del ser real y efectivo y el significado de la existencia del mundo se funda y se determina a partir de su carácter: como el asunto mismo del trato propio del cuidado (Der Sinn von Wirklichsein und Dasein der Welt gründet in und bestimmt sich auch ihrem Charakter als Womit des sorgenden Umgangs)" (NB, 6/35). De esta forma, hace su aparición el fenómeno del cuidado propiamente tal, que tiene una importancia señalada en la filosofía de Heidegger, aunque este ya había sido había tratado en los cursos de fenomenología de la religión, aquí se expone de forma concreta el rol que este cumple en la fenomenología hermenéutica, como uno de los fenómenos que se convertirá en una verdadera clave ontológica para la analítica existenciaria, concretamente, este fenómeno es el hilo conductor que sostiene de algún modo la analítica del Dasein humano. Es el sentido fundamental y primario de la actividad de la vida humana, de su ejecución, en este relacionarse con el mundo, en el estar dirigido hacia él; en el estar ocupado con las cosas se hace presente el horizonte dentro del cual se conduce el cuidado, gracias a lo cual se le manifiesta el carácter de mundo en cada caso, pero esta interpretación del cuidado es todavía provisional y revela primordialmente la intencionalidad.

El hacia dónde (Worauf) se dirige el cuidado es el con qué del trato (Womit des Umgangs) que la vida fáctica tiene con su propio mundo. Lo que nos indica, que el significado, el sentido que poseen las cosas del mundo, el ser real y efectivo como dice Heidegger, se funda en el mismo trato propio cuidado. Así el sentido del mundo y su existencia se determina a partir del carácter del cuidado. El mundo no es ya algo que esté frente a nosotros o fuera de nosotros, sino que se encuentra ya ahí como algo de lo que siempre nos cuidamos, querámoslo o no, siempre se encuentra ahí de alguna manera. Este mundo está articulado según las posibles direcciones de sentido que toma el cuidado como 
mundo circundante (Umwelt), mundo compartido (Mitwelt) y mundo propio (Selbstwelt). También en el cuidado se manifiesta la preocupación por los medios de procurarse la vida, por los quehaceres cotidianos y al mismo tiempo la preocupación por los fines últimos que la vida humana puede tener.

El cuidado tiene un carácter eminentemente dinámico, la motilidad que le es propia es uno de sus caracteres más destacados, pero esta movilidad (Bewegtheit) no es cualquier clase de movimiento, es un tipo de movilidad que solo le es peculiar a la vida fáctica, es un ente cuya característica fundamental es que su ser está en juego a cada momento, a saber, en el modo como despliega su ser temporalmente.

En función del contexto, Bewegtheit se puede traducir por "movilidad" o "actividad. Heidegger construye un sustantivo abstracto a partir del verbo bewegen ("moverse", "desplazarse") con la intención, por una parte, de resaltar el aspecto móvil y temporal de la vida humana y, por otra, de diferenciar este tipo de movilidad ontológica constitutiva del Dasein del movimiento propio de los entes naturales (Bewegung o Beweglichkeit) que responde a la kínesis que Aristóteles analiza en el libro IV de la Física" "91.

Según Gadamer, esto era justamente lo que Heidegger tenía en el punto de mira cuando utilizó este concepto, que nombra, "la dimensión ontológica original del tiempo, que se encuentra en la movilidad (Bewegtheit) fundamental de la existencia. Desde ahí no solo se ilumina la enigmática irreversibilidad del tiempo, que no lo deja emerger y siempre solo pasar, sino también queda patente que el tiempo no tiene su ser en el instante actual o en la sucesión de instantes actuales, sino en el carácter esencialmente futuro de la existencia"92.

Por otra parte, en referencia al trato ejecutivo del cuidado, se debe precisar que este tiene su propio asunto que responde a cada una de las formas del cuidado y se encuentra siempre en cierto contexto de conocimiento y familiaridad. Lo que se traduce en un conocer siempre de algún modo aquello que le rodea, aquellas cosas junto con las que se encuentra, que le hacen frente, que le parecen conocidas o familiares, es decir, no le son del todo extrañas. En otras palabras, "el trato cuidadoso siempre tiene a la vista su asunto de una manera determinada. La circunstancia está viva en el trato y contribuye a su contemporización" (NB, 7/36), por lo demás, siempre en este trato peculiar al cuidado del, se ve el mismo asunto hacia lo que está dirigido y esto de una forma determinada. La circunspección (Umsicht) es la que vive en el trato, concretamente, guía y dirige el trato. El cuidado es siempre circunspecto y, como tal, se preocupa por la forma en que se da esta circunspección y principalmente por asegurar y acrecentar la familiaridad con aquello a qué se dirige el trato, con su objeto. Esto es anterior a cualquier tipo de reflexión o teoría respecto a ello. Por tanto, los objetos a los que se dirige el trato del cuidado, se orientan hacia una u otra dirección y esto desde el primer momento de la aprehensión.

\footnotetext{
91 Adrián, J., El lenguaje de Heidegger, op. cit., p. 59.

92 Gadamer, H., "La teología de Marburgo", en Los caminos de Heidegger, op. cit., p. 44.
} 
Siempre aquello hacia lo que se dirige el trato posee un cierto significado, siempre lo que me sale al encuentro significa algo para mí, incluso en el supuesto de no significar nada, "el mundo sale al encuentro con el carácter de la significatividad (die Welt begegnet im Charakter der Bedeutsamkeit). En virtud de una tendencia originaria de la actividad de la vida fáctica, el trato cuidadoso no solo dispone de la posibilidad de renunciar al cuidado estrictamente ejecutivo, sino que es propenso a comportarse de esta manera" (NB,7/36) Aquí Heidegger introduce una distinción que será muy importante para su labor filosófica, cuando habla del trato del cuidado, ve en la vida fáctica una tendencia a dejar de lado, a abandonar el cuidado en su dimensión ejecutiva, porque no se considera como importante aquel carácter que le es peculiar al ámbito ejecutivo propio del cuidado. Además, esta no es una tendencia menor o sin importancia, sino que por lo general se es propenso a renunciar al cuidado estrictamente ejecutivo de la vida fáctica. Y según Heidegger, es justamente en esto en lo que subyace el problema, es esta propensión de renunciar al cuidado en su dimensión ejecutiva, que por lo demás, es su característica fundamental. La vida fáctica abandona la dimensión ejecutiva quedando a merced de una perspectiva meramente teórica del cuidado. Ocurre que, "la circunspección adquiere entonces el carácter de un simple observar (desprovisto de cualquier finalidad práctica). En el cuidado de la observación, de la curiosidad (cura, curiositas), el mundo también está ahí presente, pero ya no como asunto del trato ejecutivo, sino que ahora se da sencillamente según el aspecto desde el que se lo observa" (NB, 7/36), de hecho ésta es una característica propia de la constitución misma de cuidado y no un simple acontecimiento de carácter objetivo, dado que a la vida fáctica por su tendencia a la caída le es inherente la posibilidad de abandonar la orientación práctica del mundo y su trato peculiar, privilegiando una perspectiva simplemente teórica. Al cobrar esta una determinada prioridad, el cuidado deviene en una simple contemplación de objetos sin ninguna orientación ejecutiva. Por ello, "se trata, en primer lugar, de mostrar la radicalidad con que Heidegger entiende el cuidado (Sorge; del latín, curare) como sentido fundamental de la actividad de la vida fáctica. Una estructura con la que Heidegger quiere superar definitivamente el primado unilateral de la teoría y que supone una profunda transformación y crítica de la intencionalidad husserliana" ${ }^{93}$.

La ciencia caería dentro de esta categoría puesta en cuestión, como actividad teórica privilegiada ella es la contemplación teorética de la realidad del mundo. En este cuidado propio de la contemplación, de la observación, -entre las que se incluye también la curiosidad-, el mundo está presente como algo ante los ojos para un observar que lo puede convertir en objeto de contemplación, el mundo como un objeto de consideración teórica para un sujeto, que debe tender un puente para llegar a él. Y no considerándolo como una referencia del trato ejecutivo de la vida fáctica, sino que por el contrario, todo se

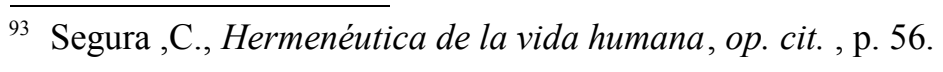


ve según el aspecto desde el que cual se lo mira. Primando así la perspectiva meramente visual y contemplativa, la simple percepción de la mirada.

Otra cuestión muy importante para el pensador de la Selva Negra, tiene que ver con la necesidad de determinar claramente la situación en la que la mayoría de las veces se encuentra el Dasein humano, en función de eso, dice que "la vida fáctica se mueve en todo momento en un determinado estado de interpretado (Ausgelegtheit) heredado, revisado o elaborado de nuevo. La circunspección ofrece a la vida un mundo ya interpretado de acuerdo con aquellas perspectivas en las que el mundo comparece y aguarda en calidad de objeto de la preocupación, en la que el mundo es puesto como problema y buscado como refugio" (NB, 8/37). Heidegger quiere indicar con esto que la vida fáctica se encuentra siempre en un estado de interpretado, que se transmite por vía de la tradición. Este estado de interpretado dicta el modo en que le hace frente el mundo, como lo interpreta, y se transforma así en el objeto de la preocupación. Y justamente este mundo es el problema para la vida fáctica, lo paradójico es que el Dasein huye del mundo porque no le dice nada, pero busca refugio justamente en él, huye del mundo justamente hacia el mundo.

Siempre el Dasein se encuentra en este estado de interpretado, por lo que se mueve por la fuerza del hábito, de la costumbre, más que por una apropiación originaria de su ser y del mundo. Así también el estado de interpretado establece la forma en que la vida se cuida a sí misma. Respecto a esto, sostiene el pensador alemán:

en la actividad del cuidado (Sorgensbewegtheit) se manifiesta una inclinación (Geneigtheit) hacia el mundo que se plasma en una propensión (Hang) a quedar absorbido por él, a dejarse arrastrar por la tendencia fáctica fundamental. Esta propensión del cuidado expresa una tendencia fáctica fundamental de la vida que la conduce hacia su propio declive (Dieser Hang der Besorgnis ist der Ausdruck einer faktischen Grundtendenz des Lebens zum Abfallen von sich selbst) y por la que se produce un movimiento de caída en el mundo que, a su vez, desemboca en el desmoronamiento de la vida misma. Este carácter fundamental de la actividad del cuidado se define terminológicamente como inclinación hacia la caída de la vida fáctica (die Verfallensgeneigtheit des faktischen Lebens (oder Kurz das Verfallen “an”)) (NB, 9/38).

De esta forma, Heidegger alude al movimiento de la caída, entendiéndolo como una tendencia fundamental de la vida fáctica, en virtud de la cual el hombre se encuentra absorbido por las cosas del mundo, arrastrado por ellas. Esto lo conduce a su propio abandono, se cae en el mundo y en este movimiento la vida misma se viene abajo, se desmorona.

Esta inclinación o tendencia hacia la caída de la vida fáctica se entiende, "en términos de una modalidad intencional de la vida. Esta propensión a quedar absorbido por el mundo es el destino más íntimo que afecta a la vida fáctica" (NB, 9/39), por ende, esta inclinación a la caída define al Dasein humano de forma indefectible, está radicada en su constitución misma, lo que significa que no es algo ajeno a él que le sobrevenga en determinado momentos y en otros no, sino que es un elemento constitutivo de su 
facticidad. (A esta tendencia a la caída le son inherentes tres movimientos, la tentación, el aquietamiento y el entrañamiento)

La caída es una tendencia privilegiada, es la actividad fundamental del trato ejecutivo y productivo, pero también en el de la circunspección y su posible determinación, que en cuanto observación e interpretación permite conocer y determinar la situación hermenéutica en la que se sostiene la vida fáctica. Por lo tanto, la vida fáctica se mueve siempre en un estado de interpretado, en el término medio propio a la publicidad, en tal sentido, se mueve siempre en medio de la interpretación dominante, es el uno o el se quien ejecuta la vida, quien la vive. De forma, que no vive su vida propiamente, la que de alguna forma le es extraña, por ello, “en cuanto tranquilizadora la tendencia hacia la caída inherente a la tentación es alienante: esto es, la vida fáctica deviene más y más extraña a sí misma en la medida en que se entrega al mundo del que se ocupa; asimismo, la actividad del cuidado, a la que se abandona la vida misma, le reduce cada vez más la posibilidad fáctica de verse a sí misma en la preocupación" (NB,10/40).

En una primera aproximación, no es difícil concluir que en este escrito se presenta un primer esquema de la analítica existenciaria que se plasmará en la obra de 1927. La caída aparece como un elemento decisivo en la estructura de la vida humana, que muestra el carácter huidizo de vida, ese querer desentenderse de sí mismo que le tranquiliza y le brinda una aparente sosiego, en ese dejarse absorber por el mundo deja de lado la posibilidad de apropiarse originariamente de la vida fáctica, se abandona en los entes del mundo de los que se ocupa. Su vida es vivida por nadie en particular, el uno, el se, es el que domina e interpreta, piensa como piensa la opinión pública, la publicidad. La vida no se encuentra consigo misma, se pierde en las interpretaciones públicas. "la tendencia hacia la caída (Verfallenstendenz) conduce a la vida hacia el desencuentro consigo misma. La manifestación más relevante de esta movilidad fundamental (Grundbewegtheit) se plasma en el modo en que la vida fáctica misma hace frente a la muerte" (NB, 11/41) Después de este rodeo con el que presenta los rasgos ontológicos fundamentales del Dasein, Heidegger expone el fenómeno de la muerte. En la forma de abordar este fenómeno por el estado de interpretado ve el síntoma más claro y contundente de esta tendencia a la caída, a saber, la forma de comportarse la vida fáctica, en como se enfrenta el uno a la muerte. Este es el fenómeno que permite a Heidegger articular la totalidad de elementos que constituyen la vida fáctica. He aquí lo novedoso de esta consideración iniciada por el pensador alemán y presentada en este informe.

La muerte es el fenómeno en el que descansa la posibilidad de hacer frente a esta tendencia a la caída y permite además apropiarse de la propia existencia, pero lo que es aún más importante es que abre la posibilidad de comprender la vida en su esencial carácter temporal-uno de los objetivos fundamentales de la filosofía heideggeriana en esta etapa de su pensamiento- lejos de interpretaciones del tiempo surgidas desde los conceptos y exégesis extraídas desde los dominios de las ciencias naturales. La cuestión de la muerte 
posee una relevancia señalada, en cuanto suministra el hilo conductor de la problemática ontológica de la vida fáctica. Heidegger sostiene que esto:

no tiene nada que ver con una metafísica de la inmortalidad y del más allá. La muerte, cuando se la asume en su inminencia y se la considera según su propio modo de hacer visible el presente y el pasado de la vida, es en cuanto elemento constitutivo de la facticidad-al mismo tiempo el fenómeno a partir del cual se debe explicar y poner de relieve la específica "temporalidad" del Dasein humano (spezifische "Zeitlichkeit" menschlichen Daseins). El sentido fundamental de lo histórico se determina en función del sentido de esta temporalidad y jamás por medio del análisis formal del proceso de elaboración conceptual de una determinada historiografía (NB,12-3/42).

Si en un primer acercamiento a la explicitación de la temporalidad propiamente humana, Heidegger había reconocido en la expectativa de la parousía una peculiar vivencia de la temporalidad de la experiencia fáctica de la vida del cristianismo primitivo, que estaba caracterizada por lo indeterminado del momento de esa segunda venida del Mesías y por la tribulación inherente a esa espera; ahora es la muerte el fenómeno que nos brinda esa oportunidad de acceder a una consideración del tiempo propiamente humano, logrando distanciarse radicalmente de la idea del tiempo extraído de la naturaleza o de las ciencias. Nos encontramos con una de las tesis principales que Heidegger presenta en este fase temprana de su pensamiento, no obstante esta formulación no dejará de ser relevante en su obra posterior a la publicación de Ser y tiempo, denominada por algunos el segundo Heidegger. En la muerte ve Heidegger un fenómeno destacado, que permite al Dasein humano distanciarse del desencuentro consigo mismo y le hace posible experienciar de forma originaria la temporalidad que le es peculiar a la vida fáctica.

Sin lugar a dudas, nos encontramos en un momento clave en la configuración del pensamiento filosófico de Heidegger, está sentando las bases de lo que será su analítica existenciaria, dando así los primeros pasos de su ontología fundamental, sustentando la posibilidad de una comprensión originaria de la temporalidad y de lo histórico en el fenómeno de la muerte, cuestión que se convertirá en el epicentro de la concepción originaria de la temporalidad en su esencial carácter advenidero. La vida fáctica "cuando toma posesión de la muerte y asume su certeza, la vida se hace visible a sí misma. La muerte, entendida de esta manera, ofrece a la vida una perspectiva y la conduce constantemente ante su presente más propio y ante su pasado, un pasado que dimana y brota de la vida misma" (NB, 12/42). De tal modo, que en este asumir la certeza de la muerte, su inminencia, la vida se hace transparente para sí misma, se vuelve evidencial. Lo que permite al Dasein verse a sí mismo a través de una mirada prístina, que es posible sobre la base de una apropiación genuina de la muerte. Esto le brinda a la vida una nueva perspectiva, lejos de ocultamientos, le conduce hacia su presente más propio y al mismo tiempo lo lleva ante su pasado que surge de la vida misma. Le abre y pone frente a sí mismo su carácter temporal. Por consiguiente, es evidente que para Heidegger este no es un fenómeno más entre otros de aquellos que se deben poner en cuestión, ni tampoco es 
una meditación más acerca de la muerte. Por el contrario, el fenómeno de la muerte es el que permite una comprensión genuina de la vida fáctica, de su ser, permitiéndole una reapropiación verdadera de su propio ser. Y esto, porque revela el carácter temporal e histórico que le pertenece esencialmente a la vida fáctica, como un ente que posee una peculiar constitución ontológica, este ente no está en el tiempo, no pasa en el tiempo sino que es el tiempo mismo, y en virtud de esto, sostiene Heidegger que "es un ente cuyo propio ser está en juego en el modo como se despliega temporalmente (Weise seiner Zeitigung auf sein eigenes Sein ankommt)" (NB, 13/43), lo que significa, que es un ente que a cada momento se juega la vida, está en juego su ser mismo, por eso le va su ser en cada ocasión, esta es la constitución originaria de la vida fáctica, que está en juego a cada momento.

Tal como comenta Heidegger, no debemos considerar esta reflexión acerca de la muerte como una posición pesimista o fatalista frente a la vida ni menos aún como una filosofía de la mortalidad o una metafísica de la muerte, nada más alejado de sus objetivos. Es una tesis ontológico fundamental, que pretende abrir el acceso a una exégesis del tiempo propio a la vida fáctica, que nos hace ver el presente y pasado de nuestras vidas, pero y ¿Qué pasa con el futuro? Aquí extrañamente, Heidegger no nos dice nada de este éxtasis que pronto adquirirá un especial protagonismo dentro de este armazón filosófico que está en un periodo de elaboración, pero queda sobrentendida su importancia en el modo de tratar el fenómeno de la muerte. No nos dice nada explícitamente, pero está latente en su interpretación la relevancia que adquiere el futuro al interior de su filosofía. Los fenómenos originarios elegidos por Heidegger para interpretar la peculiaridad del tiempo de la vida fáctica, son la expectativa de la parousía, la espera de la segunda venida del Mesías, y ahora la muerte es la que nos vincula de modo esencial con el tiempo de la vida fáctica. Pero además, esta temporalidad del Dasein humano hace posible determinar el sentido originario de lo histórico. Por medio de esta interpretación de la muerte Heidegger propone una nueva vía, que se sitúa lejos de esas consideraciones del tiempo y de lo histórico que habían sido las dominantes hasta ese momento, que aplican el modelo de las ciencias naturales para pensar el tiempo y lo histórico.

Tal como hemos visto, esta tarea ya venía siendo objeto de disquisición para Heidegger desde su escrito de habilitación, El concepto del tiempo en la ciencia histórica, y también se había expuesto de forma más elaborada en los cursos de Introducción a la fenomenología de la religión. Entiende que el fenómeno del tiempo es la llave que le permite desvelar la estructura ontológica de la vida fáctica, planteando una vía alternativa a la idea del tiempo dominante, surgida desde las ciencias naturales. Todo esto gracias a la determinación del fenómeno de la muerte.

Heidegger pretende explicar la temporalidad de la existencia por medio del análisis de determinados fenómenos, que de ninguna forma se pueden considerar como meros objetos disponibles, o ante los ojos para el análisis de un observador que los clasifique y 
ordene. Por ello señala, que "la posibilidad de la existencia es siempre la posibilidad de la facticidad concreta, entendida como un modo de temporización de la temporalidad de la existencia( Die Möglichkeit der Existenz ist immer die der konkreten Faktizität als ein Wie der Zeitigung dieser in ihrer Zeitlichkeit)" (NB, 14/44), con esto nos indica, que es la vida fáctica la que debe ser custodiada originariamente en la autenticidad de su despliegue temporal. Sin embargo, paradójicamente, en la exposición del tiempo de la existencia fáctica, hasta ahora, los fenómenos que nos permiten ese acceso se encuentran en un "más allá", en un "todavía no", indisponible, inobjetivable, del cual difícilmente se puede disponer como se dispone de algo presente ante los ojos, sino que por el contrario son en esencia algo futuro sin posibilidad alguna de objetivar. Este modo de ser futuro queda aún por determinar en su sentido originario, pero necesariamente ha de ser distinto a como se considera tradicionalmente el tiempo, y por tanto de lo que comúnmente se comprende como futuro; como un aún no pero luego sí, como un todavía no real que luego se hará efectivo. Esta distinción entre una consideración originaria del futuro y la idea tradicional del tiempo, lo dejamos por ahora solamente enunciado de forma general, en virtud de que luego adquirirá contornos mas definidos. Pero, este fenómeno originario de la muerte es el que permite al Dasein ser en la propiedad de su ser y posibilita el acceso a la estructura constitutiva de este ente, tiene un carácter temporal eminentemente advenidero.

Si se quiere aprehender la vida fáctica en su genuina constitución ontológica y que nos revele su ser, solo es posible por medio de un contramovimiento a la caída. Así lo hace saber Heidegger cuando dice, que "El ser de la vida en cuanto tal, accesible a la facticidad misma, es de tal modo que solo deviene visible y aprehensible indirectamente a través del contramovimiento que se opone a la tendencia hacia la caída del cuidado. Este contramovimiento, que es propio de la inquietud de la vida por caer en el olvido, determina el modo según el cual se temporaliza la posible aprehensión auténtica de la vida" (NB, 13/43). Lo que se presenta con esto, es una alternativa, un modo de ser que por medio de un contramovimiento (Gegenbewegung) hace posible la aprehensión auténtica y originaria de la vida fáctica. Profundizando aún más en esto el filósofo alemán dice: “el contramovimiento que se opone a esta tendencia hacia la caída no debe interpretarse como una huida del mundo. En efecto, es propio de toda huida del mundo el hecho de que no se busca comprender la vida en su carácter existencial (es decir, de que no la aprehende en su problematicidad radical), sino que la inserta en un mundo nuevo y tranquilizador" (NB, 14/44). Según lo expuesto aquí, debemos entender que en primer término este contramovimiento hace referencia a una motilidad propiamente humana distinta del movimiento de cualquier otro objeto o ente y adquiere aquí el nombre de contramovimiento por oponerse a la tendencia huidiza de la vida, que se manifiesta en la caída. Un contramovimiento tal, que permite una comprensión genuina de la vida y de su ser, y abre la posibilidad de ser propiamente. También puntualiza, qué la caída es una forma de huida, pero que no se huye del mundo como se podría pensar normalmente, sino 
que se huye justamente hacia el mundo, hacia las cosas que él nos entrega, se huye hacia un mundo nuevo y tranquilizador. Como vemos estas cuestiones están en consonancia con varias de las cuestiones tratadas en los cursos de fenomenología de la religión.

Esta inclinación de la vida fáctica a la caída, evidencia que la mayor parte del tiempo el hombre vive sumido en la interpretación de la publicidad en la que no es él mismo, se interpreta según lo que dicta el uno, en lo que ya viene predeterminado e impuesto por el uno. Situación que alcanzaría también a la filosofía, ya que ella es una interpretación concreta de la vida fáctica, por lo cual se encuentra siempre sumida en el carácter dinámico de ella misma. Toda exégesis se encuentra ya caída, sigue a lo que se da por verdadero en el estado de interpretación en el que se encuentra, y conserva una influencia importante al momento de plantear los problemas y conducir la investigación filosófica. Es por eso, que "la hermenéutica fenomenológica de la facticidad arranca necesariamente de la del corazón mismo de su situación fáctica, de un determinado estado de interpretación de la vida fáctica (Ausgelegtheit des faktischen Lebens), estado que le viene predado, que sostiene inicialmente la misma hermenéutica fenomenológica de la facticidad y que ya no puede ser enteramente erradicado" (NB, 18-9/49). En suma, toda consideración filosófica parte ya de un determinado estado de interpretado, cuestión que ya viene dada con la propia interpretación. Precisamente, "en esto consiste la tarea de la hermenéutica fenomenológica de la facticidad. Ha de desvelar la interpretación dominante según sus motivos ocultos y ha de proceder a una destrucción que conduzca la explicación de los orígenes" ${ }^{\prime 9}$.

\section{B. LA NeCESidAd DE UNA VUELTA A ARISTÓteles}

Heidegger en su análisis de la estructura ontológica de la vida fáctica ha reconocido un fenómeno enquistado en la constitución misma de este ente que impide la claridad conceptual respecto a él mismo, cuestión que es necesaria de aclarar para acceder de forma concreta a esas estructuras y al carácter esencial de dicho ente que como hemos dicho se interpreta a sí mismo desde el marco conceptual de un determinado estado de interpretado que le tradición le ha heredado, por ello se plantea como tarea fundamental la determinación de los supuestos de esa interpretación heredada, cuestión que nos remite necesariamente a Aristóteles, por lo que es absolutamente necesaria una vuelta hacia sus textos. "La razón última de esta exigencia la ha expuesto cuando, en su indicación formal de las estructuras formales de la vida fáctica, ha reconocido en ella la tendencia a la caída (Verfallenstendenz) y el estar interpretado (Ausgelegtheit)"95, lo que significa, que el acceso a las preguntas fundamentales, pasa necesariamente por el análisis de la situación hermenéutica en la que se sitúa toda interpretación, por lo cual necesariamente hemos de dirigirnos a Aristóteles.

\footnotetext{
94 Segura ,C., Hermenéutica de la vida humana, op. cit., p. 59.

95 Ibíd., p. 54.
} 
Pero vamos por partes, según Heidegger uno de los principales equívocos que sustentan este ser siempre en un determinado estado interpretativo, tiene que ver con la consideración que se hace de la vida humana como naturaleza, como evento mundano, como animal racional, de igual forma, la vida fáctica se comprende en virtud de una articulación similar a la que se lleva a cabo con la naturaleza, en la cual la exégesis se realiza desde los parámetros de las ciencias naturales. Ejemplo de ello es que se hable de naturaleza del hombre o de un compuesto de alma y cuerpo. Cuando se actúa así, nos se hace más que someter la vida fáctica a las categorías propias de las ciencias de la naturaleza, lo que conlleva que de igual forma se considere el tiempo propiamente humano según estos parámetros. La vida fáctica sigue estando dominada por una determinada visión de la naturaleza, sigue moviéndose en ese terreno del ideal de las ciencias propio de la física griega.

A juicio del filósofo de la Selva Negra, en la filosofía se sigue trabajando con una idea de hombre preconcebida desde antaño por la ética griega, pero sobretodo sigue trabajando con la consideración cristiana de hombre y de existencia humana. "La filosofía que se practica hoy en día se mueve, en gran parte y de manera impropia, en el terreno de una conceptualidad que se ha transmitido a través de una cadena de interpretaciones heterogéneas. Los conceptos fundamentales han perdido sus funciones expresivas originarias, ya que siguen el patrón de determinadas regiones de la experiencia objetiva"(NB, 19/50). He aquí una de las tareas principales que Heidegger se propone, el cuestionamiento de estas ideas heredadas desde la filosofía griega y su posterior penetración en el cristianismo, que oscurecen una indagación verdaderamente genuina de este ente.

Este estado de interpretado, que como hemos señalado, alcanza incluso a la filosofía, dado que los conceptos, los fenómenos, han perdido su sentido originario y sus funciones expresivas primitivas, ya que han sido consideradas según el esquema de un terreno de la experiencia objetiva, siguen ese modelo de interpretación. Para Heidegger, es menester recuperar el sentido primigenio propio de los fenómenos, es necesario reconducirlos a su esencial sentido ontológico, lejos de los encubrimientos propios de la tradición.

Así se va construyendo el edificio heideggeriano, su método de trabajo busca definir con claridad la tarea de la hermenéutica fenomenológica de la facticidad, esta "se ve obligada a asumir la tarea de deshacer el estado de interpretación dominante, de poner de manifiesto los motivos ocultos, de destapar las tendencias y las vías de interpretación no siempre explícitas y de remontarse a las fuentes originarias que motivan toda explicitación por medio de una estrategia de desmontaje. La hermenéutica, pues, cumple su tarea solo a través de la destrucción" (Die Hermeneutik bewerkstelligt ihre Aufgabe nur auf dem Wege der Destruktion) (NB, 20/51). Lo que el filósofo alemán pretende, es una apropiación auténtica de la vida fáctica, lejos de encubrimientos. Incluso comenta, que 
si la vida llega a renunciar a esta posibilidad de averiguación, de apropiación, está también renunciando a la posibilidad de apropiarse verdaderamente a sí misma, esta renunciando a la posibilidad de ser de modo auténtico.

De hecho, la consigna que el joven Heidegger proclamó fue bastante paradójica, y encerraba una crítica dirigida a todos lados. Fue la consigna de la hermenéutica de la facticidad. Hay que ser consciente de que esto es como una espada de madera; porque la facticidad significa precisamente la resistencia inamovible que lo fáctico opone a todo comprender y entender, y en la formulación especial que Heidegger dio a este concepto, la facticidad significa una determinación fundamental de la existencia humana ${ }^{96}$.

Es la vida fáctica la que debe ser custodiada en la originalidad y autenticidad de su despliegue temporal, lo que Heidegger quiere decir con esto, es que aquellos fenómenos que no podemos interpretar de modo auténtico, que parecen inaccesibles para una determinación de carácter originaria y precisa, se fundamenta en que no sabemos interrogarlos de forma correcta, por lo que difícilmente se nos harán accesibles en su ser propio. Por eso, "lo que realmente se echa de menos es una auténtica interpretación que se centre y se funde en la problemática fundamental de la facticidad, tal como la venimos exponiendo" (NB, 22/53). En consecuencia, tal como lo viene anunciando desde sus primeros cursos universitarios, esta es la tarea realmente importante según Heidegger; una apropiación originaria de la facticidad peculiar a la vida humana. Una apropiación de ese tipo, debe deshacerse de los encubrimientos que la tradición ha puesto sobre el fenómeno, ya que ello es lo que ha impedido acercarse genuinamente a él. En este contexto aparece la figura de Aristóteles, que por una parte sirve a Heidegger para la elaboración de su analítica existenciaria, y, por otra, es la figura clave en esta historia del encubrimiento del sentido genuino de los fenómenos, en especial de la vida fáctica y de la pregunta por el ser. Como consecuencia de esto es que plantea como tarea insoslayable una vuelta a la filosofía clásica, cuna del pensamiento occidental, pero al mismo tiempo, fuente del encubrimiento en el cual se sustenta la consideración común de la vida fáctica. Heidegger sostiene:

Aristóteles representa solo el cumplimiento y la consumación concreta de la filosofía que le precede; en efecto, Aristóteles alcanza en su física un nuevo y fundamental punto de partida del que arrancan su ontología y su lógica, y que desde ese momento, pasará a dominar la historia de la antropología filosófica. (...) el fenómeno central cuya explicación constituye el tema de la física, es el ente en el cómo de su ser movido (Das zentrale Phänomen, dessen Explikation Thema der Physik ist, wird das Seiende im Wie seines Bewegtseins $)(\ldots)$ solo a partir de un regreso a Aristóteles, resulta posible determinar y comprender la doctrina del ser de Parménides como una etapa decisiva que determinó el sentido y el destino de la ontología y de las lógicas occidentales. (NB, 24/55)

El filósofo nativo de Messkirch considera como imprescindible para llevar a cabo la tarea propia de la filosofía, que es la apropiación genuina de la vida fáctica, una vuelta a la filosofía griega, especialmente un regreso a Aristóteles. Solo en esa vuelta es posible

${ }_{96}$ Gadamer, H., "Kant y el giro hermenéutico", en Los caminos de Heidegger, op. cit., p. 63. 
reconocer la doctrina del ser que es la dominante hasta nuestros días, que expande sus influencias hacia los más amplios horizontes del pensamiento, principalmente a la filosofía, y con ello todas las consideraciones de la vida humana que han llegado hasta nosotros. Se observa claramente cual es la dirección que sigue la filosofía de Heidegger por estos años, que en principio pretende determinar el quehacer filosófico y su objeto primordial, para luego atacar a la tradición metafísica y su conceptualidad, que ha oscurecido y entorpecido una consideración originaria de la vida fáctica en su ejecución, camino que necesariamente pasa por la definición de su herramienta metodológica de la hermenéutica fenomenológica de la facticidad, con la que debe acometer la tarea de la destrucción de la tradición metafísica.

Según Heidegger, Aristóteles sería la figura emblemática en la cual se manifiesta el cumplimiento y concreción de las filosofías anteriores, en él se cristalizan las concepciones del ser que le preceden. Particularmente la Física aristotélica marca un punto de inflexión, en ella se da un nuevo comienzo, punto de partida de su consideración ontológica, que recoge como tema fundamental al ente en el cómo de su ser-movido, el ente en tanto es ser movido. No obstante, "el aspecto bajo el que Aristóteles contempla el ser del Dasein no es el adecuado, puesto que lo aborda desde la sublimación de la idea de movimiento, consecuencia de la primacía del aludido sentido de producción"997.

Este es un nuevo comienzo sobre el que Aristóteles edificó su constructo filosófico: la experiencia del movimiento. Sin embargo, para Heidegger esta experiencia tal como la entiende el Estagirita no es una determinación propia de la vida fáctica ni tampoco originada desde ella. Por eso pregunta:

El sentido ontológico que, en última instancia, caracteriza el ser de la vida humana, ¿se extrae directamente de una experiencia fundamental pura de este objeto y de su ser? $\mathrm{O}$, por el contrario, ¿se considera la vida humana como un ente radicado en el interior de un ámbito ontológico más comprensivo, es decir, se somete a un sentido del ser dominante como si obedeciera a un arconte? ¿Qué significa ser en general para Aristóteles? ¿Cómo es este ser accesible, comprensible, determinable? El ámbito de objetos que presta el sentido originario del ser de los objetos producidos, el de los útiles empleados en el trato cotidiano (con el mundo) (Das Gegenstandsfeld, das den ursprünglichen Seinssinn hergibt, ist das der hergestellten, umgänglich in Gebrauch genommenen Gegenstände) (NB, 26/57).

Heidegger se plantea aquí una de las preguntas de mayor importancia dentro de su incipiente proyecto filosófico, que tiene que ver con la cuestión de si la interpretación de la vida humana, como hombre, como animal racional o compuesto de cuerpo y alma, corresponde a una exégesis ontológica genuina obtenida desde este mismo objeto, desde el mismo fenómeno o, si por el contrario, dicha consideración es realizada desde una interpretación ontológica dominante a la cual todos lo entes se deben ajustar. Se pregunta si responden dichas interpretaciones a una consideración metafísica dominante. A todo

97 Segura, C., Hermenéutica de la vida humana, op. cit., p. 38. 
esto Heidegger responde diciendo que esta determinación del ser desde el cual se consideran e interpretan todos los entes obtiene su sentido desde los objetos producidos, desde los útiles empleados en el trato cotidiano con el mundo. Se establece así un vínculo entre la pregunta por la vida fáctica y la pregunta por el ser, que como hemos señalado expande su radio de influencia hasta la misma pregunta por la vida humana, determinándola desde siempre.

Empero, Heidegger no se contenta con esto y quiere profundizar aún más. Por eso se pregunta que entiende Aristóteles por ser, dando así un paso decisivo en su destrucción de la historia de la metafísica, cuestionando directamente a Aristóteles y a su idea del ser. "El mundo que sale al encuentro en el trato que produce y que usa es el hacia qué, hacia lo que se orienta la originaria experiencia del ser. Por ello, ser significa ser producido (Hergestelltsein)y en cuanto tal ser disponible(Verfügbarsein). En esta interpretación se contienen los elementos necesarios para que en los años siguientes Heidegger llegue a una conclusión que todavía no aparece formulada en el Informe Natorp: que ser significa presencia, Anwesenheit" ${ }^{\text {"98 }}$. Por consiguiente, ser significa para Aristóteles ser-producido (Hergestelltsein) y también ser-disponible (Verfügbarsein), como aquello que ha sido producido, finalizado, que está disponible como actividad y resultado del trato productivo, de la poíesis. Se puede decir entonces que obtiene su sentido de ser desde el trato práctico con las cosas y que propiamente es, tiene un ser en grado eminente.

Significa entonces, que Aristóteles obtiene el sentido del ser desde el ámbito de los objetos, de las cosas, de la realidad efectiva. De esta forma, "el horizonte al que tiende la experiencia originaria del ser no se asienta en el ámbito ontológico de las cosas concebidas a la manera de un objeto que se aprehende teoréticamente en su contenido real, sino que se remite al mundo que comparece en el trato de la producción, de la ejecución y del uso de los objetos producidos (sondern die begegnende Welt im herstellenden, verrichtenden und gebrauchenden Umgang ist das Worauf, auf das die ursprüngliche Seinserfahrung abzielt)" (NB, 26/57). Por lo tanto, esta comprensión del ser propia de la filosofía aristotélica es la del ser producido, lo que denota al mismo tiempo que la vida humana no adquiere sus determinaciones desde el ámbito de una aprehensión teórico contemplativa, sino más bien desde los objetos o desde la cosas que le hacen frente en el mundo y de las cuales se ocupa en el trato propiamente ejecutivo, productivo de esos objetos, en tanto ser producido. Es desde el círculo de estas consideraciones que se obtienen las estructuras de la vida humana, su estructura ontológica. Por una parte, crítica a Aristóteles y, por la otra, recoge elementos importantes de su filosofía para el desarrollo de la suya propia.

También es necesario preguntarse por cómo surgen estas estructuras ontológicas, por cómo se pueden reconocer, cuestión que solo será posible en una investigación que parta desde una situación anteriormente abierta por y desde una experiencia ontológica fundamental, una investigación de este tipo se dirige hacia una región del ser, tiene un

98 Segura,C., Hermenéutica de la vida humana, op. cit., p. 62. 
carácter ontológico. Respecto a esto, Heidegger señala: "las investigaciones que tienen por objeto el ser-movido-tal como es experimentado y mentado en su carácter ontológico y en el que además, está previamente co-dado algo así como el movimiento debe facilitar el acceso al verdadero motivo que origina la ontología aristotélica"(NB, 27/59), como vemos la pregunta por dichas estructuras ontológicas nos termina por conducir a Aristóteles, más precisamente a su Física, en la que se articularía esta interpretación del ser que ha determinado la tradición metafísica y la historia del pensamiento occidental. En esta forma de llevar a cabo la investigación, "es como lo movible se torna visible en su carácter ontológico (de la misma manera que) el movimiento en su estructura categorial y, con ello, la constitución ontológica del sentido dominante del ser"(NB, 27/59). Se ha conseguido dar con los caracteres fundamentales de la interpretación dominante del ser, cuya influencia es verificable y palpable en toda la historia del pensamiento occidental. Son interpretaciones que claramente no dan cuenta de este ente en cada caso soy yo mismo, la vida fáctica no puede entenderse o concebirse a partir de estos presupuestos metafísicos que como vemos extienden su ámbito de influencia sobre amplios dominios.

No obstante, Heidegger pretende sacar réditos de la filosofía aristotélica, buscando justamente en Aristóteles rasgos, pistas que le ayuden para desarrollar su labor filosófica, busca en él los elementos que le permitan llevar a cabo su filosofía como una hermenéutica fenomenológica de la facticidad. Esto se debe esclarecer a la luz de un análisis del trato en sus distintas modulaciones. Existe una modalidad del trato que consiste en orientarse por las cosas, ocuparse de ellas, cosas que según su constitución ontológica pueden ser de otra manera, como entes que deben ser primariamente realizados, manejados o producidos en el trato mismo. Una conclusión importante que Heidegger obtiene de este análisis, en cuanto a que esta comprensión de la vida fáctica se obtiene desde una interpretación del ser como ser producido, disponible, es decir, desde la poíesis, tiene que ver con que esta comprensión del ser se extrae principalmente desde el ámbito del trato práctico con las cosas en cuanto finalizadas y disponibles para su utilización y no se obtiene esta determinación del ser desde una exégesis que considera primeramente a las cosas al modo de un ente que se comprende teóricamente, contemplativamente, sino que se orienta hacia el mundo que comparece en el trato de la producción y disponibilidad en el uso de objetos producidos y finalizados dispuestos para su utilización, que nos remite a la dimensión de la ejecución. Por lo tanto,

es en este contexto, como ha señalado acertadamente Volpi, donde hay que situar la incorporación de la filosofía práctica de Aristóteles. Esta pues de fuera de toda duda que el interés de Heidegger no es ético sino ontológico. Y ello hasta el punto que su propósito le lleva a operar una ontologización de las virtudes dianoéticas. A su vez, la ontologización a la que está haciendo referencia exige liberar de cualquier condicionamiento metafísico o antropológico a esas mismas virtudes y para ello, “es 
necesario formular las determinaciones prácticas en términos de connotaciones ontológicas" $"$ 99.

\section{LA DIMENSIÓN ONTOLÓGICA DE LA PHRÓNESIS}

Tal como hemos visto, Heidegger entiende que en su intento de responder a las preguntas respecto a desde dónde se obtiene este sentido directivo y dominante del ser, es imprescindible una vuelta a Aristóteles, puesto que su crítica es una de carácter tal, que intenta conocer los motivos ocultos que guían dichas interpretaciones. En tal sentido, es necesario pensar lo no pensado por Aristóteles. En primer término, la exégesis que lleva a cabo el filósofo alemán se remite a la Ética a Nicómaco, libro VI. En referencia a esto, Heidegger comenta:

la interpretación de este tratado, prescindiendo provisionalmente de la problemática específicamente ética, permite comprender que las "virtudes dianoéticas" son diferentes modalidades que permiten llevar a cabo una auténtica custodia del ser en la verdad (die Vollzugsmöglichkeit echter Seinsverwahrung). Sophía (la auténtica comprensión contemplativa (eigentliches, hinsehendes Verstehen)) y phrónesis (la circunspección solícita (fürsorgende Umsicht)) se interpretan como modalidades específicas en la que se realiza el nous; el inteligir puro en cuanto tal" (NB, 29/61)

En principio se ha de hacer notar que la custodia del ser en la verdad solo es posible gracias al nous que es el que posibilita el que lleguen a ser disponibles los entes, es decir que lleguen a ser desvelados. Esta es la posibilidad que abre el nous, en esto radica su importancia capital. El nous permite que una determinada región de objetos sea accesible. La sophía y la phrónesis son los modos concretos de realización del nous. Lo que Heidegger presentará, es una contraposición entre estas dos virtudes, una contrastación entre estos dos modos de custodiar el ser para ver en cuál de los dos se da una apropiación originaria de lo que la vida fáctica es genuinamente.

La pregunta es si su constitución ontológica se puede leer con mayor claridad en la phrónesis o más bien en la sophía. Estos dos modos de custodiar el ser son comprendidos por Aristóteles como las formas auténticas de custodiar el ser, como las formas genuinas de ser del nous. Según Heidegger:

el nous abre un horizonte que siempre responde a un modo concreto de tratar con el mundo a través de una operación, de una ejecución, de una manipulación, de una determinación (Ausrichten, Herstellen, Behandeln, Bestimmen). En la medida en que el nous le proporciona al trato su horizonte ( de acción y de visión) también puede caracterizarse como aquello que esclarece el trato, pero en el sentido de que facilita la custodia del ser en la verdad (NB, 33/66).

No obstante, lo que Heidegger verdaderamente lleva a cabo es una distinción de la sophía frente a la phrónesis, pero dicha contraposición no impide que señale que son dos los modos privilegiados de custodia del ser, pero principalmente que custodian los archaí, el

99 Segura ,C., Hermenéutica de la vida humana, op. cit., p. 68. 
"a- partir-de-dónde" en su propias regiones ontológicas. "En consecuencia le interesa destacar que con la interpretación de los fenómenos que constituyen las diferentes virtudes, se ofrece la posibilidad de determinar y delimitar al ente en el cómo de su ser aprehendido y, por lo tanto, en su genuino carácter de ser"100. Puesto que, la mayor ganancia del nous es que custodia los archaí en sus peculiares ámbitos ontológicos, la sophía y la phrónesis representan la concreción, la explicitación del llevar a cabo una custodia verdaderamente auténtica del ser en la verdad, es lo que hace que sean modos privilegiados de la custodia del ser. Sin embargo, esta es solo la razón que los acerca, ahora es menester indicar la diferencia entre ellos, qué es aquello que las contrapone.

Heidegger entiende que la sophía es: "el puro comprender contemplativo custodia el ente y el "a-partir-de-dónde" ("Von-Wo-Aus") del ente que tiene la característica de ser siempre y necesariamente lo que es (notwendig und immer ist, was es ist, in Verwahrung). En cambio, la circunspección solícito-discursiva custodia un tipo de ente que en sí mismo puede ser distinto de su "a-partir-de-dónde"” (NB, 34-35/68). La sophía custodia el ser de un ente que posee una constitución ontológica de ser siempre necesariamente lo que es, de un ente que se conserva siempre de la misma forma, esto es lo que lo define ontológicamente. No obstante, la phrónesis, que según Heidegger es la circunspección solícito-discursiva, custodia un tipo de ente distinto, un ente que según su carácter ontológico puede ser de otra manera, de otro modo, que no es fijo ni determinado, esto en su archaí, en su a-partir-de-dónde. La vida humana no es nada fijo e inmóvil de una vez para siempre y necesariamente igual, sino que su característica esencial es que puede ser de otra manera. En él no hay nada fijo y acabado. Si hay algo fijo, de una vez para siempre, es que puede ser de otra manera.

Según Heidegger, la phrónesis custodia en su ser el hacia-que (Worauf)en el que se desarrolla el trato que la vida fáctica tiene consigo misma, pero también el modo de practicar ese trato, la forma de llevar a concreción ese trato. La práxis es un trato que cumple con estas características, es un trato que actúa, que solamente responde a los criterios que dicta la acción. Por lo tanto, no es un trato que responda al modo de la producción, por eso dice el pensador de Friburgo que "la phrónesis, en tanto que esclarece el trato con el mundo, contribuye al despliegue temporal de la vida en su ser" (die Phrónesis ist die Leben in seinem Sein mitzeitigende Umgangserhellung) (NB, 35/68). En la phrónesis se juega de algún modo la vida fáctica, en tanto ilumina aquel trato que el Dasein humano mantiene con el mundo, aquello hacia lo que se dirige la phrónesis es el ser que puede ser de otra manera, es una conducta eminentemente práctica que permite esclarecer el trato de la vida fáctica con el mundo, de esta forma se nos hace manifiesto aquello que la phrónesis hace posible; permite el desarrollo temporal de la vida fáctica en su ser teniendo un sentido eminentemente práctico. "Hoy en día está claro lo que Heidegger encontró en ella (phrónesis) y por qué la crítica aristotélica del bien y el

\footnotetext{
${ }^{100}$ Segura, C., Hermenéutica de la vida humana op. cit., p. 67.
} 
concepto aristotélico del saber práctico le fascinaron tanto: en ellos se describía una forma de saber (un $\varepsilon ı \delta o s ~ \gamma \omega \sigma \varepsilon \omega s)$ que ya no se podía referir a una objetivabilidad en el sentido de la ciencia, pues era un saber en la situación existencial concreta"101. Es la phrónesis es posible leer el carácter ontológico genuino de este ente, su determinación temporal e histórica.

la interpretación concreta muestra cómo se constituye en la phrónesis este ente que es kairós. La conducta práctica y solícita es siempre concreta y obedece a la forma del trato que se preocupa por el mundo. La phrónesis permite que quién actúa comprenda la situación: porque fija el ou eneka, el motivo-por-el cual actúa, porque hace accesible el para-qué $(W o z u)$ que en ese momento determina la situación, porque aprehende el "ahora" y porque prescribe el cómo (im Erfassen des "Jetzt" und in der Vorzeichnung des Wie). La phrónesis se proyecta hacia el exstaton, hacia el fin último al que apunta en cada caso la situación concreta vista de una manera determinada (konkrete Situation jeweils)(NB, $35 / 68)$.

Heidegger asigna a la phrónesis este carácter kairológico al que ya habíamos hecho referencia anteriormente, con el que alude al carácter temporal propio de la phrónesis, que de ningún modo puede equipararse al tiempo de la naturaleza. Este ente es kairós, un ente con un carácter temporal exclusivo de la vida fáctica, es un ente que es fundamentalmente phrónesis, práxis. Este tipo de conducta radicada en la phrónesis es siempre concreta, fáctica y responde de forma innegable al modo del trato que está dirigido al mundo de la vida fáctica que se ocupa u preocupa por el mundo. Por eso, en la phrónesis se hace visible y se abre el horizonte de la situación práctica para quién actúa, que le abre la posibilidad de comprender las razones, los motivos por los cuales actúa, le abre la posibilidad de comprender el hacia dónde. Esto porque le indica el para-qué que determina cada circunstancia, cada situación a la que se enfrenta, en este sentido le es posible aprehender el ahora y prescribir el cómo de la situación. "La phrónesis se proyecta hacia el exstaton, hacia el fin último al que apunta en cada caso la situación concreta vista de una manera determinada (konkrete Situation jeweils). La phrónesis, considerada en su doble dimensión de discurso reflexivo y solícito (besprechende, fürsorglich-überlegende), solo es posible porque primariamente es aistesis, una visión inmediata del instante (ein letztlich schlichtes Übersehen des Augenblicks)" (NB, 35/68). En la phrónesis se desvela el pleno momento del cómo singularísimo y peculiar de la vida fáctica. En otras palabras, es la apertura del horizonte de la situación y el motivo por el que actúa. Es así como la phrónesis se proyecta en dirección de la meta última hacia la que se dirige cada situación.

En la phrónesis descansa la posibilidad de apertura del mundo y permite al hombre dirigir sus acciones, gracias a esa virtud puede comprender la posición en la que se encuentra en el mundo, contribuyendo así al despliegue temporal de la vida fáctica. La phrónesis es la que hace accesible la situación del que actúa, porque determina aquello por lo qué actúa, determina el para qué, capta el ahora de la situación concreta, además que va

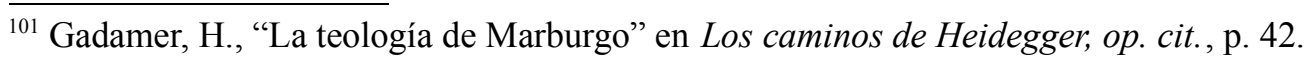


a señalar el cómo, lo que le hace patente al Dasein humano su situación fáctica concreta, porque puede captar las determinaciones particulares, la singularidad que está en juego en cada acción. En consecuencia:

el praktón, entendido como el ente que se desvela y deviene disponible en el aletheuein de la phrónesis, es algo que existe en la modalidad de todavía no ser esto o aquello ( en el sentido de que es el objeto de una disposición concreta del trato ( cuyo esclarecimiento constitutivo depende de la phrónesis). El "todavía no" y el "ya" encarnan unas determinadas formas de explicitación: determinadas, por el hecho de que en ellas el objeto es colocado en un aspecto señalado de movimiento(NB, 36/69).

El ente que ha de ser desvelado es lo praktón y este todavía no ha sido determinado, es algo que aún no está dado, es algo que no es completamente fijo ni dado de antemano. Con esto se alude justamente a la tarea de la phrónesis, es lo que tiene que llevar a cabo, esta es su constitución esencial, de dirige a lo praktón. Solo es tal, como el hacia qué de la vida fáctica que se ocupa (Worauf eines Besorgens).

Lo praktón es el objeto de la phrónesis, algo que se debe hacer, que se ha de procurar, es el hacía qué de la actividad de la vida fáctica (que se ocupa), este es su sentido. $Y$ en esa modalidad de no ser esto o aquello, como objeto del trato que se ocupa, de la acción que se ocupa, es un todavía no que solo será plenamente cuando se lleve a cabo el acto y así pasa desde el todavía no al ya presente. Nos encontramos frente a dos instancias temporales, que hacen comparecer el instante. "la aletheia praktiche no es otra cosa que el instante-desvelado cada vez en su plenitud- en el que la vida fáctica está decididamente predispuesta a habérselas consigo mismo, y ello en el contexto de una relación fáctica de la preocupación por el mundo que en este mismo instante le sale al encuentro (das innerhalb eines faktischen Besorgensbezuges zur gerade begegnenden Welt)" (NB, 36/69).

En la phrónesis se hace manifiesto el momento, el pleno instante de la vida fáctica que es trato con sí misma, por consiguiente es acto, es eminentemente práctica. Por eso:

en cuanto que ocupado el Dasein está ahí como todavía no, ya para, casi, hasta ahora, por primera vez, en definitiva. Se trata de lo que Heidegger caracteriza como los momentos kairológicos del Dasein. Señala, que además de partir de esta temporalidad (Zeitlichkeit) se hacen comprensibles, por vez primera, todos los momentos fundamentales del tiempo (...). La temporalidad (que en modo alguno es reductible al tiempo físico) y su explicación se extraen a partir del kairós porque la temporalidad del Dasein es kairológica ${ }^{102}$.

Es evidente entonces, que esta determinación de la phrónesis tendría una importancia radical, en cuanto sentaría las bases de la interpretación de la temporalidad en la filosofía de Heidegger, puesto que, la phrónesis se vincula esencialmente con la temporalidad propia del Dasein humano, con su carácter kairológico. Por otra parte, "la phrónesis es el modo de custodiar el instante en su plenitud, la circunspección custodia en un sentido

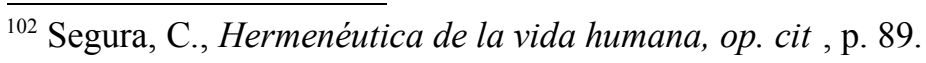


auténtico y genuino el "por-qué" de la acción, sus archaí. El arché es lo que es siempre y únicamente en la referencia concreta al instante; el arché es aquí visto y aprehendido en para este instante" (NB, 36/70).

Dado que la phrónesis custodia un ente que puede ser de otra manera, como objeto del trato que se ocupa, es un todavía no que pronto llegará a ser, el "ya" es el que hace comparecer el instante, el kairós. En esta interpretación novedosa de la prudencia es el tiempo mismo del Dasein como kairós el que se hace manifiesto, revelando un peculiar carácter ontológico de un ente que es temporal, pero no porque pasa en el tiempo, sino porque su temporalidad es kairológica:

y es que con la idea de kairós se ofrece una comprensión de la temporalidad que nada tiene que ver con la comprensión habitual del tiempo físico y que resulta adecuada para el propósito heideggeriano de comprensión del ser y el tiempo. En último extremo se puede decir que el discípulo Husserl cree encontrar en Aristóteles una anticipación, si bien a un nivel óntico, de la intuición que él eleva a una potencia ontológica en la ecuación de serahí y temporalidad ${ }^{103}$.

De manera que, Heidegger presenta una comprensión originaria de la temporalidad, cuestión que tal como habíamos visto, ya había tratado en su cursos de fenomenología de la religión, como un tiempo propiamente humano, lejos del tiempo en su acepción clásica.

La phrónesis se constituye en una modalidad de ser y el phrónimos es la ejecución de ese modo de ser, es la vida fáctica que actúa correctamente, en el sentido de que toma decisiones sobre su vida y ello a partir de la propia acción. Esto es lo que Aristóteles no fue capaz de entender, según Heidegger, lo que tuvo como consecuencia que al Estagirita se le hizo incomprensible el peculiar sentido ontológico de la phrónesis, que es justamente lo que se pretende recuperar en la filosofía heideggeriana. Heidegger resume lo anterior de la siguiente forma:

La phrónesis prescriptiva, presenta el ente bajo los rasgos de aquello de lo que ese menester ocuparse, considera y mantiene cada determinación del instante desde las siguientes perspectivas: el cómo, el para-qué, el en qué medida y el por-qué. En cuanto esclarecimiento prescriptivo, la phrónesis coloca el trato en la actitud fundamental del estar-dispuesto a ..., del desprenderse-de..., el hacia-qué al que aquí se hace referencia-el ente desvelado en el instante-comparece desde la perspectiva de la significatividadpara..., de lo que hay que ocuparse, de lo que requiere ahora una solución" (NB, 36/69).

Una vez analizado este modo de custodiar el ser en su verdad que le es peculiar a la phrónesis, es menester preguntar por el modo de desvelamiento que según Aristóteles es el más alto y eminente, nos referimos a la sophía. Heidegger sostiene que la principal diferencia entre sophía y phrónesis, es de tipo estructural y fenoménica, dado que cada una de ellas solo permite ver sus respectivos ámbitos ontológicos. Hemos de tener presente que estos son los modos fundamentales del inteligir, del nous.

${ }^{103}$ Ibíd., p. 84. 
Pero antes de esto hemos de finalizar precisando que "esta comprensión heideggeriana de la prudencia y del kairós tiene una serie de consecuencias que Franco Volpi ha puesto de relieve acertadamente. En primer lugar, hay que destacar el predominio del futuro porque el Dasein se vincula con su ser con una relación de tipo práctico y las actitudes prácticas -deliberación y decisión-tienen que ver con el futuro. Algo que contribuye también al rechazo de la metafísica presencialista"104, cuestión que como sabemos es verdaderamente fundamental y decisiva en la filosofía de Heidegger. Volpi expone la importancia de esto de la siguiente forma:

de la ontologización de la práxis y de la determinación práctica de la forma de ser del Dasein saca Heidegger consecuencias fundamentales: 1) Contra el primado metafísico del presente y la presencia, sostiene Heidegger el primado del futuro. Precisamente porque el Dasein se comporta consigo mismo en un sentido eminentemente práctico, en la medida en que decide respecto a su ser, es este ser que está en juego, en cada caso futuro, pues como Aristóteles enseña en la Ética nicomaquea, deliberar (Boulesis) y decisión (proairesis) conciernen en cada caso al futuro ${ }^{105}$.

En esta interpretación el filósofo italiano muestra lo que a su juicio es el punto de partida y desde dónde Heidegger postula esta idea del tiempo, que alude a la primacía del advenir en la interpretación de la temporalidad; sería Aristóteles la influencia decisiva que marcaría al filósofo alemán y determinaría su interpretación del tiempo como esencialmente advenidero.

\section{CONTRAPOSICIÓN ENTRE El SABER PRÁCTICO Y TEÓRICO}

Aún cuando Heidegger ha avanzado sustancialmente en la determinación de la estructura ontológica de la vida fáctica, esta no ha sido expuesta su sentido ontológico fundamental, aún no se ha dado cuenta de su ser, solo se ha expuesto en su carácter formal, como aquello que también puede ser de otra manera, que no es siempre y necesariamente de la misma forma. Esta determinación ontológica de la phrónesis se realiza por contraposición, por contraste con otro auténtico ser, porque no puede ser explicado desde el ser de la vida humana, porque en su estructura es el resultado de:

una radicalización ontológica-realizada de una manera determinada- de la idea del ente en movimiento (ontologischen Radikalisierung der Idee des Bewegtseienden). Para este mismo ente y con el fin de relieve su sentido estructural, se recurre al ejemplo prototípico del movimiento del producir según un plan. Ser significa estar-finalizado, el ser en el que el movimiento llega a su fin (Sein ist Fertigsein, das Sein, in dem die Bewegung zu ihrem Ende gekommen ist) El ser de la vida es considerado como una actividad que encuentra en sí misma su fin; el ser de la vida se encuentra en esta actividad cuando la vida humana ha llegado a su fin con respecto a su posibilidad del inteligir puro. Esta actividad es propia de la sophía" (NB, 37-38/71).

\footnotetext{
${ }^{104}$ Ibíd., p. 90.

${ }^{105}$ Volpi, F., “Ser y tiempo: Semejanzas con la Ética a Nicómaco”, op. cit., p. 138.
} 
Por lo tanto, esta idea del ser es el resultado de la radicalización ontológica que se lleva a cabo desde la idea del ente en movimiento, que para ser explicado o ejemplificado se utiliza el ejemplo del producir que a llegado a su fin, en consecuencia, ser significa ser producido o estar finalizado.

Es claro que para Aristóteles la primacía la posee la sabiduría por sobre la prudencia, dado que la sophía custodia este ser que es siempre y necesariamente. Obteniendo su sentido directivo del ser por medio de una radicalización ontológica del ente en movimiento. Además, lo más importante en este momento para Heidegger es que el ser de la vida fáctica no puede ser interpretado desde esta perspectiva, desde este criterio directivo del ser; su ser y su manifestación concreta no han sido considerados de forma correcta. Para Aristóteles el ser de la vida humana es la actividad que tiene su fin en sí misma y se encuentra en esa misma actividad cuando la vida alcanza su fin en su posibilidad más alta, que es la del inteligir puro, la actividad peculiar a la sophía. Según esta interpretación, "el ser de la vida es visto como un proceso que transcurre en ella misma pero que en realidad a llegado a su fin, por lo que respecta a su más propia posibilidad de movimiento, la del percibir puro. Una actividad que se desarrolla en la sophía" ${ }^{106}$. No obstante, Heidegger entiende que esta actividad que desarrolla la sophía no se toma en cuenta el modo de ser de la vida fáctica, esta no es parte del horizonte intencional de la sophía, puesto que el Dasein es un ente que tiene una constitución ontológica según la cual puede ser de otra manera.

El ser de la vida fáctica, según Aristóteles, solo puede entenderse como el desarrollo puro del inteligir, de la sophía, respondiendo así a la actividad que le es propia. Como sostiene Heidegger, "el nous- en tanto que inteligir puro- se encuentra en su actividad genuina cuando renuncia a toda ocupación práctica y cuando simplemente se limita a inteligir; en segundo lugar, el inteligir puro es como tal la actividad que, en la medida en que tienes a la vista lo puramente inteligible, ha llegado a su fin; es una actividad que no solo no se detiene, sino que es justamente movimiento en cuanto a llegado a su fin" (NB, 38/72). La sabiduría, el inteligir puro, solo es tal, cuando renuncia a toda ocupación práctica, renuncia al ser de la vida en su facticidad, solo es importante la actividad del inteligir puro que tiene en sí misma su propio fin, como Heidegger señala aquí, esta actividad del inteligir puro está en movimiento, pero movimiento en cuanto llega a su fin del puro inteligir. "Lo que todo esto significa, en definitiva, es que la estructura ontológica del ser del hombre va a ser comprendida desde una ontología del ente en el cómo de una actividad concreta y desde la radicalización ontológica de dicha actividad. O lo que es lo mismo, esto supone que la estructura ontológica del ser del hombre no va a ser comprendida ni originaria ni adecuadamente" ${ }^{\text {107 }}$. Asimismo:

\footnotetext{
${ }^{106}$ Segura, C., Hermenéutica de la vida humana, op. cit., p. 91.

${ }^{107}$ Ibíd., p. 71.
} 
el verdadero ser del hombre se temporiza en la realización pura de la sophía permaneciendo sin preocupaciones mundanas, con tiempo y de una manera puramente inteligible junto a los archaí de lo que siempre es (immer Seienden) (...) la estructura ontológica del ser humano, resulta comprensible a partir de la ontología del ente en el modo de una determinada actividad y a partir de la radicalización ontológica de la idea de esta actividad" (NB, 39/72).

Lo anterior atestigua que solamente el inteligir puro, la noesis, que es pura teoría, cumple con la idea suprema de la actividad pura. Esto es lo que define el ser de la vida fáctica, es el modo de custodiar más digno, más alto, eminente y supremo. Significa entonces que ha de mantenerse lejos de preocupaciones mundanas que no sean las del puro inteligir. En esta concepción del ser de procedencia aristotélica no es posible obtener el ser de la vida humana ni menos aún la actividad más peculiar a ella y ello porque, "en su inercia contemplativa, la vida fáctica llega a incluso a abandonar el cuidado de la ejecución" (NB, 41-2/74), en esto ve el pensador alemán un problema manifiesto para un proyecto filosófico como el suscrito por él, en su interpretación de la filosofía aristotélica se puede verificar desde dónde obtiene su sentido la filosofía tradicional, en relación a esto es concluyente: el trato de carácter meramente contemplativo, que determina teóricamente, se presenta como un trato en el cual queda completamente excluida la vida humana en su facticidad, queda fuera de consideración el fenómeno de la vida, vida en la que ese trato contemplativo se sustenta, que se desarrolla en ella misma, formando parte de ella. Por lo mismo:

en esta crítica de la supremacía de la teoría y a la prioridad de lo que es siempre y necesariamente se encuentran las raíces de la conocida triple articulación heideggeriana del ser, según la cual los entes intramundanos que no tienen el modo de ser del Dasein se puede considerar bien como Zuhanden, bien como Vorhanden. Por las mismas razones y en estrecha relación con lo anterior, la crítica realizada en el Informe Natorp habría de conducir a Heidegger a su rechazo de la metafísica de la presencia. Lo que acabaría rechazando de Aristóteles (como ha señalado Brague) es que midiera al Dasein con la vara de la Vorhandenheit y lo interpretara desde ella ${ }^{108}$.

Es evidente entonces que aunque el joven Heidegger no tenga del todo definido su proyecto filosófico se encuentra ya tras la pista de aquellas cuestiones que le permitirán articularlo de forma más concreta y definida.

El trato contemplativo, cuya más alta manifestación se alcanza en virtud de la contemplación pura, el theorein, en el que se cristaliza la contemplación pura como la actividad más originaria de la que es capaz la vida humana y tiene el carácter de algo divino, por ello, para Aristóteles, "el theorein encarna la actividad más pura de que dispone la vida. Por esa razón es algo divino" (NB, 42/75), en tal sentido, no tiene por objeto las cosa humanas, ni mundanas que pueden ser de otra manera, que son contingentes, el sentido del ser por antonomasia se obtiene desde el orden celestial, desde el cosmos, desde lo inmutable, eterno e imperecedero, y ese algo divino es Dios. En 
consecuencia, "el theion expresa el carácter ontológico supremo que resulta de la radicalización ontológica de la idea de ente-en-movimiento. El theon es noesis noeseos (pensamiento de pensamientos) porque solo un inteligir de éste genero-considerado en su carácter ontológico, es decir, en si actividad-es el que satisface de la manera más pura la idea del ser-movido como tal. Este ente debe ser intelección pura, es decir, estar libre de toda relación emocional" (NB, 42/76).

A la luz de esta interpretación se puede concluir que para Aristóteles la sophía que tiene como objeto de consideración aquello que es siempre de la misma forma, que no cambia, que es inmutable, sería la actividad más pura de la vida humana, por eso es lo más elevado, lo que tiene mayor dignidad ontológica, la actividad que posee la mayor excelencia. Dios representa justamente su máxima manifestación, dado que es pensamiento de pensamientos y resulta de la radicalización ontológica del ente en movimiento, solamente en este inteligir se manifiesta la forma más pura de ente en movimiento. Y esto no tiene ninguna relación con algún tipo de quehacer práctico ni de preocupaciones mundanas.

\footnotetext{
En síntesis, el Estagirita entiende que la sabiduría tiene por objeto lo inmutable y que esto es lo mejor del cosmos, lo más excelente. La prudencia (que tiene por objeto las cosas humanas que son contingentes y particulares) no puede, de ningún modo, aspirar a ser lo más alto. En consecuencia, el sentido del ser por excelencia es determinado a partir de lo que en el cosmos hay de inmutable e imperecedero y de la capacidad que tiene el alma para contemplarlo. Pero es evidente que, en este caso, no hay una experiencia originaria del ser del Dasein ${ }^{109}$.
}

Heidegger ve que esta consideración ontológica del ente en movimiento y su explicitación es el sustento de las estructuras ontológicas que luego determinarán de forma implacable la conceptualidad cristiana, la idea de Dios y la experiencia religiosa.

Además de determinar el sentido ontológico de la vida humana, "la teología cristiana, la "especulación" filosófica que se encuentra bajo su influencia, así como la antropología que la acompaña en contextos de este tipo, se expresan en categorías prestadas y ajenas a su propio ámbito ontológico" ( $\mathrm{NB}, 43 / 76)$, cuestión que es justamente lo que el filósofo alemán crítica con vehemencia, que tanto la filosofía como la teología no obtienen sus determinaciones desde sí mismas, sino que las recogen desde otra región ontológica, desde otro ámbito, por lo tanto, difícilmente pueden expresarse según determinaciones originarias y correctas extraídas desde sí mismas.

La sabiduría ostenta la prioridad porque solo ella proporciona al ser que es siempre y necesariamente. El sentido directivo del ser se obtiene a través de una radicalización ontológica de ente en movimiento. Todo esto deriva en que el ser de la vida y la actividad peculiar a este ente no se interpretan desde una perspectiva originaria.

${ }^{109}$ Ibíd., p.92. 
Es evidente que para el filósofo alemán esta radicalización ontológica del ente en movimiento tiene amplias repercusiones, puesto que, se ha erigido como una exégesis predominante en la historia de occidente, en la historia del pensamiento, siendo determinante su influencia y su penetración en distintos ámbitos de las ciencias humanas, especialmente en la filosofía, y a través de esta, en la teología y en el cristianismo. De manera que, "está claro que si se considera que el sentido primordial de ser es el que corresponde al ente que es siempre y necesariamente, entonces la teoría (el tipo de saber correspondiente a la sabiduría) adquiere la primacía. A su vez, esta concepción está vinculada e incluso, como quiere Heidegger, respaldada, por aquella a la que nos hemos referido según la cual ser significa tanto como estar terminado"110. Sin embargo, esta radicalización ontológica no permite desvelar el ser de la vida fáctica, pero sí permite desvelar los motivos ocultos que guían la interpretación dominante del ser y de la vida fáctica. Ahora es menester analizar el carácter de este movimiento, de esta radicalización ontológica del ente en movimiento. Para esto es necesario remitirse a la Física aristotélica, que es el lugar donde se concreta ontológica y categorialmente el fenómeno del movimiento. La interpretación de Heidegger tiene principalmente dos objetivos, en primer término, "habría de mostrar cuál era la experiencia fundamental operativa en la física ; esto es, el modo en que se da su objeto (Gegenstandvorgabe): el kinoumenon. El segundo objetivo sería el de destacar las referencias bajo las que es situado ese objeto y las categorías (centrales para su valoración de la ontología aristotélica y, en definitiva, occidental) que surgen a partir del análisis mencionado: las de dynamis, energeia y entelechia"111.

Según Heidegger, en la Física aristotélica, al caracterizarse la investigación como pregunta acerca del arché, su tarea sería entonces custodiar los "a-partir-de-dónde", los archaí, que, como sabemos, no se manifiestan para el trato ocupado o en la realización práctica. El hacer práctico se ejecuta en otra dirección, en la que se dirige al mundo en torno que nos sale al encuentro a cada momento en nuestro trato con él. En relación a esto el joven profesor señala que la investigación del arché es una investigación de acceso y que el punto de partida es esencialmente crítico, en tanto se sitúa en una determinada precomprensión, en una situación hermenéutica predeterminada, situada en determinados presupuestos ontológicos. Por ello, sostiene que, "toda investigación se mueve en un determinado nivel de interpretación de la vida dado con anterioridad y en unos modos de hablar sobre el mundo dados también con anterioridad. En la propia facticidad (en la que se encuentra inmersa la investigación) está presente y operativo en el modo como ya los "antiguos físicos" vieron, nombraron y abordaron la "naturaleza" en clave discursiva" (NB, 45/78), en otras palabras, en la forma en que la vida fáctica se considera a sí misma

\footnotetext{
110 Ídem.

${ }^{111}$ Ibíd., p. 135.
} 
está presente el modo en que los primeros filósofos griegos interpretaron lo que les rodeaba. Con esto se expresa de qué forma se hace sentir todo el peso y el influjo de la tradición filosófica en toda meditación actual acerca de cualquier asunto, allí ya está presente y actuando la forma en que los primeros filósofos vieron y entendieron la naturaleza, que les brindó el modelo ontológico desde el cual construyeron sus categorías.

Se pregunta Heidegger: “¿acaso el modo como la investigación tradicional accede al ámbito del ser en cuestión no se mueve de entrada en "teorías" y tesis fundamentales, que no solo no se extraen del ámbito del ser, sino que directamente le cierran el paso?" (NB,44/78). En este sentido Aristóteles juega un papel preferentemente positivo, así el sentido crítico aristotélico subyace en la forma de plantear la pregunta, lo que tiene para Heidegger un sentido positivo y que parte de una experiencia decisiva y es: que desde un principio se presupone que hay entes en movimiento.

En esta interpretación de Aristóteles que Heidegger lleva a cabo sostiene que para aquel la concepción previa del ser elaborada por lo eleatas no formarían parte de esta discusión, pues ellos niegan el movimiento, "su concepción previa del ser, su teoría del ser es tal que, por principio, impide el acceso al ente en cuanto ente en movimiento (por consiguiente, impiden el acceso a la Physis)" (NB,45/78). Lo que significaría que su exégesis del ser imposibilita desde el primer momento el acceso al ente en cuanto ente en movimiento, lo que impediría que aspectos decisivos de la investigación y sus respectivas determinaciones fueran obtenidas desde el movimiento mismo. No obstante, Aristóteles, a pesar de ello, los sigue considerando como interlocutores importantes en esta discusión, pero con la única finalidad de poder asegurar en ésta crítica, "el horizonte decisivo para toda la problemática posterior" (NB, 45/79), es por esta razón, que su crítica ha de pasar necesariamente, en primer término por los eleatas. La importancia de no perderlos de vista estriba en que:

\footnotetext{
las conexiones ontológicas decisivas del poema de Parménides, muestra cómo el eleata puso por primera vez la mirada sobre el ser del ente, si bien-por decirlo en términos ontológicos-no logró superar ésta primera "impresión ontológica". Pero esta primera a la par que decisiva mirada ontológica fue también la última. La idea de que todo aquello que es experimentado existe en el modo de ser-objeto se convirtió en una tesis relativa al ámbito de lo real, de tal manera que este mismo ser-objeto se concibió en general como el ser que "realmente es" (Die Idee, alles Erfahrene ist im Wie des Gegenstandseins, wurde eine das Sachgebiet betreffende These, so zwar, daß dieses Gegenstansein überhaupt selbst "real" als das seiende Sein vermeint wurde) y a partir de esta concepción (objetiva del ser) las restantes determinaciones ontológicas se comprendieron negativamente $\mathrm{y}$, por tanto, se procedió a su descarte" (NB, 46/80).
}

Heidegger poco a poco va concretando su crítica a la filosofía griega, su tarea destructiva de la tradición y reconoce a Aristóteles como el interlocutor que le permite fijar, gracias a sus interpretaciones, el punto de partida de la determinación dominante del ser, desde dónde parte la pregunta por el ser del ente. Punto de partida que jamás fue abandonado, la 
consideración del ser-objeto como el ser que realmente es. Interpretación que, por lo demás, alcanza al mismo ser de la vida fáctica y de los demás entes de la naturaleza y del mundo. El ser del ente se obtiene a partir de la determinación y explicitación de la quiddidad de su objeto, de la quiddidad de su contenido ontológico. Cualquier otra determinación del objeto en cuestión, como por ejemplo la dimensión práctica y ejecutiva de la vida fáctica, se descarta y se comprende negativamente. Todo esto según Heidegger, es solo una consecuencia directa de la forma de tratar el problema del movimiento, por lo tanto, es acuciante explicitar con claridad este fenómeno.

Aristóteles reconoce en Parménides a aquel pensador que se planteó por vez primera la pregunta por el ser del ente, el primero que llegó a tener una impresión ontológica del ser del ente, pero no fue capaz de ver más allá, no pudo avanzar. Respecto a esto, señala Heidegger que "la interpretación muestra como Aristóteles pone en cuestión las opiniones y las explicaciones de los "antiguos filósofos de la naturaleza", examinando en qué medida fracasan siempre en su intento de explicar este mismo fenómeno a partir de teorías ya preconcebidas sobre el sentido del ser"(NB, 46/80), lo que indicaría, que el Estagirita cuestiona desde el principio las interpretaciones e ideas de los filósofos de la naturaleza y analiza hasta qué punto ellos han considerado el fenómeno desde sí mismo, se pregunta si han dejado que el movimiento se exprese desde su propia región ontológica. A lo que responde negativamente, sosteniendo que los filósofos de la naturaleza han fracasado en su intento de explicarlo desde teorías preconcebidas acerca del sentido directivo del ser. Por eso comenta Heidegger que es menester preguntarse: “¿en qué medida se examina en cada caso el movimiento en sí mismo y en qué medida se explicita genuinamente?" (NB, 47/81), con esto el joven profesor recuerda que Aristóteles lleva a cabo el análisis ontológico del movimiento desde distintas perspectivas, puntualizando además que estos análisis aristotélicos no han logrado ser superados hasta el día de hoy y, es más, ni siquiera han sido valorados ni entendidos según su sentido.

El Estagirita aborda el problema del movimiento desde distintas perspectivas pero el análisis más importante, según Heidegger, se da en la Física, en los capítulos 1-3, en relación a esto el pensador alemán comenta:

para Aristóteles resulta decisivo mostrar que, por principio, no es posible aprehender categorialmente el fenómeno del movimiento con las categorías proporcionadas hasta ese momento por la ontología tradicional: ser y no ser, alteridad y diferencia. El fenómenos se da a sí mismo sus estructuras originarias y últimas: la dynamis (el poder disponer cada vez de...), la energeia (el empleo de esta disponibilidad) y la entelechia (el hecho de tener en cuenta dicha disponibilidad mientras se emplea) (NB, 48/82),

Sin embargo, estas estructuras no sirven para explicar o aclarar el fenómeno del movimiento, por lo cual es menester destacar que este fenómeno se hace incomprensible y es imposible de aprehender originariamente si consideramos las interpretaciones recibidas desde la ontología tradicional como verdad absoluta. Y al mismo tiempo se ha de mostrar 
en dicha exégesis cuál es la experiencia fundamental desde la que fue considerado su objeto.

A juicio de Heidegger, cuando el fenómeno del movimiento es considerado de esta forma no obtiene desde sí mismo sus estructuras ontológicas, por lo tanto, será necesario destacar las referencias desde las cuales comprende y sitúa este objeto y, de igual forma, reconocer las categorías que surgen desde ahí, que son la dynamis, enérgeia y la enteléchia. Ahora, lo importante para la investigación heideggeriana es comprender originariamente cuál es el sistema categorial que se obtiene a partir de la interpretación del movimiento que lleva a cabo Aristóteles y que se encuentra siempre en un ámbito exegético preconcebido por la tradición. En la Física es dónde se encuentra la explicación ontológica del movimiento, es ahí dónde encontramos las categorías que permiten explicarlo, que son como hemos dicho las dynamis, la enérgeia y la enteléchia, estas son las estructuras últimas del movimiento. Todas estas cuestiones nos permiten "entender que la pregunta de la Física no es una pregunta por las causas ni por su número o naturaleza. Ésta sería tan solo la apariencia pero, como ha dicho Heidegger, tras ella se oculta la verdadera pregunta; si el movimiento es visto en sí mismo y si es explicado genuinamente" ${ }^{112}$.

La pregunta fundamental que el filósofo alemán se plantea es si el fenómeno del movimiento ha sido visto desde sí mismo y si ha sido interpretado de forma correcta. Lo que verdaderamente le importa es interpretar de modo crítico las categorías que se obtienen desde la exégesis aristotélica del movimiento, que determina por una parte la consideración de la vida fáctica y al mismo tiempo la tradición metafísica.

Sin embargo, Heidegger, una vez señaladas cuales son las estructuras ontológicas del movimiento, deja hasta ahí sus interpretaciones de la Física aristotélica. Como sabemos su objetivo es realizar una exégesis crítica de las categorías que se obtienen desde la explicitación del fenómeno del movimiento. Para ello considera menester volver sobre la Metafísica, que sería el lugar donde se encontraría de forma más elaborada la interpretación directiva del sentido del ser, cuestión que a Heidegger le interesa aclarar en este momento. Por esta razón, vuelve sobre la Metafisica, libros VII, VIII, IX.

Con esta investigación Heidegger pretende principalmente lograr una explicitación de la vida fáctica en su vertiente originaria. No obstante, quiere indicar también cómo esta experiencia originaria queda oculta por la influencia del sentido dominante del ser que domina la filosofía occidental, por lo cual no se puede obtener una experiencia originaria de la vida fáctica. Teniendo en cuenta esto señala que en la segunda parte de sus investigaciones fenomenológicas sobre Aristóteles se centrará sobretodo en la Metafísica VII, VIII, IX, lugar donde el Estagirita expone el problema de la ontologicidad, y con base a lo cual lleva a cabo la construcción ontológica de la dynamis (El siempre determinado

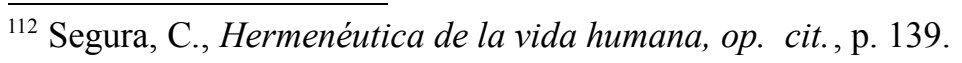


poder disponer) y la enérgeia (el hacer uso del disponer), que serían elementos constitutivos del ser del ente (Cf. NB, 48/82).

Según Heidegger, “Aristóteles desarrolla ésta problemática fundamental de la ontologicidad a través de una determinada manera de guiar la explicación de lo que es nombrado como tal en un logos determinado; al mismo tiempo, esto que es nombrado es, de acuerdo con el presupuesto (ontológico general), el aspecto de aquello que es movido de una manera o de otra y de aquello que resulta de un movimiento (kínesis, poíesis, praxis)"(NB, 48/83). Significa entonces, que existe un vínculo profundo entre el fenómeno del movimiento, su explicación ontológico categorial y la pregunta por el sentido del ser. Además, a partir de esta interpretación del ente en movimiento y de las categorías surgidas de él, estas son reconocidas como determinantes para comprender el ser de los entes. Esta interpretación aristotélica del movimiento y las categorías que se obtienen de él es lo que a Heidegger no le parece correcto. Entenderá esto como un malentendido que determinará la historia de la filosofía y la consideración de la vida fáctica. En efecto, "Hay que tener en cuenta que, como se ha destacado siempre, la cuestión que subyace a toda investigación heideggeriana (con la que está singular y directamente vinculado el problema concreto de la facticidad) no es otra que la pregunta por el ser; concretamente, por el sentido directivo del ser" $" 113$.

Otra cuestión importante a tener en cuenta es que en este carácter esencial del logos destacado por Heidegger, se esconde la pretensión de indicar cómo se presenta la intencionalidad en la interpretación aristotélica. Gracias a la intencionalidad que descubre Aristóteles es posible comprender el sentido fundamental del ser. Esto porque desde De anima Aristóteles interpreta la vida en su constitución lógico-ontológica desde la explicitación del ámbito ontológico de la vida fáctica, en virtud de la actividad que le es peculiar. La intencionalidad la entiende como una clase de actividad un cómo de la actividad de la vida fáctica, en la que su trato peculiar con el mundo se esclarece, se ilumina. Y el presupuesto ontológico para que se deje ver la intencionalidad no es otro que la del ente que se muestra según el aspecto del ente en movimiento, del ser movido, del estar ocupado en algo, con algo (Aussein auf etwas). Es la condición de posibilidad que permite descubrir la intencionalidad tal como la entiende Aristóteles, pero también es lo que posibilita ver el logos en su constitución esencial. En relación a esto, se pregunta Gadamer si:

\footnotetext{
¿era posible que Aristóteles incluso podría ayudar a superar los prejuicios ontológicos del concepto griego de logos, que Heidegger interpretaba más tarde en sentido temporal como ser-a-la-vista (Vorhandenheit) y presencia? Este impetuoso acercamiento del texto aristotélico a sus propias preguntas hace pensar que Ser y tiempo, donde es la llamada la conciencia (Gewissen) la que hace visible por primera vez aquel "ser-ahí en el ser humano" en la estructura del acontecer de su ser temporal. Porque fue solo mucho más
}

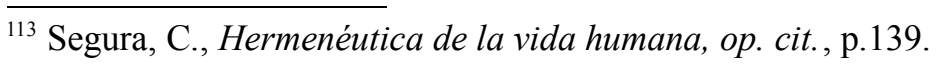


tarde que Heidegger desvinculó su concepto de ser-ahí en el sentido del claro (Lichtung), de cualquier pensamiento reflexivo trascendental ${ }^{114}$.

Como podemos ver, los alcances de este acercamiento a Aristóteles tienen consecuencias que van más allá de lo que a simple vista se puede constatar. En este mismo sentido, Heidegger comenta que de esta forma es, "como, por primera vez, se establecen los motivos concretos a partir de los cuales se hace inteligible el último estadio de la problemática ontológica y lógica alcanzada por Aristóteles" (NB, 49/83), para el pensador de la Selva Negra solamente desde lo alcanzado con la intencionalidad es posible que se hagan perceptibles, inteligibles, los problemas capitales que plantean la lógica y ontología aristotélica. Por lo tanto:

es posible y necesario entender cuál es el carácter fundamental del logos, puesto que éste resulta determinante para la configuración de las categorías y para el desarrollo de la lógica. Un asunto que también ha apuntado en sus interpretaciones de la Física (...) dentro del logos, quiere otorgar a la intencionalidad el lugar que le corresponde. Se trata de un lugar privilegiado puesto que solo es descubrimiento de la intencionalidad, realizado por Aristóteles, permite vislumbrar ese carácter fundamental del ser ${ }^{115}$.

\section{F. LA DETERMINACIÓN DEL SER COMO SER-PRODUCIDO}

Heidegger considera que para llegar todavía más a fondo en la problemática ontológico-lógica presentada por Aristóteles es necesario ampliar el círculo interpretativo hasta Metafísica III, IV, VI, X, De interpretatione y los Analíticos. Pero digamos que más que desarrollarla esta tarea solo queda indicada, no obstante, el pensador alemán anuncia cuál es el objetivo último de su interpretación y dice que "a partir de aquí resulta evidente en qué medida la ontología particular de una determinada región del ser y la lógica de un determinado nombrar discursivo se convirtieron, siguiendo la propensión a la caída de la interpretación, en la ontología y en la lógica que de una manera decisiva pasaron a dominar no solo su propia historia, sino también la historia del espíritu mismo, es decir, la historia de la existencia" (NB, 49/83). De modo que la intención última del profesor Heidegger es dejar establecido que el origen de la categorías aristotélicas no está en el logos en cuanto tal, ni que tampoco dichas categorías se obtienen de las cosas del mundo. Al mismo tiempo quiere mostrar que la lógica y la ontología, a merced de esta inclinación a la caída, se alejaron de su propio ámbito ontológico desde un principio de la elaboración aristotélica.

Dice más adelante: "las categorías son las modalidades fundamentales propias de un determinado nombrar discursivo relativo a un ámbito específico de objetos que-en el horizonte en que se mueve la investigación-tienen el aspecto de los objetos de los que se

\footnotetext{
${ }^{114}$ Gadamer, H., "La teología de Marburgo" en Los caminos de Heidegger, op. cit., p. 42.

${ }^{115}$ Segura, C., Hermenéutica de la vida humana, op. cit., p. 142.
} 
ocupa el trato ejecutivo" (NB, 50/84). Esto indica que el origen de las categorías no radica en el logos, pero no por eso se ha de creer que su origen se obtenga desde las cosas. A juicio de Heidegger, las categorías son modalidades fundamentales de un nombrar discursivo que se refiere a una región específica de objetos. Y esa región, es la de aquellos objetos de los que se ocupa el trato ejecutivo que son los que comparecen en la relación práctica del trato. Es una instancia eminentemente práctica, ejecutiva- no teórica-de la vida fáctica y las cosas del mundo. Por lo tanto, las categorías se entienden como raíces de los caracteres del como algo, como que, por medio de los cuales esa región de objetos se puede nombrar, y lo que se puede nombrar es lo objetivo. De tal forma, estas categorías, junto a las de dynamis y energeia, son las verdaderamente constitutivas para el ser de los objetos del hacer (on hos pragma) y ello a raíz de que han surgido de lo que es objetivo, "el sentido del ser remite originariamente al ser producido. Este ente solo está originariamente presente para el trato productivo, no así para el trato que hace uso del mismo; en efecto, este tipo de trato instrumental considera el objeto producido desde una perspectivas que no son las originarias del cuidado" (NB, 50/84).

Asimismo, el modo de ser del accidente no sería el propiamente constitutivo del ente, dado que el sentido directivo del ser se remite al ser producido. El ente solo está presente de modo genuino para el trato productivo, pero no está presente para el modo del trato que utiliza el mismo. Este tipo de trato que utiliza, este trato instrumental, interpreta el objeto producido desde coordenadas que nos son las originarias, aquí radicaría un malentendido fundamental de la filosofía aristotélica. Es evidente, según Heidegger, que para Aristóteles el sentido directivo del ser es el del ser producido, de modo tal, que un ente solo se da de forma genuina en el trato propiamente productivo y todo lo demás será derivado o secundario en relación a este trato productivo, el uso no posee ese carácter originario. El trato del uso tiene que ver con un objeto producido, ya terminado, por lo que dichas interpretaciones pueden obtenerse desde perspectivas que no son las originarias.

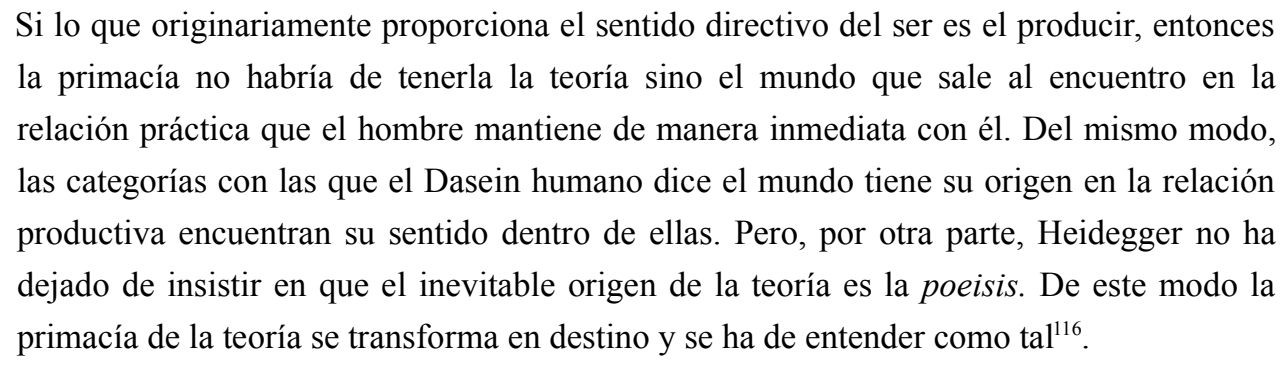

Heidegger, intentando explicar mejor esto, expone el ejemplo de una casa. Comenta que el ser de la casa es el ser construido, el ser producido, por lo tanto, el sentido del ser es completamente determinado, es decir, nada tiene que ver con un sentido vago e indeterminado del ser o de la realidad. El ser es relativo a la producción, a la poiesis, pero también a la circunspección, en la que se aclara este trato productivo. Según la interpretación del ser aquí esbozada, resulta fácil entender que los modos en lo que hacen

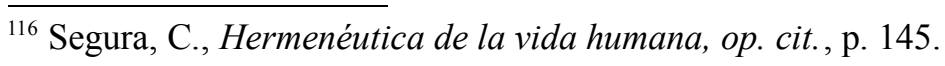


frente o salen al encuentro lo entes del mundo, los objetos del trato, se manifiestan solo de forma accidental. Para el pensador de la Selva Negra, "el hecho de que Aristóteles pueda sacar a relucir este rasgo de la accidentalidad como sentido propio del ser, es la mismo tiempo la expresión más clara de que experimentó plenamente el fenómeno del mundo circundante y de que interpretó ontológicamente la accidentalidad, aunque tomando como hilo conductor un determinado y bien definido sentido del ser" (NB, 50/85). Precisamente el sentido genuino del ser queda oculto en Aristóteles, a merced del poderoso influjo de la ontología legada a él por la tradición, por lo cual la pregunta originaria por el sentido del ser termina oscureciéndose y queda reducida a la indeterminación de conceptos tales como realidad, efectividad u objeto, nombres utilizadas por la tradición al momento de querer mentar al ser.

Aristóteles fue capaz de visualizar que el sentido del ser nace y se desarrolla con base a la relación productiva que se extrae de la relación práctica con las cosas del mundo, con las cosas que nos hacen frente en la cotidianidad, en el trato práctico. Según Heidegger, Aristóteles fue el primero que percibió esta conexión, pero por la presión de la ontología heredada no fue capaz de ir más allá, y terminó atrapado en esta concepción del ser, que acabó por delimitar la historia del pensamiento occidental y su consideración de la vida fáctica. Así la filosofía acabó por hacer suyos los asuntos de la problemática epistemológica. Tornándose la filosofía en una mera teoría del conocimiento. Dice Heidegger:

\begin{abstract}
este sentido del ser tiene su origen en el mundo circundante originariamente dado, pero ya en Aristóteles pierde- bajo el influjo de la ontología que fue elaborando- el sentido de su procedencia y, que el transcurso del desarrollo ulterior de la investigación ontológica, declina hasta quedar reducido al significado medio e indeterminado de realidad, de efectividad, de existencia real y efectiva; este significado (medio e indeterminado del ser como realidad y efectividad) el punto de partida de la problemática epistemológica, siempre y cuando la "objetividad" que a su vez resulta de la determinación teorética del objeto en términos de "naturaleza" no se convierta en el problema conductor del sentido del ser (NB, 51/85).
\end{abstract}

Como podemos ver, se hace sentir con fuerza el camino destructivo de la tradición filosofíca que Heidegger quiere llevar a cabo, que aunque aquí aparezca apenas esbozado y que en un par de años adquirirá tintes mas definidos, se puede apreciar bien hacia-dónde dirige su crítica; hacia esas categorías que han sido las privilegiadas para nombrar al ser; su crítica a la objetividad como modelo de la reflexión filosófica; su crítica a la concepción del ser como presencia.

Aristóteles elabora su constructo filosófico apoyado en dos pilares fundamentales: la lógica y la ontología, pero lo hace a través de una radicalización de la idea de movimiento y de actividad. El sentido directivo del ser es el del ser producido. Aristóteles construye su filosofía con base en la idea de movimiento, pero sin obtener una experiencia originaria de la vida fáctica. Esto último, a raíz de la tendencia de la vida fáctica a la caída, 
tendencia originaria que es propia de la vida que la mayor de las veces vive en lo inauténtico. Así se entiende que el movimiento peculiar al producir fuera víctima de una radicalización ontológica, en la cual se origina la prioridad de la sabiduría por sobre la phrónesis, y con esto la primacía de la energeía, lo que daría pábulo a la supremacía de una metafísica de la presencia, en la que se origina la concepción del ser como simple presente, es decir, la pregunta por el ser se vincula de forma esencial e inseparable con la pregunta por el tiempo. Cuestiones que el pensador de la Selva Negra no señala explícitamente, pero ya se dejan sentir e iluminan la dirección que guiará su crítica, su quehacer filosófico.

Hemos de decir al finalizar este capítulo que este informe escrito en el año 1922, para enviar a Paul Natorp con el objetivo de obtener una plaza en la Universidad de Marburgo, es de una importancia radical para nuestra investigación. Esto por varias razones, dado que en él confluyen una multiplicidad de temas que lo convierten en indispensable para la realización de nuestro trabajo. Por una parte, es claro, y así lo dice la crítica especializada $^{117}$, que podría ser considerado como un primer borrador de Ser y tiempo, donde se desarrollan algunos de los conceptos que se tratarán largamente en el escrito de 1927; y por otra, presenta un análisis novedoso y original de la muerte, como aquel fenómeno decisivo que permite la articulación de una interpretación genuina de la temporalidad propiamente humana, cristalizando uno de los objetivos principales que se había propuesto en los cursos de fenomenología de la religión, mutando su interpretación de la experiencia originaria de la temporalidad, desde una expectativa de la parousía hasta una experiencia originaria de la muerte. Sin embargo, ambos fenómenos conservan una consideración que tiene como raíz fundamental la importancia prioritaria del futuro dentro de esta consideración del tiempo peculiar a la vida fáctica. Además, a juicio de Volpi, sería precisamente en esta interpretación que Heidegger hace de la Ética nicomaquea lo que le revela este predominio del futuro, que el carácter temporal privilegiado del tiempo es el futuro, esto principalmente porque deliberación y decisión conciernen en cada caso al futuro, es decir, que el Dasein en cuanto que se comporta consigo mismo en un sentido eminentemente práctico es en cada caso esencialmente futuro en su ser ${ }^{118}$.

Esta importancia asignada al futuro, como algo que no puede hacerse disponible, ni efectivo, constituye de forma esencial la estructura ontológica originaria de la vida fáctica. Por otra parte, el informe pretende desvelar los motivos desconocidos, las razones por las cuales la vida fáctica en su constitución esencial ha permanecido oculta para la meditación filosófica, que como se ha visto, se debe a una interpretación del ser que se ha convertido en la dominante, por no decir la única, que ha influenciado tanto a la filosofía como a la

\footnotetext{
${ }^{117}$ Cf. Kisiel, Th., The Genesis of Heidegger's Being and Time, op. cit., p. 320.

${ }^{118}$ Cf. Volpi, F., "Ser y tiempo: Semejanzas con la Ética a Nicómaco”, op. cit., p. 138.
} 
teología y ha penetrado profundamente en la raíces del cristianismo, cuestión que también había quedado de manifiesto en los cursos de religión. Heidegger sostiene, que:

\begin{abstract}
la presuposición ontológica, el ente en movimiento y, la particular explicitación ontológica de este ente son las fuentes que motivan las estructuras ontológicas fundamentales que, más tarde, determinarán de una manera decisiva: el ser divino en el sentido específicamente cristiano (actus purus)y la vida intradivina (Trinidad), la mismo tiempo que la relación ontológica de Dios con el hombre y el propio sentido ontológico del hombre mismo. La teología cristiana, la "especulación" filosófica que se encuentra bajo su influencia, se expresan en categorías ajenas a su propio ámbito ontológico (NB, 42/76).
\end{abstract}

El joven profesor en esta interpretación directiva del ser, que considera como una radicalización ontológica de la idea del ente en movimiento como disponible, se encontraría ya en la cercanía de la identificación que lleva a cabo por esos años de la concepción del ser que ha dominado la historia de la metafísica, la concepción del ser como presencia. En este Informe Natorp se hace evidente, tal como en los cursos de religión, cuáles son las directrices que dominan los intereses filosóficos de Heidegger por esos años, la pregunta por la temporalidad propiamente humana y la pregunta por el ser, lo que implica poner en tela de juicio la originariedad y legitimidad, de su concepción dominante, que entiende el ser como disponibilidad, como ser producido. Esto es clave, toda vez que ya fijadas con claridad estas dimensiones de su pensamiento es posible ir analizando cómo dichas cuestiones van adquiriendo contornos más definidos, y en razón del descubrimiento heideggeriano de que de alguna forma en la comprensión griega del ser se oculta una interpretación de un carácter privilegiado del tiempo, esto le permitirá reformular la pregunta por el ser al hilo conductor de la pregunta por el tiempo. Todo esto nos permitirá ver cómo su filosofía se alimenta de aquellas cuestiones, que serán sobre las que fundamentalmente gira toda la problemática que Heidegger desarrolla en su filosofía temprana. Justamente en ello se podrá verificar la importancia que para la articulación de su proyecto filosófico tiene el futuro, el advenir como carácter fundamental del tiempo, que es lo que de alguna forma permite y posibilita tanto la crítica a la tradición como una exégesis originaria de la temporalidad de la vida fáctica, pero aún estamos en una fase primigenia del proyecto filosófico de Heidegger, por lo cual todavía esto no se manifiesta con todas sus aristas. No obstante, son estos los pilares fundamentales que alimentan su filosofía y son las cuestiones que tiene en mente cuando desarrolla su cursos de fenomenología de la religión, pero aquí se van haciendo manifiestas las conexiones entre dichos intereses, que antes solo se mantenían latentes, pero que poco a poco van adquiriendo contornos más definidos como un proyecto que ya se dejaba ver, que se intuía, pero que se va concretando en la medida en que va avanzando.

Se podría decir que en sus primeros cursos Heidegger de algún modo ya tenía claro hacia dónde iba encaminado su quehacer filosófico, pero no era consciente. Sabemos lo problemático que es hacer este tipo de afirmaciones pero creemos que esto se puede 
verificar en los mismos textos de Heidegger y en la dirección que va adquiriendo su filosofía y es lo que desarrollamos en este trabajo en relación a la cuestión del tiempo. Claramente el alcance de este texto es mayor que el que hemos señalado aquí, pero solo pretendemos dejar manifiesto qué es lo que vemos en él y por qué es tan importante para nuestra investigación.

\section{Capítulo IV: La ontologización de la vida fáctica como hermenéutica fenomenológica de la facticidad}

Si bien nuestro objetivo principal es exponer la importancia del advenir en la órbita de la obra temprana de Heidegger y su papel como articulador en la reformulación de la pregunta por el ser, en tanto es precisamente esa instancia temporal la que representa un reverso de la interpretación del ser desde la tradición metafísica que es concebida por los griegos como presencia. No podemos dejar de revisar de qué forma en la estancia temprana del pensamiento heideggeriano, en los trabajos que por la atingencia a nuestra temática hemos investigado, se lleva a cabo metodológicamente esa conjunción entre las distintas direcciones que sigue su pensamiento, decimos metodológicamente por cuanto se reúnen en un proyecto: fenomenología, hermenéutica y ontología. Heidegger pretende con esto llevar a cabo una exposición los más completa posible de la estructura ontológica de la vida fáctica, que nos lleve en último término hasta la pregunta por el ser mismo; todo esto pasando necesariamente por una investigación de la experiencia originaria del tiempo peculiar al Dasein. Según Heidegger el ser ha sido pensado desde el tiempo y desde allí pasa cualquier intento de reformulación de la pregunta por el ser. Hacia ahí debe ser reconducida la cuestión del ser para reconocer los presupuestos en los que descansa la interpretación del ser dominante en la tradición metafísica para así liberar a la pregunta por el ser de los prejuicios de la tradición y del manto de oscuridad que cae sobre dicho preguntar.

En el desarrollo de nuestro trabajo hemos podido comprobar que la pregunta por las categorías de la vida fáctica discurría por un camino aparentemente distinto al de la pregunta por el ser, aunque si bien esta pregunta no ha sido planteada expresamente, se podía reconocer que había quedado abierto el camino hacia su formulación concreta. Lo anterior, lo señalamos tomando en cuenta la dirección que ha seguido la investigación heideggeriana que en un principio denunciaba la insuficiencia de las categorías con las que la tradición filosófica pretendía dar cuenta de la estructura ontológica de la vida fáctica; razón por la cual en los trabajos que hemos revisado la meditación heideggeriana seguía un camino bastante claro, que iba desde la pregunta por la vida fáctica hasta la pregunta por el ser. Sin embargo, permanecían algo difusos los márgenes entre una pregunta y otra, y no quedaba claro el grado de importancia que poseía cada una al interior de su 
pensamiento. En estos trabajos que hemos analizado Heidegger habla de fenomenología, hermenéutica y también de ontología, ahora veremos de qué forma se conjuntan en un proyecto solidario, que pretende integrar estas direcciones metodológicas en uno y el mismo camino del pensamiento de Heidegger, que desde ahí pretende conducir su reflexión hacia la pregunta fundamental de la metafísica.

En la filosofía de Heidegger, a principios de los años veinte, principalmente en los curso de Friburgo, se manifiesta un interés creciente por la categorización ontológica de la vida humana, "en un proyecto que denomina en un primer momento "ciencia pre-teórica originaria" (Vortheoretische Urwissenschaft, 1919), algunos años más tarde "hermenéutica de la facticidad" (Hermeneutik der Faktizität, 1923), en Sein und Zeit "analítica existenciaria" (Existenzialanalityk) y "ontología fundamental" (Fundamentalontologie), y en el libro de Kant "metafísica del Dasein" (Methaphysik des Daseins, 1929)"119, todo eso indica que su principal objetivo por aquellos años era interpretar de modo original y radical esa vida fáctica, pero distanciándose de una mirada meramente contemplativa y objetivante, por lo cual su investigación debía prescindir de la prioridad absoluta de la actitud teórico-cognoscitiva propia de las ciencias naturales. Sin lugar a dudas la influencia de las filosofías de la vida que estaban en boga a principios de los años veinte habían influido en el joven profesor y desde ahí obtiene el impulso que le permite concebir la vida desde su misma facticidad, en su misma ejecución, con lo que logra posicionarse lejos de una mirada exclusivamente teórica de la realidad, que solamente lograría distanciar lo vivido y transformarlo en un objeto de conocimiento más entre otros, que se somete a un cuestionamiento que se sustenta en una relación de sujeto-objeto.

Pero, lo verdaderamente importante de estas primeras formulaciones en la filosofía del joven profesor radicaría en que ella:

\begin{abstract}
no conduce a misticismos vitalistas, ni a exaltar profundidades insondables, ni tampoco a permanecer en la consabida oposición entre razón y sentimiento ( ...) A través sobretodo de Dilthey que le enseño el carácter inmediatamente significativo de la vida, y del manejo del análisis intencional de la fenomenología, Heidegger escapa a los turbios vapores vitalistas e intenta sacar a relucir de manera inteligible la estructura elemental de ese ámbito de lo originario ${ }^{120}$,
\end{abstract}

Heidegger ha denominado a este ámbito originario experiencia fáctica de la vida, Dasein humano, vida fáctica, facticidad; todas ellas distintas denominaciones que quieren nombrar de forma originaria y radical a ese ente que en cada caso somos nosotros mismos. El filósofo alemán pretende con esto responder a una única cuestión, la comprensión originaria y auténtica de la vida fáctica y que llamará, "de forma definitiva a partir de 1922, Dasein, de acuerdo con la concisa y expresiva fórmula que aparece en el curso de 1921-22: "Vida= Dasein, "ser" en y a través de la vida" (GA 61, 85)"121.

\footnotetext{
${ }^{119}$ Volpi, F., Martin Heidegger. Aportes a la filosofia, Maia, Madrid, 2009, p. 67.

${ }^{120}$ Rodríguez, R., Heidegger y la crisis de la época moderna, op. cit., p. 188.

${ }^{121}$ Ibíd., p. 188.
} 
A juicio de algunos especialistas, la obra de Heidegger de estos primeros años de docencia universitaria, que por lo demás ahora se encuentra completamente publicada, ofrecía una pluralidad de caminos o perspectivas que guiaban su pensamiento, por lo cual el único camino del pensamiento que suponía Gadamer ${ }^{122}$ o del que hablaba Heidegger en sus escritos autobiográficos, contendría en sí una multiplicidad de $\operatorname{caminos}^{123}$. Sin embargo, a pesar de si se está de acuerdo o no con la pluralidad o univocidad de caminos del pensar heideggeriano, podemos reconocer con claridad algunas vías bien definidas que sigue su filosofía, como las que hemos analizado en nuestro trabajo, que señalaría una coherencia y unas directrices - no solo una- más bien determinadas. Con esta afirmación no pretendemos restar validez a las distintas interpretaciones existentes, solo aludimos a la diversidad interpretativa que despierta la obra de Heidegger, si las discusiones respecto a la pluralidad del camino del pensar de Heidegger son fructíferas o no, ese es otro asunto.

Consideramos como una cuestión indispensable en este momento de nuestra investigación fijar con mayor claridad la perspectiva propiamente metodológica que Heidegger utiliza para acometer su investigación respecto al tiempo. Esto, porque en este periodo de su quehacer filosófico, que media entre sus cursos de la Fenomenología de la vida religiosa, Interpretaciones fenomenológicas sobre Aristóteles: Indicación de la situación hermenéutica, Ontología: Hermenéutica de la facticidad y el tratado El concepto del tiempo, tal como comenta Pöggeler, sería el momento crucial en el cual se le habría hecho manifiesto que en la tradición filosófica el ser es pensado como ousía, como presencia, como simple presente: lo que significaría que el ser está determinado desde un modo del tiempo. Sería precisamente por entonces, que el filósofo alemán habría llegado a esta conclusión que determinaría de forma decisiva el camino de su pensamiento; lo que indicaría que ya había surgido en él la pregunta por el ser y el tiempo ${ }^{124}$. Esto último sitúa nuestra investigación en un lugar de privilegio, puesto que precisamente la textualidad de la obra de Heidegger, que hemos revisado por las necesidades propias a nuestra investigación, se enmarca dentro de este periodo de su pensamiento, en otras palabras, nos posicionan en un lugar de privilegio para reconocer cómo se articula en el pensamiento heideggeriano esta conexión entre el ser y el tiempo. Pero también dicha base textual a la que hemos hecho referencia es señalada como capital en la estructuración de la hermenéutica fenomenológica de la facticidad, sería en estos textos donde principalmente se dibujaría su estructura definitiva. Por otra parte, el conjunto de textos en los que Heidegger alude al concepto de fenómeno guardaría una gran coherencia con lo tratado en los cursos de fenomenología de la religión ${ }^{125}$. Todo esto nos permite tener una panorámica,

${ }^{122}$ Cf. Gadamer, H., "Existencialismo y filosofía existencial" en Los caminos de Heidegger, op. cit., p. 23.

${ }^{123}$ Cf. Gander, H., "La fenomenología hermenéutica del vivir fáctico de Heidegger”, en Heidegger. Sendas que vienen, (ed.)F.Duque, UAM, Madrid, 2008, p. 141.

${ }^{124}$ Cf. Pöggeler, O., El camino del pensar de Martin Heidegger, op. cit., p.401.

${ }^{125}$ Cf. Rodríguez, R., Hermenéutica y subjetividad, Trotta, Madrid, 2010, p.142-3. 
aunque no completa, sí bastante gráfica de la estructuración del proyecto filosófico que Heidegger plantea en aquellos años.

De lo anterior se desprende que es imprescindible determinar qué significa y cuáles son los alcances del proyecto heideggeriano desde la perspectiva metodológica, que justamente precisa antes de presentar de forma más acabada su categorización de las estructuras ontológicas de la vida fáctica y antes de plantear con contornos más definidos su crítica a la concepción tradicional del tiempo, a la que pretende anteponer una interpretación del tiempo capaz de superar los ocultamientos a los que ha sido sometido a lo largo de la historia de la tradición filosófica. De alguna forma, nos situamos en el meridiano entre una cosa y la otra, que en principio nos lleva por el difuso camino de la pregunta por la vida fáctica y por el sentido directivo del ser, hasta el momento en el cual se le hace visible su innegable conexión, que será aquello que dirigirá el camino del pensar de Heidegger en lo que viene: la unidad indisoluble de la pregunta por el ser y el tiempo, que pretende reformular al hilo de la pregunta por la temporalidad del Dasein.

Con esto se marca un punto de inflexión en la investigación heideggeriana, que había sometido a un profundo cuestionamiento esta idea del tiempo, asunto que se había materializado en la exposición del tiempo propio al cristianismo primitivo y también cuando señalaba que solo el fenómeno de la muerte podía abrir las puertas a la comprensión de la temporalidad del Dasein humano, de la vida fáctica (Cf. NB,12-3/42). Se inicia entonces una nueva etapa, con una determinación más definida de su tarea filosófica, lo que permite ver con mayor claridad hacia dónde conduce su trabajo. Todo esto se pone en marcha cuando el pensador alemán posee ya un arsenal conceptual más completo, lo que indica que ya se siente preparado para llevar a cabo su tarea de destrucción fenomenológica de la tradición metafísica y la elaboración de una crítica a la concepción del ser dominante en dicha tradición, que ha de pasar necesariamente por una reinterpretación del fenómeno del tiempo, fenómeno que jugará un papel absolutamente clave en su replanteamiento de la pregunta por el ser. En consecuencia, es de una importancia capital para nuestro trabajo, profundizar en lo que Heidegger denomina en 1922 hermenéutica fenomenológica de la facticidad y que en 1923 llama simplemente hermenéutica de la facticidad. Distintos nombres con los que designa su proyecto filosófico por aquellos años, con los que busca una nueva vía de cuestionamiento que se desmarque de los cánones de la tradición filosófica.

Se llevaría a cabo con esto una transformación hermenéutica de la fenomenología que, a juicio de Rodríguez, se sustentaría fundamentalmente en dos opciones básicas. En primer lugar, que esta empresa heideggeriana a pesar de sus reparos hacia la moderna cuestión del método, no le es posible dejar de contar con ciertas coordenadas metodológicas intrínsecas a su mismo tema de investigación que es la vida fáctica. La inseparabilidad entre tema y método es una de las características más marcadas de la hermenéutica de la facticidad, cuestión que hace imposible el tratamiento separado de 
ambas cosas. Si se tratara de una metodología abstracta, capaz de aplicar a un nuevo objeto su método, este no sería aplicable a la vida fáctica, dado que por la dificultad inherente al tema, es menester buscar un método que ha de saber de antemano algo sobre la vida fáctica para poder investigarla adecuadamente ${ }^{126}$.

Y la otra opción, es que la fenomenología de Husserl es el punto de apoyo que Heidegger necesita para presentar y desarrollar su hermenéutica de la facticidad, pero ello no significa que se pretenda restar importancia a la influencia de las filosofías de la vida, como la de Dilthey ni desconocer la presencia de Aristóteles o de Kant en ese proyecto heideggeriano. Sin embargo, en la construcción misma de la hermenéutica de la facticidad es decisivo el aporte de la fenomenología, lo que significa que la idea de la intencionalidad y su tratamiento de las vivencias no son consideradas por Heidegger como asuntos sin importancia, menos aún significa que las entienda como un modo más de hacer filosofía, son para él el estilo, el modo de comprensión filosófica que abre la posibilidad de llevar a buen término una interpretación de la vida fáctica, una comprensión originaria de ella, lo que conlleva una conjunción esencial de método y tema, esto porque la fenomenología no es un modo abstracto de tratar cualquier tipo de objeto, sino que comprendida auténticamente es primero que nada ciencia de la conciencia, un conocimiento de sí, por ello Heidegger la entiende desde un principio como ciencia originaria de la vida fáctica en y para sí, en consecuencia, el objetivo fundamental de la fenomenología no se diluye con la ontologización de la vida fáctica ni con la cuestión que pronto adquirirá protagonismo en la filosofía de Heidegger, la pregunta por el ser, pero eso no quiere decir que el pensador de la Selva Negra haga suyas sin más las tesis fundamentales de Husserl, sino que por el contrario son sometidas a un fuerte cuestionamiento. No obstante, hay un paralelismo esencial en la estructura metódica e importantes puntos de acercamiento entre ambas posturas, que llevan a entender este proyecto de la hermenéutica de la facticidad como una transformación hermenéutica de la fenomenología ${ }^{127}$. Estas serían las opciones básicas, los puntos de referencia obligatorios que guían esta transformación hermenéutica de la fenomenología que se plasman en este periodo del pensamiento heideggeriano, todo esto antes de abordar de lleno la pregunta por el ser y el tiempo.

\section{A. SignificAdo E IMPORTANCIA DE LA HERMENÉUtiCA DE LA FACTICIDAD}

Como habíamos dicho anteriormente, por estos años que medían entre una primera aproximación a la cuestión del tiempo peculiar a la vida fáctica, Heidegger se ve en la necesidad de plantear con mayor prolijidad su proyecto filosófico en términos metodológicos, en su forma de entender la fenomenología y así llevar a cabo una determinación algo más definida de su programa para enfrentar lo que viene. Proyecto que

${ }^{126}$ Cf. Rodríguez, R., La transformación hermenéutica de la fenomenología, Tecnos, Madrid, 1997, p. 14.

${ }^{127}$ Cf. Ibíd., p. 15. 
de ser considerado como una fenomenología de la vida fáctica, pasará a denominarse en el Informe Natorp hermenéutica fenomenológica de la facticidad, y en el curso de 1923, hermenéutica de la facticidad sin más. En relación a la publicación y al contenido de las lecciones universitarias de Friburgo, algunas de ellas publicadas recientemente, se ha de comentar, que:
a pesar del carácter incompleto, esquemático y con frecuencia abrupto, y de su terminología vacilante, esa primera obra heideggeriana encierra la clara unidad de un programa filosófico bien perfilado (...) Hermenéutica fenomenológica de la facticidad. La expresión, una vez que se adentra uno en el pensamiento heideggeriano, es transparente, porque no solo indica el "tema" y el método de la empresa propuesta, sino que deja también translucir los tres impulsos que la originan: la tradición de la teología cristiana, la fenomenología de Husserl y la filosofía diltheyana de la vida ${ }^{128}$.

Se resume así el título, el objetivo y las influencias que determinarían esta empresa filosófica que Heidegger ha decidido acometer. Todo ello habría terminado por perfilar su proyecto filosófico en el que habría operado un auténtico cambio de paradigma en cuanto a lo que se entendía por hermenéutica, situando su pensamiento como una contraparte crítica de la tradición filosófica.

Según se ha visto, Heidegger en el Informe Natorp presenta un primer esbozo de una tarea filosófica de largo alcance, en el cual, por una parte presenta una categorización ontológica de las estructuras del Dasein humano como ontología fundamental, y a la vez, sienta las bases del proyecto destructivo de la tradición metafísica, por lo tanto, resulta evidente que dicho informe tiene una importancia señalada en el camino filosófico del pensador alemán. No obstante esto, una de las propuestas más importantes contenida en la primera parte de este informe tiene que ver con que la filosofía queda definida como Hermenéutica fenomenológica de la facticidad, denominación con la cual se alude al objetivo fundamental y primero que ha de perseguir la filosofía: lograr un acceso originario al fenómeno de la vida fáctica.

A juicio de Heidegger la filosofía no sería más que el desarrollo de una dinámica que pertenece esencialmente a la misma vida humana, que lleva al Dasein a preguntarse por su carácter de ser, este sería entonces el verdadero objeto de la filosofía. No obstante, a este ente le es propia una tendencia a la caída (Verfallenstendenz), lo que significa que el Dasein humano está siempre sumido en una determinada interpretación en la que también se encuentra la filosofía y forma parte de la vida fáctica como una dinámica esencial de ella misma, por lo cual es fundamental para Heidegger aclarar la situación hermenéutica en la que se encuentra sumida la vida fáctica y la filosofía ${ }^{129}$. En estas primeras lecciones de Friburgo se llevaría a cabo según Volpi:

"el giro ontológico" que habría aparecido en la historia de la hermenéutica, por cuanto que

la comprensión ya no fue entendida como un simple conjunto de reglas técnicas

\footnotetext{
${ }^{128}$ Rodríguez, R., Heidegger y la crisis de la época moderna, op. cit., p. 186.

${ }^{129}$ Cf. Segura, C., Hermenéutica de la vida humana, op, cit., p. 27.
} 
exegéticas, sino como componente esencial de la constitución histórico-ontológica de la vida humana. Tal giro, anticipado en las reflexiones del conde Paul Yorck von Wartenburg, fue llevado a cabo por el joven Heidegger con su programa de una "hermenéutica de la facticidad" que, en efecto, ha sido para Gadamer el punto de referencia esencial para el desarrollo de su propia hermenéutica filosófica" ${ }^{\$ 130}$.

Tal como sostiene el filósofo italiano es precisamente en estos años en los cuales el pensador alemán está forjando su programa, surge esa nueva forma de concebir la filosofía que se entiende desde estas tres perspectivas fundamentales, aunando fenomenología, hermenéutica y ontología que además, sea dicho de paso, permite unificar la pregunta por la vida fáctica y la pregunta por el ser. Gadamer con el afán de aclarar el sentido de esta perspectiva hermenéutica inaugurada por Heidegger, señala:

\begin{abstract}
la paradoja heideggeriana de una hermenéutica de la facticidad no significa, ciertamente, una interpretación que pretenda "comprender" la facticidad como tal; sería un verdadero contrasentido querer comprender, pese a todo, lo nada-más-que-fáctico, lo cerrado a todo "sentido". Hermenéutica de la facticidad quiere decir más bien que hay que entender la existencia misma como la ejecución de la comprensión y la interpretación y que en ello reside su característica ontológica ${ }^{131}$.
\end{abstract}

De modo tal, en esta interpretación de la hermenéutica opera un cambio de significado, por lo cual no se utiliza nunca para significar una doctrina o teoría acerca de algo, sino que alude a la acción o actividad misma de la interpretación, se toma en cuenta el sentido griego original de $\varepsilon \rho \mu \varepsilon v \varepsilon v \varepsilon \iota v$ que significaba dar noticia; esto para referirse al hecho de que la experiencia fáctica de la vida en su quehacer cotidiano, sabe de sí misma, se da a conocer a sí misma, y este modo de saber no es reflexivo ni constatativo, sino que es esencial a la propia conducta y no tiene un carácter objetivo. La hermenéutica así entendida es para Heidegger la labor filosófica que se concibe como pura prolongación del saber inmanente que la facticidad posee de sí misma, esta sería la misión primordial de la hermenéutica y no una elaboración discursivo cognoscitiva respecto a ella. De esta forma, la hermenéutica como darse a conocer se transforma en virtud de la condición interpretativa que le es propia, se transforma gracias a ese saber de sí misma que le pertenece $^{132}$.

\title{
B. HeRmenÉutica FENOMENOLÓGICA DE LA FACTICIDAD: LA FORMULACIÓN INCIPIENTE DE LA
} PREGUNTA POR EL SER

Como podemos ver, Heidegger con su interpretación de la hermenéutica, genera una verdadera revolución en relación a la forma tradicional de entenderla y se distancia claramente de su definición clásica. La hermenéutica deja de ser considerada como simple

\footnotetext{
${ }^{130}$ Volpi, F., "Hermenéutica y filosofía práctica", en Endoxa: Series filosóficas, nº 20, 2005, UNED, Madrid, p.268.

${ }^{131}$ Gadamer, H., "Ser, espíritu, Dios” en Los caminos de Heidegger, op. cit., p. 168.

${ }^{132}$ Cf. Rodríguez, R., Heidegger y la crisis de la época moderna, op. cit., p. 194-5.
} 
interpretación del sentido o del significado de un texto o del pensamiento de una autor determinado, ahora ha de ser capaz de interpretar la vida fáctica en sí misma y desde sí misma, cumpliendo así con una tendencia esencial de la vida de interpretarse a sí misma, y como quehacer fundamental de la propia filosofía.

Heidegger en el Informe Natorp define la filosofía como conocimiento interrogativo, como una investigación que no consiste en desarrollarse de forma paralela a la vida humana como una de las tantas cuestiones que en ella se pueden llevar a cabo, sino que: "la filosofía es la consumación explícita y auténtica de la tendencia a interpretar las actividades fundamentales de la vida en las que está en juego la vida misma y su ser"(NB, 15/45). Además, comenta que la filosofía no deber perder de vista en ningún momento su objeto de estudio, por eso, si la filosofía pretende cumplimentarse y desarrollarse originariamente, si quiere ser consecuente con su tendencia fundamental:

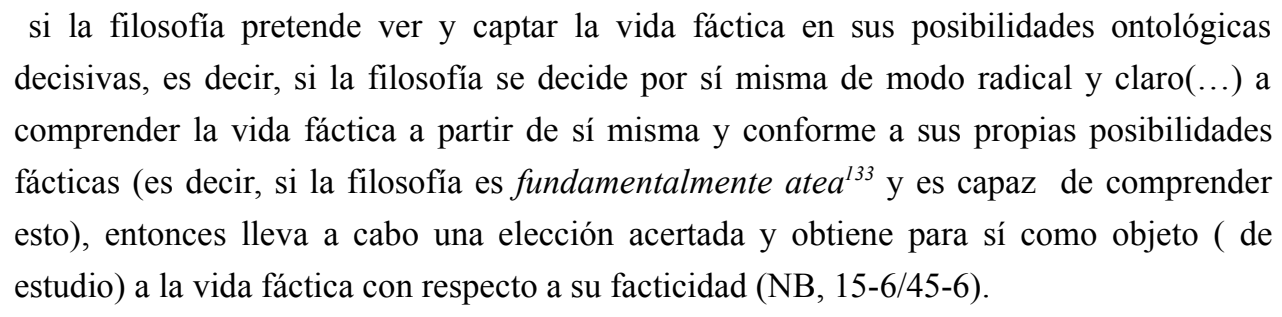

En consecuencia, la modalidad de esta investigación filosófica, que es la consumación de una tendencia propia de la vida misma a interrogar e interrogarse a sí misma, es la interpretación del sentido de ser (Seinssinnes) propio de la vida fáctica, esto en relación a sus estructuras ontológicas fundamentales (Cf. NB, 16/46). Pero además, este sentido de ser y sus estructuras categoriales fundamentales deben ser interrogados en relación a "la diferentes maneras como la vida fáctica se temporiza a sí misma y temporizándose, habla consigo misma" ( zeitigt und zeitigend mit sich selbst spricht) (NB, 16/46). Heidegger ya hace alusión aquí al sentido del ser de este ente, de sus categorías ontológicas, ya se habla de una investigación de carácter ontológico, que interroga a la vida misma, al ser de esta vida fáctica que está en juego a cada momento, cumpliendo así con una tendencia fundamental de la vida misma de interpretarse a sí misma, a partir de sí misma y desde su propias posibilidades, que están por lo demás circunscritas a su facticidad, en lo cual también se incluye su modo de temporalizarse. Una investigación de este carácter, según el joven profesor, es la que cumple con la tarea fundamental de la filosofía, cuyo objeto no ha de ser otro que la vida fáctica en su facticidad, por ello se interroga por el sentido del ser de la vida fáctica, convirtiéndose entonces en ontología fundamental, la filosofía deviene desde este momento en el pensamiento de Heidegger en ontología, la filosofía entendida como ontología fundamental (prinzipielle Ontologie).

${ }^{133}$ Heidegger en una nota a pie de página reafirma de modo enfático la obligación que la filosofía ha de tener, en cuanto a que ha de volverse sobre la facticidad de la vida humana, ha de volcarse sobre su facticidad, y según el joven profesor, esta es la única forma de permanecer leal ante Dios. $\mathrm{Y}$ una religión que no cumpla con esto en un sinsentido. Por ello, podemos afirmar que el ateísmo del que habla es un ateísmo entre comillas. (Cf. NB, 15/45) 
Anteriormente, en los cursos de Fenomenología de la vida religiosa, el pensador de la Selva Negra sostiene que la filosofía surge desde la experiencia fáctica de la vida y retorna a ella, por lo que se torna como cuestión verdaderamente fundamental aclarar este concepto de experiencia fáctica de la vida (Die faktische Lebenserfahrung), del vivir fáctico, dado que al referirse a la filosofía como comportamiento racional y cognoscitivo no se dice nada de ella, por el contrario, se cae en el ideal de la ciencia (Cf. GA60,8/43). Pero también puntualiza, que el punto de partida y la meta de la filosofía es esta misma experiencia fáctica de la vida (Cf. GA60,15/50). Con estas definiciones el joven profesor precisa cuales son los lineamientos que sigue su pensamiento en estas lecciones, que exigen desde un principio la aclaración y determinación de esa experiencia fáctica de la vida para así poder obtener una comprensión propiamente filosófica de este fenómeno. Sin embargo, para llevar a cabo esta tarea es imprescindible tomar distancia de una comprensión extraída exclusivamente de una mirada teórico cognoscitiva de objetos, fundamentada en el privilegio de la percepción visual, en la pura intuición de un objeto. La intención de Heidegger es exponer este fenómeno en sus estructuras ontológicas fundamentales, en su carácter originario.

Este fenómeno que en las lecciones de Fenomenologia de la vida religiosa llamó experiencia fáctica de la vida, adquiere distintas denominaciones en este periodo de su trabajo, tales como facticidad, vivir fáctico y Dasein humano, este último, término que comienza a adquirir su preciso carácter técnico a partir del año 1922 en el que se le da esa connotación, esto tanto en el Informe Natorp, como en el curso de Interpretaciones fenomenológicas sobre Aristóteles. Término con el que se hace alusión a ese ente que en caso soy yo mismo y nombra al mismo tiempo la facticidad que le es propia a este ente. En el informe Heidegger define como Hermenéutica fenomenológica de la facticidad la investigación fundamental que pretende llevar a cabo, agregando además, que la filosofía en cuanto trata del asunto del ser de la vida fáctica es ontología fundamental (prinzipielle Ontologie $)^{134}$, en razón de que las demás ontologías regionales que se determinan mundanamente extraen desde la ontología de la facticidad el fundamento y el sentido de sus problemas (Cf. NB,16/46).

Heidegger resume de esta forma lo que ha de ser el marco programático de su quehacer filosófico en lo que viene y estructura su proyecto como una filosofía que ha denominado ontología fundamental, porque todas las ontologías regionales necesariamente han de remitirse a ella, dado que obtienen su sentido y fundamento desde la ontología de la facticidad (Ontologie der Faktizität), la filosofía define su problemática como cuestionamiento fundamental acerca del ser de la vida fáctica (das Sein des faktisches Lebens) (Cf. NB,16/46), lo que significa entre otras cosas, que desde el momento que se pregunta por el ser de la vida fáctica ella se transforma en el hilo

${ }^{134}$ En la traducción que existe del Informe Natorp, prinzipielle Ontologie es traducido como "ontología fundamental". Heidegger en este texto no utiliza el concepto de Fundamentalontologie que será el que posteriormente acuñará en Ser y tiempo. 
conductor que permite solventar la pregunta por el ser, esto porque el cuestionamiento del ser de la vida fáctica, del Dasein humano es un primer paso, el punto de partida para la elaboración de la pregunta por el ser, por el sentido del ser. Al hacerse cuestión del status ontológico de la vida fáctica se cuestiona a un ente en relación a su ser, la pregunta es propiamente ontológica, lo que significa que Heidegger está dando aquí un paso decisivo entendiendo su filosofía como ontología de la facticidad, como prinzipielle Ontologie, lo que le llevará a concebir posteriormente su filosofía como una ontología fundamental (Fundamentalontologie).

Que la pregunta por el ser de la vida fáctica esté vinculada con la forma en que este ser es nombrado e interpretado, nos indica que la filosofía como ontología es también una interpretación del nombrar y del interpretar, por lo tanto, la filosofía es al mismo tiempo lógica. Ya no solo la ontología, sino también la lógica han de ser "reconducidas a la unidad originaria del problema de la facticidad $\mathrm{y}$, por consiguiente, deben ser comprendidas como expresiones de la investigación fundamental, investigación que puede definirse hermenéutica fenomenológica de la facticidad (phänomenologische Hermeneutik der Faktizität)" (NB, 16/47). En consecuencia, esta investigación de carácter fundamental que el profesor Heidegger emprende en este informe coliga ontología y lógica, como manifestaciones propias de la hermenéutica fenomenológica de la facticidad, de forma que las reúne e incluye en un mismo proyecto filosófico. El Informe Natorp es un texto de una extensión limitada en relación a la cantidad de folios del que consta, pero no podemos decir lo mismo en cuanto a su contenido, dado que allí se coligan una multiplicidad de cuestiones de importancia superlativa de la filosofía de Heidegger, que muestran de forma evidente en qué estado de desarrollo se encontraba su filosofía por aquellos años.

También plantea en este informe como una exigencia de primer orden de la hermenéutica fenomenológica de la facticidad, aclarar desde qué preconceptos y desde qué presupuestos se ha interpretado el vivir fáctico, desde dónde se comprende a sí mismo. Aclarando aún más el carácter de su trabajo, Heidegger sostiene:

la investigación filosófica debe elucidar categorialmente las interpretaciones en cada caso
concretas de la vida fáctica (...) debe llevar a cabo ese ejercicio de elucidación categorial
desde la perspectiva de sus presupuestos (Vorhabe) (en qué sentido ontológico
fundamental se coloca la vida a sí misma?) y en relación con los preconceptos (Vorgriff)
¿en qué modalidades del nombrar y del enunciar discursivos se habla la vida fáctica a sí
misma y en qué modalidades habla consigo misma?)(NB, 17/47).

Esto implica preguntar por los supuestos metafísicos tradicionales desde los cuales se ha situado, desde donde se inicia la consideración ontológica de este ente, en otras palabras, lo que se busca es la aclaración de la situación hermenéutica desde la que parte la interpretación del Dasein humano; cuestión que una vez aclarada, permitirá un acceso originario y auténtico al vivir fáctico, a la pregunta por el tiempo y, por medio de ella, a la pregunta por el ser, cuyo primer momento es la aclaración de la situación hermenéutica 
desde la que parte toda interpretación. Llevándonos necesariamente a la filosofía griega, particularmente a Aristóteles, que a juicio de Heidegger, es de quien proviene en gran parte la conceptualidad propia de la filosofía tradicional, y los presupuestos que ella ha heredado a toda la tradición metafísica.

Es evidente entonces que para el pensador alemán la tradición metafísica como fundamento del pensamiento occidental se sustenta principalmente en la filosofía de Aristóteles. Lo que justificaría que en la tradición filosófica no haya sido posible preguntar de forma genuina por la vida fáctica, aún más, que ni siquiera se haya logrado un acercamiento a esa experiencia originaria. Todo esto es lo que el pensador de la Selva Negra tiene en cuenta cuando propone una hermenéutica fenomenológica de la facticidad, en la cual la vida fáctica ha de seguir su tendencia fundamental de comprenderse a sí misma desde sí misma, y esto como objetivo fundamental del quehacer filosófico. Todo esto derivará en un proyecto solidario, puesto que, "los principios y el proceder que guiarán toda la investigación heideggeriana serán los de la fenomenología. Por otra parte, puesto que el objeto de la fenomenología como ciencia originaria es el Dasein fáctico, solo la hermenéutica puede acceder a él. En definitiva la filosofía (ontología y lógica) no pueden ser concebidas sino como hermenéutica fenomenológica de la facticidad"135.

No obstante, es necesario volver ahora sobre una cuestión que no hemos dejado del todo clara, nos referimos a la relación entre fenomenología y hermenéutica, relación que el pensador de la Selva Negra expone de la siguiente forma:

La hermenéutica es fenomenológica, lo cual significa que su ámbito objetivo-la vida fáctica en relación con el modo de su ser y de su hablar -se considera, según la temática y el método de la investigación, como un fenómeno. La estructura objetiva que caracteriza a algo como fenómeno, la intencionalidad plena ( el estar referido a, el horizonte de referencia como tal, el acto de referirse, el despliegue temporal de ese acto, la custodia de ese despliegue temporal), no es otra que la del objeto que tiene el carácter ontológico de la vida fáctica (Seinschakter des faktischen Lebens). La intencionalidad, entendida pura y simplemente como el estar-referido-a , es el primer carácter fenoménico de la actividad fundamental de la vida ( es decir, el cuidado) (Grundbewegtheit des Lebens, das ist des Sorgens) (NB, 17/47).

El joven profesor presenta una determinación precisa de cómo entiende el concepto de fenómeno, lo que permitiría una definición concreta de la finalidad perseguida por la hermenéutica fenomenológica de la facticidad, todo esto sería además el corolario de todo su trabajo anterior, en tanto que su fenomenología se distancia claramente de una mera posición teórica, en la cual el comportamiento se refiere al mundo absorbiéndose en él como en una trama o relación objetiva. En este texto se manifestaría un doble movimiento de identificación entre vida fáctica y fenómeno, la vida fáctica como tema de la hermenéutica es concebida metódicamente como fenómeno lo que haría posible su análisis

${ }^{135}$ Segura, C., Hermenéutica de la vida humana, op. cit., p. 28. 
en términos de intencionalidad. Y por otra parte, el fenómeno se estructura temáticamente desde caracteres intencionales que no se obtienen desde un simple dirigirse-a de una intencionalidad de carácter objetivante, sino que se obtienen desde la facticidad de la vida en su mismo ser vivida ${ }^{136}$. Sería este el lugar preciso en el cual Heidegger se desmarca de esa consideración meramente objetual y teorética de la vida fáctica y que le permite dar ese paso más allá, en que la fenomenología se vuelve fenomenología hermenéutica, en cuanto hermenéutica de la facticidad. Así la vida fáctica en cuando tema de la hermenéutica es vista en términos metodológicos como fenómeno y puede ser entendida intencionalmente, y al mismo tiempo el fenómeno puede ser caracterizado temáticamente desde sus rasgos intencionales, pero no desde la intencionalidad objtetivante, sino que desde la propia facticidad, desde su vivir fáctico como punto de partida de la hermenéutica de la facticidad. Dice Rodríguez: "es la forma de ser de la vida fáctica, precomprendida en el análisis intencional, la que obliga a ensanchar el concepto de fenómeno hacia una intencionalidad plena, la cual a su vez, solo puede ser convertida tema explícito mediante su tratamiento fenomenológico siguiendo el hilo conductor de la intencionalidad"137.

Desde esta perspectiva, la precomprensión de la vida fáctica surgida desde el análisis intencional nos lleva hasta una comprensión más acabada, más originaria del fenómeno para dar así con una intencionalidad plena, que solo puede hacerse accesible en su específico carácter temático por medio de la fenomenología, esto siguiendo las coordenadas de la intencionalidad. Así Heidegger da ese paso fundamental en su pensamiento, entendiendo la fenomenología como hermenéutica de la facticidad.

Profundizando en esto hemos de destacar otra puntualización importante que Heidegger lleva a cabo en informe enviado a Natorp. En una parte el filósofo alemán señala, "el sentido fundamental de la actividad fáctica es el cuidado(curare)" (NB, 6/35), con esto, Heidegger esta señalando concretamente el rol que cumple el cuidado en la fenomenología hermenéutica, cuidado al que si bien Heidegger ya había hecho referencia anteriormente, como por ejemplo en los cursos de fenomenología de la religión, aquí nombraría, "la especificidad de estar en movimiento que es propio de la vida fáctica, lo que expresa, podríamos decir, la forma de su vitalidad frente a otros seres vivos( ...) el Informe Natorp da carta de naturaleza como término técnico para designar la entera forma de acontecer de la facticidad a lo que en el curso de invierno de 1921-1922 consideraba tan solo como el sentido referencial de la vida"138. Con esta puntualización, Heidegger cumpliría con el objetivo de fijar el carácter de la movilidad peculiar a la vida fáctica, para distinguirlo así del movimiento propio de los otros entes del mundo. Precisamente es gracias a esa movilidad que le es propia a la vida fáctica que puede ser determinada la constitución ontológica del Dasein humano, su mismo acontecer, que no puede ser

\footnotetext{
${ }^{136}$ Cf, Rodríguez, R., Hermenéutica y subjetividad, op. cit., p.142.

${ }^{137}$ Ídem.

${ }^{138}$ Rodríguez, R., Hermenéutica y subjetividad, op. cit., p. 143.
} 
concebido como un ente más entre otros entes del mundo, sino uno de carácter tal que está constituido como cuidado.

Además, esta determinación del cuidado como sentido fundamental de la movilidad de la vida fáctica, no representaría una contradicción o rectificación respecto a formulaciones anteriores, sino que respondería a una necesidad de la misma investigación, puesto que, ella surge "de la necesidad de caracterizar la facticidad en su conjunto con un término que no se limite a reproducir la neutralidad vacía de la antropología tradicional y sea, a la vez, lo suficientemente expresivo para indicar hacia dónde debe ir la comprensión. Para ello el término que marcaba el sentido general de la referencia al mundo es el más adecuado, pues lo que prima en la facticidad entendida como fenómeno es su carácter intencional" ${ }^{\prime 139}$, la facticidad queda caracterizada de forma más completa y puede expresar mejor la dirección de la comprensión, y que mejor que hacerlo con aquel concepto con el que anteriormente se aludía al sentido de referencia al mundo propio de la vida fáctica, dado que lo que allí sobresale de forma evidente es la facticidad es su carácter eminentemente intencional.

Pero eso no es todo, porque el cuidado como carácter fundamental de la estructura de la vida fáctica es un concepto que si quiere señalar lo más propio de la vida fáctica, tiene que al mismo tiempo cumplir el papel asignado por Heidegger a los conceptos que surgen de una hermenéutica de la facticidad, como indicador formal el cuidado ha de alejar de sí cualquier primacía o prioridad teórica en la comprensión y precisamente el cuidado cumple esa función. En su significado más común lo entendemos como un ocuparse o cuidarse de cosas que acontecen cotidianamente, en el trato con las cosas y con otros Dasein humanos, por lo tanto nunca nos parece que en ello primordialmente esté involucrado una consideración puramente teórica o la mera percepción visual de alguna cosa, lo que no significa que esto quede excluido del todo ${ }^{140}$. Todo esto indica que con este concepto de cuidado, lo que el pensador de la Selva Negra pretende es:

dejar libre la posibilidad de destacar precisamente los dos sentidos constitutivos del fenómeno que la actitud teórica difuminaba u homogeneizaba: el sentido de ejecución y el de referencia (...) Heidegger se esfuerza añadir inmediatamente a la definición del "cuidado" una variedad de modalidades que no es meramente ilustrativa, sino constitutiva de su ser fáctico: el cuidado se da siempre en una modalidad ejecutiva y referencial determinada. Una multiplicidad, por tanto, que es tal a partir de la referencia y del modo como ésta es ejercida, no de su sentido objetivo (Gehaltssinn)" ${ }^{141}$.

Una de las conclusiones más importantes que podemos extraer de esta interpretación, tiene que ver con la doble función que cumple este fenómeno del cuidado, en cuanto a que por un lado nos ofrece una determinación más precisa del carácter de movilidad que es propia a la vida fáctica y solo a ella, con lo cual queda de algún modo definida su peculiaridad

\footnotetext{
${ }^{139}$ Ibíd., p. 144.

${ }^{140}$ Cf. Rodríguez, R., Hermenéutica y subjetividad, op. cit., p. 144.

${ }^{141}$ Ídem.
} 
ontológica, nombrando de forma integral el modo de ser de la vida fáctica, podríamos denominar a esto un aporte netamente ontológico, en cuanto ilumina la vida fáctica en su constitución esencial. Pero también es una importante herramienta metodológica en cuanto permite a Heidegger desmarcarse de la primacía de la consideración teórica en la comprensión y en la interpretación.

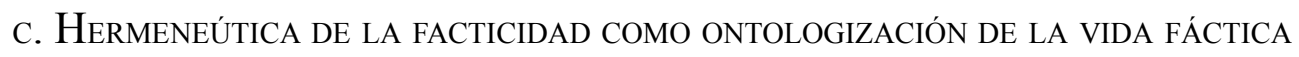

Siguiendo el rastro de esta problemática dentro de la cual se termina por estructurar la hermenéutica fenomenológica de la facticidad, nos encontramos con unas lecciones bastante emblemáticas de este periodo de su pensamiento y que tienen que ver con el asunto que aquí nos convoca, es el curso Ontología: Hermenéutica de la facticidad, que corresponde a las últimas lecciones que Heidegger dictó en Friburbo antes de partir a Marburgo. Como dato anecdótico, Pöggeler comenta que Heidegger no recordaba haber titulado de esta forma dicho curso, creía más bien que su nombre era Ontologie des $\operatorname{Dasein}^{142}$.

El pensador nativo de Messkirch presenta ahí entre otras cosas una elaboración más completa y acabada de cómo entiende la hermenéutica, la ontología y la fenomenología, y cómo estas terminan por articularse en una única dirección de su pensamiento filosófico, que por aquellos años se va estructurando como un programa con tintes más definidos. Además, denuncia ahí las insuficiencias y la estrechez fundamental en la que se sustenta la ontología tradicional, que la hace incapaz de poder preguntarse de modo originario por el ser de la vida fáctica. De la misma forma, señala que el tiempo es el que permitirá mostrar que en la ontología también residen cuestiones fundamentales. A partir de aquí, el filósofo de la Selva Negra poco a poco dejará de utilizar este concepto de vida fáctica, sustituyéndolo definitivamente por el término técnico Dasein.

Comenta el profesor Rodríguez Molinero respecto a esta lecciones, que:

por sí mismo, desde luego, el título en las mismas resulta ya orientador. Pero es, sobre todo, el examen del contenido el que nos confiera claramente como la ontologización de la vida fáctica alcanza en ellas un singular relieve (...) Heidegger comienza por no aceptar las insuficiencias fundamentales provenientes de un entendimiento de la ontología, bien como disciplina (por ejemplo, en un sentido escolástico) o, bien como equivalente a una teoría del conocimiento (por ejemplo en la acepción moderna del término) ${ }^{143}$.

Y más importante aún, es que desde un principio se vincula de forma directa la ontología con la hermenéutica de la facticidad, en otras palabras, profundiza lo que ya había iniciado en el Informe Natorp, identificando la ontología con la hermenéutica.

${ }^{142}$ Cf. Pöggeler, O., El camino del pensar de Martin Heidegger, op. cit., p. 401.

${ }^{143}$ Rodríguez, J., "Anticipación de la ontología de Ser y tiempo en los primeros escritos como docente de Martin Heidegger" en Cuadernos Salmantinos de Filosofía, nº 24, Salamanca, 1997, p. 206. 
Heidegger en su planteamiento de una hermenéutica de la facticidad, que pregunta esencialmente por la vida fáctica, no quiere que se malentienda su objetivo, que se crea que dicho cuestionamiento solo pretende hacer presente las categorías o estructuras de la vida fáctica con la mera finalidad de aplicar el método fenomenológico a ella sin otros intereses ni otras preguntas. Por el contrario, aquí termina por materializarse del todo su incipiente inquietud ontológica a la que habíamos aludido. Preocupación ontológica que estará presente a lo largo de todo el camino de su filosofía. Dicha inquietud es la pregunta por el ser mismo, que viene ahora a enlazarse de forma más directa todavía con la pregunta por la vida en su esencial facticidad, así adquiere la vida su más puro sentido y status ontológico y, por esto, tal como comenta Gadamer, "Heidegger llamó "ontología" a su primer intento de pensar desde el principio; el primer curso al que yo asistí en 1923 llevaba ese título, no en el sentido de la tradición de la metafísica occidental, que había dado una primera respuesta a la pregunta por el ser que hizo historia a nivel mundial, sino con la única pretensión de hacer una primera preparación del planteamiento de la pregunta"144. Seguramente el estudio y la discusión fructífera con Aristóteles, que en aquel periodo estaba en pleno apogeo, le han llevado a unificar ambas vías o direcciones de su pensamiento, que han terminado por confluir en una dirección meditativa.

La exégesis de las estructuras ontológicas del Dasein es lo que permitirá a Heidegger cuestionar y poner en tela de juicio a la inveterada tradición metafísica, a la concepción del ser en la que se mueve esta tradición, esto con la finalidad última de reformular la pregunta por excelencia de la filosofía, la pregunta por el ser. Todo esto, permitirá poner en marcha sus cuestionamientos a las categorías con las que la tradición metafísica ha preguntado y pregunta por el ser. Por lo cual, es menester ir al origen mismo de dichas interpretaciones, que ocultan y oscurecen un preguntar originario y genuino por la cuestión del ser. Pero es importante destacar, tal como hace Pöggeler, que esto no significa:

que Heidegger pretenda reducir la interpretación de la vida fáctica a una escolática o que
la quiera retrotraer a los conceptos tradicionales, rígidos de ser. Heidegger está buscando
aquí, más bien, escapar de un peligro: la interpretación de la vida fáctica podría arruinar la
doctrina tradicional del ser justamente porque deja intocada esa doctrina como un
contrario invencible, con lo que se deja además determinar secretamente por ella. La
interpretación de la vida fáctica tiene que replantearse a fondo la cuestión del pensar
tradicional y hacer surgir de nuevo la problemática de la doctrina del ser u ontología a
partir de la interpretación de la vida fáctica, de la hermenéutica de la facticidad ${ }^{145}$.

Es evidente entonces, que el pensador de la Selva Negra no concibe la ontología como una disciplina regional al estilo escolástico ni menos aún la comprende como una epistemología o teoría del conocimiento, sino que la entiende como una doctrina del ser, que solo nos indica aquella cuestión que se investigará temáticamente, en otras palabras,

\footnotetext{
${ }^{144}$ Gadamer, H., "Kant y el giro hermenéutico" en Los caminos de Heidegger, op. cit., p. 62.

${ }^{145}$ Pöggeler, O., El camino del pensar de Martin Heidegger, op. cit., p.35.
} 
solo anuncia que se hablará y se preguntará por el ser. Así lo hace saber, el joven profesor cuando dice: "los términos "ontología", "ontológico" van a emplearse aquí solamente (...) sin más pretensión que la de servir de indicación. Mientan un preguntar y determinar dirigido al ser en cuanto tal; qué ser y de qué modo, eso queda totalmente indeterminado" (GA 63,1/18). Con esta indicación, Heidegger pretende precisamente evitar cualquier malentendido respecto a los alcances de su trabajo y de su método filosófico, utiliza aquí el concepto de ontología al modo de un indicador formal. Su intención es apartarse de las concepciones tradicionales de ontología, que considera como esencialmente insuficientes e impotentes para dar cuenta de la pregunta por el ser o por la vida fáctica. Esta insuficiencia esencial constitutiva de la ontología tradicional, que denuncia el joven profesor, estaría sustentada principalmente en dos cuestiones.

En primer término, Heidegger considera que la ontología tradicional determina desde siempre su tema desde el ser-objeto por lo que se centra en la objetividad del objeto, establece siempre una relación teórico cognoscitivo con el objeto que pretende analizar, con las cosas de la naturaleza. Su tema desde el principio es "el ser-objeto (Das Gegenstandsein) material para determinadas ciencias que se ocupan de él, de la naturaleza o de la cultura; y el mundo, pero no considerado desde el existir (Dasein) y las posibilidades de existir, sino siempre a través de las diversas regiones de objetos" (GA 63, 3/19-20). Heidegger al decir esto, retoma por una parte la crítica a esa relación cognoscitiva de sujeto-objeto que domina el quehacer de la ontología tradicional y que reduce toda pregunta y consideración ontológica a la determinación de un objeto por medio de una reducción a la esfera teórica-cognoscitiva del fenómeno puesto en cuestión, incluido en ello la vida fáctica.

Pero además, en esta misma insuficiencia se origina la segunda, dado que una vez declarada la imposibilidad de la ontología de preguntar y considerar el mundo desde el Dasein mismo y desde sus posibilidades, esto significa que es impotente para poder comprender y acceder al ente que es verdaderamente decisivo y determinante para el desarrollo de la problematización filosófica. En consecuencia, a la ontología tal como la conocemos, le permanece cerrado el acceso al "existir, desde el cual y para el cual "es" la filosofía" (GA63,3/20). En efecto, es en virtud de esa insuficiencia esencial de la ontología tradicional, que reduce toda pregunta e investigación a aquella que surge desde el círculo de la relación cognoscitiva de sujeto-objeto, reduce el preguntar ontológico a una simple teoría del conocimiento, lo que hace que la ontología halla sido incapaz de preguntar y cuestionar el sentido originario de la vida fáctica. Significa entonces, que la ontología no se ha hecho cuestión del Dasein porque ella misma queda encerrada en el círculo de la determinación teórica de objetos, dentro de la cual también cae la vida fáctica, la ontología tradicional queda entonces deslegitimada, desautorizada para referirse o hacerse cuestión de la verdadera problemática filosófica, que por lo demás, ni siquiera ha llegado a 
reconocer, que como sabemos es la vida fáctica, que como bien resalta Heidegger, es el ente desde el cual y para el cual la filosofía es.

El joven profesor Heidegger que está a punto de partir a Marburgo, pretende con esta crítica cercar y abordar aquella cuestión que considera realmente importante para la filosofía, problema que la tradición metafísica ha pasado por alto o que en el mejor de los casos ha malentendido, esto es, la pregunta por el ser; la verdadera y auténtica tarea de una ontología que se precie de tal. Por eso dice, que "en lo que sigue se empleará el título de "ontología" siempre en la acepción vacía, con la sola pretensión de mentar cualquier preguntar e investigar dirigido hacia el ser en cuanto tal. "Ontológico" afecta por lo tanto, a las cuestiones, explicaciones, conceptos, categorías que surjan, o no, de ese mirar a lo ente en cuanto ser" (GA63, 3/20). Con esta definición, que aparece en la introducción de este curso del verano de 1923, Heidegger indica cuál es a su juicio la verdadera tarea de la ontología tal como él la entiende y al mismo tiempo deja claramente delimitado su alejamiento de la ontología tradicional que, tal como hemos visto, tiene entre sus principales defectos o insuficiencias la imposibilidad de acceder a la constitución originaria de este ente llamado vida fáctica. Esta es la razón de que una sus tareas prioritarias sea precisamente llevar a cabo una interpretación genuina de las estructuras ontológicas de la vida fáctica, que permitiría a la ontología cumplimentarse como tal y así poder llegar a aquella problemática filosófica fundamental, hacia a aquello a lo que la ontología ha de conducirse en cuanto tal, una investigación del ser en cuanto ser. Queda así planteada la dirección de la meditación heideggeriana, según la cual, "la pregunta por el ser deberá resolverse mediante la hermenéutica de la facticidad"146.

Por otra parte, en esta introducción a las lecciones, que más que introducción es una declaración de intenciones de hacia dónde se proyecta su programa filosófico, en la que hemos visto una crítica frontal a la ontología tradicional, pero al mismo tiempo Heidegger da una valiosa indicación de la orientación que sigue su filosofía en esta fase temprana. Dice Heidegger, que "precisamente en el "tiempo" se mostrará que en la ontología ¡también residen tareas fundamentales!" ("In "Zeit" soll gerade gezeigt werden, daß in Ontologie auch fundamentale Aufgaben liegen!") (GA63,3/20). Esta afirmación nos permite inferir que el filósofo alemán, aunque de una forma apenas perceptible, anuncia que la próxima estancia de su pensamiento se detendrá en la cuestión del tiempo, porque la verdadera dimensión y profundidad de la problemática ontológica solo se hará visible teniendo como base dicha cuestión.

Podríamos decir, que en esta introducción, se conjuntan las distintas perspectivas que se consideran como fundamentales de la filosofía heideggeriana de principios de los años 20; la vida fáctica, la pregunta por el ser y la pregunta por el tiempo, (importancia relativa en relación al tratamiento que Heidegger hace de otros temas y de otras

\footnotetext{
${ }^{146}$ Berciano, M., La superación de la metafísica en Martin Heidegger, Universidad de Oviedo, 1991,
} p. 37. 
cuestiones). Podemos ver de qué forma en su filosofía la pregunta por el ser, por la vida fáctica y el tiempo se encuentran ya conectadas, imbricándose ya en una sola pregunta, en un proyecto que coliga estos fenómenos como un todo unitario, como una ontología que ha de ser necesariamente una hermenéutica de la facticidad.

Sin embargo, esta alusión al tiempo y la definición de la ontología que Heidegger ha presentado, no nos autoriza a extraer conclusiones apresuradas o significativas respecto al estado de su investigación respecto a la cuestión del tiempo, ni menos aún colegir si se le ha hecho completamente manifiesta aquella vinculación entre la cuestión del ser y el tiempo. No obstante, podemos afirmar que ya tiene en cuenta aquellos fenómenos que acabarán de enlazarse de forma inseparable en su proyecto que va avanzando hacia una versión más definitiva, cuando aludimos a una versión más definitiva de su filosofía entendemos que esta afirmación puede generar reparos en relación a su significado, con aquello solo queremos apuntar a lo que representa el escrito de 1927 en la estancia temprana del pensamiento de Heidegger, en cuanto final del camino que nos ha llevado desde la pregunta por la vida fáctica hasta la pregunta por el ser mismo.

Este análisis de la estructura ontológica de la vida fáctica que es el punto de partida de la elaboración de la pregunta por el ser, "descarta expresamente el "sujeto fantásticamente idealizado" con el que moderna filosofía de la conciencia relaciona la justificación de todas las objetividades(...) la crítica que Heidegger formula de esta manera no es inmanente, sino que apunta a una deficiencia ontológica cuando crítica también el análisis husserliano de la conciencia y de la conciencia temporal como cargada de prejuicios"147, Gadamer resume de esta forma las deficiencias ontológicas que el filósofo alemán había denunciado en este escrito de 1923, donde toma distancia de su maestro fenomenólogo, pero también reconoce abiertamente el aporte que este le ha entregado para el desarrollo de su propia filosofía, empero, Heidegger no cree que el ámbito originario de la vida fáctica pueda ser entendido desde la perspectiva de un sujeto tal como lo propone la filosofía moderna, sujeto capaz de justificar y fundamentar las objetividades que encuentra en el mundo, por el contrario, el rasgo característico del ámbito originario del que habla el pensador alemán es el de la copertenencia esencial entre el Dasein y el mundo.

Según Gadamer, Heidegger en estas lecciones dirige su crítica hacia la proveniencia originaria de esas insuficiencias, puesto que:

detrás de ello se halla la crítica a los griegos mismos, a su "superficialidad", la unilateralidad de su mirada, que captaba el contorno y la figura de lo ente, pensando el ser de lo ente en este ser "invariable", pero en cambio, no plantearon la pregunta por el ser, que precede a toda pregunta por el ser de lo ente. Hablando dentro del horizonte actual, lo "ente" significa aquí lo actualmente presente, y esto no acierta la genuina constitución

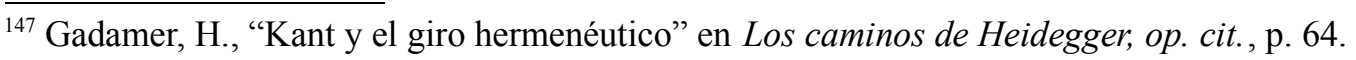


óntica del ser-ahí humano, que no es presencia, ni tampoco la del espíritu, sino que, pese a toda facticidad, está orientado al futuro ${ }^{148}$.

Como podemos ver la crítica de Heidegger respecto a la problemática de la cuestión del tiempo, se muestra ya desde dos polos bien marcados; la concepción del tiempo como presente o como esencialmente advenidero. Es evidente que a juicio de Gadamer, en estas lecciones se tratan casi la totalidad de las cuestiones, de los problemas filosóficos que preocupaban a Heidegger en aquel periodo, y que terminarán por cristalizarse en su reformulación de la pregunta por el ser desde el tiempo.

No podemos dejar de aludir a otra cuestión significativa que aparece en estas lecciones, Heidegger hace un comentario, de muy mala gana por decirlo menos, respecto a quienes considera como influencias decisivas y determinantes que han dado impulso a su pensamiento y dirección a su filosofía, pero precisa que esta referencia solo la hace para quienes no son capaces de comprender algo si no es por medio de una suma, de un cálculo de influencias filosóficas e históricas que se han recibido, a lo que llama un pseudo entendimiento de la curiosidad (Cf. GA63, 5/22), a pesar de eso, dice el joven profesor, "mentor en la busca fue el Lutero joven; modelo Aristóteles a quien aquél odiaba. Impulsos me los dio Kierkegaard, y los ojos me lo puso Husserl. (GA63, 5/22). Es curioso que a pesar de la reticencia que Heidegger manifiesta a proceder de esta forma, nos presenta aquí de su puño y letra, quién le ha dado qué cosa y quién cuál otra. Son estas las figuras que el pensador nativo de Messkirch considera como decisivas en esta estancia de su pensamiento y que han marcado su quehacer y andar filosófico.

En estas lecciones es donde el concepto Dasein acaba por consolidarse como término técnico de señalada importancia en la filosofía heideggeriana, esto porque poco a poco va dejando de usar el concepto de vida fáctica, remplazándolo por el de Dasein, que posee un carácter más preciso. Al comenzar la primera parte de estas lecciones, titulada la vías de interpretación del existir en su ocasionalidad (Wege der Auslegung des Daseins in seiner Jeweiligkeit), Heidegger analiza el concepto de facticidad y lo relaciona directamente con el de Dasein, se podría pensar que con esto el joven profesor quiere dejar establecida la equivalencia entre ambos términos antes de prescindir del de vida fáctica. Heidegger aclara esto de la siguiente forma: "la facticidad (Faktizität) es el nombre que le damos al carácter de ser de "nuestro" existir "propio" ("eigenen" Daseins). Más exactamente, la expresión significa: ese existir en cada ocasión (Jeweilig) (Fenómeno de la "ocasionalidad" (Jeweiligkeit); aquí por lo que toca a su ser. "Que el existir está aquí para sí mismo en el cómo de su ser más propio"” (GA 63,7/25). Con esta definición el pensador alemán logra uno de los objetivos principales que ha guiado su filosofía en estos años, la de alejarse de una consideración meramente teórica de la vida, apuntando más bien a una caracterización de ese fenómeno, que hace referencia a nuestra propia existencia en su ejecución, y con el término Jeweiligkeit alude al carácter del ser en cada

148 Ídem. 
ocasión, en cada caso, se refiere entonces al carácter temporal de la vida fáctica. Resumiendo lo anterior:

Facticidad dice este inmediato encontrarse viviendo y tal como se manifiesta a sí mismo. La convicción que preside esta vinculación de la filosofía a la vida fáctica es doble: por un lado, que como ya sabemos, es el nivel de lo originario, de la emergencia del sentido; por otro, que su sentido no es algo oculto que hay que buscar detrás de ella, sino justamente al revés, que reside en ella, que la facticidad es por sí misma inteligible, dotada de una significatividad propia, que puede ser reconocida si el pensamiento logra el modo adecuado de acceder a ella ${ }^{149}$.

Esta forma de entender la facticidad es para Heidegger el punto de partida del distanciamiento que toma respecto a la actitud teórica, esta no puede cumplir con los requerimientos o con la condiciones necesarias para conseguir un acceso adecuado a la experiencia originaria de la vida fáctica. La filosofía siguiendo los dictados de la ciencia se dirige primeramente al objeto y lo entiende según una estructura explicativa que pregunta por sus causas, siguiendo los cánones de una mirada teórico cognoscitiva de objetos, que es precisamente lo opuesto a lo que plantea el pensador de la Selva Negra en estas lecciones.

También es importante destacar el tratamiento que hace aquí del concepto de Jeweiligkeit, con el que quiere subrayar la constitución temporal de la vida fáctica, con este término nombra ese ente al que le es propio el tener que ser en cada instante, de tener que ser en cada ocasión. Heidegger nombra así a ese tener que ser en cada momento, no unas veces sí y otras no, sino que en cada ocasión está en juego su ser, se realiza en cada momento, tiene que ser cada vez, lo que le revela su ser como esencialmente temporal, este es un término que tendrá una vida útil reducida, dado que posteriormente será sustituido en Ser y tiempo por el término Jemeignigkeit. El término Jeweligkeit se introduce por primera vez en las lecciones del semestre de 1923, Ontología. Hermenéutica de la facticidad y puede ser entendido como momentaneidad, particularidad temporal. En el semestre de verano introduce formalmente Dasein como término técnico porque indica precisamente el momento particular que cada uno de nosotros es y tiene $\mathrm{e}^{150}$.

Tal como se ha visto, en este curso de 1923 Heidegger profundiza su crítica a la ontología tradicional, y sostiene que la pregunta por el ser solo podrá se resuelta en y por medio de la hermenéutica de la facticidad, razón por la cual se siente llamado a fijar con mayor claridad su idea de la hermenéutica, y por eso comenta que no utiliza este concepto en su sentido tradicional y que menos aún la entiende como una teoría de la interpretación, sino que se dirige más bien a su sentido originario, como realización del $\varepsilon \rho \mu \eta v \varepsilon v \varepsilon \iota v$, como interpretar que conduce al encuentro, visión y manejo de la facticidad (Cf. GA63,14/33). El objeto de la hermenéutica no es otro que la vida fáctica, la facticidad y el propio objeto de esta investigación en su ser mismo está capacitado para la

\footnotetext{
${ }^{149}$ Rodríguez, R., Heidegger y la crisis de la época moderna, op. cit., p. 188.

${ }^{150} \mathrm{Cf}$. Kisiel, Th., The Genesis of Heidegger's Being and Time, op. cit., p. 501.
} 
interpretación, y no solo eso sino que también la necesita, es propio de su ser el ser ya interpretado (Ausgelegtheit) y la tarea de la hermenéutica es hacer que el Dasein mismo en cada ocasión, en cada caso, sea accesible a sí mismo, que sea capaz de comunicarse consigo mismo, lo que está en juego con la hermenéutica es la posibilidad de que el Dasein pueda llegar a comprender y ser ese mismo comprender. Esta forma de concebir el comprender que nos presenta aquí el profesor nativo de Messkirch, nada tiene que ver con un modo de conocimiento teórico, sino que es un cómo del Dasein mismo (Wie des Dasein selbst), determinado terminológicamente lo llama, el estar despierto del Dasein para sí mismo (das Wachsein des Daseins für sich selbst). En otras palabras, el sentido primigenio de la palabra hermenéutica sería el de dar a conocer algo, de comunicar algo, por lo tanto, "se trata de que la vida fáctica se dé a conocer explícitamente a sí misma, partiendo de y manteniéndose en el conocimiento inmediato-no reflexivo -que de sí misma tiene y, en el que constantemente se desenvuelve"151.

Pero eso no es todo, en esta determinación de la hermenéutica que Heidegger desarrolla por estos años, señala que la relación que se establece entre hermenéutica y facticidad, no tiene nada que ver con la que se establece en una relación de sujeto-objeto, entre lo aprehendido y el sujeto que lo contempla, sino que el interpretar mismo es él mismo una posibilidad y carácter de ser de la facticidad, es más, la interpretación es parte del ser mismo del vivir fáctico, este mismo vivir fáctico tiene el carácter de la interpretación, podríamos decir que el mismo objeto posee al sujeto. Si la facticidad se considera como el objeto de la hermenéutica, ella misma se encuentra en su objeto, es su mismo objeto. Se podría hablar de una unidad de ser entre la hermenéutica y su objeto. (Cf. 63 15/33-4)

Puntualizando en lo que significa el estar despierto(Wachsein)del Dasein para sí mismo, que está implícito en esta idea de hermenéutica, en la cual el Dasein se encuentra consigo mismo y se pone ante sí mismo, Heidegger quiere subrayar que si el estar despierto tiene un carácter filosófico esto se juega en una autointerpretación originaria que la filosofía ha dado de sí misma, gracias a la cual se constituye esa interpretación en una posibilidad decisiva y fundamental del Dasein, como una forma en la que la vida fáctica se encuentre consigo misma, se ponga ante sí misma y aparezca ante sí misma. Esto significa para la hermenéutica que la filosofía no es una forma de conocimiento teórico contemplativo, sino que principalmente es una forma de conocer que se da en el vivir fáctico, es la forma como ese mismo vivir fáctico se arranca de sí sin contemplaciones, ello para ponerse ante sí mismo sin ocultamientos (Cf. GA 63, 18/37).

Todo esto muestra que la hermenéutica no tiene como finalidad última la obtención de ciertos conocimientos al modo de una ciencia objetivante, sino que es un conocer la propia existencia, el propio Dasein en su ser mismo, ella no habla desde un mirada teórico contemplativa que sitúa a la vida fáctica como objeto de conocimiento, sino que habla

\footnotetext{
${ }^{151}$ Rodríguez, R., La transformación hermenéutica de la fenomenología, op. cit., p. 101.
} 
desde la misma vida fáctica en su facticidad, ella habla desde lo ya interpretado y para lo ya interpretado. En esta unidad de ser entre la hermenéutica y la facticidad se localiza su punto de partida, su realización y apropiación, todo esto como temporalmente anterior al llevar a cabo cualquier investigación científica, tanto en términos fácticos como en relación al ser mismo.

El tema mismo de la Hermenéutica es en cada caso el mismo Dasein y la tarea primera de la hermenéutica, entendida de este modo, es la de determinar, acotar el lugar desde el cual es posible preguntar sin dejarse llevar por ideas preconcebidas. La interpretación tiene como punto de partida la actualidad, lo ya interpretado; la hermenéutica se asienta en la situación del caso y desde ahí hace posible la comprensión.

\section{APROPIACIÓN DE LA SITUACIÓN HERMENÉUTICA Y DESTRUCCIÓN FENOMENOLÓGICA}

Asimismo, la hermenéutica de la facticidad si pretende cumplirse de forma cabal, necesariamente ha de plantearse otras exigencias inherentes a su propia tarea, esto tiene que ver con la aclaración de la situación hermenéutica. Para llevar a cabo de forma exitosa este proyecto que Heidegger denomina en principio hermenéutica fenomenológica de la facticidad, y que luego llama sin más hermenéutica de la facticidad, se debe partir de una aclaración de la situación hermenéutica, cuyo objetivo principal es determinar con claridad de qué forma se comprende la vida fáctica a sí misma, y esto antes de cualquier mirada teórico cognoscitiva. Para cumplir con estos requerimientos es imprescindible determinar el tener previo (Vorhabe) y el concepto previo (Vorgriff).

La hermenéutica de la facticidad exige para sí misma, para su desarrollo, una aclaración de la situación hermenéutica que permita reconocer la conceptualidad transmitida en la que se encuentra situada la vida fáctica, cómo se comprende esta a sí misma. Desde dónde extrae los conceptos y los presupuestos desde los cuales se interpreta a sí misma y al mundo que le rodea. Es imprescindible saber desde dónde obtiene la dirección interpretativa según la cual se concibe a sí misma, y además saber si esa dirección interpretativa es la originaria. Heidegger dice respecto a esto: "la situación de la interpretación, en cuanto apropiación comprensiva del pasado, es siempre ya la situación de un presente viviente. La inteligibilidad de la vida misma, a modo de pasado reapropiado en la comprensión, aumenta de manera decisiva en función del grado de originariedad con que se determina y elabora la situación hermenéutica" (NB, 1-2/30).Y es precisamente en la filosofía griega y principalmente en Aristóteles el lugar donde Heidegger localiza dicha conceptualidad, que posteriormente sería transmitida a la teología medieval, al cristianismo, es la penetración no problematizada de la influencia griega en el cristianismo, este hará suyas las categorías correspondientes a aquél pensamiento, que entiende la vida fáctica principalmente como animal racional, naturaleza, persona, etc. 
Heidegger entiende que las consideraciones lógico ontológicas provenientes de la tradición no obtienen su punto de partida desde una experiencia originaria propia a su ámbito ontológico. Ve en esta cuestión un fallo fundamental en la comprensión que la vida fáctica tiene de sí misma, deficiencia que ha impedido una apropiación originaria de dicho fenómeno, y que por lo demás, se encontraría en la raíz de esa incomprensión, nos referimos a la cuestión del tiempo. Consideración del tiempo cuyo punto de partida es la interpretación aristotélica que ha determinado largamente la historia del pensamiento, ello en razón de que el ser fue comprendido desde la antigüedad como presencia, desde el presente, cuestión que ha devenido en que la comprensión del Dasein sea principalmente formulada desde lo Vorhandenheit, cuyo modelo ontológico es la naturaleza. En consecuencia, la hermenéutica de la facticidad ha de comenzar preguntándose desde qué situación hermenéutica se comprende el ser de la vida fáctica, lo que nos conduce necesariamente a plantear la pregunta por el tiempo peculiar a la existencia. No debemos olvidar, que "el objeto de la investigación filosófica es el Dasein humano en tanto que se interroga en su carácter ontológico" (NB, 3/31).

La importancia de la apropiación de la situación hermenéutica radica en que ella, por decirlo de alguna forma, muestra el suelo que se está pisando, nos abre el acceso al lugar en dónde estamos, dónde nos situamos, ha de iluminar cuál es la interpretación que tenemos de nuestra propia vida fáctica, y nos muestra cómo esa interpretación, que no es del todo explícita, termina siempre por guiar nuestra comprensión del mundo, de las cosas y de nuestra propia vida fáctica. Teniendo en cuenta lo anterior, Heidegger sostiene, que "La fijación de la actitud histórica fundamental de la interpretación resulta de la explicación del sentido de la investigación filosófica. Su objeto se definió de manera indicativa en términos de Dasein humano fáctico en cuanto tal. La caracterización concreta de la problemática filosófica debe arrancar de este objeto suyo. Por esta razón es necesario poner de relieve la específica objetividad de la vida fáctica"( $\mathrm{NB}, 5 / 34)$, esto significa, que es indispensable saber desde qué presupuestos se comprende la vida fáctica a sí misma y cómo entiende aquello que le rodea, para poder reconocer las insuficiencias que se ocultan en dichas interpretaciones, para abrir así la posibilidad de un acceso originario a la vida fáctica, en la cual se comprenda a sí misma desde sí misma de forma auténtica y originaria. Pero no solo eso, también abre la posibilidad de un acceso originario a las cosas del mundo y al mundo como tal, lo que nos permitiría una comprensión esencial de lo que nos rodea y de la relación originaria que entablamos con ello antes de cualquier consideración teórica.

Siguiendo con esta misma idea de una apropiación de la situación hermenéutica, Heidegger alude a un momento crítico fundamental que condiciona su carácter filosófico, que establece como regla general que no debemos aceptar a buenas y a primeras aquellos conceptos e interpretaciones heredadas, por el contrario, debemos de-construirlos para así recuperar la experiencia originaria desde la que surgieron, solo en este contexto se puede 
hablar de una apropiación originaria, de una comprensión plena. Por otra parte, estos conceptos o interpretaciones heredadas se han de discernir e interpretar, para así obtener una dirección de verdad correcta, un tener previo de la vida fáctica que proporcione un punto de partida valido de la hermenéutica de la facticidad ${ }^{152}$. Este, es el punto de partida desde el que debe fundamentarse este programa filosófico, si quiere ser valido debe asentarse sobre bases sólidas. Por todo esto, el filósofo de la Selva Negra entiende que es una cuestión indispensable, "comprender radicalmente lo que en cada momento una determinada investigación filosófica colocó en su situación y de la inquietud de fondo que mostró por esa situación; comprender no significa aceptar sin más el conocimiento establecido, sino repetir: repetir originariamente lo que es comprendido en términos de la situación más propia y desde el prisma de esa situación" (NB, 4/33).

El tema mismo de la hermenéutica es en cada caso el mismo Dasein y la tarea primera de la hermenéutica entendida de este modo, es determinar, acotar el lugar desde el cuál es posible preguntar sin dejarse llevar por ideas preconcebidas. La interpretación tiene como punto de partida la actualidad, lo ya interpretado, la hermenéutica se asienta en la situación del caso y desde ahí hace posible la comprensión. El objeto de la investigación heideggeriana es la facticidad, es el Dasein propio en su ser, es su carácter de ser. Y este Dasein propio solo es lo que en su ahí ocasional (Jeweiligen "Da"), en su ahí en cada caso. Una determinación importante de la ocasionalidad (Jeweiligkeit) es la actualidad, el hoy (das Heute), que es un estar siempre en el presente, en el hoy. Es fundamental considerar la actualidad en el planteamiento del análisis, de tal forma que así se haga manifiesto en él algo como un carácter de ser. La actualidad, el hoy, como modo de ser de la facticidad solo podrá ser determinado en su carácter ontológico cuando se haya hecho manifiesta de modo explícito su fenómeno fundamental, la Temporalidad. (Cf. GA 63, 2931/49-51).

En tal sentido, se ha de señalar que la actualidad, el hoy en el cual nos encontramos y que somos como un modo de ser que a cada instante estamos viviendo, es lo que Heidegger llama estar siempre en lo ya-interpretado, "lo ya interpretado(die Ausgelegtheit) delimita de modo difuso el ámbito desde el cual el existir mismo plantea cuestiones y exigencias. Lo ya interpretado es lo que da al "aquí" del estar-aquí fáctico el carácter de un estar orientado, lo que delimita concretamente su posible modo de ver y el alcance de su vista" (GA 63, 32/52). Y precisamente lo ya interpretado es lo que guía nuestra interpretación del mundo, es el horizonte dentro del cual se despliega nuestra comprensión de lo que nos rodea y de nuestra propia existencia, por lo tanto, también desde ese horizonte se comprende el tiempo y el ser mismo. El joven profesor describe esto de la siguiente forma: "La vida fáctica se mueve en todo momento en un determinado estado de interpretación heredado, revisado o elaborado de nuevo" (NB, 8/37), esto significa, que sobre ese ser ya interpretado se comprende la cotidianidad a sí misma y elabora su

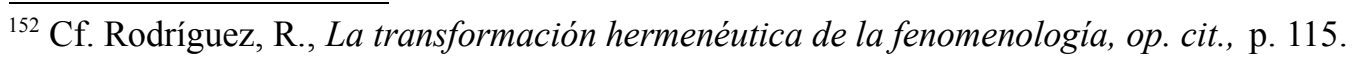


discurso respecto a la vida fáctica y al tiempo, en consecuencia, "la apropiación fenomenológica tiene como tarea primera sacar a la luz esas representaciones"153, y precisamente dentro de esta tarea de apropiación fenomenológica hay un fenómeno que debe ser escrutado de forma perentoria, dado que tiene una señalada importancia y es profundamente revelador, por eso, si la intención es llevar a cabo de forma exitosa la hermenéutica de la facticidad y reformular la pregunta por el ser, es indispensable conducir la investigación hacia el problema del tiempo, que en su comprensión cotidiana se entiende como mera sucesión de ahoras siempre presentes. Además, esta comprensión del tiempo, para nada casual, hunde sus raíces en la interpretación del ser de la tradición metafísica que es precisamente lo que ha impedido un acercamiento originario a la vida fáctica y a su experiencia originaria del tiempo.

Por esta razón, Heidegger sostiene que la "hermenéutica fenomenológica de la facticidad arranca necesariamente del corazón mismo de su situación fáctica, de un determinado estado de interpretado de la vida fáctica, estado que le viene predado, que sostiene inicialmente la misma hermenéutica fenomenológica de la facticidad y que ya no puede ser enteramente erradicado" (NB, 18-9/49). A esta comprensión del tiempo en lo ya interpretado de la vida fáctica es hacia donde necesariamente debe dirigir su tarea fenomenológica, para desvelar en ese estado de interpretado -en el que siempre nos encontramos- una experiencia originaria del tiempo que de consuno nos permita llevar a cabo una comprensión auténtica del Dasein, de sus categorías ontológicas fundamentales.

Por lo tanto, se ha de ir al fundamento mismo de estas interpretaciones que no son más que un vestigio, la herencia de una tradición antiquísima, dicho de otro modo: estas interpretaciones cargan con todo el legado y el peso de la tradición metafísica. El problema de todo esto radica principalmente en que dicha tradición y su conceptualidad se manifiestan de una forma amplia y generalizada, cuya consecuencia directa es que se utilizan y aplican dichos conceptos sin una comprensión ni una apropiación esencial de su significado y sentido, todo ello hace que los conceptos e interpretaciones que nos han sido legados y transmitidos por la tradición nos oculten y encubran su sentido originario, cuestión que muchas veces es el punto de partida de la propia problemática ontológica, como por ejemplo en lo referido al problema del tiempo.

Es en el horizonte abierto por estos cuestionamientos que Heidegger considera oportuno delimitar la tarea y los ámbitos propios de la investigación fenomenológica, en su interpretación el fenómeno no es considerado como una categoría, un objeto o un cosa, es entendido en términos de un cómo de la investigación, en consecuencia:

el fenómeno es primeramente no una categoría sino que hace referencia ante todo al cómo del acceso, de la aprehensión y verificación. En consecuencia, la fenomenología es ante todo un modo de investigar (Weise der Forschung), en concreto: hablar de algo tal como ese algo se muestra y solo en la medida en que se muestra. Es decir, para cualquier ciencia

${ }^{153}$ Ibíd., p. 116. 
pura trivialidad; y, no obstante, algo que en la filosofía, y ya desde Aristóteles, ha ido quedando más y más en el olvido (GA63, 71/95).

La fenomenología no es un método vacío y abstracto que se aplica sin más un nuevo objeto de estudio, sin importar cual sea dicho objeto. "Fenomenología es, por lo tanto, un cómo de la investigación, aquel que actualiza los objetos en la intuición y solo habla de ellos en la medida en que están ahí en la intuición. Ese cómo y su realización son algo obvio; por eso, decir "filosofía fenomenológica" resulta en el fondo equívoco" (GA63,72/96). El filósofo nacido en Messkirch entiende la fenomenología primordialmente como un método, es un cómo de la investigación bajo la cual ha de ser sometido a escrutinio el tiempo, para así revelar el carácter ontológico originario del Dasein, y a partir de ello se abrirán las puertas y la posibilidad de una reformulación de la pregunta por el ser.

La fenomenología es una posibilidad de la investigación, razón por la cual no puede ser considerada como algo manifiesto u obvio, en tanto posibilidad tiene su particular forma de asumirse y verificarse. Por eso Heidegger dice que el asumir una posibilidad significa siempre asumirla, captarla y configurarla en su propio ser, ver y comprender lo que en ella hay de posibilidad, lo posible que hay en ella. "Fenomenología es, pues, un peculiar cómo de la investigación. Los objetos llegan a determinarse tal como ellos mismos se dan. La indagación se ocupa en lograr la actualización de la cosa. Se propone con esto una vía que la hermenéutica de la facticidad trata de seguir"'(GA63,74/ 98).

Se trata entonces de que los fenómenos se muestren desde sí mismos, tal como aparecen ante el mirar fenomenológico. Sin embargo, en este mostrarse y aparecer de las cosas puede pasar que muestren un cariz tan usualmente aceptado y considerado de suyo como legítimo y verdadero según los dictados de la tradición, que sea imposible ver lo impropio que ahí se presenta. Sin lugar a dudas lo que Heidegger hace es preparar el terreno para su investigación venidera, de forma que quede completamente claro cómo esa tradición endurecida trabaja y sutilmente invade todas la esferas y consideraciones que la vida fáctica tiene de sí misma y es así como esa inveterada comprensión del ser y del tiempo llega hasta nuestros días sin ser cuestionada de forma auténtica.

De todo esto se desprende, que aquello que se muestra en sí mismo no tiene por qué ser necesariamente la cosa misma, ni mostrarse originariamente, en tal sentido si el investigador permanece sin hacerse cuestión de la legitimidad con la que dicha cosa se muestra, puede estar considerando un ocultamiento o encubrimiento como la cosa misma. Por lo tanto, la cosa que se muestra en una primera impresión, en una mirada directa, no asegura para nada que sea verdaderamente la cosa misma. Por consiguiente, con la fenomenología, "se trata de llegar a aprehender la cosa libre de encubrimientos, superando el punto de partida. Para ello es necesario sacar a la luz la historia del encubrimiento. Hay que remontar la tradición del cuestionar filosófico hasta las fuentes del asunto. Hay que 
desmontar la tradición. Solo de esta manera resultará posible un planteamiento originario del asunto. Este retorno es el que sitúa a la filosofía ante las condiciones decisivas" (GA63,75/99).

En esta investigación Heidegger habla principalmente de un remontarse a la historia misma del encubrimiento, al punto de partida desde donde se han oscurecido los fenómenos y ello solo se puede llevar a cabo a través de lo que él denomina una crítica histórica radical, considerando esta tarea no como un simple ejercicio de conocimiento o de información, sino que al contrario, la entiende como una tarea propia y esencial del quehacer fenomenológico, es más, la considera como una tarea fundamental de la propia filosofía (Cf. GA63, 75/99). Es hasta ese punto de partida donde la filosofía- entendida como fenomenología- debe dirigirse, hasta donde debe llevar la investigación, para rastrear el origen mismo del encubrimiento en el que se fundamenta la conceptualidad tradicional, la interpretación de la opinión pública de la cotidianidad, es hacia allí hacía donde dirigirá su crítica para conocer los motivos ocultos que guían la interpretación y la forma de entender la vida fáctica, que es en último término la comprensión vulgar del tiempo. Por todo esto:

la hermenéutica fenomenológica de la facticidad, en la que medida en que pretende contribuir a la posibilidad de una apropiación radical de la situación actual de la filosofía por medio de la interpretación,-y esto se lleva a cabo llamando la atención sobre las categorías concretas dadas previamente-, se ve obligada a asumir la tarea de deshacer el estado de interpretación heredado y dominante, de poner de manifiesto los motivos ocultos, de destapar la tendencias y las vías de interpretación no siempre explícitas y de remontarse a las fuentes originarias que motivan toda explicación por medio de una estrategia de desmontaje (abbauenden Rückang). La hermenéutica, pues, cumple su tarea solo a través de la destrucción (Destruktion)" (NB, 20/51).

Es menester ir a los fundamentos mismos de dichas interpretaciones, de la consideración de la vida fáctica como Vorhandenheit, del tiempo como mera sucesión de ahoras, del ser como presencia y esto, a juicio de Heidegger, solo se podrá llevar a cabo por un desmontaje, a través de la desconstrucción. Esta tarea destructiva de la tradición debe estar dirigida a los fundamentos en lo que se origina la consideración de la vida fáctica como objeto, como animal racional o como naturaleza ahí presente, debe ir al origen de la interpretación del tiempo como simple secuencia de ahoras. Empero, tal como dice Berciano:

La destrucción fenomenológica no ha de pensarse, pues, como una aniquilación, en el sentido de Zerstörung o de Vernichtung, sino más bien como un desmonte (Abbau) de la tradición filosófica que nos ha sido transmitida, en la cual se ha dado una ocultación. El preguntar filosófico hoy debe retornar hasta los comienzos y debe hacerlo de manera crítica. La crítica no es una ilustración cómoda, sino tarea fundamental de la filosofía. El principio fenomenológico "a las cosas mismas" no significa que éstas se descubran con evidencia ingenua; la historia no es una novela ${ }^{154}$.

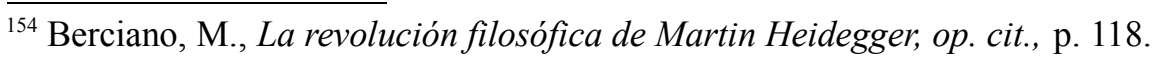


De todo esto se desprende que la propuesta de Heidegger no es una simple aniquilación que pretenda borrar si más los rastros de la tradición, sino que alude a un trabajo que implica ir quitando una a una las capas que encubren los fenómenos, esto en un proceso gradual que al final permitirá llegar al fenómeno originario libre de encubrimientos, este es el carácter del desmontaje crítico de la tradición que plantea el joven profesor, con esto procura que dejemos de fijar nuestra atención en cuestiones que aparecen como importantes pero no lo son. Como dice Heidegger:

\begin{abstract}
"Desmontar" (Abbau) quiere decir aquí: retorno a la filosofía griega, a Aristóteles, para ver cómo lo que era originario decae y queda encubierto, y para ver como nosotros estamos en medio de esa caída (...) la filosofía se mueve ahora en la tradición. Fenómeno, en cuanto categoría temática que orienta el acceso y predispone el trato con las cosas, viene a significar la constante preparación de la vía. Dicha categoría temática tiene la función de alertar críticamente la mirada reconduciéndola al desmontaje de los encubrimientos hallados mediante la crítica (GA63, 76/100).
\end{abstract}

Desde esta perspectiva interpretativa que plantea el pensador de la Selva Negra, la apropiación del sentido original de los fenómenos solo se puede obtener si nos reconducimos hacia la experiencia primigenia desde la que surgieron, esto significa que el desmontaje, la destrucción es esencialmente apropiación y no un simple descarte o rechazo a la tradición, sino que a partir de aquello en lo cual nos encontramos inmersos se quiere comprender originariamente los conceptos, desde y a partir de los cuales, interpretamos nuestra propia situación, nuestra actualidad, nuestro presente, y esto fundamentalmente dirigido a cómo entiende la cotidianidad la propia existencia, y a cómo interpreta el tiempo.

Lo que el filósofo alemán propone es ir al origen mismo del encubrimiento, por eso, "las concepciones heredadas, que son del pasado y a la vez nuestras, hay que llevarlas al horizonte de su originación e intentar verlas a partir del lugar, la dirección y el horizonte de la mirada que las instituyo: es en esa situación donde cobraron realmente la vida que aún pervive, como un residuo en nosotros. Apropiarse de la situación hermenéutica del pasado vigente es comprender la nuestra" ${ }^{155}$. En consecuencia, las teorías respecto a la realidad deben ser sometidas a una destrucción crítico fenomenológica, lo que nos lleva en última instancia a la cuestión de por qué toda referencia acerca de la realidad acaba por remitirse y explicarse por y desde un ser-real más originario. Toda investigación busca ese ser verdadero, cuyo modelo ontológico son la cosas naturales, la ontología clásica obtiene su interpretación del ser desde aquel ser de lo que siempre existe, de lo que es siempre(Immerdasein), esto tiene un carácter de ley que dicta que debe poseer cierta permanencia (Beständigkeit), una disponibilidad de lo conocido, de lo ente (Cf. GA 63, 89/114-5), en otras palabras: toda investigación ontológica debe fundamentarse en un ser que es presencia constante.

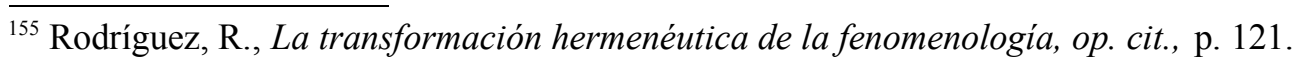


Según Heidegger, toda la historia de la lógica y de la ontología tradicional se encuentra determinada desde el ámbito de dominio y de influencia que se inicia con Parménides, lo que marca el destino de la historia del espíritu y de la tradición filosófica, cuestión que llega hasta nuestra propia existencia, todo esto se inicia con la sentencia

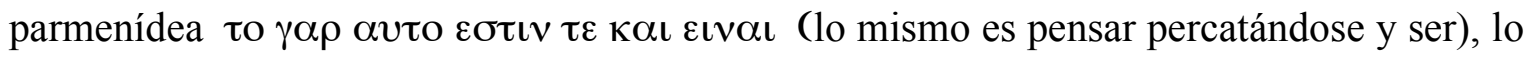
que significa, que solo aquello que es percibido por el pensar que se percata es lo verdaderamente existente, por lo tanto, la única y exclusiva vía de acceso por la cual es posible aprehender el ser verdadero es el pensar percatándose, que está dirigido principalmente por la percepción visual, es un aprehender teórico, una ciencia de lo que siempre está ya aquí (immer schon da), en otras palabras de la presencia constante de un objeto para un sujeto que lo contempla (Cf. GA63, 92/117), por lo tanto, toda la ontología posterior es deudora de aquella sentencia parmenídea, que ha determinado la historia de la filosofía. Por esta razón, si la intención es obtener una experiencia originaria de la vida fáctica, del ser o del tiempo, necesariamente la investigación debe pasar por una crítica a dicha formulación y al rango de influencia alcanzado por ella

Como resultado de esto podemos concluir que Heidegger, por esos años que van del Informe Natorp a su último curso de Friburgo, tiene más o menos claro cuál es el fallo fundamental de la metafísica hacia el que debe dirigir su tarea la destrucción fenomenológica, se encuentra además en plena posesión de un valioso arsenal conceptual y metodológico para poner en marcha su programa filosófico, que ya cuenta con coordenadas bien determinadas y que dirigirán su trabajo en lo próximos años. Todo esto le permitirá abordar aquellas cuestiones que harán de su filosofía un pensamiento innovador y revolucionario y le posicionarán en la historia de la filosofía contemporánea como un pensador de una importancia e influencia indiscutible; nos referimos a la reformulación de la pregunta por el ser al alero del la cuestión del tiempo, esto desde la temporalidad del Dasein.

Esto lo afirmamos teniendo en cuenta que la próxima parada del pensamiento de Heidegger es la concreción de este proyecto filosófico que interroga por la conexión entre el ser y el tiempo, que podemos ver materializada en el tratado El concepto del tiempo publicado recién en el año 2004. Herrmann afirma que este tratado constituye el texto embrionario de Ser y tiempo ${ }^{156}$, en el cual Heidegger se plantea como objetivo principal la pregunta por el sentido del ser histórico del Dasein y no la pregunta por el ser como tal.

Ahí Heidegger comenta que la reciente publicación de la correspondencia entre Dilthey y el conde Yorck le permitía comunicar de manera provisional una investigación respecto al tiempo en la que se encontraba trabajando (Cf. GA64, 3 /11) ${ }^{157}$. Además,

${ }^{156}$ Cf. Herrmann, F., "Nota del editor" en El concepto del tiempo(Tratado), M.Heidegger, Herder, Barcelona, 2008, p. 141. Trad. Jesús Adrián.

${ }^{157}$ Heidegger, M., El concepto del tiempo, (El tratado), Herder, Barcelona, 2008, p. 13. Trad. Jesús Adrián. 
precisa que su investigación respecto al tiempo trata de comprender la historicidad y no simplemente la historia del mundo, no quiere aclarar la objetividad de lo histórico, tampoco trata de mostrar de que modo la historia se convierte en objeto de una ciencia que la contempla y objetiviza. La tarea que él plantea es algo aún más radical, es la pregunta por el sentido del ser histórico, por tanto es una pregunta de carácter ontológico, cuya finalidad es poner de relieve la estructura ontológica del ente que es historia, es ontológica porque interroga al ente por su ser, en sus caracteres ontológicos y el único tipo de investigación que puede llevar a cabo esta tarea es la fenomenología. Esto lo gráfica Heidegger de la siguiente forma, "si hay que poner al descubierto los caracteres ontológicos de un ente, este mismo ente deberá entrar antes en el campo de visión de la investigación ontológica. El ente debe mostrarse (phainesthai) desde sí mismo(...) debe convertirse en fenómeno y ser nombrado (logos) tal como se muestra. Por eso la fenomenología es el único tipo de investigación que puede poner en marcha y sostener una investigación ontológica" (GA 64, 4 /12). Como podemos ver para el pensador alemán la fenomenología es el único tipo de investigación capaz de llevar a cabo una investigación ontológica, solo ella puede determinar el carácter ontológico de ese ente que es historia, la fenomenología es la llamada a desarrollar la pregunta por el sentido del ser del ente histórico, cuyo carácter ontológico es la historicidad.

Todo esto según Heidegger lleva necesariamente a la cuestión del tiempo, porque si la tarea que se plantea es la de desvelar la estructura ontológica de este ente, de determinar su ser mismo, esto nos conduce obligatoriamente a la cuestión de la temporalidad, porque tal como lo señala el filósofo alemán, "la constitución ontológica fundamental del Dasein, a partir de la cual resulta posible aprehender ontológicamente la historicidad, es la temporalidad. De esta manera, la tarea de comprender la historicidad nos conduce a la explicación fenomenológica del tiempo "(GA64,4/13).

Dichos cuestionamientos son los que marcarán el camino en lo que viene, pretendemos con esto dejar claramente establecido, que todo este marco que podemos llamar metodológico que Heidegger concretiza en este periodo de su pensamiento, que coliga ontología, hermenéutica y fenomenología, tiene como principal objetivo revisar y reformular la pregunta por el ser a través del tiempo, por eso decíamos que una vez que el filósofo nativo de Messkirch, cuenta ya con una sólida base conceptual y metodológica, se encuentra ya preparado para enfrentar su desafío mas importante, la determinación ontológica del ser del Dasein con la que mostrará la insuficiencia de la tradición metafísica para dar cuenta de este ente, insuficiencia fundamentada principalmente en su interpretación del ser que lo concibe como presencia, desde un modo del tiempo; el presente, negando de esta forma su esencial constitución temporal como primariamente advenidera. Será en este tratado donde Heidegger presenta esta conexión entre la interpretación del ser como ousía, como presencia, como presente, cuyo exponente primero fue Aristóteles (Cf. GA64,101/129). Y el pensador alemán entiende que es 
precisamente a esto a lo que debe dirigir su destrucción fenomenológica, para que se haga manifiesto el verdadero fundamento del Dasein.

Para una investigación de carácter originaria, tal como la que se plantea Heidegger, la interpretación de la situación hermenéutica no puede venir a ser determinada desde esta concepción del ser que se extrae desde el mundo, desde lo que es presencia constante, que toma como modelo ontológico a la naturaleza. Teniendo en cuenta esto, el filósofo de la Selva Negra, señala: "Entendida como destrucción fenomenológica, la ontología del Dasein tiene que colocarse en la posibilidad de decidir sobre la respectiva proveniencia y adecuación de la categorías transmitidas"(GA 64,102/130), fundamentalmente en lo referido a la cuestión del ser y el tiempo.

\section{Capítulo V: La concepción del ser como presencia, el tiempo como puro presente}

En la filosofía de Heidegger, en sus comienzos como docente universitario, se establecían dos vías de cuestionamiento que caminaban de forma paralela en sus primeras lecciones, la pregunta por las categorías fundamentales de la vida fáctica discurría por un camino aparentemente distinto al de la pregunta por el ser, aunque si bien esa pregunta no ha sido expresamente formulada, sin lugar a dudas su pensamiento ya estaba encaminado hacia ella. Heidegger seguramente intuía desde un principio esta esencial copertenencia entre la pregunta por el tiempo y el ser, aunque tal como dice Pöggeler, no se le había hecho manifiesta dicha conexión hasta aproximadamente el año 1922-1923, periodo en el cual habría comprendido que en la tradición filosófica el ser es pensado como ousía, como presencia (Anwesenheit), como presente (Gegenwart), lo que significaría que el ser está determinado desde un modo del tiempo. Y en razón de este descubrimiento, que en la comprensión griega del ser se oculta una interpretación de un carácter privilegiado del tiempo, será posible para Heidegger reformular la pregunta por el ser al hilo conductor del tiempo. En consecuencia:

\footnotetext{
si la filosofía no acierta la facticidad y la historicidad de la vida-su "temporalidad"-ello se debe a que desde sus comienzos los griegos han entendido el ser del ente unilateralmente desde un significado rector, es decir, como ousía o substancia, como presencia permanente de una esencia, a la que siempre puede regresarse. Esta presencia está determinada irreflexivamente desde una dimensión del tiempo, es decir, el presente o hasta un hispostasiado y eterno presente. De esta manera, desde el comienzo, el tiempo se encuentra como olvidado en la historia de la filosofía ${ }^{158}$.
}

De modo tal, que esta interpretación del ser desde tiempo y el reconocimiento que Heidegger hace de ello, marca un hito en la dirección de su filosofía y es un punto de inflexión en la misma, determinando lo que viene como una reformulación de la pregunta

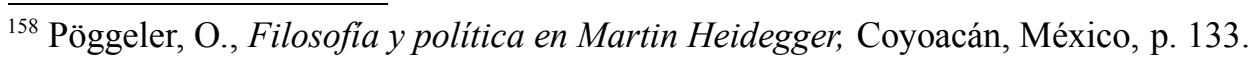


por el ser teniendo como hilo conductor el problema del tiempo y en su destrucción fenomenológica de la historia de la metafísica reconocer como esa concepción del ser ha marcado e influenciado la historia del pensamiento occidental.

Sería por entonces, por el año 1922-23, cuando el filósofo alemán habría llegado a esta conclusión, que determinaría de forma decisiva el camino de su pensamiento, lo que significaba que por aquel entonces ya había surgido en él la pregunta por el ser y el tiempo ${ }^{159}$. Esto se lo habría comentado directamente Heidegger a Pöggeler, sin embargo, este último se pregunta : ‘ es efectivamente verdadero que ya en 1923 esté unida la pregunta por el ser de estar en cuanto temporalidad con la experiencia de que el ser en cuanto asistencia no sea sino mero presente y, por ende, esté pensado a la luz del tiempo solo de un modo insuficiente? ¿ no fue más fuerte la ruptura del invierno de $1925 / 1926 ? " 160$.

Podemos decir que con la publicación de los escritos y lecciones de Heidegger de aquellos años, especialmente del tratado El concepto del tiempo que viene a completar la conferencia homónima, que data del año 1924, y recién publicada en 2004 en el tomo 64 de sus Obras completas, esta duda parece disiparse, ya que ahí Heidegger presenta con claridad la conexión existente entre la pregunta por el ser del Dasein y la interpretación del ser como ousía, como presencia, como simple presente, cuestión que si bien en los escritos o lecciones de fechas anteriores se podía intuir, terminaba por afirmarse con claridad.

Heidegger tiempo después, en un texto que dictó a Jean Beaufret veinte años después de la publicación de Ser y tiempo en septiembre de 1946, llamado La pregunta fundamental por el ser mismo, se refiere a la importancia que tuvo para su filosofía este descubrimiento, ahí dice, que "por haberme dado cuenta temprano de que, para los griegos, y sin que ellos mismos lo pensaran, el ser fue determinado como presencia ( o sea, a partir del tiempo), aquello me dio el guiño decisivo, de que el ser está puesto de algún modo oculto en el claro del tiempo" (GA16, 424), de esta forma, el filósofo alemán reconoce años después el alcance y el significado que tuvo para su filosofía el descubrimiento de esta determinación del ser como presencia que subyace en la filosofía griega y cuya influencia se extiende hasta la teología y la filosofía posterior, cuestión que marcaría la conceptualidad de la tradición metafísica y la comprensión misma de la temporalidad propiamente humana. La importancia de esta conexión incluso trasciende este periodo de su pensamiento y se relaciona con la pregunta por el ser mismo desde el claro del tiempo.

Hemos podido ver de qué forma en esta estancia del pensamiento de Heidegger se han presentado estas dos líneas de investigación que terminarán por confluir en una y la misma pregunta, la pregunta por el sentido del ser, cuestión que se le hará manifiesta a la

\footnotetext{
${ }^{159}$ Cf, Pöggeler, O., El camino del pensar de Martin Heidegger, op. cit., p.401. 160 Ídem.
} 
luz de la pregunta por la vida fáctica. Por una parte, veremos cómo en esta destrucción de la historia de la metafísica que el filósofo alemán pretende llevar a cabo se le revela aquella conexión entre la interpretación griega del ser como presencia, es decir, a partir del tiempo. Y por otra, en el análisis de la vida fáctica, de la temporalidad inherente a ella, se nos revelará que su ser tiene como carácter temporal primordial el futuro, cuestión en la que Heidegger no dejará de insistir y que formulará de distintas maneras, reafirmando en todas ellas la radicalidad y la importancia de esta dimensión temporal, esto hasta más allá de Ser y tiempo, aunque en este último tratado apuesta por una formulación más tímida de esta prioridad, cuestión que sin embargo, en una interpretación global de dicho trabajo, nos atrevemos a decir, sostiene el marco argumental y conceptual de la analítica existenciaria y de su proyecto de una fenomenología hermenéutica como posibilidad esencial del quehacer filosófico.

La tarea que desarrollaremos a continuación es seguir a Heidegger en su cuestionamiento del problema del tiempo, que poco a poco va adquiriendo una forma más definitiva. En esta exégesis el pensador alemán atacará el fundamento mismo de la idea tradicional del tiempo a través de la interpretación del tiempo propiamente humano, será este el acceso privilegiado para dar con la cuestión del tiempo mismo. Así lo hace saber cuando dice: "La constitución ontológica fundamental del Dasein, a partir del cual resulta posible aprehender ontológicamente la historicidad nos conduce a la explicación fenomenológica del tiempo" (GA64,4/13), este es el camino elegido por Heidegger, que nos lleva desde la determinación ontológica del Dasein hasta una explicación del tiempo mismo. Y en esta misma tarea, que es:

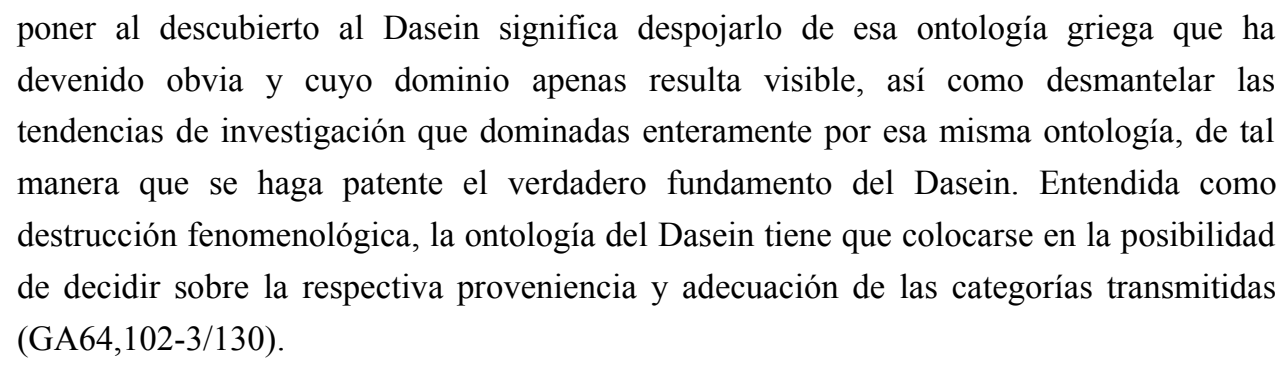

Por lo tanto, esa interpretación de la temporalidad del Dasein, es la que entrega a Heidegger los elementos necesarios para precisar su crítica a la tradición metafísica.

Expondremos de qué forma confluyen en una misma dirección: el problema del tiempo mismo, la temporalidad humana, la destrucción crítica de la tradición metafísica y la pregunta por el ser. Aunque claro está, la meditación que Heidegger emprende por aquellos años va mucho más allá de la problemática que hemos señalado, va mucho más allá, pero sin ir más lejos de lo que plantean esas preguntas fundamentales. Ya que, si bien son muchos los flancos que Heidegger abre en esta fase decisiva de su pensamiento, no dejan de ser estos problemas señalados los que en último término conducen su reflexión, y los que él considera como verdaderamente fundamentales. 
Sin embargo, ese vínculo entre el fenómeno del tiempo y la pregunta por el ser, tal como hemos señalado, no se encuentra desde siempre en la filosofía temprana de Heidegger, por el contrario, para dar con esto ha tenido que recorrer un camino largo y sinuoso, que le ha terminado por revelar la conexión indisoluble entre ambas cuestiones. Parece plausible preguntarse en esta fase de nuestra investigación: ¿Cómo llega Heidegger a esta determinación tan importante para su filosofía? ¿Qué le lleva a concluir esta conexión entre el ser y el tiempo? ¿Qué papel juega aquí la determinación de las estructuras de la vida fáctica?; ¿La pregunta por la vida fáctica y la pregunta por el ser recorren caminos completamente distintos o siempre subyace en ellas una cierta conjunción? ¿ En qué momento se le hizo visible a Heidegger qué en la concepción del ser como presencia se oculta un modo del tiempo? ¿Cumple alguna función en este descubrimiento el problema ontológico del advenir? Estas son algunas de las interrogantes esenciales que trataremos de dilucidar en este capítulo clave en esta fase de nuestra investigación; interrogantes todas ellas, que tienen una finalidad: mostrar la progresión del problema del tiempo en la filosofía temprana de Heidegger y de este modo hacer visible la importancia y la radicalidad que le es propio al problema ontológico del advenir como clave en la articulación de la pregunta por el ser y como alternativa a la concepción del tiempo de la tradición filosófica y, por lo tanto, como reverso del tiempo de la metafísica.

En su investigación, Heidegger se vuelca sobre la facticidad de la vida (como lo señala en sus primeras lecciones universitarias), poniendo en duda la comprensión del tiempo elaborado por la tradición metafísica. Cuestión que se ha podido apreciar en la interpretación que Heidegger realiza de las epístolas paulinas, de las Confesiones de Agustín y del Lutero de la reforma, marco conceptual que nos han entregado un poderoso material de análisis en el recorrido que sigue Heidegger en su discusión con la tradición. Es precisamente, en el marco de esta discusión con la filosofía precedente, que aparece Aristóteles como aquel que le brindará al pensador de la Selva Negra el aparato conceptual para llevar a cabo este trabajo destructivo. Empero, no debemos olvidar que ha sido Aristóteles el gran responsable de esta comprensión del ser, que ha determinado la historia de occidente.

La interpretación del tiempo de la vida humana es determinante para el descubrimiento heideggeriano que el ser, desde la filosofía antigua, es interpretado como simple presencia, como puro presente. Toda vez, que desde sus lecciones de filosofía de la religión, donde expone la temporalidad de las comunidades cristianas primitivas, y en sus primeros esbozos de una analítica de la existencia que realiza en el Informe Natorp; la temporalidad de la existencia se comprende como algo indisponible, más allá de una posible objetivación, como un ser abierto de forma señalada hacia el futuro, y no como algo que está ahí presente que se puede verificar y calcular. 


\section{A. El tratado y la conferencia El concePto del tiempo}

Entre los trabajos en los que Heidegger profundiza en el problema del tiempo, aparecen dos del mismo nombre El concepto del tiempo, en los cuales de alguna forma se da ese paso entre su filosofía temprana, cristalizada en sus lecciones universitarias de Friburgo y una que podríamos denominar como segunda etapa, en la que se puede ver una configuración más estructurada de su analítica del Dasein y la reformulación de la pregunta por el ser, tomando como fundamento la conexión entre ser y tiempo que se oculta en la interpretación del ser de origen griego. Una de ellas es la conferencia el concepto del tiempo, que Heidegger presento ante la Sociedad Teológica de Marburgo el día 25 de julio de 1924, publicada en el año 1989 por la editorial Max Niemeyer, y algo distinto es el tratado que lleva el mismo nombre y que como hemos dicho se publicó en el año 2004 en el volumen 64 de la Gesamtausbage y que había permanecido inédito hasta esa fecha. Este tratado, según el editor de la conferencia Harmut Tietjen fue preparado en el año $1924^{161}$.

Este trabajo es de vital importancia para nuestra investigación, dado que en él se desarrollan con mayor detenimiento y profundidad, los fenómenos que constituirán la estructura de la analítica existenciaria. Si bien su esquema argumentativo y conceptual es aparentemente similar al que tiene la conferencia, puesto que se profundiza aún más en dichos fenómenos y se muestra como un proyecto más acabado. Además, en rigor, se plantea ya la problemática ontológica que le es inherente a la cuestión del tiempo, el vínculo entre la cuestión del ser y del tiempo, cuestión que no es tratada en la conferencia. Otra cosa a tener en cuenta, es que ya se utiliza en gran medida el aparato conceptual con el que se plantea la destrucción fenomenológica de la tradición metafísica. Esto lleva al editor F.-W. von Herrmann a señalar:

el tratado de El concepto del tiempo contiene, pues, los elementos fundamentales de Ser y tiempo y, en cuanto tal, incluye también la temática de la sección tercera de Ser y tiempo, ya que en las últimas páginas de la abreviada sección IV del tratado se expone la interpretación del sentido del ser a partir del tiempo. Y, finalmente, también se menciona explícitamente la destrucción de la historia de la ontología, es decir, la problemática de la segunda parte de Ser y tiempo. Por todo ello se puede afirmar con todo derecho que el tratado El concepto del tiempo del año 1924 constituye el texto embrionario de Ser y tiempo (GA64,132-3/141).

Lo que el editor viene a decir, es que este tratado viene a iluminar de forma notable y desconocida hasta el momento, el camino que lleva a Ser y tiempo y permite conocer el nivel de desarrollo que la investigación heideggeriana acerca del tiempo había alcanzado en este periodo de su pensamiento, cuestión que por lo demás, quedaba sino cerrada, bastante limitada con la sola publicación de la conferencia dado que, "La conferencia no ofrece ninguna información acerca de si el autor en el verano de 1924 había conseguido ya

${ }^{161}$ Cf. Harmut, T., "Epílogo" en El concepto del tiempo, op. cit., p. 63ss. 
un esbozo completo de su obra principal, ni sobre la medida en que lo había conseguido. Aunque solo sea por causa del propósito limitado de la conferencia, no se aborda la cuestión del sentido del ser en general" ${ }^{162}$, se podría pensar entonces que solamente se trataría de un trabajo abreviado, especialmente preparado para un auditórium particular y formaría parte de un estudio mas profundo y extenso del concepto del tiempo que contendría el germen de la obra de 1927.

La información respecto a este tratado provenía principalmente del trabajo de Kisiel de 1993, The Genesis of Heidegger's Being and Time, razón por la cual solo se tenía una información de segunda mano. Por ello, su publicación supone una verdadera novedad con una importancia señalada para nuestra investigación. Además, tiene un valor añadido, también encontramos ahí una serie de notas, llamadas por el editor notas marginales (Randbemerkungen), concretamente 194, que presumiblemente datarían del período comprendido entre 1924 y 1926, es decir, Heidegger las escribió mientras trabajaba en la elaboración de Ser y tiempo (Cf. GA64,128/136). Estas notas permiten contrastar las distintas formas de plantear la cuestión del advenir, que a veces adquiere formulaciones realmente interesantes, pero que no se materializan más que en notas y no en los trabajos o lecciones que conocemos.

Este tratado nunca llego a publicarse tal como lo tenía presupuestado Heidegger para el año 1925 en la Deutsche Vierteljahresschrift für Literaturwissenchaft und Geistesgeschichte. Según Herrmann, este trabajo habría sido motivado en gran parte por la reciente publicación del intercambio epistolar entre Dilthey y el conde Yorck, cuestión que el mismo Heidegger refrenda al comenzar su trabajo cuando comenta: "la publicación de la correspondencia entre Wilhelm Dilthey y el conde Paul Yorck me brinda la ocasión para comunicar de manera provisional la siguiente investigación sobre el tiempo" (GA64,3/11). Es decir, al momento de la publicación de dicha correspondencia, el filósofo alemán ya trabajaba en una investigación sobre el tiempo.

Heidegger en una carta enviada a Rothacker (el editor de la futura publicación del tratado) desde Marburgo con fecha del 15 de diciembre de 1923, le comenta lo siguiente: "tengo entendido que la publicación de las cartas de Dilthey es realmente inminente. Si usted lo considera oportuno, a propósito de la publicación me gustaría pronunciarme en su revista con más detalle sobre el trabajo de Dilthey" (GA64,130/139). El joven profesor consideraba de suma importancia para su trabajo poder opinar sobre esta correspondencia entre Dilthey y Yorck que estaba próxima a publicarse, dado que entendía que ahí se encontraban importantes elementos que debía incluir obligatoriamente en su incipiente investigación respecto al tiempo.

Sin embargo, este proyecto no llegó a materializarse por múltiples problemas, que más que nada tenían que ver con la extensión de su trabajo, razón por la cual terminó por

${ }^{162}$ Ibíd., p. 67. 
desechar dicha publicación, si era imposible decir lo que él estimaba que tenía que decir, no creía oportuno publicarlo. Con cierta ironía le comenta a Löwith en una carta del 17 de diciembre de 1924, "Mi "tiempo" era demasiado grande para Rothacker (...) la recensión aparecerá ampliada en el Jahrbuch" (GA64,132/140). Pero este trabajo no llegó a publicarse hasta 2004, en la edición de la Gesamtausbage volumen 64, por lo cual de alguna forma permaneció en el anonimato, lo que por años impidió conocer cual era el estado real de la investigación heideggeriana acerca del tiempo en aquel entonces.

En cuanto a la ya mencionada relación entre El tratado El concepto del tiempo y Ser y tiempo, hacemos hincapié en que estos trabajos no se sitúan en una amplitud conceptual y temporal muy marcada, sino al contrario, podemos decir, que por $1923 \mathrm{y}$ 1924 ya estaba en marcha ese proyecto filosófico que culminaría en Ser y tiempo, más que en marcha, se puede sostener que el desarrollo de la investigación respecto a la cuestión del tiempo estaba ya bastante avanzada, por lo que este tratado supone un verdadero punto de inflexión en la investigación de la génesis del escrito publicado en 1927. Así lo indica el editor, cuando sostiene que "en la primera frase del tratado Heidegger habla de "una comunicación provisional de la siguiente investigación sobre el tiempo". La expresión "comunicación provisional" alude a la obra capital Ser y tiempo, que en aquel momento estaba en una fase de desarrollo y con la que el tratado se estrechamente ligado" (GA64,132/141). Queda claro que este trabajo es relevante para el estudio de la génesis del pensamiento heideggeriano, pero también tiene una enorme importancia para nuestra investigación, sobre la importancia, el significado del problema ontológico del advenir en la obra temprana de Martin Heidegger, dado que esta problemática toma aquí su lugar de privilegio en el proyecto filosófico emprendido por el filósofo alemán en la llamada primera etapa de su pensamiento, cuestión que si bien se ha hecho patente en las lecciones universitarias de principios de los años 20, ahora adquiere contornos más definidos y de la misma forma esta problemática permite a Heidegger el reconocimiento de la concepción del ser como presencia, como simple presente, es más, permite articular su crítica a concepción griega del ser desde el tiempo. Desde la cual se abre un nuevo camino, una nueva vía de problematicidad para la filosofía en su crítica y destrucción de la historia de la metafísica.

Como hemos dicho, el problema ontológico del advenir adquiere en este tratado un lugar de privilegio, pues Heidegger trata de forma más elaborada y completa la estructura temporal de la existencia, ratificando lo dicho en la conferencia anteriormente, en relación a que el fenómeno fundamental del tiempo es el futuro. Además, presenta ya en sus rasgos mas definidos su crítica a la concepción del ser como presencia (Anwesenheit), entendido desde una perspectiva temporal privilegiada, el presente (Gegenwart). También, desarrolla de forma explícita su crítica al concepto del tiempo del reloj, del tiempo como medida, cuestión que habría sido tratada por vez primera por Aristóteles en la Física. 
En esta fase de nuestra investigación no profundizaremos en la analítica existenciaria, en la constitución ontológica de este ente llamado Dasein, porque esto lo trataremos largamente en el estudio de Ser y tiempo que llevaremos a cabo en la segunda parte de este trabajo. Por ahora, lo que nos interesa es la reflexión heideggeriana sobre el tiempo, su crítica a tradición, la forma en que se vincula la pregunta por el ser y el tiempo. Pero también, veremos cómo en esa interpretación de la constitución ontológica del Dasein salta por los aires la concepción del ser como presente, esto en la prioridad señalada que Heidegger le asigna al futuro. Lo que analizaremos es cómo en estos textos, en los que Heidegger se ha propuesto tratar el tema del tiempo, paso a paso se va materializando ese proyecto filosófico, que termina por estructurarse gracias a esa conexión entre el ser y el tiempo. Se hará visible además, qué papel juega ahí la pregunta por la constitución ontológica originaria de este ente, que lejos de ser un objeto o cosa que está ahí es existencia.

\section{B. San Agustín y el PRoblema del tiempo}

Heidegger en el tratado, al iniciar la caracterización ontológica del Dasein, indica que si la investigación tiene como objetivo acceder al fenómeno del tiempo, debe tener en consideración los dos hechos que han determinado el camino que ha seguido la tradición filosófica al momento de preguntar por el tiempo. Lo primero, es que todos los acontecimientos y los hechos que se producen en el mundo, en la vida cotidiana, y también, los procesos y cambios de la naturaleza se dan en el tiempo, son en el tiempo. Dice Heidegger: "La vida humana se orienta en su quehacer más cotidiano por el tiempo. La vida humana encierra en sí misma una regulación temporal. Ella tiene su tiempo para trabajar, para comer, para descansar y divertirse. La regulación del tiempo queda fijada públicamente por el calendario" (GA64,17/26), en consecuencia, todos los acontecimientos y quehaceres de la vida humana tienen que ver con el tiempo, se dan y son en el tiempo. El punto de partida de la investigación heideggeriana, es una aproximación fenomenológica a cómo se da el tiempo en la experiencia cotidiana que tenemos de él.

La otra cuestión tiene que ver con que la vida humana en tanto investiga y pregunta por el tiempo, lo hace con la finalidad de preguntar qué es el tiempo viendose necesariamente remitida al alma y al espíritu, en último término, a la conciencia. Se plantea entonces como legítima la pregunta : ¿Es el alma, es el espíritu el tiempo como tal? o si por lo menos son el receptáculo del tiempo. El pensador alemán reconoce así las principales interpretaciones del tiempo en la historia de la filosofía. Al aludir a estas, nombra sin precisar a dos de sus interlocutores privilegiados en la discusión acerca de la cuestión del tiempo que mantiene con la tradición filosófica y que le permitirán concretar su analítica de la temporalidad de la existencia. Aunque ambos tienen un status distinto en esta discusión, nos referimos a Aristóteles y San Agustín. 
En el tratado Heidegger recoge gran parte de la problemática que había planteado en la conferencia de julio, en la que se preguntaba por la conexión existente entre el tiempo y nuestra propia experiencia vital. Lo que nos remite a las Confesiones de San Agustín, libro XI, lugar en el que el obispo de Hipona ha tematizado la conexión interna entre el tiempo y nuestra propia experiencia.

Heidegger plantea desde el principio un cuestionamiento a la exégesis tradicional del tiempo, esto con la finalidad de disolver todas aquellas capas de encubrimiento que se posan sobre la interpretación tradicional, para así mostrar el tiempo en su carácter originario. Se pregunta:¿Qué es el tiempo? De lo que se habla es del tiempo, exactamente del concepto del tiempo. Sin embargo, "no se trata tanto de encontrar una respuesta, más o menos nítida en su formulación, más o menos arrastrada en y por una sistemática filosófica, cuanto más bien de repetir la cuestión del tiempo hasta el punto que seamos nosotros mismos-yo mismo, en cada caso, que pregunto-los que seamos puestos en cuestión"163. Este modo de plantear la cuestión del tiempo, nos muestra que Heidegger no se propone como objetivo desarrollar una meditación vacía y abstracta respecto a qué es el tiempo, entendiéndolo de partida como un ente en el que se desarrollan los acontecimientos y que de alguna forma contiene a los entes del mundo, de la naturaleza, incluidos también ahí los entes que tienen la forma de ser del Dasein. Por el contrario, esta pregunta quiere llevarnos hacia nosotros mismos, para que pensemos el tiempo tal como se da en nuestra existencia, tal como lo vivenciamos.

Si Heidegger se hace problema del tiempo, es primordialmente- pero no exclusivamente-, porque quiere iluminar la temporalidad de la vida fáctica del Dasein, asunto que le viene preocupando desde sus primeros trabajos. Puesto que el carácter temporal de la vida fáctica ha sido muchas veces entendido desde los parámetros de las ciencias naturales, debe estar sometida a otro status ontológico, a otra forma de entenderla en su temporalidad. Heidegger quiere cumplir así con un viejo anhelo filosófico, que ya se había planteado en su trabajo de habilitación El concepto del tiempo en la ciencia histórica, que también había formulado en la Introducción a la fenomenología de la religión, y que de igual forma trata en el Informe Natorp. Todo esto circunscrito en el marco de la discusión que mantiene por esos años con la teología y los pensadores cristianos. San Pablo, Agustín, Lutero, le han brindado una ayuda inestimable para poder construir su aparato conceptual e hilvanar su crítica a la tradición metafísica, en último término para plantear su pregunta por el tiempo.

Si en principio, al momento de formular e interpretar la experiencia del tiempo en las comunidades cristianas primitivas las influencias principales le vienen dadas de San Pablo, ahora es San Agustín quien toma el relevo, quien le entrega los elementos

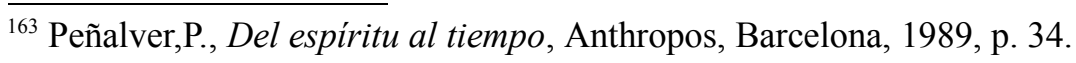


necesarios para dirigir la pregunta por el tiempo hacia la propia existencia. Según Peñalver:"en el texto de la conferencia concede a un filósofo paradigmático en la articulación de la filosofía y el cristianismo, a San Agustín, el origen de la indicación decisiva para desplazar o resituar el problema del tiempo desde la naturaleza a la propia disposición, a la affectio, que Heidegger traduce como Befindlichkeit (el estado de ánimo, "el encontrarse") del alma, para así sugerir la apertura de la cuestión del tiempo a una nueva consideración de la vida humana como ser-ahí" ${ }^{64}$. Gracias a San Agustín, Heidegger puede dar ese paso que resulta decisivo, que traslada la cuestión del tiempo, desde una consideración cuyo como modelo es la naturaleza, hasta llevarla al ámbito de la propia existencia.

El obispo de Hipona, en sus Confesiones en el libro XI se pregunta si el alma misma, si el espíritu mismo es el tiempo, Heidegger parafraseando ${ }^{165}$ a Agustín señala:

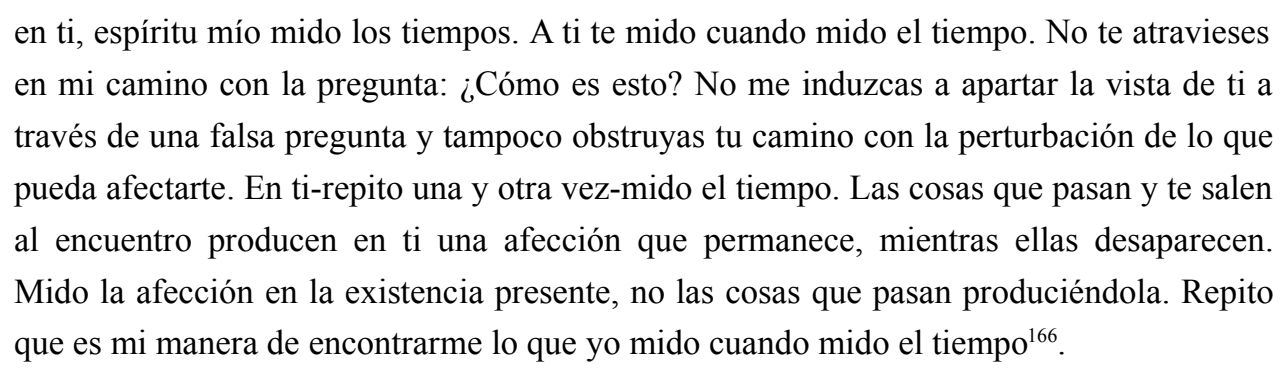

Sin lugar a dudas, se podría argüir que el filósofo africano sigue en la misma dinámica que considera el tiempo como medida, sigue trabajando con la conceptualidad heredada de la Física aristotélica, sin embargo, la medición de la que habla Agustín es puesta en relación con el alma, en otras palabras, se vincula directamente con la afectividad, sería en tal caso una medición que lleva a cabo el espíritu mismo, el estado de ánimo. Por lo cual, si aún sigue presa de la idea del tiempo como medida, del mismo modo, se distancia de la interpretación del tiempo propio de la física, que circunscribe su investigación a la mensurabilidad de los fenómenos de la naturaleza en el ámbito de un sistema de relaciones espacio-temporales.

Ahora, el fenómeno del tiempo es considerado desde la propia vida, San Agustín sitúa esta problemática en el interior de la propia existencia, en la propia constitución del espíritu, esto significa que relaciona el tiempo con la disposición del alma, que es lo que Heidegger entiende como estado de ánimo; el encontrarse propio de la existencia. Teniendo en cuenta esto, señala:

\footnotetext{
${ }^{164}$ Peñalver,P., Del espiritu al tiempo, op . cit., p. 36.

${ }^{165}$ Este fragmento de San Agustín que recoge Heidegger, más que simplemente ser traducido por el filósofo alemán, este lo hace suyo y lo parafrasea con su propio lenguaje, para acercarlo así a sus propios objetivos. Cf. Ibid., p. 43.

${ }^{166}$ Esta es una traducción de San Agustín que lleva a cabo el mismo Heidegger. Dice el traductor de la versión española que, "en la versión del propio Heidegger los términos latinos animo y affectio son traducidos por Geist (espíritu) y Befindlichkeit (afección, estado de ánimo, disposición o temple), respectivamente". Gabás, R y Adrian, J., "Nota de los traductores" en El concepto del tiempo, M. Heidegger, Trotta, Madrid, 2006, p.34.
} 
la pregunta acerca de qué es el tiempo ha acabado por remitir nuestra investigación al serahí, si por ser-ahí se entiende el ente en su ser que conocemos como vida humana; este ente en el respectivo instante(Jeweiligkeit) de su ser, el ente al que apuntamos en la afirmación fundamental: yo soy. La afirmación "yo soy" es la auténtica enunciación del ser que ostenta el carácter del ser-ahí del hombre. Este ente es en el respectivo instante como mío (GA 64,111-2/34).

San Agustín fue capaz de comprender que el "yo soy" tiene una vivencia del tiempo que es inmediata en cuanto afecta directamente al estado de ánimo, además, esta experiencia del tiempo, por ser inmediata, es anterior a cualquier tipo de reflexión o a una actitud teórica, es el puro encontrarse de la existencia consigo misma.

Aunque en San Agustín permanece trabajando el criterio de la medición propio de la concepción tradicional del tiempo, del cual la física moderna es heredera, por medio de la teoría de la relatividad de Einstein, Heidegger reconoce un aporte inestimable del filósofo africano, dado que si bien esa medición del tiempo se conserva, esta se pone en relación con el espíritu, con el alma, que la vincula en último término con la propia existencia. Se reconduce la pregunta por el tiempo hacia la propia vida.

La pregunta por el tiempo ahora va desde la naturaleza hacia mi propio ser, que en caso soy yo mismo. Como dice Peñalver: "ciertamente el texto de San Agustín sigue vinculado el tiempo a la medida: pero medida del alma misma, o de su afectividad (para lo que tiene como paradigma-pero este elemento no juega papel alguno en la lectura de Heidegger-no es el movimiento local, ni tampoco el movimiento genérico y confuso del alma que piensa, sino la palabra rítmica, el verso con su alternancia de sílabas largas y breves, y su delimitación por el silencio"167.

Como hemos señalado el pensador alemán considera que San Agustín le ha entregado un valioso apoyo para el desarrollo de su pregunta por el tiempo, no obstante, "por más que Heidegger lo mencione en sus trabajos en esta dirección-como en la conferencia de 1924 titulada el concepto del tiempo y también en Ser y tiempo- la verdad es que no se encuentra en éstos una verdadera confrontación con San Agustín. Sin embargo, éste ocupa, incluso en Ser y tiempo, un lugar mucho más importante en la analítica exisntencial"168. Siguiendo la misma línea, Peñalver sostiene que lo que Heidegger realmente recoge de Agustín, está en la analítica existenciaria, y ello no tiene que ver tanto con la pregunta por el tiempo, sino que más bien, tiene que ver con la relevancia de la afectividad o del "encontrarse", la Befindlichkeit(...) así como en el de la constitutiva opacidad del ser ahí para sí mismo ${ }^{169}$.

\footnotetext{
${ }^{167}$ Peñalver, P., Del espíritu al tiempo, op. cit., p. 44.

${ }^{168}$ Lara, F., “ Heidegger y el cristianismo de San Pablo y San Agustín” en Eidos: Revista de Filosofía de la Universidad del Norte, №7, 2007, Universidad del Norte, Colombia, p. 37.

${ }^{169}$ Cf. Peñalver, P., Del espíritu al tiempo, op. cit., p. 44.
} 


\section{TIEMPO Y ETERNIDAD}

Desde el análisis que Heidegger lleva a cabo de la pregunta por el tiempo en San Agustín, es claro que su investigación ha de pasar necesariamente por el análisis del Dasein. De la misma forma, es indispensable una tarea destructiva de la concepción del tiempo de la tradición metafísica, dentro de la que se incluye la consideración teólogica que comprende el tiempo en términos de eternidad.

En relación a esto último, es necesario recordar que la preocupación de raigambre teológica por el problema del tiempo como eternidad ya está presente en el escrito de habilitación El concepto del tiempo en la ciencia histórica, que es el primer trabajo en el cual Heidegger tematiza de forma precisa el problema del tiempo, claro está que desde una perspectiva distinta, sin embargo, su investigación sigue la línea programática que ahí propone, a saber, que el tiempo sirve para distinguir las regiones ontológicas de la naturaleza y de la historia. En su trabajo de habilitación, Heidegger comienza su disquisición con un cita del Maestro Eckart, en la que dice: "el tiempo es lo que cambia y se diversifica, la eternidad de mantiene simple" (GA1,415/14). De esta forma se nombra la aparente diferencia y contraposición que existiría entre el tiempo y la eternidad. Precisamente esta referencia, que Heidegger elige como lema del escrito, expresa la marcada distancia entre lo que es propiamente temporal y la eternidad. Resplandece así la incipiente preocupación ontológica que invade al joven Heidegger, puesto que encontramos ahí ciertas ideas respecto al tiempo, ciertas consideraciones ontológicas de este fenómeno, que abren un vía originaria de cuestionamiento, que se aleja de los cánones y directrices de las ciencias naturales. Tiempo que es cambio y mutación constante, que es pura diversificación como una constante movilidad. Sin embargo, Heidegger en su trabajo de habilitación aún entiende el tiempo desde el ámbito de una contraposición con lo propio de la eternidad. Es precisamente a ello, a lo que se refiere de entrada en la conferencia, desde un principio se esfuerza en rechazar esta contraposición y, más aún, duda incluso de la legitimidad de su planteamiento.

Si el problema que se plantea es que el tiempo obtiene su sentido desde la eternidad, sería necesario comprender el tiempo desde ella, lo que nos lleva por un camino que va desde la eternidad al tiempo, podríamos decir, que es un camino que nos lleva desde Dios al tiempo. Esto significaría, según Heidegger, que comprendemos desde ya el significado de la eternidad, lo que nos permitiría concluir, entre otras cosas, que no es la filosofía la disciplina más adecuada para acceder a la cuestión del tiempo. Pues,

\footnotetext{
si la eternidad fuera una cosas distinta del vacío ser siempre, del aei (siempre), si Dios fuera la eternidad, entonces la manera de considerar el tiempo inicialmente propuesta habría de mantenerse en un estado de perplejidad mientras no conozca a Dios, mientras no comprenda la pregunta que interroga por él. Si nuestro acceso a Dios pasa por la fe y si el entrar en el tema de la eternidad no es otra cosa que esa fe, en tal caso la filosofía jamás tendrá acceso a la eternidad (GA64,107/23-4).
} 
Por lo tanto, la filosofía también tendría cerrado el acceso hacia el tiempo mismo. Entonces, sería la teología la llamada a preguntar por el tiempo, porque siempre ha tenido que ver con el tiempo. Heidegger en referencia a esto, señala que, "la teología trata de la existencia humana en cuanto ser ante Dios y de su temporalidad en su relación a la eternidad (...) la fe cristiana debe tener en sí misma una relación con algo que aconteció en el tiempo; en un tiempo que, según el mensaje que hemos oído, fue el "de la plenitud de los tiempos..."'(GA64,107/24). No obstante, el camino que el pensador alemán propone para su investigación va en una dirección absolutamente opuesta al de la teología, quiere recorrer un camino inverso, se quiere deshacer de cualquier implicación teológica que pueda afectar o influenciar su investigación acerca del tiempo, en consonancia con esto, incluso llega a señalar, "que el filósofo no cree. Cuando el filósofo plantea la cuestión del tiempo, entonces está dispuesto a comprender el tiempo a partir del tiempo" (GA64,107/25), en consecuencia, el filósofo no puede siquiera plantear la pregunta por el tiempo dirigida a la eternidad, puesto que tal pregunta en último término se dirige a Dios.

A juicio de Heidegger, el filósofo ha de ser capaz de comprender el tiempo a partir del tiempo, en una mirada, en una meditación puramente filosófica del asunto, lejos de cualquier consideración aunque sea mínimamente teológica, esto porque, "para el filósofo, la eternidad no es más que un concepto vacío de un ser permanente que, lejos de ser el origen del tiempo, es en realidad derivado de nuestra experiencia originaria de la temporalidad"170. De todo esto se desprende, que Heidegger quiere delimitar el ámbito propio de la teología y el de la filosofía, principalmente para evitar malentendidos y que la pregunta filosófica por el tiempo no sea oscurecida o encubierta por un manto teológico, que no hace más que desvirtuarla. Esta posición, además de marcar su propio distanciamiento de la fe que se venía gestando precisamente por estos años, se sostiene en la convicción de que la filosofía ha de ser esencialmente atea, puesto que el filósofo no cree. Posiblemente sea por esta razón, que justamente en una conferencia ante una Sociedad Teológica, Heidegger se esmere en fijar claramente su posición y su distanciamiento frente a determinadas consideraciones teológicas, para evitar precisamente cualquier confusión y dejar claro que sus interpretaciones acerca del tiempo no se obtienen ni se pueden alcanzar desde la idea de eternidad y, por tanto, nada tienen que ver con la teología. Según Safransky:

las insinuaciones son suficientes para expresar un rechazo claro a una tradición poderosa de la teología y la metafísica. Es la tradición que establece a Dios o el ser supremo como una esfera sustraída al tiempo, en la que nosotros podemos participar sea por la fe, sea por el pensamiento. Heidegger interpreta esto como un esquivar la propia temporalidad. La supuesta vinculación a lo eterno, dice, no se remonta más allá del tiempo, sino que retrocede con espanto ante él, no amplía nuestras posibilidades, sino que permanece por debajo de ellas ${ }^{171}$.

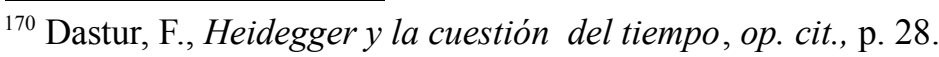

${ }^{171}$ Safransky, R., Un maestro de Alemania, op. cit., p. 169.
} 
Pero es cierto, que también Heidegger dice que sus tesis ni siquiera alcanzan el rango de filosofía, pues no pretende con ellas dar una definición acabada e inserta en un sistema de alcance universal, que sea concluyente respecto a qué es el tiempo. Según el pensador alemán la única coincidencia que tiene su propia investigación con la filosofía, es que ninguna de las dos llegan a ser teología. Se puede ver de esta forma como se conecta aquella cita con la que inicia su lección de habilitación El concepto del tiempo en la ciencia histórica y el análisis de la cuestión del tiempo de la conferencia de julio de 1924.

\section{El REVERSO DEL TIEMPO DE LA METAFÍSICA, EL ADVENIR COMO CARÁCTER FUNDAMENTAL DEL} TIEMPO

La problemática de la vida fáctica lleva a Heidegger hasta la pregunta por el ser, dicha pregunta le ha revelado la insuficiencia de la tradición metafísica para dar cuenta de este ente llamado Dasein, teniendo en consideración esto Pöggeler comenta:

¿En dónde estriba el fallo del pensar que nosotros (según el uso que hace Heidegger del lenguaje en sus últimos trabajos) señalamos aquí de forma harto sumaria como "metafísica"? Estriba en que el pensamiento metafísico (y el conocimiento de este punto significó para Heidegger el paso decisivo en el camino hacia Ser y tiempo) piensa el ser como constante presente y, por ende, no puede dar satisfacción a la temporalidad que se cumplimenta la vida fáctica" ${ }^{\prime 172}$.

Heidegger en su investigación de principios de los años 20, se ha propuesto como objetivo fundamental la determinación ontológica de las categorías de la vida fáctica, pasando primero por un análisis de la experiencia fáctica de la vida en el cristianismo primitivo, que luego refrendará en el Informe Natorp, donde la muerte adquiere un rol protagónico, en tanto es el fenómeno que nos permite acceder a una experiencia originaria del tiempo, porque ella es, un "elemento constitutivo de la facticidad-al mismo tiempo el fenómeno a partir del cual se debe explicar y poner de relieve la específica "temporalidad" del Dasein humano(...) el sentido fundamental de lo histórico se determina en función del sentido de esta temporalidad" (NB, 13/42). Como se puede ver, estas interpretaciones son las que en gran medida le han abierto los ojos a Heidegger y le han permitido iluminar esa comprensión griega del ser como presencia y, al mismo tiempo, enfrentar a la tradición metafísica determinando la temporalidad del Dasein-de la vida fáctica-, con una tesis que sería precisamente la opuesta a aquella que ha dirigido el destino de la tradición filosófica, que ha determinado en gran medida la historia del pensamiento occidental. A todo esto se enfrenta cuando sostiene, que "el sentido de la temporalidad es el futuro" (GA21, 265/212), o que "el carácter fundamental del ser-temporal reside en el ser futuro"(GA64, 81/104), es evidente entonces, que con estas distintas formulaciones de una misma tesis, Heidegger presenta una posición completamente opuesta a la de la tradición en relación a la cuestión del tiempo.

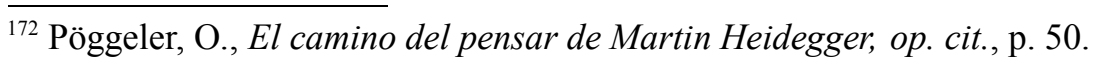


De tal modo, que esta exégesis de la historicidad del Dasein, de la temporalidad de la vida fáctica, si pretende ser una investigación originaria, no puede comprender el tiempo desde el paradigma de la presencia constante.

En la conferencia, a pesar de que no encontramos mayores indicaciones respecto a si Heidegger en el verano de 1924 había logrado dar con un esbozo general de su obra de 1927, puesto que no alude a la cuestión del sentido del ser en general ni al vínculo entre la cuestión del ser y del tiempo, sí señala que "el fenómeno fundamental del tiempo es el futuro(das Grundphänomen der Zeit ist die Zukunft)" (GA64, 118/47), con lo cual deja claro que el carácter fundamental del tiempo es el futuro. Sobre la conferencia dice Peñalver:

No solo por los "temas"; es ya también en el radicalismo casi violento del planteamiento de las cuestiones, en la libertad frente a tópicos y estructuras filosóficas establecidas, en la vigilancia analítica a lo "trivial"( preguntarse, por ejemplo, qué significa usa un reloj), pero incluso, o sobre todo, en el lenguaje, tanto en el léxico (Dasein, Befindlichkeit, Eigentlichkeit, Sorge, Unheimlichkeit...) como en la sintaxis, ("el tiempo es temporal"): en todo ello este texto de 1924 se deja reconocer como obra de un Heidegger ya en el camino auténtico de su pensamiento. Tras resumir brevemente algunos motivos de la conferencia que significan una fase bastante elaborada ya de la analítica existenciaria-y registrar asimismo la no aparición de tópicos como la angustia, la comprensión del ser, la destrucción de la historia de metafísica- M. Haar puntualiza la importancia del documento como la primera aparición pública de una manera inaudita de filosofar ${ }^{173}$.

Este comentario, resume de forma muy acertada, los fenómenos, la temática, la importancia y el valor que para los investigadores tenía esta conferencia el concepto del tiempo. Sin embargo, el tratado nos ofrece un marco relativamente novedoso en relación al estado de avance real de la investigación del problema del tiempo que Heidegger realizaba por aquellos años, en razón de que se presentan ahí fenómenos y cuestiones que no se abordaban en la conferencia, puede ser que por tratarse justamente de una conferencia el pensador alemán conjuntó y abrevió muchas de las cuestiones que consideraba fundamentales de su estudio respecto al tiempo, además de tener en cuenta el público para el cual estaba dirigida dicha presentación. Entre esas ausencias y presencias, es notoria la ausencia del fenómeno de la angustia y la conjunción esencial entre la pregunta por el ser y la cuestión del tiempo, que como sabemos es la llamada a articular la destrucción de la historia de la metafísica. Sin embargo, se presentan muchas cuestiones que son importantes para nosotros, como cuando dice que "el tiempo es temporal" (GA64, 124/59) o que "el fenómeno fundamental del tiempo es el futuro"(das Grundphänomen der Zeit ist die Zukunft) (GA64, 118/47), todo esto nos indica que Heidegger se encontraba ya en plena posesión de parte importante del marco conceptual de su interpretación del tiempo.

Heidegger considera como cuestión esencial determinar la constitución del Dasein en su estructura temporal, en su historicidad, referida a una forma propia del gestarse la

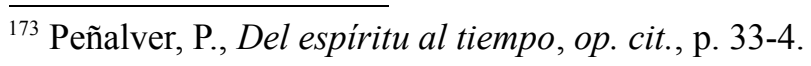


vida humana entre el nacimiento y la muerte, el propio llevarse a cabo y hacerse a sí misma de la existencia, cuestiones que como sabemos bien, a juicio de Heidegger, no han sido tratadas originariamente a lo largo de la historia de la filosofía. La vida humana es un constante hacerse en un mundo ya significativamente comprendido, en el cual nos encontramos ya siempre con anterioridad a cualquier meditación o reflexión gnoseológica respecto a él y a las cosas que ahí encontramos. Con esta analítica, Heidegger pretende distanciarse de las concepciones de un yo trascendental, de una conciencia pura o de cualquier reflexión que sitúe o comprenda al Dasein como un objeto de una posible reflexión teórico cognoscitiva, que deja de lado esa constitución del Dasein como esencialmente temporal e histórico, y situado en un mundo que posee para él ya un significado. Pretende con esto superar las filosofías de la conciencia y todo pensamiento que pase por alto la consitución del Dasein en su esencial historicidad, con esto quiere tomar distancia de la consideración que concibe a este ente como un sujeto que contempla y objetiviza las cosas que están en su entorno.

El pensador alemán hace un importante puntualización respecto a la forma en que se plantea su investigación en el tratado, sostiene que su análisis ontológico, no tiene como finalidad última hacer manifiesta las estructura del Dasein para llegar a conocer mejor a este ente que en cada caso somos nosotros mismos, o por un afán de conocimiento de la especie humana, por eso dice: "la siguiente interpretación ontológica del Dasein no pretende ser la interpretación del Dasein. Su propósito se centra en las estructuras fundamentales del Dasein en las que se hace visible el tiempo Todo intento que se mueva en esta dirección desembocará antes o después en fenómeno del tiempo"(GA64,51/68), por ende, esta investigación tiene un carácter ontológico, cuya finalidad es la exposición de la constitución ontológica de este ente que nos revelen su carácter temporal, se debe aclarar el sentido del ser histórico, para así llegar en último término a una comprensión del sentido del ser, que sea capaz de revelar la estrechez e insuficiencia de la ontología tradicional para lleva a cabo la pregunta que interroga por el ser. Esta investigación que Heidegger emprende tiene una finalidad ontológica. Empero, es menester destacar que al principio del tratado, precisa que su en investigación, "se trata de comprender la historicidad y no de reflexionar sobre la historia (la historia del mundo). Por historicidad se entiende el ser histórico de aquello que es en cuanto historia" (GA64,3/11).

El camino que sigue la indagación heideggeriana respecto al fenómeno del tiempo ha de pasar necesariamente por un análisis de la estructura ontológica del Dasein. Esto, porque las investigaciones clásicas del tiempo de Aristóteles y Agustín, remiten en primera instancia a la vida humana, tal como comenta Heidegger, "el tiempo se da en la existencia humana, es decir, la existencia humana tiene en cuenta el tiempo. "Alma” y "espíritu", conceptos a los que se remiten las investigaciones "clásicas" sobre el tiempo, constituyen la "sustancia" de la "existencia humana"” (GA64,18/38). Por lo tanto, del 
grado de claridad con el que se aborden estas estructuras ontológicas del Dasein dependerá el nivel de originariedad con el que se nos manifieste el fenómeno del tiempo, lo que significa, que el grado de originalidad del exégesis del tiempo dependerá de la determinación ontológica del Dasein. Con esto, Heidegger puntualiza que su trabajo no pretende aclarar qué sea este ente ni tampoco fijar sus estructuras fundamentales con una intención antropológica. Su finalidad es meramente ontológica, por lo tanto, se han de fijar sus estructuras desde las que es posible ver el tiempo, solo siguiendo esta dirección, se llegará al fenómeno del tiempo, con ello se llegará de una forma u otra hasta el ser mismo.

Como hemos dicho anteriormente, en este tratado Heidegger lleva a cabo un análisis de las estructuras ontológicas del Dasein, pero al mismo tiempo plantea lo que sería la tarea de la segunda parte de Ser y tiempo, como destrucción de la historia de la metafísica. Si bien en la conferencia Heidegger había desarrollado a grandes rasgos su analítica existenciaria, no aludía de forma explícita a la otra vertiente fundamental de su quehacer filosófico por aquellos años, nos referimos a la destrucción fenomenológica de la historia de la ontología, cuyo principal foco de atención es la interpretación del ser como presencia. Es decir, en el tratado ya se presenta de forma explícita la línea investigativa que seguirá su derrotero filosófico en los próximos años, lo que evidencia que ya está en el camino franco a Ser y tiempo.

En la segunda parte de nuestro trabajo profundizaremos en las estructuras ontológicas del Dasein que Heidegger presenta en Ser y tiempo, por ello ahora solo abordaremos de forma sucinta el análisis que Heidegger lleva a cabo en el sección tercera del tratado, ya que ahí nos muestra la forma en que aborda este problema del tiempo en relación al propio Dasein y nos muestra qué nivel de importancia le asigna al advenir, al futuro (Zukunft).

Heidegger destaca como un rasgo ontológico esencial del Dasein, que es un ente que está abierto de modo originario hacia algo que todavía no es pero puede ser, es una posibilidad de ser. Para que este ente pueda proporcionar una base suficiente debe hacerse explícito como una totalidad, lo que le permitirá servir de guía para el análisis. Por consiguiente, solo cuando el Dasein es lo que puede ser resulta aprehensible como esa totalidad, cuestión que se logra solamente en su haber llegado al fin, que es propio a la muerte, de esta forma está completamente ahí. Pero paradójicamente, este ente en su estar finalizado ya no es más. Este fenómeno señalado, la muerte, es la posibilidad suprema del Dasein porque en cuanto posibilidad ha de mantenerse siempre como posibilidad. La posibilidad de la muerte es indeterminada en su cuándo, pero cierta en su venida. Así entendida, la facticidad del Dasein está determinada esencialmente por esta posibilidad insuperable que es la muerte. Por ello, la exégesis ontológica de este ente, se logrará llevar a cabo según la forma de acceso que resulte la más originaria de acuerdo al propio ente 
que se investiga, en este caso desde la posibilidad más extrema y propia de este ente. Comenta Peñalver respecto a esto:

la consecuencia más visible en lo que se refiere al tiempo, tras este rodeo por el tema de la muerte y el carácter formal de la existencia, es el primado del futuro. Justamente porque el ser-ahí en su ser propio nihiliza en cierto modo su existencia, ésta viene a consistir sobre todo en una anticipación, en un proyecto. Heidegger lo dice rotundamente: "el fenómeno esencial del tiempo es el futuro". El tiempo es la anticipación del futuro pero en la medida en que éste se mantenga en una rigurosa indeterminación. Cuando el ser-ahí intenta "calcular" o prever el cuándo de su totalidad ya acabada y su qué hacer durante ese trecho, entonces está intentando determinar lo que es y debe mantenerse como indeterminado ${ }^{174}$.

El carácter de inconcluso que constituye a este ente guarda en sí mismo la indicación de la forma correcta de acceder a este, para poder llegar a su constitución estructural esencial. Para conseguir esto, es indispensable evitar la consideración del Dasein como Vorhandenheit, como substancia, sino que debe ser considerado en su carácter ontológico fundamental. De esta forma, "la muerte se revela como la más originaria constitución ontológica del Dasein. La respectiva facticidad del Dasein es su posibilidad más extrema" (GA64,51/68). Esta constitución ontológica del Dasein, por ser la originaria, en cuanto posibilidad más extrema, es la que permite asegurar un terreno fenoménico para preguntar por el tiempo de forma originaria. Solamente, "la facticidad puesta de manifiesto en su posible propiedad mostrará aquellos elementos que efectivamente constituyen el fenómeno del tiempo, si es que el tiempo está en el Dasein" (GA64,52/69).

Este ente en cuanto es un ser posible, ha de mantenerse siempre en la posibilidad en cuanto posibilidad, ha de soportar y cargar con la posibilidad como posibilidad, puesto que, solo de esta forma la posibilidad se mantiene como posibilidad; es lo que es. "El Dasein, pues se adelantará a su inminente ser-posible. El ser de este adelantarse es el modo de ser en que el Dasein es propiamente su posibilidad más extrema"(GA64,70/52), de manera que en este adelantarse en el que para el Dasein se hace patente su posibilidad más extrema, como el haber pasado (vorbei) ya -en-el-mundo, como el posible no ser más en el mundo. Significa entonces, que el mundo pierde todo significado para el Dasein, se ve remitido a ser ante la nada del mundo. Se coloca así ante su haber pasado en el modo de la propiedad y rescata al Dasein de la interpretación pública, de estar perdido en el uno. Es de este modo que el haber pasado propio del Dasein le señala la posibilidad más extrema de su ser que es la muerte, en la que tiene que ser propiamente como sí mismo. El Dasein se hace cargo de su posibilidad más extrema, se hace cargo del ser que tiene que ser de modo propio, para de esta forma ser propiamente lo que él es. En cuanto posibilidad este ente se caracteriza ontológicamente por el poder elegir. En el adelantarse se le hace patente al Dasein su más propio haber pasado y se enfrenta a la elección, en la que se juega la posible propiedad de su ser.

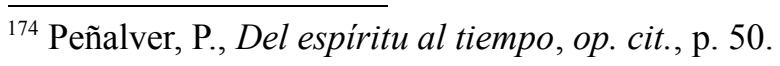


El adelantarse enfrenta al Dasein a la posibilidad de elegirse, le hace patente aquello que se puede elegir; ser su posibilidad más propia, ser él mismo o ser en el cómo de la cotidianidad. El adelantarse es el que hace manifiesta la posibilidad de la elección de ser sí mismo o de no serlo. "El adelantarse (Vorlaufen) es propiamente la posibilidad extrema cuando el Dasein la aprehende como cierta. La certeza del "haber pasado" (Vorbei) no implica la indubitabilidad de algo que está-ahí-presente (Vorhanden)y de algo que no-está-más-ahí-presente de forma mundana. Este ser posible no es objeto de un conocimiento constatativo" (GA64,55/73). Como podemos ver, en esta interpretación Heidegger se distancia respecto de cualquier intento de asignar a estos fenómenos una cualificación en términos de objetos o de algo al modo de la Vorhandenheit, que en unos momentos esté presente y en otros no. Tampoco quiere decir que dichas estructuras sean constatables al modo como lo hace el conocimiento científico, dado que un conocimiento de ese tipo no hace más que oscurecer los fenómenos, en este caso, el haber pasado.

Este ente que se adelanta hasta su ser más propio ha de tener la certeza de su propio haber pasado. De esta forma, el adelantarse se convierte en un estar cierto propio, que en su elección, en el haber elegido el cómo propio determina el adelantarse en términos de un estar resuelto(Entschlossensein). Se obtiene así una caracterización de un forma de ser del Dasein del modo propio de su ser, que en cuanto adelantarse le abre la posibilidad de su propiedad. "La resolución (Entschlossenheit) se mantiene en cuanto estar-descubierto en la correspondiente disposición afectiva (Befindlichkeit) de la angustia serena. Esta angustia soporta la inhospitalidad del ser más propio como ser-posible" (GA64,57/75). En términos generales y bastante acotados, estos fenómenos son los que Heidegger considera como determinantes para clarificar y mostrar el tiempo desde su vertiente originaria, cuestión que solo se puede hacer visible a través de la analítica del Dasein.

En la consideración ontológica del Dasein en cuanto adelantarse que descubre ya se hizo manifiesto el tiempo. El Dasein no es un ente que pasa en el tiempo, ni el tiempo es algo ajeno o añadido a él,

El respectivo Dasein mismo es (el)"tiempo" (...) El Dasein es un ente al que le va el ser en su respectivo ser propio e impropio. El adelantarse ((o el precursarse)) significa: ser en el "pre" de la posibilidad más propia y extrema. Este pre=ser se revela como ser=futuro. En su adelantarse el Dasein es futuro (Das Dasein ist im Vorlaufen Zukunft) (...)la aprehensión anticipativa de la muerte cierta no es un estar a la espera de un acontecimiento futuro. Esperar significa: esperar en y para el presente. Lo venidero de la espera es $\mathrm{lo}=\mathrm{que}=$ todavía $=\mathrm{no}=\mathrm{ha}$ llegado $=\mathrm{a}=\mathrm{ser}=$ presente $(\ldots)$ El adelantarse no deja advenir algo a si en un presente que se entiende como un todavía -no-actualmente presente (...) el adelantarse deja ser al ser-futuro justamente lo que es (GA64,57-8/76-7).

Según Heidegger, este adelantarse es la forma esencial de la temporalidad del Dasein, gracias a la cual es en la propiedad de su ser, lo que no significa que sea un ente que es en el futuro, sino que es el futuro mismo del ser que este ente es. Como dice Heidegger, "este 
adelantarse a la posibilidad más extrema que me es propia, que todavía no soy, pero que seré, es ser futuro. Yo mismo soy mi futuro a través del adelantarse. Yo no soy en el futuro, sino el futuro de mi mismo"(KV,164/84) $)^{175}$.

Heidegger señala claramente que el sentido de este ser-futuro es el ser temporal, que el futuro es el tiempo mismo ${ }^{176}$. Pero, este carácter temporal del que habla, no puede ser entendido como algo que está constituido por un estar o pasar en el tiempo, sino que es el tiempo mismo, y ahí está implícito el ser pasado y el ser presente. Si comprendemos el tiempo como algo que es, o entendemos cada una de las dimensiones temporales como algo que es en el tiempo; el futuro como algo que todavía no es pero luego será, y el pasado como algo que ha sido pero dejó de ser, estamos intepretando el tiempo de la misma forma en que lo hace la tradición metafísica. "Lo que "es" en el futuro, en cambio, todavía no es "en" el presente y todavía menos "en" el pasado. El Dasein, que en su ser es su posibilidad más extrema, es decir, es "futuro", es-en cuanto es este ser-el propio serpasado y el propio ser-presente. Solo así este ser es el tiempo mismo" (GA64,58-9/77), esto significa que el Dasein es el tiempo y no es un ente que pasa en el tiempo. Gracias a este análisis que Heidegger desarrolla aquí, se hace comprensible y manifiesto que la dimensión privilegiada del tiempo es el futuro. Esto se hace visible desde un principio, el análisis y estudio del tiempo se desarrolla desde un comienzo relacionándolo con el futuro, de forma tal, que es este adelantarse en el que descansa la posibilidad del Dasein de ser sí mismo.

En la caracterización ontológica del Dasein como ser posible resplandece ese carácter de ser futuro, incluso se indica que este ser futuro significa de modo primordial el ser temporal, este ser temporal significa el tiempo mismo y solo en virtud de esta determinación aparecen señalados el ser presente y el ser pasado, desde ahí adquieren su sentido. Es en el adelantarse hacia su posibilidad más extrema que el Dasein puede ser futuro de modo propio y desde allí pueden ser de forma propia el pasado y el presente, y solo en esta posibilidad de ser auténticamente su futuro este ser es el tiempo mismo.

Además, "en el adelantarse, si es que éste debe tomarse como el ser-futuro del Dasein, tiene que hacerse visible la plena existencia fenoménica del "tiempo". El estarresuelto, que se describió como el adelantarse, es ser=futuro" (GA64, 59/78). Heidegger al finalizar esta referencia, en una de las notas marginales, dice "ésta es la esencia del tiempo" (GA64, 59/78), lo que está claramente referido al ser futuro en cuanto adelantarse; el futuro sería entonces la esencia del tiempo. En otras palabras, el ser futuro, ese adelantarse es en el que se nos revela la esencia del tiempo, el tiempo mismo en su dimensión temporal privilegiada es un adelantarse, un ser que esencialmente es futuro y no presente, ni presencia constante. Heidegger comenta en las Conferencias de Kassel de

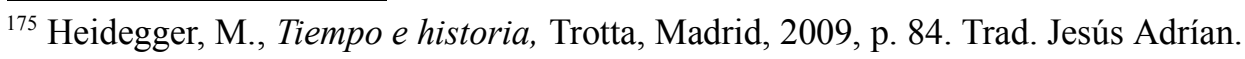

${ }^{176}$ En una de las llamadas notas marginales, que según el editor presumiblemente se habrían escrito entre el año 1925 y 1926, Heidegger dice: "el tiempo, empero, es el futuro" ( Zeit aber ist Zukunft) $(\mathrm{GA} 64,51 / 69)$ 
1925, que "resulta curioso que en el actuar orientado al futuro se vivifique el pasado y desaparezca el presente. En realidad actúan aquellos que viven a partir del futuro. Éstos pueden vivir a partir del pasado y el presente se realiza por sí mismo. El tiempo constituye la totalidad de mi Dasein y también determina mi propio ser en cada instante. La vida humana no acontece en el tiempo, sino que es el tiempo mismo"(KV,169/85).

Sin embargo, no debemos olvidar que esta resolución del mismo modo nos abre a nuestro esencial haber sido y al presente en medio del cual nos encontramos. El adelantarse en la resolución nos sitúa frente a nuestro esencial haber pasado y nuestro peculiar ser ahora. Este adelantarse se manifiesta como un ser-futuro-pasado-presente, nos abre a una plena estructura de la temporalidad, como un ser que es temporal. Esta explicación del fenómeno del tiempo que Heidegger busca explicitar a través de las investigación de la estructura ontológica del Dasein, es mucho más amplia de lo que aquí hemos explicado, pero sin lugar a dudas, queda manifiesta esta prioridad que el pensador alemán le asigna al ser-futuro, como una clave desde la cual es posible acceder al sentido originario del tiempo. Además, en tanto el Dasein mismo es capaz de adelantarse, puede ser su sí mismo por medio de esta forma de futuro, se juega la posibilidad de ser su ser mismo de modo auténtico:

el adelantarse se reveló como ser-futuro-pasado-presente, es decir, como ser-temporal. Este ser al mismo tiempo "pasado" y también "presente" no debe llevarnos a ver el "todo" del tiempo como una suma de entes presentes en el mundo. El "al mismo tiempo" y el "también" remiten a un carácter ontológico del Dasein mismo y al hecho de que éste es "el tiempo". Pero el adelantarse establece el ser posible propio del Dasein que en su facticidad está constituido como ser-posible. El ser propio del Dasein está constituido como ser-posible. El ser propio del Dasein es ser-temporal. De hecho, el Dasein es "el tiempo" que es en el modo de ser temporal; el ser del Dasein está determinado como temporalidad. Hasta qué punto "el" tiempo es y cómo el tiempo en cuanto tal es temporal, solo se puede comprender a partir del ser propio "del tiempo"(GA64,61/80).

Heidegger entiende que el futuro es la esencia del tiempo, además agrega en su análisis de la muerte, que la facticidad del Dasein es su posibilidad más extrema, y en una nota marginal comenta , "qué es- ser en cada caso la propia muerte en cuanto Dasein propio-ser futuro-tiempo- el tiempo, empero, es el futuro" (GA64,61/69). Lo que ratifica que el carácter fundamental del tiempo es el futuro, la muerte entonces tiene un valor ontológico esencial, porque le revela al Dasein su sentido temporal fundamental que es el ser futuro. Por lo demás, todas las estructuras ontológicas temporales de este ente deben ser reconocidas desde esta radicalidad que posee el advenir al interior de su constitución como temporalidad. Pero todo esto lo veremos con mayor detenimiento, en la interpretación de esta problemática a la luz de Ser y tiempo.

En este mismo orden de cosas, hemos de aludir a una cuestión altamente sugerente y que expresa de forma notable la relevancia que tiene para Heidegger esta determinación del tiempo como futuro. Señala en una nota pie de página, que esta idea no es algo que se 
le haya ocurrido exclusivamente a él, ni que sea una interpretación original de su propia creación. En el marco del análisis ontológico del tiempo de la ocupación, en la cual indica que todos los momentos ontológicos de la ocupación aluden a un modo de ser temporal, dice: "el traer aquello de lo que uno se ocupa a la dimensión presente de la ocupación (...) también este ser-temporal del estar-en tiene su carácter fundamental en un ser-futuro" (GA64, 65/85). Heidegger dice que el ser temporal de la ocupación también obtiene su carácter fundamental desde el ser futuro, y en la nota a píe de página comenta, que en relación a la conferencia el concepto del tiempo, él se había dado cuenta de que también H. Cohen en su Logik der Reinen Erkenntnis, "ve en el futuro el carácter fundamental del tiempo", pero agrega luego en una nota marginal, "tiempo en sentido kantiano-o bien en sentido todavía extremadamente formalizado" (GA64,65/85). Lo que de alguna forma nos muestra que para Heidegger esta tesis, más que ser una determinación importante de la temporalidad humana, le interesa y ve en ella algo decisivo, Cohen ha sido capaz de ver esta determinación fundamental del tiempo comentará Heidegger en 1924, pero luego caerá en cuenta de que aquél lo ve en sentido kantiano y no tal como él lo entiende.

Heidegger ha planteado una crítica a la idea del tiempo que domina la tradición metafísica, que toma como modelo la interpretación vulgar del tiempo propia de la cotidianidad. Dicha exégesis comprende el tiempo principalmente como presente, como tiempo del ahora, desde el cual se determina toda consideración del tiempo. El ahora presente, el ahora todavía no presente y el ahora ya no presente, son todas instancias temporales se comprenden desde el ahí presente, el Dasein mismo es comprendido como presente, en cuanto a que es considerado desde la categoría de la Vorhandenheit, desde la substancialidad de la substancia. Esta óptica interpretativa peculiar a la cotidianidad como modo privilegiado de comprender el tiempo, se rige por el uso del reloj en el cual está implícita una medición, un contar con el tiempo, es "estar en el mundo haciéndolo presente (gegenwärtigend in der Welt sein)" (GA64,73/95).

El filósofo alemán hace una importante puntualización respecto al fenómeno del tiempo, más precisamente, al presente como modo del tiempo, señala que en dicha palabra se oculta una peculiar ambigüedad:

La palabra presente (Gegenwart) encierra en su significado una peculiar indiferencia; por una parte, significa presencia (Anwesenheit) en el mundo circundante (la presencia) (die Praesenz) y, por otra parte, el "ahora" (el presente) (die Praesens). Esta indiferencia es la expresión del fenómeno que constituye efectivamente (tatbestanden) al Dasein, es decir, aquel nombrar el mundo diciendo "ahora", en cuanto ocupación absorbida en el mundo, se interpreta a sí mismo a partir de ese mundo como algo presente y disponible (GA 64,74/96).

Esta precisión es importante, dado que en la palabra Gegenwart se conjuntan la comprensión del ser como presencia (Anwesenheit) de algo en el mundo y también el significado plenamente temporal que conlleva en términos de presente, en su perspectiva exclusivamente temporal como un modo específico del tiempo, que nombra el ahora. 
Heidegger al analizar en este tratado el tiempo desde la perspectiva de la tradición, como tiempo de la naturaleza, como tiempo del reloj, en cuanto que este tiempo es y comparece en el trato mundano con el reloj que constantemente dice ahora, ahora, ahora, es decir como presente; cae en cuenta así de lo problemático y ambiguo que es hablar del presente (Gegenwart), que envuelve la presencia de algo en un lugar, pero también alude a un modo del tiempo.

Es esta peculiar indiferencia y ambigüedad de la expresión Gegenwart, supone un problema mayor, dado que se produce una indistinción entre lo que significa que una cosa este ahí presente en el mundo en torno, que esté ahí al frente como un posible objeto de contemplación y aquello otro que nombra el ahora, como presente pero con un carácter indiscutiblemente temporal. Efectivamente:

según Heidegger, ovoı $\alpha$ entendida como presencia solo expresa el modo de ser de los
entes privilegiando el modo de ser del presente, por el que este ente es en cuanto subsiste
y permanece inmutable a través del cambio. De ahí que la entidad suprema sea la entidad
que está constantemente presente, a saber la entidad divina. Esto muestra, pues, que los
griegos solo entendieron el tiempo desde la dimensión temporal del presente (Gegenwart).
A partir del tratado El concepto del tiempo de 1924, y de las reflexiones que se llevan ahí
a cabo, Heidegger comienza a considerar las dificultades que entraña comprender
"presente" (Gegenwart) en el sentido temporal del "presente" (Präsenz) a la vez que en el
sentido de la "presencia" (Anwesenheit) de una cosa en su lugar177.

Esto tiene una importancia capital para el proyecto filosófico de Heidegger, en cuanto a que gracias ello da un paso clave, que le permite vincular directamente la cuestión del ser con el problema del tiempo, asunto que subyace en la comprensión del ser de la filosofía griega como ovoı, como Anwesenheit, lo que ya ha tematizado anteriormente, por ejemplo en su Introducción a la investigación fenomenológica, pero que ahora que ahora se manifiesta en su radicalidad. Heidegger llega a esta concepción del ser como presencia (Anwesenheit), que identifica como la tesis principal en la que se sostiene la metafísica griega, por medio de distintas formulaciones que no lo terminaban de convencer del todo. Este concepto surge a partir de la discusión que mantiene con Aristóteles a finales del año 1923 en sus lecciones de Marburgo, donde señala que "la ousía proporciona el carácter fundamental del ente como ser: la presencia (Anwesenheit)" (GA17, 46/63). Sería esta una de las primeras oportunidades en la que Heidegger habla expresamente de que la interpretación privilegiada en la filosofía griega concibe el ser como ousía, entendiéndola en términos de presencia.

No obstante, precisamente cuando ha determinado que el carácter temporal fundamental del tiempo es el futuro, se le hace visible la problemática plenamente temporal que se oculta en la interpretación del ser de la tradición metafísica en cuanto presencia, como simple presente (Gegenwart), cuestión que Heidegger no había tratado de forma tan directa y precisa hasta este periodo de su pensamiento, y que específicamente se

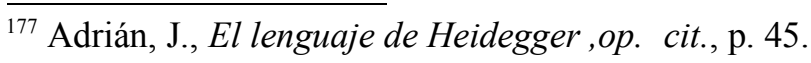


plantea en el curso de verano de 1924 llamado Conceptos fundamentales de la filosofía aristotélica. Todo esto supone un punto de inflexión en la filosofía heideggeriana, a saber, que la reformulación de la pregunta por el ser pasa necesariamente por el análisis de esa conexión indisoluble entre el ser y el tiempo, tal como lo señala al concluir el tratado $E l$ concepto del tiempo. Cuestión que nos ofrece una información bastante relevante, en cuanto a que si bien Heidegger, como hemos dicho, ya ha identificado la concepción dominante del ser como oúsia, no había hecho referencia directa al tiempo, sino a la presencia (Anwesenheit) sin más.

El sentido esencial de este término Heidegger solo lo obtiene plenamente en la elaboración del curso de Aristóteles del semestre de verano de 1924, con el título de Gegenwärtigen, presencia. Pero aproximadamente en noviembre del mismo año, se da cuenta de que esto implica que sentidos distintos y contrapuestos se reúnan en este concepto de presente (Gegenwart), como presencia (Anwesenheit) en un lugar o en un lugar o en un contexto (die Präesenz) y la dimensión temporal del ahora. Sin embargo, en 1925 tiene a utilizar como sinónimos Gegenwärtigkeit, Anwesenheit y Präesenz ${ }^{178}$. Empero, en el tratado Heidegger se preocupa de dejar claramente establecido que el descubrimiento fundamental al que ha llegado es que en la interpretación del ser como presencia (Anwesenheit), se oculta un modo del tiempo, el presente (Gegenwart).

En este curso de verano de 1924 Heidegger llega a la conclusión, que "ser para los griegos es ser presente (Gegenwärtigsein), es decir, ser siempre presente (Immer Gegenwärtigsein)" (GA18,112). Y además sostiene ahí, que el significado de ousía se entiende en el sentido de disponibilidad, de la presentación de algo que esta ahí en el sentido de la presencia. Además aclara que ousía es una abreviación de parousía, de ser presente, presencia(Cf. GA18,33).

El paradigma ontológico en la Física aristotélica indica que el ser es considerado como un producto terminado, enfocándose en el qué (eidos) de un "algo", que sería lo adecuado para la interpretación ontológica de la vida humana; en la primeras semanas del semestre de verano de 1924 Heidegger advierte con gran detalle que el cómo de una cosa producida, finalizada que se encuentra a nuestra disposición está presente, es Gegenwärtigkeit, parousía, Heidegger plantea esta pista temporal hacia una destrucción histórica a ser efectuada por primera vez desde las referencias a la Física aristotélica en la cual aparece el problema del tiempo operativo en el día a día y en la ciencia"179.

Precisamente en el momento en que Heidegger presenta una elaboración más precisa de la estructura ontológica del Dasein, donde reconoce que el carácter fundamental del tiempo es el futuro, llega también a la conclusión de que la comprensión griega del ser como presencia oculta una determinación temporal del ser como presente, es decir, da con

\footnotetext{
${ }^{178}$ Cf. Kisiel, Th, The Genesis of Heidegger's Being and Time, op. cit., p. 491

${ }^{179}$ Cf. Ibíd., p. 320.
} 
esta tesis precisamente a la luz de la exposición del tiempo del Dasein. En último término, el filósofo alemán lleva a cabo una contraposición clara y directa entre el tiempo de la metafísica y el tiempo del Dasein, con lo que encuentra una forma de expresar esta temporalidad inherente a la vida fáctica, lejos de la disponibilidad y la presencia constante para una mirada teórico cognoscitiva de objetos. Justamente como un tiempo que no tiene nada que ver con el tiempo tal como es interpretado por la tradición metafísica.

Nos parece además bastante llamativo, por decirlo de alguna manera, el camino que recorre Heidegger en estos textos que hemos analizado, en estos se refiere directamente al problema del tiempo de la vida fáctica y a sus estructuras ontológicas, para luego llegar hasta la pregunta por el ser, es decir, se plantea en primer término la cuestión de las estructuras ontológicas de la vida fáctica, del tiempo inherente a ella, para terminar planteando la pregunta por el ser, ya sea por medio de la influencia no problematizada de la filosofía griega en San Agustín, sea la pregunta por el sentido directivo del ser, y por último, en la determinación de la interpretación griega del ser como presencia, desde el presente. El tratado El concepto del tiempo sigue la misma dirección. En múltiples ocasiones Heidegger ha sido cuestionado porque en sus lecciones o trabajos no termina por desarrollar aquellos asuntos que se ha propuesto tratar al inicio de los mismos, termina por dirigirse a otros problemas. Podríamos decir, en concordancia con aquellas interpretaciones que sostienen que Heidegger en sus trabajos se deja llevar por las cosas mismas, lo cual justificaría que muchas veces el itinerario que se había propuesto en un principio termina siendo modificado y le lleva hacia otras cuestiones que le surgirían en el mismo ejercicio de su filosofar. Esto nos hace suponer que esta idea del tiempo de la vida fáctica le permite articular esa otra idea del ser como presencia, como presente, en otras palabras: que la interpretación del ser de la tradición filosófica, que ha de ser destruida fenomenológicamente, se ha podido reconocer y articular, entre otras cosas, pero fundamentalmente, en virtud de esta interpretación del tiempo de la vida fáctica como esencialmente futuro. Tesis que no dejará de repetir y replantear hasta finales de los años veinte con distintas formulaciones tales como, el ser futuro es la esencia del tiempo(Cf. GA64,59/78), "el fenómeno fundamental del tiempo es el futuro" (GA64,118/47), "el carácter fundamental del ser temporal reside en el ser-futuro" (GA64,81/104), y luego en el curso de lógica de invierno de 1925-1924, reafirma pero con una formulación distinta, "no que la esencia del presente es el futuro, sino que el sentido de la temporalidad es el futuro"(GA21,265/212), podemos ver que si bien matiza la forma de plantear dicho privilegio del futuro sigue siendo algo fundamental en su proyecto filosófico con el paso de los años.

Otra cuestión no menos importante, tiene que ver con que Heidegger se refiere aquí al tiempo sin más, ni de la temporalidad del Dasein ni del tiempo de la vida fáctica, dice que el futuro es el fenómeno fundamental del tiempo mismo. No sabemos bien si Heidegger en este periodo piensa el tiempo como tiempo sin más o se refiere 
puntualmente al tiempo del Dasein, es decir no hace la distinción entre la temporalidad del Dasein y el tiempo del ser, parece ser que todavía no ha llegado a diferenciar una cosa y la otra. Podríamos decir, que se sitúa en una ambivalencia ontológica, entre la dimensión del ser mismo y del Dasein, parece ser que aún no ha distinguido claramente ambas cuestiones, esclarecimiento al que solo llegará posteriormente. De algún modo, los sigue pensando dentro del mismo ámbito ontológico. Además, aquí todavía no afirma que la pregunta fundamental de la filosofía es la pregunta por el ser, pero sí que el tiempo es el fenómeno decisivo que permite revelar el sentido del ser de las correspondientes ontologías.

Además, sostiene que el propio mundo peculiar al trato es interpretado como presencia, teniendo como modelo la imagen del cielo, de la naturaleza, de lo que está ahí siempre presente, solo lo que comparece de forma permanente y constante es la auténtica realidad y la presencia por definición, la presencia constante del ser siempre y el modelo perfecto de esta presencia, el ente auténtico por antonomasia es el cielo, esto porque su presencia y permanencia es indubitable e imperecedera. Esto implica que el Dasein mismo interpreta su propio ser desde el mundo, pero entendiendo el mundo como naturaleza, como mundo de la ocupación más inmediata, concretamente: comprende su ser desde los entes del mundo. En consecuencia, el camino que se ha de seguir, si se pretende "poner al descubierto al Dasein significa despojarlo de esa ontología griega que ha devenido obvia y cuyo dominio apenas resulta visible, así como desmantelar las tendencias de investigación dominadas enteramente por esa misma ontología, de tal manera que se haga patente el verdadero fundamento del Dasein"(GA64,102/130). Desde ahí obtiene el sentido de su ser y el sentido del ser mismo, todo esto lo resume Heidegger como sigue:

el sentido del ser se interpreta a partir del tiempo (...) pero en la medida que el tiempo mismo es, éste se interpreta siguiendo el hilo conductor del concepto del ser dominante. Para Aristóteles, quién interpretó por primera vez el tiempo, "ser" significa "presencia" (presente). A la luz de este concepto de ser, el futuro es el no-ser-todavía, mientras que el pasado es el no-ser-más. La correspondiente interpretación del fenómeno del tiempo se convierte así en el elemento discriminante que revela el sentido del ser de la correspondiente ontología (GA64,100-1/129).

Y es más, en cuanto la analítica del Dasein, es concebida "como destrucción fenomenológica, la ontología del Dasein tiene que colocarse en la posibilidad de decidir sobre la respectiva proveniencia y adecuación de las categorías transmitidas"(GA64,103/130). Significa entonces, que la tarea primordial de la filosofía es ir al fundamento mismo desde donde parten estas interpretaciones, que no hacen más que oscurecer y malentender la esencia de este ente que es tiempo, se ha de ir a la raíz misma de este malentendido fundamental; la comprensión del ser como presencia, como simple presente. La constitución ontológica de este ente que es histórico y cuyo carácter temporal primario es el futuro, le ha revelado a Heidegger la procedencia esencial y originaria de 
esa comprensión del ser, que impedía una apropiación genuina de este ente. Esta conclusión a la que ha llegado el pensador de la Selva Negra, que se venía fraguando desde sus interpretaciones de la fenomenología de la religión, le revela ese carácter temporal decisivo y privilegiado, que marcan un reverso del tiempo de la metafísica y hacen manifiesta la constitución de este ente, con un carácter temporal que precisamente es el contrapuesto al de una simple presencia, de una presencia constante o de algo simplemente presente.

El pasado puede ser de algún modo sometido al escrutinio objetivador, como algo que ya se ha tenido frente a los ojos pero que ya ha pasado, qué decir del presente, es aquello que tenemos frente a los ojos como la presencia inmediata que podemos contemplar y objetivar, sin embargo, el futuro es aquello que no podemos hacer disponible, que no es posible objetivar ni calcular, este carácter temporal, en cuanto fenómeno, tal como lo comprende Heidegger, posee todas aquellas características del ser, o de este ente privilegiado, con la cuales la tradición metafísica no ha contado, que no ha tomado en cuenta, en otras palanras, la constitución esencialmente advenidera mienta a un ente cuya constitución ontológica fundamental es ser una posibilidad, tiene una constitución ontológica distinta a los entes de la naturaleza, por todo esto, es que ha sido imposible para la tradición filosófica dar cuenta de este ente, esta tradición todo lo piensa en términos de presencia constante, desde un modo del tiempo, el presente, ocultándose bajo esta consideración del ser la constitución originaria del Dasein, lo que ha derivado en que la pregunta por el ser haya terminado por quedar completamente oscurecida.

Es en esta interpretación, que el joven profesor venía esbozando desde hace algún tiempo,- a partir de sus interpretaciones de fenomenología de la religión-, que se le revela ese carácter temporal decisivo y privilegiado, que marcan el reverso del tiempo metafísico y hacen manifiesta la constitución de este ente como justamente lo contrario de una mera presencia, o de una presencia constante, lo que fundamentalmente somos es aquello que no puede ser de ningún modo un objeto, algo que está ahí delante, ante los ojos, ni un ente más de la naturaleza, ni como algo simplemente presente. Es el tiempo mismo el que permitirá a Heidegger articular de forma genuina y originaria la pregunta por el ser, retomar esta pregunta olvidada que en el mejor de los casos ha sido malentendida en su carácter, al preguntar por el ente en lugar de formular la pregunta por el ser mismo. Este es el camino que Heidegger retoma, y que gracias a esta determinación del ser como advenidero, en cuanto que "el fenómeno fundamental del tiempo es el futuro" (GA64, 118/47), o que "el carácter fundamental del ser temporal está radicado en el ser futuro" (GA64,81/104), nos muestra claramente la importancia de este fenómeno al interior del edificio filosófico que Heidegger está construyendo por esos años, por eso no sería casual que sea precisamente este fenómeno el que le ha abierto los ojos y le ha permitido ver el fallo fundamental de la tradición metafísica. En este tratado Heidegger plantea con claridad ese vínculo, que él considera indisoluble, entre la pregunta por el ser y el tiempo, 
esto significa que esta interpretación del tiempo como simple presente, propio de la comprensión griega del ser como presencia, le abre los ojos respecto al camino que ha de seguir un replanteamiento originario de la pregunta por el ser, que la reconduzca hacia una formulación genuina, que no puede ser, desde ningún punto de vista la concepción del ser que ha guiado hasta ahora el pensamiento occidental, que la entiende como presencia constante. La conclusión fundamental a la que llegado Heidegger la presente de la siguiente forma:

para los griegos "ser" significa : disponibilidad (Verfügbarkeit), presencia (Anwesenheit), todavía en Aristóteles la palabra ovøı $\alpha$ conserva tanto el sentido terminológico, como el sentido originariamente más concreto de patrimonio, posesión, hogar-propiedad,

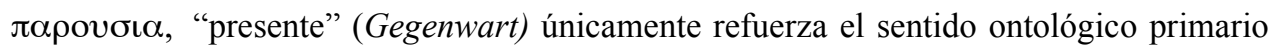
de oovı $\alpha$. Solo con la elaboración de este sentido del ser se hacen comprensibles las distinciones ontológicas fundamentales realizadas por Aristóteles, quien establece los auténticos fundamentos de la ontología griega prefigurada por Parménides (GA 64, 127/178).

Todo esto significa, que en último término la filosofía griega ha comprendido el ser como disponibilidad, como presencia (Anwesenheit), prevaleciendo esta forma de comprenderlo, por sobre el significado originario de ovoı $\alpha$, que nombraba de forma más concreta la posesión de algo. Este sentido original queda desplazado por la interpretación del ser como ousía, entendido como presencia constante, por lo tanto queda vinculada a un modo del tiempo, el presente. Esta interpretación adquiere sus presupuestos ontológicos desde la filosofía del propio Parménides, y su máximo exponente sería Aristóteles. La filosofía posterior no haría más que seguir sus pasos sin hacerse cuestión de la validez ontológica de dichos presupuestos.

Por todo esto, el tiempo mismo se interpreta como algo que es y en la tradición posterior el tiempo permanece bajo la misma interpretación que "siguiendo el hilo conductor del concepto del ser dominante. Para Aristóteles, quién interpreto por primera vez el tiempo, "ser" significa "presencia" (Anwesenheit) (presente) (Gegenwart)" (GA64, 101/129), constituyéndose esta forma de entender el ser como la privilegiada y eminente, por lo que todos los entes del mundo, la existencia misma se comprenden desde esta perspectiva, y el tiempo se piensa siguiendo los cánones que dicta esta interpretación aristotélica. Heidegger se preocupa de dejar expresamente marcada esta distinción y al mismo tiempo conexión entre una cosa y otra, entre Anwesenheit y Gegenwart. Que el ser esta pensado y concebido por la filosofía griega desde el tiempo.

Hemos podido seguir el camino que ha recorrido Heidegger y que le ha permitido llegar a esta conclusión; que el ser en la tradición metafísica ha sido pensado desde el tiempo, desde una perspectiva unilateral del tiempo: el presente. El pensador de la Selva Negra desde sus primeras lecciones de Fenomenología de la vida religiosa, como también en el Informe Natorp, se muestra en abierta discrepancia con esta interpretación, él no comprende la experiencia del tiempo de la vida humana desde esa perspectiva. En más, en 
estas lecciones y en su Aristóteles, Heidegger ha abierto una nueva perspectiva, una forma originaria de comprender el tiempo, que no se condice con la comprensión de la tradición metafísica que él ha sido capaz de desvelar. Si bien, estos trabajos pertenecen a una fase incipiente de su producción intelectual, la filosofía de Heidegger se muestra claramente antagónica a esa comprensión del tiempo dominante, que sería la que en último término también determinaría la comprensión del ser de procedencia griega. Heidegger ve en esta interpretación el fallo decisivo de la metafísica, además, el reconocimiento que hace de esta cuestión le permite dar el paso hacia Ser y tiempo. Ahora que se han conjuntado los caminos que han guiado la pregunta por el ser y la determinación de la constitución ontológica de la vida fáctica, es el momento oportuno para llevar a cabo una investigación de la estructura ontológica del Dasein, pero como hemos dicho, ahora ya en una elaboración más completa de dichas estructuras, que si bien, ya se han ido plasmando poco a poco en sus lecciones universitarias y conferencias, especialmente es sus lecciones de fenomenología de la religión, en el Informe Natorp y en Ontología: Hermenéutica de la facticidad, que también trató abreviadamente en la conferencia El concepto del tiempo, no obstante, es en el tratado del mismo nombre donde se lleva a cabo una presentación más acabada de dicha interpretación del Dasein. Aquí también ya se ha abandonado en gran medida, la terminología que hablaba de vida fáctica o de la facticidad de la vida, trocándola definitivamente por el término Dasein.

Precisamente, al fijar este carácter temporal como el esencial, como el sentido o el fenómeno fundamental del tiempo, está afirmando con claridad la importancia que le concede a este fenómeno en esta fase temprana de su pensamiento, más aún, nos permite sostener que gracias a esta determinación del tiempo, a Heidegger se le hace plenamente manifiesta que en aquella concepción griega del ser como presencia se esconde un modo del tiempo: el presente. Significa entonces, que el ser es interpretado desde el tiempo, aunque sea desde una perspectiva unilateral del tiempo, esto ha impedido un preguntar originario acerca de la vida fáctica $y$, por lo mismo, dirigir la meditación hacia la pregunta filosófica por excelencia, la pregunta por el ser. En el desvelamiento de este carácter fundamental del tiempo de la vida fáctica, que ahora acabará por formular de forma explícita y le permite determinar con exactitud el vínculo entre el ser y el tiempo, cuestión que hasta ahora solo se podía deducir, dado que solo aparecía como algo latente en su filosofía, pero que no acababa de dejar plenamente manifiesto, tal como habíamos expuesto en los apartados anteriores.

\section{E. El TIEMPO COMO HORIZONTE PRIVILEGIADO DE LA PREGUNTA POR EL SER}

El desvelamiento del problema del tiempo, como el horizonte privilegiado de la pregunta por el ser, se le ha hecho presente a Heidegger gracias al esclarecimiento de la concepción del ser dominante en la filosofía griega, en la cual el ser es esencialmente comprendido como presencia constante, lo que indica que está intepretado desde un 
señalado modo temporal que es el presente. Esto ha llevado al filósofo alemán a concebir el tiempo como un fenómeno de un carácter ontológico privilegiado que ha de ser cuestionado en su procedencia, en su origen primigenio y,además, deben ser investigadas las consecuencias que se derivan de dichas interpretaciones obtenidas desde la tradición metafísica. En necesario sopesar si corresponden a una comprensión originaria del fenómeno, o por el contrario, si aquella es una interpretación derivada e incuestionada de él. Estas conclusiones a las que Heidegger ha llegado, las expone ya en forma de tesis en sus lecciones del semestre de verano de 1925, llamado Prolegómenos de una historia del concepto del tiempo, que es en el que se muestra ya un camino franco a Ser y tiempo.

Señala ahí, que "el concepto del tiempo no es un concepto cualquiera, sino que tiene un nexo íntimo con la cuestión fundamental de la filosofía, siempre que ésta sea acerca del ser de lo ente, de la realidad de lo real" (GA20,6/21), esto significa, que una vez que Heidegger reconoce el vínculo indisoluble entre la cuestión del tiempo y la pregunta por el ser, entiende que la pregunta por el tiempo no es una pregunta más entre otras preguntas que la filosofía pudiera llevar a cabo, sino que es una pregunta de carácter fundamental, porque nos conduce directamente a la cuestión del ser. Por lo tanto, es el tiempo mismo el que ha de ser cuestionado en su constitución genuina, lo que nos permitiría llegar hasta la pregunta por el ser, y en ello subyace la posibilidad de superar las insuficiencias de la metafísica y de la ontología tradicional, que imposibilitan el desarrollo de la pregunta por el ser y por la vida fáctica.

Por eso, para Heidegger se transforma en una cuestión verdaderamente determinante llevar a cabo un cuestionamiento acabado y preciso de dicho concepto, para poder dar cuenta de los malentendidos y de los supuestos ontológicos en los que descansa la interpretación tradicional del tiempo, para conducirnos en último término a develar aquellos supuestos ontológicos en los que descansa la comprensión del ser de la tradición metafísica. Esto lo ilustra Heidegger de la siguiente forma:

\begin{abstract}
la historia del concepto del tiempo es la historia del descubrimiento del tiempo y la historia de la interpretación conceptual del tiempo. Dicho de otro modo, esa historia es la historia acerca del ser de lo ente, la historia de los intentos de descubrir lo ente en su ser, una historia que era guiada por la manera de entender el tiempo, según el grado de elaboración conceptual del fenómeno del tiempo en cada momento. Así más exactamente, la historia del concepto del tiempo es en definitiva la historia del decaimiento y la historia del enmudecimiento de la cuestión fundamental de la investigación científica acerca del ser de lo ente: la historia de la incapacidad para replantear de modo radical la cuestión del ser y reelaborarla en sus fundamentos primeros-una incapacidad que está fundada en el ser del Dasein (GA20,8/22).
\end{abstract}

Es este fenómeno el que le ha permitido a Heidegger conjuntar en una misma vía gran parte de de sus preguntas filosóficas fundamentales; la pregunta por el ser y por la vida fáctica, gracias a este fenómeno puede abordar lo que considera las cuestiones esenciales de la filosofía, por ende, es la investigación del problema del tiempo la que le abrirá el 
acceso hacia la cuestión verdaderamente fundamental y decisiva: la pregunta por el ser, que no se ha planteado a lo largo de la historia de la filosofía, o si se ha hecho, ha sido de forma incorrecta, lo que ha derivado en una consideración del ser desde el ámbito de la naturaleza, y por ende, ha terminado en el enmudecimiento de la pregunta por el ser. Pero, esto no se debe solamente a un fallo de la tradición metafísica, o a que Aristóteles no haya sabido plantear la pregunta de forma correcta, por el contrario, esta deficiencia en la consideración del ser y del tiempo, se origina en una incapacidad del propio Dasein, basado en su propia constitución ontológica, como un ente que se interpreta a partir de los entes del mundo, de la naturaleza.

El profesor Heidegger considera ahora como una cuestión de suma importancia tener siempre en cuenta, para evitar cualquier tipo de malentendidos en cuanto a la dirección que sigue su trabajo, que su investigación es de carácter ontológico, tal como recuerda Berciano cuando señala que, "la pregunta filosófica de Heidegger es, ante todo pregunta por el ser. Pero es precisamente esta pregunta la que lo lleva a la pregunta por el tiempo. Y es también esta pregunta la que lo lleva al análisis fenomenológico del Dasein" ${ }^{180}$. Pero como sabemos, las constantes precisiones que Heidegger hace acerca de esta cuestión no han evitado que en múltiples ocasiones se caiga en esto que él considera una incomprensión, puesto que lo que guía su trabajo en este periodo de su pensamiento, una vez que ya ha dado con la cuestión del ser y el tiempo, es un interés puramente ontológico. Si bien se pregunta por el Dasein, lo hace desde el ser de este ente, su pregunta es por el ser mismo y por el ser del Dasein. Por lo tanto, "de lo que se trata es de poner al descubierto el Dasein en su constitución básica, tal como normalmente se lo entiende, para así poder plantear de modo diáfano la cuestión del ser” (GA20,204/191).

Gracias a la intelección de esta conexión esencial entre el ser y el tiempo a la que Heidegger ha llegado, gracias a este diálogo, a esta discusión que entabla por estos años con la tradición filosófica, se abre una nueva vía que da nuevos impulsos a esa pregunta por excelencia de la filosofía.

La pregunta por el ser deber ser reformulada, repetida, llevada hasta el fundamento ontológico desde donde se origina la interpretación dominante del ser, y esto gracias a la consideración del tiempo, que será el hilo conductor de esta tarea que Heidegger se ha propuesto, como destrucción de la historia de la metafísica. Esta conexión entre el ser y el tiempo le brinda la clave para dar nuevos bríos a la investigación filosófica. Tal como señala con rotundidad en los cursos de Lógica: La pregunta por la verdad:

Los griegos no atisbaron nada de esta problemática abisal que se abre una vez que se ha visto esta conexión, y a partir de ella también se puede explicar ahora la diferencia entre comparecencia y presente, y el propio presente y sus modos, y al mismo tiempo hacer comprensible por qué es posible identificarlos primeramente a ambos en un estadio

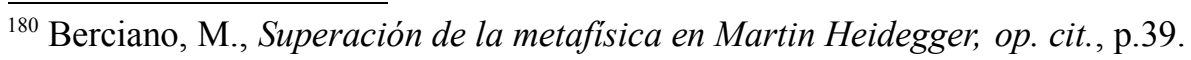


preliminar de la interpretación del ser. Si se ha comprendido de una vez esta problemática de la conexión interna de la comprensión del ser a partir del tiempo, entonces se tiene ciertamente de alguna manera una luz para alumbrar ahora hacia atrás la historia del problema del ser y la historia de la filosofía en general, de modo que ahora obtengan su sentido(GA21, 193-4/158).

Este es el paso fundamental del que hablaba Pöggeler, que permite a Heidegger reelaborar la pregunta por el ser mismo, que se ha permanecido oscurecida, encubierta, e incluso olvidada para la tradición metafísica.

En consecuencia, para llegar a alumbrar la historia de la metafísica, para aclarar desde su origen los presupuestos ontológicos en lo que se fundamenta la determinación del ser tal como la ha entendido la tradición, ha de iluminarse ese vínculo esencial entre el ser y el tiempo, solo a la luz de esta conexión es posible comprender las motivaciones y presupuestos desde los que surge la propia historia de la filosofía. Esto, es lo que nos permitiría dar ese paso más allá que nos conduciría a una planteamiento originario de la cuestión del ser, para conseguir ir más allá de las interpretaciones de la ontología tradicional y así poder superar su insuficiencia e impotencia. Se puede apreciar de qué forma el tiempo adquiere para Heidegger un papel protagónico, es en dicho fenómeno en el que se sostiene la posibilidad de dar ese paso más allá que supere la insuficiencia esencial de la metafísica, que permita llegar a la verdadera problemática filosófica. Se debe cuestionar a cabalidad este fenómeno, es sus supuestos ontológicos, en su historia y en las consecuencias que presuponen la comprensión tradicional de él.

Como dice Heidegger: "para dar este paso se requiere una comprensión del tiempo que rompe fundamentalmente con la tradicional" (GA21, 194/158), esta es para el pensador alemán la única y exclusiva vía que le permitiría un cuestionamiento radical de la tradición y posibilitaría encausar la pregunta por el ser hacia sus cauces originarios. Según los cánones que dicta la tradición metafísica, el tiempo se considera como algo que es, como un ente más que forma parte del mundo, importante. Esta idea del tiempo tiene una larga data y ha determinado desde siempre a la filosofía, esta consideración sigue los mismo parámetros de la interpretación del tiempo que ha dominado a la tradición metafísica de procedencia griega y constantemente nos movemos en esa comprensión del tiempo heredada, tal como sostiene Heidegger: "que o bien se construye un concepto del tiempo mediante el cual la temporalidad no tanto se determina o siquiera se indica, sino que se oculta, hasta el punto de que se niega absolutamente otra comprensión del tiempo. El ejemplo permanente de esta tendencia de la interpretación del tiempo es la primera interpretación filosófica del tiempo que tenemos, la de Aristóteles" (GA21, 410/322).

Como podemos ver, Heidegger entiende que ha llegado a una conclusión que es verdaderamente determinante para su trabajo filosófico: que la reformulación y replanteamiento de la pregunta por el ser pasa necesariamente por clarificar y cuestionar de forma genuina esa interna y esencial vinculación entre el ser y el tiempo, cuestión que 
ha de resolverse por medio de la determinación de la estructura ontológica de la existencia humana en su raíz temporal. Sin embargo, Heidegger no pretende con esto decir la última palabra respecto a esta reformulación de la pregunta por el ser, que a su juicio necesariamente ha de llevarse a cabo desde el horizonte del tiempo, por el contrario, deja abierta la posibilidad de que ella pueda llevarse a cabo desde otra perspectiva, no presenta su tesis como una de carácter absoluto e indiscutible, no es una conclusión última. Teniendo en cuenta esto, es que señala: "no quiero ser tan absolutamente dogmático y afirmar que el ser solo puede concebirse desde el tiempo: quizá mañana alguien descubra una nueva posibilidad. Por eso jamás se puede decir que el espacio o la naturaleza o cualquier otro ente es el tiempo" (GA21, 267/214). Por lo tanto, el filósofo alemán quiere dejar planteada la discusión y abrirla a nuevos ámbitos de reflexión, a renovadas direcciones interpretativas, pero por el momento tal como comenta, su camino sería el que ha de seguir la filosofía para una meditación esencial respecto a la verdadera pregunta filosófica por excelencia.

\section{F. Aristóteles y El tiempo DESDE El MODELo DE LA NATURALEZA}

El filósofo alemán al comenzar su investigación en el tratado El concepto del tiempo, considera que es imprescindible para su éxito, situarla dentro del horizonte del tiempo con el que encontramos en nuestra propia vivencia del día a día, en la cotidianidad en la estamos inmersos; que principalmente se entiende como tiempo de la naturaleza, del mundo, esto lo señala, teniendo en cuenta, "que la vida humana se orienta en su quehacer más cotidiano por el tiempo. La vida encierra en sí misma una regulación temporal"(GA64,17/25), por tanto, sería esta la experiencia del tiempo según la cual nos conducimos y regimos. A Juicio Heidegger, la pregunta de qué es el tiempo está de nuevo en boga, ha recuperado su interés en razón del desarrollo que han adquirido en este periodo las investigaciones de las ciencias naturales, especialmente la física. Y esto, sobretodo en lo que tiene que ver con la reflexión y el cuestionamiento respecto a la misión, alcance y definición de lo que le es propio a la física en cuanto física, en lo relativo a su tarea primordial, cuestión que en la obra de Einstein La teoría de la relatividad, adquiere su máxima expresión.

La labor de la física se entiende como una medición de la naturaleza en el ámbito de un sistema de relaciones espacio-temporales. Esto lo concluye Heidegger, recogiendo algunas de la proposiciones fundamentales que encuentra es la obra principal de Einstein, como por ejemplo la que dice: "el espacio no es nada en sí mismo; no existe ningún espacio absoluto. Solo existe a través de los cuerpos y de las energías contenidos en él. Coincidiendo con una antigua afirmación aristotélica, tampoco el tiempo es nada en sí. Solo existe como consecuencia de los acontecimientos que tienen lugar en el mismo. No hay un tiempo absoluto, ni una simultaneidad absoluta"(GA64,109/28-9). A pesar de que la actitud de Heidegger es eminentemente crítica frente a la teoría de la relatividad de 
Einstein, sin embargo, ve en ella un aspecto positivo, dado que muestra la equivalencia de la ecuaciones que describen los procesos de la naturaleza en cualquiera de sus cambios, y la tesis aristotélica que sostiene que "el tiempo es aquello en lo que se producen los acontecimientos" (GA64,109/29), este es un punto fundamental para la investigación del tiempo, que tiene que ver con el encuentro, con el enfrentamiento que el pensador de la Selva Negra mantiene con el Estagirita, como se ha dicho anteriormente, la relación de Heidegger con Aristóteles es ambigua, por una parte, reconoce el merito y el aporte que el pensador de Estagira ha entregado a la meditación filosófica y a su problemática esencial, en tanto que de él ha surgido gran parte del armazón conceptual del que se vale el pensador alemán para acometer su tarea destructiva de la tradición metafísica, pero al mismo tiempo, le reprocha y le crítica ácidamente, considerándolo como el gran responsable de la comprensión del tiempo y del ser que ha dominado la meditación de la tradición metafísica.

Esta definición general del tiempo, que lo entiende como aquello que se encuentra siempre tras las ecuaciones que describen los cambios y procesos de la naturaleza en sus transformaciones, sería para Heidegger, lo mismo que sostiene Aristóteles en la Física, "el tiempo es aquello en lo que se producen los acontecimientos". Esta cuestión Aristóteles ya la había visualizado al plantearse la forma de ser fundamental de lo entes de la naturaleza que es el movimiento y las distintas posiciones que un ente puede ocupar al interior de una sucesión. Es pues, el movimiento, el cambio, un carácter esencial de los entes de la naturaleza. Pero, el tiempo mismo no puede ser un movimiento, no obstante, es algo que de alguna forma está relacionado o está en conexión con el movimiento. En primer término nos encontramos con el tiempo de lo entes que cambian, es decir, el cambio se materializa en el tiempo. De modo, que el tiempo se nos muestra en la perspectiva tradicional como esencialmente ligado al cambio, al movimiento, lo que implica entenderlo como un receptáculo, como un ente en el que se producen los cambios, los hechos y acontecimientos del mundo. Por este motivo,

\footnotetext{
Heidegger "denuncia" la inadecuación del acceso al fenómeno compartida por experiencias tan diferentes aparentemente como la teoría de la relatividad de Einstein, la especulación aristotélica y la conducta cotidiana. La tres coinciden en determinar el tiempo a partir de la categoría de medida. Inicialmente la teoría einsteniana de la relatividad se presenta aquí como instancia principal del estado actual de la ciencia física, dentro del proyecto característico de la física moderna de medir los fenómenos en un sistema de relaciones espacio-temporales ${ }^{181}$.
}

De esta forma se obtiene una caracterización del tiempo más completa, que nos habla de movimiento, cambio y medida. Es a través de la medición, de la mensurabilidad, que se nos hace accesible el tiempo y esto es igual en las tres modalidades del tiempo antes mencionadas. En otras palabras, el tiempo es determinado y comprendido según el carácter de la medición.

${ }^{181}$ Peñalver,P., Del espíritu al tiempo, op. cit., p. 41. 
Siempre es una tarea de suma importancia en la filosofía heideggeriana asegurar el punto de partida de la interpretación que se va a emprender, y asegurar el suelo desde el que parte una determinada exégesis. Asegurar este punto de partida es el primer requisito que se ha de cumplir si se quiere tener éxito en la tarea propuesta. Por esta razón, es imprescindible dirigirse al origen mismo desde donde parte una determinada interpretación. Así pues, al preguntar por el tiempo se debe plantear la tarea de la destrucción de la tradición metafísica en lo referido a sus conceptualizaciones fundamentales, pero especialmente en la que hace referencia al tiempo, puesto que la interpretación que la tradición filosófica hace de este fenómeno en sus primeras e inveteradas formulaciones, se convierten en el punto de partida en el cual se fundamentan los ocultamientos y malentendidos que han determinado la historia del pensamiento occidental y su pregunta por la vida humana, o por el tiempo mismo, por todo esto, para Heidegger se torna un trabajo ineludible plantear una crítica al concepto del tiempo de Aristóteles, que ha quedado plasmado en la Física, que a juicio del filósofo de la Selva Negra él es el fundamento del tiempo tal como lo entiende la ciencia física, la filosofía y la cotidianidad. En esta concepción del tiempo, Heidegger ve el origen de las determinaciones que se ha convertido en las dominantes al momento de preguntar por el tiempo y por el ser. La concepción aristotélica del tiempo es el fundamento plenamente vigente e incuestionado de la forma de concebir el tiempo, cuestión que perdura hasta nuestros días.

Sin embargo, hemos de señalar que el análisis de la interpretación del tiempo en Aristóteles más completo que Heidegger desarrolla, está contenido en las lecciones del semestre de verano de 1927 titulado Problemas fundamentales de la fenomenología, texto que a juicio de algunos especialistas ${ }^{182}$ es la segunda parte de Ser y tiempo. No obstante, en el tratado y en la conferencia a la que nos hemos referido, y también en las lecciones de Marburgo, especialmente en Los prolegómenos de una historia del concepto del tiempo y en los cursos de Lógica: la pregunta por la verdad, se va configurando esta crítica al concepto del tiempo de Aristóteles, por ello, lo que aquí hacemos es reconstruir los pasos de esa crítica, para dar una visión general de aquello a lo que Heidegger se dirige en su tarea destructiva, esto permitirá que se nos vayan haciendo visibles los distintos pasos que va dando en esta investigación que pregunta por el tiempo, y que el pensador alemán ha iniciado en su lección de habilitación El concepto del tiempo en la ciencia histórica.

En este último trabajo, Heidegger hace referencia principalmente a la comprensión del tiempo de la física moderna, como mensurabilidad, como medición del movimiento, pero llama la atención que en ninguna parte de este escrito, en el que se hace cuestión el problema del tiempo en la ciencia histórica, hace referencia alguna a la Física de Aristóteles, que se supone es el punto de partida de las interpretaciones del tiempo de la

${ }^{182}$ Cf. Hermmann, F., La segunda mitad de Ser y tiempo, Trotta, Madrid, 1997, p. 25. Trad. Irene Borges. 
física moderna y de la cotidianidad, tal como lo señalará en el tratado El concepto del tiempo. Podríamos decir, que en aquel momento en que su filosofía estaba en una fase incipiente la figura de Aristóteles no adquiría aún el rol protagónico que adquirirá a principios de los años veinte, interés que se mantendrá inalterable con el pasar de los años manteniéndose siempre en un lugar de privilegio al interior de la filosofía heideggeriana, pero siempre envuelta en esa curiosa ambigüedad. Este reconocimiento de Aristóteles, como el filósofo que acuño y pensó por vez primera el problema del tiempo desde sus coordenadas originarias, surgió seguramente al fragor de la discusión que mantenía con él por aquellos años, investigación que por lo demás seguía distintas motivaciones, entre ellas, la lógica, la metafísica, la ética, siendo la pregunta por el tiempo, uno más de los múltiples flancos de investigación abiertos por Heidegger en aquellos años, lo que le ha llevado a una revisión minuciosa de los textos aristotélicos.

\section{G. EL TIEMPO COMO MEDICIÓN}

En relación con esto último, dice Heidegger: "el primer tratado científico sobre el tiempo que nos ha sido transmitido y cuyos resultados han resultado decisivos hasta la actualidad - a saber, el tratado de la Física de Aristóteles (ontología del mundo)- se atiene al modo de comparecencia más inmediato del tiempo"(GA64,77/100), el Estagirita sostiene ahí que "el tiempo justamente es el numero del movimiento según el antes y el después" (Física 219 b 1s). Por lo tanto, uno de los planteamientos principales de la Física aristotélica es que el tiempo se nos presenta primeramente a través de la categoría del medida, lo que viene a señalar que se nos muestra el tiempo como una medición, una medida que viene a señalar, más precisamente, a cuantificar el tiempo y precisar el cuándo, un desde cuándo hasta cuándo, ¿cuánto tiempo he trabajado? ¿cuánto he descansado? ¿cuánto tiempo tengo para hacer tal o cual cosa? Estas preguntas que comúnmente nos hacemos, supuestamente tendrían como pretensión preguntar por el tiempo, pero en realidad no hacen más que preguntar por un cuanto, por un numero, por una medida. Según esto, dichas preguntas nos deberían conducir o poner en la pista del tiempo, sin embargo, solo nos ponen en relación a una suma en términos de cuánto tiempo. Y existe un instrumento que nos lleva hacia el tiempo, que nos señala el tiempo, nos referimos claro está al reloj. Dice Heidegger: "el reloj mide el tiempo en la medida en que la extensión de la duración del acontecimiento se compara con las secuencias idénticas el reloj $y$, a partir de ahí es determinado en su secuencia numérica"(GA64,110/31). De tal forma, que el reloj sería aquel sistema físico, que una vez explicado y determinado en su ser, nos puede indicar con claridad qué es el tiempo, o por lo menos, nos daría la posibilidad de que se nos haga manifiesto el propio ser del tiempo.

Sin embargo, esta idea no puede ser compartida por Heidegger, en esta experiencia del tiempo que nos muestra el reloj se entiende el tiempo como algo que se puede fijar de forma antojadiza en un determinado punto que es un ahora, de forma que puesto en 
conexión con dos puntos de la secuencia temporal se puede decir que uno es anterior y el otro posterior. Así es precisamente como Aristóteles entiende y define el tiempo, que “justamente es el número de movimiento según el antes y el después”, es decir, considera el tiempo como una medición cuantitativa, en la cual ningún punto del ahora en el tiempo se distingue de otro, a no ser por el lugar que ocupan en la secuencia temporal. Todo punto en cuanto es un ahora, es un posible antes o después, por lo tanto es un tiempo uniforme y homogéneo, y en tanto tiene esas características puede ser medido.

Según esta idea del tiempo, toda consideración de un antes y un después, de la anterioridad y la posterioridad puede ser determinado desde un ahora arbitrariamente dispuesto. Entonces, "la determinación fundamental que en cada caso realiza el reloj, más que indicar el "cuánto tiempo", la cantidad de tiempo en su fluir presente, consiste en determinar la fijación respectiva del ahora. Lo primero que digo cuando saco el reloj es: "ahora son las nueve; treinta minutos desde que ocurrió aquello. Dentro de tres horas serán las doce"(GA64,110/32). Por lo tanto, el tiempo es entendido a partir del carácter de medida, es una cuantificación de hechos y acontecimientos dentro de una sucesión de temporal caracterizada por el reloj, que apunta hacia aquel carácter homogéneo y uniforme del que antes hablábamos, es el tiempo propio de la física moderna, de las ciencias naturales. Tal como la entendemos, "La física moderna se limita a medir los fenómenos naturales en el marco de un sistema de relaciones espacio-temporales. Incluso la experiencia cotidiana del tiempo parece estar filtrada por esta por la medición y el cálculo de acontecimientos. Heidegger ilustra el carácter homogéneo y cuantitativo del tiempo con la imagen del reloj, instrumento que plasma gráficamente esta noción de sucesión lineal y uniforme del tiempo"183, es esta idea del tiempo, extraída de la naturaleza, del mundo físico, es propia de "un tiempo impropio y vulgar como el de la vida cotidiana y el tiempo homogéneo y cuantitativo de la ciencias objetivas, que Heidegger ilustra con el tiempo secuencial del reloj y de la sucesión cíclica de las estaciones del año"184.

A juicio de Heidegger, toda pregunta que interroga qué es el tiempo, que pregunta por su esencia, se mantiene siempre en ámbito de la experiencia cotidiana que se tiene de él, como dice Aristóteles, "el tiempo es el cielo o bien su cambio repentino" (Física, IV 10, 218 a 31-b 8) o "el tiempo es movimiento", en estas dos tesis aristotélicas se resume a grandes rasgos aquello a lo que Heidegger dirige su crítica, para él el reloj es solamente un artilugio que se construye a imagen y semejanza de ese reloj natural que siempre está en movimiento, nos referimos al reloj que marca la sucesión del día y la noche; el cielo, que en último término es la naturaleza.

Para Aristóteles, toda posibilidad de mostrar el fenómeno del tiempo y aprehenderlo ontológicamente se sustenta en que comprendamos filosóficamente el movimiento. Dice Heidegger:

\footnotetext{
$\overline{183}$ Adrián, J., El programa filosófico del joven Heidegger, op. cit., p. 50. 184 Ídem.
} 


\begin{abstract}
Aristóteles descubrió el movimiento como un carácter ontológico del ente y lo conceptualizó ontológicamente, con lo que conquistó frente a Platón un terreno más originario en el marco de la misma tendencia investigadora. Con la comprensión ontológica del "movimiento" se dio por primera vez la posibilidad de revelar ontológicamente "el tiempo". El concepto "movimiento" (kínesis) incluye en sí todos los fenómenos del cambio de...a (metabolé): llegar a ser distinto (por ejemplo, en la coloración), aumentar y disminuir, cambio de lugar (...) el movimiento es entelechia (GA64,101/78).
\end{abstract}

Para Heidegger, la entelechia es "un carácter ontológico del ente y significa: mantenerse en el estar concluido (Fertigsein), estar ahí delante (presencia) (Vorhandenheit (Anwesenheit)). El movimiento es precisamente el estar ahí delante (la presencia) de un ente en su poder ser como tal" (GA64, 78/101). El movimiento así entendido hace referencia al estar ahí delante, a la presencia (Anwesenheit) de un ente en su posibilidad, en su poder ser como tal y está en cada caso dirigido u orientado hacia algo.

Si un ente en cuanto poder ser como tal está presente en su posibilidad de realización, en su disponibilidad mientras se emplea, está en movimiento mientras así permanezca. De la misma forma, está presente el ente en su poder cambiar o trasladarse de un lugar a otro. Por ello, la mirada que en el mero ocuparse sigue al ente que se mueve, dice ahora aquí, ahora allí, ahora ahí. Este decir ahora, ahora, ahora, significa que es un mirar el antes o después de los lugares señalados por el antes y del después que ocupa el ente en cuestión, con lo cual se alude al ente que se mueve en relación a su presencia y de este modo la hace accesible. Según Heidegger, "el decir ahora "numera", "cuenta". La función fundamental del numerar más inmediato tiene que entenderse fenomenológicamente como un poner al descubierto en su presencia aquello que está presente y hacerlo de este modo disponible. El numerar es un presentar. Lo que es "numerado" con respecto a aquello que se mueve son los "ahora"”'(GA64,78-9/102). En consecuencia, el tiempo es considerado como arithmos, un numerar, un contar el tiempo según una secuencia temporal, al decir constantemente ahora, ahora, lo que se lleva a cabo es un cómputo del tiempo, una contabilidad de tiempo, y esto es justamente para Heidegger, lo que representa la definición aristotélica del tiempo, como "el número de movimiento según el antes y el después" (Física, 219 b 1s).

Sería precisamente esta definición del tiempo, la que se ha transformado en la dominante en la tradición del pensamiento occidental, es el punto de partida en el que se sostiene el concepto del tiempo y ha adquirido un rango de privilegio, por no decir la única, al momento de interrogarlo y entenderlo, esto es así en la historia de la filosofía como en la física moderna y en la vida cotidiana, es una comprensión del tiempo que lo concibe como un fluir sucesivo de ahoras, que se suceden y se numeran una y otra vez. Además, este contar es principalmente un hacer presente un ente. "Numerar es un hacer presente. La historia ontológica del origen del concepto del tiempo muestra, por tanto, que 
el Dasein-incluso en el caso en que pregunta explícitamente por la esencia del tiempopregunta y responde en el sentido de la ocupación presentante"(GA64,79/103). No es difícil concluir que Heidegger entiende que, desde la antigüedad hasta nuestros días, el concepto del tiempo se mueve en derroteros bien definidos, dentro de los cuales se le considera como un numerar constante de ahoras medidos por un reloj, por lo que se tiene a la vista un determinado modo del tiempo, se considera el tiempo desde una dimensión privilegiada, el presente, desde el cual el pasado y el futuro obtendrían su ser. Pasado y futuro solo jugarían un papel secundario y derivado en relación aquel modo privilegiado que designa al tiempo, el simple presente, como un flujo constante y sucesivo de ahoras, con carácter de un fluir eterno

Y esto ha sido así a lo largo de toda la historia de la filosofía, desde el origen de la pregunta por el tiempo, e incluso, cuando la vida misma pregunta por el tiempo, lo hace ya desde esta interpretación del tiempo como presente, lo que niega el acceso a una meditación originaria y genuina de él, por ello dice Heidegger:

el análisis del sentido ontológico del reloj y la interpretación del arithmos en Aristóteles ha dejado claro que el trato que cuenta con el tiempo es un determinado temporalizar que se da en el modo del presentar. La "irreversibilidad", que constituye el predicado distintivo del tiempo se expresa en una semejante forma de contemplar el "tiempo", que en realidad quiere invertirlo, es decir, repetirlo y hacerlo enteramente disponible en el presente de un estar ahí disponible en el presente de un estar-ahí delante (GA64,80/103).

\section{H. LA CRÍTICA HeIDEgGeriana A LA COMPRENSIÓN DEL DASEIN COMO VORHANDENHEIT}

Consecuente con esta comprensión del ser como presencia con el que Heidegger ha logrado dar después de largos rodeos en torno al sentido directivo del ser, a la interpretación griega del ser que ha dominado la meditación filosófica, sostiene el pensador de la Selva Negra, que el Dasein mismo es entendido desde esos parámetros, lo que significa que se comprende él mismo como estar presente, como Vorhandenheit.

En efecto, como observa K Lehman, al establecer la incompatibilidad existente entre la concepción cristiano-paulino-luterana del ser y la griego-platónica, Heidegger ha encontrado el "punto arquimédico" a partir del cual la interpretación griega del ser y con ella la entera metafísica occidental debía a sus ojos necesariamente hacer crisis. En opinión del joven Heidegger, el pensamiento griego, desde sus mismos comienzos, se habría orientado hacia el modelo del "ver". Los griegos concibieron el pensar como ver y, en consecuencia, pensaron el ser como presencia en el sentido del estar-a-la-vista (vorhanden). El ser así entendido está presente "en" el tiempo, pero solo desde uno de sus modos, el presente. Es claro que desde esta concepción no se puede dar plena cuenta de la facticidad y temporalidad de la vida ni de a experiencia cristiana originaria del tiempo, volcada hacia el futuro"185.

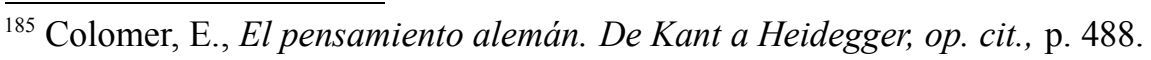


Es precisamente en este sentido del ser como ser a la vista, como presencia constante, pero principalmente como Vorhandenheit que se comprende a la vida humana, por eso ha sido imposible acceder a su constitución originaria. La Vorhandenheit es un concepto fundamental en la filosofía de Heidegger, con este término se alude a una forma de ser que es la absolutamente opuesta a la del ser del Dasein, sin embargo, bajo el influjo de la tradición metafísica, la mayor de la veces se comprende la vida fáctica desde esta categoría ontológica, surgida según él, en el seno de la filosofía griega, como lo señalara posteriormente el Ser y tiempo. Según Kisiel significa presencia, inmediatez, presencia a la mano. En principio empleado terminológicamente para describir lo que está a la mano, (ya ahí disponible a la mano) que se revela en el mundo circundante, y por lo tanto aún no se ha hecho la distinción respecto de lo accesible a la mano (GA63,97/124), igual que en noviembre de 1924. De hecho este término es tan indeterminado que en noviembre de 1924, incluso la facticidad del "yo soy", su qué es se describe en términos de "ser a la mano". El análisis más sutil y preciso se da en el semestre de verano de 1925 en el cual los distintos niveles de presencia inmediata consigue dar con la distinción clara de los modos de encontrarse el desocultamiento entre lo Zuhandenheit y lo Vorhandenes frente a la presencia en el trasfondo del mundo circundante ${ }^{186}$.

Como podemos ver, "el origen y el significado de este concepto están lejos de ser claros. Con toda evidencia, Heidegger lo ha formado de una expresión alemana extremadamente común y que no tiene nada de técnico: "algo es "vorhanden"" es decir: podemos tenerlo, porque lo hay. Esta inapariencia de la expresión la hace difícil de comprender, y prácticamente imposible de traducir" ${ }^{\prime 187}$, dificultad señalada por Brague, que se puede comprobar en las distintas traducciones al español con las cuales se ha vertido este concepto ${ }^{188}$.

Según la interpretación heideggeriana el pensamiento griego desde siempre se habría conducido y comprendido desde la primacía manifiesta del ver, y por ello entendieron el pensar mismo como ver, como contemplación de algo presente en su presencia. Es decir, todo el aparato conceptual de la metafísica se conduce según esa primacía del ver, lo que determina que su modo de acceso a la realidad se funda principalmente en la percepción sensible, con la primacía evidente del ver, por lo cual ha sido imposible pensar el ser adecuadamente. "El pensamiento metafísico no consigue conceptualizar en su originariedad la experiencia fáctica, es decir, históricamente

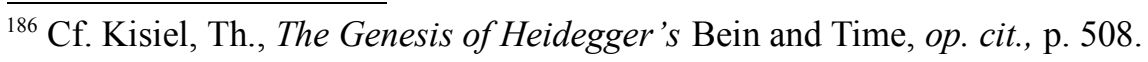

${ }^{187}$ Brague, R. "La fenomenología como vía de acceso al mundo griego. Notas sobre la crítica de la Vorhandenheit como modelo ontológico en la lectura de Aristóteles" en Revista de filosofía (Madrid), nº 6/ vol. 4, 1991, p. 407. Trad. Irene Borges Duarte.

188 "ser ante los ojos" en Heidegger, El ser y el tiempo, op.cit., Trad. J. Gaos; "estar ahí delante", "estar-ahí presente", "simple presencia" en Adrián, J., El lenguaje de Heidegger,op. cit ; "estar ahí dado" en R, Rodríguez., Heidegger y la crísis de la época moderna, op. cit ; "estar ahí" en Ser y tiempo, op. cit., Trad. Jorge Rivera, p. 462, "lo fundamental de la idea de Vorhandenheit es que la cosa simplemente está presente". 
acontecida, de la vida. El pensar orientado hacia el ver apunta a contenidos intrínsecos representables, echando así a perder la cumplimentación irreductiblemente temporal de y acontecida históricamente, la cumplimentación que da madurez y tiempo al tiempo"189. Por lo tanto, en esta comprensión de la vida fáctica como Vorhandenheit no es posible comprender la peculiaridad de la vida fáctica en su temporalidad, en su historicidad, dado que es concebida como un objeto, como un estar ahí delante ante los ojos. En esta primacía del ver, de la intuición, no es posible dar cuenta de este ente que en cada caso somos nosotros mismos. "vivir para los griegos, significa "estar presente". Cuando más constante sea esa presencia de lo que está presente, tanto más intensa deberá ser su vida. Efectivamente, una "vida" así poco tiene en común con la vida facticia del "Dasein", que es más bien una fuga, un fluir perpetuo"190.

Esta primacía de la intuición como fuente de todo conocimiento sitúa a la existencia como un objeto más entre otros objetos de la naturaleza que se puede conocer a través de este ver. Aristóteles hablaba ya de esta verdad de la intuición. Como dice Brague en relación a esto:

Husserl lleva a Aristóteles. Pero lleva también más lejos. Ofrece, en efecto, una formulación explícita del primado de la intuición que quedaba explícito en Aristóteles. Como consecuencia este primado deja de ser evidente para convertirse en una tesis sobre la que cabe preguntarse de dónde la ha extraído Husserl, siendo la respuesta que la recibe de la tradición y, en primer lugar, de su fuente griega, Aristóteles lleva a Husserl. Pero permite, a su vez, sacar a la luz del día "como" presupuesto el primado de la intuición y del objeto de ésta. El dominio indiscutible, por ser inconsciente, de este objeto es lo que define la metafísica. Al modo de ser un objeto tal, Heidegger lo llama "Vorhandenheit"191.

Es precisamente de esto, de lo que se ha de librar la metafísica, para lograr una apropiación originaria de su objeto. $\mathrm{Y}$ es precisamente el dominio de esta forma de entender el ser que por lo mismo implica la forma de entender al Dasein, del que es necesario liberarse, es una insuficiencia de la metafísica, de la filosofía, una estrechez fundamental que reconoce Brague. El reinado de esta concepción del ser como presencia, que concibe a todo los entes del mundo, entre ellos el Dasein, como Vorhandenheit es de lo que es preciso despercudirse para lograr un acceso originario a la vida fáctica en su historicidad.

Tal como comentaba Heidegger en los cursos del verano de 1923, la ontología ha de superar aquellas insuficiencias esenciales, que no le permiten acceder a los problemas fundamentales de la filosofía, puesto que no es a través de la ontología tradicional que podremos dar cuenta de la historicidad del Dasein, su ser histórico, y esto, principalmente porque, "la filosofía estaba cerrada en gran medida a diversos dominios de ser, en que era

\footnotetext{
${ }^{189}$ Pöggeler, O., El camino del pensar de Martin Heidegger, op. cit., p. 51.

${ }^{190}$ Brague, R. "La fenomenología como vía de acceso al mundo griego. Notas sobre la crítica de la Vorhandenheit como modelo ontológico en la lectura de Aristóteles", op. cit., p. 417.

${ }^{191}$ Ibíd., p. 405.
} 
ciega frente a ellos, encerrada y limitada a un determinado círculo del ser, el ser de la naturaleza real de lo físico y lo psíquico, que era considerado el único”(GA21,53/52).

Este concepto de Vorhandenheit extrae su sentido primordial esencialmente desde los entes de la naturaleza, todo aquello que se comprende desde la perspectiva de la naturaleza en general es vorhanden, pero caben aquí también los entes matemáticos, lo utensilios, los demás seres vivos que no tienen la forma de ser de la vida fáctica, en otras palabras podría significar, todo aquello con lo que nos encontramos en el mundo, los entes del mundo, de la naturaleza, en otras palabras, todos aquellos entes que no tienen el ser del Dasein, ese sería el sentido dominante y conductor de la Vorhandenheit. Ejemplo de esto es, que:

en los casos en que la vida humana, el Dasein o el hombre son objetos de un preguntar que interpreta y determina, hallamos que esta objetividad se pre-comprende como un evento mundano, como "naturaleza" (lo psíquico, al igual que el espíritu y la vida se comprenden en una articulación categorial semejante a la de la naturaleza). El hecho de que en la actualidad sigamos de la "naturaleza" del hombre o del alma-o, en general, de la naturaleza de las cosas"- (...) tiene sus motivos histórico espirituales (IN 19/50).

Un ejemplo de esto es para Heidegger la consideración del tiempo propia a la tradición filosófica, cuya tesis dice que "el tiempo es el cielo o bien su cambio repentino" (Física, IV 10, 218 a $31 \mathrm{~b} 8$ ), con lo cual queda del todo manifiesto que el cielo, la naturaleza es el modelo ontológico desde cual se obtiene la idea de tiempo.

Según Brague, Vorhandenheit, y todos aquellos conceptos que giran alrededor de ella se interpretan desde una determinación temporal que es el presente, o "el "ya presente" (schon Anwesende) y que derivaría en último término en la Anwesenheit, concepto que posteriormente Heidegger utilizará de forma recurrente para resumir todos aquellos conceptos del ser ofrecidos por la metafísica" ${ }^{192}$.

De esta forma, al igual que la comprensión aristotélica del tiempo, la Vorhandenheit como concepto que nombra la realidad, lo real, toma como modelo a los entes de la naturaleza, por ello la metafísica aplica a todas sus interpretaciones, ya sea la pregunta por el ser, por el tiempo o por la vida fáctica, el modelo de la naturaleza, por lo que toda interpretación ha de someterse a las categorías que desde allí se obtienen, esto quiere decir, que:

los griegos no se contentaron con lo que se encuentra en el interior del mundo. Pero lo erigieron como modelo de lo que es, según ellos, si queremos comprender lo que significa "ser" tenemos que comenzar por comprender lo que significa "ser" para las realidades del mundo. Según Heidegger, es un estrechamiento idéntico el que nos encontramos a lo largo de la historia de la metafísica. El modelo de lo que puede presentarse como ser, aquel que tenemos que elegir para leer en él lo que significa "ser" sigue siendo substancialmente idéntico"193,

\footnotetext{
${ }^{192}$ Cf. Ibíd., p. 408.

${ }^{193}$ Ibíd., p. 409.
} 
En esto radica la principal dificultad a la hora de plantear al pregunta por el ser, por el Dasein, por el tiempo, en virtud de que ninguno de estos fenómenos tiene el carácter de ser un ente de la naturaleza al modo como encontramos las cosas que nos hacen frente en el mundo, por el contrario, tienen precisamente otra constitución que la del estar ahí presente frente a los ojos, como un objeto de posible contemplación y estudio. Y por ello, precisamente no pueden ser definidos como entes meramente presentes. Además:

El modo de presencia considerado como paradigmático es aquel de lo que es permanente.

"Según el modelo antiguo de ser, es auténticamente lo que es siempre. "Ser" significa estar presente, porque el tiempo presente es la dimensión de la percepción, es decir de la aprehensión de lo que es "vorhanden". Esta unión explíca por qué la crítica de la "Vorhandenheit" va necesariamente acompañada de la crítica del primado de la percepción, tal y como reina indiscutiblemente desde los orígenes hasta Husserl ${ }^{194}$

Como puede observarse, esta crítica del filósofo alemán a la consideración del ser como simple presencia, tiene múltiples consecuencias y podríamos decir que influencia todas las esferas de la reflexión filosófica. Esta crítica a la percepción visual como modo privilegiado de conocimiento, que ya habíamos tratado en el análisis de los cursos de fenomenología de la religión, muestra ahora claramente, que detrás de la crítica a la percepción visual, a la Vorhandenheit, se esconde principalmente el cuestionamiento a la interpretación del ser que las determina e influencia, puesto que, el tiempo presente es la dimensión temporal de la percepción y de la Vorhandenheit. Cuestión que si bien Heidegger a principios de los años 20 , no tenía tan claro, ahora, que ya ha dado con la cuestión del ser y el tiempo, ya comprende y ve desde todas sus perspectivas y conexiones ontológicas.

Para los griegos "lo que hay de mejor podrá ser, o bien las ideas, o bien el universo que está dotado de la capacidad de aprehender lo que es "vorhanden" en grado supremo; en todas los casos, "la Vorhandenheit"será el criterio último"195, este criterio último que se aplica a todos lo entes y que mide la realidad en todas sus formas.

El Dasein no es un ente que perviva eternamente como el cosmos o los cuerpos celestes, ni tampoco tiene el carácter de los entes matemáticos, sino que su ser es histórico, se prolonga entre el gestarse de la vida y su muerte, en su constitución es historicidad, existencia. A juicio de Brague en esta interpretación metafísica propia de la filosofía griega, subyace una consideración sustentada esencialmente en la física, lo que indicaría que la metafísica adquiere su fundamento y raíz desde la física ${ }^{196}$.

Significa entonces, que filosofía griega extrae sus conceptos ontológicos tomando como principal punto de referencia a los entes de la naturalezas, principalmente el cielo, el cosmos que es presencia constante, por esta razón, la cuestión del ser no ha podido ser

\footnotetext{
${ }^{194}$ Ibíd., p. 417.

${ }^{195}$ Ibíd., p. 418.

${ }^{196}$ Cf. Ibíd., p. 419.
} 
planteada desde parámetros que nos aseguren un acceso adecuado al fenómeno cuestionado. El problema radica en que, "la cuestión acerca de la estructura del ser del mundo se ha planteado siempre en cuanto pregunta por la estructura del ser de la naturaleza, y no solo hoy en día o desde que hay ciencia moderna de la naturaleza, sino en cierto sentido ya desde los griegos, de modo tal que el acervo completo de conceptos de que disponemos para caracterizar el ser del mundo tiene sus raíces en esa manera de contemplar el mundo, tomándolo en cuanto naturaleza"(GA20,231/216), es este mismo estado de cosas es el que ha llevado a que incluso el tiempo histórico sea considerado desde la perspectiva de las ciencias naturales, tal como Heidegger lo planteaba en su lección de habilitación el concepto del tiempo en la ciencia histórica.

Teniendo en cuenta esto, es que se hace imprescindible si se quiere avanzar en la dirección correcta, someter a un cuestionamiento estas interpretaciones que comprenden todos los fenómenos como si fueran entes de la naturaleza, es decir, todo se considera desde una perspectiva eminentemente física, "en otros términos, la metafísica tiene que constituirse como metafísica en y por una "física"(...) se trata más bien de que la existencia misma de una física, existencia que por otra parte, no es nada evidente, supone el acceso a la dominación del paradigma ontológico de la "Vorhandenheit", acontecimiento que no podría ser establecido por la física, pero que define la constitución de la metafísica; por lo cual la física es como una metafísica" ${ }^{\text {197, }}$, lo que con esto se quiere decir, es que esta crítica de Heidegger a la Vorhandenheit está principalmente dirigida a Aristóteles, que en su Física, "está ocultando lo que en él es decisivo para la fundación de la filosofía occidental como metafísica, a saber el hecho de que la física, en este caso, es en él metafísica, y a la inversa(...) La metafísica tradicional sigue siendo una física(...) La "Física" de Aristóteles es el libro que funda la metafísica porque introduce un conjunto de conceptos que suponen y consolidan todos el modelo de la "vorhanden" como tal"198. En consecuencia, lo que Heidegger quiere destacar es que no puede ser la naturaleza el modelo o la imagen desde las que se proyecten todos los fenómenos y los problemas fundamentales de la filosofía.

No obstante, el filósofo alemán entiende que esta actitud que prevalece en la filosofía no es algo casual o simplemente accidental, sino que más bien responde a una constitución ontológica del Dasein, por eso, dice por ejemplo, que "el intento de aplicar a la existencia humana el esquema de perfección de la naturaleza celestial no es más que otra expresión de esta disposición a caer presa del mundo"(NB, 10/39), por ende, no se debe entender está crítica que plantea Heidegger a la filosofía griega como un malentendido que podamos superar una vez conducida la reflexión filosófica a un nivel superior, que sea capaz de corregir dichas interpretaciones, sino que más bien, Heidegger señala que dicha posición tiene su raíz en la misma constitución ontológica del Dasein, en

\footnotetext{
${ }^{197}$ Ibíd., p.418.

${ }^{198}$ Ibíd., p.419.
} 
cuanto disposición a caer en el mundo de los entes que nos hacen frente, a la caída de la existencia, dado que "esta propensión a quedar absorbido por el mundo es el destino más íntimo que afecta a la vida fáctica"(NB, 10/39). Por ahora esta cuestión solo queda enunciada para no llevar a malos entendidos, luego en el análisis de la estructura ontológica del Dasein volveremos sobre ello.

El Dasein es un ente histórico, no porque pasa en el tiempo, sino porque él mismo es historia, no es un ente más de la naturaleza, o un objeto más para la filosofía, sino que es el ente desde el cual y para el cual la filosofía es lo que es. La vida fáctica, el Dasein, no es un objeto más de conocimiento,

\begin{abstract}
no es una postura que quepa tomarse, explícita o tácitamente, sino algo en lo que siempre ya nos encontramos, origen entonces de toda posición posible. Ahora bien, en este estrato originario, el hombre no se aparece a sí mismo como un ser natural más de los que pueblan el mundo. Tal visión no responde a lo que se da como tal, sino a la adopción inadvertida de un preciso y tradicional sentido de ser, el de la cosa que está ahí dada (realitas, Vorhandensein) y cuyo correlato es una actitud esencialmente teorética, una mirada que contempla y objetiva ${ }^{199}$.
\end{abstract}

\title{
I. El SENTIDO DEL SER COMO OUSÍA Y SUBSTANCIA
}

Dentro del ámbito de reflexión filosófica que abre Heidegger respecto a la comprensión del ser en términos de presencia heredado de la filosofía griega, que interpreta a todos los entes desde el modelo ontológico de la Vorhandenheit, sostiene el pensador de la Selva Negra que dicha interpretación griega se sustenta en el privilegio de una concepción del ser por sobre cualquier otro sentido del ser.

A Heidegger desde un comienzo le había interesado de sobremanera el problema de los múltiples significados del ser, o de la multiplicidad de sentidos que poseía el concepto del ser. Teniendo en cuenta esto, ha llegado a concluir que el sentido del ser que mantenía un nivel superlativo de influencia, que dominaba y subyacía en esta interpretación de la filosofía griega, aunque de forma inconsciente, y que aplicaba su modelo a todos los entes, era la categoría de substancia. Además, ello determinaba de alguna forma a toda la metafísica posterior, lo que significa que la entera tradición filosófica "se ha movido preferentemente dentro del marco de una ontología de las "cosas" (res), es decir, realista: aquel modo de pensar el ente según el cual las cosas, las substancias, son el modelo y punto de referencia de todo ente en general; cualquier otro modo de ser se lo refiere, de manera privativa, a la substancialidad" ${ }^{200}$, por consiguiente, esta interpretación según la cual la substancia, la ousía es el modelo, el espejo sobre el cual se han de proyectar todos los entes, incluida la vida fáctica, es el punto de partida desde el que se ha originado esa consideración del Dasein como Vorhandenheit. Por lo

\footnotetext{
${ }^{199}$ Rodríguez, R., Heidegger y la crisis de la época moderna, op. cit., p. 41.

${ }^{200}$ Carpio, A., El sentido de la historia de la filosofia, Eudeba, Buenos Aires, 1977, p.203.
} 
tanto, esta es una de las interpretaciones que Heidegger intenta superar, porque oscurecen completamente la pregunta por el ser del Dasein e imposibilitan cualquier acercamiento a la pregunta por el ser mismo, puesto que, "las "categorías" de la filosofía tradicional-“substancia", "sujeto", "realidad" (realitat), etc.-son radicalmente ineptas para apresar y expresar el ser del hombre, puesto que están pensadas solo en función y a partir de los "vorhanden"",201.

Así pues, todos los entes caen presa del influjo de esta interpretación, que sería la que guía toda exégesis filosófica, lo que significa que determinación se transforma en el modo privilegiado y casi exclusivo de considerar los entes y pregunta por un qué inalterable, como un rasgo que identifica al ente de modo invariable, y que se mantiene constante, lo que constituiría propiamente su naturaleza a la que se refieren y relacionan todas las demás características que dicho ente pueda poseer, sería entonces un sustrato último sobre el cual se asientan todas las características y rasgos de un ente, el filósofo nativo de Messkirch comenta al respecto, que "al hablar de una substancia, la mayoría de las veces está hablando en sentido estricto de substancialidad, y la substancialidad es una manera de ser, es decir: el modo primario de ser que puede convenir a un ente. Lo entes, las cosas que son, en el más amplio de los sentidos, que tienen el modo de ser de la substancialidad, son substancias" (GA20,216/232). En consecuencia, el modo fundamental de ser de todo ente se concibe según esta substancialidad, que parece dominar y determinar toda meditación respecto a la realidad, todo ente es entendido bajo la categoría de substancialidad, lo cual significaría que todos los entes son substancias. Heidegger precisa que el concepto susbtantia tiene un significado dual: por una parte, significa el ente mismo que tiene la forma de ser de la substancia, y por otra, la substancialidad, que tiene que ver con una distinción entre el mundo en tanto cosas y entes que están presentes en el mundo y la mundanidad como forma de ser propia del mundo.

Heidegger precisa aún más en el concepto de substancia y apunta que, "por substancia no cabe entender sino algo que "es" de manera tal que no necesita de ningún otro ente. Substancialidad significa estar-ahi (Vorhandenheit), lo que en cuanto tal no necesita de otro ente. La realidad es una res, la substancialidad de una substancia, el ser de un ente significan en sentido estricto: estar-ahí sin necesidad de nada (Vorhandenheit im Sinne der Unbedürftigkeit), ni un productor ni un ente que conserve o soporte lo producido" (GA20,217/233). Por tanto, esta interpretación dominante de un sentido del ser - la substancia-, sería el fundamento que influencia y determina a la tradición filosófica, según la cual interpreta a los entes del mundo y guía al mismo tiempo su interpretación del ser, razón por la cuales sobre esta interpretación dominante del ser, razón por la cual no puede salir del cerco de un pensamiento que todo lo entiende en términos de substancia, derivando en una consideración substancialista del mundo y de la existencia, que todo lo

${ }^{201}$ Ibíd., p. 204. 
mide en términos de presencia constante, que sería la forma eminente de la compresión del ser, de la existencia como ousía, como substancia.

Heidegger se refiere a esta relación de equivalencia entre ousía y substancia de la siguiente forma:

el término ousía, que de modo tan totalmente absurdo se ha ido divulgando en la historia de la filosofía como substancia, no significa otra cosa que la comparecencia en un sentido que hay que captar de modo determinado. Pero aquí es necesario enfatizar que aunque los griegos, Platón y Aristóteles, definen el ser como ousía, estaban muy lejos de comprender que significa en realidad determinar el ser como comparecencia y presente (wenn sie das Sein als Anwesenheit und Gegenwart bestimmen) (GA21,193/158).

En palabras del profesor Heidegger, ni Platón ni Aristóteles fueron capaces de avizorar que en su conceptualización de ser en términos de ousía, se ocultaba una conexión fundamental del ser con el tiempo, en ese desconocimiento se incoaría uno de los olvidos esenciales de la filosofía griega o un desconocimiento, en términos de no haberse hecho cuestión ni haber reconocido esa interna conexión entre ser y tiempo, que sería la idea rectora de la metafísica inaugurada por ellos, que señala que el ser es entendido en términos de presencia.

El pensador alemán puntualiza que en la interpretación de la ovoı́ que la entiende como substancia opera un malentendido, dado que si ovoı $\alpha$ es considerada en su sentido primigenio, este no se correspondería con el significado de substancia, según Heidegger, "ovoı $\alpha$ todavía conserva, en Aristóteles mismo e incluso más tarde, el sentido originario practico de bienes familiares, de bienes patrimoniales, de bienes disponibles para el uso en el marco del mundo circundante. El término ovoı $\alpha$ designa, pues, "bienes", "posesión", "propiedad", "hacienda". Aquello que en el trato custodiado como el ser del ente, aquello que caracteriza al ente como bien, posesión, propiedad o hacienda es su ser producido (sein Hergestelltsein)" (NB, 27/58), lo que se pretende con esto es recuperar el sentido originario de la expresión, sin embargo, esa equivalencia queda sin ser cuestionada en su procedencia y se convierte en un concepto obvio, profundizando en esta cuestión, señala que, "para los griegos "ser" significa: disponibilidad, presencia. Todavía en Aristóteles la palabra ovoı $\alpha$ conserva tanto el significado terminológico como el sentido originariamente más concreto de patrimonio, posesión, hogar-propiedad, $\pi \alpha \rho o v \sigma \iota \alpha$, "presente" únicamente refuerza el sentido ontológico primario de ovoı $\alpha$ " (GA64,100/127), por lo tanto, este concepto tendría un doble significado, sin embargo, siempre sería entendida unilateralmente desde la perspectiva de la presencia, es entendida como substancia.

Todo esto Heidegger lo ratificará más tarde, en sus lecciones de lógica, en el contexto de su crítica a Lotze, señala que en la interpretación que este último hace de Platón, sigue hablando desde el presupuesto de que ousía significa substancia, e incluso hipóstasis, lo cual sería según el filósofo alemán, “un giro tardogriego de la expresión que 
no acierta en absoluto con el significado del término. Ousía no significa substancia, cosa, algo, real, "existente" en el sentido de Lotze; ousía es lo que comparece, o la comparecencia, lo siempre presente" (GA21, 71/65). De esta forma, Heidegger reafirma su rechazo a la interpretación que vincula y convierte en equivalentes a estos conceptos que son claves en la filosofía griega, pero sí deja claro que ovoı $\alpha$ originariamente significa presencia, presente. No obstante, puntualiza que la filosofía griega no es el lugar desde donde surge esta equivalencia entre ousía y substancia, lo que nos indica que sería una formulación posterior carente de legitimidad en cuanto a su origen. Heidegger pretende con esto hacerle justicia a Platón y Aristóteles, en torno a cuestiones que él considera manifiestos malentendidos respecto a algunos de sus más importantes planteamientos filosóficos.

Según Rodríguez, "si el análisis de Heidegger es correcto, la permanencia en la presencia no es una idea explicitada por el pensamiento griego como un carácter de ser, no coincide con ninguno de los sentidos de ente, pero sin embargo está latiendo en ellos y gobierna la idea de la primacía de la ousía (sustancia)sobre los demás sentidos de ser" ${ }^{202}$, según esto, Heidegger ha podido identificar en la filosofía griega aquel sentido dominante y eminente del ser para los griegos, y esto, desde la misma filosofía de Parménides, con lo cual ha dado de bruces con aquella comprensión del ser que ha determinado la historia de la filosofía, y que de una forma u otra a conducido, influenciado, determinado toda consideración del ser del ente, no solo en la filosofía griega -cuestión que sin embargo no era consciente para los griegos, no se hicieron cuestión de ello-, sino que su influjo y poder se mantiene hasta nuestros días. La preocupación inicial de Heidegger por los múltiples sentido del ser, por la diversas formas de nombrarlo, le han permitido reconocer aquel sentido dominante sobre el cual se fundamentan y sostienen los demás sentidos del ser, cuestión que ha determinado a la tradición a interpretar el ser desde este sentido eminente y privilegiado, y a juicio del pensador alemán esto es algo bastante peculiar, incluso dice que "resulta llamativo el hecho de que los griegos interpretaran el ser a partir del tiempo: ousía significa presencia, presente. Porque el ser significa esto, se puede decir que el verdadero ser es aquello que jamás está ausente, es decir, lo que está siempre ahí: aei on"(KV,176/97), entonces, el verdadero ente, el ente por excelencia es el que está constantemente ahí, que está presente en grado máximo.

\section{J. Dios como substancia Perfecta, LA PReSEnCia CONSTANTE POR ANTONOMASia}

Este diagnóstico que Heidegger presenta respecto al sentido primario del ser como substancia, nos conduce más allá, en una dirección propiamente teológica, hacia la consideración de aquel ente en el que se materializan, por decirlo así, todos los atributos y las características de la interpretación del ser que el filósofo de la Selva Negra ha reconocido como la determinante de la filosofía griega, la que gracias al poder de su

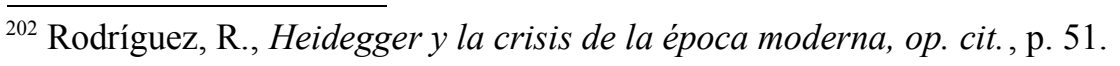


influjo ha influenciado y determinado la historia de la filosofía occidental. En la discusión que sostiene con la filosofía medieval en Prolegómenos para una historia del concepto del tiempo, principalmente en su interlocución con Descartes, señala a grandes rasgos que si la substancia es aquello que subsiste, que tiene una presencia constante que subyace a cualquier tipo de cambio o modificación y que posee una constitución que no necesita de ningún otro ente para ser tal, necesariamente se ha de tomar como referencia al ente que es el modelo eminente y privilegiado de la substancialidad, de la presencia constante, Heidegger sostiene que:

El único ente que satisface el sentido mencionado de substancialidad es Dios. En otros
términos: términos "Dios" es el nombre del ente en que se realiza en sentido auténtico la
idea de ser. Aquí "Dios" es sencillamente un concepto puramente ontológico y por eso se
llama también ens perfectissimun. En esta caracterización del ser de Dios no hay nada en
absoluto de religioso, sino que Dios es sencillamente en nombre del ente en que
comparece ante nosotros lo que verdaderamente es, dicho sea en el sentido del concepto
de ser que es el estar-ahí (Vorhandenheit). Dios es, por lo tanto, la única substancia, esto
es, lo único ente, lo único que- en sentido supuestamente "verdadero" de ser- es ( GA 20,
233/217).

Por lo tanto, Dios es el ente que representa de forma cabal la concepción del ser de la filosofía griega, en términos de presencia constante, es la substancia por definición, empero, a este concepto no se le debe conferir una connotación religiosa, sino que más bien nombra el ente perfecto, que es substancia por antonomasia y que posee todos aquellos atributos que caracterizan la comprensión del ser dominante en la tradición metafísica y que han permanecido inconscientes. La historia de la filosofía no se ha cuestionado la validez y la proveniencia de esta interpretación del ser y su conceptualidad. En esta exégesis el ser y el ente permanecen sometidos a esos criterios ontológicos que les suministra esta idea de ser, según la cual se comprenden como presencia y simple estar ahí presente, cuestión que ni siquiera los griegos, quienes formularon por vez primera esta interpretación del ser y el ente, fueron capaces de ver con claridad.

Interpretación que sostiene todos los entes para ser tal necesitan de la presencia y del estar ahí delante del ente que es substancia perfecta, por lo cual, todo ente que no tiene la constitución ontológica de Dios, necesita en virtud de su propio sentido ser mantenido y producido, en cambio Dios en su estar-ahí no necesita de ese algo otro para ser lo que es, es propio de él la falta de necesidad. El ente creado es aquel que ser tal, para estar-ahí, necesita ser producido porque no subsistente por sí mismo, su ser verdadero en el ens creatum.

"Ser" significa aquí ser producido, siguiendo el hilo conductor de este sentido del ser se determina también el ser de Dios (de lo no producido). Pero este concepto es el de la ontología griega. Solo que, por decirlo así, ha sido arrancado de sus raíces griegas y ha quedado suspendido en el aire, es decir, se ha convertido en un concepto "obvio". Sin embargo, para los griegos "ser" significa disponibilidad, presencia. Todavía en Aristóteles la palabra ovota conserva el sentido tanto el sentido terminológico como el sentido 
originariamente más concreto de patrimonio, posesión, hogar-propiedad, $\pi \alpha \rho o v \sigma \iota \alpha$, "presente" únicamente refuerza el sentido ontológico primario de ovoı $\alpha$. Solo con la elaboración de este sentido del ser se hacen comprensibles las distinciones ontológicas fundamentales de la ontología griega prefiguradas por Parménides (GA64,100/127).

Dios cumple con ese carácter de ser que es presencia constante, en cuanto, es aquello que subsiste de forma indefectible, que no necesita de algún otro ente para ser tal, es el ente subsistente por definición, no por nada es el ente eterno, cuya presencia es constante de forma indefinida y absoluta. Por ello, es el ente absoluto y supremo de la metafísica.

\section{K. LA INSUFICIENCIA ONTOLÓGICA DE LAS CONCEPCIONES GRECO-CRISTIANAS DEL HOMBRE}

En la elección del término técnico Dasein está en juego precisamente la intención de liberar la reflexión ontológica acerca de la vida humana, de la existencia, de esta influencia del concepto de Vorhandenheit que caía sobre ella. Esto, a raíz de que la mayor parte de definiciones que intentan dar cuenta de esta realidad que en cada caso somos nosotros mismos, está fuertemente influenciada por esta forma de pensar de la filosofía griega, según la cual todo fenómeno se considera desde el modelo de la naturaleza, desde el cosmos. Situación interpretativa que conduce a que muchas otras consideraciones, que siguiendo la misma línea, obtiene su fundamento desde una fuerte raigambre teológica, cuya proveniencia tiene influencias griegas que no han sido suficientemente cuestionadas. Entre las que se encuentra la interpretación de la vida fáctica como hombre, animal racional o persona, que a juicio de Heidegger no serían acertadas, en virtud, de que no se obtienen desde una experiencia o interpretación originaria de este fenómeno, por lo que impiden poder ver aquello que justamente se ha de tomar en cuenta en una meditación filosófica originaria de este ente en cuestión: su facticidad. Por eso dice Heidegger:

\footnotetext{
al llamar "hombre" al existente que se va a investigar se le pone de antemano dentro de una determinada concepción categorial, puesto que el examen se lleva a cabo siguiendo la pauta de la definición tradicional de "animal racional". Con tal definición por pauta viene prescrita la descripción de una perspectiva determinada, sin que con ella se recuperen activamente, haciéndolos propios, los motivos originarios de tal perspectiva(...) la perspectiva que se tiene del hombre según la pauta de la definición de "animal rationale" hace que se le vea dentro del ámbito de los entes que junto con él existen en el modo de lo viviente (plantas, animales) (GA63,27/48)
}

En otras palabras, esto significa que se le considera desde el horizonte de la naturaleza y, por ello, cuando se habla de hombre, de animal racional, ser vivo, se oculta el ámbito intuitivo desde el cual se origino esta interpretación del ser de la vida fáctica."Heidegger somete a una severa crítica a la que podríamos caracterizar haciendo observar que se ve en la definición clásica del hombre como animal racional una suerte de tautología en la que el género próximo, y tanto como él, la diferencia específica, remiten ambos al mismo modelo ontológico, la "Vorhandenheit", modelo que conviene al "hombre", pero de ninguna modo 
al Dasein"203. Precisamente por esta interpretación del ser como presencia, que considera al Dasein como Vorhandenheit, se sigue esa vía que concibe todo pensamiento como ver, como intuición, como un preguntar que objetiviza y determina todo fenómeno y lo reduce a naturaleza, de tal forma, que:

lo psíquico, al igual que el espíritu y la vida se comprenden en una articulación categorial semejante a la de la naturaleza(...) el hecho de que en la actualidad sigamos hablando de la "naturaleza" del hombre o del alma-o, en general, de la "naturaleza de la cosa"-así, como el hecho de que sigamos refiriéndonos a estos objetos en términos categoríales (es decir, que hagamos uso de categorías surgidas de una determinada explicación y de una determinada visión de la "naturaleza"), tiene sus motivos históricos-espirituales(NB, 19/50),

Todas estas son cuestiones que hemos puesto de manifiesto anteriormente, es decir, son consecuencias directas de la comprensión del ser que prevalece en la filosofía occidental y que considera a todos lo fenómenos según el modelo de la naturaleza. Es justamente desde este tipo de objetividad y sobre este carácter ontológico del ser como presencia constante, que se interpreta y caracteriza a este ente llamado hombre, las distintas interpretaciones de este ente, que se obtienen desde diversos ámbitos sus presupuestos, todas ellas coinciden en sustentar su idea de la vida humana desde esta presuposición ontológica que domina toda la doctrina del ser de la metafísica.

Según lo expuesto anteriormente, se hace evidente la importancia y el alcance que tiene para la filosofía de Heidegger y para su crítica de la tradición metafísica este descubrimiento esencial con el que ha dado en estos años de su andar filosófico. El sentido ontológico que guía desde siempre la determinación de la vida humana se sustenta en una comprensión del ser que ha sido insuficiente e impotente para dar cuenta de la constitución esencial de este ente, ello por su proveniencia de una comprensión del ser eminentemente naturalista, física, que no le permite acceder a este ente que es finitud, que es historicidad.

No se puede comprender el ser o la vida fáctica desde el ámbito de las cosas naturales o desde un horizonte que lo considera como un objeto que se intenta determinar teoréticamente al modo de un ente de la naturaleza. Por esto, el rumbo de debe seguir nuestra investigación queda dado de antemano, se han de comprender las motivaciones y los fundamentos que guiaron las interpretaciones precedentes -y en las que se originan- $y$ poder así obtener un terreno verdaderamente firme sobre el cual solventar una interpretación que tenga la posibilidad de acceder a este fenómeno desde una perspectiva originaria, por eso Heidegge sostiene:

Si se trata de investigar al Dasein en términos ontológicos, para semejante interpretación la situación hermenéutica no puede estar entonces determinada por el concepto de ser que se obtiene del mundo (...) sin embargo, con el dominio ejercido por la ontología griega en la historia de nuestro propio Dasein y en la historia de sus interpretaciones (véase la lógica

${ }^{203}$ Brague, R.,"La fenomenología como vía de acceso al mundo griego. Notas sobre la crítica de la Vorhandenheit como modelo ontológico en la lectura de Aristóteles", op. cit., p. 414. 
de Hegel) queda encubierto el acceso ontológico al Dasein. Poner al descubierto al Dasein significa despojarlo esa ontología griega que ha devenido obvia y cuyo dominio apenas resulta visible, así como desmantelar las tendencias de investigación dominadas enteramente, de tal manera que se haga patente el verdadero fundamento del Dasein" (GA64,102/130).

\section{Capítulo VI: Lógica filosofante, la pregunta por el ser y su vinculación con el tiempo}

Como hemos señalado, Aristóteles es un interlocutor de primera línea para Heidegger. Tal como señala en el Informe Natorp el Estagirita elabora su edificio filosófico sobre dos pilares fundamentales: la ontología y la lógica, y lo hace por medio de una radicalización de la idea de movimiento, cuyo sentido directivo es el ser como producido. El filósofo alemán ve en esta cuestión una confusión elemental de la exégesis ontológica operada por Aristóteles, lo que le ha llevado a un cuestionamiento del origen y la procedencia de tales interpretaciones, por lo tanto la lógica también debe ser objeto de investigación, para desencubrir los prejuicios y equívocos en los que se sustenta, pero además es indispensable verificar la validez y procedencia de las exégesis que le anteceden. El objetivo de la investigación es reconocer los motivos ocultos que guían las interpretaciones precedentes en las que se sustenta la lógica de escuela y al mismo tiempo mostrar la posibilidad de una lógica filosofante capaz iluminar las tendencias fundamentales que se esconden tras las interpretaciones heredadas de la tradición. Esta es la pretensión que guía la labor filosófica de Heidegger en esos momentos en que su filosofía da pasos importantes en la elaboración de un constructo filosófico plenamente ajustado.

Dice Heidegger en el Informe Natorp, en una referencia a los motivos concretos que guiaron la problemática lógica y ontológica en Aristóteles, que desde ahí "resulta evidente en qué medida la ontología particular de una determinado nombra discursivo se convirtieron, siguiendo la propensión a la caída de la interpretación, en la ontología y en la lógica que de una manera decisiva pasaron a dominar no solo su propia historia, sino también la historia del espíritu mismo, es decir, la historia de la existencia" (NB, 49/83). Heidegger entiende que Aristóteles elabora su ontología y su lógica con base a una radicalización ontológica de la idea de movimiento y actividad, ideas que determinarían la historia de la lógica y de la ontología, lo que indica que no solo influenciaron su propio ámbito de dominio, por decirlo así, sino que también la historia del espíritu, la historia de la existencia misma, esta es la razón por la cual debemos volver sobre las interpretaciones que dieron origen y que determinan la historia del pensamiento occidental.

En una primera aproximación hemos podido ver algunas pinceladas del ejercicio heideggeriano de destrucción de la historia de la metafísica, esto por medio de la exégesis 
respecto a la proveniencia de las categorías ontológicas que poseen la primacía al momento de plantear la pregunta acerca del ser del ente o la pregunta por el ser mismo.

Si tanto la lógica como la ontología se presentan como los pilares fundamentales en los que se sostiene la filosofía de Aristóteles y por ende la tradición filosófica, una vez que ya se ha puesto en cuestión la problemática que se escondía en la ontología aristotélica, Heidegger estima pertinente preguntar por aquella otra raíz que guía el pensamiento del Estagirita, la lógica. Dentro de esta órbita meditativa, surgen algunas preguntas que tienen que ver con la pertinencia de la pregunta por la lógica: ¿Tiene algo que decir la lógica frente a la problemática ontológica que estamos investigando? ¿ La lógica guarda alguna relación con la pregunta por el ser? ¿Existe relación entre la lógica y la pregunta por la temporalidad humana? ¿Como entiende Aristóteles la lógica? Estas son algunas de las interrogantes que pueden surgir en un primer acercamiento a la problemática lógica, dentro del contexto en que se ha planteado el presente trabajo.

Dentro de este contexto están las lecciones de lógica que el autor alemán dictó en el semestre de invierno de 1925-1926 en la Universidad de Marburgo, publicado con el título de Lógica: la pregunta por la verdad, ( Logik: Die Frage nach der Wahrheit), lecciones de una importancia señalada. Una de las cosas que desarrolla ahí, es la distinción entre la lógica de escuela y la lógica filosofante. En este curso plantea un ejercicio destructivo de la historia de la lógica, además denuncia la impotencia e incapacidad de la lógica contemporánea, lo cual le lleva a proponer la necesidad de una vuelta a Aristóteles para reinterpretar originariamente sus escritos y tratar de encontrar en ellos una interpretación genuina acerca de la verdad, que se contraponga a la concepción de la verdad como validez. Esto, puesto que:

la definición de la verdad también se rige en primer lugar y en lo fundamental según este modo de discurso como proposición enunciativa, es decir, este descubrimiento enunciado del ente es verdadero. En consecuencia, la verdad del conocimiento teoréticamente científico pasó a ser la forma fundamental y primigenia de verdad en general. La verdad del conocimiento obtuvo una prioridad universal; en tanto que otras formas de verdad aparecieron luego en el foco de la reflexión, fueron medidas conforme a la verdad del conocimiento y comprendidas como derivaciones o modificaciones de esta" (GA21, $11 / 19)^{204}$.

Para Heidegger es fundamental que la verdad se abra a su ámbito más propio que es la cuestión del ser, este camino ha de conducirnos obligatoriamente hacia el horizonte de la temporalidad del Dasein. Dentro de los parámetros que fija nuestra investigación, mostraremos de qué forma interpreta la lógica el pensador alemán y cómo ella adquiere un lugar de privilegio e ilumina este proyecto filosófico que Heidegger propone, cuyo interés primordial es iluminar la pregunta por el ser y su intrínseca vinculación con el tiempo y con la temporalidad originaria peculiar al Dasein. Se hará visible entonces la de qué modo se manifiesta la problemática ontológica del advenir en el contexto de estos cursos de

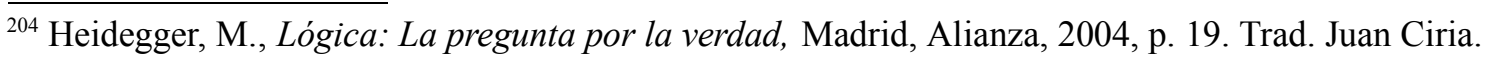


lógica y la importancia que adquiere dicha cuestión al interior de la lógica filosofante que Heidegger plantea. Para todo esto, es indispensable una vuelta a Aristóteles, una destrucción de la tradición en su interpretación de la lógica, por lo cual se ha de volver a los textos del pensador de Estagira. Esto, principalmente porque, "la tradición manifiesta, la tradición en su capa más aparente, no solo ha transmitido que el lugar de la verdad es la correspondencia entre el pensamiento y el ente sino que adjudica a Aristóteles la responsabilidad - y la autoridad- de esas dos tesis" ${ }^{205}$. En estas tesis, Heidegger reconoce el origen de los principales malentendidos con los que se debe lidiar, lo que significa que su validez ontológica debe ser cuestionada, para así poder reconocer los fenómenos originarios que subyacen en aquellas interpretaciones, de las cuales Aristóteles sería el responsable y autor.

\section{A. LóGiCA DE ESCUELA Y LÓGICA FILOSOFANTE}

Lo primero que haremos será enfocar nuestra atención en la discusión que Heidegger mantiene con la lógica de escuela, a la que enfrenta de forma vigorosa, a través de su apuesta por una lógica filosofante ( philosophierenden Logik). Al parecer, el filósofo alemán no tiene una buena opinión de la lógica tradicional de escuela, es más, siente una especie de desprecio por ella, o al menos es lo que parece al tomar nota de las referencias que hace de ese tipo de lógica, que según él, no se sabe bien que cosa es, dado que ella "no es ni filosofía y ni siquiera una ciencia particular (...)una comodidad para el docente, en tanto que no da más trabajo que volver a repetir un inventario fijo y masticado de enunciados, fórmulas y reglas y definiciones. Las diferencias en la exposición de esta lógica se limitan a las diferencias de la disposición externa, del grado de minuciosidad, de la elección de los ejemplos" (GA21,12/20). Son evidentes los reparos que Heidegger tiene con la lógica de escuela, opinión que dista mucho de ser benevolente, apenas siquiera para decir respetuosa, sin lugar a dudas es una crítica aguda y descarnada, esa lógica no puede pretender ser filosofía, ni siquiera llega a ser una ciencia especial, es más que nada una comodidad para esos profesores, que solo repitiendo ejercicios, esquemas, fórmulas, definiciones, ponen en ejercicio esa lógica, en ella "el lógico jamás entra el peligro de tener que pagar consigo mismo, una necesidad a la que está encadenada todo filosofar" (GA21,12/20). Sin embargo, esta lógica que el pensador alemán crítica ácidamente no ha nacido recientemente, sino que más bien tiene una larga data, que va hasta mucho antes de la edad media.

Según el filósofo de la Selva Negra, este modo de concebir la lógica solo sería consecuencia de que la lógica desde su génesis fue producto de la decadencia, su propio punto de partida es el decaimiento mismo de un preguntar verdaderamente originario porque, "la lógica tradicional de escuela es el contenido enajenado, desarraigado y por tanto anquilosado de un preguntar filosófico original que en Platón y Aristóteles era

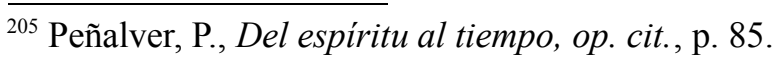


viviente, un preguntar que el anquilosamiento escolástico asfixió por completo" (GA21,13/20). Tal como podemos ver, este desprecio por la lógica de escuela, que expresa Heidegger, no nos debe conducir a confusiones, en cuanto a sus intenciones, lo que pretende con esto es obtener una apropiación originaria de sus fundamentos, de la verdad que esconde en ellos, como un preguntar filosófico original que era viviente, dinámico, pero que terminó siendo desarraigado y enajenado de su ámbito ontológico, por lo tanto, "el rechazo de la lógica de tradicional de escuela que se ha señalado no es por consiguiente otra cosas que la tendencia a la apropiación filosófica del auténtico contenido filosófico que se encierra en ella" (GA21,18/25).

La pregunta verdaderamente fundamental para una lógica filosofante no tiene nada que ver con una meditación que oriente sus esfuerzos al reconocimiento de las distintas teorías o presupuestos que regirían la verdad, la pregunta esencial de la lógica filosofante es: qué es la verdad, esta lógica señalada es el recorrido de un preguntar que se dirige por ella misma. Solo en este modo de proceder se hace posible entender las distintas formulaciones interrogativas que adelantaron este preguntar por la verdad y reconocer en ellas sus insuficiencias, en consecuencia, "es inherente a la limitación por esencia de la lógica el que se oriente según la verdad del determinar perceptivo teórico y pensante, y por tanto de la verdad teorética. Para derrocar la esclerosada lógica escolástica-tradicional, la lógica filosofante tiene como tarea someter el punto de partida ingenuo de la lógica tradicional a la sacudida de un planteamiento más radical’"206.

Este es el camino que permitirá desvelar cómo este preguntar esencial y originario se fue oscureciendo gradualmente hasta desaparecer por completo en manos de la lógica de escuela, "la pregunta por lo original y auténticamente verdadero, es decir, por el ser primario de la verdad, es el asunto fundamental de la lógica, pero solo cuando pretende ser lógica investigadora, científica y filosofante" (GA21, 12/20), de esta forma caracteriza y define Heidegger a la lógica filosofante; como una ciencia de la verdad, que descubra los presupuestos en los que se sitúa la lógica de escuela, ciencia de la verdad que se distancia de las verdades obtenidas desde el ámbito de las ciencias naturales. Una ciencia originaria de la verdad, teniendo en cuenta esto el filósofo de la Selva Negra señala que "tenemos que ponernos en condiciones justamente de levantar la auténtica tradición de entre los escombros de la inauténtica, de apropiarnos realmente de lo productivo y lo viviente que yace sepultado en la lógica de escuela; pero solo cuando nosotros mismos practicamos la lógica de modo filosofante nos ponemos en confrontación directa con la antigua lógica filosofante" (GA21,13/21).

${ }^{206}$ Herrmann, F., "Lógica y verdad en la fenomenología de Heidegger y Husserl", en Anales del Seminario de Historia de la Filosofia , n ${ }^{\circ}$ 13, UCM, Madrid, 1996, p. 40. Trad. Irene Borges Duarte. 
Como hemos señalado, la discusión que Heidegger mantiene con Aristóteles tiene un largo recorrido, en algunas ocasiones aquel crítica sin más a este, pero en otras lo defiende a ultranza de los posibles malentendidos. Algo así ocurre con el planteamiento de la cuestión de la verdad. Para Heidegger la vuelta a Aristóteles es algo imprescindible, pero no por un mero afán investigativo de las filosofías precedentes, o con la finalidad de cotejar las distintas interpretaciones de la verdad que se han venido haciendo a lo largo de la historia, lo que se propone es preguntar "por las raíces específicas de la interpretación de la verdad y de su realidad efectiva remontándonos al origen histórico. Es decir, si hacemos un esfuerzo histórico por saber lo que pensaba Aristóteles, cuál es su opinión sobre la verdad no lo hacemos por algún tipo de interés anticuario, sino que la pregunta preguntada históricamente tiene que forzarnos hacia nosotros mismos, hacia nuestra historia" (GA21,124/105-6), de tal modo, que la investigación que Heidegger propone, pretende llevarnos hasta nosotros mismos, hacia nuestra propia historia y el modo de hacerlo es preguntando históricamente, para ser reconducidos hasta el origen mismo de las interpretaciones de la verdad que llegan hasta nuestro días y dejar ver los supuestos en los que dichas exégesis se sostienen, logrando así una confrontación directa con la lógica de escuela, no obstante, esta tarea solo se podrá llevar a cabo, cuando seamos capaces de practicar la lógica de modo filosofante. Resultará entonces que "la lógica de Aristóteles, o, dicho más exactamente, su trabajo referido a este círculo de investigación es algo enteramente distinto de la lógica de escuela que gusta apelar a él" (GA21,13/21), todo esto significa que Heidegger considera como una labor de carácter prioritario rescatar a Aristóteles de estos malentendidos, para lograrlo es necesario un regreso a sus textos fundamentales. De esta forma, se podrá reconducir la lógica hacia una lógica filosófica. "La lógica filosofante, tal como Heidegger la ha definido al inicio de su curso, tiene que preguntarse si la verdad interpretada a partir del intuir es o no algo postrero y fundado y si resultará ser acertado esto último, qué planteamiento de la cuestión de la esencia de la verdad sería más radical' ${ }^{207}$.

\section{B. LA PREGUNTA POR EL LUGAR DE LA VERDAD: DESTRUCCIÓN DE LOS PREJUICIOS}

Según los cánones de la lógica de escuela, lo que posibilita la verdad en cuanto verdad es la proposición. A la que seguiría la idea de que Aristóteles el primero que presentó la tesis que sostiene, que la proposición es el lugar de la verdad. Y por último, a estas tesis se suma también aquella que señala que también fue el Estagirita aquel que primeramente definió el concepto de verdad, entendiéndola como concordancia (adecuación) del pensamiento con el ente. Heidegger presenta esto resumiendo las tres proposiciones, "1) el lugar de la verdad es la proposición;2) la verdad es la concordancia del pensamiento con el ente; 3) Aristóteles es el autor de ambos enunciados. Estas tres tesis que hoy y desde hace tiempo son usuales, son tres prejuicios" (GA21, 128/108), 
precisamente, de estos prejuicios es de los que Heidegger intentará desprenderse, para desplegar un preguntar originario por la verdad.

Heidegger lo que hace es enfrentarse a esta idea bastante extendida, poniendo en tela de juicio que el lugar de la verdad sea la proposición, dado que ello significaría que el ser verdadero es el carácter de un modo determinado de habla, el habla enunciativa, de forma que la proposición estaría definida en referencia a la verdad, y no el caso contrario, es decir, que la verdad se obtendría desde la proposición.

La pregunta que se está haciendo el filósofo alemán es por el lugar de la verdad, por la legitimidad de la tesis que sostiene que la proposición es el lugar de la verdad, la que supuestamente sería obra de Aristóteles, cuestión que Heidegger pone seriamente en duda. Según este, el Estagirita en ninguna parte de su obra ha expuesto algo semejante, sino que por el contrario, haría un ejercicio inverso, ya que definiría la proposición por medio de la verdad, o por medio del poder ser verdadero (Wahr-sein-können). Pero no solo eso, también sostiene que Aristóteles define la proposición enunciativa como aquel discurso que tiene la posibilidad de ser verdadero o falso, es decir, tiene la posibilidad de la verdad y de la falsedad. Para explicar esto se remite directamente a Aristóteles, quien dice que, "aunque todo hablar remite a algo (significa algo en general) mostrando, por el contrario no todo hablar hace ver, sino solo aquel en el que sucede el ser verdadero o ser falso" (De interpretatione 4,17a 1-3). A juicio de Heidegger, esta tesis aristotélica permitiría aclarar dicha confusión, dado que para el pensador de Estagira, en primer lugar, a la proposición le es propia esta doble posibilidad de ser verdadero o falso, por lo cual tampoco podría ser la proposición aquello en virtud de lo que la verdad sea lo que es. Por otra parte, dice que el ser verdadero es el carácter distintivo del habla enunciativa. La proposición queda así definida en referencia a la verdad, concretamente, en referencia al poder ser verdadero o falso. Según lo anterior, sería el mismo Aristóteles quien echaría por tierra aquellas interpretaciones que lo señalan a él como el autor de la tesis que dice que la proposición es el lugar de la verdad.

\section{LA POSIBILIDAD DE LA VERDAD Y LA FALSEDAD EN EL ENUNCIADO}

Aristóteles en ningún caso llega a decir que la proposición es el lugar de la verdad, sino que más bien señala que la proposición puede ser verdadera como también falsa. Heidegger comenta, que "la proposición no es aquello en lo que la verdad se hace posible por primera vez, sino que al revés, la proposición solo es posible en la verdad, en la medida que se ha visto el fenómeno que los griegos designaban como verdad y que Aristóteles captó conceptualmente con nitidez por primera vez. La proposición no es el lugar de la verdad, sino que la verdad es el lugar de la proposición" (Satz ist nicht der Ort der Wahrheit, sondern Wahrheit der Ort des Satzes) (GA21,135/113), con esto se pretende, dejar suficientemente claro que la proposición en cuanto habla es la expresión que no es 
verdadera ni falsa en cuanto tal, sino que tiene la posibilidad de ser verdadera o falsa. A esto último dirigirá Heidegger su atención en lo que viene, esto es, a la estructura esencialmente dual del logos, que indica que este no es originariamente verdadero, desencubridor. De la misma forma que puede desencubrir, desvelar, puede también ocultar.

Dicho de otra manera, el enunciado puede ser verdadero, desencubridor, pero solo porque también puede encubrir, ocultar. Esta posibilidad de ocultar y desencubrir descansa en la estructura dual del lógos, el poder ser verdadero y falso se constituyen en su posibilidad sobre esa misma estructura doble. Es más, "la estructura de la verdad del enunciado es fundamentalmente la de la falsedad" (GA21, 135/113), esto significa para Heidegger que no se trata solamente de la posibilidad del logos de ser falso, sino que al mismo ser falso le es propia una cierta prioridad por sobre el ser verdadero. Justamente esta estructura de logos es la que hace posible la verdad y la falsedad. El logos en tanto enunciado, es tratado por Aristóteles respecto a sus determinaciones, cuando dice que "ocultamiento, igual que el descubrimiento, está (siempre) en el campo del componer y del descomponer" (De intepretatione 1,16 a 12), según Heidegger, aquí el Estagirita está haciendo clara referencia a la síntesis y a la diarésis, pero esto no quiere decir que la proposición sea tanto sintética como diairética, sino más bien, que toda proposición es tanto sintética como diairética.

La síntesis como enlace es la condición de posibilidad del descubrir, de la verdad, por su parte, la diaíresis como separar es la condición de posibilidad del ocultar. De modo tal, que la síntesis y la diaíresis son las que determinar en último término a la proposición, es lo que posibilita aquel distintivo de la proposición en tanto dual, su posibilidad doble; como poder ser verdadero o falso, lo que revela en último término el carácter relacional de la estructura de la proposición, por un lado, el poder ser verdadero, y por otro, el poder ser falso, de este modo se constituyen como partes inseparables de la estructura de la proposición. Dice Heidegger respecto a esto:

\footnotetext{
sintético-diairético es una estructura del enunciado como tal y se encuentra respectivamente antes de la afirmación y de la negación, antes de una atribución y de cada denegación, y concretamente en absoluto; y no como si el atribuir fuera acaso primariamente un enlazar y el denegar fuera primariamente un separar, y después fuera además, lo otro, sino que el atribuir no es más separar que enlazar. Pero ello implica que el enlazar y el separar son previos al atribuir y al denegar como sus condiciones de posibilidad de ocultar y descubrir (GA21,140/117).
}

Esto quiere decir, que esta estructura de la proposición es anterior a la afirmación y a la negación, y a su ser verdadera o falsa, lo que significa que afirmar no es equivalente a desencubrir ni negar a ocultar, lo que a juicio de Heidegger, es indicio de que la cuestión se ha vuelto problemática y se ha terminado por sumir en la más compleja oscuridad.

La estructura del logos se nos ha hecho aún más enigmática. Es menester ahora profundizar en esta estructura doble del logos, que es en sí misma enlazar y separar, y esto 
anterior al afirmar y enlazar. Esta estructura es la que hace posible que el logos pueda ser descubridor $\mathrm{u}$ ocultador, verdadero o falso ( Wahr oder falsch, entdeckend oder verdeckend sei kann). La estructura fundamental del logos como enunciado se ha tornado más compleja, por esta razón, "solicita una profundización en la función "delótica", reveladora del logos, en lo que hace que el logos sea logos tinos, de algo"208. El carácter primordial del logos, en cuanto tal, es su carácter de ser un discurso sobre y acerca de algo, la función fundamental del logos es la apofansis, un discurso que hace ver y que muestra, por ello es logos tinos, porque es un discurso de algo.

En toda proposición (enunciado) se expone algo, se dice algo de algo. Según Rodríguez en la concepción del logos como esencialmente apofántico, se encuentra el primer gran descubrimiento que Heidegger ha logrado gracias al estudio de Aristóteles que ha llevado a cabo por esos años,

su idea de logos apofántikós es interpretada por Heidegger de forma que la función básica el logos consiste en hacer ver, en manifestar aquello de que se habla. Al hablar, hablamos con alguien de algo; el sentido genuino de ese habla no es otro que dejar ver ese algo, hacerlo patente y, por tanto, comprensible. Un enunciado concreto, más acá de cualquier análisis de su estructura lingüística, ha de ser entendido desde esa fundamental función. Todas las demás caracterizaciones que un análisis del enunciado pueda establecer suponen la idea básica de apofánsis ${ }^{209}$

En suma, el sentido primario del logos es ser apofántikós y apofánsis significa primariamente enunciado, mostración, Heidegger le asigna el significado que supone está presente en el fenómeno mismo del logos, por eso enunciado quiere decir, "lo dicho desde la propia cosa, de modo que en este discurso su "acerca de qué" se haga visible, accesible a la captación" (GA 21, 133/112); sería este el carácter fundamental del enunciado: decir algo sobre algo.

Siguiendo en esta línea de argumentación, Heidegger quiere retrotraer la investigación acerca de la verdad a un fenómeno ontológicamente aún más originario, anterior al hablar de algo, anterior al concepto de logos como discurso, nos remite entonces a una estructura previa a cualquier expresión lingüística, nos lleva hasta la existencia. En toda proposición, en la formulación de un juicio, en tanto, que es un quehacer de la propia existencia ha de estar fundamentado en la misma existencia, en cuanto que ella está abierta al mundo, se refiere a algo que siempre está de alguna forma en la apertura, que está descubierto con anterioridad a cualquier hablar de algo.

Todo ente está ya descubierto de alguna forma, todos los entes están ya abiertos con anterioridad, y ello en la forma del para qué de su utilidad, tienen su ser de un modo señalado, en razón de su significado. Así lo sostiene Heidegger, cuando dice que todo ente, "está descubierto a partir del "para-que" de su utilidad; está puesto ya en un

\footnotetext{
${ }^{208}$ Peñalver, P., Del espiritu al tiempo, op. cit., p. 87.

${ }^{209}$ Rodríguez, R., Heidegger y la crisis de la época moderna , op. cit., p. 27.
} 
significado: está de-signado" (Seiende entedeckt ist aus dem Wozu seiner Dienlichkeit her; es ist schon in eine Deutung gestellt-es ist be-deutet) (GA21, 144/120). Son estos para-qué (Wozu) los que precisamente conocemos primariamente y aprehendemos de los entes. El percibir las cosas, los entes, el tenerlos al frente, nos muestra y nos sitúa en este grado de conocimiento sobre ellas, nos revela el fundamental y primordial "para-qué" de su utilidad. Cualquier ejercicio enunciativo, predicativo, es derivado en relación a la constitución del ser propio de la existencia, en virtud de la cual el mundo le aparece ya con un cierto significado y familiaridad, como anterior a la proposición, como puesto previamente en una determinada interpretación. Por lo tanto, nuestra existencia en tanto orientada a las cosas, a los entes, se maneja en esta estructura del "en tanto-que" ( $\mathrm{Als}$ Struktur) (como qué- en cuanto qué). Esta estructura posee un carácter antepredicativa y es lo que posibilita por vez primera la estructura del enunciado, de la proposición. En consecuencia, "todo tener ante sí y percibir algo es en sí mismo un "tener" algo en tanto que algo. Nuestro ser orientado a las cosas y a los hombres se mueve en esta estructura de algo en tanto que algo, o, dicho brevemente tiene la estructura del "en tanto que (Als Struktur)" (GA 21,144/120), esto significa, que ya entrada y con anterioridad a cualquier otra cosa, siempre vivo en estos contextos de los "para que" (Zusammenhängen des Wozu), pero eso no quiere decir, que esté realizando algún enunciado temático ni mucho menos.

Por consiguiente:"la clave del logos, de esa enigmaticidad del logos esencialmente doble, se encuentra en una estructura que es previa al lenguaje puesto que se inscribe en el plano de la comprensión del mundo, en una apertura preobjetiva. Se trata de la estructura que llama Heidegger el como (als) hermenéutico, sobre la cual se funda el como apofántico" 210 . Por ello, para aclarar la naturaleza del como (als), del en tanto que, se debe aclarar además el modo de significar peculiar a él, que se realiza como un tener que ver (zu-tun-haben) con algo, en que se fundamenta la proposición en cuanto tal. Este en tanto que corresponde al significar y al comprender primario. Este als ( el en tanto que hermenéutico)es desde el cual es entendido algo como algo, en su significar siempre hay algo ya comprendido, algo como lo cual me sale al encuentro un ente. La existencia, su ser es este moverse en medio de los entes, pero un moverse antepredicativo y comprensivo de los entes que me hacen frente, que me salen al encuentro. Y eso lo comprendo en el horizonte de aquello para lo que sirven los entes. Exclusivamente desde el ámbito del en tanto que algo ( $A l s$ was) y del para que (Wo zu) se puede utilizar aquello que nos hace frente, los entes del mundo. Es desde este para lo que por el cual siempre estoy ya vuelto hacia lo que me hace frente, estoy dirigido hacia lo que me encuentro en el mundo. Este es el en tanto que hermenéutico.

Podemos ir visualizando cómo Heidegger en su interpretación de la lógica va vinculando el problema de la verdad, del logos, con la determinación de la existencia misma. La pregunta por la verdad debe ser reconducida hacia una dimensión ontológica

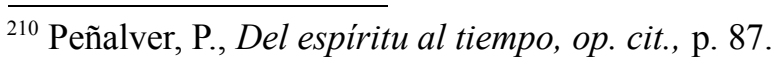


más originaria de aquella en la que se encuentra, debe ser reconducida hasta la estructura de la existencia misma, no obstante, en este paso el joven profesor va más allá, se dirige a aquel fenómeno desde el que adquiere su sentido originario este ente que es existencia, nos referimos al tiempo.

En esta dirección señala Heidegger, que "el llano concebir precisamente las cosas del mundo circundante que hay dadas del modo más natural es un continuo retornar a algo que me sale al encuentro, y un continuo retornar que es necesariamente un retornar porque mi ser propio, en tanto que tener-que-ver-en-el-mundo procurando (besorgendes In-derWelt-zu-tu-haben), se caracteriza como ser-siempre-ya-por anticipado-cabe-algo (Immerschon-vorweg-sein-bei-etwas). Porque mi ser es siempre de tal modo que yo soy por anticipado respecto de mi mismo, para captar algo que me sale al encuentro tengo que retornar desde este ser por anticipado (Vorwegsein). Hasta lo que me sale al encuentro" (GA21, 147/123). De alguna forma, Heidegger aquí resume el camino recorrido hasta ahora en su análisis de la verdad, que desde el comienzo se ha orientado a cuestionar los prejuicios que sobre ella existen y que le llevan a poner en tela de juicio las tesis que señalan que la proposición es el lugar de la verdad, y que la verdad es una copia de la realidad. Este camino nos ha llevado hasta la estructura misma de la existencia, hasta la estructura misma del Dasein. La pregunta por la verdad, atendiendo a los textos aristotélicos, nos ha permitido visualizar la conexión entre la verdad y la existencia, en otras palabras, la pregunta por la verdad nos remite a la estructura ontológica de la existencia, teniendo en cuenta esto, es que Heidegger considera necesario fijar y determinar esta estructura, es más, ahí se hace presente algo aún más originario, la dimensión temporal del Dasein. El retornar desde el de dónde en el que yo ya estoy, tiene esa peculiar función de la apertura. Dice Heidegger que "la estructura del "en tanto que" (Als-was) atañe a una conducta primaria y que en esta conducta significativa es un modo de ser que ahora caracterizamos brevemente así: "un retornar, que en cada caso se detiene ya en el "de dónde" del significar y el comprender a algo que me sale al encuentro" (GA21, 148/123).

En suma, Heidegger ha logrado concluir, que existe una conexión esencial ente el logos y el tiempo, una conexión fundamental entre lenguaje y temporalidad, es justamente este vínculo el que mostrará la radicalidad que posee el problema ontológico del advenir para la estructuración de su constructo filosófico.

Con el afán de indicar esta conexión, Heidegger se remite a una estructura que posee un valor señalado al interior de su filosofía, que se convierte en un pilar fundamental de su analítica existenciaria, hablamos del cuidado (Sorge). Lo importante para nosotros es que con esto se determina el carácter temporal que le es peculiar a la existencia, y es lo que le permite a Heidegger vincular la pregunta por la verdad con la existencia y, más importante aún, conecta la pregunta de la verdad con la pregunta por el ser. Pero también en esta estructura es posible verificar la importancia que se le asigna al 
advenir, al futuro, que se manifiesta en el vorweg sein, en el ser por adelantado, en el anticiparse del que habla el pensador de la selva negra. Sobre eso Heidegger comenta que "ser-siempre-ya-por-anticipado-cabe-algo" es propia y esencial al llano concebir algo, es una estructura del la conducta del "en tanto que", pero no solo eso, sino que "en un análisis más preciso resulta ser el tiempo. (...) Y este serse por anticipado en tanto que retorna es si puedo decirlo así, un movimiento peculiar que la propia existencia hace continuamente"(GA21,147/123). Nos encontramos de plano con una estructura fundamental, que ni más ni menos es según Heidegger, el tiempo mismo, que se nos hará manifiesto en un análisis más minucioso de este orden estructural, que nos revelará su dimensión temporal, por lo tanto, esta es una estructura originaria del tiempo, en la cual se muestran los tres momentos de la temporalidad. Pero, por ahora no nos detendremos en este punto, lo importante para nosotros es exponer el camino que nos lleva desde la formulación de la pregunta genuina por la verdad, hasta la pregunta por el ser y el tiempo, que Heidegger desarrolla en estas lecciones de verano de 1925-1926.

Como decíamos anteriormente, en esta formulación primitiva de la estructura del cuidado, son verificables las instancias temporales que constituyen el tiempo, lo que revela de forma indiscutible el interés de Heidegger por plantear el problema del tiempo como un asunto radical y ontológicamente originario, tanto en su enfrentamiento con la tradición metafísica como en su crítica a la lógica de escuela. En su cuestionamiento de la ontología y de la lógica tradicional, Heidegger curiosamente tiene como aliado a Aristóteles, fiel compañero, tanto para lo bueno como para lo malo, en cuanto le crítica por aquello que ha malentendido, como también le agradece por la ayuda inestimable que le ha brindado, por aquel apoyo decisivo que le dado para el desarrollo de su propia filosofía. Heidegger se ha servido de Aristóteles para reconducir la pregunta por la verdad hacia un ámbito más genuino de aquel en que se encontraba, que le ha llevado a la pregunta por la estructura de la existencia, y en último término hacia una meditación originaria del tiempo mismo. En la estructura del cuidado que Heidegger ha presentado, en la composición de las expresiones que la articulan resuena un sentido temporal, que a simple vista podría hacerse apenas perceptible, pero que sin lugar a dudas expresan el tiempo mismo.

Otra conclusión importante que Heidegger ha obtenido en el rumbo de esta investigación, que nos lleva desde la pregunta por la verdad al tiempo, tiene que ver con que, "la relación lenguaje-tiempo se muestra también en una perspectiva más amplia: en la medida en que el lenguaje está implantado en el ser ahí, esto es, un ser radicalmente histórico. También es histórico el lenguaje como totalidad de expresiones que crece y se transforma la comprensión de cada Dasein en su ser con otros" ${ }^{211}$, lo que significa, que para Heidegger es de una importancia señalada cuestionar un fenómeno como el lenguaje, pero para ello es menester reconducirlo hacia su dimensión originaria, hacia su ser histórico, en virtud de que el ser del lenguaje es esencialmente histórico. La existencia que

${ }^{211}$ Peñalver, P., Del espíritu al tiempo, op. cit., p. 88. 
es comprensiva y significativa es en sí misma histórica, por lo mismo, es histórico el vocabulario, las palabras, el lenguaje, por esta razón, el lenguaje solo se hará comprensible desde la historicidad de la existencia.

\section{Nivelación de la estructura originaria del $A L S W_{A S}$ COn el $A L S$ Propio del} DETERMINAR

Ahora es importante, por el rumbo mismo que ha seguido la investigación heideggeriana, ver de qué forma en la modificación de la estructura del "en tanto que" (Als-Sruktur)que se da en el determinar se nivela como una estructura del "en tanto que" $(A l s)$ apofántico. "La mostración tiene el sentido de hacer ver la presencia de algo con y cabe algo: algo, y en tanto que copresente en él algo otro" (GA21, 154/128). Heidegger entiende esto como una nivelación de la estructura originaria que debe ser verificada en el fenómeno mismo, y con ello se ha de hacer visible la conexión del "en tanto que" primariamente descubridor con el "en tanto que" nivelado del determinar.

Heidegger, en esta interpretación del logos que se ha revelado como una estructura, y que en cuanto desencubrir posee la estructura del en tanto que, considera que es indispensable dar un paso más allá y precisar el sentido de este Als y específicamente en su función como fundamento del enunciado. Lo que se ha de llevar a cabo es hacer visible la conexión del en tanto que primariamente descubridor con el en tanto que nivelado del determinar. El enunciado es, ““"un tener que ver con” comprensivo cuya preocupación es el descubrir, que conforme a lo dicho, tiene necesariamente estructura de "en tanto que" (Als-Struktur)en un sentido remarcado.(...) Cuando el "con qué" de un llano "tener que ver con" (Zutunhabens) sale al encuentro de tal modo que se produce un enunciar sobre ello, aquello se convierte en "acerca de qué" (Worüber)(GA21,155/129), significa entonces, que la temática que a la cual se alude por medio del enunciado se mueve dentro de esa misma dimensión, es un hacer ver (Sehenlassen), una mostración. Motivo por el cual, el enunciar como tal es un descubrir, procura la apofainestai, por lo tanto, este "como que" (en tanto que lo cual) (als was) quiere principalmente comprender el acerca de qué (Worüber) y esto se obtiene desde aquello mismo de lo que se trata.

El "en tanto que algo" no se obtiene del "para qué" como en la estructura del "en tanto que" hermenéutico, sino que desde aquello mismo desde dónde se construye el enunciado, que es desde el ente mismo; se obtiene entonces desde lo propio tratado. El sentido originario del enunciado, del decir algo en tanto que algo, necesita tener explícitamente el en tanto que algo desde lo cual se determina lo tratado. Al enunciado le pertenece la estructura de un tener que ver con de carácter comprensivo, que procura el descubrir, su preocupación por tanto es el descubrir mismo. El "tanto que algo" tiene que tener de alguna forma con aquello desde lo que se determina lo tratado, en otras palabras, con el ente mismo acerca del cual se enuncia algo. Heidegger respecto a esto dice: 
en el enunciado tenemos esta dualidad: el "en tanto que algo" se realza según la tarea conforme al sentido del procurar que se encierra en el propio enunciar; y en segundo lugar, el "en tanto que algo" no se destaca a partir de una función cualquiera, de una orientación con arreglo a algo distinto, sino a partir de lo propio tratado. en esto consiste el tercer momento característico, en que el peculiar hacer ver y descubrir que corresponde al enunciado en cierto modo se concentra puramente en aquello sobre lo cual ha de hablarse (GA21,155-156/129),

Este último punto es fundamental para el filósofo alemán, ahí sostiene que en un tener que ver comprensivo con un ente cualquiera, este no se concibe de forma temática, ni tampoco la comprensión del objeto se alcanza desde la funcionalidad propia de dicho ente, sino que lo principal es que el ente debe estar presente de algún modo. Lo importante de esto es que el enunciado se concentra en el propio ente en cuanto presente. El mostrar propio del enunciado tiene el sentido de hacer presente aquello de lo que se trata, pero también el acerca de lo que está al mismo tiempo presente, esto es lo que Heidegger precisa terminológicamente como determinar (Bestimmen), que es el modo de hacer presente, es una mostración de algo presente como aquello que está presente. Por eso dice Heidegger, "ahora el enunciado en el sentido de la tendencia de que aquél se ocupa, a saber de hacer ver, se une por así decirlo con lo presente en tanto que presente, y únicamente en esta tendencia a aproximar lo presente en tanto que presente (das Vorhandene als ein Vorhandenes) para el concebir" (GA21, 157/130). Por lo tanto, este determinar es una forma peculiar de hacer presente, de mostrar, de desencubrir, pero no es la originaria. Es una estructura determinada del en tanto que (Als-Struktur).

Dice el filósofo nativo de Messkirch, "hemos definido el determinar como el aportar algo presente mostrándolo en su estar presente de este y aquel modo. Este determinar, en tanto que, una mostración, es un modo del descubrir, y por eso tiene necesariamente la estructura del "en tanto que". En la medida en que es modo, la estructura hermenéutica original de "en tanto que" está modificada" (GA21,158/131). Sin embargo, a pesar de esta modificación de la estructura del "en tanto que" ahí se presupone la estructura original, por ello, la comprensión de lo que se nivela en el enunciado, es una nivelación de la estructura original. La comprensión de lo que se nivela en el enunciado determinador no es nunca un descubrir primordial, no puede nunca determinar una relación originaria y primaria con el ente, con las cosas del mundo. Aquello acerca de lo que se habla, lo que es enunciado, pasa a ser un simple todavía presente, y solo se trata de captar el tema del enunciado en su presencia.

En el tratamiento de aquello originalmente utilizado, que se entendía desde su relación pragmática, deviene ahora en una mera cosa presente, por lo cual, el original carácter de ser de la cosa, del ente, queda oculto, dado que no existe primordialmente como utensilio, en su para qué, sino que deviene en un simple objeto presente para un espectador que lo contempla, una cosa presente de la que se atribuyen y concluyen propiedades, esto significa que en la misma atribución se determina la cosa. Hacia lo que 
se orienta el ocuparse, como entes del mundo circundante, que se consideraba antes en el sentido de una conducta no teórica, se ha nivelado ahora con los entes simplemente presentes como objetos de una contemplación y no como utensilios con una cierta utilidad, que aquello que lo que los constituye originalmente.

\section{E. LA PREGUNTA POR LA VERDAD Y LA PREGUNTA POR EL SER}

Por todo esto, el determinar enunciante no puede bajo ningún punto de vista llegar a ser el hilo conductor de la pregunta qué es el ente, este logos no puede tener la capacidad de articular y aclarar la pregunta por el ser del ente. Según Heidegger, esta interpretación del logos, en cuanto determinación de un objeto en su posible determinibilidad, es la que ha dominado largamente la ontología griega y la lógica tradicional, llegando a convertirse en el hilo conductor de la pregunta por el ser y por la existencia. El ente que nos hace frente, las cosas del mundo, están ahí presentes como objetos de una posible determinación que constata, prevaleciendo de este modo, una clase de conocimiento contemplativo y exclusivamente teórico del ente. En virtud de esto, dice Heidegger, "que este fenómeno del determinar no puede constituirse en punto de partida de una pregunta por el ser, en la medida en que esta pregunta ha de captar el fenómeno del ser en su raíz" (GA 21,160/132). El pensador alemán interpreta que estas son las consideraciones que han determinado la historia del pensamiento, la historia de la lógica tradicional, una visión presencialista, que vincula directamente el problema de la verdad con la pregunta por el ser, -pero en el caso de la lógica tradicional, es la comprensión del ser como presencia constante, la que domina su exégesis-, cuestión que indicaría, en último término, que la señalada comprensión del tiempo, es el fundamento de la mentadas interpretaciones, pero el tiempo entendido desde una dimensión que lo determina todo y dicta de qué forma se han de comprender los entes del mundo y la existencia, desde el simple presente, desde el paradigma de la presencia constante.

Gradualmente se va haciendo manifiesta la interna vinculación de la pregunta por el ser con la indagación respecto de la verdad. En la interpretación tradicional de la verdad, según Heidegger, opera un malentendido sustancial que ha oscurecido dicha pregunta en su vertiente originaria. La consideración de la verdad según los cánones de la tradición descansa en una interpretación del ser que ha gobernado sin contrapeso la historia de la filosofía, pero no solo eso, además esta interpretación del ser expande su ámbito de influencia hacia la consideración tradicional del logos, en la cual subyace el privilegio de una dimensión temporal privilegiada, que Heidegger considera como tarea imprescindible sacar a la luz y hacerla manifiesta. Aquí el filósofo alemán está presentando, a través de la pregunta por la verdad, una tesis fundamental en su crítica a la tradición filosófica, la interpretación del ser como simple presente, lo que llevaría a pensarlo como un ente. Como sabemos, en la nombrada exégesis Heidegger ve indicios claros de un vínculo directo entre la pregunta por el ser y la cuestión del tiempo, más bien 
con una dimensión del tiempo, el presente, que sería el modo exclusivo y privilegiado de pensarlo, consideración que según él alcanzaría a la propia existencia, al Dasein mismo. En esta línea argumentativa, comenta Heidegger:

esta concepción del tiempo es la concepción tal como la Aristóteles la descubre y determina por vez primera en su Física: en ella, el tiempo se toma y se obtiene mirando al mundo objetivo experimentado. Mirando al mundo y a los procesos del mundo y a la forma de sus determinaciones se puede hallar el tiempo en este sentido mencionado, y si él da luego la posibilidad de ser interpelado filosóficamente de modo diverso. Pero si este acceso al tiempo, a saber, atendiendo al mundo objetivo y a sus procesos, es el único, y caso de que hubiera otros posibles, siquiera el primario y determinante de entre estos (GA21,204/166).

Por el momento, no queda claro del todo como Heidegger llega a estas conclusiones, por lo cual se ha de precisar aún más la forma en que opera su interpretación y muestra ese vínculo entre verdad, ser y tiempo. En la revisión de lo conseguido hasta ahora, desde la explicación del en tanto que hasta la determinación de la presencia (como rasgo determinante del enunciado determinador), se debe dejar establecido sin lugar a dudas, por qué en su caracterización de la verdad del enunciado se utilizaba la estructura formal de la síntesis. Heidegger había señalado que lo importante es el hecho de que la síntesis aparece al interior de la determinación de la verdad y, concretamente, en conexión al propio ente que se ha de mostrar. Pero al mismo tiempo, quiere liberar a la lógica aristotélica de los prejuicios infundados que caen sobre ella.

Según Heidegger, Aristóteles no entiende la síntesis solamente como estructura del logos, sino más bien del acerca de qué como tal, dado que en general, el ente tiene que ser ente en sentido verdadero. Además, el propio ente que corresponde al enunciar mostrativo es captado por medio de la síntesis. Estas características nos demostrarían que no hay razón alguna para interpretar las tesis aristotélicas de la verdad como un reproducir. En suma, la verdad no puede ser considerada como reproducción de un ente en la conciencia ni como concordancia ni tampoco como imitación. Por el contrario, el mostrar está con el ente mismo, aunque el acerca de qué del enunciado no esté aún ahí presente y solo sea mentado el propio ente, y no una imagen o representación que se asemeje a este ente no presente.

Para el Estagirita, es en el ente mismo y en su modo de ser posible donde radica la posibilidad de la falsedad, es en el ente mismo y en su posible modalidad de ser, desde donde se extrae la condición de posibilidad de la falsedad, con esta idea logra liberarse de esa pesada carga que conlleva la sentencia parmenídea, que sostiene que "el ente es y el no ente no es", es decir, que la falsedad y el error, en cuanto negativos y falsos, no eran reales y tampoco tenían posibilidad de ser. Esto a juicio de Heidegger, habría sido subsanado por Platón, quién en uno de sus logros inmortales ha conseguido mostrar que la falsedad y el error también pueden ser (Cf. GA21,168/139). Lo que reafirma la tesis que sostiene que el ente mismo es el lugar de la verdad o de la falsedad, de su misma posibilidad, es evidente 
entonces, que es imprescindible comprender la verdad de un modo genuino, por eso dice Heidegger: "si el fenómeno de la verdad ( como descubrimiento) se entiende de modo más radical, a partir de la propia existencia y a partir de lo que se dio a conocer como la estructura hermenéutica fundamental, entonces ya puede entenderse mejor que la falsedad depende necesariamente del propio ente del cual son posibles los enunciados" (GA21,169/139), es decir, la pregunta por la verdad nos remite al propio ente, puesto que la verdad se entiende como descubrimiento del ente, por lo que necesariamente en cuanto logos mantiene una relación esencial con el ente, dado que es una forma de ser de la existencia hacia el mundo y hacia sí misma. En otras palabras, es un ser hacia el ente, orientado esencialmente hacia el ente y hacia sí mismo.

Según esto, si el logos se relaciona al ente, y en el ente se da la posibilidad de la falsedad, el logos ha de tener una conexión con la falsedad, la falsedad misma tiene relación con la estructura del logos. Por consiguiente, la falsedad se determina desde el propio ente y desde su ser, en relación a la cual el logos es como tal. Pero al mismo tiempo se determina desde la conducta que corresponde a la propia existencia. Siguiendo a Aristóteles, quien señala que la síntesis es la condición de posibilidad de la falsedad, la que se referiría por tanto a esta constitución doble, al ente como lo presente en el acerca de qué, y en la propia conducta que enuncia. Así la verdad puede caracterizarse en relación a su constitución como descubrimiento del ente. En cuanto descubrimiento, es por una parte un carácter del propio ente, pero por otra, en cuanto descubrir, es un carácter de la propia conducta, del quehacer del Dasein. En la estructura de la verdad que Heidegger nos ha hecho visible, la síntesis se dirige hacia el ente mismo, hacia el acerca de qué del enunciado en tanto descubrir, pero también hacia la propia conducta de la existencia.

El próximo paso que se ha de dar es dilucidar cómo en Aristóteles la verdad y la falsedad se hacen comprensibles desde la síntesis, como condición de posibilidad de ellas. Y siguiendo la misma dirección, se podrá aclarar de qué forma en la filosofía griega la meditación acerca de la verdad se considera primariamente desde la idea de conocimiento como intuición, cuestión que por lo demás determinaría la meditación venidera en la pregunta por la verdad. El filósofo alemán recuerda que el objetivo fundamental que pretende alcanzar por medio esta investigación, es que se "mostrará en un sentido más concreto que hasta ahora de qué modo el problema de la verdad se adhiere a la pregunta por el ser" (GA21,171/141). Es evidente, que Heidegger ha llegado a un momento crucial de su investigación, cuyo próximo paso será presentar de forma concreta y precisa, de qué forma la verdad se vincula con la pregunta filosófica por excelencia: la pregunta por el ser. Se revelará así la dimensión ontológica fundamental de la verdad, del logos. Esto se logrará, como no, en la discusión con Aristóteles, específicamente en la revisión del libro $\mathrm{X}$ de la Metafisica. No ahondaremos mayormente en la discusión, solamente en las conclusiones que Heidegger obtiene desde el análisis aristotélico. 
F. Ser como presencia: el PRESENTE COMO horizonte FUndAMENTAL DE LA PREGUNTA POR EL SER EN LA TRADICIÓN METAFÍSICA

El pensador alemán, en este análisis del libro X de la Metafísica, nos indica en principio que aquello que se logrará con esta exégesis de la obra aristotélica, es que se "ha de mostrar cómo mediante la caracterización del ser a partir del alethes, el ser llega por primera vez a su determinación plena y auténtica, y en qué medida se alcanza con ello el grado superior de la consideración del ser" (GA21,179/147), se reafirma expresamente lo dicho con anteriormente, cómo desde la determinación de la verdad cómo alethes se postula al mismo tiempo cierta idea del ser, cómo por medio de esta se llega a una determinación del ser más precisa. El joven profesor está ya tras la pista de la relación entre ser y verdad, en tanto que hemos llegado ya directamente a la pregunta por el ser, a su determinación desde el alethes, desde la verdad, obteniendo de esta forma una caracterización relativamente concisa de su relación con el ser. Si esta determinación a la que hace referencia Heidegger, es la correcta, la auténtica, eso es otra cosa.

Lo que subyace en el fondo de esta consideración, es una determinación del ser a partir de la alethes, desde ella, pero también, y esto es lo importante, a partir de una idea de tiempo, desde la interpretación del tiempo como presente. Es por ello que se hace imperativa la pregunta por el ser, entonces, "Si el ser hay que captarlo en su sentido más propio, entonces hay que preguntar, en relación con el ser, por aquello que siempre hay ya de entrada en todo ente presente en la medida en que es, es decir, por un elemento presente eminente. En último término, la pregunta por el ser tiene que dirigirse a la esencia y a su ser (por sí decirlo, la pregunta por el ser del ser)" (GA 21,179/147). Nos encontramos ahora frente a la pregunta por la forma en que se determina el ser, la esencia de lo que es desde el ámbito de la alethes, lo que también incluye la cuestión de cómo puede comprenderse el ser del ente desde el horizonte de la verdad. A juicio de Heidegger, Aristóteles sostiene que ser significa conjunción y unidad, y el no-ser significa disyunción y pluralidad. Sin embargo, esta caracterización del ser desde la alethes es insuficiente, impotente en su intención de dar cuenta de la pregunta por el ser de modo originario, ya que la esencia de un ente es algo que se sustrae a la propia conjunción, lo que significa que no es posible comprender su ser por medio de la conjunción ni tampoco por la unidad de la conjunción.

Esta interpretación aristotélica se ha vuelto aún más problemática, al parecer ha perdido su utilidad y ya no le sirve a Heidegger con miras a alcanzar su objetivo que es obtener una interpretación del ser desde el alethes, esto porque el ente según su propia constitución no es conjunción ni tampoco unidad, por lo tanto no se podría hablar de un descubrir mostrativo. Entonces, "el ser de este ente, si ha de determinarse al hilo conductor del descubrimiento, solo puede obtenerse mirando cómo este ente se muestra a partir de sí mismo en ese descubrir que el ente que sale al encuentro 
permite"(GA21,181/148), de todo esto se desprende que ahora la orientación se obtiene exclusivamente desde aquel ente que hay que captar y no desde otra cosa desde la cual pudiera ser posible dicha determinación. De tal modo, el propio mirar es el puro descubrir, y no necesita ninguna otra determinación para ser tal, sino que es el ente mismo que encontramos, que está próximo y que sale al encuentro en sí mismo, como lo presente puramente en sí mismo, el que brinda la orientación para su determinación.

En consecuencia, la "respuesta a la pregunta por la verdad asume la sustitución por la pregunta por el ser auténtico. Dicho a grandes rasgos: el ser se determina "mediante" el pensamiento, ambos son identificados" (GA21, 182/149). Heidegger presenta así una de las conclusiones capitales de la filosofía tradicional, que identifica el ser y el pensamiento, interpretación que conlleva múltiples consecuencias para la historia de la filosofía y principalmente para la lógica tradicional.

Con el afán de profundizar en esta conclusión, Heidegger considera necesario retrotraernos a la problemática de la síntesis, entendida como condición de posibilidad de la falsedad y el ocultamiento. En primer término, debemos recordar que en la síntesis descansa la posibilidad de la falsedad y el ocultamiento, en el sentido de que es conjunción de algo con algo y, en segundo lugar, en tanto que es un hacer ver que muestra junto a lo que se ha de mostrar, es algo que puede estar junto con ello. Es un hacer ver sintético, que es un mostrar desde y orientado a algo otro. De modo tal, que la conjunción de algo con otro algo, es en el ente mismo condición de posibilidad de que algo sea posible de determinar en general en atención a algo otro. Este hacer ver desde cierta atención a algo otro que posea el carácter de la posible conjunción con, es hablar de algo, aludir a una cosa, determinándolo como enunciado, como un enunciado determinador. Se hace visible de este modo, el vínculo interno entre la estructura de ser y la estructura del "en tanto $q u e ́$ " como estructura hermenéutica fundamental.

Para Heidegger las condiciones de posibilidad de la falsedad son fundamentalmente tres: "la tendencia a descubrir algo: el anterior mentar y tener el "acerca de qué". (Worüber)(...) En esta conducta descubridora, en tanto que dominada y guiada por ella, un hacer ver el "acerca de qué" a partir de otro, pues solo en base a esta estructura se da la posibilidad de hacer pasar algo por algo" (...) Este hacer ver a partir de algo se fundamenta a su vez en la posibilidad de la conjunción de algo con algo" (GA21,187/153), estas son a juicio del pensador alemán estas las condiciones estructurales de la posibilidad de la falsedad, pero falta por saber cuál es la forma que tienen de relacionarse entre ellas, cómo se vinculan entre sí. La primera condición se explica, en virtud de que siempre es necesario que yo tenga dado algo previamente, algo que se me acerca, esta es la apertura ya previa del mundo en la que ya siempre estoy. En segundo lugar, es menester que en este dirigirme hacia algo, lo considere como algo (als was), esto es posible en la medida en que aquello que sale al encuentro, dejo que me salga al encuentro, dejo que me salga al encuentro en atención a algo, y este algo puede 
mostrarse en tanto que algo ( como algo). Y por último, para conseguir tal atención, este algo solo puede mostrarse así como algo, como una cosa, si aquello puede estar presente en el mundo circundante ( no como por ejemplo un triangulo cuadrado), es decir, que efectivamente se da en el mundo en torno, tiene que ser algo que encuentro en el mundo, y esto en la medida en que es en el ente mismo en el qué se da la posibilidad de la conjunción y, al mismo tiempo, de la confusión.

Sin lugar a dudas estas tres condiciones de posibilidad de la falsedad tiene un vínculo interno, sin embargo, no es del todo visible el carácter de ese vínculo, en la determinación del carácter de ese vínculo subyace la posibilidad de poder comprender de forma genuina el origen de la falsedad, esto desde el fundamento de la conexión entre esas condiciones, por esta razón, es imperativo captar unitariamente desde su génesis esta conexión y así se hará visible el fundamento mismo que la hace posible. Por lo tanto, se ha de establecer de qué forma se vinculan entre sí las condiciones antes descritas. La segunda se vincula a la primera, ya que, el atender "en tanto qué" (Worüber), que es un dirigirse hacia algo, se mueve siempre en un descubrir, en un mantenerse y moverse en la apertura en la que ya siempre se está, es la razón de que la segunda condición se mueva en la primera.

Heidegger, en relación a estas conexiones, dice que "es claro que la segunda condición se fundamenta en la tercera. Atención a un "en tanto que algo" solo la hay cuando hay tal cosa como algo otro. Pero de igual modo la segunda conexión se sustenta en la primera. Atención a un "en tanto que algo" (Worüber etwas) realizada en y para un tener ya previamente algo que debe poder estar en el en "tanto que". Por tanto también, la estructura de ser de la conjunción se relaciona con la primera" (GA21, 188/154). El acerca de qué, ese algo que me sale al encuentro, ese atender a algo se mueve en un descubrir y mantener descubierto, en la apertura que ya se está. Por ello la segunda se mueve en la primera. Y la tercera, en tanto conjunción es una presencia-con, que solo es posible en una unidad de presencia que se encuentra en su base. La pluralidad de lo presente como un ente que me sale al encuentro solo es posible como tal, en la unidad anteriormente dada de un estar ahí que lo incluye de entrada, desde el cual aparece en cuanto múltiples presentes. La conjunción indica una estar ahí delante anterior, en virtud del cual la presencia-con algo otro es posible como un modo. La tercera condición se fundamenta en un fenómeno original.

La constitución del ser que no se ajusta al ente que sale al encuentro en la conjunción, Aristóteles lo entiende como unidad, la unidad de algo presente y co-presente. De esta forma, la conjunción es co-presencia (die Mitvorhandenheit) (estar ahí-con), que solo es posible al interior de una unidad de presencia que presenta y que subyace en ella. Se puede apreciar que la pluralidad de lo presente que me hace frente, es tal solamente en la unidad de lo presente que lo reúne desde el principio, a partir del cual se manifiesta aquella en cuanto múltiples presentes. Esta unidad indica una presencia anterior, en virtud 
de la cual la co-presencia es posible por vez primera como forma o modo. Lo que significa que la tercera condición se fundamenta en un fenómeno originario, en una presencia primaria (einer primären Vorhandenheit), según esto, serían dos los fenómenos hacia los que es menester reconducir la segunda condición; el uno es el descubrimiento preliminar, la apertura previa y, el otro, la condición a la que llega la tercera; la presencia preliminar, de este modo se vinculan por medio de una conexión primaria. "La presencia preliminar de lo simple, del ser de ese algo que sale al encuentro. Aristóteles dice: el ser "es" el descubrimiento. (...) es decir, el descubrimiento asume la respuesta a la pregunta por el ser. Con el descubrimiento se determina un carácter de ser del ente, y concretamente el carácter del auténtico ente, de lo simple" (GA21,190/155). Por ende, la segunda y la tercera condición estructural de la falsedad se originan en la conjunción unitaria de ser y descubrimiento. En otras palabras, la determinación más propia del ser es el descubrimiento, la verdad.

Heidegger sintetiza sus reflexiones anteriores preguntando directamente, “¿qué significa ser para que la verdad pueda comprenderse como carácter de ser?" (GA21, 191/156). Aristóteles gracias a la determinación de la conjunción que ha llevado a cabo, concluye que ser significa primordialmente presente (Vorhandenheit), específicamente en el sentido de la co-presencia de algo junto a algo y ello en la unidad de algo también presente. Sin embargo, "esta presencia, a saber la presencia que fundamenta la copresencia, hay que entenderla como comparecencia(Anwesenheit), como estar presente(Präsenz)" (GA21,191/156). Según Heidegger, Aristóteles al plantear esta tesis, al decir que la verdad y el descubrimiento son los caracteres primordiales del ser, no se hizo cuestión de la legitimidad de dicha tesis, no se preguntó por la validez de la proposición que señala que la verdad es igual al ser o que la verdad es la manifestación más propia de él. Por eso, es necesario para el pensador alemán remontarse al origen de esta tesis y cuestionarla en su legitimidad y originalidad, tarea que solo se puede llevar a cabo si conducimos la meditación hacía su proveniencia primigenia, hasta su punto de partida. Se debe hacer comprensible en sus presupuestos implícitos, en la misma comprensión del ser que subyace en la filosofía griega, especialmente en Aristóteles. Es necesario investigar en qué presupuestos se fundamenta esta conexión entre ser, verdad y descubrimiento. Todo lo anterior se puede resumir de la siguiente forma:

Ser significa ante todo Anwesenheit, Präsenz o Gegenwart( presente), como lo que hace frente al enfrentar o presentarse algo. Este esquema de comprensión tiene su operatividad en la crítica del sistema de traducción de la lengua griega dominante en la historia de Occidente: ousía significaría ante todo Anwesenheit, presencia en un sentido eminente, y no "sustancia", como se ha divulgado en general. Así, pues, es ser a la luz de la verdad se revela como temporal, se relaciona con el tiempo presente. Pero de esa relación entre ser y tiempo no tomó consciencia el pensamiento griego; ni desde luego, mucho menos el pensamiento posterior ${ }^{212}$.

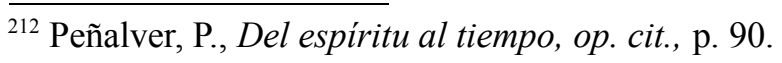


Aristóteles entendía que el ser de la conjunción significa presente como co-presencia de algo con algo en la unidad de algo presente, cuya presencia primaria está fundamentando dicha co-presencia (estar-ahí con) lo que se entiende como comparecencia constante de un ente presente como Präsenz. Heidegger reafirma aquellas cuestiones que considera realmente importantes para su programa filosófico, en relación a los lineamientos que marcan de forma indefectible su filosofía. Además de explicitar aún más un concepto clave para el desarrollo de su crítica a la tradición metafísica, nos referimos al concepto de Vorhandenheit, que aquí se traduce como presencia, pero como hemos visto anteriormente, se traduce como ser ante los ojos o estar ahí delante. A lo anterior se suman los conceptos de Anwesenheit y Präsenz, que aquí se traducen como comparecencia y estar presente. Conceptos que sin lugar a dudas tienen una función bastante precisa en razón de los objetivos que la propia investigación heideggeriana persigue.

El principal objetivo del filósofo alemán ha sido mostrar que también la lógica, la verdad quedan sometidos al influjo y al dominio de esta determinación del ser como puro presente, como presencia constante, como comparecencia, determinación del ser que domina sin contrapeso la historia de la metafísica. Esta crítica es la que Heidegger desarrolla en estas clases de lógica y que aparece también en los escritos y lecciones anteriores que hemos revisado, pero aquí verifica la forma concreta de cómo esta interpretación dominante de la filosofía griega expande su radio de acción hacia vastos ámbitos de influencia, como en este caso, hacia la lógica tradicional y la interpretación tradicional de la verdad. Además presenta una singular distinción entre los conceptos llamados a nombrar la comprensión determinante del ser en la historia del pensamiento occidental.

\section{H. Desde la interpretación del Ser como simple PRESENTE, haCia la CONCEPCiÓn DEL FUTURO COMO SENTIDO DE LA TEMPORALIDAD}

Después de esta larga discusión con la lógica de escuela, cuyo objetivo primero era vertebrar una pregunta originaria acerca de la verdad, el filósofo alemán nos ha llevado inesperadamente a la cuestión del tiempo, más precisamente, del ser y el tiempo. Esto, porque el ser de la verdad se muestra como temporal, desde una dimensión del tiempo, lo que es verdad en grado sumo es lo que está ahí presente. No obstante, según Heidegger, esta conexión entre ser, verdad y tiempo, no es completamente reconocible ni explícita, sino que más bien es inconsciente, por eso, se plantea como prioridad reconducir la pregunta por la verdad hacia el origen de esos presupuestos implícitos sobre los que gira la lógica tradicional de escuela, presupuesto que determinan también a la entera tradición filosófica, según los cuales se comprende el ser como presencia, como comparecencia; sería esta la interpretación dominante y conductora del ser. Heidegger resume esto como sigue: "Si ser significa y se comprende, aunque a menudo de modo no explícito, como 
estar presente, como comparecencia (als Präsenz, Anwesenheit), entonces la conducta genuina correspondiente hacia el ser en tanto que ente es una conducta que, en tanto que conducta, tiene ella misma carácter de presente" (GA21,192/156). Se podría concluir que con esto Heidegger alude a una conducta presentificadora, pero no porque dicha conducta se circunscriba a manifestarse en el sentido de presentar un hecho de la conciencia o un hecho psíquico, sino que cuando hablamos de una conducta presentificadora se nombra un carácter de la conducta como presentación, que no se diferencia mayormente del simple estar presente de una cosa, por lo tanto, es presentificadora en relación a algo, que por lo mismo en cuanto conducta posee un carácter de presente.

En esta conducta que presenta, o que es presentificadaora se considera la misma conducta como tal en cuanto presente, puesto que tiene el sentido de presentar (den Sinn hat des Präsentierens), de hacer algo presente, por eso recibe el nombre de Gegenwärtigens, que es el hacer presente algo. Así pues, en este hacer presente algo (Gegenwärtigens von etwas) la conducta posibilita que lo que comparece, que lo que me sale al encuentro pueda ser tal. Heidegger señala, que "con el hacer presente, con el presentar algo, se corresponde la comparecencia de aquello que subyace a la presentación y que la satisface, de aquello que está descubierto y abierto en el propio hacer presente" (Dem Gegenwärtigen, dem Präsentieren von etwas entspricht die Anwesenheit dessen, was der Gegenwärtigung genügt, unterliegt, im Gegenwärtigen selbst entdeckt und erschlossen ist) (GA21, 192/157). Todo esto significaría, que el error que subyace en la raíz de la lógica tradicional radica en que en el continuo dejar salir al encuentro, en el dejar comparecer como simple hacer presente algo en su inmediata comparecencia, este simple hacer presente no es otra cosa, que un ““'dejar salir al encuentro en su presente a lo compareciente(Anwesendes in eine Gegenwart begegnen lassen)". Lo que se abre en tal hacer presente ahí se lo comprende como saliendo al encuentro en un presente como algo presente en su comparecencia" (GA21, 192/157). Heidegger no se ahorra precisiones para explicar la comprensión del ser que se da desde la alethes, dominada como hemos dicho, por una dimensión temporal del presente. Todo lo que me aparece, lo que se manifiesta, lo que es, es determinado en términos de comparecencia, de presente. Todo ente, todo lo que es es concebido en términos de presencia, como simple presente.

Por eso tiene aquí una especial importancia, el tratamiento que da Heidegger a la Vorhandenheit, Anwesenheit, Präsenz y Gegenwart, que como hemos señalado son distintos conceptos que reúnen todos ellos el modo según el cual es mentado el ser de la tradición metafísica.

Sin embargo, Heidegger considera como una cuestión de vital importancia dejar claramente establecida la estrecha vinculación entre estos conceptos, pero al mismo tiempo es quizás más importante, distinguir el sentido de presencia, el presente y la comparecencia. En este orden de cosas: 
La introducción del concepto latinizado Präsenz se produce en el contexto de problemas abordado en el tratado el concepto del tiempo (1924) en conexión con la ambigüedad inherente al termino "presente" en las lenguas indogermánicas. De acuerdo con ella, como apunta Kisiel en su glosario, Heidegger distingue entre la presencia de algo en un lugar (Präsenz) y el sentido temporal de lo presente (Präsens). En 1925, el término todavía se utiliza con sus sinónimos alemanes Anwesenheit y Gegenwärtigkeit. Pero en las lecciones del semestre de invierno de 1925-1926 (GA21), Präsenz indica el ser como presencia (Anwesenheit) y la verdad como hacer presente (Gegenwärtigen $)^{213}$.

Es justamente en este puro hacer presente el ente al que hay que descubrir como este ente se hace absolutamente presente, no queda ninguna no presencia en él, lo que significa que es enteramente compareciente en el puro hacer presente algo y no puede dar más que aquello como lo cual está presente compareciendo. Así lo hace saber Heidegger cuando comenta:

dicho con otras palabras: el puro descubrimiento del ente, tal como Aristóteles lo piensa con relación a lo simple, este puro descubrimiento no significa otra cosa que puro presente incubierto e incubrible de lo compareciente (Gegenwart des Anwesenden). Descubrimiento, es decir, aquí puro presente (reine Gegenwart), en tanto que presente es el modo supremo de la comparecencia (Anwesenheit). Pero la comparecencia es la determinación fundamental del ser (Anwesenheit aber ist die fundamentale Bestimmung von Sein). es decir, el descubrimiento, en tanto que el modo supremo de la comparecencia, a saber, en tanto que presente, es un modo del ser, y en concreto el modo más propio del ser, la propia comparecencia compareciente (anwesend Anwesenheit) (GA21,193/157).

Paso a paso Heidegger ha ido descombrando los motivos ocultos que han guiado las interpretaciones de la tradición filosófica. Desde la exégesis aristotélica de la verdad obtiene la determinación privilegiada del ser, que señala que el modo más propio del ser es la comparecencia (presencia), que tiene como forma suprema el descubrimiento, pero un descubrimiento fundado en el simple hacer presente algo, un descubrimiento entendido como puro hacer presente, y este presente considerado como el modo eminente de la comparecencia, en cuanto carácter fundamental del ser, por lo tanto, sería la dimensión temporal auténtica y primordial al momento de nombrar al ser en la tradición metafísica. El modo propio del ser se entiende por medio de la comparecencia, del hacer presente, del puro presente presentificador.

Si entendemos el ser como comparecencia (presencia), y de la misma forma entendemos el descubrimiento como presente, estamos considerando ambas cosas como estar presente, por consiguiente, el ser mismo ha de determinarse necesariamente como presencia porque la verdad misma se ha considerado como presente. Resumiendo, el presente es la forma eminente de la comparecencia, entendiéndose el ser como simple presente. Para Heidegger esto ha sido uno de los signos decisivos de la tradición metafísica, tanto es así que:

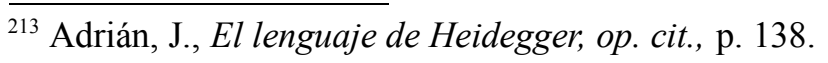


ya Platón designa el ser como presente (als Gegenwart). Y el término ousía, que de modo totalmente absurdo se ha ido divulgando en la historia de la de la filosofía como substancia, no significa otra cosa que la comparecencia (als Anwesenheit) en un sentido de modo determinado. Pero aquí es necesario enfatizar que aunque los griegos Platón y Aristóteles, definen el ser como ousía, estaban muy lejos de comprender qué significa en realidad determinar el ser como comparecencia y presente (Anwesenheit und Gegenwart). El presente es un carácter del tiempo. Entender el ser como comparecencia a partir del presente significa entender el ser a partir del tiempo (Sein verstehen als Anwesenheit aus der Gegenwart heisst Sein verstehen aus der Zeit) (GA21,193/158)

Llegamos por otro camino a la tesis fundamental del pensamiento heideggeriano, en cuyo horizonte adquieren su pleno sentido los problemas que no han dejado de aparecer una y otra vez en sus escritos de juventud, en su lecciones de los años veinte, esto lo afirma concretamente cuando sostiene que en esta comprensión del ser a partir de la comparecencia (Anwesenheit), se está comprendiendo el ser desde el tiempo. Esto tiene un valor señalado, en cuanto, Heidegger reafirma la relevancia que tiene para su filosofía la conexión indisoluble entre el ser y el tiempo. Empero, en estas lecciones llega a esta conclusión por la vía de la pregunta por la lógica, de la pregunta por la verdad, con lo que expresa de forma clara las amplias repercusiones que tiene esta cuestión para la filosofía en sus diversas manifestaciones y problemáticas. Este vínculo indisoluble sobre el que Heidegger ha vuelto una vez más, es una tesis fundamental de su filosofía que marcará su meditación en esta fase temprana de su quehacer intelectual, pero en términos generales, será una idea que acompañará su meditación filosófica hasta el final. Ratifica aquí algo que ya anunciado en el tratado el concepto del tiempo, pero que en esta lecciones desarrolla de modo más preciso, a saber, la distinción entre la presencia de algo en el mundo o ahí al frente, y el presente como modo del tiempo. Todo esto lo resume Rodríguez de la siguiente forma:

\begin{abstract}
lo decisivo estriba en que el puro estar descubierto de los entes no significa en el fondo más que la pura, imperturbada e imperturbable presencia actual de lo presente. La presencia actual es así el modo de la presencia de los entes. La codeterminación de verdad ( descubrimiento, presencia actual) y ser (presencia) es posible porque ambas se mueven en el mismo horizonte de significativo: presencia, estar presente (Präsenz). Ahora bien, concluye Heidegger, el concepto clave Gegenwart (presencia actual) es la palabra con la que nos referimos al presente temporal e incluye por tanto, un momento del tiempo ${ }^{214}$.
\end{abstract}

Heidegger pretende con esto aclarar los presupuestos, la proveniencia de esta determinación del ser como comparecencia y presente, en la cual se comprende el ser desde el tiempo. No obstante, hay que decir, que si bien se comprende el ser desde el tiempo, bajo la influencia de la tradición esto se hace desde el privilegio de una idea de tiempo dominada por el presente, cuestión que, como hemos visto, abre un horizonte de problematicidad fundamental para su quehacer filosófico que pretende entablar un diálogo destructivo con la tradición, para descifrar la proveniencia esencial de sus supuestos, para

${ }^{214}$ Rodríguez, R., La crisis de la época moderna, op. cit., p. 31. 
así cuestionarlos en su legitimidad al momento de inaugurar una nueva y original forma de hacer filosofía, nueva pero a la vez antiquísima, que intenta recoger lo no pensado por la misma filosofía, cuya única orientación son los fenómenos mismos, y no se rige por meras teorías del conocimiento ni por una actitud meramente contemplativa.

Heidegger se preocupa de presentar con precisión las conclusiones a las que ha llegado en su investigación. Para él es importante dejar claramente establecidos sus logros y la importancia que ello conlleva para la discusión filosófica, esto se hace visible cuando dice que, "Si se ha comprendido de una vez esta problemática de la conexión interna de la comprensión del ser a partir del tiempo, entonces se tiene ciertamente de alguna manera una luz para alumbrar ahora hacia atrás la historia del problema del ser y la historia de la filosofía en general, de modo que ahora obtengan su sentido"(GA21,194/158), esto nos permite ratificar lo dicho con anterioridad, que para Heidegger este es un descubrimiento decisivo, al que ha llegado a través de un largo recorrido, que le ha llevado al cuestionamiento de las categorías con las que la tradición filosófica pretendía dar cuenta de la realidad y del ser. Esta conclusión a la que ha arribado, tiene una importancia capital, dado que le permitiría, como él dice, alumbrar la historia del ser y de la filosofía en general, esto hará posible desvelar su sentido último. Se ha dado un paso importante, que permite ir más allá de la historia de la filosofía y de la tradición metafísica, y que nos enfrenta a la problemática fundamental que subyace en ella, gracias al fruto de la investigación que Heidegger ha emprendido desde hace ya algunos años, que le ha revelado esa conexión interna e indisoluble entre ser y tiempo.

Sin embargo, en dicha interpretación tradicional el ser y el tiempo son simplemente comprendidos desde el presente, desde la comparecencia. Si bien se ha avanzado en la tarea de la destrucción, en la tarea de la crítica a la tradición metafísica, aún queda mucho por hacer, es necesario ir aún más allá, es menester poner ahora en cuestión la legitimidad y originalidad de esta interpretación del ser, ha de ser sometida a un duro examen que deberá cuestionar su procedencia inveterada, su vigencia y su propiedad para referirse al ser y al tiempo de forma auténtica. Pues bien, para ir más allá, para dar ese paso en necesario avanzar retrocediendo, ir hasta la raíz misma de dicha interpretación del ser desde el tiempo y del tiempo como presente, para ello, se "requiere una comprensión del tiempo que rompe fundamentalmente con la tradicional" (GA21,194/159), Heidegger nos habla aquí de una ruptura con esa idea de tiempo, que ha dominado sin contrapeso la historia del pensamiento occidental, así de importante es la tarea que se propone, romper con esa comprensión del ser y del tiempo que se ha hecho indiscutible, como la forma privilegiada de nombrarlos. Esta es de algún modo, una declaración de principios de la labor que Heidegger viene desarrollando desde hace algún tiempo y que se puede verificar en el trabajo que hemos expuesto anteriormente, en el que la pregunta por la dimensión temporal de la existencia corre paralela a la determinación preponderante del ser en la tradición. Sin embargo, el rumbo que toman estas lecciones es difuso, puesto que: 
el análisis de la proposición y la verdad a partir de Aristóteles, que se lleva a cabo en la primera parte de las lecciones, da paso a un estudio pormenorizado del tiempo ¿Cómo se explica este cambio de temática? La proposición no tiene necesariamente la forma del juicio, sino que más bien descubre algo en el acto de presentar (gegenwärtigen). El ser es la presencia de algo que puede ser descubierto (verdad) o encubierto ( falsedad); "Ser significa presencia (Anwesenheit). Verdad significa presente (Gegenwart). Presencia y presente como modo de la Präsenz son modos del tiempo" (GA21, 199/163). Esto implica que el análisis de la proposición, es decir, el logos apophantikos, se orienta ahora hacia el tiempo, poniendo de relieve el carácter temporal de los fenómenos lógicos. Aristóteles mismo no se interroga por el sentido de esta identidad entre el ser y la verdad. Por ello, es necesario radicalizar la cuestión de la verdad para llegar a la raíz de su génesis a partir de la temporalidad ${ }^{215}$.

He aquí la importancia de estas lecciones, en las que Heidegger determina con mayor claridad ese vínculo esencial entre la pregunta por el ser y su determinación desde el tiempo. Ahora en adelante, la investigación habrá de preguntar si esa determinación del ser desde la comparecencia, desde el puro hacer presente, es la autentica y originaria determinación del ser. Se ha de cuestionar en profundidad las tesis que se han obtenido a lo largo de esta pregunta por la verdad, que dicen: ser significa comparecencia, verdad significa presente, la comparecencia se entiende a partir del presente, el presente es un modo del tiempo. Se ha de preguntar si estas tesis dan cuenta genuinamente de la verdad y del ser o si por el contrario, son impotentes y quedan cortas para referirse ellos. En esta línea de acción, Heidegger acuña un nuevo concepto que luego abandonará, nos referimos a la cronología fenomenológica (der phänomenologischen Chronologie), con ella se intentará hacer comprensibles los caracteres del tiempo peculiares a los fenómenos anteriormente interpretados en relación a la pregunta por la verdad, y las características en virtud de la cuales dichos fenómenos son temporales, Heidegger les llama caracteres temporarios (als temporale Charaktere), con la acuñación de estos conceptos pretende dar un nuevo aire a la pregunta por el tiempo, para lo que considera imprescindible dotarlos de una nueva conceptualidad, que sea capaz de dar nuevos bríos a dicha pregunta, que se ha anquilosado en razón de la influencia directa del aparato conceptual heredado de la tradición, en especial, en la que tiene relación con la pregunta por el tiempo.

Así lo hace saber, cuando señala que en la utilización de estos caracteres temporarios no se trata de una acuñación antojadiza de conceptos por el mero afán de complicarse y complicarnos, dice que "si nos vemos forzados a introducir (...) expresiones abstrusas y acaso nada lúcidas, no es por capricho mío ni porque tenga especial afición a emplear terminología propia, sino por imperativo de los fenómenos mismos" (GA20, 203/190), es por seguir a los fenómenos en su esencial constitución, el por qué de estas dificultades inherentes al lenguaje que Heidegger utiliza, que no lo hace con la intención de complicar las cosas, sino que por el contrario, dice expresamente:

${ }^{215}$ Adrián., J., Heidegger y la genealogía de la pregunta por el ser, op. cit., p. 356-7. 
utilizo expresamente este préstamo lingüístico "temporario", porque el término "temporal" (zeitlich) se emplea primeramente en nuestro discurso natural y prefilosófico, y porque, en este discurso "temporal" (zeitlich) significa simplemente que algo transcurre, que sucede, que se realiza en el tiempo (in der Zeit), mientras que cuando decimos que un fenómeno es temporario (Phänomen ist Temporal) no estamos diciendo que éste fenómeno sea un proceso o un movimiento, y menos aún estamos diciendo que se realice en el tiempo. Es decir, temporal, transcurrir en el tiempo, no es idéntico a temporario, que en principio significa lo mismo que "caracterizado por medio del tiempo. Si acerca de los fenómenos preguntamos en qué medida se caracterizan por medio del tiempo, estamos tomando su estructura temporaria o, dicho brevemente, su temporariedad (Temporalität) (GA 21,199/163).

Así Heidegger en la distinción que lleva a cabo cumple entre otras cosas, con un viejo anhelo que ha dirigido su labor filosófica, contraponerse a aquella interpretación del tiempo y de lo temporal, que los considera como aquello que pasa en el tiempo, que se realiza en el tiempo. Consigue de este modo, desmarcarse de aquella consideración de lo temporal como aquello que transcurre, que pasa en el tiempo, o que dice que es un proceso que se realiza en el tiempo, y aunque sea necesario para ello la acuñación de nuevos conceptos, la recuperación de otros, esto se hace con la sola intención de exponer y entender los fenómenos en su genuina y originaria constitución, y no siguiendo la comprensión e interpretación que de ellos lleva a cabo la tradición que no hace más que oscurecen su sentido primigenio.

Este concepto de temporario es el llamado a diferenciar una concepción del tiempo que ha sido la dominante en la tradición metafísica, frente a la que Heidegger quiere oponer una consideración originaria del tiempo y de la temporalidad propiamente humana. Esta distinción aquí presentada, representa la cristalización de un largo camino que Heidegger ha transitado, en la búsqueda de una nueva forma de plantear y desarrollar la pregunta por el ser y el tiempo, que sea capaz de expresar estos problemas fundamentales de la reflexión filosófica. Dice Peñalver:

En líneas generales se destacan dos elementos "imprevistos". Por un lado, cuestión de la
verdad y la falsedad se sitúa en el horizonte de la analítica del Dasein pero en la medida
en que está explícita la temporalidad. El "resultado" dicho dogmáticamente, de la
explicación precedente a través de Aristóteles ha sido el de mostrar que el ser como
verdad es presencia, e.e., un modo de mostrar que el ser como verdad es presencia, e.e.,
un modo de tiempo. La verdad es un fenómeno temporale, temporario, caracterizado por
el tiempo, y no zeitlich; temporal que ocurre en el tiempo. A la consideración filosófica
que tiene como tarea el tiempo y la determinación temporale de los fenómenos ( no lo que
está en el tiempo) le da Heidegger aquí el nombre de "cronología filosófica" al que
renunciará posteriormente

La tarea en adelante será preguntar por la temporariedad de los fenómenos en un trabajo que se dirige a estas determinaciones del tiempo mismo, es una pregunta por el tiempo en su carácter original. El pensador de la Selva Negra dice respecto a su trabajo:

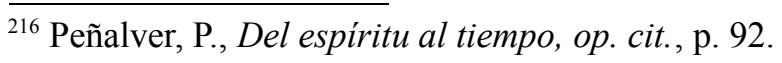


a esta reflexión filosófica fundamental que tiene como tema el tiempo la designamos cronología, y concretamente cronología fenomenológica (...) con el añadido cronología "fenomenológica" ha de indicarse que este logos del tiempo, esta investigación del tiempo está orientada filosóficamente, y que en principio no tiene nada que ver con el cómputo del tiempo ni con la doctrina del cómputo del tiempo. la tarea de una cronología filosófica es la investigación de la determinación temporaria de los fenómenos, es decir, de su temporalidad, y por tanto la investigación del propio tiempo (GA21,200/163),

Se puede concluir que este no es precisamente el final de una investigación que ya ha llegado a su fin una vez obtenidos ciertos resultados, por el contrario, se abre aquí una nueva vía de problematicidad, es un nuevo comienzo para la investigación filosófica, con lo ganado hasta ahora, cree Heidegger poder reconducir la filosofía hacia su problemática fundamental.

aquí es donde entra en juego el (...) proyecto de una cronología fenomenológica que analiza la estructura temporaria de los fenómenos y que, a la postre, implica una investigación del tiempo mismo (...) el efímero nombre de "cronología fenomenológica" no indica tanto la fundación de una nueva disciplina filosófica como una redefinición de la tarea de la filosofía. Desde un punto de vista estrictamente etimológico, la cronología fenomenológica consiste en concebir el pensamiento (logos) en su propia temporalización (chronos). Esta idea evita caer en una simple subjetivación del tiempo (Agustín) o en una subjetividad absoluta (Husserl), a la vez que permite pensar esta extraña identidad de Dasein y tiempo ${ }^{217}$.

De esta forma es posible superar las insuficiencias y la estrechez de la ontología clásica, de la filosofía tradicional que "estaba cerrada en gran medida a diversos dominios del ser, en que era ciega frente a ellos, encerrada y limitada a un determinado círculo del ser, el ser de la naturaleza real de lo físico y de los psíquico, que era considerado el único" (GA 21, $53 / 52)$.

Al concluir estas lecciones Heidegger ya ha realizado un análisis profundo de la estructura del Dasein, de la analítica existenciaria, que luego repetirá en Ser y tiempo, razón por la cual no nos detendremos en ello. No obstante, vuelve sobre algunas conclusiones que había obtenido anteriormente, para luego sacar a relucir aquello que buscaba en estas lecciones de lógica.

Por ende, todo este trabajo le ha permitido reconducir la pregunta por la lógica, por la verdad, hasta la misma existencia, pero no en cuanto a un análisis más o menos completo de este ente, sino especialmente hacia esa estructura temporal que posee la existencia y el cual se da el reverso del tiempo metafísico como hemos dicho con anterioridad, solo en esa dirección investigativa descansa la posibilidad de una lógica filosofante, de una lógica que se reconduzca hacia su más genuino elemento. El enunciado en cuanto es primordialmente un enunciar determinador de lo que está ahí, enuncia lo presente en tanto presente, y se fundamenta en este mismo hacer presente, solamente se conduce con una visión limitada del tiempo y del ser de los entes, por lo que es

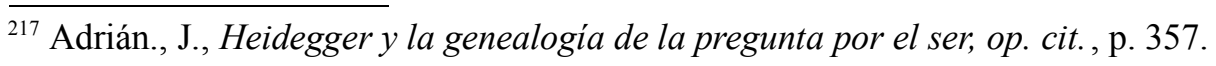


esencialmente insuficiente para formular la pregunta por el ser de los entes, o de los entes en su originaria constitución, fallo cuyo punto de partida está en la comprensión misma del ser que ha campeado sin mayores contratiempos a lo largo de la historia de la metafísica y que ha influenciado desde siempre los fundamentos de la verdad, especialmente los de la lógica. Por estas razones Heidegger sostiene:

la lógica es la más incompleta de todas las disciplinas filosófica, y solo se la puede sacar
adelante si ella reflexiona sobre la estructuras fundamentales de sus fenómenos temáticos,
sobre las estructuras primarias del ser de lo lógico en tanto que una conducta de la
existencia, sobre la temporalidad de la propia existencia. Pero el fundamento inexpresable
de la lógica tradicional es una determinada temporalidad que se orienta primariamente con
arreglo al hacer presente, lo cual expresa de modo extremo en la formulación del concepto
griego de conocimiento como $\tau \varepsilon \omega \rho \varepsilon ı v$ puro, como intuir puro. Toda verdad de esta lógica
es verdad de la intuición. Intuir como hacer presente (GA21, 415/326).

Por último, en estas lecciones de lógica, que Heidegger ha llevado por un rumbo difuso, que nos ha conducido desde el problema de la verdad hasta el problema del ser y luego hasta la cuestión del tiempo mismo, sobre el cual se ha explayado largamente en una discusión con Aristóteles, Bergson y sobre todo con Kant, nos deja Heidegger una particular reflexión respecto al tema de nuestra investigación, y entrega una referencia presisa respecto a esta problemática, que a nosotros nos sugiere nuevamente que para el filósofo alemán este es un problema fundamental que esta en la raíz de su crítica a la tradición metafísica. Dice Heidegger:

Desde que (...) Aristóteles expusiera este concepto del tiempo por vez primera y con una profundidad conceptual que ya no se ha vuelto a alcanzar, él ha seguido siendo la autoridad para toda reflexión filosófica sobre el tiempo. Desde Aristóteles hasta Hegel-y también para el período posthegeliano de la filosofía-este concepto del tiempo sigue siendo el hilo conductor para la pregunta por el tiempo. Esto tiene su motivo específico en que el tiempo así tomado es el tiempo que se impone primera y constantemente en la experiencia cotidiana (GA21, 249/201).

De modo, que esa interpretación aristotélica del tiempo es la que domina y determina sin contrapeso la pregunta por el tiempo en la historia de la filosofía, pero no solo la consideración del tiempo, sino también del ser.

En esta lecciones Heidegger ha señalado de forma directa las conexiones entre la Anwesenheit, Präsenz, Gegenwart, Gegenwärtigen y la pregunta por el ser, estableciendo claras distinciones entre ellas, que significan en último término que la interpretación del ser de la filosofía clásica esta realizada desde una determinada comprensión del ser desde la presencia, desde un modo temporal el presente. Por ello, ahora Heidegger plantea con toda claridad que la pregunta por el ser nos remite al tiempo mismo, y una nueva fundamentación de la pregunta por el ser necesariamente ha de ser reconducida a una investigación originaria por el tiempo. En un momento de esta discusión que Heidegger mantiene con la tradición filosófica, específicamente con Hegel, el pensador de la Selva Negra se retrotrae a un texto temprano de este titulado Lógica de Jena, que como 
recuerda en estas lecciones del semestre de invierno de 1925-1926, de modo casual le trajo a recuerdo un alumno. En esa interpretación del tiempo, anterior a la Enciclopedia, Hegel sostiene que la esencia del futuro es el presente; justamente sobre está frase arremete Heidegger, diciendo que es justamente la tesis contraria a la suya, que sostiene no que la esencia del presente es el futuro, sino que afirma que el sentido de la temporalidad es el futuro. Heidegger comenta que Hegel,

siguiendo la comprensión natural del tiempo, ve el tiempo y el devenir como corriendo desde el futuro. Hegel dice incluso directamente: "el futuro es la esencia del presente" y aquí entiende esencia en sentido griego, a saber, como aquello de donde cada ahora surge en tanto que ahora, a saber, a partir de su ahora-todavía-no. Recalco intencionadamente esta tesis: la esencia del presente es el futuro, porque yo mismo remarqué en una conferencia anterior (semestre de verano de 1924 no que la esencia del presente es el futuro, sino que el sentido de la temporalidad es el futuro (Der Sinn der Zeitlichkeit ist die Zukunft). Pero el significado de la tesis que defiendo aquí es diametralmente opuesta a lo que aquí dice Hegel (GA21, 264-5/212).

Es justamente en estas lecciones de importancia capital en la filosofía de Heidegger, en las que profundiza en el vínculo indisoluble entre el problema del ser y el tiempo, en el que crítica de forma precisa la concepción del ser como simple presente, como tiempo del ahora con dos brazos abiertos al no-ser; tesis de las cuales precisamente Hegel sería un exponente privilegiado, como aquel que justamente se encontraría en las antípodas de una consideración originaria del tiempo como la propuesta por Heidegger. Esta idea del tiempo que subyace en la interpretación hegeliana como tiempo de la naturaleza, es desde donde se obtienen las ideas básicas de la interpretación vulgar del tiempo. Pero además, llama la atención que Heidegger comente que su interpretación de la temporalidad originaria, es diametralmente opuesta a la de Hegel, como si su interpretación pretendiera justamente eso, oponerse a la del padre del idealismo alemán. Pareciera que Heidegger tuviera una deuda pendiente con él y con la tradición metafísica que precisamente quisiera saldar aquí. Esto, porque Heidegger al contrastar su interpretación del tiempo con la hegeliana, busca enfrentar su concepción de la temporalidad con la ontología tradicional, afirmando de este modo su propia filosofía.

Para Heidegger, es verdaderamente significativo que Hegel se refiera al tiempo justamente en su filosofía de la naturaleza, lo que significaría que entiende el tiempo como ligado esencialmente a la naturaleza, dentro de ella, por lo que sería una interpretación realista del tiempo, es decir, que las cosas mismas, los entes de la naturaleza son temporales. Y por contraposición, no dice que la esencia del tiempo es el futuro, ni que este es el carácter fundamental del tiempo, sino que el sentido del tiempo es el futuro, con lo que Heidegger reafirma una vez más la importancia para su filosofía de esta idea del tiempo, que formula de distinta manera en este periodo, pero que mantienen una constante, la radicalidad que le confiere a esta instancia temporal. El ser futuro es la esencia del tiempo (Cf. GA 64, 59/78), “el fenómeno fundamental del tiempo es el 
futuro"(GA64,118/47), "el carácter fundamental del ser temporal reside en el ser-futuro" (GA64,81/104) y ahora reafirma, pero de un modo distinto, "el sentido de la temporalidad es el futuro" (GA21,265/212), todas estas son cuestiones que nos indican la importancia y radicalidad de esta problemática en su proyecto filosófico en esta etapa de su pensamiento, como articulador de la reformulación de la pregunta por el ser, la crítica a la concepción del ser de la metafísica tradicional, como reverso del tiempo de la metafísica, y siguiendo la interpretación de Brague, por que no decirlo, como fundamento metafísico de la metafísica; apartándose del modelo físico que la había determinado desde la Física aristotélica, precisamente con esta interpretación del tiempo se cumpliría dicho proyecto. "Heidegger ha roto-o mejor: afirma haber visto romperse de suyo-el espinazo, la columna vertebral de la metafísica occidental, a saber: la estrechísima pero oculta conexión entre el ser y el tiempo, entre la presencia (la presencia de lo que es verdad, de lo que no cambia) y el presente" 218 .

Es a esta determinación de la temporalidad propia del Dasein, del tiempo mismo, que ha de remitirse la pregunta por la lógica, si pretende ser una lógica constructiva, una lógica filosófica, por ello dice Heidegger al concluir estas lecciones que "si en la temporalidad de la existencia hubieran de encerrarse posibilidades temporales más radicales, entonces éstas tendrían que poner un límite esencial a la lógica y a la ontología tradicionales. Que la investigación filosófica pueda ser lo suficientemente intensa y fuerte como para hacer de hecho estos límites es una cuestión de su destino" (GA21,249/201), y precisamente alude a esa interpretación de la temporalidad de la existencia, cuya constitución más propia se ha de revelar, este es el próximo paso de esta filosofía, que ha problematizado y se ha enfrentado con la entera tradición metafísica, en esta concepción de la temporalidad del Dasein, cuyo sentido es el futuro, es en dónde estriba la posibilidad de poner límites a la lógica y a la ontología tradicional, y poder así reconducir a la metafísica hacia su propio destino como preguntar fundamental del ser.

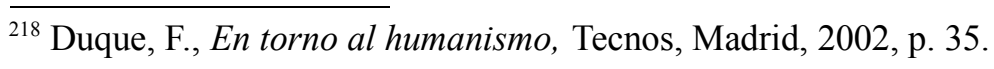




\section{SEGUNDA PARTE}

\section{Capítulo I: El tiempo como articulador de la reformulación de la pregunta por el ser}

En la introducción con la que Heidegger presenta su tratado de 1927, conjunta una serie de conclusiones y resultados a los que ha llegado a lo largo de sus primeros años de docencia universitaria. Esto, tanto en lo propiamente temático (la pregunta por el ser y la cuestión del tiempo) como en lo metodológico. Podríamos decir que antes de acometer la tarea de la analítica del Dasein considera oportuno resumir de forma cabal los resultados principales de su trabajo anterior y, al mismo tiempo, proyectarlos hacia su investigación venidera.

Paso a paso el pensador alemán ha ido construyendo su edificio filosófico, que le ha llevado a concluir que la cuestión del tiempo tiene una importancia superlativa para conducir la filosofía hacia su problemática verdaderamente esencial, en cuanto es el fenómeno sobre el cual descansa toda interpretación y comprensión del ser, es el elemento decisivo, gracias al cual es posible desvelar el fallo fundamental de la metafísica, que tiene como punto de partida una determinada e inveterada interpretación del ser, que lo piensa como presencia, desde el presente, lo que ha impedido obtener una comprensión originaria de este ente llamado Dasein.

El tiempo cumple el papel de hilo conductor que guía el intento heideggeriano de reformular la pregunta por el ser y por ello ha de ser cuestionado en profundidad. Por tanto, es menester entender esta introducción como un punto de llegada y un punto de partida. Punto de llegada en cuanto sintetiza aquí varias de la conclusiones que ha ido obteniendo a lo largo de sus lecciones universitarias tanto en Friburgo como en Marburgo, principalmente respecto a la pregunta por el tiempo que hemos presentado en la primera parte de nuestro trabajo y, además, en cuanto radicaliza la importancia que posee la cuestión del tiempo al momento de reformular la pregunta por el ser. Y por otro, como punto de partida, en cuanto ya no es la temporalidad sin más la que le interesa escrutar, sino que más bien es la Temporalität del ser la tarea ontológica fundamental hacia la que dirige sus esfuerzos, entendiendo esto como fin último hacia el que se conduce su investigación. Estableciendo una distinción entre el tiempo propiamente humano y el tiempo del ser (cuestión que no había llevado a cabo hasta entonces). Ahora la pregunta por la estructura ontológica del Dasein, solo tiene una importancia derivada respecto a la pregunta fundamental. 
En un primer momento de nuestra investigación se ha podido constatar que la pregunta que dirigía la meditación heideggeriana era la pregunta por la vida fáctica, por la experiencia fáctica de la vida humana, no obstante, aquello no significaba que dejara completamente de lado la pregunta por el ser. La dirección que seguía el trabajo de Heidegger cuando se hacia cuestión del tiempo, en sus lecciones de fenomenología de la vida religiosa y el Natorp Bericht era clara. En primera instancia se hacia una exposición de la estructura ontológica de la vida humana en su facticidad, cuyos resultados revelaban la insuficiencia del aparato conceptual de la tradición metafísica para dar cuenta de dicha experiencia fáctica de la vida, lo que llevaba a Heidegger a preguntarse desde qué ámbitos ontológicos surgían las consideraciones de la vida humana que llevaba a cabo la tradición filosófica. En otras palabras, se preguntaba por la comprensión del ser que subyacía en aquellas interpretaciones de la metafísica.

El camino que ha seguido su investigación le ha permitido concluir que esta interpretación del ser desde la que parte cualquier exégesis de la vida fáctica, tiene como punto de partida que la metafísica desde sus primeros pasos ha pensado el ser como presencia.

La falta de la metafísica-esta ha sido la intelección decisiva de Heidegger-estriba en que piensa el ser como "ver", el ser como constante ser-ante-los-ojos, como constante asistencia, y así no puede hacer la experiencia de la cumplimentación de la vida-fáctico histórica misma, cumplimentación en la que no cabe sosiego. Y sin embargo, ¿no se yerguen acaso tras toda metafísica facticidad e historicidad como aquello por ella olvidado? Si la metafísica piensa el ser como constante asistencia, ¿no piensa entonces a partir de un determinado modo temporal, a partir del presente? ¿No cae la decisión sobre el sentido del ser dentro de un ámbito que en su esencia es "tiempo”? ¿Pertenece el tiempo al sentido del ser, y es este tiempo lo impensado y olvidado de la metafísica? ${ }^{219}$.

Pöggeler presenta aquí de forma precisa una de las conclusiones más importantes de lo que ha sido el camino que Heidegger ha recorrido a lo largo de sus primeros años de docencia universitaria, tanto en Friburgo como en Marburgo. Este fallo en la metafísica es el que ha impedido una interpretación de carácter originario de la vida fáctica y de la historicidad. Y ello principalmente, a causa de la forma en que la tradición metafísica ha concebido el ser, esto es como presencia constante, desde un determinado modo temporal, el presente.

Necesariamente la pregunta sobre el sentido del ser que Heidegger se dispone a acometer, se enmarca dentro del horizonte del tiempo, y este mismo tiempo que se conjunta y pertenece esencialmente a ese sentido del ser es lo olvidado por la tradición filosófica. Y si no olvidado, en el mejor de los casos, ha sido pensado considerando como modelo ontológico la naturaleza, lo Vorhandenheit.

Esta discusión que Heidegger ha mantenido con la filosofía precedente, especialmente con Aristóteles, le ha permitido llegar a estas conclusiones y a señalar con

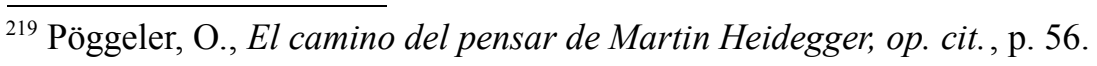


respecto al tiempo, que el carácter temporal fundamental de este es el futuro, por lo que su tesis respecto al tiempo es precisamente la contrapuesta a la que propone la tradición metafísica. Junto con ello la interpretación del ser como presencia constante, como Vorhandenheit, ya no puede ser considerada como una tesis de validez absoluta, en razón de esto, Heidegger se pregunta por el sentido del ser, desde la pregunta por el ser y el tiempo. Dicha cuestión se viene prefigurando tal como hemos señalado desde el Natorp Bericht, haciéndose aún más explícito en el tratado El concepto del tiempo, en Prolegómenos del concepto del tiempo y en Lógica la pregunta por la verdad.

Sin embargo, es en Ser y tiempo donde se hace explícita con mayor claridad dicha pregunta, aunque como bien sabemos no termina por desarrollar del todo, para él la pregunta por el sentido del ser es la pregunta verdaderamente fundamental de la filosofía. En este horizonte, se abre

el ámbito en el que el pensar cumplimenta la transición del ente al ser, el horizonte trascendental para la determinación del ser en cuanto ser, es interpelado ahora en su esencia. La doctrina metafísica del ser, la ontología es cimentada de manera ontológicofundamental por medio de la pregunta por el sentido del ser en cuanto fundamento de todo posible significado del ser (...) Ser y tiempo es el despliegue de la cuestión sobre el modo de pertenencia del tiempo al sentido del ser. Ser y tiempo es el intento de recoger de modo pensante aquello que permanece impensado, el fundamento olvidado de la metafísica sobre el cual descansaba desde luego todo lo pensado por el ella ${ }^{220}$.

Según Pöggeler, lo que hace Heidegger es puntualizar de modo más concreto, el vínculo que existe entre el ser y el tiempo, que se pertenecen esencialmente, y esto con el afán de llevar a cabo una nueva fundamentación de la metafísica, que retome y reconduzca la pregunta por el ser desde el horizonte del tiempo.

La vía que se propone para obtener claridad respecto a la cuestión de tiempo, establece como primer paso una analítica del Dasein, que nos brinde una determinación de su constitución temporal y desde la temporalidad del Dasein es como debe ser entendido el tiempo.

Como sentido del ser de este ente que llamamos ser ahí, se muestra la "temporalidad"(...) con esta interpretación del ser ahí como temporalidad no queda aún dada la respuesta a la pregunta directiva, que interroga por el sentido del ser en general, aunque si queda preparado el terreno para obtener esa respuesta (...) mostraremos que aquello desde lo cual el "ser ahí" en general comprende e interpreta, aunque no expresamente, lo que se dice "ser", es el tiempo. Este tiene que sacarse a la luz y concebirse como genuino horizonte de toda comprensión y toda interpretación del $\operatorname{ser}^{221}$.

Heidegger en esta introducción a Ser y tiempo indica claramente cuales son los objetivos, la intención que guía su analítica, esto al margen de si su tarea queda incompleta. Ya no es la pregunta por las categorías ontológicas de la vida fáctica sin más el objetivo de su

\footnotetext{
${ }^{220}$ Ibíd., p. 56.

${ }^{221} \mathrm{ST}, 27$
} 
investigación, su intención ahora es que por medio de la analítica del Dasein sea posible ganar el horizonte para una interpretación del ser en general. Es la temporalidad peculiar al Dasein la que revela el sentido del ser de este ente, y es desde ahí, desde donde debe ser comprendido el tiempo, y la modalidad en que forme parte del sentido del ser, que abra por tanto, ese ámbito de pertenencia al ser en cuanto ser. Desde la temporalidad del Dasein a la pregunta por el sentido del ser. "El camino hacia el ser pasa por el camino de la exégesis especial de un determinado ente, el ser-ahí, en el que la pregunta por el ser encuentra su horizonte trascendental de comprensión. En una palabra, el desarrollo de la problemática ontológica exige como paso previo la analítica existencial del ser-ahí'”22.

Sin embargo, tal como precisa Heidegger, con la exégesis de la temporalidad de Dasein no se da respuesta a la pregunta última que guía su investigación, que es la pregunta por el sentido del ser en general, pero sí la interpretación de la temporalidad del Dasein, pavimenta el camino hacia esa pregunta, este es el resultado que se ha obtenido en la parte publicada de Ser y tiempo. Con esta indicación que Heidegger hace pareciera que desde un principio tuviera claro que la tarea que se proponía en este tratado terminaría finalmente por quedar inacabada, inconclusa y que, sin embargo, lo importante sería dejar preparado el camino para llegar a dicha respuesta, quizás por ello hace alusión a la provisionalidad de su trabajo. Lo fundamental es exponer qué papel juega el tiempo en esta reformulación de la pregunta por el ser que él pretende llevar a cabo, que considera la pregunta filosófica por antonomasia. Consecuente con esto, su interés fundamental ha sido mostrar que desde el tiempo es desde donde el Dasein comprende el ser, aunque ello sea implícitamente e inmerso en la cotidianidad. Por ello, la exigencia que plantea al respecto, es que la cuestión del tiempo debe ser aclarada en su genuina y originaria constitución ontológica, en cuanto horizonte de toda comprensión del ser y toda forma de interpretarlo. Lo que se pretende con esto es dar paso más precisos y lograr configurar de forma más definitiva esa pertenencia esencial entre el ser y el tiempo que según Heidegger le permitirán reconducir la filosofía hacia su pregunta primigenia. Por ello señala, que "se ha menester de una explanación originaria del tiempo como horizonte de la comprensión del ser, partiendo de la temporalidad como ser del ser-ahí que comprende el ser,"223.

A juicio de Heidegger, el tiempo no puede ser ahora un criterio óntico de distinción de las distintas regiones del ente, tal como sucedía desde la antigüedad. Desde sus primeras lecciones de Friburgo la consideración del tiempo, de lo temporal, como aquello que pasa en el tiempo, ha dejado de tener validez ontológica para el pensador alemán, por lo que ha sometido a dicha noción a un cuestionamiento constante, lo que le ha llevado a preguntarse por cómo llega esta interpretación del tiempo a ser una de carácter tal, que sea la privilegiada al momento de referirnos al tiempo. Y siguiendo esta misma dirección, quiere sacar a la luz cómo tras esta utilización o modo de interpretar el tiempo subyace y

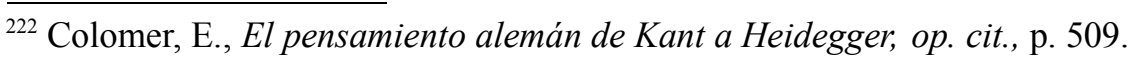

${ }^{223}$ ST, p. 27. 
se muestra una interpretación del ser que ha dominado sin contrapeso la historia de la metafísica. Por ello, "frente a esto hay que mostrar, sobre la base de la pregunta que interroga por el sentido del ser bien desarrollada, que en el fenómeno bien visto y explanado del tiempo tienen sus raíces los problemas centrales de toda ontología y cómo las tienen" ${ }^{224}$. Aunque esta tarea que Heidegger se propone aquí quedará inconclusa, dado que no llegará a determinar de forma concreta dicho sentido del ser, sí en cambio, muestra de forma innegable la importancia que para él tiene la cuestión del tiempo, como aquel fenómeno sobre el cual se sostiene y sostiene toda la problemática ontológica fundamental, pero no queda del todo claro porqué esa cuestión sea así, lo que sí es esclarecedor es la importancia que le asigna el pensador de la Selva Negra.

Siguiendo en esta línea puntualiza que el objetivo primordial de su investigación en lo que viene es la pregunta por el sentido del ser y al interior del ámbito que abre esta pregunta fundamental se pretende pensar el tiempo del ser mismo, y no solamente la temporalidad del Dasein. Lo que implica una importante distinción y delimitación de la cuestión del tiempo, que hace referencia a un tiempo propiamente humano y el tiempo del ser. Si el ser se concibe desde el tiempo, y desde ahí se hacen comprensibles las distintas formas y modulaciones que el ser mismo adquiere, significa que es el ser en cuanto tal , y no solamente el ente que está en el tiempo el que se ha mostrado y presentado en su carácter temporal. Este preciso carácter temporal del ser y no del Dasein ha de tener su propia expresión. Dice Heidegger:

\footnotetext{
llamamos a la determinación original del sentido del ser y de los caracteres y modos de éste oriundos del tiempo, su determinación "temporaria" (temporale Bestimmtheit). El problema ontológico fundamental, de la exégesis del ser en cuanto tal, abarca por ende el poner de manifiesto la "temporariedad" del ser (Temporalität des Seins). En la exposición de la temporariedad se da por primera vez la respuesta concreta a la pregunta que interroga por el sentido del $\operatorname{ser}^{225}$.
}

Se muestra aquí algo que ya habíamos dicho con anterioridad, en Ser y tiempo se lleva a cabo una radicalización ontológica del preguntar heideggeriano que va en dirección al ser mismo, al puro ser, donde la pregunta por el ser adquiere un peso y protagonismo indiscutible al interior de su pensamiento y de su quehacer filosófico, cuestión que no dejará de ser así hasta el final de su vida.

La pregunta por el ser es la que guía la filosofía de Heidegger de ahora en adelante, en ella la pregunta por el tiempo juega un rol determinante, decisivo, en cuanto ambas preguntas se incluyen y copertenecen de forma esencial e inseparable. La interpretación ontológico fundamental del ser incluye necesariamente la aclaración de su temporalidad y solo en ella se hará visible la pregunta misma por el sentido del ser. Esta introducción fija un nuevo punto de partida, al hablar Heidegger de la Temporalität des Seins, quiere

\footnotetext{
${ }^{224}$ ST, p. 27.

${ }^{225}$ ST, p. 29.
} 
establecer sin lugar a dudas una clara distinción entre esta idea del tiempo propia al ser mismo y la temporalidad peculiar al ser del Dasein. Heidegger hace referencia con esto al tiempo del ser y al tiempo del Dasein humano, de ahí que quiera delimitar con rigurosidad el concepto con el que alude a este tiempo del ser mismo.

Antes de esto, la meditación heideggeriana se movía en una ambivalencia ontológica respecto a la cuestión del tiempo, marcado por la absoluta falta de distinción o precisión en relación a esto, dado que en algunos momentos, especialmente en sus primeras lecciones de Friburgo, hablaba del tiempo sin más. Por eso muchas veces cuando hace referencia al futuro como carácter fundamental del tiempo queda en la oscuridad si esta es un carácter del tiempo predicable al tiempo en general o solo a la temporalidad del Dasein, con lo que se nos presentan muchas preguntas, ¿es el tiempo mismo el que tiene dicho carácter o solo la temporalidad del Dasein? ¿es adjudicable este señalado carácter prioritario del futuro a la Temporalität del ser?

Por lo tanto, son múltiples las preguntas que pueden surgir a partir de esta ambivalencia ontológica en la cual se mueve la pregunta por el tiempo que Heidegger lleva a cabo en el periodo anterior a Ser y tiempo, sin embargo una cuestión incontrastable es que si bien Heidegger no volverá a repetir las primeras formulaciones con las que presenta esta cuestión que tiene que ver con la importancia del futuro y el papel que juega este modo temporal en la interpretación del tiempo, sí dirá aquí que la "La temporalidad original y propia se temporacía desde el advenir propio, por modo que advenideramente sida despierta ante todo el presente. El fenómeno primario de la temporalidad original y propia es el advenir" ${ }^{\prime 226}$. Ahora el futuro es el fenómeno primario y fundamental, pero no del tiempo mismo sino de la temporalidad originaria y propia del Dasein. Heidegger modifica, transforma el significado de dicha tesis para puntualizar su sentido en el marco de un proyecto filosófico que ya posee contornos más definidos y es lo que se muestra en esta introducción. Sin embargo, la influencia y la importancia que posee dicho éxtasis temporal se podrá verificar en la interpretación de la temporalidad originaria que lleva a cabo Heidegger.

Retomando la tesis heideggeriana acerca de la temporalidad y el sentido del ser, Pöggeler se pregunta por la legitimidad de lo allí planteado y lo hace en los siguientes términos: “¿es necesario, empero, que el ser venga en general a ser concebido "a partir del tiempo? La afirmación de que el tiempo pertenece al sentido del ser y de que el camino hacia ese tiempo pasa por la temporalidad de la existencia fáctica, ¿ no es una hipótesis arbitraria, un "nuevo punto de vista”, cuyo derecho no está legítimamente probado?"227, se reflejan en estas reflexiones las dudas y posibles reparos que pueden surgir a partir de estas tesis heideggerianas, si bien el pensador alemán, en su camino a Ser y tiempo, ha interpretado el tiempo como sentido del ser del Dasein, como su constitución ontológica

\footnotetext{
${ }^{226}$ ST, p. 357.

${ }^{227}$ Pöggeler, O., El camino del pensar de Martin Heidegger, op. cit., p. 60.
} 
fundamental, ahora lo considera como horizonte de comprensión del ser en general, cuestión que no llegó a tratar en la sección publicada de esta obra, pero sí deja enunciada. Como dice Löwith, "la primera mitad del el ser y tiempo no cumple, sin embargo, con lo que promete el título, sino que simplemente conduce hasta la interpretación del ser a partir del tiempo que se encuentra en la temporalidad de un Dasein finito"228.

No obstante, la dirección que seguía la investigación heideggeriana, proponía en principio asegurar el terreno ontológico desde el cual se solventaba su tesis, en cuanto a que el ser desde principios de la filosofía griega había sido concebido desde el tiempo, aunque ello haya sido una cuestión implícita para los griegos y, por ello, algo de lo que no se hicieron cuestión. Consciente de esta situación, Heidegger propone una vuelta atrás que permita mostrar y comprender de qué forma en la historia de la filosofía se ha comprendido el ser y cómo esa interpretación se llevaba a cabo precisamente desde el tiempo:

Si ha de lograrse en punto de la pregunta misma que interroga por el ser el "ver a través"
de su peculiar historia, es menester ablandar la tradición endurecida y disolver las capas
encubridoras producidas por ella. Es el problema que comprendemos como la destrucción
del contenido tradicional de la ontología antigua, llevada a cabo siguiendo el hilo
conductor de la pregunta que interroga por el ser, en busca de las experiencias originales
en que se ganaron las primeras determinaciones del ser, directivas en adelante ${ }^{22}$.

La destrucción de la historia de la ontología tiene como objetivo principal reconocer el punto de partida desde el cual se origina esta comprensión del ser que, según Heidegger, perdura hasta nuestros días, y que ha hecho que generalmente esta pregunta por el ser haya caído en el olvido, se malinterprete, o simplemente se le considere como superflua o sin sentido. Solo en esta destrucción llevada a cabo al alero de la pregunta por el ser, se podrán reconocer las experiencias decisivas desde las que se obtuvieron los caracteres primigenios que marcaron dicha inveterada concepción del ser y determinaron el modo de pensar de la entera cultura occidental, según la interpretación del ser como presencia. Y es precisamente esta tarea de destrucción de la historia de la filosofía la que nos revelará de qué forma la pregunta por el ser ha de venir necesariamente relacionada con el tiempo:

La destrucción de la historia acontecida de la ontología tiene que mostrar la manera en que la pregunta por el ser le viene impuesta al pensar por la ontología tradicional, aunque en esta ontología la pregunta por el ser no venga propiamente a emplazarse. La ontología pregunta por el ser del ente orientándose, en su preguntar, hasta lo ente con que se topa en el mundo y que puede poner, pues, ante-los-ojos. Es a partir del ente presente y representable como viene entendido el ser de cada ente y hasta el ser del hombre, del $\operatorname{estar}^{230}$.

\footnotetext{
${ }^{228}$ Löwith, K., Heidegger, pensador de un tiempo indigente, FCE, Buenos Aires, 2006, p. 190. Trad. Román Setton.

${ }^{229}$ ST, p. 33.

${ }^{230}$ Pöggeler, O., El camino del pensar de Martin Heidegger, op. cit., p. 60.
} 
Tarea destructiva apenas esbozada en la parte publicada. Otra cuestión importante, tiene que ver con el carácter mismo de la destrucción, para Heidegger si esta tiene un sentido negativo o perjudicial, esto solo es implícito e indirecto, secundario si se quiere. En efecto, la destrucción posee un sentido eminentemente positivo y para nada pretende borrar de un plumazo la endurecida tradición ontológica ni sus consecuencias correspondientes, como si se la considerara algo inservible y de lo cual se debiera prescindir. Por el contrario, lo que pretende el pensador alemán con esto, es enmarcarla y situarla dentro de lo positivo de sus propias posibilidades ontológicas y dentro también de sus propias limitaciones, para extraer desde allí las experiencias fundamentales que determinaron la historia de la ontología y con ello la misma pregunta por el ser. Estas posibilidades y limitaciones solo se mostrarán en sus propias proyecciones una vez alcanzado el sentido y las posibilidades que abre la filosofía antigua desde el ámbito de la pregunta por el ser que se pretende reformular aquí. Dice Heidegger:

En otras palabras: la destrucción se ve colocada ante el problema de la exégesis de la base (des Bodens) de la ontología antigua a la luz de los problema de la temporariedad (Temporalität). Entonces se hará patente que la interpretación antigua del ser de los entes se orienta por el "mundo" o la "naturaleza" en el sentido más amplio, y que en efecto saca del "tiempo" la comprensión del ser. La prueba extrínseca de ello-pero solo esto-es la determinación del ser sentido del ser como parousía u ousía, que significa ontológicamente presencia. El ente se concibe, en cuanto a su ser, como "presencia", es decir, se le comprende por respecto a un determinado modo del tiempo, el "presente"

En esta tarea de la destrucción que nos lleva directamente al suelo mismo desde el que la ontología griega piensa el ser desde el tiempo, nos muestra que desde la filosofía antigua se comprende el ser en general y el Dasein mismo desde el modelo ontológico de la Vorhandenheit, desde la naturaleza, en decir, a partir del mundo. A raíz de ello, permanece inaccesible desde un principio el camino que nos llevaría a una interpretación originaria de la vida humana. "Cuando en la edad moderna el "sujeto", "el espíritu", la "persona" son colocados en el centro del preguntar, entonces son entendidos en su ser a partir de una ontología orientada a lo presente y representable. El "repertorio de categorías de la ontología tradicional" es transferido también al sujeto, al espíritu, a la persona" ${ }^{232}$. Lo que significaría que todo el conjunto de conceptos y categorías con que la ontología tradicional trabaja y con el que ha pensado el ser no son problematizadas ni cuestionadas en su fundamento ni en la validez ontológica de su aplicación al ente llamado Dasein y así, sin más, se traspasan a este ente recibiendo distintas denominaciones tales como sujeto, espíritu, persona, dependiendo cada cual del ámbito interpretativo desde el cual surgen, como por ejemplo, la filosofía griega, el cristianismo de la primeras comunidades o la neoescolástica, cuestión que se traduce en malentendidos e interpretaciones que no dan con la constitución originaria de este ente que en cada caso somos nosotros mismos.

\footnotetext{
${ }^{231}$ ST, p. 36.

${ }^{232}$ Pöggeler, O., El camino del pensar de Martin Heidegger op. cit., p. 61.
} 
En estas consideraciones a las que hacemos referencia, la pregunta por la vida fáctica, por el ser, viene ya predeterminada y no vuelve a ser reformulada de un modo originario, sino que solo se entiende desde la interpretación del ser como Anwesenheit, bajo cuyo dominio el pensar se entiende a sí mismo como esencialmente percepción visual, y el Dasein como Vorhandenheit, el ser y el ente se piensan desde un determinado modo temporal; el presente. Diciendo esto Heidegger reafirma aquello en lo que ha insistido en su lecciones universitarias y trabajos anteriores a la publicación de Ser y tiempo, en cuanto a que si se entiende el ser como Vorhandenheit, como Anwesenheit, esta exégesis viene a realizarse teniendo en cuenta un señalado y exclusivo modo temporal, el presente. Por esto:

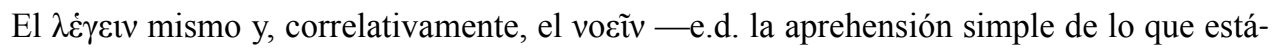
ahí en su puro estar-ahí, que ya había sido tomada por Parménides como guía para la interpretación del ser- tiene la estructura temporaria de la pura "presentación" (Gegenwärtigens) de algo. El ente que se muestra en y para ella, y es entendido como el ente propiamente dicho, recibe, por consiguiente, su interpretación por referencia al presente, es decir, es concebido como presencia (ov̉oía) ${ }^{233}$.

Para Heidegger, la interpretación del ser que lleva a cabo la filosofía griega se sustenta en un desconocimiento explícito del hilo conductor que guía dicha exégesis, ello porque no se han hecho cuestión de dicha situación, no la han problematizado, simplemente se ha asumido y considerado como válida, como sustento ontológico de todo preguntar por el ser, por la vida fáctica, por el tiempo.

No se ha cuestionado la validez ontológica de esta consideración del ser en la que subyace una consideración del tiempo que privilegia de forma absoluta un determinado modo temporal. Heidegger ha dirigido todos sus esfuerzos para llegar a este punto de inicio, a este suelo que es el "desde dónde" surge la filosofía griega y ha conseguido llegar hasta ahí a través de continuos rodeos y cuestionamientos a la tradición filosófica y su idea del tiempo, todo ello le ha permitido detectar el fallo fundamental de la metafísica. En su afán de señalar esto con la mayor claridad, comenta:

esta interpretación griega del ser se realiza sin un saber explícito acerca del hilo conductor que la guía, sin conocer ni comprender la función ontológica fundamental del tiempo, sin penetrar en el fundamento que hace posible esta función. Por el contrario: el tiempo mismo es considerado como un ente entre otros entes, un ente cuya estructura de ser se intenta captar desde el horizonte de una comprensión del ser que tácita e ingenuamente se rige por el propio tiempo"234.

El filósofo alemán es contundente al señalar los fallos en los que ha incurrido la tradición metafísica, tradición endurecida que considera al tiempo mismo como un ente más entre otros, según ello, el tiempo mismo ha de ser considerado desde el ámbito ontológico de la filosofía antigua inaugurada por Parménides, que concibe el ser como presencia, desde un

\footnotetext{
${ }^{233}$ ST, p. 49. Rivera.

${ }^{234}$ ST, p.49.
} 
modo del tiempo, el presente. Por esta razón, no es difícil para Heidegger concluir que el tiempo desde la óptica de la tradición metafísica es eminentemente presente, el tiempo del ahora. En conclusión, "lo que el ser sea es algo que viene descifrado en aquel ente que está en el mundo, y por ende, en el tiempo. El tiempo mismo es pensado en su ser según esta comprensión del ser. Con ello, el pensar no se hace problema en modo alguno del tiempo mismo, es decir, no se hace cuestión del tiempo en cuanto perteneciente al sentido del ser" ${ }^{235}$.

En esta revisión de la introducción a Ser y tiempo más que hacer un análisis acabado y completo de lo allí expuesto, y de si Heidegger cumplió o no con los objetivos que ahí se planteaba, para nosotros es importante mostrar cómo en esta obra fundamental de la filosofía contemporánea se cumple aquello que sosteníamos anteriormente, en cuanto que por una parte representa un punto de llegada de su filosofía, en la cual condensa y unifica la pluralidad de resultados a los cuales ha ido llegando a lo largo de estos fructíferos años de docencia universitaria anteriores a su obra de 1927, que muestran una cierta coherencia y un ejercicio gradual de cuestionamiento del problema del tiempo, que poco a poco se ha ido transformando en el fenómeno verdaderamente decisivo en el replanteamiento y reformulación de la pregunta por el ser. De esta cuestión hemos podido ir tomando nota a través de las distintas formulaciones que Heidegger presenta a lo largo de estos años. Y punto de partida, porque una vez que se encuentra en plena posesión tanto del aparato conceptual, como del punto clave que sostiene su crítica a la tradición filosófica, su formulación de la cuestión del tiempo (superada en principio dicha ambivalencia ontológica), se encuentra ya preparado para plantear y desarrollar aquellas cuestiones que considera verdaderamente decisivas y fundamentales para la filosofía, la destrucción de la historia de la ontología la hilo de la pregunta por el sentido del ser desde el horizonte del tiempo, pero teniendo muy claro que es el tiempo del ser mismo lo buscado, y no solo la temporalidad del Dasein:

\begin{abstract}
"Sentido del ser" significa lo comprendido cuando se comprende el ser, lo comprendido en la comprensión del ser que forma parte esencial del ser del Dasein. Pero eso que es comprendido cuando se comprende el ser, lo es desde algo así como un horizonte, que en su abrirse hace posible que el ser sea comprendido. El horizonte de la comprensión del ser-nos dirá Heidegger-es el tiempo. El ser es comprendido desde el tiempo. Ser y tiempo no es tan solo el título de una obra, es el tema de fondo de la pregunta que va hasta el fondo, de la Grundfrage de todo el pensar heideggeriano ${ }^{236}$
\end{abstract}

Se plantea así de un modo radical la pregunta por las posibilidades y los límites de la misma filosofía, lo que solo se puede llevar a cabo por medio de la pregunta por el ser siguiendo el hilo conductor del tiempo. Esto a pesar de no desarrollar estas cuestiones en la parte publicada de Ser y tiempo.

\footnotetext{
${ }^{235}$ Pöggeler, O., El camino del pensar de Martin Heidegger, op. cit., p.62.

${ }^{236}$ Rivera, J., Heidegger y Zubiri, Universitaria, Santiago, 2001, p. 49.
} 


\section{Capítulo II: La determinación del ente privilegiado: el Dasein, el ente que es comprensión del ser}

A juicio del filósofo de la Selva Negra, es imprescindible para el éxito de su investigación asegurar el suelo sobre el que se sostiene la analítica existenciaria de Ser y tiempo, de modo que para nuestro trabajo es necesario determinar cuál es el sustento de la analítica, su punto de partida y hacia dónde se dirige la investigación heideggeriana.

Es importante tener siempre en consideración que la interrogante que guía este trabajo en Ser y tiempo es la pregunta por el ser y por el sentido del ser. Toda su elaboración tiene como fin último alcanzar su plena formulación. De tal forma, que siempre es dicha pregunta la que conduce la meditación del pensador alemán, no es una pregunta simplemente por el ser del ente, o por ente en su ser, sino la pregunta por el ser mismo. Su principal objetivo es cuestionar los conceptos clásicos de la filosofía, dado lo cual su analítica existenciaria no puede venir a plantearse al modo de una vacía especulación respecto a los entes en general o a meras abstracciones respecto al ser. Si la investigación tomara este camino, debería comenzar la meditación definiendo géneros o tipos de entes. Heidegger cree que si eligieramos esta opción la analítica caería bajo el influjo de una máxima abstracción, cuya consecuencia directa sería que nos tendríamos que detener largamente en buscar y definir distintas clases de entes. Sería una clasificación más de las entidades presentes en el mundo. Por lo tanto: "No se habrá dado ningún paso con decir que es a los entes a los que hay que dirigirse porque el ser es el ser de los entes. Estos son muy diversos y esa multiplicidad impide que la pregunta avance, se oriente a su objetivo" ${ }^{237}$. Si el filósofo alemán respondiera a estas coordenadas, seguiría el camino recorrido por la filosofía clásica, que es justamente lo que él pretende superar. Menos aun se puede permitir que la pregunta por el ser se convierta en la pregunta por el ente supremo y fundante, ello porque "de acuerdo con la relatividad del ser y la verdad respecto de un Dasein puesto de antemano y que se pre-supone a sí mismo, Heidegger combate en el ser y el tiempo la fe en las verdades eternas, como un resto de la teología cristiana que todavía no fue expulsado del todo de la filosofía"238

Lo primero que Heidegger hace, con el afán de que la analítica existenciaria obtenga los resultados esperados, es determinar aquello que debemos interrogar antes que a cualquier otra cosa, algo así como un ente privilegiado. Este es el primer paso, imprescindible para el sustento de la totalidad de la analítica: la elección de un ente privilegiado. No obstante, es necesario impedir que la elección de este ente señalado sea arbitraria o artificial, lo primero que se debe tener en cuenta es la preeminencia de este ente en relación a la pregunta por el ser.

\footnotetext{
${ }^{237}$ Peñalver, P., Del espíritu al tiempo, op. cit., p. 101.

${ }^{238}$ Löwith, K., Heidegger, pensador de un tiempo indigente, op. cit. , p. 189.
} 
Heidegger sostiene que debemos fijar nuestra atención en un ente que por su misma constitución nos pueda brindar algún tipo de indicación respecto al ser mismo. Por tanto, en primer lugar, se debe preguntar, “¿En qué ente debe leerse el sentido del ser, de qué ente debe tomar su punto de partida el proceso que nos abra al ser? ¿Es este punto de partida arbitrario o tiene un determinado ente una preeminencia en el desarrollo de la pregunta que interroga por el ser? ¿Cuál es este ente ejemplary en qué sentido tiene una preeminencia?"239. En otras palabras, la pregunta que Heidegger lleva a cabo es: ¿Existe algún ente que por sus características, por su constitución, por su cercanía, nos pueda brindar mayor claridad al momento de interrogarlo respecto de su relación con el ser? Desde un principio, la investigación pretende determinar si existe un ente que guarde cierta relación de privilegio con el ser, que posea una modalidad de relación distinta a la que sostienen los demás entes con el ser. Este es el punto de partida de la analítica, la base en la que se sostiene el tratado de 1927, para que se pueda sustentar sobre sólidas raíces, por ende, "La preeminencia relevante no es, pues, la que haría de un ser algo sublime o perfecto, sino la que hace que el ser que la tenga contribuya específicamente a salir de la comprensión del ser como algo múltiple o indeterminado. La búsqueda de este ente ejemplar es ya metódica"240.

Se pregunta por un ente privilegiado en cuanto a su relación con el ser. Es el ser mismo el buscado, es la relación de privilegio con el ser la que determina al ente en cuanto privilegiado. Por eso, "desarrollar la pregunta que interroga por el ser quiere según esto, decir: hacer "ver a través" de un ente-el que pregunta-bajo el punto de vista de su ser. El preguntar de esta pregunta está, en cuanto modo de ser de un ente, él mismo determinado esencialmente por aquello por lo que se pregunta en él-por el ser. Este ente que somos en cada caso nosotros mismos y que tiene entre otros rasgos la "posibilidad de ser" del preguntar, lo designamos con el término "ser ahí"”,241. El Dasein es aquel ente que tiene la posibilidad de interrogar al ser y más aún, es la posibilidad misma de este ente de preguntar por el ser lo que define su relación con el ser mismo, de tal manera, que elaborar la preguntar por el ser lleva implícita también la tarea de aclarar la constitución de ese ente que puede preguntar por él, es decir, al elaborar la pregunta por el ser estamos transparentando la esencia del Dasein y esto está determinado por el ser mismo. A éste ente se le interroga porque el que pregunta es él mismo. Lo interrogado en la pregunta por el ser es el ente, pero no cualquier ente, sino el ente privilegiado, al que se pregunta por el sentido del ser y este ente que pregunta lo hace a partir de la comprensión de su propio ser. "En el caso que deba hacerse la pregunta por el ser, hay un ente bien determinado que dentro de lo óntico, o sea, de lo ente, tiene la primacía. Este ente es el hombre, en la medida que él es "estar" (Dasein). El estar se distingue de los otros entes porque no viene ${ }^{239}$ ST, p. 16.
${ }^{240}$ Peñalver, P., Del espíritu al tiempo, op. cit., p. 101.
${ }^{241}$ ST, p. 17. 
a darse simplemente entre los otros entes, sino que a él le va en su ser este ser. El estar y -solo él- tiene relación al ser, por tanto comprensión del ser"242.

Si se dirige la mirada hacia el ser, si se pregunta por él, se está haciendo la pregunta por cómo se interroga por el ser. La pregunta que se plantea y se debe aclarar: cómo es el ente que comprende el ser, es decir, la pregunta por el ser, por el sentido, se dirige primariamente al Dasein. En este camino propuesto por Heidegger, el ser ha de aparecer en el análisis mismo del ente que pregunta. Es el ser mismo el que transparece en la pregunta. "Comprensión del ser es una determinación o característica del ser (Seinsbestimmtheit) del Dasein. En otras palabras, la comprensión del ser se da en el Dasein como una determinación o característica de su ser; pertenece al ser del Dasein. Esto significa que una comprensión del ser debería ir precedida de un hacer explícito el ser del Dasein mismo" 243. Determinar el ser del Dasein constituye el arranque de la analítica, el punto de partida de la pregunta por el sentido del ser, lo cual significa que la respuesta a dicha pregunta por el ser mismo es posible solo desde la comprensión del ente que en cada caso somos nosotros mismos. En consecuencia, la comprensión del ser se transforma en el cimiento que guía el desarrollo de la pregunta por el ser, esto es así, ya que a partir de la comprensión señalada se pregunta por el sentido del ser mismo.

Se destaca aquí un rasgo importante que luego tendrá consecuencias en el todo de la obra, en lo que refiere a sus resultados últimos y a su desarrollo: al preguntar por el ser, lo estamos interrogando a través del ser del Dasein. A través del Dasein se pretende alcanzar una comprensión del ser, de su sentido. La determinación de este ente privilegiado posibilita la articulación y el desarrollo de la cuestión del ser, de la pregunta por el ser. Es este ente el que permite hacer la pregunta y al hacer la pregunta es él mismo determinado en su ser.

Es necesario precisar que el análisis propuesto por Heidegger no puede llevarse a cabo si se considera al Dasein como un ente cualquiera, que está ahí al frente, como posible objeto de estudio, como un ente más del mundo al modo de una cosa, "el hombre concreto en cuanto tal, en cuanto ente, no es nunca un "hecho real mundano", porque el hombre jamás se limita a estar presente, sino que existe" ${ }^{244}$. Heidegger pregunta por nuestro mismo ser, lo que somos, y en ello indaga respecto a sus estructuras esenciales. Eso que somos nosotros mismos, es con aquello que mantenemos una mayor cercanía, es nuestro mismo ser el indagado, sin embargo, ese carácter de cercanía implica al mismo tiempo, que sea lo más lejano. Su máxima cercanía ontológica se puede representar como esa fuerte luz que nos enceguece si la miramos directamente. Por lo tanto, esta analítica se transforma en una búsqueda compleja y oscura en los rincones más ocultos de nuestro

\footnotetext{
${ }^{242}$ Pöggeler, O., El camino del pensar de Martin Heidegger, op. cit., p. 58.

${ }^{243}$ Berciano, M., Superación de la metafisica en Martin Heidegger, Universidad de Oviedo, p. 50.

${ }^{244}$ Pöggeler, O., El camino del pensar de Martin Heidegger, op. cit., p. 91.
} 
propio ser. Como dice Heidegger: "el "ser ahí" es ónticamente "lo más cercano" a él mismo, ontológicamente lo más lejano, pero, sin embargo, preontológicamente no extraño"245. Lo importante no es el ente como tal, sino aquello que oculta y que puede llegar a resplandecer en el análisis de sus estructuras ontológicas, en sus estructuras constitutivas. El pensador alemán llama a esas estructuras ontológicas fundamentales del Dasein "existenciario" (existenzial), que expresan estructuras fundamentales del ser del Dasein, esto para distanciarse claramente de las tradicionales categorías, con las que la filosofía clásica daba cuenta de la realidad. Por otra parte, llama "existencial" (existenziell), a aquello que señala el ámbito propiamente óntico del Dasein, es decir, las características propias del Dasein concreto, del existente en su fáctica e individual interpretación, y en la concreción de su existencia.

En los primeros parágrafos de Ser y Tiempo, Heidegger inicia su analítica destacando un fenómeno fundamental y primario, esencial para el desarrollo y sostén de ella. Se señala que es inherente al Dasein una cierta comprensión del ser (Seinsverständnis). Anterior a cualquier ejercicio de la voluntad, o a toda elaboración teórica de una cierta idea del ser. Aunque su comprensión del ser sea vaga, cotidiana, indeterminada, se dice de ella que es un hecho, que siempre se da de una forma o de otra. Se señala incluso que al cuestionarnos-“" ¿qué es ser?, nos mantenemos en cierta comprensión del "es", sin que podamos fijar en conceptos lo que el "es" significa. Ni siquiera tenemos noción del horizonte desde el cual debamos apresar y fijar el sentido. Esta comprensión del ser, "de término medio" y vaga es un factum"2246, se alude con esto, a que es una comprensión pre-ontológica (vorontologisch) del ser, anterior a cualquier tipo de conocimiento o acto intelectual, algo presente en la estructura misma del Dasein que le posibilita comprender lo que lo rodea como algo que simplemente es. Aquello que le aparece, que le hace frente, no lo entiende en principio o primordialmente a través de definiciones o conceptualizaciones, sino solamente como algo que es. "Vivimos ya en cada caso en una comprensión del ser de la que por cierto no podrá prescindir en ningún momento la ontología científica. Pero en esa previa comprensión del ser no deja claro el ser, ni siquiera su propio carácter de comprensión"247.

En esta comprensión primaria del ser que Heidegger reconoce se da un paso importante para el desarrollo de la analítica existenciaria. Es la base para la pregunta por el sentido del ser, se parte de la determinación del Dasein, en cuanto que este ente antes de realizar cualquier tipo de función intelectual comprende el ser aunque sea vaga e indeterminadamente. Este es el punto de partida concreto para el despliegue de la

\footnotetext{
${ }^{245}$ ST, p. 26.

${ }^{246}$ ST, p. 15.

${ }^{247}$ Peñalver, P., Del espiritu al tiempo, op. cit., p. 99.
} 
investigación, desde donde se inicia el camino con miras a ganar una elaboración teórica del sentido del ser; esto a partir de la relación de privilegio entre el Dasein y el ser. Se presenta así una de las primeras intenciones que persigue el tratado de 1927, que "consiste en desentrañar el ser del Dasein para descubrir -teoréticamente- el ser en cuanto tal, que se encuentra entrañado en ese ser del Dasein. Y al descubrirlo, hacerlo ver en su sentido, en sentido que ya está "sentido" en el propio Dasein. Al ser solo se llega a través de un análisis del Dasein, de una analítica existencial (exiztenzial)" ${ }^{248}$. En el Dasein se $d a$ el ser y él es al mismo tiempo su comprensión. Es en virtud de la constitución misma del Dasein, como ahí del ser, que en él se hace patente el ser, manifestándose el ser mismo en su constitución.

Heidegger ha hecho referencia al privilegio del hombre en cuanto ente que formula la pregunta por el ser, que es comprensión del ser. Pero ésta determinación no nos basta para brindarnos una visión completa y acabada de la razón por la que se elige precisamente al Dasein como el ente privilegiado, para profundizar en ello es menester indagar aún más en esa relación de privilegio que mantiene el Dasein con el ser mismo. Específicamente debemos detenernos en esa triple preeminencia del Dasein sobre los demás entes que enuncia Heidegger, que nos llevará a una comprensión clara de este carácter de privilegio que posee sobre los demás entes, sobre todo al momento de realizar la pregunta que interroga por el ser.

En primer término, su preeminencia óntica se sustenta en que al Dasein le va en su ser su ser mismo; tiene una relación de ser con su ser en la que su ser le va a cada momento, lo que significa que comprende su ser de una manera u otra. "La comprensión del ser es ella misma una "determinación de ser" del "ser ahi”. Lo ónticamente señalado del "ser ahí" reside en que éste es ontológico"249. Esa comprensión del ser no es conceptual, ni teórica, el Dasein simplemente comprende lo que le rodea como algo que es, lo que nos muestra que este ente tiene que ser su propio ser, ejecutándolo, viviéndolo, existiendo. De modoque el Dasein, en tanto es comprensión del ser, puede comprender lo que le rodea, el mundo y los entes que le aparecen en él. Este ente tiene que ser su propio ser y lo puede ser gracias a esta comprensión del ser que le es peculiar.

A partir de esta señalada preeminencia óntica, Heidegger señala que está también en juego una segunda, que es de carácter ontológica, "en razón de su ser determinado por la existencia (Existenzbestimmtheit), es el "ser ahí" en sí mismo ontológico" 250, por tanto, para el Dasein siempre está en juego su existencia, y por estar en juego su ser está obligado a comprender el ser, su propio ser. Está determinado a comprenderse a sí mismo y a lo que le rodea; obligado de forma ineludible a comprender su propia

\footnotetext{
${ }^{248}$ Rivera, J., Heidegger y Zubiri, op. cit., p. 17

${ }^{249}$ ST, p. 22.

${ }^{250} \mathrm{ST}, \mathrm{p} .23$.
} 
existencia, ya que él es su existencia, es lo que define su ser, por tanto, su ser es ontológico en esencia.

Por último, la tercera preeminencia a la que hace alusión Heidegger, es la óntico ontológica, que según Löwith ya había sido advertida por Aristóteles, "cuando señala que el alma del hombre es, de algún modo, todo el ente, ya que solo ella podría percibir y captar, mediante aisthesis y noesis, todo el ente en lo que es y cómo es"251

El hombre es esencialmente comprensor del ser mismo, de su propio ser y de los demás entes; aunque sea de forma vaga. La comprensión señalada nos da la indicación de que toda elaboración teórica o conceptual de la ontología descansará en la comprensión del ser propia del hombre, por lo cual se puede concluir, que el Dasein es el ente en el que descansa la condición de posibilidad óntico-ontológica de cualquier tipo de ontología. Se entiende este ente como aquel al que se debe interrogar ontológicamente con anterioridad a cualquier otro ente, si la intención es la de poder aclarar la pregunta por el sentido del ser. Es necesario en primer lugar, interrogar a este ente en su esencia, toda vez que el Dasein comprende no solamente su mismo ser, sino que también manifiesta su comprensión del ser en general. Es más, el Dasein es condición de posibilidad de la pregunta por el ser, por su sentido, por consiguiente: "la cuestión del sentido del ser solo resulta posible si es algo que pueda llamarse comprensión del ser. A la forma de ser del ente que llamamos "ser ahí" es inherente la comprensión del ser (Seinsverständnis)"

Se determina la esencia del Dasein como la de un ente que comprende el ser mismo y que al mismo tiempo comprende su propio ser, ser que le interesa y compete primordialmente, porque él es esencialmente interés y preocupación por su propio ser, porque es un ente al que le va su propio ser, su ser le va a cada instante.

De esta forma, queda determinada con mayor claridad la importancia del análisis del Dasein. Lo fundamental en la formulación de la pregunta por este ente privilegiado, es que su esencia es comprensión del ser. Nuestro camino nos lleva desde el Dasein a la pregunta por el sentido del ser. Podemos decir que este ente a analizar, que posee una triple preeminencia sobre los demás entes, el Dasein, es lo que "nombra el punto en que se cruzan el hombre y el ser. Este cruce es la dimensión esencial en que se encuentra el hombre" ${ }^{253}$.

Solo a través un análisis concienzudo de la estructura del Dasein la investigación podrá cumplir con el camino trazado, que va desde el ser del Dasein al ser mismo, a través del Dasein se intentará preguntar por el sentido del ser. Su ser es comprensión del ser y todo lo demás que le haga frente o le importe, lo será solo en la perspectiva y el modo de su respectiva comprensión del ser. El hombre es el único ente privilegiado que

\footnotetext{
${ }^{251}$ Löwith, K., Heidegger, pensador de un tiempo indigente, op. cit., p. 176.

${ }^{252}$ ST, p.221.

${ }^{253}$ Cruz, D., Filosofía sin supuestos, Sudamericana, Buenos Aires, 1970, p. 205.
} 
tiene una relación esencial y fundamental con el ser, que consiste en ser la comprensión del ser.

El Dasein es como es por y gracias a la comprensión del ser que le es propia, en virtud de la cual, él se conduce respecto de sí mismo y de los demás entes. Comprende su propio ser y el mundo desde el fundamento de la comprensión preontológica que le es peculiar en cada caso, y desde ahí puede comprender el ser de una manera u otra. Es menester precisar, que preontológico significa: "un modo de comprensión del ser que es previo a toda ontología explícita. Preontológica es la comprensión del ser que es constitutiva del ser mismo del Dasein. Y no se trata únicamente de la comprensión del ser del Dasein, sino a la vez, del ser de los entes que forman parte del mundo al cual el Dasein esta abierto por su propio ser" ${ }^{254}$.

El pensador alemán se valdrá de esta comprensión de término medio, vaga, preontológica, para iniciar su camino. Es conveniente advertir que esta analítica del Dasein, no puede ser entendida como un análisis realizado en vistas de resolver una problemática propia de lo antropológico o ético, en la modalidad clásica de abordar las llamadas ciencias humanas. Sin embargo, no podemos negar que por su originalidad, profundidad y claridad ontológica, las distintas ciencias llamadas sociales pueden obtener importantes aportes para sus disciplinas de estudio. Pero, el camino trazado en el texto es otro. Su objetivo es estudiar aquellas estructuras de este ente, que nos permitan responder a la pregunta por el ser del Dasein, para luego formular la pregunta por el sentido del ser, por el ser mismo.

Heidegger en el análisis de este ente privilegiado, establece una distinción fundamental entre sus modalidades de ser, lo que hace es establecer una diferenciación entre las modalidades fundamentales de ser posible de este ente. Para ello debe indagar en la constitución del Dasein, en su ordenamiento estructural. El Dasein es el ente que "somos en cada caso nosotros mismos. El ser de este ente es, en cada caso, mío( Je meines). En el ser de este ente se conduce este mismo relativamente a su ser. Como ente de este ser es entregado a la responsabilidad de su peculiar "ser relativamente a". El ser mismo es lo que le va a este ente en cada caso" ${ }^{255}$. En esta referencia Heidegger resume lo que había expuesto en la introducción de Ser y tiempo, en relación a que la preeminencia óntica del Dasein, como efectivo punto de partida de la investigación, distingue dos caracteres fundamentales, la existencia y la autoposesión (Jemeinigkeit) ${ }^{256}$.

El filósofo alemán, en primer lugar hace una importante precisión respecto a los modos de ser de la propiedad y de la impropiedad, modos de ser posibles para el Dasein en cuanto posibilidad. Cuando se dice que el Dasein es ser cada vez mío (Jemeinigkeit) esto

\footnotetext{
${ }^{254}$ Rivera, J., Heidegger y Zubiri, op. cit., p. 20.

${ }^{255}$ ST, p. 54.

${ }^{256}$ Cf. Peñalver, P., Del espiritu al tiempo, op. cit., p. 144.
} 
hace referencia al concepto de la autoposesión que define a este ente, tiene un ser que retorna sobre sí mismo, tiene un ser que es suyo. El ser que le va a este ente en su ser está en relación a sí mismo, como a su posibilidad más propia, en consecuencia es un rasgo ontológico fundamental. Poseedor de ese mismo ser, autoposesión, poseerse a sí mismo, son formas de nombrar esa relación originaria de un ente con su propio ser, relación de ser con el propio ser, que no la puede tener ninguna otra clase de ente.

Este ser cada vez mío, implica para Heidegger que "se ha decidido ya siempre de alguna manera en qué modo es el "ser ahí" mío en cada caso. El ente al que en su ser le va este mismo se conduce relativamente a su ser como a su más peculiar posibilidad”257. Es decir, ya siempre se ha escogido el modo de ser del Dasein, en cuanto está constituido fundamentalmente como posibilidad, puede en esa elección de sus posibilidades ganarse a sí mismo, poder ser su esencial sí mismo (Selbst). Pero también puede perderse entre los entes a los que hace frente en el mundo, en la cotidianeidad, en la opinión pública. Estas son las modalidades de ser del Dasein, la propiedad e impropiedad. Pero no debemos entender esta distinción fundamental, situando una modalidad de ser del Dasein por sobre otra en cuanto a su dignidad ontológica, ambos modos están a un mismo nivel, no se trata aquí que una forma de ser este por sobre otro en términos de graduación de ser.

En otro trabajo posterior, Heidegger clarificará, que -"la expresión en "cada caso mía" significa: la ex - sistencia me ha sido arrojada para que mi yo mismo (Selbst) sea la existencia"258, lo que señala de forma inequívoca, que este ente debe hacerse cargo de su propio ser, le ha sido arrojada su existencia, para que cada Dasein la haga suya; la viva, la ejecute, en cada caso mía y de nadie más. Al Dasein le cabe la elección de ser en su posibilidad más propia o en la impropiedad de su ser. Teniendo en cuenta esto, Heidegger expone uno de los caracteres fundamentales del Dasein; un ente que esencialmente es posibilidad (Möglichkeit). El Dasein es un ente al que en su ser le va éste mismo, es decir, que cada día se está ganando o perdiendo en relación a su ser propio, él está en relación al ser y solo en él hay comprensión del ser, sea propia o impropiamente.

Con esto se alude al mismo tiempo a la forzosidad de este ente a tener que ser, "la "esencia" de este ente consiste en su tener que ser" (Zu-sein)" ${ }^{259}$. El Dasein está interpelado por su ser a ser en la aperturidad, no puede rehuir de su esencial constitución ontológica, está destinado, forzado a cargar con la responsabilidad de ser su propio ser, y debe además tomarlo como carga, su carga. La relación con su ser constituye su posibilidad más propia. En relación a esto, dice Heidegger: "la "esencia" del "ser ahi" está en su existencia"260. Hay que decir que con estas comillas sobre el concepto de esencia, el filósofo alemán pretende aclarar que la esencia no se piensa como quidditas a la

\footnotetext{
${ }^{257}$ ST, p. 54.

${ }^{258}$ Heidegger, M., Introducción a la metafisica, Gedisa, Barcelona, 1993, p. 35.

${ }^{259}$ ST, p.42.

${ }^{260} \mathrm{ST}, \mathrm{p} .42$.
} 
manera clásica, en la cual se entiende su qué como algo perfectamente delimitado, como una cosa estática, acotada. No determina lo que es el Dasein de una vez y para siempre, lo único que tiene determinado de ese modo, es que su ser es existencia. Por otra parte, la existencia viene a significar ahora el modo de ser del Dasein. El Dasein no es una cosa, un ente inmóvil, fijo, invariable; lo único estable en él, su qué al modo de la esencia es su estar abierto, su estar en la aperturidad; tener que moverse en el ser, tener que estar siempre sosteniendo su ser, su propio ser. "Según Heidegger, la concepción tradicional que encuentra también un "ser" en la essentia, no tiene que ser eliminada sino más bien revisada en la medida en que la tradicional distinción entre essentia y existentia es pensada unilateralmente desde el ser como permanente presente, razón por la cual no es aplicable, por ejemplo, a la existencia humana" ${ }^{261}$. Como podemos ver, desde un principio la obra de Heidegger está encaminada a superar esa concepción del ser como simple presencia.

Ex -sistencia significa estar afuera, en lo otro, en lo abierto del ser; la posibilidad de estar en la apertura, en lo vivido, es un ente entregado a mantenerse en esta apertura. Solo en este caso se afirma que la esencia del Dasein es la existencia, "como un ser que se ocupa y se preocupa de su propio ser, que es por lo pronto posibilidad, poder ser (Seinkönnen), con la comprensión del propio ser que ello implica y, en último término, del ser en general" 262 . Gracias al sentido originario que rescata Heidegger de estos conceptos fundamentales de la filosofía,- existencia, esencia-, podemos reconocer la forma cómo trabaja este pensamiento. Estos conceptos se desprenden de la carga que la metafísica tradicional les había asignado; que por existentia entendía lo ante los ojos (Vorhandenheit), lo presente, cualquier ente que no es al modo del Dasein.

Lo fundamental del Dasein, aquello que lo distingue y diferencia de los demás entes es su ser como existencia; un ente que es un poder ser (Seinkönnen), una posibilidad de ser, un ser posible (Möglichsein). Un ser constituido como posibilidad; constitución entitativa que no es nunca concreta, ni acabada, sino que es existencia, cuestión que, "en el caso del hombre ha de entenderse en el sentido etimológico de exsistere, estar fuera, sobrepasar la realidad simplemente presente en dirección de la posibilidad"263. Estas precisiones respecto del ser del Dasein, le abren un nuevo horizonte interpretativo a algunos conceptos acuñados o reinterpretados por Heidegger. Gracias a lo cual, terminan por apartarse del contenido y significación que les confería la tradición filosófica y adquieren una determinación novedosa, lo que permite obtener una comprensión original de ellos e interpretación genuina del ser del Dasein. La analítica consigue en principio desprenderse de las categorías metafísicas, en virtud de la cuales la filosofía clásica comprende la existencia como simple presencia, como algo dado y substante. La tradición filosófica no ha sido capaz de interpretar la existencia como un poder ser, como una

\footnotetext{
${ }^{261}$ Pöggeler, O., Filosofía y política en Martin Heidegger, op. cit., p. 74.

${ }^{262}$ Olasagasti, M., Introducción a Heidegger, Revista de occidente, Madrid, 1967, p. 23.

${ }^{263}$ Vattimo, G., Introducción a Heidegger, Gedisa, Barcelona, 1993, p. 26.
} 
posibilidad, que es la manera como se define originariamente la existencia, y que ha sido rescatada en el pensamiento heideggeriano.

Este es un primer acercamiento a la problemática inherente a Ser y Tiempo, cuyo principal objetivo es que los conceptos queden expuestos con la mayor claridad, ya que, aparecerán una y otra vez a lo largo de esta parte de nuestro trabajo y son esenciales para la comprensión cabal de la obra y de sus resultados, son la base de la analítica del Dasein.

\section{Capítulo III: Ser-en-el-mundo como estructura fundamental del Dasein}

En un primer momento, Heidegger estableció como base sólida para el desarrollo de su investigación la determinación de un ente al que debemos interrogar antes que a ningún otro. El ente elegido es el Dasein, el ente privilegiado que se ha de cuestionar con anterioridad a cualquier otro ente. Se ha fijado el punto de partida, el sustento del todo de la analítica, el Dasein es comprensión de su propio ser y primordialmente del ser mismo, este es el punto de partida del desarrollo y explanación de la analítica en toda su complejidad. El Dasein es comprensión del ser y en él se hace manifiesto el ser, esto anterior a cualquier otra función intelectual, a cualquier teorización o conceptualización, en esencia este ente es comprensión del ser.

Una vez dado este paso, Heidegger considera menester, dirigir la atención hacia la constitución de ser que le es propia a este ente. Podemos decir que, "su meta inmediata es poner fenoménicamente de relieve la estructura original y unitaria del ser del "ser ahí", de las que se derivan ontológicamente las posibilidades y modos "de ser" de éste"264. La investigación heideggeriana, en pos de develar el todo estructural del Dasein, debe apuntar ahora en dirección a los fenómenos que constituyen este orden estructural del ente privilegiado. "el hombre es al existir; él existe en la ejecución de la apertura, de lo abierto, de su ser y del ser de todos los otros entes. Solo porque yo existo como apertura de ser, como comprensión de ser, es que puedo comportarme conmigo mismo como ente y con los otros entes" ${ }^{\prime 265}$.

Heidegger ha expuesto ya algunos de los caracteres del ser de este ente, que servirán para esclarecer la investigación posterior y que le permitirán desarrollarse sobre un suelo seguro. Gracias a esta investigación dichos caracteres obtendrán su sentido y su lugar en el todo estructural. Dice Heidegger: "es forzoso que estas determinaciones del ser del "ser ahí" se vean y comprendan a priori sobre la base de aquella estructura del ser del "ser ahí" que llamamos el "ser en el mundo". El justo punto de partida de la analítica del "ser ahí" está en la interpretación de esta estructura"266. Esta estructura del ser del Dasein

\footnotetext{
${ }^{264}$ ST, p. 147.

${ }^{265}$ Herrmann, F., "El concepto del tiempo según Heidegger", en Revista de filosofía, Vol.35, nº107, Universidad Iberoamericana, México, 2003, p. 88.

${ }^{266}$ ST, p. 65.
} 
debe ser entendida como una estructura de carácter fundamental y unitaria, es decir, como una totalidad unitaria inseparable. Sin embargo, la irreductibilidad de esta estructura a elementos distintos o separables no impide que se puedan reconocer en ella una multiplicidad de elementos que la constituyen y que son esencialmente tres.

El In-der-Welt, es una estructura unitaria que contiene en sí tres fenómenos, que en primer lugar, sugiere la estructura ontológica de mundo y desde ahí determina la idea de mundanidad. Por otra parte, hace referencia al ente que es en cada ocasión en el modo de ser-en-el-mundo, pero se pregunta por el quién es en el mundo y no por el qué y, por último, también alude al ser-en como tal ${ }^{267}$. Este ser-en ha de ser iluminado en su genuina constitución ontológica y, además, debe aclararse cuál es el sentido ontológico de ese en del ser-en-el-mundo, se pregunta por su eneidad. Este ser-en (In Sein) generalmente se comprende como un estar algo dentro de otra cosa, haría alusión entonces a un estar dentro ( Sein in), esto en términos de una relación con un carácter espacial. En otras palabras, este en se entiende comúnmente como una relación de ser que se establece entre dos entes que se encuentran en el espacio y alude al lugar respectivo que ambos ocupan dentro de ese mismo espacio. No obstante, para Heidegger el in- Sein nombra la constitución fundamental del Dasein y es un existenciario por lo que no puede ser pensado como un estar del Dasein dentro de otro ente, en este caso del mundo. Por lo tanto, no hace referencia a una relación espacial, sino que este en remite ontológicamente a un habitar en, a un estar acostumbrado, estar familiariarizado. Este in Sein, "comprendido como existenciario, significa "habitar cabe...", "ser familiarizado con..." "Ser en" es, según esto, la expresión existenciaria formal del ser del "ser ahi", que tiene la especial estructura del ser-en-el-mundo"268. Heidegger con esta precisión da un paso importante en la determinación de este ente y de la peculiar relación que mantiene con el mundo.

El Dasein no es un ente que está en el mundo al modo de una cosa que se relaciona con otra en términos espaciales, en la que de algún modo, el ente mundo serviría de contenedor del ente llamado Dasein. La relación es otra, el In Sein nombra la familiaridad que el Dasein tiene desde siempre con ese mundo, que no le es para nada extraño y que no implica primariamente una relación espacial, de la cual se pudiera concluir que existe una distancia ente una cosa y la otra. El Dasein es un ser-en-el-mundo, y este es su propio mundo en cuanto está familiarizado con él, en un habitar en él y con él. Con esto se nombra una estructura ontológica que solo puede ser entendida como una relación de esencial copertenencia del Dasein con el mundo y no se piensa en un ente que tiene que construir algo así como un puente para llegar a eso algo otro llamado mundo, como en una relación de sujeto-objeto. Como sostiene Pöggeler: "Más bien el estar, en cuanto ser-en-elmundo, está ya siempre cabe las cosas, así como ya siempre con otros (...) el mundo en el que el estar está no es captado por Heidegger como la suma total de lo ente, sino al modo

\footnotetext{
${ }^{267}$ Cf. ST, p. 65ss.

${ }^{268}$ ST, p. 67.
} 
del cómo (Das Wie), en el cual es capaz de mostrarse en cada caso lo ente en total. Según el sentido de este concepto de mundo, el "está en" el mundo; la mundanidad del adviene"269. Este ser cabe (estar en medio) el mundo, las cosas, no debe ser comprendido como un simple estar juntas las cosas al modo de los Vorhandenheit, no está el mundo junto al Dasein y además junto a otras cosas.

\section{A. La CRítica De HeIDEgGer a LA CONCEPCiÓn DEL MUNDO COMO NATURALEZA AHÍ PRESENTE}

Debemos tener claro que la mundaneidad (Weltlichkeit) del mundo es un concepto ontológico que nombra un elemento constitutivo fundamental de la estructura del ser en el mundo y por ser esta última un existenciario (existenzial) significa que la mundaneidad misma tiene ese carácter. "El "mundo" no es ontológicamente una determinación de aquellos entes que el "ser ahí", por esencia, no es, sino un carácter de "ser ahí" mismo"270. A juicio de Heidegger, este existenciario de la mundaneidad ha sido generalmente pasado por alto, omitido por la investigación filosófica, y se le ha interpretado como mundo desde el ser del ente que está ahí en el mundo (innerweltlichen vorhanden), dentro del mundo y que no está para nada descubierto, es decir, se interpreta a partir de la naturaleza. Sin embargo, "la naturaleza es captada en el sentido de lo que está "presente". Pero de esta manera se hace de ella "un caso límite del ser del ente posible intramundano", en cuyo caso es precisamente la mundanidad del mundo la que no se muestra" ${ }^{271}$. Esto significa, que al considerar la naturaleza como naturaleza que está ahí presente se produce una señalada desmundanización del mundo, no se le concibe para nada en su mundanidad, y se la considera simplemente como naturaleza ahí presente sin más.

Esta interpretación que pasa por alto el fenómeno del mundo tiene una larga data en la tradición filosófica y partiría explícitamente en Parménidesm y, precisamente siguiendo la estela de la omisión de esta cuestión, surge la figura de Descartes que considera el mundo como res extensa, significa entonces, que para alcanzar conocimiento de este ente la única vía de acceso es el conocimiento físico matemático, y ello no por simple capricho de Descartes, en razón de sus intereses, sino por el carácter peculiar de este conocimiento, que está dirigido al ente que puede ser siempre, y que permite al mismo tiempo estar seguro de poseer ciertamente el ser del ente que se aprehende ${ }^{272}$.

Por lo tanto, aquel ente que por su misma modalidad de ser se adecua a las exigencias mismas que plantea el conocimiento matemático, es verdadera $\mathrm{y}$ auténticamente el ente que es:

\footnotetext{
${ }^{269}$ Pöggeler. O., El camino del pensar de Martin Heidegger, op. cit., p. 63.

${ }^{270}$ ST, p. 77.

${ }^{271}$ Pöggeler. O., El camino del pensar de Martin Heidegger, op. cit., p. 64.

${ }^{272}$ Cf. ST, p. 110ss.
} 
Este ente es el que es siempre lo que él es; de donde se constituya el verdadero ser del ente empírico del mundo, un ser del que puede mostrarse que tiene el carácter del constante permanecer (...) En sentido propio es lo que perdurablemente permanente. Es lo que conoce la matemática. Lo que en los entes es accesible por medio de ellas, es lo que constituye su ser. En conclusión: partiendo de una determinada idea del ser que yace embozada en el concepto de sustancialidad, y de la idea de un conocimiento que conoce los entes que son en tal forma, se le dicta al "mundo" su ser, por decirlo así. Descartes no se deja dar por los entes intramundanos la forma de ser de éstos, sino que basándose en una idea del ser de origen no desembozado y de legitimidad no comprobada (ser: constante "ser ante los ojos"), prescribe al mundo, hay que repetir, su "verdadero" $\operatorname{ser}^{273}$.

Lo fundamental para Descartes, aquello que determina su idea de mundo no lo obtiene como respuesta de su predilección y ejercicio de las ciencias matemáticas, sino que le viene impuesto por la orientación ontológica que guía su pensamiento, que concibe el ser como presencia constante, como permanente estar ahí; precisamente la aprehensión de dicho carácter se lleva a cabo por medio del conocimiento matemático.

Descartes ni siquiera se hace cuestión del planteamiento de una adecuada vía de acceso al ente intramundano dado que la influencia y el dominio incontrarrestable de la ontología tradicional ya ha decidido desde siempre cuál es la verdadera y auténtica forma de dirigirse a los objetos. La forma de aprehender lo propiamente ente es por medio del noein, "el pensar en tanto que "ver", está ya siempre orientado hacia lo que está fijamente presente, mientras que la matemática conoce preferentemente lo que está siempre ahí, lo que permanece fijo y sigue durando por encima de todo cambio"274. Con esta referencia a Descartes, Heidegger ejemplifica de qué forma esta comprensión del ser de la tradición filosófica extiende su ámbito de dominio e influencia en la filosofía moderna, determinado completamente su exégesis, que se manifiesta en la interpretación del mundo que hace Descartes, que en última instancia entiende el pensar como ver, lo que es una prueba palpable de la permanencia de una interpretación que proviene desde la antigüedad, que considera que el ente verdaderamente real es aquel que es presencia constante, que está ahí presente. Dice Heidegger:

la idea de ser como constante "ser ante los ojos" no se limita a tener por consecuencia una definición extrema del ser de los entes intramundanos y la identificación de este ser con el mundo en general: impide al par traer a la vista de una manera ontológicamente adecuada modos de conducirse del "ser ahí" (...) Descartes toma el ser del "ser ahí", a cuya constitución fundamental es inherente el "ser en el mundo", del mismo modo que el ser de la res extensa, como substancia ${ }^{275}$.

Lo que Heidegger pretende mostrar con esto es que la orientación ontológica que subyace en el pensamiento de Descartes proviene de la tradición metafísica, además, dicha orientación no ha sido cuestionada por este, causa por la cual se le ha hecho imposible el

\footnotetext{
${ }^{273}$ ST, p. 111.

${ }^{274}$ Pöggeler. O., El camino del pensar de Martin Heidegger, op. cit., p. 64.

${ }^{275}$ ST, p. 113.
} 
planteamiento correcto de la estructura originaria de la vida humana, y se le ha vuelto inaccesible el fenómeno original del mundo. Así la ontología del mundo deviene en ontología de un determinado ente intramundano, comprendiendo al Dasein como substancia, en otras palabras lo substancializa.

No obstante, en pensador de la Selva Negra con el afán de profundizar en el influjo que esta comprensión del ser tiene en la filosofía de Descartes añade otra característica que nos permite apreciar con mayor claridad todavía, esa influencia señalada, y que nos muestra las consecuencias que se derivan de ella. Para Descartes, la naturaleza material es el fundamento sobre el que subyace el ente intramundano, y que funda en su ser todo otro ente, todo ente se funda en la naturaleza material, la res extensa, según esto, es entendida como estrato fundamental de la realidad, sobre la que se construyen la demás capas de la realidad intramundana, por tanto, "solo se hace valer el ser que está presente o el ser extenso como "capa fundamental" sobre la que otras cualidades específicas: bello, utilizable, etc., deben ser edificadas"276.

En la mentada exégesis, en la que se considera a los entes del mundo como primariamente cosas, las cualidades mismas son consideradas como predicados de valor, a través de lo cuales la res extensa, la naturaleza material, recibe ahora, en virtud de estas cualidades, la caracterización de un bien. Pasa de ser simplemente una cosa a ser un bien, con esta estratificación de cosa a bien se logra llegar al ente que se caracteriza ontológicamente como útil a la mano. Con esto se hace posible la construcción segura de la constitución de lo inmediatamente a la mano. Pero, a juicio de Heidegger: "la adición de predicados de valor no es capaz de dar en lo más mínimo nuevos datos sobre el ser de los bienes, sino que se limita a presuponer una vez más en los últimos la forma de ser del puro "ser ante los ojos". Los valores son determinaciones "ante los ojos" de una cosa. Los valores tienen a la postre su origen ontológico únicamente en el previo sentar la realidad de las cosas como capa fundamental"277. Según esto, Descartes no ha logrado dar con el camino correcto, ya que ni en la interpretación de la cualidades valiosas que complementan el análisis del mundo ni cuando sostiene que la constitución fundamental del ser del Dasein tiene el mismo ser que el de la res extensa, y que lo entiende como substancia, llega siquiera a mostrar o poner como problema el ser como estar a la mano ni tampoco lo convierte en problema ontológico, en consecuencia, pasa por alto dicha problemática actuando en consonancia con la tradición filosófica. "Descartes restringió todavía más la cuestión del mundo a la de "ser cosa natural" como el ente intramundano inmediatamente accesible"278. Este asunto es el que Heidegger quiere replantear originariamente para lograr despercudirse de la influencia y la carga que esta tradición endurecida arroja sobre el concepto de mundo, de la mundanidad. "Cuando la

\footnotetext{
${ }^{276}$ Pöggeler. O., El camino del pensar de Martin Heidegger, op. cit., p. 65.

${ }^{277}$ ST, p. 115 .

${ }^{278}$ ST, p. 115 .
} 
mundaneidad del mundo vuelve a ser ganada, el conocer no puede ser ya entendido como mero representar una cosa continuamente presente"279.

El ser-en-el-mundo nombra una interrelación dinámica que establece el Dasein en cuanto está en medio del mundo, que se sustenta en la forma que tiene este ente de comportarse y del trato que mantiene con los entes que le salen al encuentro en el mundo. El Dasein tiene una constitución ontológica distinta a la de los demás entes. Este modo de comportarse, de relacionarse el Dasein con el mundo en torno recibe el nombre de ocupación (Besorgen) ${ }^{280}$. "Puesto que al Dasein le pertenece por esencia el ser - en - el mundo, su estar vuelto al mundo es esencialmente ocupación”281. La Besorgen mienta un ocuparse con los entes del mundo que me hacen frente, que me salen al encuentro en el mundo en torno y no tienen la forma de ser del Dasein.

Queda también por determinar una cuestión fundamental para la investigación heideggeriana, se ha de mostrar el genuino sentido ontológico de estos entes que comparecen, que me salen al encuentro en el mundo y son objeto de la ocupación. Heidegger a estos entes que están ahí en el mundo al modo de la Vorhadenheit los llama los entes pertenecientes al mundo (weltgezugehörig) o entes intramundanos (innerweltlichen). Sin embargo, al preguntar por el ser de estos entes, es necesario puntualizar que estos no pueden ser considerados como meras cosas que están ahí presentes, puesto que, con "este llamar a los entes "cosas" (res) se hace tácitamente por anticipado una caracterización ontológica. El análisis que pasa de hacerse cuestión de tales entes a hacerse cuestión del ser da con el "ser cosa" y el "ser real" (...) pero los entes que hacen frente en en la ocupación son en este ser inmediatamente ocultos, incluso preontológicamente" 282 .

\section{B. El ÚTIL COMO SER A LA MANO: LA RELACIÓN PRAGMÁTICA CON LAS COSAS DEL MUNDO}

Heidegger recuerda que los griegos nombraban ya con un concepto preciso a las cosas, le decían prágmata, y se mentaba así a las cosas con las que le hombre se relaciona de forma directa en el trato peculiar a la ocupación, como aquello que se refiere directamente con la praxis. Hacia este carácter pragmático que poseen los entes que nos hacen frente en el mundo, es a lo que Heidegger dirige su atención y quiere resaltar. Antes de establecer una relación de conocimiento con los entes en el trato de la ocupación, o

\footnotetext{
${ }^{279}$ Pöggeler. O., El camino del pensar de Martin Heidegger, op. cit., p. 65.

${ }^{280}$ Gaos traduce Besorgen por "curarse de". Nos parece que Gaos utiliza en este caso, tal como dice Rivera, una expresión poco usual en castellano y de difícil comprensión. Pensamos que "ocuparse" nos indica con mayor claridad el fenómeno señalado, en tanto nombra el trato del Dasein con los entes que nos aparecen en el mundo y con los cuales nos mantenemos ocupados.

${ }^{281}$ ST, p. 83. Rivera.

${ }^{282}$ ST, p. 81.
} 
antes de nombrarlos como meras cosas ahí presentes para un sujeto que las contempla y objetiviza, es menester mostrar y resaltar el sentido originario que le es propio a estos entes, que tiene que ver con su carácter pragmático, con la utilidad que le es inherente a estos entes en cuanto sirven para algo. Por ello llama a esta clase de entes útil, utensilio (Zeug). Este debe ser determinado en su forma de ser, en su constitución ontológica original, lo que se conseguirá especificando qué es lo que hace que sea un útil en cuanto útil, lo que significa se ha de mostrar la pragmaticidad del útil (Zeughaftigkeit) en cuanto $\operatorname{tal}^{283}$.

El útil pertenece siempre y le pertenecen siempre una totalidad de útiles, totalidad dentro de la cual el útil puede ser lo que es. El hombre en cuanto ocuparse del ente que le hace frente en el mundo, tiene el carácter de un ocuparse primeramente siempre con útiles y no simplemente con cosas. Un útil es siempre un para algo, sirve o tiene utilidad para algo determinado. Este para algo contiene una indicación que alude a un hacia algo, le es propia una referencia de algo hacia algo, algo sirve para algo. Dentro de esta multiplicidad de entes que están constituidos primariamente como un para algo se estructura una totalidad de útiles (Zeugganzheit). "En la estructura expresada con el "para" (Um-zu) hay una "referencia" de algo a algo" ${ }^{284}$.Y en consonancia con su pragmaticidad, el útil solo es tal desde su pertenencia a otros útiles, cuestión que se estructura en función de un totalidad siempre ya abierta como totalidad y no como unidad separable de cada uno de ellos.

El trato adecuado al útil en su pragmaticidad, en su utilidad, que es la forma genuina en que este ente se puede iluminar, no lo entiende como una mera cosa que está ahí presente para un ente que lo contempla ni menos aún toma conocimiento de su estructura pragmática en su misma utilidad. La única forma en la que el útil puede mostrarse de forma transparente en su propio ser es en el trato adecuado, en su utilización, que no implica aprehenderlo como algo ante los ojos. El escribir de un lápiz no sabe del carácter pragmático estructural del lápiz, sino que lo ha hecho suyo de la forma más originaria que es posible. En esta forma del trato que es el mismo uso, la ocupación obedece al para-algo esencial del mismo útil. Es en el escribir mismo donde se abre la manejabilidad (Handlichkeit) propia del lápiz, su peculiar pragmaticidad. "A la forma de ser del útil, en que este se hace patente de sí mismo, la llamamos "ser a la mano" (Zuhandenheit). Solo porque el útil tiene este "ser en sí" y no se limita simplemente a ofrecerse, es manejable en el sentido más lato y "disponible". El más agudo dirigir la vista al "aspecto", sea éste o aquél, de las cosas, si es "no más que" un dirigir la vista al "aspecto" de estas, no es capaz de descubrir lo "a la mano" ${ }^{285}$. Lo que Heidegger denuncia con esto, es que la simple mirada teórico contemplativa independiente de su profundidad, adolece siempre de un fallo fundamental, no es capaz de comprender el carácter

\footnotetext{
${ }^{283}$ Cf. ST, p. 85.

${ }^{284}$ ST, p. 82.

${ }^{285}$ ST, p. 82.
} 
pragmático de estos entes, le falta la comprensión de este ser a la mano. El ser a la mano es la forma de ser del útil que comparece (que hace frente) en el mundo circundante, en el mundo que tenemos en frente. En relación a esto, Volpi comenta: "el estar a la mano (Zuhandenheit) (...) caracteriza la forma en que el Dasein se comporta respectivamente de manera constatadora, verdadera, o manipuladora y productora hacia el ente"286

Pero, este trato que utiliza tiene su propia forma de ver que orienta y dirige el manejo del útil. Y este trato con los útiles se enmarca dentro de un plexo de referencias (Verweisungsmannigfaltigkeit) más amplia que los abarca en cuanto para-algo. Esta forma de ver propia del trato es la circunspección (Umsicht). Lo más propio de lo a la mano es la obra, lo que tiene que ser producido, en la obra se condensa esa totalidad referencial en la que el útil comparece como útil ${ }^{287}$.

Podríamos decir que lo primero es la obra misma y después los útiles. Esta obra que se quiere producir, es el para-qué ( Wozu) del útil y tiene además el respectivo modo de ser del útil. En nuestro ejemplo, el lápiz es para escribir, la obra que hace frente, que comparece primeramente en el trato mismo de la ocupación hace comparecer al mismo tiempo en su uso el para-qué de su utilización, de su manejabilidad.

Esta obra que implica un producir es siempre un empleo de algo para algo, por lo que siempre remite también a ciertos materiales. El lápiz remite a la madera, la madera al árbol, el árbol al bosque. "El utensilio no solo dice referencia a otros utensilios. Remite también a los materiales de que está hecho. Así la pluma, la aguja y el vehículo son de hierro, acero, madera, etc. En el utensilio usado es co-descubierta la "naturaleza" la misma naturaleza se ofrece también como útil: el bosque es parque forestal, la montaña cantera, el río fuerza hidráulica" ${ }^{288}$. En el mismo mundo circundante (en torno) se abre la posibilidad del acceso a entes que no necesitan por sí mismos ser producidos, ya son siempre a la mano. Como en el caso del lápiz que remite al árbol, la madera, el bosque, dice Heidegger, "en el útil usado es codescubierta por medio del uso la "naturaleza", la "naturaleza" a la luz de los productos de la naturaleza"289. Pero no debemos entender la naturaleza en el sentido de lo puramente presente, de lo Vorhandenheit. Con la apertura del mundo circundante comparece también la naturaleza como descubierta. El suelo, el árbol, el bosque, a los que remite el lápiz hacen que comparezca la naturaleza como tal. Se pude prescindir de su ser a la mano y considerarla solamente como lo que está ahí presente, como puro estar ahí (in ihrer puren Vorhadenheit), pero con ello se niega el carácter

\footnotetext{
${ }^{286}$ Volpi, F., “ Ser y tiempo: Semejanzas con la Ética Nicomaquea” en Signos filosóficos, Vol.VIII, $\mathrm{n}^{\circ} 16$, 2006, p.136. Trad. Luis Cesar Santiesteban. Tomado de Philosophisches Jahrbuch, Bd.96 1989, Verlag Kart Alber, Freiburg/München, pp.225-240.

${ }^{287}$ Cf. ST, p. 83. Verweisungsmannigfaltigkeit Rivera lo traduce como "complejo remisional".

${ }^{288}$ Colomer, E., El pensamiento alemán de Kant a Heidegger, op. cit., p. 511.

${ }^{289}$ ST, p.84.
} 
originario de la naturaleza en cuanto tal, "como lo que "se agita y afana", nos asalta y cautiva como paisaje" ${ }^{" 290}$.

Por último, es menester señalar que todo útil en cuanto hace referencia a otro útil, esto entraña una relación de algo hacia algo, de un útil con otro útil, y esto de forma continúa y ascendente, cuestión que termina por constituir una trama de referencias (plexo de referencias) que contiene un determinado entramado de significaciones, y que en cuanto significativo no puede hacer referencia únicamente a un ente de sus mismas características y misma constitución ontológica, sino que dicho entramado significativo se refiere o relaciona en último término con el Dasein mismo.

El ser de lo a la mano tiene la estructura de la referencia (Verweisung), lo que significa que tiene en sí mismo el carácter del ser referido (Verwiesenheit), razón por la cual este ente se muestra en la perspectiva de un ente que según su carácter ontológico está necesariamente remitido a otro algo, tiene su cumplimiento en algo otro. "El carácter del ser de lo "a la mano" es la conformidad (Bewandtnis)". La conformidad implica: "conformarse con" algo "en" algo (bewenden lassen mit etwas bei etwas). La relación "con...en..." es lo que indica con el término de referencia (Verweisung)" "291. Esta trama de referencias en la que ya está siempre el útil, tiene la estructura ontológica de la Bewandtnis. La totalidad de útiles se inserta siempre en una totalidad de conformidad, a partir de la cual nos sale al encuentro en el mundo en torno el útil con su respectiva utilidad.

La Bewandtnis es el ser del ente intramundado, ser desde el cual este ente se ha puesto en libertad, el ente es siempre en una condición respectiva, lo que quiere decir que siempre está vuelto, dirigido, en conformidad hacia algo y la adquiere desde la totalidad de conformidad (Bewandtnisganzheit), lo que es así dado que el hacia qué se dirige la conformidad es el para-qué de la utilidad, el en-qué de la utilización, y este para qué de la utilidad tiene al mismo tiempo una nueva conformidad, y así sucesivamente. Pero esto llega hasta cierto límite, en el cual se llega a un para-qué que no tiene ninguna conformidad más, siempre encontramos un para-qué que ya no puede ser un qué para otro para qué, sino un por-mor-de, " ya no es un ente de la forma de ser de lo "a la mano" dentro de un mundo, sino un ente cuyo ser es inherente la mundanidad. Este primario "para qué" no es ningún para qué" en el sentido del posible "en qué" de una conformidad. El "para qué" primario es un "por mor del que" (Worum-willen). Pero el "por mor de" conviene exclusivamente al ser del "ser ahi", al que en su ser le va esencialmente este ser mismo"292.

\footnotetext{
${ }^{290}$ ST, p.98. Rivera.

${ }^{291}$ ST, p. 98. Rivera traduce Verweisung como "remisión", Verwiesenheit como "estar remitido", Bewandtnis como "condición respectiva", y Bewandtnisganzheit como "totalidad respeccional".

${ }^{292}$ ST, p. 99.
} 
Según Heidegger, este conformarse (Bewendenlassen) comprendido ontológicamente, tiene que ver con el dejar ser libre a los entes que son a la mano, en cuanto ser a la mano dentro del mundo circundante, es desde el en qué (Wobei) del conformarse que se da la libertad, deja ser al con qué de la conformidad, al ente que está en conformidad y puede entonces comparecer para la ocupación como ente a la mano. $\mathrm{Y}$ cuanto a la ocupación le aparece un ente que queda descubierto en su ser, es un ente a la mano, y no solo una cosa que está ahí frente a los ojos ${ }^{293}$.

La misma conformidad como ser de lo a la mano, solo puede quedar descubierta en virtud de un previo estado de descubierta de una totalidad de conformidad. A dicha conformidad descubierta, en lo a la mano que comparece como previamente descubierto, Heidegger le llama la mundiformidad de lo a la mano (WeltmäBigkeit des Zuhandenes). El conformarse sobre el cual se da la libertad (se deja ser) a lo entes en una totalidad de conformidad, tiene que haber abierto al mismo tiempo ya lo mismo sobre el fondo de lo cual (Woraufhin) es dada esa libertad, y sobre este horizonte se da la libertad al ente de lo a la mano; de tal forma que por primera vez lo vuelve comprensible como ente intramundano, pero este fondo sobre el cual, no puede ser entendido como un ente que tenga el mismo modo de ser de aquello que ha sido descubierto, "es esencialmente algo no susceptible de ser descubierto, si en adelante adoptamos la expresión "estado de descubierto" (Entdecktheit) como término técnico para designar una posibilidad de ser de todo ente que no tiene la forma del "ser ahí"”,294.

Sin embargo, se ha de concebir este abrir previo del fondo sobre el cual se da la libertad al ente que comparece en el mundo, como un comprender el mundo, en vistas al cual se conduce desde siempre el ser ahí como ente. Al comprender el plexo de relaciones el ser ahí se ha referido, se ha relacionado siempre con un para-algo (Um-zu verwiesen), desde su poder ser propio o impropio. El Dasein ya se ha referido a sí mismo y hacia un para algo. El Dasein se refiere desde siempre desde un por-mor-de al ente que está en conformidad, lo que significa que desde siempre deja que comparezca en ente como lo a la mano. Aquello dentro y en lo cual el ser ahí se comprende anteriormente en su referencia, es el horizonte sobre el cual es primariamente permitido que comparezca el ente, este fondo sobre el cual es aquello en vistas a lo que es dejado comparecer el ente. "“el aquello dentro de lo cual" (Woraufhin) del comprender refiriéndose, en cuanto "aquello sobre el fondo de lo cual" del permitir que hagan frente entes en la forma de ser de la conformidad, es el fenómeno del mundo. Y la estructura de aquello sobre el fondo de lo cual se refiere al "ser ahí" es lo que constituye la mundanidad del mundo" 295.

Es importante advertir que esta determinación ontológica de mundo, alude a la familiaridad que ya desde siempre mantiene el Dasein con el mundo y no tiene que ver

\footnotetext{
${ }^{293}$ Cf. ST, p. 99.

${ }^{294}$ ST, p. 100.

${ }^{295}$ ST, p. 101.
} 
con una familiaridad a la cual le sea menester una contemplación, o un ejercicio teórico cognoscitivo respecto a los elementos constitutivos del mundo. El mundo ya siempre le dice algo al Dasein, siempre tiene algún significado para él, lo que está fundametado en el comprender peculiar al Dasein, que en cuanto tal, mantiene siempre abiertas las referencias, los para algo, manteniéndose en la familiaridad, por lo que se deja referir en estas relaciones. A esta tejido de referencias es a lo que Heidegger llama significatividad, que es la estructura del mundo, aquello en lo que el ser ahí se encuentra desde siempre. "el "ser ahí" es, en su familiaridad con la significatividad, la condición óntica de la posibilidad del descubrimiento de entes que hacen frente en la forma de ser de la conformidad ("ser a la mano") en un mundo y pueden hacerse así notar en su "en sí'" ${ }^{296}$. Heidegger quiere hacer notar que al Dasein en cuanto tal, le está esencialmente descubierto un contexto de entes a la mano, lo que indica que este ente está ya siempre referido a un mundo que le hace frente, y ese estar referido a (Angewiesenheit) ${ }^{297}$ es una constitución esencial de este ente.

La significatividad, como existenciario del Dasein, es la condición óntica del posible descubrimiento de una totalidad de conformidad. Entonces, entendemos el ser de lo a la mano como conformidad, y la mundanidad como el plexo o contexto de referencias. La significatividad con base a la cual el ser ahí está familiarizado en cada caso, guarda en sí misma la posibilidad ontológica de que el Dasein que es comprender, pueda interpretar o abrir dichas significaciones.

Dentro de este contexto, Heidegger lleva a cabo una determinación ontológica de los distintos tipos de entes. En primer lugar, alude al ser de los entes intramundanos que comparecen inmediatamente, el ser a la mano, lo Zuhandenheit. En segundo lugar, al "ser ante los ojos" (Vorhandenheit) que se encuentra presente ahí delante frente a los ojos y se determina gracias a un descubrimiento de estos entes que comparecen inmediatamente. $Y$ por último, "el ser de la condición óntica de posibilidad del descubrimiento de entes intramundanos en general, la mundanidad del mundo. El ser últimamente nombrado es una determinación existenciaria del "ser-en-el-mundo", es decir, del "ser ahí"”298, con esta distinción, el pensador alemán quiere dejar establecida sin ambages, los diversos modos de ser de los entes que él ha podido reconocer en su investigación. Pero también, se manifiesta en esta distinción otra cuestión, que tiene que ver según Colomer, con que ontológicamente lo Vorhandenheit se fundamenta en el ser a la mano, esto porque el conocimiento teórico es solo una instancia secundaria o derivada del conocimiento activo práctico, por ello lo que antes era ser a la mano, ahora se transforma en un mero ser ante los ojos como posible objeto de un juicio. En otras palabras, encontramos que junto al Dasein aparecen dos tipos de entes cuya forma de ser es distinta a la del Dasein, el ser de

\footnotetext{
${ }^{296}$ ST, p. 102.

${ }^{297}$ Cf. ST, p. 102.

${ }^{298}$ ST, p. 102.
} 
lo a la mano, y el ser ante los ojos, forma de ser del útil que no está a la mano, sino que está como presente ante los ojos y está disponible. Es evidente que para Heidegger el conocimiento teórico cognoscitivo pasa primero por el ser a la mano, para posteriormente llegar a lo Vorhandenheit, ello porque el ser del útil se descubre utilizándolo 299 . Por otra parte, Volpi en su interpretación señala que habría una marcada correspondencia entre estas tres formas de ser y las determinaciones aristotélicas de la poiesis, la práxis y la theoría. En la Zuhandenheit se retoma la determinación de la poiesis, en el Dasein la de la práxis, y en la Vorhandenheit la de la theoría ${ }^{300}$.

\section{Capítulo IV: La constitución del Dasein como estado de abierto}

El Dasein en cuanto está constituido como ser- en-el-mundo siempre lleva consigo su $D a$, siempre tiene que ser su ahí. El Dasein es un ente que en su ser siempre es ahí. Podemos decir que su forzosidad se le hace manifiesta en ese tener que ser ( $Z u$ sein) a cada momento su ahí, lleva sobre sí la carga de tener que ser, no unas veces sí y otras no, sino que por el contrario está forzado a ser. Pero no a ser sin más, sino que ser su ahí, no el de otros sino tener que ser su propio ahí. Esta constitución que le es propia al Dasein, al ser-en, supone una "diferencia de la interioridad "ante los ojos" de algo "ante los ojos"; el "ser en" no como una condición de un sujeto "ante los ojos" operada ni siquiera suscitada por el "ser ante los ojos" de un mundo; el "ser en", antes bien, como esencial "forma de ser" (Seinsart) de este ente mismo" 301 . De modo, que en esta misma constitución del Dasein como aperturidad se puede reconocer la distinción entre este ente y los demás entes, entendidos como ante los ojos, como substancia, como cosas. Gadamer decía, que "lo que le importaba a Heidegger desde siempre era el "ahí" en el ser ahí ser humano, esta distinción de la existencia de encontrarse fuera de si y expuesta como ningún otro ser viviente" 302 . Hay en este tener que ser su ahi (das Da zu sein) una indicación que muestra la constitución esencial del Dasein, de su esencia, de su ser; un ente al que le va su ser, y que se determina esencialmente como aperturidad, un estar abierto en el ahí. Un ente que en su esencia es radical apertura, abierto al mundo, a sí mismo, pero fundamentalmente abierto al ser mismo, por eso,"el ente constituido esencialmente por el "ser en el mundo" es el mismo en cada caso su "ahí"

Aquello que este ente trae es su propio ahí, sin lo cual no podría ser al modo del Dasein, en otros palabras, este ente es su estado de abierto, por tanto, este estado no es algo que se le sume desde algo ajeno o que le venga dado desde fuera. El ser que a este ente le va en su ser es tener que ser su ahí, ser su aperturidad, su estado de abierto. El

\footnotetext{
${ }^{299}$ Cf. Colomer, E., El pensamiento alemán de Kant a Heidegger, op. cit., p. 540.

${ }^{300}$ Volpi, F., “Ser y tiempo: Semejanzas con la Ética Nicomaquea”, op. cit., p. 135.

${ }^{301}$ ST, p.149.

${ }^{302}$ Gadamer, H., "Ser, espíritu, Dios" en Los caminos de Heidegger, op. cit., p. 170.

${ }^{303}$ ST, p. 149.
} 
Dasein es su ahí, él es esta apertura como tal, es él mismo en cada caso su ahí, cuestión que nos revela el estado de abierto que le es propio: "el estado de abierto (Erschlossenheit) constituye la constante posibilidad mediante la cual el Dasein experimenta el Da (ahí) de su ser ahí que es en cada caso el ser del ahí. El ser en cada caso ahí indica que el Dasein no es un ente cerrado en sí mismo, sino un ente abierto en su existencia" ${ }^{304}$.

Este estado de abierto, no denota una característica más entre otras muchas que este ente pudiese poseer, ni tampoco una propiedad que el Dasein posee en un momento y en otros no. Por el contrario, esa constitución que lo determina a tener que ser su ahí, es un ingrediente esencial de su ser, en virtud del cual, tiene que ser siempre y a cada momento en la apertura que él propiamente es. El ahí como su constitución esencial, "el ser que este ente le va en su ser (seinem Sein geht), es tener que ser su "ahí" (sein "Da" zu sein)" "305. El Dasein es un ente que es necesaria y originariamente aperturidad, si su constitución fuera distinta, no podría ser existencia. Él es esta apertura como tal, es esa apertura originaria que se abre a sí mismo y abre a los demás entes en el mundo. Este ahí que tiene que ser, no es -como antes habíamos señalado- algo que se sume a su constitución. Por el contrario, es parte de su ser mismo, en su propio ser trae su ahí, lo que le permite poder ser comprensión del ser, manifestación del ser. Es algo que el Dasein trae desde sí mismo, es su esencia. "Conviene tener presente que esta apertura del Dasein no es un simple modo de ser particular. La apertura que se da en el Dasein es la apertura del ser, al cual pertenece también el Dasein. La apertura se da en y por el Dasein"306. El estado de abierto del Dasein no es otra cosa que su enraizamiento en el ser, es decir, la manifestación del ser que es constitutiva al Dasein. Tal como comenta Herrmann: "el hombre solo es hombre por su manera de ser de la existencia, en cuya ejecución se devela el ser como apertura o luminidad del ser en su totalidad, Heidegger le da expresión terminológica Dasein. En esta palabra la sílaba Da-nombra la apertura del ser, mientras que la sílaba -Sein indica la manera de ser del hombre, la existencia, en cuya ejecución se devela el ser en su totalidad"307.

De forma que, abierto solo lo es propia y formalmente el ser. Y es así, por el hecho de que el ser está por esencia más allá de todo ente. Ese estar más allá de todo ente es la apertura en la que consiste el ser mismo. Por tanto, esta apertura que el Dasein es, nos señala de manera precisa su pertenencia al ser mismo, solo en la apertura del ser el Dasein puede ser lo que es. "El estado de abierto del Ser en general abre al Dasein la posibilidad

\footnotetext{
${ }^{304}$ Másmela, C., Martin Heidegger: El tiempo del ser, Trotta, Madrid, 2000, p. 36.

${ }^{305} \mathrm{ST}, \mathrm{p} .150$.

${ }^{306}$ Berciano, M., Superación de la metafísica en Martín Heidegger, op. cit., p. 64.

${ }^{307}$ Herrmann, F., "El concepto del tiempo según Heidegger", op. cit., p. 88.
} 
de experimentar no solo su ser-ahí, sino también el ser-ahí en su totalidad. El Da es así el punto de convergencia del ser del Dasein y el ser en general" ${ }^{\prime 308}$.

Esta aperturidad para ser tal no depende de otros entes que permitan o posibiliten dicha apertura, sino que por el contrario le viene de lo más profundo de su ser, al modo de una claridad (Lichtung) esencial a él, que ilumina esta aperturidad y la constituye como tal, que viene desde su propio ser, por tanto, del ser mismo. "Es "iluminado" quiere decir: iluminado es sí mismo en cuanto "ser en el mundo"; no por obra de otro ente, sino de tal suerte que él mismo es la iluminación (Lichtung). Solo a un ente así existenciariamente iluminado se le vuelve lo "ante los ojos" accesible en la luz, oculto en la oscuridad"309.

\section{A. El cómo “Le va” al Dasein en cuanto encontrarse}

El análisis desplegado por Heidegger tiene la particularidad de preguntar fundamentalmente por aquello que somos en cada caso nosotros mismos. Por ser este análisis una búsqueda en los rincones más ocultos de nuestro propio ser, al mismo tiempo es un interpelar a aquello más cercano y propio: lo que intentamos aclarar es nuestro propio ser. Siguiendo en esta dinámica, Heidegger comienza por reconocer la importancia ontológica de los estados de ánimo, de los sentimientos, en tanto que nos informan del modo en que el Dasein se encuentra en el mundo, cómo se halla en él. Para lograrlo toma como referencia el concepto de Befindlichkeit, que nombra el encontrarse, el modo en el que el Dasein se halla en el mundo del Dasein, con el que se alude a la situación afectiva propia de la existencia, mientras nos mantenemos en ella siempre existimos en determinados temples o estados de ánimo (Stimmung). Estos últimos, han sido entendidos tradicionalmente como sentimientos aislados, meramente subjetivos, propios de un sujeto determinado, por lo tanto, no tendrían mayor valor, para una investigación ontológica, entonces, escaso sería su aporte si se pretende dar cuenta de rasgos determinantes y esenciales del Dasein. Como dice Poggeler:

la mostración del "encontrarse" hace notar que también la "teoría pura", también la
ciencia se dan en un encontrarse, o sea, que están "acordes" (gestimmt), y que tampoco
ellas aprehenden, pues, las cosas en "ensimismamiento" (Ansich) puro y neutral, sino
dentro del ser-en-el mundo del encontrarse entendedor, cuyas "producciones
constituyentes" están originariamente anudadas con el ser-ya-siempre cabe las cosas ${ }^{310}$.

Heidegger abre una nueva perspectiva a la filosofía en este campo, recoge de estos estados de ánimo, importantes indicaciones para el análisis esencial del ser del Dasein. Es más, les asigna incluso un rango de importancia decisivo para los resultados de la analítica, esto en desmedro del conocimiento teórico cognoscitivo, por eso, señala que, "las posibilidades de "abrir" de que dispone el conocimiento se quedan demasiado cortas frente al original

\footnotetext{
${ }^{308}$ Másmela, C., Martin Heidegger: El tiempo del ser, op. cit., p. 36.

${ }^{309} \mathrm{ST}$, p. 150.

${ }^{310}$ Pöggeler, O., El camino del pensar de Martin Heidegger, op. cit., p. 87.
} 
“abrir" (Erschließen) que es peculiar a los sentimientos (Stimmungen), en los cuales el ser ahí es colocado ante su ser como "ahí" 311 . Lo que pretende el filósofo de la Selva Negra, es primeramente recoger el significado ontológico de este abrir originario propio del encontrarse, del hallarse, situándolo incluso en un nivel de mayor originalidad e importancia que la del conocimiento, esto en relación a la determinación de la estructura ontológica fundamental del Dasein. Se puede verificar en esta tesis uno de los aportes más novedosos que hace Heidegger, puesto que, el conocimiento, que había sido uno de los pilares fundamentales para describir y definir al hombre, pasa a un segundo plano, y deja de ser el completamente determinante para caracterizar ontológicamente a este ente llamado Dasein.

El encontrarse se le patentiza constantemente al Dasein y es posible de reconocer en frases con las que nos referimos a cómo en cada caso le va al Dasein, cómo nos va en el mundo, cómo nos encontramos, cómo nos hallamos en el mundo, cómo uno está situado en el mundo. Estas alusiones se refieren a los estados de ánimo, a los sentimientos, en los que se encuentra el Dasein, en su modo de hallarse en el mundo.

Los estados de ánimo (Stimmung) nos revelan en cada caso cómo el Dasein se encuentra; cómo esta situado, cómo es afectado en medio del ente que le hace frente o cómo es afectado por los demás entes que son al modo del Dasein. Este cómo le va le revela al Dasein su propio ser. "Los temples de ánimo no son meros estados subjetivos de un sujeto aislado, separado del mundo y de los otros, sino que son una de las maneras como la existencia humana se abre a la claridad del ser y desde ella a la totalidad de lo ente" ${ }^{\text {312 }}$, por consiguiente, el encontrarse es un modo fundamental del Dasein. Es el modo como afronta el hombre el ahí en el que se encuentra o enfrenta la apertura en la que está situado. Esa constitución del Dasein, según la cual, siempre y a cada momento se halla, se encuentra, en un determinado temple o estado de ánimo, demuestra de manera indiscutible la constitución afectiva propia de nuestro ser, la afectividad inherente al Dasein en tanto ser-en-el-mundo.

Siempre en cada caso nos encontramos o somos afectados de tal o cual manera. Siempre nos hallamos dispuestos o situados de una u otra forma. Cuando Heidegger señala que se nos hace patente el encontrarse por medio del cómo nos va o cómo uno está, no quiere decir con esto, que el encontrarse sea lo mismo o sea equivalente a los estados de ánimo, ya que el encontrarse es su condición de posibilidad. Estos son propios del ámbito óntico y por su parte, el encontrarse en cuanto es condición de posibilidad de los estados de ánimo pertenece a la dimensión ontológica. Por eso, Heidegger sostiene: "lo que designamos ontológicamente con el término "encontrarse" es ónticamente lo más conocido y más cotidiano (Alltäglichste): el temple (Stimmung) o estado de ánimo

\footnotetext{
${ }^{311}$ ST, p. 151.

${ }^{312}$ Rivera, J., Heidegger y Zubiri, op. cit., p. 95.
} 
(Gestimmtsein)"313, es decir, a cada momento estamos sintiendo, somos afectado de algún modo, nos podemos sentir bien o mal, o no saber como, pero siempre somos afectados de un modo u otro.

El encontrarse es condición de posibilidad para que el Dasein se sienta existente. Este fenómeno le revela al hombre de manera primordial que él existe, anterior a cualquier conocimiento o conceptualización. Además, que esa existencia que le pertenece de suyo le va; este le va propio de nuestro ser no puede entenderse como un estado interno o reflexivo de nuestra interioridad o de nuestra alma, sino que más bien designa la forma de cómo nos hallamos, cómo nos encontramos en la apertura, en el mundo, dándonos noticia de cómo nos encontramos en el mundo, de cómo nos va en él. Llevándonos ante nuestra propia situación, como un Dasein que tiene que ser-en-el-mundo, y esa existencia debe sostenerla y llevarla, es su propia carga o responsabilidad. Como señala muy bien Heidegger en una nota al pie en la edición alemana de la Obras completas: "Cargar: tomar a su cargo la pertenencia al ser mismo" (Tragt: übernehmen aus der Zugehörigkeit zum Sein selbst)" ${ }^{314}$, esto quiere decir, que no es simplemente una carga más que deba sostener el Dasein, sino que es la carga de su esencial pertenencia al ser mismo, su relación con él, la cual debe llevar y tomar bajo su custodia, la carga de su pertenencia al ser mismo es lo que de manera esencial debe llevar siempre a cuestas. Por tanto, "en el estado de ánimo (Gestimmtheit) es siempre ya "abierto" afectivamente (stimmungsmäßig) el "ser ahí" como aquel ente a cuya responsabilidad se entregó al "ser ahí" en su ser como el ser que el "ser ahí" ha de ser existiendo ${ }^{315}$.

Sin embargo, eso no es todo, porque además de irle su ser en ella la existencia ya siempre es situada, concreta. Por medio del encontrarse se le hace patente al Dasein su condición de arrojado; rasgo esencial para aclarar la estructura de la existencia, por la cual se le manifiesta al Dasein de forma invariable que siempre está existiendo; con cierto pasado, siempre ya arrojado al mundo. En un sitio o circunstancia determinada y no definida por él. Lo que significa que está arrojado a una situación histórica, familiar, política, económica, la cual no ha elegido. Su condición de arrojado es el campo de juego, la facticidad del Dasein:

el "encontrarse" es visto como determinación ontológica. Ónticamente corresponde a ella el temple o estado de ánimo. El Dasein se conoce en él en su desnudo "que es" y "que tiene que ser". La expresión "que es" indica su facticidad, quedando totalmente ocultos su "de dónde" y su "hacia dónde". A ese "que es" la llama Heidegger Geworfenheit, carácter de arrojado. Esta expresión no solo indica que es, sino también su responsabilidad de tener que ser ${ }^{316}$.

\footnotetext{
${ }^{313}$ ST, p. 151.

${ }^{314}$ ST, p. 159. Rivera.

${ }^{315}$ ST, p. 152. Rivera.

${ }^{316}$ Berciano, M., Superación de la metafisica en Martín Heidegger, op. cit. , p. 65.
} 
Lo que se aclara con esta determinación de la Geworfenheit es importantísimo para el resultado final del análisis de la constitución de este ente llamado Dasein. Hay que señalar que: "antes bien "abierto", este "que es", lo llamamos la condición de arrojado (Geworfenheit) de este ente en su ahí, de tal suerte que en cuanto es un ser en el mundo, es el "ahí" $(D a)$. La expresión condición de arrojado busca sugerir la facticidad (Faktizität) de la entrega a la responsabilidad"317. Por lo tanto, este encontrarse que abre, en lo fundamental nos sitúa de manera originaria ante el mudo hecho de nuestra propia existencia, lo que en otras palabras es, la facticidad de nuestra propia existencia, como siempre siendo ya en un mundo. Ésta es la clave ontológica de la Befindlichkeit, que abre nuestro propio ser a su condición más originaria, la de nuestro propio ser como existencia. "El "encontrarse" o estar acorde de cada caso hace aflorar la facticidad del ser-en-elmundo. Que haya ser-en-el-mundo en general, que yo sea y que las cosas sean, que yo me pueda dirigir a las cosas y que ellas puedan concernirme" ${ }^{\text {318. }}$.

Por otra parte, la condición de arrojado equivale a la facticidad (Faktizität), nos patentiza la facticidad de la entrega a la responsabilidad en la que ya siempre nos encontramos, en la que nos hallamos desde siempre, con anterioridad a cualquier tipo de conocimiento o teorización de algun tipo, y nombra de manera precisa esa constitución peculiar del Dasein como un ente que es siempre su ahí; a cada momento debe cargar con su existencia, él es su aperturidad. Siempre se encuentra arrojado al mundo, esto es lo grave, sin su previo consentimiento. Y además, -he aquí un rasgo fundamental-, esto se le revela como responsabilidad. Tiene que tomar a su cargo su ser mismo, es decir: "en sentido estricto, el estado- de -yecto equivale a la facticidad (Faktizität). Ésta, a su vez, significa dos cosas. En primer lugar, señala que el hombre es sin que- digámoslo así - se le haya preguntado si quería existir o no, sino que por el contrario se encuentra existiendo antes de cualquier decisión suya; por ello precisamente se dice que se encuentra "arrojado" (yecto) en la existencia" ${ }^{119}$. Esto hace referencia a que somos arrojados en la existencia, y eso mismo que no hemos elegido es nuestra propia responsabilidad, debemos cargar con ella, con la pertenencia al ser mismo.

Aquello hacia lo que estamos arrojados es una responsabilidad con la que debemos cargar, que debemos llevar con nosotros, la responsabilidad de no ser simplemente sin más, sino por el contrario, estamos obligados a hacernos cargo de nuestro propio ser, en un tener que ser irreversible. A ser no esto o lo otro sino a ser nuestro propio ser. Tenemos ahora la posibilidad de reconocer un hecho fundamental en esta analítica, en la constitución del Dasein, éste está constituido fundamentalmente por el factum de que somos ya arrojados en el ser mismo. "Que el estar (Dasein) sea no es algo fundado en un

\footnotetext{
${ }^{317}$ ST, p.152. Gaos traduce Geworfenheit como "estado de yecto", que en el idioma español no es un término corriente, ni fácilmente comprensible, nos parece que la traducción más correcta y comprensible es la de "condición de arrojado".

${ }^{318}$ Pöggeler,O., El camino del pensar de Martin Heidegger, op. cit., p. 66.

${ }^{319}$ Carpio, A., El sentido de la historia de la filosofia, Eudeba, Buenos Aires, 1977, p. 222.
} 
proyecto libre hecho por él mismo; el estar está siempre más bien entregado su "que él es". El estar está "yecto" en lo ente. El estado de yecto es la "facticidad" del estar. Ésta facticidad se diferencia, sin embargo, esencialmente del carácter factual del venir a darse una cosa presente; es la facticidad de la entrega del estar a sí mismo",320.

La condición de arrojado, la facticidad que nos hace patente el encontrarse, se presenta como una señal que apunta en dirección de la determinación, de la fatalidad, se enmarca de lleno en los límites del poder-ser del Dasein. Su condición de arrojado, su facticidad, representan cierto límite a las posibilidades, ya que son posibilidades situadas, arrojadas, concretas; pero en fin posibilidades, que en cuanto tal tienen su campo de elección, no abstractas sino que concretas. Dice Álvarez Gómez respecto a esto: "la facticidad no simplemente es considerada en cada caso particular, sino que ella no hace sino expresar lo que es cada uno y para cada uno. Es la fuerza de lo que Heidegger atribuye o confiere a un concepto que es tan difícil de traducir en fuerza y razón precisamente de su concreción, la Jemeignigkeit que en alemán no podría ser más expresivo y que responde a eso que en casa caso mío o de casa uno"321

En este análisis, Heidegger recoge y analiza los sentimientos, los estados de ánimo, confiriéndoles un sentido originario, asignándoles una importancia esencial en la constitución del Dasein, estos temples o estados de ánimo son la forma fundamental de encontrarse, de hallarnos con nuestra situación original y concreta. En esta exégesis no se les considera simplemente como meros estados internos de un sujeto, de un alma o de una conciencia, significados todos ellos que no tienen mayor relevancia, si el objetivo es un análisis ontológico fundamental, como el propuesto por Heidegger. Por el contrario, se reconoce en estos un modo esencial de encontrarse el Dasein con el mundo, con otros Dasein, es el sentirse existente, los temples son una modalidad originaria de la apertura de nuestro ser al mundo, e incluso el mismo Heidegger nos señala que los estados de ánimo, los sentimientos, pueden llegar más lejos en su abrir que el propio conocimiento.

\section{B. El COMPrender ( $V$ ERSTEHEN): La Determinación originaria del Dasein como poder SER, COMO POSIBILIDAD}

Dentro del análisis de la estructura del Dasein, de su aperturidad, son dos los existenciarios que poseen el mismo grado de originalidad, es decir, participan de una cooriginariedad (Gleichursprünglichkeit) que les es inherente y constitutiva, lo que nos indica que se implican mutuamente, constituyendo así la aperturidad, el estado de abierto originario del ser en el mundo. Hemos analizado antes el encontrarse que corresponde a uno de ellos, el otro es el comprender. Para entender esta mutua implicación y

\footnotetext{
${ }^{320}$ Pöggeler, O., El camino del pensar de Martin Heidegger, op. cit., p. 66.

${ }^{321}$ Álvarez, M., Teoría de la historicidad, Síntesis, Madrid, 2007, p. 155.
} 
copertenencia hay que señalar que el comprender es siempre un comprender encontrándose y el encontrarse es siempre un encontrarse comprendiendo.

El comprender, la comprensión originaria del Dasein es un fenómeno tratado constantemente a lo largo de la analítica desplegada por Heidegger en Ser y tiempo, como un concepto verdaderamente importante para su investigación $y$, al mismo tiempo, determinante para sus resultados, además de ser fundamental, para nuestro propio análisis del problema ontológico del advenir. En primera instancia, Heidegger presenta como carácter fundamental del Dasein la relación de privilegio que mantiene con el ser, es el ente que comprende el ser, tiene siempre una comprensión del ser, aunque ella es vaga e indeterminada, es una comprensión preontológica del ser (vorontologischen Seinsverständnis).

Si bien el concepto de comprensión adopta distintas modulaciones,-el comprender propiamente dicho, la comprensión del ser (Seinsverständnis), la precomprensión, la comprensión preontológica del Dasein-, se ha de señalar, que subyace en todas ellas una íntima vinculación y poseen un sentido unitario.

El comprender es un existenciario propio de la aperturidad del Dasein, es un modo fundamental del ser de este ente y constituye las posibilidades del Dasein, su poder ser (Seinkönnen), gracias al cual el Dasein siempre sabe de algún modo o de otro sobre los demás entes o sobre sí mismo. Pero no a la manera del conocimiento intelectual, ni de la teoría:

\footnotetext{
lo que se puede (Gekonnte) en el comprender en cuanto existenciario (existenzial) no es ningún "algo", sino el ser en cuanto existir (Existieren). En el comprender reside existenciariamente la forma de ser (Seinsart) del ser ahí como "poder ser". El "ser ahí" no es algo "ante los ojos" (Vorhandenes) que posea además como dote adjetiva la de poder algo, sino que es primariamente "ser posible" (Möglichsein). El "ser ahí" es en cada caso aquello que él puede ser y tal cual él es en su posibilidad ${ }^{322}$.
}

La primera característica que sobresale en la caracterización del comprender hecha por Heidegger, es que el comprender está esencialmente determinado como un poder (Können), como una posibilidad. Esto no se debe entender como una posibilidad de algo específico, concreto, ni tampoco como un poder lograr o realizar algo objetivo o subjetivo, sino la posibilidad del existir en cuanto tal, la del existir como posibilidad. Este poder propio del comprender está esencialmente referido al ser mismo del Dasein, es la posibilidad de ser, de existir. Es lo podido propio de la existencia.:

En cuanto poder-ser o entender (Verstehen), el estar es "primariamente ser.posible": a él no advienen posibilidades como si se tratara de algo aún no efectivamente real que adviniera a una cosa ya presente; el ser posible del estar (Dasein) en general no tiene que ser caracterizado como lo aún no efectivamente real y en ningún caso necesario, pues

322 ST, p. 161. 
entonces sería pensado como modalidad de lo presente, pero nunca como el poder ser de la existencia ${ }^{323}$.

La esencia del comprender es el Dasein en cuanto poder ser. En este sentido se entiende el Dasein como un ser posible, un ser que es su posibilidad de ser. Determinación que caracteriza a este fenómeno esencialmente, el comprender no es algo así como un tipo de conocimiento o teoría al modo de una ciencia, lo que este poder ser es, es "previo a toda forma de conocimiento: se trata de un existencial (existenzial). De tal forma, que el Dasein no se define o entiende en primer término como realidad efectiva podríamos decir, sino que como posibilidad de ser. El primario comprender del Dasein consiste en que está abierto a sí mismo en su más peculiar ser, en su "existencia", como un "poder ser" y, por tanto, como "proyecto" (Entwurf)"324, esto viene a decir, que la comprensión propia de este ente define la constitución de un ser qué es un poder ser, un proyecto, una posibilidad de ser, determinaciones que son las que definen al Dasein en cuanto comprensión, en cuanto existencia, destacándose claramente la diferencia, la distinción con el comprender entendido como una especie de conocimiento.

La determinación originaria y esencial del Dasein es su ser como posibilidad y no como una realidad efectiva, ni como substancia, menos aún como objeto. En esta interpretación del filósofo alemán, la posibilidad adquiere un rango ontológico novedoso y original, como carácter decisivo de la existencia, cuestión que había permanecida oculta o desfigurada en la conceptualidad de la tradición filosófica. "El "ser posible" que es existenciariamente en cada caso el "ser ahí" se diferencia así de la vacía posibilidad lógica como de la contingencia de lo "ante los ojos", en tanto que con esto puede pasar esto o lo otro" ${ }^{325}$. Desde está perspectiva abierta por Heidegger, la posibilidad no pude ser considerada como una mera posibilidad lógica no contradictoria. La posibilidad, el poder ser, es aquello que es mí propia posibilidad de ser a cada momento, en cada situación. Lo que lleva al Dasein a mantenerse siempre como posibilidad, pero no concebida como la realización específica de una posibilidad o de otra. Yo soy esa misma posibilidad. El Dasein es entendido como un ser que es esencialmente posibilidad

La posibilidad es considerada de forma completamente distinta a como la concebía la tradición filosófica, para la cual era una propiedad o categoría de algo ante lo ojos. Ella es propiamente un existenciario y no una categoría, toda vez, que: "en cuanto categoría modal del "ser ante los ojos", significa posibilidad lo aún no real y lo nunca jamás necesario. Caracteriza lo solo posible. Es ontológicamente inferior a la realidad (Wirklichkeit) y la necesidad (Notwendigkeit). La posibilidad en cuanto existenciario es, por el contrario la más original y última determinación ontológica (ontologische

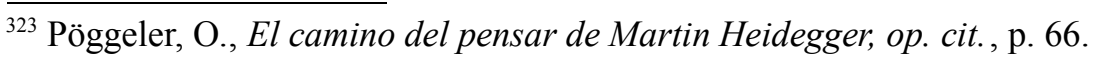

${ }^{324}$ Olasagasti, M., Introducción a Heidegger, op. cit., p. 29.

${ }^{325}$ ST, p. 161.
} 
Bestimmtheit) positiva del ser-ahí" ${ }^{226}$. Heidegger hace hincapié en la importancia radical de la posibilidad en el horizonte de su analítica. La posibilidad, en cuanto determinación de este ente, es la más original y última determinación positiva del Dasein, por lo tanto, no debemos perder de vista el rango ontológico de ésta determinación del Dasein revelada en el comprender. Esto es así, fundamentalmente porque el Dasein, que es equivalente a ese ente llamado hombre, deja de ser entendido en términos de substancia, como algo ante los ojos, que además accesoriamente tendría la capacidad de poder algo. El Dasein es entendido esencialmente como ser posible (Möglichsein), como poder ser (Seinkönnen), como posibilidad (Möglichkeit), siendo éstas determinaciones las que constituyen a este existenciario fundamental que es el comprender.

Comprender es equivalente a poseer o ser un poder ser, de manera que el poder ser de la comprensión es el poder existir. La existencia se mueve en el ámbito de las posibilidades, es fuente de éstas, solo a la luz del comprender las posibilidades de la existencia se revelan como tales, en cuanto poder ser que abre (erschließendes Seinkönnen) el Dasein es sus posibilidades, comprender es ser sus propias posibilidades. Como dice Heidegger: "Y solo porque el "ser ahí" es, comprendiendo, su ahí, puede extraviarse y desconocerse. $\mathrm{Y}$ en tanto que el comprender está determinado por el encontrarse y como éste entregado existenciariamente a la condición de arrojado, se ha extraviado y desconocido en cada caso ya el "ser ahí". En su "poder ser", es por ende, entregado a la responsabilidad de encontrarse de nuevo en sus posibilidades" 327 . El Dasein es en la forma de comprender el ser de una manera u otra, esto significa, que por su peculiar modalidad de comprensión del ser y de sus posibilidades comprendiendo su ahí puede extraviarse o ser su sí mismo (Selbst), puede ganarse o perderse. Puede ser en la propiedad o el la impropiedad de su ser.

Para Heidegger, estas posibilidades abiertas en el ahí no son meras posibilidades abstractas o lógicas, sino que:

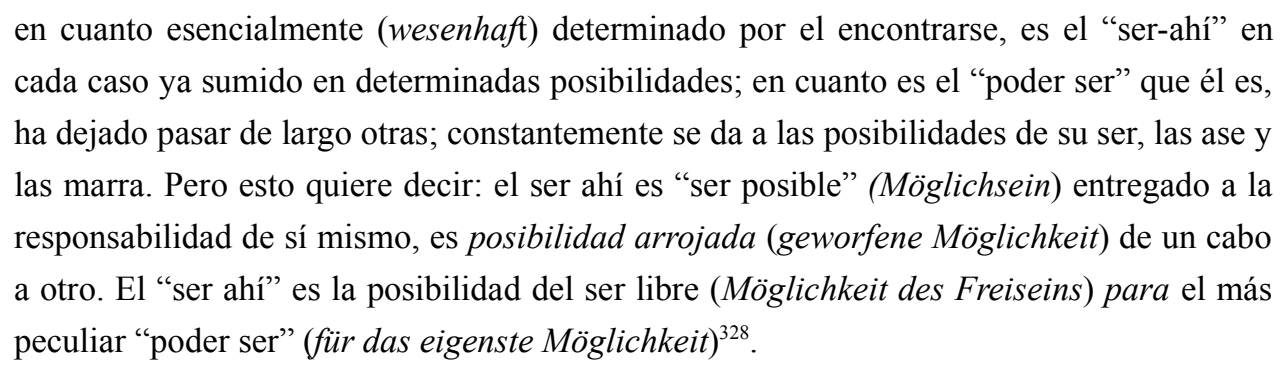

De esta manera se estructura el campo de juego de estas posibilidades, son posibilidades situadas, determinadas por la condición de arrojado. Lo que quiere decir, que estas posibilidades no son ilimitadas, infinitas o sueltas, sino por el contrario, están

\footnotetext{
${ }^{326}$ ST, p. 161.

${ }^{327}$ ST, p. 162.

${ }^{328}$ ST, p. 161.
} 
comprimidas, situadas, son posibilidades arrojadas. Además, el Dasein es esa posibilidad más peculiar de ser su propio poder ser, de ser en la propiedad de su sí mismo.

El poder ser revela la constitución de este ente como una forma de tensión hacia el futuro, de un ir primariamente hacia el futuro, hacia algo aún no acabado y definido. El Dasein está esencialmente abierto hacia el futuro, a las posibilidades; que en cuanto tales no son nunca realidad efectiva para él. La existencia es a cada momento una realización de determinadas posibilidades, de hacer esto o lo otro, estamos siempre eligiendo, a veces sobre cosas importantes y otras sobre meras nimiedades, pero siempre hay tras aquella elección una realización de posibilidades, lo que mantiene al Dasein en el ámbito de lo posible, lo que nos muestra de manera precisa la constitución del Dasein como un poder ser, como posibilidad.

El comprender es ser las posibilidades, lo que es equivalente a proyectar las posibilidades. El proyecto es el modo de ser de las posibilidades del Dasein; no como posibilidades infinitas o sueltas sino posibilidades arrojadas, como posibilidades existenciales. "El comprender (Vestehen) es, en cuanto proyectar (Entwerfen), la forma de ser (Seinsart) del "ser ahí" en que este es sus posibilidades en cuanto posibilidades (Möglichkeiten)" ${ }^{329}$. El Dasein es sus posibilidades y las es de manera que comprende estas posibilidades, las proyecta y proyectándolas les da ser a las posibilidades que él mismo es.

El comprender implica un movimiento hacia delante. Un adelantarse que le da ese carácter de pro-yecto (Entwurf), como comenta Heidegger, "el carácter de proyección del comprender constituye el "ser en el mundo" respecto al "estado de abierto" de su ahí en cuanto "ahí" de un "poder ser". La proyección es la estructura existenciaria del ser del libre espacio del fáctico "poder ser". Y en cuanto arrojado, es el "ser ahí" arrojado en la forma de ser del proyectar" ${ }^{330}$. El pro equivale al adelantarse, un movimiento al futuro, hacia adelante, hacia las posibilidades, hacia lo aún no, "lanzándose hacia su ser posible, es decir futuro, el Dasein se abre a sí mismo como futuro y se abre a las cosas del mundo como posibilidades para ser" 331 . En el proyectar el Dasein adelanta por medio del proyecto la posibilidad como tal, arroja hacia adelante la posibilidad; se proyecta, se lanza con anterioridad, se adelanta, se anticipa. "Ese ser que está por delante y al cual se va es el ser del Dasein en cuanto poder ser, en cuanto posibilidades. En el comprender el Dasein se las ha con sus posibilidades, es decir, como su ser posible" ${ }^{332}$. De esta manera, el Dasein le $d a$ ser a la posibilidad, la posibilita en cuanto posibilidad gracias al proyecto. Ser posibilidad, nuestras posibilidades, es ser arrojado hacia adelante, es ser pro-yectando, que es la relación originaria y fundamental con nuestras propias posibilidades. No obstante,

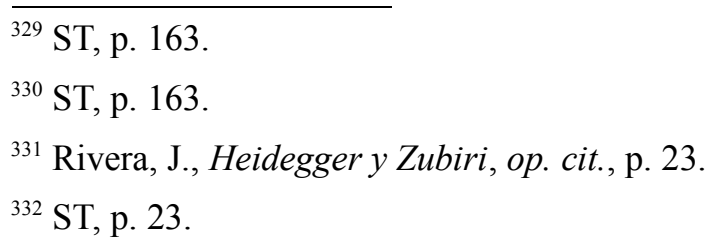


Heidegger no concibe este proyectar como algo óntico o temático, sino como algo ontológico.

Soy posibilidad proyectada, no después que teórica o intelectualmente elabore algo así como un proyecto de vida o un pensamiento que planifica, sino que anterior a cualquier planificación de nuestra vida o alguna acción de ese tipo, ya somos posibilidad proyectada. Es importante no confundir esto, como acontece de forma recurrente en algunas interpretaciones de este concepto, en las cuales se le asimila con algo así con un proyecto de vida, que se construye luego de una reflexión interior, a una meditación acerca de aquello que queremos hacer de nuestras vidas, como una hoja de ruta que podríamos marcarnos y que deseamos recorrer y hacia la cual nos proyectamos. Aquí al hablar de proyecto, Heidegger se refiere a una determinación ontológica del Dasein en la que este se define como un ser arrojado pero hacia delante, hacia lo aún no, con lo que nombra esa relación esencial con nuestras propias posibilidades, es nuestra constitución existenciaria, anterior a cualquier tipo de reflexión o al pensar sobre ellas. Por el contrario, este proyecto concebido ontológicamente es el que hace posible que se puedan elaborar o plantear determinados proyectos de vida.

Lo que soy es lo que puedo ser, lo que somos es lo que podemos ser. Esto significa que, "el comprender no es en Ser y Tiempo nada pura y exclusivamente intelectual. No se trata de un acto particular de la inteligencia. Se trata, más bien, de un modo de ser: de ese modo de ser que consiste en la proyección del ser del Dasein hacia sus posibilidades de ser" ${ }^{\prime 333}$. Nada más y nada menos que eso, el comprender es el modo de ser que proyecta al Dasein a su posibilidad de ser.

El comprender está siempre afectivamente dispuesto, lo que circunscribe sus posibilidades. El proyecto está siempre situado, dispuesto, limitado por posibilidades determinadas. La condición de arrojado es la que marca el campo de las posibilidades, las convierte en posibilidades finitas, solo de esta manera el proyecto se puede constituir como tal, ya que éste es siempre finito. La condición de arrojado, la facticidad, son los que establecen los límites de la finitud, el rayado de cancha dentro del cual el proyecto se mueve, sin tal estrechamiento de las posibilidades se contaría con una infinidad de posibilidades abstractas. Circunscritas de este modo las posibilidades, puede en la comprensión aparecer en su plenitud el proyecto, en caso contrario no se podría constituir como tal. "El estar (Dasein) (...)está caracterizado de manera igualmente originaria, tanto por la existencialidad (Existenzialität) como por la facticidad (Faktizität); e existencia en el sentido más propio de la palabra: el poder ser proyectante (Heidegger llama existencia en el más amplio sentido de la palabra al todo de la existencia)",334.

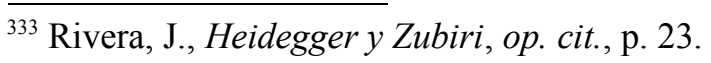

${ }^{334}$ Pöggeler, O., El camino del pensar de Martin Heidegger, op. cit., p. 66.
} 
La condición de arrojado, la facticidad, establecen las limitaciones al poder ser. El proyecto constituye la apertura de las posibilidades que en esta limitación o determinación se abren para él, la misma delimitación de sus posibilidades le abre al Dasein su campo de posibilidades efectivas que él puede ser. En efecto, aquellas limitaciones son a la vez condiciones concretas que en cada caso el Dasein trasciende en el proyectarse. En razón de su constitución como existencia, él nunca puede ser más de lo que es fácticamente, dado que a su constitución como poder ser le es inherente su facticidad como parte inseparable de ella, es ser su propia facticidad, que le pertenece irremediablemente. Como bien dice Pöggeler, "todo entender (Verstehen) se da dentro de un encontrarse; mediante el estado de yecto le son dadas siempre al proyecto del entender determinadas posibilidades y le son retiradas determinadas posibilidades" ${ }^{\prime 335}$.

Pero por otra parte, si la posibilidad es la determinación fundamental del Dasein, éste ente puede ser más allá, en términos existenciarios puede ser lo que aún no es, " solo porque el ser del "ahí" debe su constitución al comprender con su carácter de proyección (Entwurfcharakter), solo porque es lo que llega a ser o no llega a ser, puede decirse, comprendiéndose, a sí mismo: “¡llega a ser lo que eres!'”" (Werde, was du bist) ${ }^{336}$, y nos dice Heidegger, en la nota a pie de página de la edición alemana de las Obras completas, “¿Pero, quién eres "tú”? Ese que tú, librándote de ti mismo, proyectas al lanzarte decididamente hacia delante (als den du dich los wirfst)-el que devienes ${ }^{337}$,

Es la posibilidad esencial del Dasein de proyectarse en posibilidades propias, ser el que en esencia eres, lejos de encubrimientos y ocultamientos del propio ser, en el ser como posibilidad subyace la posibilidad esencial de ser en la propiedad, ser su sí mismo más auténtico, no ser de modo impropio, no ser al modo de los otros, sino ser tu propio ser, el que ya eres; lo solo lo puede ser así proyectándose hacia posibilidades propias de ser, hacia delante, hacia el futuro, proyección hacia las posibilidades que ya eres. Cumplir con el destino que ya eres.

Heidegger hace una clara distinción entre la posibilidad proyectada existenciariamente y la posibilidad arrojada fácticamente abierta en el encontrarse, que muestra que el Dasein es siempre en su ser facticidad arrojada ya en un mundo, de la que no cabe desprenderse ni liberarse, de tal modo, que la condición de arrojado es la que sustenta su facticidad. En el proyecto se establece el marco de acción del poder ser. Por una parte, las posibilidades abiertas en el ser-ahí, en la existencia y, por otra, las limitaciones propias del encontrarse.

El sentido solo puede aparecer gracias al proyecto, gracias al respectivo poder ser, a la posibilidad que en cada caso el Dasein es. Comprender equivale a situar aquello que

\footnotetext{
${ }^{335}$ Ibíd., p. 67.

${ }^{336}$ ST, p. 163.

${ }^{337}$ ST, p. 169.
} 
se ha comprendido dentro de la estructura del proyecto que somos en cada caso y de las posibilidades abiertas en él. Por eso, el sentido que tengan los entes, las cosas, lo intramundano, solo se alcanza en función del sentido peculiar al Dasein. La comprensión y el proyecto son siempre particulares, únicos, cada vez mío, están siempre arrojados. Su estado de abierto, su aperturidad, no es absoluta o pura aperturidad, sino que es una apertura con ciertas limitaciones; apertura delimitada, situada. Heidegger sostiene: "en el proyectar sobre posibilidades (Im Entwerfen auf Möglichkeiten) es ya anticipada una comprensión del ser (Seinsverständnis). En la proyección es el ser comprendido (Sein ist im Entwurf verstanden); no, concebido ontológicamente. Un ente de la forma de ser de la esencial proyección del "ser en el mundo" tiene como ingrediente constitutivo de su ser la comprensión del ser"338. En la estructura del Dasein, en el comprender, se nos manifiesta que el Dasein es comprensión del ser. El ser está ya abierto en la claridad que abre el Dasein y por eso podemos comprenderlo, porque el hombre está en la claridad del ser y en ella puede comprender el ser, "el ser solo es en la comprensión del ente a cuyo ser es inherente lo que se llama comprensión del ser" ${ }^{\prime 339}$. El hombre es comprensión del ser y el ser es en la comprensión que de él hay en el Dasein. Solamente el hombre comprende al ser y es comprensión de él.

Podemos afirmar, sin temor a equivocarnos, que posterior al análisis de la comprensión, se impone una perspectiva interpretativa fundamental: el Dasein es entendido esencialmente como posibilidad, siendo ésta la determinación última y originaria del Dasein. Heidegger una vez más toma distancia de las concepciones de la tradición metafísica, en este caso, de la idea de posibilidad como aquello que es ontológicamente inferior a la realidad y a la necesidad. En otras palabras, la posibilidad adquiere una nueva y original dignidad ontológica, desconocida hasta aquel momento. Esta determinación de la posibilidad inaugurada por Heidegger es importante para los resultados y la perspectiva de la totalidad de la analítica, convirtiéndose en una clave fundamental para la comprensión de lo tratado.

Al mismo tiempo, es importante recordar que con lo dicho no se pretende dejar a un lado o restarle importancia a los demás fenómenos que se han analizado y se analizarán a continuación; la intención es destacar la prioridad o la primacía que adquieren algunos fenómenos-en este caso la comprensión- a lo largo de la investigación que Heidegger lleva a cabo y que son decisivos para las conclusiones finales de la investigación en curso; además, porque no decirlo, decisivos en vistas de los resultados de la analítica existenciaria. Por eso, creemos que es necesario destacar una cierta primacía de este existenciario en la elaboración heideggeriana, ya que, el fenómeno, "que suministra el hilo conductor de esta parte del análisis es, en efecto la comprensión. El Dasein está en el

\footnotetext{
${ }^{338}$ ST, p. 165.

${ }^{339}$ ST, p. 203.
} 
mundo ante todo y fundamentalmente como comprensión antes que como afectividad" 340 . De esta forma, Vattimo da cuenta de la importancia señalada de la comprensión y de la prioridad que ella posee en la investigación heideggeriana, jugando un papel decisivo en el todo de la analítica, correspondiéndole nada menos que el papel de hilo conductor. Pero, volvemos a insistir que no se pretende con esto restarle importancia ni negar la cooriginalidad propia a los existenciarios, en este caso el encontrarse. Pero si hemos de señalar, que "al tema de la comprensión se ha llegado aquí, no como la instancia interior del ser-ahí - la comprensión del ser- que hacía de éste el ente ontológico por excelencia, sino como un exponente de la estructura formal del ser-en, dentro a su vez del ser-en-elmundo cotidiano. Lo que ocurre es que en el análisis de esta estructura relativamente "superficial" ha relampagueado el tema de fondo de toda la inquisición"341. Lo que se insinúa aquí es algo que posteriormente en el análisis de la temporalidad originaria se hará plenamente manifiesto y explícito, señalando cierta primacía del futuro o del advenir en las estructuras de este análisis existenciario, lo que hemos denominado como el problema ontológico del advenir.

\section{Capítulo V: La unidad estructural del Dasein}

Al preguntar por el ser del Dasein preguntamos por algo que nos aparece como lo más cercano y más que aparecer como cercano, es algo que sentimos, vivimos y somos a diario. A cada momento somos aquello por lo que preguntamos, lo que se debiera traducir en una ventaja para la analítica del Dasein, puesto que, es nuestro propio ser el que investigamos, sin embargo, esa misma cercanía, ese mismo ser en cada caso yo mismo, es lo que entraña una mayor dificultad. Como aquella fuerte luz del sol que nos enceguece cuando fijamos la mirada en ella, su misma luminosidad es la que nos impide ver, algo similar es lo que acontece cuando cuestionamos a nuestro propio ser, al ser nuestra misma constitución por la que preguntamos, es precisamente esa cercanía lo que la convierte en una búsqueda compleja y oscura en los lugares más recónditos de nuestro propio ser, ese ser tan propio a cada Dasein. A la cercanía óntica le es esencial una peculiar lejanía ontológica.

La riqueza interpretativa del análisis del ser del Dasein, radica en gran medida en que por vez primera se ilumina de manera original eso tan cercano y a la vez tan lejano que resulta ser nuestra propia esencia. La originalidad del tratado está en que este posee la particularidad de alejarse profundamente de un análisis antropológico, ético o de uno propiamente psicológico acerca del hombre. Si bien, por los resultados alcanzados, muchas veces se le confiere a la analítica esa connotación, ello no significa que lo

\footnotetext{
${ }^{340}$ Vattimo, G., Introducción a Heidegger, op. cit., p. 30.

${ }^{341}$ Peñalver, P., Del espíritu al tiempo, op. cit., p. 151.
} 
realizado o la intención del filósofo sea un mero análisis antropológico, aunque si bien, como hemos dicho ya, por su claridad y sus alcances puede fácilmente ser considerado de esa forma, sin embargo, nunca ha sido éste el sentido o el objetivo que ha guiado al pensador de la selva negra. Lo que aquí está en juego es una interpretación del ser del Dasein, para poder así responder a la pregunta por el sentido del ser, la pregunta por el ser mismo. Su análisis es propiamente ontológico, solo quiere determinar las estructuras fundamentales que le son propias a este ente llamado Dasein, no las particularidades de este o aquel Dasein ni tampoco obtener una caracterización pormenorizada de cierta cantidad de caracteres presentes en él, lo que Heidegger hace es preguntar por aquella estructura esencial, verificable en cualquier ente con la constitución del Dasein. La pregunta no apunta a un qué sino a un cómo, cómo es este ente, cuál es su estructura fundamental.

\section{A. LA CAÍDA, LA TENSIÓN INSUPERABLE ENTRE LA PROPIEDAD E IMPROPIEDAD}

Teniendo esto en cuenta, Heidegger indica que debemos volver sobre aquello que ha quedado atrás, que no ha sido analizado, pero que ha sido un punto de referencia importante al comienzo de la analítica, nos referimos a la cotidianidad, que a lo largo del análisis aparece como un concepto desprovisto de una carga ética o teológica, es un término simplemente descriptivo, en el que se da a entender aquello en lo que estamos inmersos a cada momento en nuestro trato con los entes y con los demás Dasein, se entiende como aquello en lo que inmediata y regularmente estamos absortos. El análisis de la cotidianidad sobrepasa largamente los resultados de un simple análisis de lo cotidiano, y lo sobrepasa porque nos entrega rasgos ontológicos determinantes y esenciales del Dasein. Es una forma fundamental de ser del ser ahí, es un fenómeno irreductible de la existencia, por lo tanto, se plantea la revisión de la cotidianidad, de su estructura, para verificar precisamente su significación ontológico- existenciaria, pero también posee una importancia metodológica indiscutible.

Heidegger abre un camino, que a primera vista podría ser discutible o puesto en duda como método correcto de acceso al ser del Dasein, en el intento de develar su estructura esencial. Esta nueva vía plantea la cuestión de cómo es el Dasein en su día a día, cómo es en su cotidianeidad, cómo se muestra este ente a diario, en sus vivencias con los demás Dasein, en su simple y cotidiano pasar la vida, en sus quehaceres más inmediatos, "esto quiere decir que el ente deberá mostrarse tal como es inmediata y regularmente, en su cotidianeidad media (Alltäglichkeit). Por los demás, en esta cotidianeidad no deberán sacarse a luz estructuras generales o accidentales, sino estructuras esenciales, que se mantengan en todo modo de ser del Dasein fáctico como determinantes de su ser" 342 . Este es el camino que Heidegger nos invita a recorrer para dar con el ser del Dasein.

${ }^{342}$ Rivera, J., Heidegger y Zubiri, op. cit., p. 40. 
Podría parecer paradójico buscar la propiedad del Dasein en la cotidianidad. Puede surgir la duda razonable, en términos de si se ha elegido el camino correcto de acceso al ser de este ente. Se puede dudar de la supuesta validez ontológica de está cotidianidad, de la comprensión de término medio. Por lo que cabría preguntarse- ¿Por qué se ha de estudiar y aclarar lo que sea el Dasein y sus estructuras más esenciales a partir de su vida diaria, de su cotidianeidad, de su inmediatez? ¿No serán estos datos por su naturaleza y simplicidad engañosos a la hora de develar su constitución más esencial?, ¿No debiéramos fijar la mirada en otro tipo de fenómenos más "profundos" que nos puedan entregar información de otra especie?, ¿Por qué no preguntar por algún fenómeno que esté más oculto que aquello que aparece a diario, a simple vista, que por lo mismo puede carecer de importancia?-¿No sería más indicado cuestionar a este ente desde categorías ya reconocidas de ser y realidad? En una primera aproximación se podrían considerar como absolutamente razonables estos cuestionamientos, en cuanto a si el camino elegido por el filósofo alemán es el correcto.

Sin embargo, nos dice Heidegger que, "aquello que de un modo inmediato y regular precisamente no se muestra, aquello que queda oculto (verborgen) en lo que inmediata y regularmente (zunächst und zumeist) se muestra, pero que al mismo tiempo es algo que pertenece esencialmente a lo que inmediatamente y regularmente se muestra, hasta el punto de constituir su sentido y fundamento (Sinn und Grund)"343. En esta referencia, el filósofo alemán expone con claridad la tarea propia der Ser y Tiempo, y define la fenomenología en relación a su tarea y alcances, además, permite justificar de modo indiscutible el análisis de la cotidianidad. Hemos de preguntar por aquello que precisamente se oculta y se esconde en lo que cotidiana y regularmente se muestra, lo que se oculta o se esconde es lo que precisamente constituye el sentido y fundamento de lo que se muestra en la inmediatez. Se ha de cuestionar aquello que se muestra a cada momento, pero que oculta su sentido y fundamento. De aquello que nos aparece y somos a cada momento, es donde precisamente hemos de buscar lo que se oculta, que es justamente lo que da sentido a lo que se muestra. "El estar tiende en su carácter de término medio y en su cotidianeidad a rechazar de sí su propio ser, con lo que no logra llegar al sentido de este ser. De costumbre, y justamente por esto, no ve de ordinario el estar en sentido propio de su ser en el mundo" 344 .

Aquello que inmediata y regularmente se muestra, que es parte inseparable de nuestra existencia, lejos de ser desdeñado por Heidegger por carecer de importancia o de valor para un análisis profundo de las estructuras del Dasein, es precisamente lo que nos entrega los rastros, las señales, en las que se debe leer, en las que debemos detenernos, en razón de determinar las estructuras fundamentales de este ente. Es necesario preguntar “¿cuales son los caracteres existenciarios del "estado de abierto" del "ser en el mundo" al

\footnotetext{
${ }^{343}$ ST, p. 58. Rivera.

${ }^{344}$ Pöggeler, O., El camino del pensar de Martin Heidegger, op. cit., p. 69.
} 
mantenerse éste, en cuanto cotidiano, en la forma de ser del "uno"?" ${ }^{345}$. Se ha de extraer el ser del Dasein desde su cotidiano existir; debemos buscar en lo que cotidianamente se muestra las indicaciones que nos permitan el acceso al ser de este ente, pero especialmente aquellas que nos puedan mostrar cuál es su modalidad de ser más propia. Es necesario tomar nota de la forma en que se van abriendo las vías de acceso a ser del Dasein, el ente que en su ser es comprensión del ser, y por tanto, en él descansa cualquier posibilidad de preguntar por el sentido del ser.

En Ser y tiempo Heidegger destaca como una de las principales características del ser del Dasein, que es un ser que es cada vez mío. Lo que tiene como consecuencia directa que, "el Dasein es mío en esta o aquella manera de ser. Ya siempre se ha decidido de alguna manera en qué forma el Dasein es cada vez mío"346. Esta precisión indica en primer lugar, que no hay una forma única y exclusiva en la cual el Dasein sea cada vez mío. Por el contrario, nos dice que se puede ser cada vez mío de un modo u otro. Esto en un principio nos puede parecer enigmático, por lo que cabe preguntarse, ¿Se puede ser cada vez mío unas veces y otras no?, la respuesta seguramente será por lo menos dudosa, cómo puede ser un ente cada vez mío de una forma y luego de otra, o unas veces sí y otras no, parecería una contradicción lógica, sin embargo es necesario tener en cuenta que el trabajo de Heidegger consiste en replantear los conceptos y revestirlos con orientaciones genuinas.

Siempre el Dasein es cada vez mío (Jemeignigkeit), no unas veces sí y otras no, no se trata de que el Dasein sea en algunas oportunidades cada vez mío y en otras pierda aquella constitución. Este carácter no es algo accesorio del cual quepa desprenderse para posteriormente volver a recuperar. Tampoco es algo que en principio no le pertenezca y después como consecuencia de determinados actos pueda ganar para sí. Con el afán de entenderlo plenamente, es necesario recordar que el Dasein no es un ente con las características de una cosa que está ante los ojos, sino un ser que es: "cada vez esencialmente su posibilidad. Este ente puede en su ser,- “escogerse”, ganarse a sí mismo, puede perderse, es decir no ganarse jamás o solo ganarse "aparentemente"" 347 . En efecto, el Dasein en cuanto está constituido por la Jemeignigkeit, es una posibilidad de su ser, lo que indica que está constantemente enfrentado a sus propias elecciones. En cuanto elige una posibilidad se le cierran otras. Elección que también se le hace presente cuando elige su modo de ser, su propio existir, es decir, siempre se es cada vez mío, y esto puede serlo en la propiedad o en la impropiedad, puede ser cada vez mío propia o impropiamente. Pero solo se es cada vez mío esencial y propiamente en la modalidad de la propiedad, en la que carga sobre sí su ser más peculiar, cuando es cada vez mío de un modo propio responde a su más propio ser sí mismo.

\footnotetext{
${ }^{345}$ ST, p. 186.

${ }^{346}$ ST, p. 68. Rivera.

${ }^{347}$ ST, p. 68. Rivera.
} 
En su modalidad de existir cada Dasein inmediata y regularmente puede ganarse o perderse, puede ser su más original y peculiar poder ser o puede ser en la impropiedad, todo Dasein en su estado de abierto, elige ser en la propiedad o en la impropiedad, es decir, escoge atender su llamada más original a ser sí mismo(Selbst), a ser en la propiedad, o puede también dejarse llevar por una falsificación de su más peculiar poder ser; puede escoger perderse, estar en la impropiedad, inmediatamente caído. Pero esto no significa que el Dasein sea en unos casos propiamente y en otros impropiamente, sino que vive en una tensión constante entre ambos. Pero no podemos confundirnos y malentender lo que Heidegger quiere expresar, no nos está diciendo que una de las modalidades de ser del Dasein, - la propiedad-, sea buena, positiva y que, por otra parte, la impropiedad posea una carga nefasta o perjudicial.

Heidegger no entiende la impropiedad o a la caída en un sentido negativo o perjudicial. Por eso dice: “También se entendería mal la estructura ontológica existenciaria de la caída(ontologisch-existenziale Struktur des Verfallens), si se le quisiera dar el sentido de una mala y lamentable propiedad óntica que quizás pudiera eliminarse en estadios más avanzados de la cultura humana" ${ }^{348}$. Tampoco la considera como un estado del cual todo hombre debiera recuperarse en un sentido moral o teológico, puesto que, "la interpretación tiene un propósito puramente ontológico, y que está muy lejos de una crítica moralizante del Dasein cotidiano y de cualquier tipo de aspiraciones propias de una "filosofía de la cultura" 349 , por el contrario, este fenómeno, es considerado como un elemento ontológico del Dasein en cuanto ser-en-el mundo y ser con otros, es un componente más de esa unidad de la que también son parte la existencia y la facticidad; es una determinación existenciaria que nos revela una esencial estructura ontológica del Dasein. Por lo tanto, es inviable creer que en Ser y tiempo, se pretenda dar fórmulas de comportamiento o ideales de vida, que una vez cumplidos se pueda alcanzar el modo de la propiedad, del más propio poder ser sí mismo, por lo tanto, "Pertenece al estar el estar "yecto" en lo ente y en el ser-con otros; en tanto que él esté, seguirá estando "en proyección", vertiginosamente arrastrado al arrebato por aquello que hay en el mundo y por aquello que se impone en cuanto evidente estar-con los otros" ${ }^{350}$.

Menos pretende el filósofo alemán asignarle a la propiedad un status ontológico superior al de la impropiedad, en otras palabras, "el "estado de caído" (Verfallenheit) del ser-ahí tampoco debe tomarse, por ende, como una caída (Fall) desde un "estado primitivo" (Urstand) más alto y puro" ${ }^{351}$, queda claro con esto, que la pretensión de Heidegger es dar cuenta de los modos de ser que el Dasein es en el mundo,

\footnotetext{
${ }^{348}$ ST, p. 196.

${ }^{349}$ ST, p. 190. Rivera.

${ }^{350}$ Pöggeler, O., El camino del pensar de Martin Heidegger, op. cit., p. 69.

${ }^{351}$ ST, p. 195.
} 
inmediatamente y cotidianamente en el ahí de su ser, su afán es revelar sus estructuras ontológicas fundamentales.

Ambos modos de ser del Dasein- propiedad e impropiedad- están fundados en este ser cada vez mío. Solo un ente de estas características puede ser en la propiedad o impropiedad de su ser, en caso de no ser esta su constitución ontológica no podría ganarse o perderse a sí mismo. Lo propio e impropio solo pueden ser posibilidades de un ser que es cada vez mío: “el "ser ahí" se determina como ente (bestimmt sich als Seiendes), en cada caso (je), partiendo de una posibilidad que él es y que en su ser comprende de alguna manera. Éste es el sentido formal (formale Sinn) del tener el "ser ahí" por constitución la existencia (Existenzverfassung)" "352, con esto, el filósofo nativo de Messkirch quiere decir que el Dasein en cuanto es cada vez mío, en cuanto es un poder ser, tiene la posibilidad de ser cada vez mío propia o impropiamente. Ello, en virtud de su misma constitución, por serle inherente la comprensión del ser puede este ente en su cotidianeidad encontrarse caído, puede ser o es en la impropiedad, en la interpretación de la medianía, en la inautenticidad. Sin embargo, esa misma constitución le abre la posibilidad de ser en su posibilidad más propia. La caída es una estructura ontológica fundamental del ser ahí, porque ella nos hace patente la pérdida del sí mismo. Es gracias a esta patencia que revela la caída por la cual el Dasein puede intentar recuperarse, empuñarse en la búsqueda de su autenticidad, de su propiedad. La caída lejos de ser una instancia confusa o carente de significado, nos patentiza la pérdida del sí mismo en la que nos encontramos.

El Dasein puede asumir aquella responsabilidad a la que ha sido arrojado, la de sostener su propio ser de una manera auténtica o propia. Pero también la puede rehuir y dejarse llevar por la impropiedad para no tener que sostener el peso de esa carga. Como comenta Heidegger: "La proyección del más peculiar "poder ser" es entregada a la responsabilidad del factum de la condición de arrojado en el "ahí" "353. Es esta responsabilidad, esta carga entregada a la existencia, la que el Dasein esquiva en cuanto estar sumergido en la cotidianeidad; inmediata y regularmente entre el mundo, frente al mundo, con otros entes que también son Dasein. En la cotidianidad el Dasein esquiva dicha responsabilidad y lo hace absorbiéndose en los entes. "Heidegger ha puesto de manifiesto insistentemente cómo el estar "sucumbe" (verfällt) a lo ente intramundano que le sale al encuentro, de manera que se entiende a sí mismo y al ser en general a partir del ente con el que cabe toparse" 354 .

Se manifiesta a lo largo del tratado cierta identificación de la caída con lo que entendemos como impropiedad. Siempre el Dasein en la cotidianeidad está caído. La propiedad, ser su más peculiar poder ser, su más propia posibilidad, se alcanza siempre desde la caída en la que desde siempre nos encontramos en la cotidianeidad. "la existencia

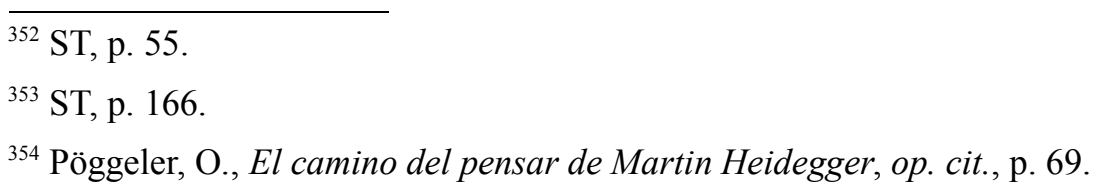


propia (eigentliche Existenz) no es nada que flote por encima de la cotidianidad cadente (verfallenden alltäglichkeit), sino que existenciariamente (existenzial) solo es una manera modificada de asumir esta cotidianidad"355, en otras palabras, esta recuperación de la caída si bien es posible, es más propiamente una modificación de ella, una modulación, por tanto, ese rescatarse de la caída no implica sustraerse completamente a ella. La existencia es una constante tensión entre propiedad e impropiedad, nunca puede recuperarse absolutamente de la caída, en la que se encuentra sumido desde siempre, esto en virtud de su propia constitución como existencia. No obstante: "el hecho de que pueda en general hundirse muestra que, según su ser, es modificable; esto es, que es impropiamente, pero que también puede ser propiamente. Solo en lo que tiene carácter de propio puede llegar a ser entendido el sentido de su ser"356.

\section{B. EL QUIÉN DE LA COTIDIANIDAD: EL UNO}

El Dasein es inmediata y regularmente preocupándose del mundo, en el cual "con igual originalidad que el mundo en torno y sus cosas aparecen al ser humano los otros. Ser hombre (Dasein) es ser-con (Mitsein)" ${ }^{\prime 357}$. No es solo el mundo o los entes intramundanos, los que le hacen frente al Dasein, también existen otros entes de su mismo carácter de ser, de igual constitución entitativa, entes que no son al modo de lo vorhanden, "el "ser ahí" es inmediatamente siempre ya "caído" "de" sí mismo en cuanto poder ser sí mismo y caído en el mundo. El "estado de caído" "en" "el" "mundo" mienta el absorberse en el "ser uno con otro"" 358 , en efecto, el Dasein en cuanto caído es siempre un ser-con otros Dasein, un ser-con otros entes que tiene su misma constitución ontológica, lo que significa que este es un carácter constitutivo de su estructura. Por lo tanto, si alguien no quisiera ser-con, si optara por estar solo sin otros Dasein, su ser de igual manera tendría la modalidad de un ser-con, es algo que no depende de su elección, de si desea o no estar acompañado de otros Dasein, su constitución misma es ser-con. En esa determinación del Dasein del sercon estriba un carácter determinante de la cotidianeidad y es que en ella,"el Dasein está bajo el dominio de los otros: no es "él mismo". Pero esos "otros" no son nadie determinado; es cualquiera y ninguno, uno de tantos" ${ }^{359}$, esto quiere decir, que el Dasein además de encontrarse absorto en el mundo, frente a los entes, en tanto es un ser- con, está perdido en el uno, en la publicidad de éste. El Dasein en cuanto es ser con, es siempre ser en común, es co- existir, por eso mismo es que se absorbe, se pierde en el ser uno con otros.

\footnotetext{
${ }^{355}$ ST, p. 201. Rivera.

${ }^{356}$ Pöggeler, O., El camino del pensar de Martin Heidegger, op. cit., p. 70.

${ }^{357}$ Olasagasti, M., Introducción a Heidegger, op. cit., p. 27.

${ }^{358}$ ST, p. 195.

${ }^{359}$ ST, p. 27.
} 
Como consecuencia de esta constitución ontológica del Dasein como ser-con otros, él no es su más propio sí mismo a diferencia de los otros, sino que su propio ser está como extraviado, perdido en los otros, y no se distingue o diferencia de estos otros. "en cuanto cotidiano "ser uno con otro" está el "ser ahí" bajo el señorío de los otros. No es él mismo, los otros le han arrebatado el ser. El arbitrio de los otros dispone de las cotidianas posibilidades de ser del "ser ahí". Mas estos otros no son otros determinados. Por lo contrario puede representarlos cualquier otro" ${ }^{" 360}$, por lo tanto, el Dasein no es su propio sí mismo, lo otros son los que disponen de su ser, que le ha sido arrebatado, en otras palabras, ha entregado su ser al arbitrio y dominio de los demás, que son los que disponen y se adueñan de las posibilidades cotidianas de existencia del Dasein. Pero esos otros tienen tal grado de indeterminación, que ni siquiera es posible distinguir o precisar quién es ese otro, esto significa que a fin de cuentas puede ser cualquier otro. Los otros son lo que en nuestro cotidiano ser-con nos encontramos inmediata y regularmente. Al preguntar por el quién del Dasein, se interroga al Dasein de la cotidianidad, a la pregunta por el quién de los otros, nos encontramos con que no es este, ni el otro, ni la totalidad de ellos, "el "quién" (Wer) no es este ni aquel; no uno mismo(nicht man selbst), ni algunos, ni la suma de otros. El "quién" es cualquiera (Das Neutrum), es "uno" (Das Man)"361. Este uno del que habla Heidegger no es ninguno, no es nadie en concreto, de modo, que a la pregunta por el quién de los otros, solo podemos decir que es cualquiera, es uno entre otros muchos. El uno o el se es el que domina todo como una verdadera dictadura. Todo se hace, se piensa, se opina en la forma que lo hace uno, por lo tanto, "el "uno", "el se" (das Man) es el verdadero sujeto del cotidiano ser-con, de la diaria convivencia. El uno es la mismidad (Man-selbst, uno mismo) en su modo de impropiedad o inautenticidad"362; cuestión que equivale a una caída del sí mismo, un esquivar el ser propiamente, es un perderse en el uno

En el ser mismo del Dasein subyace siempre la posibilidad de perderse en el uno, en la cotidianeidad; que es siempre una constante tentación a la caída. En este movimiento de la caída se muestra con claridad el dominio del uno en la cotidianeidad de término medio (Durchschnittlichkeit). "El "uno", que no es nadie determinado (kein bestimmtes) y que son todos, si bien no como suma, prescribe la forma de ser de la cotidianidad (Seinsart der Alltäglichkeit)" ${ }^{\text {363 }}$. El aquietamiento propio de la caída pretende negar o encubrir la necesidad de un comprender- encontrándose al modo de la propiedad y, solo le interesa continuar con la aparente tranquilidad que le brinda el uno, gracias a la cual, no se siente directamente llamado a hacerse cargo de su más peculiar ser sí mismo, sino que por el contrario la encubre.

\footnotetext{
${ }^{360}$ ST, p. 143.

${ }^{361}$ ST, p. 143.

${ }^{362}$ Olasagasti, M., Introducción a Heidegger, op. cit., p. 28

${ }^{363}$ ST, p. 143.
} 
Este movimiento de la caída, es en el que se oculta, se cierra el Dasein a su posibilidad más propia; que es la de ser su más propio sí mismo, y por el contrario, se sumerge en la impropiedad, en la cual la arrolladora tiranía del uno todo gobierna, solo es uno entre muchos, "todos son otro y ninguno él mismo. El "uno", con el que se responde a la pregunta del "quién" del "ser ahí" cotidiano (alltäglichen Daseins), es el "nadie" (Niemand), al que se ha entregado en cada caso ya todo "ser ahí" en el "ser uno entre otros"” 364 . Pero a pesar de esto, siempre permanece latente la más originaria posibilidad, la más alta y peculiar posibilidad de que el Dasein se rescate, se recupere para asumir así su más propio ser sí mismo; su existencia propia, su peculiar posibilidad, el modo de la propiedad. Siempre permanece abierta la más originaria posibilidad de que el Dasein sea en el modo de la propiedad, en la autenticidad de su ser.

El Dasein es siempre en alguna modalidad de ser, aquel que es en el modo de la propiedad es sí mismo en el doble sentido de la autoposesión que nombra la Jemeinigkeit. En cuanto se comprende a sí mismo en lo que esencialmente él es, se comprende en su ser más peculiar y propio. Él es esa misma comprensión de ser su sí mismo. Es cada vez mío en un doble sentido, en tanto cada Dasein tiene el carácter de ser cada vez mío, al asumirlo en el modo de la propiedad le pertenece propiamente su ser cada vez mío. Por una parte, es cada vez mío en cuanto este es su rasgo ontológico fundamental, y por otra, es cada vez mío en la propiedad de su ser, posee en propiedad su sí mismo, es su más peculiar ser sí mismo, es cada vez mío propiamente en concordancia con su posibilidad más propia.

El Dasein en la impropiedad no es su más propio sí mismo, sino que es un uno, cuando mucho un uno mismo. Este carácter ontológico de la impropiedad hace visible el fenómeno de la fuga, de la huida del Dasein ante su poder ser propiamente, fenómeno que Heidegger ha definido como la caída. En el plano óntico este fenómeno se nos muestra como una fuga, en la que el Dasein deja de lado la posibilidad de la propiedad. Este cerrarse en el uno hace patente la fuga de este ente ante sí mismo, dice Heidegger: "la fuga peculiar de la caída intenta evitar este carácter inhóspito del mundo refugiándose en el "uno" de la cotidianeidad"' 365 , el Dasein al no ser de modo propio, huye, se refugia en el uno y esto solo lo puede gracias a que este ente es su estado de abierto. Puesto ante sí original y ontológicamente puede huir ante sí mismo de sí mismo.

Resumiendo, la impropiedad es un modo posible de ser cada vez mío, que le es peculiar a un ente que es él mismo, por lo que, “"impropio" o "no-propio" no debe ser entendido en modo alguno a la manera de una simple negación, como si en este modo de ser el Dasein perdiera pura y simplemente su ser" ${ }^{366}$. Por el contrario, para Heidegger la impropiedad nombra esa modalidad de ser en el mundo, en la cual este ente está esencialmente ocupado con los entes que le hacen frente en tanto absorto en el mundo, es

\footnotetext{
${ }^{364}$ ST, p. 144.

${ }^{365}$ Olasagasti, M., Introducción a Heidegger, op. cit., p. 32.

${ }^{366}$ ST, p. 198. Rivera.
} 
la forma de ser inmediata del ser en el mundo, en la que se mueve cotidiana y constantemente, y que se entiende principalmente por esa relación pragmática que mantiene con los entes del mundo. Por esto, no debe de ser entendida de forma negativa u ontológicamente inferior, aquí está dotada de una importante dignidad ontológica, ya que,"funciona como posibilidad positiva (positive Möglichkeit) del ente que ocupándose esencialmente (wesenhaft besorgend), se absorbe en un mundo (Welt aufgeht)" ${ }^{\prime 367}$.

Por ser el Dasein su estado de abierto puede huir o fugarse. Estos fenómenos abiertos en la caída dan la posibilidad de apresar ontológicamente de lo huye el Dasein, el ante qué de la huída en cuanto tal. Esto permite entender la importancia del abrir óntico de la caída, y de lo abierto en ello en la inmediatez, en la cotidianeidad.

\section{La Angustia, EnCONTRARse fundamental que singulariza al Dasein}

Una vez que Heidegger ha analizado y expuesto estos tres existenciarios fundamentales del estado de abierto del Dasein, el comprender (Verstehen), el encontrarse (Befindlichkeit) y la caída (Verfallen), que revelan los rasgos ontológicos fundamentales de la estructura unitaria de este ente privilegiado llamado Dasein, la analítica heideggeriana ha dado sin lugar a dudas pasos importantes en el desarrollo de la pregunta por el ser del Dasein. Sin embargo, Heidegger plantea ciertos reparos respecto a la validez de lo conseguido hasta el momento, este es un ejercicio recurrente en la analítica existenciaria, el de revisar lo ganado en cada etapa de la investigación, lo que permite al mismo tiempo ir detectando qué cuestiones permanecen en la oscuridad al interior de la analítica. Esta forma de acceder a los fenómenos, lejos de ser antojadiza, refleja un peculiar carácter metodológico, que a cada momento va revisando lo ganado, rodeando la problemática, cercando aquello que debemos analizar, pero no olvidando en ningún momento la totalidad hacia la que se conduce la analítica, sus objetivos últimos, en cada paso se ve resplandecer la totalidad de la problemática, pero siempre a distintos niveles de profundidad propios al momento específico en los que se encuentra la investigación.

Los rasgos constitutivos del Dasein son cooriginarios, lo que significa que poseen el mismo grado de originalidad. Heidegger se pregunta por la unidad de esta estructura, cómo es posible que se estructuren unitariamente estos existenciarios constitutivos del Dasein que se han expuesto, cómo se puede alcanzar fenoménicamente esa unidad. La pregunta que se hace el profesor Heidegger es: “¿cómo se debe definir ontológicoexistenciariamente (existenzial ontologisch) la totalidad (Ganzheit) del indicado todo estructural (Strukturganzen)? ${ }^{368}$. La posible unidad estructural por la que se pregunta, no ha de ser concebida como una simple unidad que se obtiene por medio de un mero amontonamiento de partes que se acoplan sin más, tampoco podemos entender esto como

\footnotetext{
${ }^{367}$ ST, p. 195.

${ }^{368}$ ST, p. 203.
} 
una estructura que es posible de unificar a través de una acumulación de fenómenos ordenados según el grado de importancia o en razón de su peculiar dignidad ontológica, lo cual desde ya es imposible por serles inherente la cooriginalidad (Gleichursprünglichkeit). Al poseer el mismo grado de originalidad es imposible poder determinar la unidad de la estructura a partir de uno de los fenómenos, que pudiera cumplir la función de fundamento, de base de la unidad de sus elementos. No obstante, esto no es contradictorio con plantear, como hacemos nosotros, que alguno de estos existenciarios cumple el papel de hilo conductor de la analítica o que algún fenómeno pueda poseer algún tipo de prioridad o primacía por sobre los demás en la totalidad de la analítica. La pregunta que surge ahora es:

¿cómo pensar en su posibilidad-o mejor, ¿Cómo experimentar fenomenológicamente?-la unidad de aquellos tres constitutivos existenciarios del ahí, asumiendo que son de una esencial igual originalidad (Gleichursprünglichkeit),-y en consecuencia ninguno de ellos puede servir de base desde la que deducir los demás-, teniendo en cuenta por otra parte que la unidad buscada no puede resultar de una síntesis hecha desde fuera? $?^{369}$.

Para dar cuenta fenomenológicamente de esa unidad del todo estructural constituido por el comprender, el encontrarse y la caída, Heidegger señala que la analítica:

deberá buscar, para la realización de su tarea preliminar, que consiste en sacar a la luz el ser del Dasein, una de las más amplias y originarias posibilidades de apertura (weitgehendsten und ursprünglichsten Erschließungsmöglichkeiten), implícita en el Dasein mismo. El modo de la apertura en la que el Dasein se lleva ante sí mismo debe ser tal que en ella se haga accesible en una forma, por así decirlo simplificada. Con lo abierto en ella, la totalidad estructural (Strukturganzheit) del ser buscado deberá entonces salir a la luz de un modo elemental ${ }^{370}$.

Con el afán de llevar a cabo un análisis originario y esencial del Dasein en esta etapa preparatoria, es necesaria la determinación de un encontrarse que cumpla con las exigencias metodológicas planteadas por Heidegger.

En primer lugar, ha de ser un fenómeno cuya posibilidad de apertura sea la más original y fundamental del Dasein, además, esta posibilidad de apertura ha de ser determinada desde el ser mismo de este ente, en virtud de la cual este ente se pueda hacer comprensible con la menor dificultad, y principalmente, que pueda hacer accesible este ente como una unidad estructural inseparable. El fenómeno que cumple con los requerimientos metodológicos y sirve de instancia reveladora de esa unidad, es la angustia; "la angustia (Angst) como posibilidad del ser ahí (Seinsmöglichkeit) y a una con el ser ahí mismo abierto (erschlossenen) en ella, da la base fenoménica (phänomenalen Boden) para apresar en forma explicita la totalidad original del ser ahí (ursprünglichen Seinsganzheit des Daseins). Este ser se desemboza como cuidado (Sorge)" ${ }^{371}$. Heidegger

\footnotetext{
${ }^{369}$ Peñalver, P., Del espiritu al tiempo, op. cit., p. 155.

${ }^{370}$ ST, p. 204. Rivera.

${ }^{371}$ ST, p. 202.
} 
considera que en el abrir de este encontrarse fundamental de la angustia, es posible aclarar la estructura del ser del Dasein. De modo, que lejos de ser la angustia un encontrarse más entre un número importante de temples o estados de ánimo que constituyen al Dasein, surge en este análisis como un encontrarse fundamental, un abrir óntico en el que descansa nada menos que la posibilidad de hacer accesible el ser del Dasein como unidad estructural.

Heidegger ilumina así la radical importancia de este fenómeno, gracias al cual podemos conseguir la totalidad original del Dasein. En la angustia descansa la posibilidad última de alcanzar la totalidad del ser de este ente, en cuanto es un encontrarse que singulariza al Dasein y lo enfrenta a la huída de sí mismo. Pero la angustia no es la totalidad del ente privilegiado, ella solo hace accesible esa totalidad, abre la unidad indisoluble que como estructura el Dasein es. Dice Colomer: "con su análisis de la angustia Heidegger pisa conscientemente el sendero abierto anteriormente por la antropología teológica cristiana, particularmente por los autores que, como san Agustín, Lutero y Kierkegaard, se enfrentaron radicalmente con el ser-para Dios del hombre"372.

Sin embargo, como a lo largo de todo el escrito, Heidegger quiere asegurar la validez metodológica y ontológica del fenómeno elegido, para ver si cumple con las exigencias propuestas, si puede servir para la investigación. Si la angustia cumple con estos requerimientos y si puede ser el sustento donde podamos leer la unidad estructural del Dasein, es algo que para Heidegger solo puede asegurarse en la misma analítica. Su propia legitimidad como fenómeno, la ganará en el despliegue mismo del análisis fenomenológico de la angustia, legitimidad y validez, que no se puede obtener de manera artificial o antojadiza. El punto de partida para asegurar este terreno fenoménico, será la misma cotidianidad, la caída, por eso: "el absorberse dentro (Aufgehen) del uno y cabe el "mundo" del que se ocupa hace patente una especie de fuga del "ser ahí" (Flucht des Daseins) ante sí mismo como "poder ser sí mismo" propio (eigentlichem Selbst-seinkönnen). Pero este fenómeno de la fuga del "ser ahí" ante sí mismo y su propiedad parece ser el menos apropiado para servir de base fenoménica a la investigación que sigue" ${ }^{373}$. Heidegger plantea de esta forma las posibles dificultades y contrariedades que supone la elección del fenómeno destacado, este modo de proceder es recurrente a lo largo de Ser y tiempo, dado que nunca debe quedar un fenómeno sin ser justificado de manera suficiente, siempre deber ser plenamente fundamentada su elección como fenómeno esencial del Dasein. Es imprescindible también destacar su validez ontológica, como carácter esencial de la estructura del Dasein, pero al mismo tiempo, se ha de establecer con claridad su validez metodológica.

El filósofo alemán llama la atención sobre la aparente paradoja que supone acceder al fenómeno de la angustia, precisamente desde la caída, que podría ser considerado como

\footnotetext{
${ }^{372}$ Colomer, E., El pensamiento alemán de Kant a Heidegger, op. cit., p. 522.

${ }^{373}$ ST, p. 204.
} 
el fenómeno absolutamente opuesto a la angustia. La caída es precisamente esa instancia en la que el Dasein no es de modo propio, sino que se sumerge en un estado de interpretado, caído y cerrado de sí mismo, absorto en los entes. Sin embargo:

ese estado de cerrada (Verschlossenheit) es solo la privación de un "estado de abierta" (Erschlossenheit) que se hace fenoménicamente patente en la circunstancia de ser la fuga del "ser ahí" fuga ante sí mismo (Flucht des Daseins Flucht vor ihm selbst ist). En el "ante qué" (Wovor) de la fuga (Flucht) viene el "ser ahí" a hallarse justamente "tras" de sí. Solo en tanto que el "ser ahí" es puesto esencial y ontológicamente ante sí mismo por el "estado de abierto" que en general le es inherente puede huir ante sí (kann es vor ihm (liehen) $)^{374}$.

De modo tal, que a la misma constitución de la caída, (en la que el Dasein se cierra a sí mismo, a su propiedad), le es inherente un estado de abierta, puesto que, solo puede cerrarse algo que alberga en sí su propia apertura. Es constitutivo de este ente el estado de abierto, pero cotidianamente se cierra el Dasein a la propiedad, a su sí mismo, pero solamente en el modo de una privación. En esta fuga que le es peculiar, el Dasein huye de sí mismo, se fuga de su propiedad. Y esto solo lo puede llevar a cabo, si él es esencialmente ese estado de abierto, si él es esa posibilidad de ser sí mismo. La caída se constituye como un fenómeno profundamente revelador de las estructuras esenciales del Dasein.

En principio, Heidegger aludió a la caída en términos de una huida del Dasein ante sí mismo, a la cual le es inherente un desvío (Abkehr), y con la finalidad de determinar con claridad de qué se fuga el Dasein, "es necesario recordar el "ser en el mundo", la estructura fundamental de este ente. El "ante qué" de la angustia es el "ser en el mundo" en cuanto tal (In der Welt sein als solches)" "375. En el encontrarse de la angustia se siente el mundo como tal, se abre el ser mismo del Dasein, su ser en el mundo como tal. De aquello que se angustia la angustia es de su ser en el mundo, de su ser mismo. Propiamente dicho, no se angustia por nada específico, el ante qué de la angustia es enteramente indeterminado, por lo cual no es un ente intramundano de lo que huye, más bien esos entes intramundanos no tienen relevancia ni importancia para el Dasein. Ningún ente a la mano o ante los ojos es lo que angustia al Dasein. Todos aquellos entes que le hacen frente en el mundo han perdido su importancia, no le dicen nada al Dasein, no significan nada para él. El mundo ha perdido su significatividad, se sume en una completa insignificatividad (Unbedeutsamkeit) para el Dasein. Esta misma falta de determinación, de significatividad del mundo, de los entes, provoca que ese ante qué de la angustia no vea ni encuentre lo amenazador en ninguna parte, en ningún lugar específico. La angustia no puede saber que es aquello que le angustia, no puede saber ante qué se angustia. Respecto a esto, dice Heidegger: "el ante qué de la angustia se hace patente en el "no es nada ni en ninguna parte". La insistencia del "nada" y el "en ninguna parte" quiere decir fenoménicamente: el

\footnotetext{
${ }^{374}$ ST, p. 204.

${ }^{375}$ ST, p. 206.
} 
"ante qué" de la angustia es el mundo en cuanto tal" "376. El ante qué de la angustia es el ser-en-el-mundo, es en la angustia donde se abre originaria y primariamente el mundo como tal. De este modo, se verifica que no es algo determinado o concreto de lo que se angustia la angustia, muestra que el Dasein se angustia de su propia condición como ser en el mundo, no es de una cosa o de un ente intramundano de lo que huye el Dasein. La angustia como un fundamental abrir óntico, abre por vez primera y de manera fundamental el mundo como mundo, el mundo en cuanto mundo.

Además, a la angustia no solo le es peculiar un ante qué, sino que también un por, pero ese por qué (Worum)se angustia la angustia, no es por una posibilidad o por una determinada modalidad de ser del Dasein. Aquello por lo qué se angustia la angustia es por su propio ser en el mundo como tal, al perder el mundo toda significatividad, el mundo nada le dice al Dasein, nada le ofrece. La angustia le sustrae al Dasein la posibilidad de interpretarse por el mundo, desde el mundo. Por eso, dice Heidegger, que la angustia:

arroja (wirft) al "ser ahí" contra aquello mismo por que se angustia, su "poder ser en el mundo" propio (eigentliches In-der-Welt-sein-können). La angustia "singulariza" (vereinzelt) al "ser ahí" en su más peculiar "ser en el mundo", que en cuanto comprensor se proyecta esencialmente sobre posibilidades (wesenhaft auf Möglichkeiten sich entwirft). Con el "por qué"(Worum) del angustiarse (Sichängstens) abre, por ende, la angustia al "ser ahí" como "ser posible" y como aquello que únicamente es sí y por sí puede ser como singularizado en la singularización (vereinzeltes in der Vereinzelung sein (kann $)^{377}$.

Con esto, el filósofo de la Selva Negra quiere hacer ver que al perder las cosas del mundo toda significatividad, al no decirle nada al Dasein, él ya no puede interpretarse ni comprenderse desde el mundo, desde los entes que le hacen frente en el mundo, ni tampoco puede comprenderse desde las posibilidades que le abren los objetos. Desde ahí el Dasein es llevado a la posibilidad de comprenderse desde sí mismo, es entregado a la responsabilidad de comprenderse desde sus posibilidades más propias. Y esto lo puede conseguir gracias al aislamiento, a la singularización hacia la que es llevado en la angustia. Peñalver comenta respecto a esto: "Heidegger no insiste en este tema de la nada ni siquiera lo subraya. En lo que insiste es en la identidad del ante qué de la angustia y su por qué o por mor de qué (worum): son dos caras, por así decirlo, del ser-en-el-mundo, lo abierto y el abrir, el mundo asignificativo y la existencia entregada a la responsabilidad singular de sus posibilidades" ${ }^{978}$.

Solo gracias a esta singularización es posible que el Dasein pueda comprender su ser desde sus posibilidades más propias, pueda comprender su posibilidad más propia y peculiar de existencia. He aquí un rasgo fundamental de la angustia, ella lleva al Dasein a la singularización de su ser, lo conduce a un completo aislamiento, en virtud del cual es

\footnotetext{
${ }^{376}$ ST, p. 207.

${ }^{377}$ ST, p. 208.

${ }^{378}$ Peñalver, P., Del espíritu al tiempo, op. cit., p. 158.
} 
capaz de comprender sus posibilidades más propias, no desde el mundo o desde los objetos, sino que desde sí mismo, donde descubre la más originaria y fundamental posibilidad de su ser, que es ser en el modo de la propiedad. "La angustia hace patente en el "ser-ahí" el "ser relativamente al más peculiar "poder ser"”, es decir, el ser libre para la libertad del elegirse y empuñarse a sí mismo. La angustia pone al "ser ahí" ante su "ser libre para" (propensio in) la propiedad de su ser como posibilidad que él es siempre ya. Pero este ser es al par aquello a cuya responsabilidad es entregado el "ser ahí" en cuanto "ser en el mundo" 379 . La angustia le patentiza al Dasein su posibilidad más propia, la de poder ser-en-el-mundo propiamente, poder ser su más peculiar sí mismo, ser libre para ser sí mismo que es siempre la posibilidad que esencialmente el Dasein ya es. "La angustia hace posible la manifestación del ser mismo y del ser propio del Dasein y, al hacer esto, nos arranca del olvido en que estábamos sumidos por la interpretación del uno" ${ }^{380}$, nos conduce ante la esencial posibilidad del Dasein: la de asumir aquella responsabilidad de empuñar y sostener su propio ser, como su esencial y suprema posibilidad.

\section{EL SER-EN-EL-MUNDO COMO ANTE QUÉ Y EL POR QUÉ DE LA ANGUSTIA}

En la fenomenología de la angustia llevada a cabo por Heidegger, se destaca la identidad propia del ante qué y del por qué de este fenómeno, puesto que, tienen el mismo objeto: el ser-en-el-mundo es de lo que se angustia la angustia, ante lo qué se angustia.

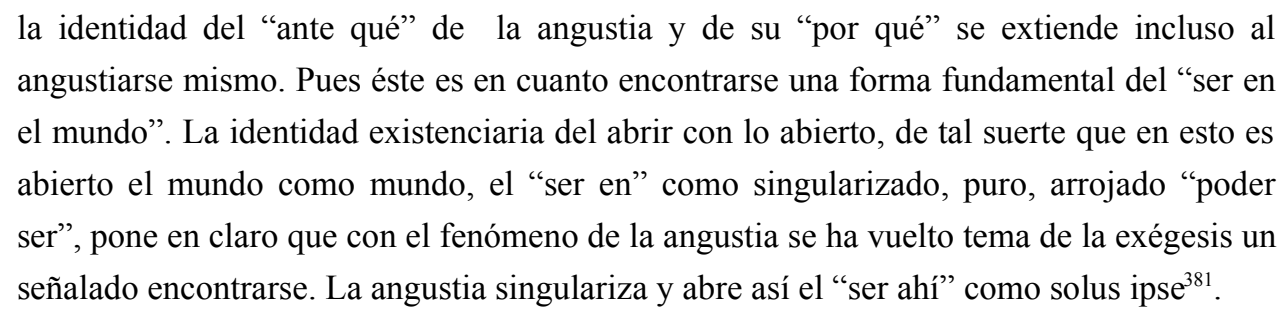

Pero esta identidad del ante qué y el por qué de la angustia como ser-en-el mundo, muestran una dualidad en la que hace hincapié Heidegger. Por una parte, está lo abierto en el ser el mundo, y por otra, está el abrir propiamente dicho.

Lo abierto es el ser en mundo como carente de significatividad, se abre el mundo como mundo. El abrir mismo que nos revela al Dasein en la singularización, es su ser como entregado a la responsabilidad más esencial de ser su propias posibilidades. Lo conduce hacia sí mismo. Le revela de una manera peculiar su posibilidad de existir en el modo de la propiedad. Esta identidad del ante qué y el por qué de la angustia es por su ser en el mundo. El ante qué de la angustia es por la condición de arrojado de su ser en el mundo, y el por qué se angustia, es por su ser en el mundo como poder ser sí mismo.

\footnotetext{
${ }^{379}$ ST, p. 208.

${ }^{380}$ Rivera, J., Heidegger y Zubiri, op. cit., p. 44.

${ }^{381}$ ST, p. 208.
} 
El Dasein en cuanto caído se fuga ante su más propio y peculiar poder ser sí mismo o no, huye de su ser-en-el-mundo propiamente y se refugia en los entes. El Dasein no huye de ningún ente intramundano, sino que huye justamente hacia ellos, se absorbe en ellos, se interpreta en ellos. En este radical encontrarse compresor de la angustia, en lo que abre puede ser comprendido originaria y fundamentalmente el Dasein. En el mismo sentido, comenta el filósofo alemán: "En la angustia le va a uno "inhóspitamente" (unheimlich). En ello encuentra inmediatamente expresión la peculiar indeterminación de aquello cabe los cual se encuentra el "ser ahí" en la angustia: el "nada" y en "ninguna parte" (das Nichts und Nirgends). Pero inhospitalidad (Unheimlichkeit) quiere decir al par "no estar en casa" (Nicht-zuhause-sein)"382. La angustia le abre al Dasein el ser-en-el-mundo en la inhospitalidad, cómo le va al Dasein, le va inhóspitamente, y justamente de ello se huye en la caída. Ante lo que se fuga es lo inhóspito que le va en el mundo al Dasein, no huye "ante los entes intramundanos sino que justo hacia ellos"383. Lo que la angustia abre pura y originalmente es lo inhóspito que le va al Dasein, la inhospitalidad que siente el hombre en su mundaneidad. Se angustia de su desnudo ser en el mundo, no se siente en casa, no se siente familiarizado, todo le parece extraño y ajeno. "Con su oscura e inquietante amenaza la angustia cumple la importante función de sacar al ser-ahí de su olvido cotidiano sentirse en casa y de introducirlo en el modo existencial del sentirse fuera de casa" ${ }^{" 384}$.

El Dasein se angustia de su misma constitución ontológica, que le hace patente la gravedad o la responsabilidad de esa entrega a la carga que él es. Y lo que reviste una significación e importancia esencial es que le revela su carácter originario, en cuanto está en su ser, entregado a la responsabilidad de ser su sí mismo. Es esta responsabilidad la que lo angustia; le abre la propiedad y la impropiedad como posibilidades que él en su ser mas íntimo es. Este estado de ánimo singulariza al hombre rescatándolo del estado de interpretado, del encubrimiento en que se encuentra su ser, desfigurado en su ser con otros o por los entes del mundo.

Es importante destacar que todo encontrarse le hace patente al Dasein el ser-en el mundo, pero la angustia de forma privilegiada, "porque la angustia singulariza. Esta singularización saca al "ser ahí" de su caída y le hace patente la propiedad e impropiedad como posibilidades de su ser. Estas fundamentales posibilidades del "ser ahí", que es en cada caso el mío, se muestran en la angustia en sí mismas, sin desfigurar por los entes intramundanos, a que se aferra inmediata y regularmente el "ser ahi" "385. La angustia abre la posibilidad al Dasein de rescatarse de la caída y de instalarse ante la propiedad e impropiedad como posibilidades esenciales de su ser; pero, lo más importante, es que la angustia nos hace patente de manera irrefutable la estructura del Dasein como totalidad, y

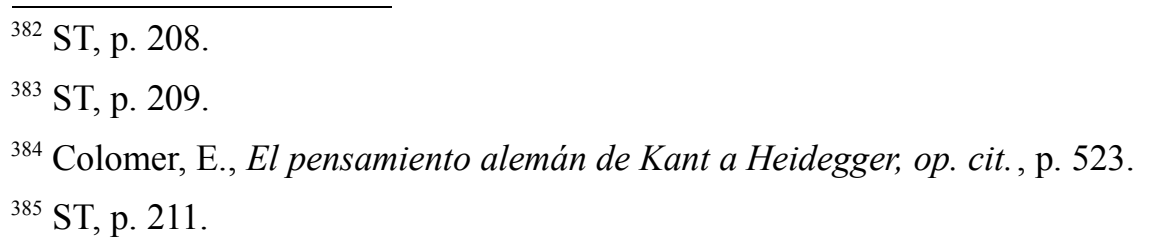


nos permite reconocer la doble importancia de este encontrarse de la angustia. Por una parte, revela al Dasein su posibilidad de la propiedad e impropiedad como posibilidades de su ser. Por lo qué se angustia el Dasein, es por poder ser su posibilidad más propia. Por otra parte, es la angustia la que primeramente muestra de manera clara esa estructura, esa totalidad fenoménica que constituye al Dasein de manera esencial.

\section{E. El cuidado como sustento ontolóGico de la unidad estructural del Dasein}

La angustia como encontrarse fundamental abre el camino de acceso a la unidad de esta estructura que es el Dasein, unidad de una estructura trimembre, en la cual se distinguen fundamentalmente tres elementos: la comprensión, el encontrarse y el ser caído. Son caracteres esenciales del Dasein a los cuales es inherente la cooriginariedad, es decir, no se puede derivar un fenómeno a partir del otro ni menos pueden ser pensados según la idea de una fundamentación venida desde fuera. En cada uno de ellos resplandece el todo de la estructura:

el pleno fenómeno de la angustia muestra, según esto, el "ser ahí" como un "ser en el mundo" fácticamente existente (faktisch existierendes). Los caracteres ontológicos fundamentales de este ente son la existenciariedad (Existenzialität), la facticidad (Faktizität) y el ser caído (Verfallensein). Estas determinaciones existenciarias no son como trozo de algo compuesto en que a veces pudiera faltar uno, sino que en ellas se traba un complejo original que constituye la buscada totalidad del todo estructura ${ }^{386}$.

El análisis heideggeriano de la angustia, muestra primeramente y de forma clara la constitución del Dasein como un poder ser arrojado, caído en la cotidianidad, la angustia nos hace presente esa totalidad estructural llamada Sorge. Dice Rodríguez, en relación a esto: "la totalidad de la existencia comprendida en el cuidado no es una construcción, un "arreglo" que el filósofo hace en aras de la coherencia y la sistematicidad, es lo que testimonia la angustia. Este modo fundamental del "encontrarse" nos sitúa de golpe ante la globalidad de nuestro ser en el mundo" ${ }^{\$ 37}$.

Siguiendo a Heidegger hemos analizado los fenómenos fundamentales del ser-ahí cotidiano y de término medio, en la que se encuentra por lo pronto caído en el uno, en la impropiedad de su ser sí mismo. Hemos reunido en la presente investigación aquellos fenómenos que conforman esta unidad: la facticidad, la existenciariedad y el ser caído, fundamentales en la totalidad de la estructura unitaria del cuidado y en la estructura de la temporalidad originaria. Esos caracteres ontológicos son distintas partes de un todo; en el que cada elemento está en una última y estrecha relación originaria con los demás fenómenos. El cuidado es una totalidad estructural que conforma una unidad, que no puede ser pensada como totalidad separada del todo, sino como parte del todo, pero no del todo del ente, sino del ser, de modo que el cuidado es el fundamento ontológico de cada

\footnotetext{
${ }^{386}$ ST, p. 211.

${ }^{387}$ Rodríguez, R., Heidegger y la crisis de la época moderna, Pedagógicas, Madrid, 2002, p.103.
} 
determinación del ser del Dasein en su posibilidad estructural. Pero es necesario indicar que como totalidad referida al ser esta estructura no puede entenderse como un amontonamiento de modos de ser del Dasein. Ahora es menester dar el paso que va de la exposición de los existenciarios fundamentales de esta aperturidad que es el Dasein hacia la determinación del ser de esta estructura, el cuidado. Colomer sostiene que, "Heidegger ha elegido cuidadosamente este término que viene a remplazar otros términos consagrados por la tradición, como alma, espíritu, yo, sujeto, etc., para evitar cualquier malentendido sustancialista. Todo lo que el ser-ahí conoce y hace, ocupación y preocupación, teoría y praxis, querer y desear, impulso e inclinación, todo son manifestaciones del cuidado" ${ }^{388}$.

El angustiarse como radical encontrarse comprensor, es un modo del Dasein tan fundamental que en él se hace plenamente presente el Dasein como ser en el mundo fácticamente existente, que alude a la proyección más allá de sí mismo, pero también como ya arrojado en un mundo, es un ente determinado, situado en determinadas circunstancias, pero también y esencialmente como posibilidad. El cuidado es una estructura a priori de toda existencia, es existenciariamente anterior a cualquier comportamiento, a toda situación fáctica a la que se deba enfrentar el Dasein, la estructura del cuidado es anterior a cualquier fáctico modo de ser de este ente. Es una estructura a priori de todo ente al que le va su ser, esta determinación es la que subyace en la interpretación del Dasein como cuidado, en ella se revela fenomenológicamente que le va su poder ser. El Dasein en cuanto su ser le va no es solo su ser el que le va, sino que fundamentalmente le va el ser mismo, ello en el ámbito ontológico existenciario que abre el cuidado. En este irle su poder ser se fundamenta la posibilidad más propia del Dasein, por la que se mantiene como un ser posible relativamente al poder ser. El Dasein es siempre anticipándose, es previamente, adelantándose, es más allá de sí mismo, que es lo que constituye su ser. Este ser más allá de sí mismo se le descubre en la apertura de su poder ser, gracias al cual él es siempre sus posibilidades. No podemos dejar de reconocer que a la estructura del cuidado le es esencialmente inherente ser un más allá de sí mismo, un adelantarse, esta estructura en esencia es propia de la constitución del Dasein, en tanto a este ente le va su ser, le va el ser mismo en su ser.

El concepto ontológico del cuidado se ha obtenido gracias al encontrarse fundamental de la angustia, que determina a un ente que es existencia, una estructura unitaria triple. Pero lo que de verdad es aun más importante para Heidegger es, que "la analítica del ser ahí, que penetra hasta el fenómeno de la cuidado (Sorge), tiene por misión preparar los problemas ontológico-fundamentales, la cuestión del sentido del ser en

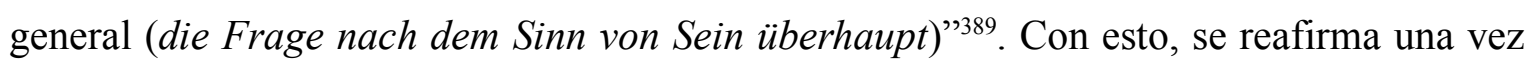
más, que lo realizado lejos de pretender ser solamente una ontología del Dasein, es fundamental y esencialmente una fase provisional del desarrollo de la pregunta por el

${ }_{388}$ Colomer, E., Del pensamiento alemán de Kant a Heidegger, op. cit., p. 524.

${ }^{389}$ ST, p. 203. 
sentido del ser, la pregunta por el ser mismo, por esta razón, más que una simple meditación por el ente privilegiado, se pregunta por él porque es comprensión del ser. Descansa en él la posibilidad última de la pregunta por el ser.

El cuidado, se manifiesta como la unidad esencial propia de la estructura del Dasein, que se nos hace accesible a través de la angustia. Esta totalidad estructural unitaria no puede ser entendida como una constructo elaborado de modo artificial o forzado, realizado con la exclusiva finalidad de aportar la coherencia necesaria para la validez del análisis. Menos podemos concebir a la angustia como un fenómeno meramente informativo del ser en el mundo, al que solo cabe asignarle un valor metodológico, cuya finalidad sea la de alcanzar un ordenamiento sistemático peculiar de una investigación filosófica, por el contrario, "la angustia no es la totalidad del ser-ahí, sino el fenómeno aislado (que sucede con "fáctica rareza") que hace accesible esa totalidad o el ser del serahí, lo que se llamará Sorge, cuidado"390.

La angustia revela el ser del Dasein, como "pre-ser-se-ya-en (el mundo) como ser cabe(los entes que hacen frente dentro del mundo)(Sich-vorweg-schon-sein-in-(der-Welt) als Sein-bei (innerweltlich begegnendem Seienden)). Este ser es lo que constituye, en conclusión, el significado del termino "cuidado" (Sorge), que se emplea en esta su acepción puramente ontológico-existenciaria" ${ }^{391}$. Con esta definición, Heidegger hace presente el todo estructural del Dasein, con los elementos constitutivos del cuidado, que es su estructura fundamental, pero esto, en la forma en que este ente por lo general y la mayor de las veces se encuentra en su cotidianidad, absorbida en su mundo en torno. Esta estructura incluye en sí los caracteres ontológicos fundamentales del Dasein que hemos analizado. En primer término, aparece el pre-ser-se (vorweg), que nos habla de un ente que es anticipadamente, que es un adelantarse, un ser que es previamente. Pero también hace alude a un ente que es esencialmente arrojado, lanzado a determinadas posibilidades concretas que constituyen su facticidad, es su ser como, ““ya” en”(schon) en el mundo. “"'Ser-ya-en" no es otra cosa que la facticidad, el arrojamiento en el mundo, en el que siempre ya nos encontramos. Mundo es, así, ámbito de posibilidades y término de

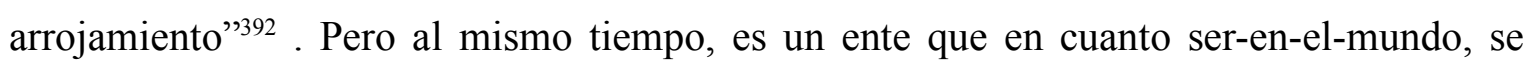
encuentra inmediata y regularmente entre el mundo, frente al mundo, absorto en los entes, se encuentra cabe (bei) los entes del mundo, por lo tanto: "que este "proyecto arrojado en el mundo" sea, a la par un ser cabe los "entes intramundanos" es el resultado de la "caída" en la que se encuentra el sujeto anónimo de la existencia" ${ }^{393}$. Heidegger muestra de esta forma la unidad estructural del Dasein en la que se nombran los fenómenos determinantes de esta unidad ontológica. Se determina el cuidado como el sustento ontológico de la

\footnotetext{
${ }^{390}$ Peñalver, P., Del espiritu al tiempo, op. cit., p.156.

${ }^{391}$ ST, p. 213.

${ }^{392}$ Rodríguez, R., Heidegger y la crisis de la época moderna, op. cit., p. 103.

${ }^{393}$ Ídem.
} 
unidad esencial del Dasein en la cotidianidad. Esos fenómenos están en una estrecha y fundamental relación; la existencia, la facticidad y la caída, son nombrados a su vez por el pre ser se (vorweg), el ser ya en (schon) y el ser cabe (bein), que a su vez refieren al encontrarse comprendiendo constantemente sumido en la inmediatez. Estos elementos son los que constituyen esa unidad llamada cuidado; totalidad estructural del ser en el mundo en la cotidianidad.

Es importante tener en cuenta, que si bien el cuidado señala la estructura fundamental del Dasein, por el momento ella solo se refiere al modo peculiar a la cotidianidad, es la estructura que posee este ente en el salir al encuentro del mundo, es su estructura inherente al modo de ser de la cotidianidad. No debemos olvidar, que "El cuidado tiene como base fenoménica la cotidianidad, y en diversas ocasiones hemos podido entrever que la existencia cotidiana posee un cierto carácter desfigurador de nuestro propio ser, una cierta tendencia a la inautenticidad"394.

Vamos a profundizar en una de las determinaciones esenciales del Dasein que se lleva a cabo en Ser y tiempo. Este ente ha sido caracterizado como un ente al que le va su ser mismo, la existencia en su más pura definición se aclara en el fenómeno fundamental del comprender, que representa ese carácter esencial de posibilidad del Dasein, como un ente que es un poder ser, en efecto, su ser se define como posibilidad. De modo, que: "el "ser relativamente al más peculiar "poder ser" (Das Sein zum eigensten Seinkönnen) quiere decir ontológicamente el "ser ahí" es para sí mismo en su ser (das Dasein ist ihm selbst in seinem Sein) y en cada caso ya previamente (vorweg). El "ser ahí" es siempre ya "mas allá de sí", no como un conducirse relativamente a otros entes que él no es, sino como "ser relativamente al "poder ser" que es él mismo (als Sein zum Seinkönnen, das es selbst ist)" ${ }^{395}$.

Este carácter de proyecto, como un ser que es proyectándose al poder ser más propio, nos refiere a un ente que es esencialmente un poder ser, una posibilidad. Es un ser más allá de sí, abierto primariamente al futuro hacia lo que adviene: "esta estructura del ser del esencial "le va" (es geht um...) es la que vamos a llamar el "pre-ser-se" del "ser ahí" (Sich-vorweg-sein des Dasein)" ${ }^{396}$. Para Heidegger, el pre-ser-se es la determinación primaria de esta estructura, gracias a ella el Dasein puede conducirse relativamente a su poder ser sí mismo, puede cargar sobre sí el adelantarse propio al cuidado. De modo, que este pre-ser-se es el carácter primario, fundamental, es en el que descansa la posibilidad de un conducirse hacia el poder ser más propio, que carga sobre sí el ser previamente inherente al cuidado. Además de ser el que abre la posibilidad (en un ente al que "le va" su ser) de ser su posibilidad más propia.

\footnotetext{
${ }^{394}$ Ibíd., p. 104.

${ }^{395}$ ST, p. 212.

${ }^{396}$ ST, p. 212.
} 
Este carácter de pre-ser-se nombrado en el cuidado, adquiere en la investigación de Heidegger un rango de importancia peculiar en relación a los resultados de la analítica, convirtiéndose en un fenómeno decisivo de la estructura, esto por el papel que cumple en ella, este carácter articula la unidad estructural del cuidado, en cuanto investigación ontológica del ser del Dasein. En otras palabras, “el Dasein descubre el más allá de sí mismo en la apertura del poder ser, con relación al cual él es siempre desde sus posibilidades. A la cura le pertenece un más allá, que se instaura en el poder ser y con el cual la existencia experimenta su carácter extático"397.

Para lograr una comprensión cabal de lo aquí tratado, es menester no olvidar que ninguno de estos caracteres del Dasein pueden ser comprendidos por sí solos, o separadamente, ya que tal como hemos señalado, se constituyen como una unidad indisoluble. De modo, que el pre-ser-se no constituye la totalidad del cuidado. Nuestra intención solo es destacar la prioridad que le es propia a uno de estos caracteres, que cumple el papel de hilo conductor de la analítica, la comprensión, cuestión que se establece claramente en la analítica heideggeriana. Esto lo podemos verificar a simple vista, en el tratamiento que Heidegger le da en la estructura del cuidado, puesto que, juega el rol de articulador de la estructura, a través del pre-ser-se, el fenómeno que sustenta la unidad del cuidado, es el elemento común del todo estructural.

En el análisis realizado se manifiestan ya importantes indicaciones del giro que supone la analítica heideggeriana en relación a las interpretaciones de la metafísica tradicional, en las cuales la relación sujeto objeto, la comprensión de ser como substancia, son las determinantes y decisivas a la hora de preguntar por el ser y por la relación de hombre y mundo, en las que se comprende fundamentalmente al Dasein como cosa, como un ente ante los ojos (Vorhandenheit).

Por todo esto, podemos afirmar que dentro de la estructura del Dasein expuesta por Heidegger, se manifiesta cierta primacía a ciertos fenómenos-(que guardan una interna vinculación entre sí)- como la comprensión, el poder ser; la proyección hacia las posibilidades más propias, que se constituyen en el sustento de la analítica en su afán de determinar la posibilidad de un modo de ser del Dasein, en que sea propiamente su sí mismo, en la que se haga manifiesta, "el fenómeno de la verdad más original en el modo de la propiedad" 398 .

No queremos decir con esto que en la analítica se relega a un nivel ontológico secundario a los demás caracteres. Lo que pretendemos, es aludir a la importancia primordial del pre-ser-se en la concepción heideggeriana del cuidado. Interpretación que está llamada a nombrar al Dasein, al hombre y su relación con el mundo, de una forma originaria como ontología fundamental.

\footnotetext{
$\overline{397}$ Másmela, C., Martin Heidegger: El tiempo del ser, op. cit., p. 43.

${ }^{398}$ ST, p. 242.
} 
Se destaca el pre-ser-se como aquel fenómeno, donde en primer término está en juego la posibilidad o la condición originaria de una posibilidad de:"ser libre para posibilidades existenciales propias"399. Asimismo, el pre-ser-se como anticiparse a sí, como existenciariedad abre la posibilidad peculiar de ser sí mismo en la propiedad de nuestro ser, ilumina la estrecha relación entre la comprensión y la libertad, en cuanto el Dasein comprende más cabalmente sus posibilidades propias puede ser libre para empuñarlas.

El otro carácter ontológico fundamental, cooriginario con la existenciariedad, es la facticidad o la condición de arrojado, "el ser entregado a la responsabilidad de sí mismo, el ser en cada caso ya arrojado en un mundo" ${ }^{400}$. La existencia está determinada por la facticidad, ser ya (schon) en un mundo muestra manifiesto este carácter ontológico del Dasein de ser fácticamente existente, el ser arrojado, que significa ser-ya-en determinadas circunstancias, como posibilidad situada. Pero también, como ser cabe (bei), el tercer elemento de esta unidad estructural, que hace alusión a ese otro carácter ontológico, que es el estar siempre fácticamente existiendo absorbido por lo inmediato; por la cotidianeidad, en la impropiedad. El Dasein lejos de ser su más peculiar sí mismo, es como ser cabe, perdido entre los entes. La estructura del cuidado no puede entenderse exclusivamente como pre-ser-se, como adelantarse, al mismo tiempo le es inherente el ser ya en, ser arrojada en un mundo cabe los entes intramundanos, es un pre-ser-se arrojado en la facticidad propia del mundo. "La estructura del ser-ahí está dada en estas preposiciones (...) Este sería el contenido analítico de la Sorge. La explicitación analítica de la Sorge es una ocasión para confirmar la irreductibilidad de la analítica ontológica a pensamiento reflexivo, la irreductibilidad del ser-ahí consciencia o a subjetividad" ${ }^{\prime 41}$, por todo esto, es indispensable no perder de vista estos fenómenos nombrados del pre ser se, el ya en y el ser cabe, que han sido determinados de forma provisional en el modo de existir impropio, significa entonces, que subyacen en estos elementos determinaciones esenciales que constituyen su sustento ontológico, que solo podrán ser descubiertas a la luz de la investigación por el ser del Dasein en el modo de la propiedad, en la cual se desvela el sentido del ser del Dasein, gracias al cual, todos y cada uno de los fenómenos adquirirán su sentido esencial.

Al finalizar la primera sección de Ser y Tiempo, se ha alcanzado la unidad organizadora en cuanto concepto ontológico: el cuidado unidad estructural del Dasein. El ser del Dasein se concibió como cuidado, pero este análisis está elaborado teniendo en consideración cómo es esta unidad estructural en la inmediatez, en la cotidianeidad, en el existir impropio o de término medio.

\footnotetext{
${ }^{399}$ ST, p. 213.

${ }^{400}$ ST, p. 212.

${ }^{401}$ Peñalver, P., Del espíritu al tiempo, op. cit., p. 159.
} 
No obstante, Heidegger entiende que con estos resultados la analítica no puede pretender ser completamente originaria. Aún queda por andar un trecho importante del camino si se pretende llegar a una analítica existenciaria originaria y total, por ello habla de una insuficiencia esencial de lo conseguido hasta el momento, aunque esta unidad estructural está de suyo articulada es menester fundamentarla, con lo cual da cuenta del carácter provisional del análisis, que por el momento solo se ha ocupado de la estructura originaria del ser del Dasein como cuidado, pero que no ha investigado el fundamento de tal estructura, ni tampoco se ha expuesto el Dasein en su propiedad. Heidegger resume lo anterior preguntándose:

¿es que con el fenómeno del cuidado (Sorge) es abierta (erschlossen) la constitución
ontológica-existenciaria más original (ursprünglichste existenzial-ontologische
Verfassung) del "ser ahí"? ¿Es que el complejo de elementos encerrado en el fenómeno
del cuidado da la totalidad (Ganzheit) más original del ser del "ser ahí" fáctico? ¿Es que
las investigaciones hechas hasta aquí han puesto ante nuestra vista el "ser ahí" como un
todo (als Ganzes)? $?^{402}$.

Sin lugar a dudad el filósofo de Messkirch ha logrado avances sustanciales en la investigación por el ser del Dasein, y mostrado su estructura como cuidado, como totalidad, pero no en su carácter completamente originario, ya que ella no da cuenta cabalmente del ser del Dasein, no da cuenta del sentido del ser de este ente ni del horizonte de comprensión del ser, por lo tanto, "el estudio del fenómeno del cuidado nos permitió echar una mirada al interior de la constitución concreta de la existencia, es decir, a su conexión igualmente original (gleichursprünglichen) con la facticidad y la caída del ser ahí" ${ }^{\prime 403}$. Heidegger partiendo de la cotidianeidad del término medio, desentraña la unidad de esta totalidad estructural. En esta primera aproximación a una circunscripción ontológica del ser del Dasein lograda en el cuidado, se obtiene por vez primera una visión de la unidad estructural articulada de sus elementos, de la que hemos destacado la existencia, la facticidad y el ser caído. Sin embargo, no se muestra aún en ella la consistencia, el sentido de la totalidad unitaria de su estructura, por ello se habla de una insuficiencia esencial de la unidad estructural que se ha presentado, en cuanto estructura formal, abstracta y a priori.

En esta provisionalidad es en la que el autor se apoyará para llegar a un análisis de la totalidad (Ganzheit), propiedad (Eigentlichkeit) y originalidad de la estructura. Heidegger se pregunta: “¿No será esto el signo fenoménico de la necesidad de hacer avanzar aún más la cuestión ontológica, hasta poner de manifiesto un fenómeno todavía más original, que sustente ontológicamente la unidad y multiplicidad de la estructura del cuidado?" ${ }^{404}$, lo que quiere decir, que investigación se ha de remontar a un fenómeno todavía más original, que es el fundamento y sustento del cuidado, que descubre el sentido

\footnotetext{
${ }^{402}$ ST, p. 252.

${ }^{403}$ ST, p. 253.

${ }^{404}$ ST, p. 217.
} 
del ser del Dasein, como horizonte de la comprensión del ser. Esta investigación tiene un carácter peculiar, es un avanzar retrocediendo, retrocede hacia los fundamentos mismos de este ente llamado Dasein, al que se le asigna un rango de privilegio en la pregunta que interroga por el ser. Heidegger deja claramente establecidas las falencias e insuficiencias de lo ganado hasta el momento, pero también indica la dirección que ha tomar la investigación, el hacia dónde se dirige la meditación, al revelar la insuficiencia de lo ganado se da también la nueva dirección que ha de guiar la analítica.

\section{Capítulo VI: La muerte y la conciencia, fenómenos fundamentales del Dasein, que le enfrentan a su más propia posibilidad de ser: su ser total y propio}

La próxima tarea de la analítica heideggeriana es tomar en cuenta al Dasein en la posibilidad de su propiedad y totalidad, de forma que los fenómenos analizados en un primer momento en la cotidianidad, puedan obtener sus determinaciones esenciales desde el modo de la propiedad y totalidad de su ser, fundamentalmente desde la temporalidad originaria, desde donde alcanza su pleno sentido el Dasein, revelándose la temporalidad como el ser del Dasein.

En el \& 45, Heidegger reclama, que el trabajo realizado hasta el momento, carece de la profundidad y originalidad necesaria para ser considerado un análisis verdaderamente fundamental del ser del Dasein. Se ha de retomar el hilo de la analítica en el mismo lugar en que la dejamos, se ha vuelto una necesidad ineludible la elaboración precisa de una pregunta por el ser del Dasein, que se arraigue en el modo de la propiedad de su ser, para que de ese modo se revele la estructura originaria del ser de este ente, y se muestre el peculiar sustento ontológico de lo ganado hasta aquí, lo que hará posible que cada uno de los fenómenos puedan ser determinados en su pleno sentido y obtengan así la claridad ontológica de su constitución fundamental y originaria. Y ello, presupone que, "para que llegue a ser original la exégesis del ser del "ser ahí" como base para hacer en la debida forma la pregunta ontológica fundamental, tiene que poner antes a la luz existenciariamente el ser del "ser ahí" en su posible totalidad (Ganzheit) y propiedad (Eigentlichkeit)" ${ }^{405}$. A juicio de Heidegger, es una cuestión acuciante asegurar el correcto acceso a la elaboración de la pregunta por el ser, ello implica que la interpretación del ser del Dasein debe ser lo más originaria posible, y la deseada originalidad solo es posible si alcanzamos la determinación existenciaria del ser del Dasein en la peculiar posibilidad de la propiedad y totalidad de su ser, en la determinación de su poder ser total y propio.

Se debe responder a la exigencia impuesta por la investigación, responder al requerimiento impuesto por las cosas mismas, hemos de cumplir con la tarea de iluminar y

${ }^{405}$ ST, p. 242. 
determinar al Dasein de la forma más originaria que sea posible, para que se nos muestre en la posibilidad de su totalidad y propiedad. Para conseguir este objetivo, Heidegger busca un fenómeno que pueda atestiguar la propiedad y la totalidad de este ente como posibilidades de su ser. Se ha de buscar en el Dasein mismo aquellos fenómenos que permitan leer la posibilidad de su ser total y propio (Ganzseinkönnen), fenómenos que abran la propiedad y totalidad del ser de este ente. Pero estos deben ser elegidos en función de una comprensión exclusivamente ontológica, alejada de cualquier comprensión antropológica o teológica.

Teniendo en cuenta estos antecedentes, Heidegger elige dos fenómenos que son el ser relativamente a la muerte (Sein zum Tode) y la conciencia (Gewissen). Para él, es obligatorio probar las condiciones ontológicas de la posibilidad de que la existencia se arraigue en la propiedad y totalidad del Dasein, y esto es posible gracias a los fenómenos de la conciencia y de la muerte. En ésta última, se hace accesible el Dasein en su poder ser total, y en la conciencia, se testimonia su poder ser como propio. El análisis por el momento está principalmente enraizado en la interpretación que nos brinda la existencia en su día a día, en la cotidianeidad. Empero, surge ahora el imperativo fundamental de obtener una interpretación que se arraigue en la propiedad, que es una elección en la cual el Dasein se hace cargo de sí mismo, de sus posibilidades más propias. Es menester, determinar un fenómeno que nos muestre al Dasein en la posible totalidad de su ser.

\section{A. La mUerte La POSIBILIDAD MÁs PROPIA DEl DaSein}

Según Heidegger la mejor manera de acceder originariamente al ser del Dasein, es preguntar por la posibilidad más propia y auténtica del Dasein, la posibilidad cada vez mía que abre al Dasein en la propiedad y totalidad de su ser. Heidegger nos hace avanzar retrocediendo hacia la profundidad de los fenómenos, preguntando aquello que define radicalmente al Dasein. El Dasein es ser un poder ser, pero, ¿Cuál es su posibilidad más propia, más originaria?, ¿Cuál es su posibilidad más esencial? Heidegger se interroga por aquella posibilidad que nos abra a la verdad más originaria, en la que el ser ahí propio, "se abre para "sí mismo" en su más peculiar y como su más peculiar "poder ser"" 406 . Esta es la dirección que toma el análisis en lo que viene, en la búsqueda del ser del Dasein en la propiedad, en su poder ser total y propio. Este ente tiene que ser interpretado originariamente en sí mismo en relación a su ser más propio.

La investigación con el afán de volver sobre aquello que le había quedado a espaldas, ha de preguntar entonces por aquella posibilidad más peculiar del Dasein. Se hace necesario entonces, revisar lo que en el modo de la propiedad es el cuidado,-que en un primer acercamiento se concibe como aquel ámbito abstracto, formal, a priori- , que se

${ }^{406}$ ST, p. 242. 
ha expuesto en principio. Aún estamos en el ámbito de la existencia impropia, es necesario entrar en esa otra dimensión de la existencia, que es el modo de la propiedad.

Con el "cuidado" como estructura global de la existencia parece que hemos alcanzado la situación hermenéutica necesaria para llegar a la comprensión del sentido ontológico de la existencia (...) En primer lugar, es dudoso que el cuidado nos entregue el ser total de la existencia; es la estructura en que se dan unidos los distintos momentos constitutivos del existir, pero precisamente, en virtud de la estructura anticipativa del proyecto, la existencia es siempre lo que todavía no es, es decir, nunca es del todo; solo la muerte “cierra”, por así decir, la existencia y nos ofrece algo así como una perspectiva total ${ }^{407}$.

Por lo tanto, la interpretación existenciaria de la muerte se presenta como una tarea indispensable, en cuanto abre la totalidad del ser del Dasein, la muerte se revela entonces como la posibilidad esencial y originaria del hombre; que por lo demás siempre será uno de los principales referentes en la obra del autor, tanto es su fase temprana como en la tardía. Heidegger considera a la muerte como un fenómeno relevante y fundamental en su concepción filosófica.

No obstante, la totalidad que brinda el fenómeno de la muerte sería mal comprendida, si la interpretaramos como una suma total de posibilidades en la cual la muerte es una posibilidad más entre otras, cuya peculiaridad consiste en que con ella se completa el conjunto de posibilidades del Dasein. Esta totalidad concebida como el resultado de una suma de posibilidades hechas ya reales, que una vez agregada la última posibilidad de la muerte entrega la totalidad deseada, no puede dar cuenta de la constitución del Dasein como existencia, al contrario, lo concibe como simple presencia. Esto, porque así entendida la posibilidad de la muerte, presupone un ente que se completa o realiza plenamente, cuando se reúnen en él todos sus modos de ser, de forma tal, que se van conjuntando uno a uno sus formas posibles de ser real, sumándose constantemente una posibilidad con otra, de tal manera que con el agregado de la muerte, que es su última modalidad de ser real, se llega a su plenitud o totalidad. Si la muerte se interpretara de esta forma, se le estaría negando su carácter de posibilidad suprema y absoluta, la posibilidad más propia del Dasein. Esta no es la forma de entender el ser total y propio del Dasein que busca Heidegger, no es esta comprensión de la muerte la que subyace en su concepción de Ser y tiempo. La muerte definida en términos ontológico-existenciarios:

es una posibilidad de ser que ha de tomar sobre sí en cada caso el "ser ahí" mismo. Con la muerte es inminente para el ser ahí él mismo en su "poder ser" más peculiar. En esta posibilidad le va a "ser ahí" su "ser en el mundo" absolutamente. Su muerte es la posibilidad del "ya no poder ser ahí". Cuando para el "ser ahí" es inminente él mismo como esta posibilidad de él, es referido plenamente a su "poder ser" más peculiar. Así inminente para sí mismo, son rotas en él todas las referencias a otro "ser ahí". Esta posibilidad más peculiar e "irreferente" es a la par extrema. En cuanto "poder ser" no puede el "ser ahí" rebasar la posibilidad de la muerte. La muerte es la posibilidad de la absoluta imposibilidad del "ser ahí" (Daseinsunmöglichkeit). Así se desemboza la muerte

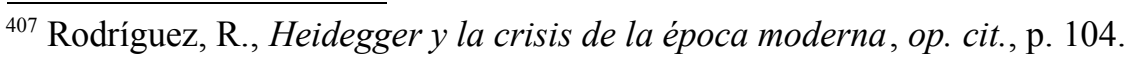


como la posibilidad más peculiar (eingeste), irreferente (unbezügliche) e irrebasable (unüberholbare). En cuanto tal, es una señalada inminencia (Bevorstand $)^{408}$.

Heidegger precisa de esta forma los caracteres fundamentales del fenómeno de la muerte, como aquella posibilidad que define al hombre originaria y fundamentalmente; la muerte es su posibilidad más propia. Como dirá en escritos postreros, el hombre es definido como mortal antes que como animal racional. Los rasgos fundamentales de la muerte son la inminencia, irrebasabilidad, irreferencia, todas estas determinaciones se obtienen en razón de la constitución fundamental de la muerte como posibilidad, la más extrema y absoluta posibilidad del Dasein.

La posible comprensión de su más propia posibilidad es decisiva para la comprensión del Dasein en la autenticidad o propiedad del sí mismo, del ser en el mundo en su totalidad. La relación que el Dasein pueda mantener con su propia muerte es lo que posibilita la comprensión del Dasein en su totalidad y propiedad, por todo ello, "la dimensión mortal forma parte esencial del ser humano: la muerte es una "posibilidad" mas aún, la muerte representa la posibilidad más peculiar del hombre, puesto que es la posibilidad (necesaria)de la imposibilidad de la ulterior existencia, la necesaria posibilidad del acabamiento humano, el non plus ultra del resto de sus posibilidades" ${ }^{\prime 409}$, la muerte es determinada por Heidegger en su carácter concreto de posibilidad suprema del Dasein. Es en esta posibilidad última del hombre, en la que descansa la posible propiedad de la existencia, de su poder ser total, pero todo esto solo es posible, en virtud de la relación que el Dasein pueda establecer con ella. La muerte es su posibilidad absoluta, es la posibilidad de la imposibilidad de la existencia, la posibilidad del cierre de las posibilidades. En su carácter de posibilidad suprema, la muerte se nos muestra como esencialmente imbuida por ese ser temporal que le es peculiar al Dasein, como esencialmente advenidero en el fondo de su ser, posibilidad que adviene ineludiblemente desde el futuro, indeterminada en el cuándo pero segura de su advenimiento como la posibilidad más cierta del Dasein.

En esta radical y decisiva posibilidad de la muerte, y en la forma en que el Dasein la cargue sobre sí, se abre la posibilidad de iluminar la verdad originaria; gracias a la cual es posible desvelar la esencia del Dasein, su ser total y propio. Esta concepción de la muerte, es uno de los resultados más notables de este pensamiento, que destaca y presenta como fundamental la posibilidad del Dasein de mantener una relación auténtica con la propia muerte, conexión originaria que queda encubierta en el modo de la impropiedad, ello porque en la caída el Dasein se niega a mantener un vínculo esencial con la muerte, y prefiere esquivar esa posibilidad a través de la interpretación pública del uno, de aquello que dice el uno acerca de la muerte.

En esta fuga, en este encubrimiento peculiar a la cotidianidad, no se asume la muerte con la propiedad y la singularización que le es inherente; no se la asume con la

\footnotetext{
${ }^{408}$ ST, p. 274.

${ }^{409}$ Olasagasti, M., Introducción a Heidegger, op. cit., p. 38.
} 
radicalidad que le es propia. La cotidianidad que se interpreta a través del uno, muestra que, "el análisis del "uno morirá" desemboza sin ambigüedad la forma de ser del cotidiano "ser relativamente a la muerte". Este se comprende en semejante habla como un algo indeterminado que ha de llegar algún día de alguna parte, pero que por lo pronto es para uno mismo algo aún no "ante los ojos" y por ende no amenazador" ${ }^{10}$, esto expresa, que en el mejor de los casos, en esta interpretación de la cotidianidad se encubre a la posibilidad en cuanto tal, toda vez que se generaliza la posibilidad de la muerte por medio del uno, que es el que morirá, que a fin de cuentas no es nadie en particular. Se relativiza la muerte en la publicidad del uno, diciendo que es uno el que morirá, en consecuencia es un hecho público propio de lo cotidiano, que acontece para el uno, y tiene lugar de forma constante. La muerte es considerada como algo real, ante los ojos, negando así su carácter de posibilidad. La forma en la cual el uno considera la muerte no es el modo propio de ser relativamente a la muerte, sino que más bien hay un encubrimiento de la muerte, una huida frente a ella.

La muerte es una certidumbre del Dasein, inminente, irrebasable e irreferente, nadie puede vivir mi muerte, es mía, propia y de nadie más. Esta posibilidad me singulariza, me rescata del uno, es mi muerte, yo soy el que muere. El Dasein tiene que tomar sobre sí esta posibilidad como su más peculiar posibilidad, ni esquivándola ni menos encubriéndola- cuestión que nunca puede hacer del todo-, sino que asumiendo y viviéndola como su más propia posibilidad de ser, aunque sea justamente la posibilidad de dejar de existir. Pero cabe preguntarse, ¿Cómo es posible tener una relación auténtica con la muerte? A juicio de Heidegger, no es tarea fácil para el Dasein hacer suya la posibilidad más propia, dado que no es una posibilidad cualquiera, sino que es la posibilidad de la imposibilidad de su ulterior existencia, por tanto, no se puede entender esta relación del Dasein con la muerte al modo de la relación del Dasein con las otras posibilidades de su existencia, de las que podemos decir que son realizables, pueden llegar a concretarse o no, pero no este el caso de la muerte. Tomar sobre sí la posibilidad absoluta, no puede significar de ninguna manera realizarla.

\section{B. El Dasein como ser Relativamente a la muerte y el adelantarse hasta la} POSIBILIDAD DE LA IMPOSIBILIDAD

El Dasein ha sido caracterizado por Heidegger como un ser relativamente a la muerte, ahora se debe determinar cómo puede este ente relacionarse originariamente con su posibilidad más extrema y propia. Para alcanzar este objetivo es necesario dejar que la muerte se despliegue como tal, lo que para nada significa que tenga que hacerla realidad, ella está lo más lejos posible de cualquier cosa real o efectiva. La muerte no puede ser considerada como una cosa, como un ente o algo ante los ojos, que más tarde se hará real,

${ }^{410}$ ST, p. 276. 
dado que es una posibilidad, la posibilidad absoluta del Dasein. Tampoco se puede tratar de un continuo pensar en la muerte, calculando y pensando en cuando sobrevendrá. Dice Heidegger: "En el "ser relativamente a la muerte" por el contrario y si es que ha de abrir, comprendiendo, la caracterizada posibilidad en cuanto tal, ha de comprenderse la posibilidad sin debilitación alguna en cuanto posibilidad, ha de desarrollársela en cuanto posibilidad, y en el conducirse relativamente a ella ha de aguantársela en cuanto posibilidad"411, en otras palabras, si se quiere tener una relación auténtica con la posibilidad de la muerte, hemos de dejar que se despliegue como posibilidad, en cuanto posibilidad, se debe dejar ser a la posibilidad de manera que se posibilite en tanto posibilidad. Cuestión que solo se puede lograr en la forma de un adelantar la posibilidad, por eso, "el "ser relativamente a la posibilidad" (Sein zur Möglichkeit) en el caso del "ser relativamente a la muerte" (Sein zum Tode) debe conducirse relativamente a ésta de tal manera que ésta se desemboce en este ser y para él en cuanto posibilidad. Este "ser relativamente a la posibilidad" lo designamos con la expresión adelantarse ${ }^{412}$ hasta la posibilidad" (Vorlaufen in die Möglichkeit)" ${ }^{\text {413 }}$.

Este adelantarse hacia la posibilidad no significa llevar a cabo algo así como una realización de la posibilidad de la muerte, sí podemos hablar de un acercamiento o proximidad a la posibilidad, pero eso no significa hacerla real o disponible. La mayor cercanía de la posibilidad, del ser relativamente al fin es lo más lejano de cualquier cosa real o disponible. En tanto más claramente y de forma auténtica se comprenda esta posibilidad, más libre y originariamente se podrá comprender a la posibilidad en cuanto posibilidad de la imposibilidad de la existencia. El ser relativamente a la muerte, en tanto adelantarse hasta la posibilidad, hace primariamente posible esta posibilidad, y la deja ser libre en cuanto posibilidad esencial de ser del Dasein, que es una forma de futuro.

En este adelantarse hasta la posibilidad de la muerte, está en juego adelantar el más propio poder ser, que solo lo puede ser un ente que tiene en sí mismo la constitución de ser del adelantar, lo que permite al Dasein abrirse a la posibilidad de comprender y de comprenderse en su posibilidad absoluta que es la muerte. Permitiéndole comprenderse y proyectarse en el poder ser más peculiar, "pero proyectarse sobre el más peculiar "poder ser" (eigensten Seinkönnen) quiere decir: poder comprenderse a sí mismo en el ser del ente así desembozado: existir (existieren). El adelantarse se revela como posibilidad de comprender el más peculiar y extremo "poder ser" (eigensten äußersten Seinkönnens), o sea, como posibilidad de una existencia propia (Möglichkeit eigentlicher Existenz)" ${ }^{414}$. En efecto, en el adelantarse hasta la posibilidad más original y propia que es la muerte, se

\footnotetext{
${ }^{411}$ ST, p. 285.

${ }^{412}$ El término Vorlaufen Gaos lo traduce como "precursar", preferimos en este caso "adelantarse" o "anticiparse" que creemos refleja más claramente el sentido temporal del concepto, en cuanto es una forma de futuro.

${ }^{413}$ ST, p. 286.

${ }^{414}$ ST, p. 286.
} 
juega la posibilidad ontológica de una existencia que se arraigue en la propiedad; un proyectarse sobre su más peculiar poder ser, sobre su posibilidad más propia, su ser está puesto en juego de forma radical, no es una posibilidad más, sino la posibilidad de la imposibilidad.

La comprensión de este poder ser le ilumina al Dasein la posibilidad de reconocer por vez primera la pérdida de su ser más propio en lo inmediato y regular, su pérdida en la cotidianidad. La posibilidad más propia es también irreferente, la muerte como la posibilidad más propia le hace manifiesto al Dasein su más absoluta singularidad y aislamiento, singularidad de la cual nunca puede escapar del todo, aunque intente disfrazarla constantemente. El adelantar la muerte le hace comprender al Dasein su carácter irreferente, nadie puede vivir su muerte por él, es su posibilidad más propia, que singulariza al Dasein llevándolo al aislamiento de su propio ser, gracias al cual puede comprender la pérdida de su ser más propio, en tanto está constantemente inmerso en la cotidianidad, en medio de lo que le ocupa.

El Dasein puede ser de modo propio cuando él mismo adelantándose se posibilita para la propiedad de su ser. Por esto, "el adelantarse hasta la posibilidad irreferente (unbezügliche Möglichkeit) fuerza al ente que "precursa" (vorlaufende Seiende) a la posibilidad de tomar sobre sí, desde sí y por sí su más peculiar ser” ${ }^{415}$. Además de ser irreferente esta posibilidad es irrebasable, insuperable, lo que le da ese carácter de posibilidad extrema, absoluta, que en cuanto tal no puede ser superada por el Dasein, no puede ir más allá de ella.

El adelantarse la muerte tampoco logra superar ese carácter de irrebasable de la muerte, pero sí le abre al Dasein la posibilidad de posicionarse libremente frente a ella, sin encubrimientos ni ocultamientos, el adelantarse le abre la posibilidad de la libertad hacia la muerte, que lo libera al mismo tiempo de perderse en simples posibilidades azarosas o fortuitas que se le presentan, lo cual hace comprender de modo original las posibilidades fácticas en su carácter de puras posibilidades, anteriores a la posibilidad de la imposibilidad. Otro carácter de la muerte es que ella es cierta (Gewiss), es propia a su certidumbre la posibilidad de la muerte de realizarse en cualquier momento, si hay algo cierto en la vida, es que vamos a morir, certeza pero indeterminable en su cuando, sin embargo, cierta en el advenimiento de esa posibilidad, puede ser más tarde o más temprano pero su certeza es absoluta. Al momento de nacer ya estamos preparados para morir, de alguna forma, en cuanto nacemos ya estamos muriendo en el acto.

Cuando comprendemos la naturaleza de las posibilidades más propias, somos libres para ellas, pero estas posibilidades son siempre determinadas por su carácter de finitas, comprendidas como finitas. La muerte abre las posibilidades en cuanto tales y las abre principalmente como posibilidades finitas. Toda vez, que "el adelantarse hasta la

${ }^{415}$ ST, p. 287. 
posibilidad irrebasable abre con ésta todas las posibilidades que están antepuestas a ella: por eso reside en él la posibilidad de un tomar por anticipado existencialmente el "ser total"',416. La importancia y radicalidad de este adelantarse hasta la posibilidad de la muerte se convierte en fundamental en el análisis heideggeriano, ya que en su ausencia se hace imposible comprender ontológicamente al Dasein en su totalidad y en su propiedad, en su temporalidad originaria. El adelantarse es, "ese reconocer la muerte como posibilidad auténtica es la anticipación de la muerte, que no significa un "pensar en la muerte", en el sentido de tener presente que vamos a morir, sino más bien equivale a la aceptación de todas las otras posibilidades en su naturaleza de puras posibilidades" ${ }^{\text {417. }}$.

Este adelantarse es el que hace que esta posibilidad pueda abrirse como tal, sin encubrimientos, permite a esta posibilidad radical desplegarse como posibilidad, en otras palabras, es asumir la finitud que es propia del hombre, su mortalidad. Por lo tanto, "el "ser ahí" que soy yo mismo y como "poder ser" solo puede ser propiamente precursando (als Seinkönnen eigentlich erst vorlaufend sein kann)" 418 . Solo por medio del adelantarse se puede desentrañar la esencia del Dasein en la propiedad, en otras palabras, si se asume la finitud es posible comprender la esencia de este ente, gracias al reconocimiento de la posibilidad esencial que es la muerte, en el adelantarse hasta la muerte es posible desentrañar el ser total del Dasein. En el adelantarse descansa la posibilidad del Dasein de confirmar su más propio ser en su irrebasable totalidad. El análisis del adelantarse hasta la posibilidad extrema que es la muerte, propia del ser relativamente a la muerte, nos entrega una visión plena de sus características esenciales, y nos muestra el rasgo fundamental de este adelantarse, que hace posible que la posibilidad más propia del Dasein se abra como tal, en cuanto posibilidad insuperable de la ulterior existencia.

\section{LA ANGUSTIA Y LA COMPRENSIÓN DE UN PODER SER TOTAL Y PROPIO}

Es necesario ahora determinar el papel que juega la angustia en este adelantarse hasta la muerte que se ha tornado como fundamental para la comprensión de un poder ser total y propio (Ganzseinkönnen). Este encontrarse fundamental de la angustia es el que hace posible mantener como constante la radical amenaza del sí mismo, que surge desde la esencia del Dasein, en su ser más propio y singular. En la angustia el Dasein se encuentra frente a la nada de la posibilidad insuperable de su existencia, de lo que se angustia la angustia es de su ser como poder ser en una posibilidad extrema e insuperable. Es en virtud del adelantarse mismo, que puede darse algo así como una singularización extrema del Dasein, en la que se aísla radicalmente en sí mismo, y le hace posible por vez primera

\footnotetext{
${ }^{416}$ ST, p. 288.

${ }^{417}$ Vattimo, G., Introducción a Heidegger, op. cit., p. 49.

${ }^{418}$ ST, p. 289
} 
el volverse cierto de la buscada totalidad de su poder ser. Mas aún, se revela en el análisis de este carácter del adelantarse abierto por la angustia, que ésta, lejos de ser un fenómeno más en el todo del adelantarse hasta la muerte, constituye al Dasein como ser relativamente a la muerte, en tanto que es un ser para la muerte él es esencialmente angustia, como sostiene Heidegger: "el encontrarse capaz de mantener patente la amenaza constante y absoluta que para el ser más peculiar y singularizado del "ser ahi" asciende de este mismo, es la angustia. En esta se encuentra el "ser ahi" ante la nada de la posible imposibilidad de su existencia" ${ }^{\prime 419}$.

Hemos presentado uno a uno los fenómenos que Heidegger considera fundamentales para obtener un análisis original de este ente privilegiado, y que permita romper con la tranquilidad aquietadora del uno, de la cotidianeidad de término medio. El análisis comienza a descender hacia la profundidad conceptual de los fenómenos, en este caso de la muerte, de modo tal que la investigación se va radicalizando, en aras de arrojar luz sobre el ser del Dasein, el ser de la vida humana, pero todo esto, desde una originaria perspectiva interpretativa de los fenómenos, dándoles una nueva orientación, más allá de los encubrimientos, a los que según Heidegger, han sido sometidos estos fenómenos, bajo los dogmas de la conceptualidad propia a la tradición filosófica. En este asumir la finitud se abre la posibilidad de aprehender ontológicamente un poder ser total y propio del Dasein Al hacerse cargo de su esencial finitud puede este ente existir en la propiedad de su ser. Heidegger resume esto desde el punto de vista ontológico existenciario del ser relativamente a la muerte propio, y lo hace en los siguientes términos: "el adelantarse desemboza al "ser ahí" el "estado de perdido" en el "uno mismo", poniéndolo ante la posibilidad - primariamente falta de apoyo en el "procurar por" ocupado- de ser él mismo en la apasionada LIBERTAD RELATIVAMENTE A LA MUERTE (FREIHEIT ZUM TODE), desligada de las ilusiones del uno, fáctica, cierta de sí misma y que se angustia ${ }^{\natural 20}$.

Hemos analizado con detenimiento este adelantarse hasta la posibilidad extrema que es la muerte, a la cual le es propia un adelantar, que es una forma de futuro, que hace posible a la posibilidad y la mantiene como tal, gracias a lo cual aparecen las demás posibilidades en su carácter de simples posibilidades, como posibilidades finitas, determinadas por su ser relativamente al fin. Este es un concepto clave en el todo de la analítica, es también fundamental para nuestra particular investigación, este adelantarse en el que se juega la posibilidad ontológica de un ser total y propio es una forma de futuro, adelantarse en virtud del cual podemos tomar sobre nosotros mismos esa posibilidad radical que es la muerte, que fundamentalmente es-(pero no exclusivamente)- una forma de futuro. Se adelanta la posibilidad cogiéndola entre manos, pero no como algo real, sino en su carácter esencial de posibilidad, la más propia y esencial posibilidad del Dasein.

\footnotetext{
${ }^{419}$ ST, p. 289

${ }^{420}$ ST, p. 290.
} 
Pero, en el adelantarse hasta la muerte se visualiza tan solo la posibilidad ontológica de un poder ser total del Dasein, es la posibilidad ontológica de ser existencialmente un ser relativamente a la muerte de modo propio. Para Heidegger lo realizado hasta el momento tiene sin lugar a dudas una importancia fundamental para la totalidad del análisis y de sus resultados, sin embargo, esto no sirve de nada, sino se puede verificar como posibilidad en la existencia concreta del Dasein, no puede poseer validez fenomenológica para nosotros sino se puede exponer desde el Dasein mismo en su peculiar poder ser óntico, en el mismo Dasein fáctico es donde se debe probar esa posibilidad ontológica.

\section{El testimonio de la propiedad como modo fundamental del Dasein: la voz de CONCIENCIA}

Heidegger se pregunta de qué forma y hasta donde el Dasein testimonia algo así como una posible propiedad de la existencia, como un poder ser propio. Esto no es un simple requisito, necesario para probar las tesis aquí elucubradas o para comprobar existencialmente su posibilidad, sino que por el contrario, deberá verificarse el testimonio que se da en el Dasein de la propiedad y de la totalidad como posibilidades esenciales de su ser más propio, testimonio que ha de ser exigido desde su más propio e íntimo ser.

Aquello por lo que pregunta el filósofo alemán, es por un poder ser del Dasein en el modo de la propiedad, en el cual sea testimoniado esa posibilidad existenciaria del Dasein de ser de modo propio, pero que el origen mismo de esa atestiguación le venga al Dasein desde sí mismo. El buscado poder ser tiene que ser al mismo tiempo un poder ser sí mismo propio (eigentliche Selbstsein), que por lo demás es una modalización existencial del uno. Ha de ser una modalidad en la que el Dasein pueda recuperarse de la pérdida en el uno, que cotidianamente le ha arrebatado siempre la elección de su ser más propio, nunca queda claramente determinado quién es el que elige, por lo cual el Dasein se pierde en medio de lo entes que le hacen frente, sumido en la impropiedad. La única forma de recuperarse de esa impropiedad es si el Dasein puede rescatarse de la tiranía del uno, volviéndose hacia sí mismo propiamente. Es una modificación existencial del uno mismo para que se convierta en el sí mismo propio, a través de esta modificación existencial del uno el Dasein pretende recuperarse, por medio de un retorno, de una vuelta atrás para reparar esa falta de elección inherente a la pérdida en el uno, pero eso solamente lo puede lograr en la realización plena de esa elección, escogiendo su ser desde su posibilidad más propia, posibilitándose a sí mismo por vez primera desde su más propio sí mismo, en otras palabras, elige elegir. Para lo cual es necesario que se testimonie en él su poder ser sí mismo propio, que por lo demás, él es siempre ya en tanto posibilidad

El fenómeno que da testimonio de ello es lo que cotidianamente se llama la voz de la conciencia (Stimme des Gewissen), que en cuanto testimonio, será el fenómeno que nos 
sirva de guía para la verificación de la posibilidad de la atestiguación de un modo propio de ser sí mismo venido desde el Dasein. "Lo que le es propio al Dasein le es indicado por la voz de la conciencia, entendida en sentido ontológico, que precede a todo análisis psicológico y tiene relación con las estructuras ya indicadas: Encontrarse en, comprender, habla, estado de decaído"421. Consecuente con esto, no debemos perder de vista que este es un análisis ontológico de la conciencia, es decir, está estrechamente relacionado con los fenómenos que forman esa estructura unitaria que es el cuidado. Además, para realizar esta delimitación ontológica de la conciencia, no puede servir de guía para comprenderla las interpretaciones clásicas de la conciencia, ni menos se la puede concebir desde un punto de vista psicológico, ético o teológico, su interpretación ha de ser puramente ontológica $^{422}$.

En primer lugar, hay que decir que la conciencia (Gewissen) no es algo así como un acontecimiento del Dasein, que suceda de forma ocasional, sino que es un fenómeno que solo se da en la existencia fáctica del Dasein, es un modo de ser de este ente, de su ser cada vez mío, significa entonces, que no puede convertirse esto en un análisis cuyo objeto es algo así como una conciencia universal o un ideal de conciencia. Debe quedar claro, que la conciencia nos hace entender algo, da a conocer algo, la conciencia en su abrir da a entender algo, abrir que la remite de forma necesaria a la constitución del Dasein como estado de abierto.

Como hemos señalado, la analítica heideggeriana avanza retrocediendo, en este caso, a través del análisis de la conciencia se pretende ir hacia la raíz misma del Dasein, hacia su ser más propio. Es necesario, que el Dasein comprenda su más propio ser sí mismo, de forma que pueda ganar para sí la propiedad, lo que a la vez significa una ruptura, un quiebre de su comprensión a partir de la interpretación del uno, que en otras palabras es una comprensión que se fundamenta en la constitución del Dasein, en tanto, ser uno con otros, en la que se comprende a sí mismo no desde sí mismo, sino desde los otros, es un oír a los otros. El Dasein debe oír el sí mismo, al que ha dejado de escuchar por oír a los otros, debe desatender la escucha al uno, para poder desde sí mismo abrirse a la posibilidad de un oír que rompa con aquel oír al uno. Para poder ser sí mismo el Dasein debe liberarse del dominio del uno, para encaminarse a la propiedad debe romper con la tiranía del uno y de esta forma abrir la posibilidad de la realización fáctica de su ser sí mismo, cuestión que solo es posible, si el Dasein es invocado directamente. La llamada así caracterizada será capaz de romper el oír al uno, de acabar con la escucha de la interpretación pública.

Esta vocación (Ruf), esta llamada de la conciencia abre al Dasein en su constitución como ser caído, y en la propiedad como posibilidad de su ser, pero principalmente hace presente la distinción fundamental entre ambas. La vocación, debe

\footnotetext{
${ }^{421}$ Berciano, M., Superación de la metafisica en Martin Heidegger, op. cit., p. 74. ${ }^{422}$ Cf. ST, p. 293.
} 
tener la característica de ser silenciosa, voca sin ruido y sin ambigüedades, es inequívoca, se lleva a cabo desatendiendo la interpretación de la cotidianidad, "Lo que da a comprender vocando de tal forma es la conciencia" ${ }^{\prime 23}$. El Dasein mismo es el invocado en esta vocación y es invocado hacia su sí mismo más propio, y esto porque en la invocación se deja de lado el estado de interpretado propio de la cotidianidad, es la conciencia la que posibilita ese quiebre con el estado interpretativo, con esa comprensión inherente al uno, quiebre que le conduce a la posibilidad de recuperarse de ese estado de perdido en que se encuentra desde siempre, el uno mismo gracias a la vocación de la conciencia es vocado a ser sí mismo propiamente. La conciencia voca al Dasein, le interpela a que asuma su poder ser sí mismo en el modo de la propiedad, le abre al Dasein la posibilidad de ser su ahí más propio $^{424}$.

La conciencia tiene el carácter de una vocación, de una llamada, es una forma del habla (Rede), un existenciario del Dasein que es propio de su estado de abierto, de modo que ella se articula a una con el comprender encontrándose. Esta vocación es silenciosa, sin ruidos, en esta llamada la conciencia voca al Dasein a comprender su propio ser como ser sí mismo, para liberarse de la impropieda en la que se mantiene arraigado en el uno mismo, en la cotidianidad. El Dasein puede comprender este llamado si está dispuesto a escucharlo. Este escuchar auténticamente el llamado de la conciencia posibilita por vez primera la comprensión del Dasein como poder ser sí mismo de modo propio. En la conciencia se voca el Dasein a sí mismo, se llama a sí mismo. Es por una parte el vocador y a la vez el invocado. Esta llamada, esta vocación, tiene además la característica de que aunque viene desde mí, procediendo de mí, sin embargo, viene de más allá de mín ${ }^{425}$.

Si el Dasein escucha auténticamente la vocación de la conciencia, comprende por vez primera su poder ser sí mismo de modo propio. A este comprender propio del estado de abierto del Dasein le es inherente un encontrarse, le es peculiar un comprender encontrándose. Dicho encontrarse fundamental no es otro que la angustia, la angustia se angustia por su poder ser propiamente. El encontrarse le revela al Dasein su condición de arrojado, le patentiza de forma clara su facticidad, su arrojo al mundo, cuestión que muchas veces queda cerrada por el estado de ánimo, que le oculta su condición de arrojado, de la que huye, para no tener que asumirla como tal, para no tomarla entre sus hombros. Esta huida ha sido caracterizada con anterioridad como una huida de la inhospitalidad en la que se encuentra el Dasein, inhospitalidad que lo conduce hacia su más propia singularización y aislamiento.

La inhospitalidad que abre la angustia, lleva al Dasein frente a la nada del mundo, el mundo ya no le dice nada, pierde su significación, la angustia se angustia por poder ser su ser más propio. Al Dasein en la inhospitalidad, arrojado como ser en el mundo, como

\footnotetext{
${ }^{423}$ ST, p. 295.

${ }^{424}$ Cf. ST, p. 295.

${ }^{425}$ Cf. ST, p. 297.
} 
no en su casa, se le muestra el nudo hecho de que es y tiene que ser en la nada del mundo. Heidegger ha encontrado en la angustia, la base fenoménica, el carácter peculiar al Dasein de vocador e invocado, de modo que:

La conciencia se revela como vocación del cuidado (Das gewissen offenbart sich als Ruf der Sorge): el vocador (Rufer) es el "ser-ahí" que se angustia, en la condición de arrojado ("ser-ya-en..."), por su "poder ser". El invocado es justamente este "ser ahí, avocado a volverse hacía su más peculiar "poder ser" (pre-ser-se). Y avocado es el "ser ahí" por la invocación salir de la caída en el uno ("ser-ya-cabe en el mundo del que nos ocupamos"). La vocación de la conciencia (Der Ruf des Gewissens), es decir, ésta misma tiene su posibilidad ontológica en la circunstancia de que el "ser ahí" es, en el fondo de su ser, cuidado (das Dasein im Grunde seines Seins Sorge ist) ${ }^{426}$.

Hemos podido constatar que en este análisis de la conciencia se han hecho presentes los elementos constitutivos de la estructura del cuidado, es más, la conciencia propiamente se explica y entiende en la propia estructura del cuidado, de forma que tal como se había anunciado, los fenómenos constitutivos de la estructura van adquiriendo nuevas y fundamentales determinaciones, que las abren a su sentido original. La vocación proviene de sí mismo pero al mismo tiempo va más allá de sí mismo.

La vocación y el correspondiente oír originario, permite al Dasein la posibilidad de poder escuchar a su sí mismo, de forma que puede elegirse a sí mismo en el modo de la propiedad. Pero esto, solo puede ser en su posibilidad existencial, fáctica del caso. La vocación de la conciencia, que viene desde la inhospitalidad y abre al Dasein en su poder ser más propio desde la absoluta singularización a la que es conducido por la angustia, que lo sitúa en un peculiar aislamiento en el que se pone a sí mismo ante sí mismo. La vocación no dice nada de aquello que se deba discutir, discurrir o comentar, no da noticia ni información alguna, voca de forma silenciosa al Dasein hacia delante, hacia su poder ser y lo voca desde la inhospitalidad. Por ende: "la vocación no da a comprender ningún "poder ser" ideal, universal: abre el "poder ser" como el "poder ser" singularizado del "ser ahí" del caso" ${ }^{427}$. En esta determinación de la conciencia llevada a cabo por Heidegger, se demuestra con claridad el carácter peculiar de este pensamiento, toda vez, que la conciencia tal como es tratada por el filósofo alemán, está lejos de ser una conciencia que dicta normas de comportamiento, o que enjuicia sobre lo bueno o lo malo, ni menos es una conciencia que nos pueda conducir hacia un ideal de poder ser del Dasein, ella simplemente nos sitúa frente a la posibilidad de ser en la propiedad, de ser un poder ser sí mismo propio. Es gracias a la conciencia, que el Dasein desde la singularización a la que es conducido, puede rescatarse y ser su posibilidad más propia: "Por la "voz" de la conciencia es vocado el estar a su más propio poder-ser, a su "resolución". Así es como se da cuenta de que es "culpable"',428.

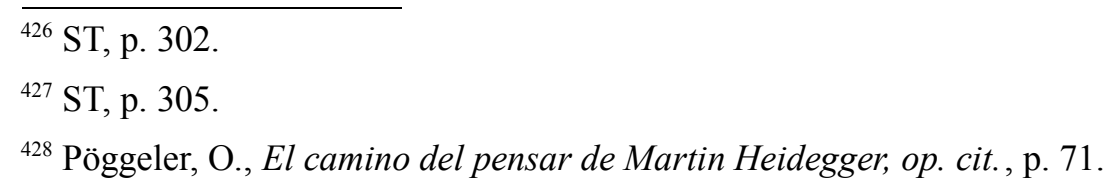


Pero como es costumbre, Heidegger precisa que en lo realizado hasta el momento, persiste cierto grado de indeterminación en relación a la caracterización de la atestiguación de la conciencia, falta por circunscribir de forma clara el carácter que le es propio a ese oír la vocación. La escucha originaria de la llamada debe ser determinada de manera suficiente. Aquello que es vocado, de qué modo lo recibe el Dasein, cómo es ese escuchar que corresponde originariamente a la vocación. El fenómeno de la conciencia no podrá ser concebido de forma originaria sino puede comprenderse desde la vocación (llamada) y a una con ella. Para resolver esto Heidegger nos lleva nuevamente al plano fenoménico de la cotidianidad, terreno fértil desde el que siempre es posible recoger información que nos permitan una comprensión propia de los fenómenos.

\section{E. El DASEIN UN SER QUE ES FUNDAMENTO DE UNA NIHILIDAD: LA CULPA ORIGINARIA}

Heidegger al analizar fenómenos como el de la conciencia, la muerte, el tiempo, parte de lo que la interpretación pública opina de ellos, de cómo nos habla de ellos, somete a estos fenómenos al rigor fenomenológico. Siempre en el modo de ser de la impropiedad se ocultan ideas, rastros del fenómeno original, solo hay que saber leer en ellos estas indicaciones. Siguiendo en esta línea, el pensador de la Selva Negra elige el fenómeno de la culpa (Schuld), con el objetivo de profundizar en la atestiguación del poder ser propio del Dasein. La concepción vulgar o cotidiana de la expresión alemana Schuldigsein, la entiende como un concepto principalmente ligado al contraer una deuda, al tener una deuda, haber contraído una deuda, por lo que subyace en ella la idea de una privación o a la falta de algo, de la que se ha hecho de alguna manera deudor, se ha convertido en dueño y responsable de una deuda, es responsable del ser deudor, esta interpretación del ser deudor está principalmente referida a entes de los que cabe ocuparse ${ }^{429}$. Pues bien, "este ser deudor (Schuldigsein) no tiene carácter jurídico ni de culpabilidad, sino que tiene carácter de "no", de la negación" ${ }^{330}$. Se considera a la culpa (deuda), el ser culpable (ser deudor) como un modo originario del ser ahí, no como algo que adquiera el Dasein en razón de alguna deuda de carácter económico, ni por algún tipo de falta de carácter moral o jurídico, sino que es un modo esencial de ser del Dasein que está determinado por un no, dice Heidegger, que "sin embargo, la idea de "culpable" lleva consigo el carácter de no. Si la "culpabilidad" ha de poder determinar la existencia, se hace ineludible el problema ontológico de aclarar existencialmente el carácter - de - no de este no" ${ }^{\$ 31}$.

El pensador de la Selva Negra plantea en la analítica existenciaria una peculiar comprensión de este ser culpable, al que es inherente ese no, esa nihilidad que le es propia, ese no que está enraizado en su ser. De modo, que esta determinación que muestra la

\footnotetext{
${ }^{429}$ Cf. ST, p. 300. Rivera.

${ }^{430}$ Berciano, M., Superación de la metafisica en Martin Heidegger, op. cit., p. 74.

${ }^{431}$ ST, p. 302. Rivera.
} 
Schuldigsein, va más allá de su comprensión como un simple haber contraído una deuda o de un haberse hecho deudor, más allá de un plano jurídico o económico, se lleva este ser culpable a un plano ontológico anterior a cualquier otra determinación, puesto que, es la que posibilita que alguien pueda hacerse deudor, que pueda contraer una deuda. Definido existenciariamente: "ser fundamento de un ser que está determinado por un no-es decir, ser fundamento de una nihilidad (...) ser - culpable no es el resultado de haberse hecho culpable, sino al revés: éste solo es posible "sobre la base" de un originario ser culpable ${ }^{\prime 432}$.

Frente a esta determinación del ser culpable, es importante para Heidegger, preguntarse si en el Dasein se muestra algo así como un ser culpable del modo recién caracterizado, cómo es existenciariamente posible en términos generales ese ser culpable. Esto se resuelve reconduciendo el análisis una vez más a la estructura del cuidado, ya que:

abarca la facticidad (la condición de arrojado), la existencia (la proyección) y la caída. Siendo, es el "ser ahí" arrojado, no puesto por sí mismo en su "ahí". Siendo, es determinado como "poder ser" que es inherente a sí mismo y sin embargo no se ha dado como él mismo por peculiar. Existiendo no retrocede más allá de su condición de arrojado, de manera que pudiera en cada caso despedir expresa y exclusivamente de su "ser sí mismo" y transferir al "ahí" semejante "que es y ha de ser"433.

Es decir, en esta misma estructura del cuidado, en la constitución del Dasein se muestra esta negatividad, este no, que le revela su esencial ser culpable, pero no en un sentido corriente, en el que el Dasein se haya hecho culpable, sino que se piensa en un plano ontológico; cómo puede ser que alguien se sienta culpable, como un ente que es menesteroso, que es deficiencia, es nihilidad en su esencia. Su propio ser con un no en su constitución más radical. Esto lo resume Pöggeler como sigue: "El estar no es capaz de hacerse cargo de su ser; sus posibilidades tienen su origen en una imposibilidad última. Al tomar sobre sí su estado de yecto, el estar en cuanto tal tiene que ser un fundamento cuyos cimientos no ha echado él mismo, dado que tiene que estar ya siempre, más bien, entregado a ese fundamento" 434 . Ser culpable originariamente es sentirme yo deficiente, yo soy el fundamento de una deficiencia que se alberga en mi ser, algo en mi ser como culpable. Al ser fundamento vivo mi ser propio como deficiencia, una especie de manquedad ontológica. Y esa deficiencia, esa nihilidad que hay en mi ser, es lo que se despierta en la culpa, que no es otra cosa que culpa por ser el fundamento de un no ser.

No se es culpable por una culpa contraída o concreta, sino que se es esencialmente culpable, el Dasein no es culpable por una acción o culpa determinada. Este Schuldigsein como fundamento del Dasein da cuenta de un ente que en su ser alberga un no y este es parte de su esencia, como fundamento de un ser determinado por el no ser, "Por serle

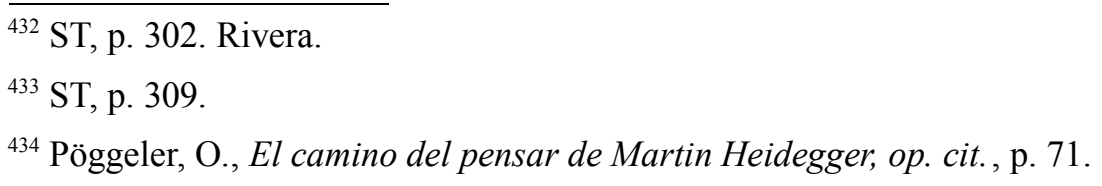


esencial el estado de "posibilidad", el hombre está siempre en "deuda" consigo mismo, está a "falta de", "no es dueño" de su propio ser. Su "sí mismo" al ser siempre un "poder ser" es un no ser "sí mismo". El Dasein, en su más propio ser es siempre deudor; esto es lo que constituye ante todo su condición de "arrojado" (estado de yecto)" $\$ 335$. Es por este ser culpable esencial al hombre que se origina la culpa originaria y esencial, que alude a ese no de nuestro propio ser. En consecuencia, cualquier consideración de la culpa, en términos morales, teológicos, es secundaria y derivada de esta constitución esencial del Dasein. El ser culpable es un elemento constitutivo de este ser que llamamos cuidado.

En esta interpretación de la culpa desaparece esa connotación moral que siempre había caracterizado a este fenómeno y que se entendía como uno de sus rasgos fundamentales. Ahora, por el contrario, se la concibe en su riqueza ontológica y en su carácter original. Estamos en un plano de la meditación puramente ontológico, despojado de la siempre cuestionable carga valórica que se asigna a los conceptos fundamentales, lo que es secundario si pretendemos captar el fenómeno en su vertiente originaria, Heidegger dice al respecto: "El ente cuyo ser es el cuidado no solo puede cargar con una culpa de hecho (faktischer Schuld), sino que es culpable en el fondo de su ser (ist im Grunde seines Seins schuldig) y este ser-culpable (Schuldigsein) constituye la condición ontológica para que el Dasein pueda llegar a ser culpable en su existir fáctico(Dasein faktisch existierend schuldig werden kann)" ${ }^{\$ 36}$. Por lo tanto, cualquier forma de concebir el ser culpable, ya sea de forma jurídica, moral, teológica, se sustenta en la constitución ontológica del Dasein como ser culpable, no como una culpa adquirida fácticamente, sino como una culpabilidad constitutiva de su ser. Esta no es una conciencia que enjuicia sobre lo bueno o lo malo, ni menos aún que dicta normas de conducta o comportamiento ideales, "en la voz de la conciencia se nos anuncia una culpabilidad originaria del Dasein que no es posterior a ningún acto culpable, sino que, antes bien, constituye el fundamento y la base de la posibilidad de cualquier culpa individual" ${ }^{\prime 37}$. Lo que obtenemos desde este horizonte conceptual es que logra ir al fundamento mismo de los fenómenos, gracias a lo cual pueden mostrarse en su constitución originaria de sentido, alejada de encubrimientos, como el que se supera gracias al análisis de la culpa originaria, como fundamento de cualquier tipo de culpa individual o fáctica, que solo pueden ser tal, en razón de esa culpabilidad originaria que constituye al Dasein de modo inequívoco, incluso, como dice Heidegger: "el originario ser culpable no puede determinarse por la moralidad, porque ésta lo presupone ya para sí misma"

\footnotetext{
${ }^{435}$ Olasagasti, M., Introducción a Heidegger, op. cit., p. 40.

${ }^{436}$ ST, p. 305. Rivera.

${ }^{437}$ Vattimo, G., Introducción a Heidegger, op. cit., p. 53.

${ }^{438}$ ST, p. 305. Rivera.
} 
Debemos entender este análisis heideggeriano, como un esfuerzo por ir al origen, al fundamento mismo de los fenómenos, en el cual podamos encontrar su sentido primigenio, que muchas veces permanece oculto por las desfiguraciones y ocultamientos propios de la tradición metafísica. En esta analítica los conceptos clásicos se llenan de un nuevo significado y de un sentido que hasta ese momento les eran desconocidos. Según Heidegger, estos fenómenos habían permanecido en una oscuridad conceptual y no habían sido tematizados originariamente.

También es necesario entender, que esta interpretación de la culpa,- "no "acentúa" ninguna forma "sombría" de considerar al "estar". Mas bien pertenece al intento de lograr una fundamentación última del pensar en la que este se "pone de antemano" a la nada delante de sí y, en ella, al ser entendido como "fundamento" de sí mismo" "439. Se muestra aquella condición originaria del Dasein, según la cual, no me puedo hacer cargo de lo fundante, de ese no ser fundamento de sí mismo, es un no ser que cruza toda la estructura unitaria de este ente que es cuidado. Ese no que constituye su ser, que hace presente su estar arrojado como su sí mismo, pero no por sí mismo. Es un ente despedido del fundamento, tiene que asumirse a sí mismo, su ser le es dado, es puesto en su ahí no por sí mismo, sino como un ente que no es fundamento de sí mismo.

La proyección de este ente está atravesada de punta a cabo por un no, por una limitación en sus posibles, se le revela de esta manera su esencial condición de arrojado, en otros términos: ““'Siendo fundamento", es decir, existiendo como arrojado, queda constantemente el "ser ahí" a la zaga de sus posibilidades. El "ser ahí" no es nunca existente antes de su fundamento, sino en cada caso partiendo de él y en cuanto es él. "Ser fundamento" quiere decir, según esto, no ser dueño nunca y "desde el fundamento", del más peculiar ser" ${ }^{440}$, así entendido, el Dasein no puede ir nunca más allá de sus posibilidades, no puede retroceder mas allá de su condición de arrojado. Con esto, Heidegger destaca la dualidad constitutiva del Dasein, que por una parte no es fundamento de sí mismo, por su ser ya en; pero por otra, tiene que tomar esa carga, esa responsabilidad sobre sí mismo, en cuanto es comprensión proyectándose, pre-ser-se, existencia. Se hace cargo de sus posibilidades, existe, incluso se hace cargo de aquella posibilidad que deviene en imposibilidad, este no, esta nihilidad esencial al Dasein es al mismo tiempo el sustento del libre abrir posibilidades.

El Dasein por un lado es fundamento de sí mismo en cuanto toma sobre sí ese esencial ser ya en, su condición de arrojado, toma sobre sí ese no en su ser mismo, que"es existiendo, el fundamento de su "poder ser". Aunque él mismo no ha puesto el fundamento, descansa sobre su peso, que le hace patente como una carga el estado de ánimo" ${ }^{441}$. En otras palabras, fundamento y no fundamento, pero no como resultado de una

\footnotetext{
${ }^{439}$ Pöggeler, O., El camino del pensar de Martin Heidegger, op. cit., p. 72.

${ }^{440}$ ST, p. 309.

${ }^{441}$ ST, p. 309.
} 
sucesión de acontecimientos o actos, que en unas ocasiones lo lleve a ser fundamento y en otras no, sino que ontológicamente constituyen al Dasein al mismo tiempo y en el mismo sentido, se pertenecen, son parte de una dualidad que los supone a ambos. Esta nihilidad que le es peculiar al Dasein, este no, el no ser fundamento no es un carácter o una propiedad del Dasein que se le haga manifiesta ocasionalmente al modo de una oscura cualidad de la cual pueda desprenderse o apartar de sí en un futuro, al lograr un progreso o un avance suficiente en la obtención de un supuesto ser ideal o de una existencia perfecta.

La esencia del Dasein como cuidado es ser culpable, está en su esencia este no, esta deficiencia cruza toda su estructura, al momento de tomar esta tarea, de empuñarla, hay algo ya hecho. El Dasein está puesto en su ahí no por fundamento de él mismo, sino que arrojado en la apertura; son posibilidades circunscritas a mí ser arrojado, que le hace patente su determinación. "El estar no solo es nulo general debido a su estado de yecto, sino que lo es en su proyecto concreto, en la medida en que éste mismo es una elección; cabe elegir una cosa, pero otra tiene que ser abandonada" ${ }^{42}$. El Dasein como posibilidad, como proyectarse sobre sus posibles, está enraizado en una última imposibilidad, ese no que alberga en su ser; como aquella determinación última, propia de su estar arrojado. El Dasein es en su esencia ser culpable, es aquello que lo constituye primariamente en su condición de arrojado.

Aquello que atestigua en nosotros esta posibilidad del Dasein de asumir la propiedad de su existencia y que puede iluminar esta radical posibilidad que es un oír propiamente lo que la conciencia voca en nosotros, es la voz de la conciencia, por la que es vocado el Dasein a ser su más propio sí mismo, a asumir la propiedad como su más peculiar modalidad de ser, y a empuñarla como tal.

Esta posibilidad se hace patente gracias al encontrarse fundamental de la angustia, que singulariza al Dasein y que desde la inhospitalidad de la cotidianeidad, del uno, le manifiesta su posibilidad más propia de ser fuera de encubrimientos, es decir, lejos del estado de interpretado, de la tiranía del uno. Dice Heidegger:

la vocación es vocación del cuidado (Der Ruf ist Ruf der Sorge). El "ser deudor (el ser culpable) constituye ese ser que llamamos cuidado (Das Schuldigsein kostituiert das Sein, das wir Sorge nennen). En la inhospitalidad coincide el "ser ahí" originalmente consigo mismo. La inhospitalidad pone a este ente ante su desenmascarado "no ser" (Nichtigkeit), que es inherente a la posibilidad de su más peculiar "poder ser". En la medida en que al "ser ahí"-en cuanto cuidado-le va su ser, se voca desde la inhospitalidad a sí mismo (ruft es aus der Unheimlichkeit sich selbst), como "uno mismo" fácticamente caído, que se vuelva hacia su "poder ser"

En consecuencia, la inhospitalidad gracias a la singularización que le es propia, le abre la posibilidad al Dasein de rescatarse de la interpretación de la opinión pública, que a fin de

\footnotetext{
$\overline{442}$ Pöggeler, O., El camino del pensar de Martin Heidegger, op. cit., p. 72.

${ }^{443}$ ST, p. 312.
} 
cuentas es una interpretación de todos y a la vez de nadie. Solo saliendo de este estado de interpretado se le puede manifestar su posibilidad más propia de ser, lo que es posible gracias a la voz de la conciencia. Se oye esta voz silente de la conciencia cuando el Dasein toma a cargo su primordial ser culpable, que lo voca a ser su ahí en el modo propio.

\section{F. EL QUERER TENER CONCIENCIA Y EL ESTADO DE RESUELTO}

Lo que la conciencia hace es dar testimonio del modo de ser de la propiedad, esta voz lo voca silenciosamente hacia su posibilidad más original. Cuando atiende esa llamada a su más peculiar poder ser, se hace cargo de su ser culpable, de su origen a partir de una nihilidad, -“el hombre oye la voz de la conciencia cuando se comprende a sí mismo en su más peculiar "poder ser" o, lo que es lo mismo, cuando se acepta como deudor; ello implica querer tener conciencia" ${ }^{444}$. Al atender este llamado silente de la conciencia, se abre la posibilidad de un oír originario a aquello que voca en nosotros, que es un llamado a ser en la propiedad de la existencia, por eso dice el filósofo de la Selva Negra, que:

el justo oír la invocación (Anrufs) resulta entonces lo mismo que un comprenderse sobre el más peculiar poder ser (Sichverstehen in seinem eigensten Seinkönnen), es decir, que un proyectarse sobre el más peculiar "poder hacerse deudor" propio" (poder llegar a ser culpable) (Sichenwerfen auf das eigenste eigentliche Schuldigwerdenkönnen) (...)Comprendiendo la vocación, el ser-ahí oye a su más peculiar posibilidad de existencia (rufverstehend hörig seiner eigensten Existenzmöglichkeit): Se ha elegido a sí mismo $^{445}$.

Cuando el Dasein comprende de modo propio la vocación, se comprende en un querer tener conciencia (Gewissen haben-wollen); que implica un elegirse y hacerse cargo de esa peculiar posibilidad, de esa limitación que le es propia, esto, por medio de un proyectarse sobre la posibilidad fáctica y peculiar de cada caso, de su poder ser en el mundo de modo propio. Lo que en esa comprensión, en ese proyectarse se abre, es fundamental, ya que en ello hay un peculiar estado de abierto del ser ahí, que muestra lo que se perseguía en un comienzo: la posibilidad de la verdad de la existencia.

El querer tener conciencia es una modalidad del estado de abierto del Dasein, en la cual se hace comprensible la concreta atestiguación del poder ser más propio del Dasein, de la posibilidad de su propiedad existencial. Y más que eso, el querer tener conciencia es el más original y peculiar supuesto existencial de la posibilidad de un fáctico y concreto hacerse culpable (Schuldigwerdens). La conciencia se manifiesta principalmente como un testimonio propio del Dasein, como una atestiguación peculiar y originaria de él y en él, que viene desde él pero más allá de él. Este ente es llamado ante su más propio y peculiar poder ser.

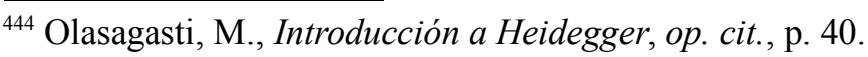

${ }^{445}$ ST, p. 313.
} 
Heidegger gracias a esta interpretación existenciaria de la conciencia, abre el acceso a una comprensión existencial más original que el alcanzado hasta ahora, no obstante, no se debe dejar de lado la constitución óntica de este ente, principalmente, porque esta investigación no se puede permitir que los fenómenos ontológicos tan precisamente determinados corten su vinculación o se alejen de la experiencia concreta, de la experiencia óntica. La posibilidad de la elección existenciaria del Dasein de su poder ser propio, que caracteriza y nos revela el querer tener conciencia, lleva directamente hacia un concepto fundamental de la construcción heideggeriana, el estado de resuelto.

La conciencia ha atestiguado a través del querer tener conciencia un estado de abierto que como tal está constituido por el encontrarse fundamental de la angustia, el comprensivo proyectarse sobre el más peculiar ser culpable y el habla en el modo del silencio: "este señalado "estado de abierto" propio, atestiguado en el "ser-ahí" mismo por su conciencia- el silencioso proyectarse, dispuesto a la angustia, sobre el más peculiar "ser deudor"" 446 . Este estado de abierto propio es el estado de resuelto, en el que el Dasein puede ser propiamente, y esto es atestiguado por la conciencia. El estado de resuelto que por su esencia es en cada caso, un Dasein fácticamente existente, solo viene a darse como resolución (Entschluss), de modo que se proyecta comprensivamente descubriendo la posibilidad fáctica del caso, de forma que la abre como un poder ser fáctico.

El estado de resuelto (Entschlossenheit) es el acto de tomar sobre sí, de forma silenciosa y desde la inhospitalidad que abre la angustia, la propia culpa esencial al Dasein, en el estado de resuelto subyace la estructura existenciaria de la escucha auténtica de la vocación de la conciencia. En el estado de resuelto le va al Dasein la posibilidad de ser su más propio poder ser. Es el modo originario y fundamental de la aperturidad del Dasein. Nos dice Heidegger, que con el estado de resuelto se ha alcanzado la verdad, que como propia, es la verdad más originaria del Dasein. El fundamento en que descansa dicha proposición, tiene que ver con que: "La existencia resuelta está cierta de la verdad de su resolución solo en cuanto que arranca de esta verdad de la no-verdad del "se" sin olvidar el carácter situacional de esta verdad. A la existencia no le está permitido aferrarse a la verdad de una determinada situación, sino que tiene que estar presta a retractación posible o a la repetición resuelta" ${ }^{447}$, en consecuencia, el estado de resuelto no queda ajeno a la existencia, sino que abre lo posible fácticamente y posibilita al Dasein a salir del estado de interpretado, de la dictadura del uno. Este oír la voz de la conciencia es un comprender el llamado silencioso a recuperarse de la caída, rescatarse de la impropiedad, para poder ganarse en la propiedad.

\footnotetext{
${ }^{446}$ ST, p. 323.

${ }^{447}$ Pöggeler, O., El camino del pensar de Martin Heidegger, op. cit., p. 73.
} 


\section{Capítulo VII: La temporalidad originaria como sentido del ser del Dasein}

Hemos llegado a una instancia clave en la investigación emprendida por Heidegger en Ser y tiempo, directamente relacionada con nuestro trabajo, es la posible conexión de los fenómenos analizados y su sentido ontológico, es la conexión entre el cuidado y la temporalidad. Aparece ahora de forma concreta en el horizonte de la investigación heideggeriana el problema de la temporalidad propiamente dicho, decimos de forma concreta, por que si bien ha resplandecido en cada momento su peculiar conexión con los fenómenos fundamentales constitutivos del Dasein, esto solo se ha manifestado de forma apenas perceptible. Dicho de otra manera, Heidegger no ha expuesto con suficiente claridad y precisión, la esencial conexión ontológica entre el cuidado y la temporalidad, ni tampoco ha planteado rigurosamente la problemática ontológica del advenir, cuestión que solo ha relampagueado en las estructuras analizadas anteriormente. Pero a partir de ahora, comienzan a adquirir su específica caracterización temporal los fenómenos fundamentales de la estructura del cuidado, abriéndose a una comprensión originaria y esencial de su sentido.

A inicios del \& 61 de Ser y tiempo, Heidegger lleva a cabo una sintética revisión de lo conseguido hasta el momento, pero en lo fundamental reclama para su investigación la determinación y esclarecimiento fenoménico de la posible unidad o conexión de los fenómenos de la muerte y la culpa, pero recordando, que esta conexión no puede sercomo nada en la analítica heideggeriana- realizada u obtenida de forma artificial o desde fenómenos externos al Dasein, ni menos aún puede realizarse de manera forzada, tiene que revelarse como una conexión fenoménica esencial que sea intrínseca a ellos. Es precisamente aquí, donde se plantean una serie de interrogantes, que más que ser interrogantes, son las claves que guían la investigación en adelante.

\section{A. EL PRECURSOR ESTADO DE RESUELTO COMO LA POSIBILIDAD ORIGINARIA DE LA PROPIEDAD DEL DASEIN}

Heidegger se pregunta si es posible relacionar los fenómenos del adelantarse hasta la muerte y el estado de resuelto y de ser así, de qué modo se puede llevar a cabo dicha conexión, poniendo al mismo tiempo en duda, la posible validez de la conexión buscada. Se pregunta el pensador alemán:

¿no nos remitirá el "estado de resuelto", en la tendencia misma existencial y más peculiar de su ser, al "estado de resuelto" precursando como a su más peculiar posibilidad propia? (...) ¿Si el "estado de resuelto", como verdad propia del "ser ahí", solo en el adelantarse hacia la muerte alcanzase la certidumbre propia perteneciente a él? ¿Si solo en el adelantarse hacia la muerte fuese toda fáctica "provisionalidad" del resolverse comprendida propiamente, es decir, alcanzada existencialmente? ${ }^{448}$.

${ }^{448}$ ST, p. 329. 
Estas interrogantes abren el horizonte de la meditación en lo que viene. El ser culpable se determinó como un ser afectado por un no, por una nihilidad, un no en su fundamento, de modo tal que la existencia está constituida sobre el fundamento de un no ser. En el estado de resuelto el Dasein carga sobre sí existencialmente ese no y lo comprende como constante. En un primer momento se determina la conexión entre el adelantarse y el estado de resuelto, de la siguiente forma:

El "estado de resuelto" llega a ser propiamente aquello que puede ser como comprensor "ser relativamente al fin" (als verstehendes Sein zum Ende), es decir, como un adelantarse hasta la muerte (als Vorlaufen in den Tod). El "estado de resuelto" no tiene simplemente una conexión con el adelantarse como algo distinto de él mismo. Alberga en sí el "ser relativamente a la muerte" propio como la posible modalidad existencial de su peculiar propiedad ( Sie birgt das eigentliche Sein zum Tode als die mögliche existenzielle Modalität ihrer eigenen Eigentlichkeit) ${ }^{449}$.

Por ahora, esto es solamente una definición existenciaria, a la que se debe dotar de un sustento fenoménico, en el que se haga existencialmente visible y comprobable esta conexión.

En el estado de resuelto se asume propiamente el más peculiar ser culpable, el Dasein se proyecta sobre este ser culpable como su posibilidad más original, comprendiéndolo como constante (ständiges). El estado de resuelto solo comprende el poder ser culpable propiamente cuando se comprende como finito, como un ser relativamente a la muerte. El estado de resuelto se constituye plenamente como tal, en el momento en el que el Dasein asume su esencial finitud, en un adelantarse hacia la posibilidad extrema de la muerte, posibilidad atestiguada por su poder ser total y propio que le muestra esta como su suprema posibilidad. La muerte no puede ser entendida como algo que viene desde fuera y le cierra al Dasein sus posibilidades. Este ente en su ser, en cuanto arrojado en la posibilidad propia, en la posibilidad de la imposibilidad de la existencia, posee ese carácter ontológico fundamental, en razón de su constitución como cuidado.

El "no ser" que domina total y originalmente el ser del "ser ahí" se le desemboza a éste mismo en el "ser relativamente a la muerte" propio (eigentlichen Sein zum Tode). El adelantarse hace patente el "ser deudor" únicamente emergiendo del "fundamento" del ser total del "ser ahí". El cuidado alberga en sí con igual originalidad la muerte y la deuda (Die Sorge birgt Tod und Schuld gleichursprünglich in sich). El "estado de resuelto" "precursando" es lo único que comprende el "poder ser deudor" propia y totalmente, es decir, originalmente" (Die vorlaufende Entschlossenheit versteht erst das Schuldigseinkönnen eigentlich und ganz, das heißt ursprünglich $)^{450}$.

El adelantarse (Vorlaufen) es un fenómeno que está en la constitución misma del estado de resuelto, es parte fundamental de él y no es un añadido u otro elemento que se le agrega desde algo ajeno a él, sino que se alberga (birgt) en su constitución esencial como la

\footnotetext{
${ }^{449}$ ST, p. 332.

${ }^{450}$ ST, p. 333.
} 
posible modalidad existencial, fáctica, de su peculiar propiedad. El estado de resuelto en cuanto deja a la posibilidad desplegarse como tal, la adelanta y al mismo tiempo la deja aparecer como posibilidad exclusiva de dejar en libertad un original y esencial ser relativamente al más peculiar poder ser. Es en esta modalidad de ser del Dasein, en la que resuelto carga propiamente sobre su existencia ese no, esa nihilidad presente en su fundamento como parte constitutiva de su ser-en-el-mundo, lo que nos revela de forma indiscutible que el Dasein está ineludiblemente afectado en su fundamento por un no ser, está constituido en su ser por una nihilidad esencial.

Este precursor estado de resuelto es en el cual se puede comprender el poder ser sí mismo propio en su totalidad y en su posibilidad más peculiar, toda vez, que "ahora con el "estado de resuelto" se ha obtenido la verdad más original del "ser ahí", por ser la propia" ${ }^{451}$. Este fenómeno es el que logra que se instale en la conciencia el poder ser culpable como lo más propio de él, como su posibilidad más peculiar. Pero, es imprescindible tener en cuenta que la verdad más original abre la situación concreta, fáctica del caso y se pone en ella, puede mantenerse en ella.

La muerte y la conciencia son los fenómenos fundamentales que conducen al Dasein a su singularización y aislamiento más absoluto, gracias al cual se pone a sí mismo ante sí mismo, ante la posibilidad de ser en la propiedad como lo más peculiar a él. La voz de la conciencia pone al Dasein frente a su posibilidad última y le exige hacerse cargo de esta radical posibilidad, sin fugas, sin encubrimientos, como un imperativo de su sí mismo de ser en el modo de la propiedad. De esta manera esa voz silenciosa:

\footnotetext{
sin indulgencia alguna, singulariza al ser ahí en su "poder ser deudor", exigiéndole serlo propiamente. El infrangible rigor de la esencial singularización en el más peculiar "poder ser" abre el adelantarse hacia la muerte como posibilidad irreferente (erschließt das Vorlaufen zum Tode als der unbezüglichen Möglichkeit). El "estado de resuelto" "precursando" permite que se imponga totalmente en la conciencia el "poder ser deudor" como más peculiar e irreferente (Schuldigseinkönnen als eigenstes unbezügliches) ${ }^{452}$.
}

La voz silenciosa de la conciencia lo voca, exigiéndole salir de aquel estado de interpretado en el que por lo pronto siempre se encuentra, he ahí el fundamento de la tensión constante entre propiedad e impropiedad en la que se instala el Dasein en cuanto poder ser. Tensión de la cual el hombre nunca se puede sustraer del todo, ya que su existencia consiste en ser aquella tensión que le es inherente, que nunca podrá superar absolutamente: la irremediable tensión entre la propiedad e impropiedad como posibilidades de su ser.

En el precursor estado de resuelto se alcanza la radical posibilidad de ser en el modo de la propiedad, ese estado de abierto propio que se atestigua en la existencia, en un adelantarse como su más peculiar poder ser. Cuestión que acontece si la existencia se

\footnotetext{
${ }^{451}$ ST, p. 323.

${ }^{452}$ ST, p. 334.
} 
comprende propiamente como resolución, como posibilidad de la autenticidad en el estado de resuelto fácticamente existiendo, se da cuenta de esta posibilidad de la propiedad si el Dasein adelanta la posibilidad en cuanto resuelto, es decir fácticamente existiendo. Hemos de entender que el fenómeno del poder ser total buscado es una cuestión fáctica, propiamente existencial, no se determina en un ámbito puramente ontológico existenciario, el Dasein solo la responde en cuanto resuelto, en el acto de resolución:

la cura (cuidado) es, en su carácter de propio, resolución precursante. En cuanto serse ya de antemano en el mundo, la cura es un ser adviniente que precursa a la muerte, pero es de esta manera como vuelve en sí, tomando resueltamente sobre sí la "culpa" de ser ya en el mundo. En el precursar resuelto a la muerte, vuelve a partir de su advenimiento, el estar a su carácter de sido, de suerte que es de propio lo que en cada caso ya era. Solo teniendo carácter de sido adviniente es el estar presencia, pudiendo hacer presente lo que le sale al encuentro en la situación ${ }^{453}$.

Heidegger muestra una posible modalidad del Dasein en la que se puede esbozar la estructura de su poder ser total y propio, la posibilidad de su propiedad, ahora este ente se revela originalmente en su constitución ontológica. La muerte y la conciencia emergen como aquellos fenómenos fundamentales del Dasein, que lo llevan a una radical singularización y aislamiento, en que se pone a sí mismo ante sí mismo, alcanzando así la singularización de la existencia. Como señala Pöggeler: "los rasgos de irrebasable, cierta y sin embargo indeterminada, que aparecieron -junto con el de irreferente -como característicos de la muerte precursada se confirma en la modalización del estado de resuelto, en el querer tener conciencia. Si no se diera tal confirmación, el proyecto del precursar la muerte o ser hacia la muerte propio se mantendría solo en una posibilidad ontológica, incluso como una posibilidad ficticia"454. En consecuencia, este adelantarse hacia aquello que es posibilidad cierta, irrebasable, inminente, pero posibilidad, es lo que permite una comprensión esencial de las posibilidades más peculiares y propias del Dasein.

Comprensión propia que atiende el llamado de la conciencia, la oye propiamente y de esta forma puede dejar ser libre a la muerte para ser aquello que se ha encubierto en las interpretaciones anteriores; aquello que queda obscurecido por la opinión pública, por la cotidianidad. El filósofo nacido en Messkirch muestra así la posibilidad de conexión entre la muerte y la conciencia, del adelantarse y del estado de resuelto, en tanto: "la posible modalización de este último por aquél ha dado por resultado el mostrar fenoménicamente un "poder ser total" propio del ser ahí. Si en éste fenómeno se tiene un modo de ser del "ser ahí" en que éste se pone a sí mismo ante sí mismo, es forzoso que permanezca óntica y ontológicamente incomprensible para la interpretación cotidiana y comprensiva del "ser ahí" que hace el uno"455, por lo tanto, la posible modalización existencial inherente al

\footnotetext{
${ }^{453}$ Pöggeler, O., El camino del pensar de Martin Heidegger, op. cit., p. 73.

${ }^{454}$ Peñalver, P., Del espiritu al tiempo, op. cit., p. 187.

${ }^{455}$ ST, p. 337.
} 
precursor estado de resuelto, sitúa al Dasein lejos de fugas y encubrimientos, lo lleva lejos de la interpretación de la opinión pública, del uno. Por el contrario, lo enfrenta a su condición primera, a su constitución más radical, la que en último término nunca puede esquivar del todo, nunca puede huir de su esencial finitud. Este situarse a sí mismo ante sí mismo, le permanece constantemente incomprensible al uno, a la interpretación de la cotidianidad, para la cual es algo completamente desconocido.

Se abre la posibilidad para comprender la muerte como lo que ella es, la más radical y peculiar posibilidad del Dasein, cuestión fundamental para la comprensión propia de la existencia, solo así se nos revela esta posibilidad con todo su peso ontológico y con la radicalidad que le pertenece, como un fenómeno que define de forma esencial al Dasein.

En esta analítica se entiende el precursor estado de resuelto, como aquella posibilidad originaria de la propiedad del Dasein; la posibilidad de ser su sí mismo. Es menester tener en cuenta, que este fenómeno, como sostiene Heidegger, esto "no es ninguna salida inventada para "superar" la muerte, sino el comprender que sigue a la vocación de la conciencia y que da a la muerte la posibilidad de hacerse potencia dominante de la existencia del "ser-ahí ( das dem Tod die Möglichkeit freigibt, der Existenz des Daseins mächtig zu werden)" ${ }^{356}$, y esto fuera de cualquier encubrimiento o huída frente a esta posibilidad, inquietante, estremecedora, pero la más propia del hombre. Posibilidad que el Dasein propio enfrenta a cara descubierta, no encubriéndola en el uno. Gracias al precursor estado de resuelto es posible comprender las fácticas posibilidades de la existencia.

Paso a paso se ha ido desentrañando la estructura del Dasein en toda su complejidad y originalidad. Al hablar de un poder ser total y propio, o de la propiedad del Dasein, Heidegger ha evitado de forma sistemática que la exposición de la existencia propia sea considerada como el resultado final de algo así como un manual de conducta que tenga por objetivo la determinación de una supuesta idea del ser, dotada de un carácter universal, menos aún ha sido su intención obtener una determinación de algo así como un ideal de hombre. Esta investigación es puramente ontológica, por lo cual sería completamente equívoco conferirle a lo aquí planteado un significado moral, ético o teológico. Precisamente, aquello era lo que el filósofo de la Selva Negra quería evitar a toda costa, que se malinterpretara su obra, que se la confundiera con un manifiesto de carácter ético. Aquello que se quiere esclarecer, son los modos en que el Dasein es en el mundo, cómo es este ente en su ser, se trata de mostrar la posibilidad ontológica de un modo propio de la existencia.

Pero también, no es menos cierto, que a pesar de que todas sus indicaciones y sugerencias a este respecto, y que tal como dice Rodríguez:

${ }^{456}$ ST, p. 337. 
todo su lenguaje está dirigido a evitar una lectura moral de la contraposición existencia auténtica- existencia inauténtica, no resulta fácil seguirle en este propósito. No solo un trasfondo ético, sino la idea religiosa, pero secularizada del pecado original acude de forma ineludible a la mente. Tras la lectura de las páginas de Ser y tiempo sobre la muerte y la finitud, resulta imposible no dar razón a Levinas cuando consideraba este libro "un discurso sobre la ausencia de Dios ${ }^{\$ 457}$.

Esta última interpretación, con la que si bien no concordamos del todo, es un ejemplo concreto, que la obra de Heidegger, por su riqueza y profundidad conceptual puede ser entendida desde múltiples perspectivas interpretativas, sin que agote la multiplicidad de posibilidades exegéticas, que le son propias exclusivamente a las obras de la envergadura y de la originalidad del escrito que analizamos en esta fase de nuestra investigación

Heidegger ha llegado a un punto crucial en el continuo de la tarea emprendida, la determinación de la posibilidad de un modo de ser total y propio de la existencia: el precursor estado de resuelto, que en última instancia es asumir la finitud propiamente, un adelantarse en el sentido de querer tener conciencia. En el dominio del uno se enmascara, se encubre el sí mismo (Selbsheit) más peculiar, se le oculta al Dasein la posibilidad de la propiedad de la existencia. Un ser que no es substancia, ni cosa, ni alma, ni espíritu, sino que es ex sistencia, aquello es lo que define más radical y originalmente a este ente.

En este planteamiento presentado por Heidegger en Ser y tiempo, se evidencia un giro radical en la aplicación de los conceptos propios de la tradición filosófica, este giro se traduce en que se aparta aquella mirada ontológicamente equívoca y errónea que define al hombre como cosa, como algo ante los ojos. Ésta es precisamente una de las desfiguraciones fundamentales de la conceptualización propia de la tradición, que pretende ser superarada en este pensamiento, aquella substancialización del hombre y del ser en la tradición metafísica. Hay que ir más allá en profundidad, en originalidad, para desencubrir aquello que ha quedado oculto en la relación sujeto objeto, en la metafísica de la subjetividad, aquello que oculta el pensar representativo, en cuyos análisis predomina la concepción de ser como substancia, según el cual, la relación sujeto objeto es la determinación exclusiva para nombrar la relación del hombre y el mundo, perspectivas interpretativas que solo permiten encubrir la constitución propia del Dasein.

Para Heidegger el estudio de la temporalidad es una cuestión verdaderamente fundamental, si es posible dar cuenta originariamente de ella, se podrá acceder entre otras cosas, a la esencia del Dasein. Una interpretación de dichas características, ha de ser capaz de superar aquellas concepciones derivadas y desfiguradas de la temporalidad; que son las que en último término encubren la esencia del Dasein. Siguiendo este camino que abre la analítica existenciaria, será posible llegar a una comprensión del Dasein, que sea a la vez, original y esencial.

${ }^{457}$ Rodríguez, R.,Heidegger y la crisis de la época moderna, op. cit., p. 108. 
La temporalidad (Zeitlichkeit), es el fenómeno más original y esencial en el cual se sustenta toda la estructura del cuidado, cimenta su unidad y multiplicidad. Cuando preguntamos por la temporalidad originaria, preguntamos por el sentido del cuidado en la propiedad. Si el Dasein comprende el sentido de su ser puede ser en la propiedad, puede ser su sí mismo.

Lo que Heidegger hace es preguntar por la posibilidad ontológica y original en la que el Dasein se vuelve esencial, la que hace posible el precursor estado de resuelto, en la que este ente se hace cargo, responsable, de su posibilidad más original; la muerte. Hemos de recordar que cuando se habla de responsabilidad no se da a esta palabra una connotación ético-moral, sino que expresa en toda su magnitud la sentencia pindárica que como bien dice Heidegger recuerda primero Nietzsche, y luego él en Ser y Tiempo; sé el que eres. Este imperativo es el que el autor tiene en cuenta cuando menciona esa responsabilidad de ser sí mismo, en la propiedad de su ser, responsabilidad para aquello a lo que somos entregados. El uno frente a este imperativo, se comporta de manera esquiva y rehuye dicha carga absorbiéndose en la cotidianidad.

En su esencia el ser del Dasein se reveló como cuidado; estructura unitaria indisoluble de la existencia, la facticidad y caída. Como bien sabemos, esta estructura no es un amontonamiento de partes, realizado de forma superficial o forzado, sino que dicha articulación se consigue gracias a la unidad original y esencial propia de los fenómenos, unidad y acoplamiento intrínseco a los mismos fenómenos.

Ahora, lo más apremiante para Heidegger es determinar aquel fenómeno que articula dicha estructura, que le da sentido a esa unidad articulada que es el cuidado, se pregunta, ¿cuál es el sustento último de la unidad del cuidado?, se interroga por la condición de posibilidad en la que se fundamenta la unidad estructural del cuidado; aquello que posibilita al Dasein a ser en la aperturidad, y que al mismo tiempo posibilita todas las formas de ser.

La pregunta por el sentido (Sinn), por el horizonte en el que se fundamenta la unidad última del cuidado, se dirige hacia aquello que abre posibilidades; por aquel horizonte de comprensión de cualquier ente determinado, y en especial el horizonte de comprensión del Dasein. "Comprender el sentido de algo es entender lo que lo hace posible, que no supone un entidad distinta o ajena a la cosa, sino la misma cosa en cuanto enteramente comprendida. En nuestro caso el sentido de ser del Dasein quiere decir entender lo que hace posible en su estructura interna el "cuidado" (Sorge) tal como se muestra en la existencia auténtica"458. El sentido es concebido como aquello en lo que se sustenta la comprensibilidad de algo. Heidegger pregunta por aquello que permite comprender de forma auténtica la existencia. Hemos de ir un paso atrás, retroceder hasta aquello que abre posibilidades. Es el momento de dirigir la mirada hacia esa condición

${ }^{458}$ Ibíd., p. 122. 
originaria de sentido que es el fondo sobre el cual se realiza el proyecto primario de la comprensión del ser. Por lo tanto, "Mostrar el sentido del cuidado significa indicar el "hacia dónde" del cuidado, que es, por ahora, el que sirve de base y sintetiza las estructuras del Dasein, preguntar por el sentido del cuidado significa, pues, preguntar por el cuidado y por el ser de la totalidad de las estructuras del Dasein" ${ }^{459}$. Comprendemos siempre en un determinado proyectar, es solamente en un proyecto donde puede aparecer algo como algo, sino lo hay proyecto hay sentido; sin proyecto que le de sentido no se puede comprender lo que está a nuestro alrededor y menos aún comprender originariamente la esencia del Dasein. El proyecto primario de la comprensión del ser es el que $d a$, dona el sentido. Este proyectar es el que genera el sentido.

\section{B. El Sentido temporal del precursor estado de Resuelto. El ser del Dasein como} ESENCIALMENTE ADVENIDERO

El sentido del Dasein que existiendo es él mismo y que se comprende en sus posibilidades más esenciales, atiende a aquello que le es donado por el ser como lo más propio y auténtico de él. Se caracterizó su poder ser total y propio en su sentido más original y radical como ese Dasein que se comprende a sí mismo, a su posibilidad más peculiar y la toma sobre sus hombros en su existencia fáctica, en su ser posible. "Lo proyectado en la proyección existenciaria original de la existencia se desembozó como precursor estado de resuelto. ¿Qué es lo que hace posible este "ser total y propio" del "ser ahí" en la unidad de su todo estructural con miembros?"460. Esta es la pregunta que conduce la investigación de Heidegger en lo que viene, la determinación de aquel fenómeno en que se sustenta el todo de las estructuras de la existencia, de la unidad del cuidado. Aquello que hace posible que el Dasein pueda ser un ente al que le va su ser. Pero para llegar a ello, antes debemos detenernos de forma obligada, en el precursor estado de resuelto, que aparece como el fenómeno fundamental de la determinación de una posibilidad existenciaria del ser total y propio del Dasein, es necesario determinar qué nos dice este fenómeno y a qué nos remite.

En el desarrollo de la investigación, Heidegger ha determinado esta posibilidad de la propiedad del Dasein, proyectada en la proyección originaria de la existencia, de tal forma, que: "el ser ahí se vuelve "esencial" en la existencia propia, que tiene la constitución del "precursor estado de resuelto"461, que es un adelantarse hacia la posibilidad extrema que es la muerte; es el asumir radical de este poder ser, de esta posibilidad que es la imposibilidad de toda otra posibilidad.

\footnotetext{
${ }^{459}$ Berciano, M., Superación de la metafisica en Martin Heidegger, op. cit., p. 75.

${ }^{460}$ ST, p. 352

${ }^{461}$ ST, p. 351.
} 
Heidegger determina como cuestión fundamental en su analítica del Dasein en el modo de la propiedad, la importancia radical de la aperturidad primera de la existencia hacia lo que adviene. Esto, en términos de que:

La "decisión anticipadora"-el ser humano en su forma de autenticidad- tiene sentido temporal. El ser-hacia-la-muerte, incluso en su forma inauténtica, es un ser futuro. "La "anticipación" de la "decisión anticipadora" presupone un ser humano que "es" futuro; el hombre solo puede anticipar la muerte si constitutivamente se precede a sí mismo, esto es, si en su ser mismo es futuro (Zukunftig) ${ }^{462}$.

En efecto, en la analítica heideggeriana comienza a emerger de forma precisa y clara el sentido temporal de este fenómeno del precursor estado de resuelto, y se presenta en todo su peso ontológico, como la esencial asunción de la finitud, a la que le es inherente de modo esencial un carácter temporal, gracias al cual puede constituirse como tal. En primera instancia, el precursor estado de resuelto es una apertura a un radical por-venir; advenir de esa posibilidad, la más propia y auténtica, mientras el Dasein existe la posibilidad más peculiar no se realiza nunca, sino que se mantiene siempre como un posible. El precursor estado de resuelto abre a las posibilidades como tales, en su calidad de puras posibilidades de ser.

Este precursor estado de resuelto, es un adelantarse hacia aquella posibilidad más propia, y lo que primero que Heidegger quiere resaltar es su sentido temporal, por eso dice: "Adelantándose, el Dasein se libra de quedar rezagado tras de sí mismo y del poderser ya comprendido, y de hacerse "demasiado viejo para su victoria" (Nietzsche). Libre para las posibilidades más propias, determinadas desde el fin, es decir, comprendidas como finitas $" 463$. Este adelantarse resuelto es ir hacia algo que está por-venir, que adviene. Esto solo puede ser de tal forma si un ente es en esencia futuridad, en tanto está constituido como existencia es un proyecto abierto hacia su más radical posibilidad que es la muerte. Asumir esto es la condición de posibilidad del poder ser total y propio, en la que el Dasein pueda advenir a sí originariamente.

La muerte es la posibilidad que siempre se mantiene como tal para el Dasein, no es nunca para el Dasein realización, jamás es experimentada por él como algo simplemente dado o real, cuando ella se hace realidad el Dasein ya no es más en el mundo, lo que nombra su carácter de posibilidad suprema. La muerte mientras el Dasein existe se mantiene como posibilidad irrebasable de principio a fin. "La muerte posibilita las posibilidades, las hace aparecer verdaderamente como tales y así las pone en posesión del Dasein, que no se aferra a ninguna de ellas de manera definitiva, sino que las inserta en el contexto siempre abierto del proyecto propio de la existencia" ${ }^{" 464}$. En consecuencia, si pensáramos a la muerte como una posibilidad más entre otras muchas, que cuando se

\footnotetext{
${ }^{462}$ Olasagasti, M., Introducción a Heidegger, op. cit., p. 40.

${ }^{463}$ ST, p. 283. Rivera.

${ }^{464}$ Vattimo, G., Introducción a Heidegger, op. cit., p. 51.
} 
realiza se llega a la totalidad del Dasein, es decir, como una posibilidad que se suma a otras y en su cumplimiento se alcanza la totalidad del Dasein, pensaríamos siguiendo los cánones de la conceptualidad de la tradición metafísica, de la cual Heidegger precisamente se quiere distanciar: pensar al hombre como substancia, como ente ante los ojos, como simple presencia. Si entendiera la totalidad del Dasein de esta forma, ello significaría que este ente se completa o realiza plenamente cuando se completan en él todos sus modos de ser, que se van conjuntando uno a uno en sus modos posibles de ser real, agregándose de modo constante uno con otro, de forma que con el agregado de la muerte, que es su último modo de ser real, se alcanza su plenitud o totalidad. Pero Heidegger entiende al Dasein como proyecto, como posibilidad abierta, que siempre se mantiene en su apertura como tal, es decir, se mantiene como posibilidad. Por lo tanto, no estamos pensando al Dasein como algo meramente presente o ante los ojos, sino que fundamentalmente como exsistencia.

El camino abierto en Ser y tiempo, es una meditación gracias a la cual la finitud inherente al Dasein se nos muestra como potencia dominante de la existencia, como lo más propio del hombre. En la comprensión de esta finitud, se abre el acceso a una comprensión de la verdad de la existencia, que solo puede ser tal, si el Dasein en su constitución esencial puede advenir a sí en su posibilidad más peculiar. Un rasgo fundamental en esta analítica es que interpreta la muerte como la posibilidad más propia de la existencia, que como tal, se mantiene siempre como posibilidad mientras el Dasein existe. Gracias a este pensamiento, se reconoce la radical importancia de la posibilidad de la muerte en el todo de la estructura del Dasein, adjudicándole a ella un papel absolutamente determinante, decisivo para la totalidad y propiedad del Dasein, comprendiéndola en su carácter originario de posibilidad, posibilidad que lejos de cerrar al Dasein, lo abre a sus posibilidades más peculiares.

Este advenir es lo primero que aparece en la exposición heideggeriana de la temporalidad. La posibilidad de la imposibilidad, la muerte, constituye las demás posibilidades y en cuanto tales las posibilita. La muerte es lo que hace que las demás posibilidades se entiendan como puras posibilidades, si no hay muerte no hay posibilidades, la muerte es mi constante posible, que lejos de cerrar al Dasein lo abre en su modo más propio y auténtico. La comprensión de esto nos ayuda a entender ese carácter esencial del Dasein como pura posibilidad, el estar abierto originalmente a lo que adviene, y nunca ser al modo de la simple presencia o realidad, sino ser lo que aún no es, su ser no es real al modo de un ente ante los ojos. Se puede decir, que el "Dasein no es aún su propio ser. El Dasein es algo que tiene que llegar a ser, es un poder ser (Seinkönnen). Ahora bien, el Dasein puede ser así (poder-ser) si tiene que llegar a ser sí mismo; y esto significa ser futuro en su ser más fundamental”465, de este modo, la ontología realista

\footnotetext{
${ }^{465}$ Berciano, M., "Temporalidad y ontología en el círculo de Ser y tiempo", en Themata: Revista de filosofía, $\mathrm{n}^{\circ}$ 7, Sevilla, 1990, p.23.
} 
queda puesta en entredicho, gracias a la perspectiva interpretativa que Heidegger propone, y que resume en una tesis fundamental de Ser y tiempo: "Más alta que la realidad está la posibilidad (Hörer als die Wirklichkeit steht die Möglichkeit)"466.

El precursor estado de resuelto, que es un asumir y adelantarse hacia la posibilidad más propia y más peculiar de la muerte, como el advenir desde sí de esta posibilidad:

solo es posible si el "ser-ahí", en general, puede "advenir" a sí en su posibilidad más peculiar y en este "poder advenir a sí" (Sich-auf-sich-zukommenlassen) mantiene la posibilidad como posibilidad, es decir, existe. El poder advenir a sí (auf Sich Zukommenlassen) en la señalada posibilidad, manteniéndola, es el fenómeno original del "ad-venir" (ursprüngliche Phänomen der Zukunft $)^{467}$.

Esta determinación del ser de este ente como advenidero es el primer carácter del Dasein que Heidegger trata, tanto en el orden de la exposición de la temporalidad originaria, como también en relación a su importancia. La esencia del Dasein como temporalidad, alude a un ente al que le va su ser mismo, es un ser abierto a sus posibles, un ente que es pura aperturidad y posibilidad, esencialmente la posibilidad de asumir su propia finitud. Por esto dice Gadamer:

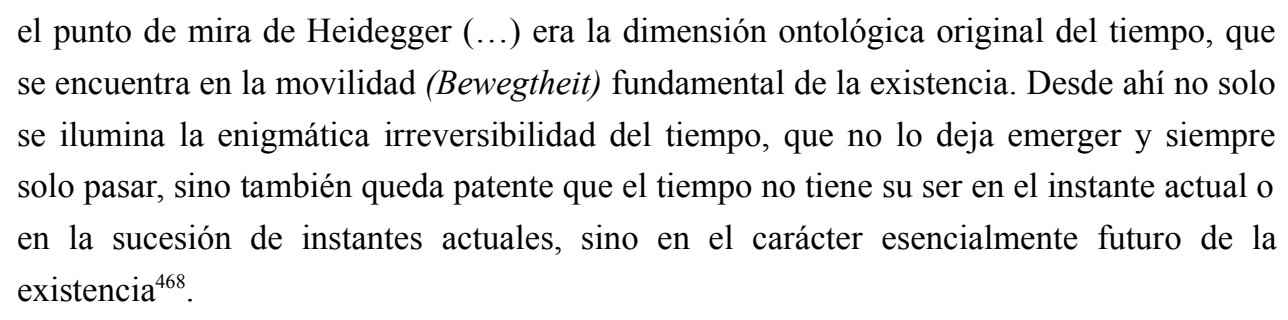

Comprendiendo su ser como advenidero, el Dasein puede asumir su ser total y propio, soy mi seré, yo soy eso que seré. En esa radical constitución de ser lo que seré, lo primero que se nos hace patente, es la constitución de un ser que es primariamente advenidero. Pero, este "“'advenir" no mienta aquí un ahora que aún no se ha vuelto "real", pero que llegará a ser, un buen día, sino el venir en que el "ser ahí" adviene a sí en su más peculiar "poder ser" ${ }^{\prime 69}$. En consecuencia, cuando se habla de advenir o de futuro, se tiene en cuenta este sentido, por lo tanto, no se trata de un ente que tiene la forma de ser de un aún no pero luego más adelante sí, sino de un ser que está a cada momento siendo su futuro, su posibilidad más propia, es un ser que siendo adviene siempre a sí. Esta posibilidad que en tanto se mantiene como tal, nombra el fenómeno original del advenir (Zukunft), de lo porvenir, del futuro. Empero, este: "futuro no es, pues, primordialmente una porción de tiempo que aún no ha llegado, sino el movimiento de futurición propio de la existencia. Solo hay un futuro para un ser que es futurición, apertura a sus propias posibilidades"470.

\footnotetext{
${ }^{466}$ ST, p. 49.

${ }^{467}$ ST, p. 353.

${ }^{468}$ Gadamer, H., "La teología de Marburgo" en Los caminos de Heidegger, op. cit., p. 44.

${ }^{469}$ ST, p. 353.

${ }^{470}$ Rodríguez, R., Hermenéutica y subjetividad. Ensayos sobre Heidegger, op. cit., p. 37.
} 
El Dasein en la propiedad o impropiedad es siempre futuro en su ser, siempre adviene a sí esencialmente desde el porvenir. Gracias a esta constitución que le es propia, es posible algo así como el precursor estado de resuelto, en virtud del cual el Dasein se hace propiamente advenidero, y solo puede ser propiamente advenidero si es advenidero en su ser mismo.

Al mismo tiempo, en el precursor estado de resuelto el Dasein asume también de manera propia su ser culpable, asume su radical nihilidad, ya que, en este adelantarse, toma sobre sí la responsabilidad de su más propio ser culpable. Comprende como lo más propio de él su condición de arrojado, su facticidad; asume en plenitud su ser como ya era, su ser como sido (Gewesenheit), un ser pasado: su ser como ya-en una circunstancia, situado, determinado de forma concreta por su facticidad esencial:

En cuanto anticipación de la muerte, la decisión posibilita auténticas posibilidades, no se
petrifica en ninguna realización particular alcanzada: tiene un porvenir, un futuro. Por otra
parte la decisión anticipante de la muerte es una salida del estado de inautenticidad. Pero
ese estado es reconocido como tal solo en la decisión, abriéndose al futuro propio, asume
(reconociéndola por primera vez) su propia culpabilidad, en la cual de encuentra ya
sumida desde siempre y de la cual debe salir. El ser lanzado como ser culpable es el
pasado del Dasein" ${ }^{971}$.

Podemos reconocer que solo en este advenir que comprensivamente se vuelve hacia su más peculiar sido, es posible adelantarse hacia la posibilidad más peculiar. Heidegger dice:

Propiamente advenidero (Eigentlich zukünftig), es el "ser ahí" propiamente sido (eigentlich gewesen). El adelantarse hasta la posibilidad extrema y más peculiar es el comprensivo retrovenir (verstehende Zurückkommen) al más peculiar sido. El "ser-ahí" solo puede ser sido propiamente en tanto es advenidero (eigentlich gewesen sein, sofern es zukünftig ist). El sido surge en cierto modo del advenir (Die Gewesenheit entspringt in gewisser Weise der Zukunft) $)^{472}$.

De esta manera, es cómo se ensamblan los elementos de esta unidad originaria, se pertenecen uno a otro, no como partes separables que se van agregando en un proceso, sino una unidad esencial, según la cual: "el pasado, que no es ya el conjunto de acontecimientos anteriores a un ahora, no es que perviva en el presente y conforme el futuro, es que es parte esencial de ellos. En primer lugar, porque las posibilidades que en cada instante son mis posibilidades son en función de mi haber ya sido y siempre voy a partir de ellas; $y$, en segundo lugar, porque la vuelta desde las posibilidades es un retorno a lo que ya soy" ${ }^{473}$. El (haber) sido en cierta manera surge del advenir, en tanto, que el adelantarse le hace presente de forma clara al Dasein su esencial ser culpable, lo abre así a su esencial propiedad como su posibilidad más propia.

\footnotetext{
${ }^{471}$ Vattimo, G., Introducción a Heidegger, op. cit., p. 54.

${ }^{472}$ ST, p. 353.

${ }^{473}$ Rodríguez, R., Hermenéutica y subjetividad. Ensayos sobre Heidegger, op. cit., p. 38.
} 
Este sido emerge y solo puede ser sido desde el advenir. Es desde el advenir siendo sido desde donde surge el presente. Siempre el Dasein existe siendo sido inmediata y regularmente sumergido en las cosas, caído, frente de lo a la mano, como dice Rivera: "El punto de encuentro de aquel futuro y de este pasado del Dasein es el presente, lo que apremia mientras estamos entre los entes. Con estos entes en medio de los cuales se encuentra el Dasein tiene que proyectar su futuro: es esencialmente presente" ${ }^{\text {474 }}$. Hemos de recordar, que si bien en este trabajo se apuesta por la primacía del advenir en la estructura de la temporalidad, al mismo tiempo se deja establecido con claridad el rasgo de cooriginariedad de los fenómenos. Por lo tanto, al presente le pertenece una determinación originaria igual que al pasado y al futuro, lo que nos señala, que solo como presente puede el Dasein recuperarse de la impropiedad, gracias al precursor estado de resuelto, que le permite y le posibilita a comprenderse propiamente.

\section{TEMPoralidad ORIGINARIA, LA UNIDAD DEL ADVENIR, PRESENTE Y HABER SidO. LA ESTRUCTURA DEL CUIDADO A LA LUZ DE LA TEMPORALIDAD ORIGINARIA}

Ahora podemos apreciar con mayor claridad, como comienzan a adquirir un peculiar contenido ontológico los fenómenos, lo que hace posible penetrar en ellos y descubrirlos en su más originaria determinación de sentido, que es la propiamente temporal. Les pertenece un peculiar sentido temporal que desvela una relación esencial, intrínseca entre los fenómenos constitutivos del Dasein, y que se articulan en virtud de la temporalidad, pero dicha unidad no se entiende como un amontonamiento de partes separables que se ensamblan una tras otra.

El sido surge del advenir (Gewesenheit entspringt der Zukunft), pero de tal suerte que el advenir sido (gewesene Zukunft) (mejor que va siendo sido) emite de sí el presente (Gegenwart). A este fenómeno unitario de esta forma, como "advenir presentando que va siendo sido" (gewesend-gegenwärtigende Zukunft), lo llamamos la "temporalidad" (Zeitlichkeit). Solo en tanto el "ser ahí" es determinado como temporalidad, se hace posible a sí mismo el caracterizado "poder ser total y propio" del "precursor estado de resuelto" (Ganzseinkönnen der vorlaufenden Entschlossenheit). La temporalidad se desemboza como el sentido del cuidado propio (Sinn der eigentlichen Sorge) ${ }^{475}$.

Así pues, lo primero que debemos comentar respecto a esto, es que en la concepción de la temporalidad originaria presentada por Heidegger en Ser y tiempo, es concebida como un fenómeno que se constituye fundamentalmente como unidad indisoluble, significa entonces, que al nombrar uno de los fenómenos se alude al todo de la unidad articulada, que se despliega a una con la totalidad de sus elementos, este fenómeno original y unitario es la temporalidad originaria.

\footnotetext{
$\overline{474}$ Rivera, J., Heidegger y Zubiri, op. cit., p. 43.

${ }^{475}$ ST, p. 354.
} 
Si comprendemos la esencia del Dasein como temporalidad, podemos entender su articulación unitaria, en virtud de la cual se hace posible para el Dasein el precursor estado de resuelto, que se traduce en la posibilidad existencial de un ser total y propio, en la que este ente pueda ser en la autenticidad, en la propiedad de su existencia y de su ser. Posibilidad en la que el Dasein pueda ser plenamente en su verdad más original.

En una primera instancia, habíamos delineado los elementos constitutivos del Dasein, sus existenciarios fundamentales: el comprender, el encontrarse y la caída. Fenómenos fundamentales que constituyen la unidad de la estructura del cuidado. Si bien en principio, el sentido temporal de la estructura del cuidado no había sido determinada de forma explícita, permanecía latente su determinación temporal. Heidegger precisa de esta forma, que la estructura unitaria de la Sorge no es la más originaria, sino que la unidad esencial de la estructura radica en la temporalidad. Toda vez, que "solo un Dasein temporal y futuro, en sentido indicado, puede tener la estructura del cuidado, con todas las estructuras derivadas que ésta sintetiza y fundamenta" ${ }^{\text {476 }}$. La existencia, la facticidad y la caída van adquiriendo su plena caracterización ontológica, es decir, empieza a reverberar en dichos fenómenos, aquella dimensión temporal que les pertenece y constituye indefectiblemente, que no se había mostrado con la suficiente claridad, y de alguna manera permanecía encubierto en el análisis del cuidado en la impropiedad.

Con miras a profundizar en el fenómeno de la temporalidad originaria, Heidegger considera apropiado volver una vez más sobre aquella estructura unitaria del cuidado, que ha definido como: pre-ser-se-ya-en (un mundo) como ser cabe (entes que hacen frente dentro del mundo) (Sich-vorweg-schon-sein-in-(der-Welt) als Sein-bei (innerweltlich begegnendem Seienden). La analítica se detiene en esta definición del cuidado, para destacar el componente temporal de cada fenómeno, para de esta forma, ir al fundamento mismo de los fenómenos, a su condición originaria de sentido, que solo puede ser tal, en tanto son fenómenos esencialmente temporales. En relación a esto, el filósofo alemán hace la siguiente puntualización:

El "pre" y el "preserse" indican el advenir (vor und vorweg zeigt die Zukunft), en el sentido de aquello que pura y simplemente hace posible que el "ser ahí" sea de tal suerte que le vaya su "poder ser" (daß es ihm um sein Seinkönnen geht). El proyectarse "por mor de sí mismo" que se funda en el advenir (in der Zukunft gründende), es una nota esencial de la existenciariedad. El sentido primario de ésta es el advenir ("Umwillem seiner selbst" ist ein Wesencharakter der Existenzialität. Ihr primärer Sinn ist die Zukunft) ${ }^{\$ 477}$.

Esta explicitación del significado temporal del pre-ser-se del cuidado, hace referencia primariamente al advenir, en el sentido de aquello que abre posibilidades, que hace que el Dasein sea un poder ser, que sea un ente al que le va su ser mismo. En esta caracterización, el pre-ser-se obtiene su peculiar carácter temporal, que lo constituye en

\footnotetext{
$\overline{476}$ Berciano, M.,"Temporalidad y ontología en el círculo de Ser y tiempo”, op. cit., p. 23.

${ }^{477}$ ST, p. 355.
} 
condición de posibilidad de las posibilidades; condición que es el advenir en cuanto abre sus posibles al Dasein, lo abre a la posibilidad de su poder ser más propio. Tal como comenta Rivera: "Existir, estar siendo, es salir hacia fuera, hacia ese fuera que es el propio sí mismo en tanto que venidero"478. El sentido originario de la existenciariedad proviene del advenir, desde el cual el Dasein puede ser su auténtico poder ser, existe. Es gracias a ese advenir, que el Dasein alcanza su sentido temporal esencial, puede ser su más propia posibilidad de ser, de ahí que le vaya en su ser su ser mismo, como un ente que es esencialmente posibilidad abierta.

Por otra parte, el ya-en implica el carácter de sido, se refiere a la condición de arrojado inherente al Dasein. Un ente que en tanto exista siempre será ya en, arrojado a determinadas circunstancias, su existencia siempre será situada, concretada en su facticidad. Esto lo explica Olasagasti de la siguiente forma: "ya significa "sido", en cuanto que el ser humano está "arrojado"; mientras existe fácticamente el hombre no es pasado, pero en todo momento es "sido": "yo soy sido" y solo puede ser "sido" mientras es; el sentido primario de la facticidad reside en el "sido" ${ }^{479}$. Mientras el Dasein existe nunca es pasado, sino que es siempre sido, él no pasa como algo ahí delante ante los ojos que ya quedó atrás y que ya no está más al modo de una cosa o de una substancia, que es precisamente lo que Heidegger quiere superar. Fundamental es la recuperación en el análisis de la temporalidad de esta dimensión que también quedaba oscurecida en las anteriores interpretaciones, hablamos del sido, del pasado (Gewesen). Pero no en términos del simple pasado (Vergangenheit). "Solo porque el cuidado se funda en el sido puede el "ser ahí" existir como el ente arrojado que él es. "Mientras" el "ser ahí" existe fácticamente, no es nunca pasado, pero sí que es siempre ya sido, en el sentido de yo soy sido. Y solo puede ser sido mientras es. Pasado llamamos, por el contrario, al ente que ya no es "ante los ojos" 480 . El haber sido lo debemos entender como un pasado que no pasa simplemente y queda atrás inerte, inmóvil. Por el contrario, es un pasado que podemos decir es dinámico, por eso decimos que es un pasado que sigue pasando. Este ya-en nombra primariamente el encontrarse siempre ya dispuesto, de una u otra manera, señala su carácter esencial como condición de arrojado; que muestra su ser mismo como siendo lo que ya era, un ser que en su constitución esencial es sido, siendo sido. El sentido originario del encontrarse, de la condición de arrojado, de la facticidad, reside en el sido, desde donde adquiere su fundamento temporal primigenio

Sin embargo, parece que Heidegger le da un trato distinto al tercer elemento, la caída, este elemento constitutivo como ser cabe (Sein bei), que hace alusión al Dasein en cuanto está inmediatamente sumergido, caído en medio de los entes. Este elemento obtiene su determinación desde el presente, pero solo en cuanto es parte de la

\footnotetext{
${ }^{478}$ Rivera, J., Heidegger y Zubiri, op. cit., p. 17.

${ }^{479}$ Olasagasti, M., Introducción a Heidegger, op. cit., p. 41.

${ }^{480}$ ST, p. 355.
} 
temporalidad originaria, a una con el advenir y el sido, pero de tal forma, que en el precursor estado de resuelto el Dasein se puede recuperar de la caída gracias al instante (Augenblick) $^{481}$, en el que el Dasein es propiamente en la situación abierta. Heidegger sintetiza esto diciendo, que "El tercer ingrediente de la preocupación (cura) -el-ser-juntoa, la "caída", das verfallende Sein-bei- tiene sentido de presente"482. El fundamento existenciario de la caída reside en el presente, solo desde el presente puede el Dasein en el estado de resuelto recuperarse de la caída en el instante de la situación abierta. En cuanto resulta incluido en "esta constante fusión de pasado y futuro se hace presente nuestra situación, los asuntos o cosas de nuestra circunstancia, lo que llamamos nuestro presente, que no es un momento puntual de un discurrir infinito, sino un instante (Augenblick), la concreción o fusión, en el trato con el mundo, de las posibilidades de lo que ya somos" ${ }^{\$ 483}$. La temporalidad emerge como aquel fenómeno, que en último término hace posible esta articulación unitaria del cuidado, su unidad solo es posible por el original fenómeno de la temporalidad. En esta estructura se nos hacen presentes esos tres existenciarios fundamentales de dicha articulación unitaria:

La temporalidad se temporacía en cada éxtasis totalmente (Die Zeitlichkeit zeitigt sich in jeder Ekstase ganz), es decir, en la unidad extática de la plena temporación de la temporalidad en cada caso se funda la totalidad del todo estructural integrado por la existencia, la facticidad y la caída esto es, la unidad de la estructura del cuidado (Zeitigung der Zeitlichkeit gründet die Ganzheit des Strukturganzen von Existenz, Faktizität und Verfallen, das ist die Einheit der Sorgestruktur $)^{484}$.

Se descubre la esencia del ser ahí, su original unidad estructural, que solo es tal desde el fenómeno de la temporalidad; desde donde se hacen posibles todos los fenómenos. Heidegger nos lleva hacia un nivel de profundidad desconocido que nos revela la esencia del hombre como temporalidad. El Dasein como un ser esencialmente temporal, histórico. Se ha desentrañando la esencia del Dasein como temporalidad. Como dice Álvarez Gómez:

Visto así, el fenómeno es sin duda unitario, pues el futuro deja de ser algo lejano al ser
visto como dimensión que adviene, en virtud de la resolución de ser ahí de tomar
decisiones, que sin duda recaen en el futuro, que automáticamente pasa, sin embargo, a
constituirse en ad-venir o por-venir, que a su vez solo puede tener consistencia, en cuanto
que presencializa las posibilidades, latentes que han sido. Dicho tal vez de la forma más

${ }^{481}$ Augenblick: este concepto es traducido por Gaos como "la mirada". Dice Rivera: "La palabra alemana Augenblick significa una mirada que, como un rayo, ilumina y abarca de golpe toda una situación esa mirada es la forma propia del presente. No se trata de que esa mirada tenga lugar en un presente, porque esto significaría entender el tiempo en forma inadecuada y derivada. El instante es, él mismo el tiempo presente, en cuanto abarca todo aquello en medio de lo cual el Dasein se encuentra proyectando su futuro". Por lo tanto, entendemos Augenblick como "mirada" o como instante. ST, p.495. Rivera, Notas del traductor.

${ }^{482}$ Olasagasti, M., Introducción a Heidegger, op. cit., p. 41.

${ }^{483}$ Rodríguez, R., Hermenéutica y subjetividad. Ensayos sobre Heidegger, op. cit., p. 37.

${ }^{484}$ ST, p. 379. 
sencilla posible, pero sin duda no suficientemente precisa: mirando al porvenir rescatamos lo que ha sido aquella posibilidad que nos permite actuar en el presente ${ }^{485}$.

Paso a paso hemos seguido el camino trazado por el autor, camino que avanza retrocediendo, en dirección a las profundidades de los fenómenos, en que se nos hace visible la originariedad propia a ellos. Hemos llegado al punto en que nos muestra con claridad aquel fenómeno en el que reside el sentido último del cuidado, en el que se sustenta su unidad original. Se muestra la esencia del cuidado, del Dasein, como temporalidad. Su ser resplandece como temporalidad. "El Dasein, en conclusión es temporal: adviene (su ser) presentando (posibilidades) a través de las cuales va siendo sido" ${ }^{486}$.

En la investigación heideggeriana se ha mostrado en sus distintos niveles como una totalidad estructurada con plena coherencia. Ahora cada elemento propio del cuidado en la cotidianeidad adquiere su sentido temporal, sentido que había quedado tenuemente esbozado en la primera parte de nuestro trabajo. Pero, ahora resplandece la esencia de esta estructura del cuidado, que revela la constitución del Dasein como temporalidad, de manera que, tal como sostiene Heidegger: "la unidad original de la estructura del cuidado reside en la temporalidad" ${ }^{487}$, de todo esto se desprende, que es gracias a la temporalidad originaria que el cuidado adquiere su sentido último, y se completa como un todo esencial. En consecuencia, aquello que el Dasein es puede ser entendido desde la temporalidad; es esta la que hace posible esta unidad última, esta totalidad del cuidado.

Comprendiendo propiamente la temporalidad puede el Dasein ser en el precursor estado de resuelto, que abre la posibilidad de desplegar el ser total y propio. Emerge así el fenómeno de la temporalidad como la condición de posibilidad del cuidado. La temporalidad no tiene el modo de ser de un ente que esta ahí, ni se puede decir que la temporalidad es, sino que la temporalidad temporaliza distintos modos de ella misma. La temporalidad esencia de distintos modos. Consecuente con esto, el tiempo no tiene el modo de ser de otro ente, sino que el tiempo temporaliza, y este temporalizar constituye su temporalidad. La temporalidad se despliega de distintas maneras de ella misma, se modula de distintos modos; ella no es, sino que esencia, porque lo que es siempre es el ente, no la temporalidad. Por eso, dice Heidegger: "los elementos del cuidado no están simplemente amontonados, como tampoco la temporalidad misma va "con el tiempo" componiéndose de advenir, sido y presente. La temporalidad no "es" en general, un ente. No es sino que se “temporacía" (zeitigt sich)" 488 . La temporalidad entendida originariamente no es algo que transcurre en un tiempo lineal que esté constituida de sido presente y advenir, sino que

\footnotetext{
485 Álvarez, M., Teoría de la historicidad, op. cit., p. 166.

${ }^{486}$ Trias, E., "Prólogo" en Interpretaciones sobre la poesía de Hölderlin, M.Heidegger, Ariel, Barcelona, 1983, p. 18.

${ }^{487}$ ST, p. 355.

${ }^{488}$ ST, p. 356.
} 
temporacía. La temporalidad misma esencia de distintos modos, en posibles modalidades de ella misma y es el esenciar de la temporalidad lo que hace posible los distintos modos de ser del Dasein, tanto a la propiedad como a la impropiedad.

Todo ello nos indica, que "esta temporalidad esencial del Dasein repercute en su comprensión del propio ser, si el Dasein es en el modo de la propiedad asumirá su propio ser como temporal. La temporeidad constituye el ser mismo del Dasein"489. Se hace visible ahora con claridad necesaria el sentido último de esta interpretación temporal inaugurada por Heidegger. El Dasein no se define por ser una cosa, un ente que es simple presencia, sino que se define esencialmente en virtud de la temporalidad, en las formas de temporaciar la temporalidad que le son propias, es decir se define por las modalidades de ella misma, lo que significa que "la temporalidad no es un $\chi \rho \circ$ oo solo dependiente del movimiento, ni es un marco en el que suceden las cosas, sino tiempo humano. Pero tampoco ha de ser entendida como criatura del Dasein o producto del mismo" ${ }^{490}$, en este contexto podemos entender que esa temporalización de la temporalidad peculiar al Dasein tiene una fundamental importancia, ya que en ella se juega la posibilidad de la propiedad o impropiedad del Dasein, en la forma en que éste temporalice la temporalidad, en el modo que la comprenda.

La temporalidad es el radical éxtasis, el radical fuera de sí. La ex-sistencia es estar en la aperturidad, en el claro (Lichtung) del ser. El estar en la apertura es lo propio del Dasein, estar en el éxtasis; es la íntima vinculación entre hombre y ser. Es su referencia a lo que no es él, lo otro que él adviene a su presencia. El Dasein es un ser intervenido por algo que es, en definitiva, el ser mismo, un ser referido a otro, un estar fuera, un ex -. Ese fuera con respecto al cual está fuera el hombre es el ser, expuesto a él, abierto en el ser. Este estar fuera es propio de los éxtasis temporales, "la temporalidad es el original "fuera de sí" en y para sí mismo" 491 , así se identifican los distintos modos de la temporalidad; ese original fuera de sí son los éxtasis de la temporalidad, advenir, sido, presentado. El Dasein en su esencia es un estar fuera, en la aperturidad, en el claro del ser, pura ex-sistencia, una salida fuera de sí mismo. Esto lo explica Herrmann de la siguiente forma:

a cada éxtasis pertenece también ahora el que en ello, al comprender, estoy abierto saliendo de mí hacia algo. Ese hacia lo que estoy fuera de mí, en y hacia donde cada uno de los tres éxtasis en sí mismo está abierto, recibe de Heidegger la expresión terminológica de horizonte(...) el horizonte de un éxtasis es cada extensión abierta en y hacia donde ésta está fuera de sí. La temporalidad existenciaria no es caracterizada adecuadamente sino hasta que es entendida como temporalidad éxtatico-horizontal ${ }^{492}$.

\footnotetext{
${ }^{489}$ Rivera, J., Heidegger y Zubiri, op. cit., p. 43.

${ }^{490}$ Berciano, M.“Temporalidad y ontología en el círculo de Ser y tiempo”, op. cit., p. 24.

${ }^{491}$ ST, p. 356.

${ }^{492}$ Herrmann, F., “El concepto del tiempo según Heidegger”, op. cit., p.100.
} 


\section{LA PRIMACÍA DEL ADVENIR EN LA ESTRUCTURA DE LA TEMPORALIDAD ORIGINARIA}

Es importante recalcar una vez más que ésta es una articulación unitaria, los éxtasis constituyen una radical y profunda unidad, se copertenecen uno y todos, no se constituyen como un todo que en sus partes se agrega uno y luego otro, o que se da en el tiempo, primero uno, luego otro y después un tercero. Para Heidegger, "la temporación no significa un "uno tras otro" de los éxtasis. El advenir no es posterior al sido y éste no es anterior al presente. La temporalidad se temporacía como advenir presentante que va siendo sido"493. Si se comprendiera el advenir como un aún no pero luego más tarde sí, estaríamos definiendo a un ente que pasa en el tiempo. Con la interpretación de la temporalidad se ha llegado a un nivel de originalidad radical, y se ha señalado a un fenómeno, en el cual descansa la unidad del cuidado y de sus componentes, y que le da sentido a esta estructura.

La concepción de la temporalidad de Heidegger, según Trías es realizada con base a una, "privilegización del futuro, que se desvela como fundamento de la temporalidad y del ente" 494 . Como podemos ver, esta problemática se ha presentado de una forma o de otra, en cada nivel de la presente investigación, lo que nos ha llevado a considerarla como una cuestión fundamental en Ser y tiempo, y en el camino que nos lleva hasta ahí, esto es el problema ontológico del advenir, éxtasis temporal que como hemos podido ver posee una cierta prioridad o primacía en la concepción del tiempo. Heidegger le ha conferido una cierta primacía a un determinado modo temporal, que es el advenir, lo por-venir, el futuro. Prioridad que si bien se podría concluir en una primera aproximación a la analítica, se hace explícito de forma concreta cuando el filósofo determina como fenómeno primario y fundamental de la temporalidad originaria: el advenir, lo que queda principalmente expuesto a lo largo del \& 65, parágrafo de una importancia señalada, en cuanto a los resultados y a la elaboración total de la obra. Es menester señalar que esta problemática del advenir, no se presenta solamente en esta parte Ser y tiempo, sino que se ha expuesto de una forma u otra a lo largo de la investigación emprendida por Heidegger en el tratado de 1927, y como hemos visto, ha estado presente desde los primeros trabajos en los que se ha hecho cuestión del problema del tiempo.

Pero hemos de insistir una vez más, que los distintos éxtasis de la temporalidad tienen el mismo nivel de originalidad, es decir, que los momentos extáticos son igualmente originarios. Pero a juicio de Heidegger, son distintos los modos de temporalizar la temporalidad según sus éxtasis. Su multiplicidad se origina en que el temporalizarse de la temporalidad se determina de manera distinta desde cada uno de los éxtasis. Es decir, los modos de temporalizar la temporalidad serán distintos según el éxtasis desde el cual se temporalice primariamente la temporalidad del Dasein. Al llegar a este punto de nuestro

\footnotetext{
${ }^{493}$ ST, p. 379.

${ }^{494}$ Trias, E., "Prólogo” en Interpretaciones sobre la poesía de Hölderlin, op. cit., p. 19.
} 
trabajo, lo hecho hasta ahora obtiene su pleno sentido. La posibilidad del modo de la propiedad del Dasein, de la verdad de la existencia, de la posibilidad del precursor estado de resuelto, del poder ser total y propio; descansa en un primordial modo de temporalizar la temporalidad. Es lo que Heidegger como corolario explicita en esta última parte, y dice:

La temporalidad original y propia se temporacía desde el advenir propio, por modo que advenideramente sida despierta ante todo el presente. El fenómeno primario de la temporalidad original y propia es el advenir (Das primäre Phänomenon der ursprünglichen und eigentlichen Zeitlichkeit ist die Zukunft $)^{495}$.

Lo menos que podemos decir, es que Heidegger se refiere a esta primacía señalada, con una frase contundente, en cuanto a los alcances y a la importancia que posee esta problemática al interior de su constructo filosófico, además debemos tener en cuenta que aquí, habla no solo de temporalidad originaria, sino que también es la temporalidad propia.

Se ha recorrido un largo camino, presentando los fenómenos que constituyen esta unidad originaria del cuidado, para llegar al fundamento último del Dasein, el ser del Dasein como temporalidad, y precisamente, en esta interpretación de la temporalidad originaria, el fenómeno fundamental y primario es el advenir. De tal forma, que podemos sostener sin equivocarnos, que esta problemática es verdaderamente importante y adquiere cierta prioridad en la obra de Heidegger, en el todo argumental de su escrito, cruzando de punta a cabo su consistencia interpretativa. Incluso él señala que:"la primacía del advenir tomará ella misma diversas inflexiones, respondiendo a la modificada temporación de la temporalidad impropia, pero será visible incluso en el "tiempo" derivado" 496 . Con esto queda de manifiesto, que esta primacía adoptará distintas modulaciones en el todo de Ser y tiempo. Sin embargo, aquella importancia radical que tiene para el autor el futuro, la posibilidad que adviene, esencialmente la posibilidad de la muerte, son aserciones que se mantendrán como cuestión invariable en el todo de su investigación. El ser del Dasein como posibilidad, en tanto, fundamentalmente abierto a lo posible como lo constitutivo de este ente, lo define como un ser que es primariamente futuro.

El adelantarse hasta la posibilidad más peculiar en el precursor estado de resuelto, es el modo de existir en el que el Dasein es en la propiedad de su ser, asumiendo su radical posibilidad que le adviene; arrojado a la muerte, pero no al modo de un ente que se completa cuando muere, pues cuando esto pasa él ya no existe más. Dice el pensador alemán: "El "ser ahí" no tiene un fin al llegar al cual pura y simplemente cesa, sino que existe finítamente. El advenir propio que temporacía primariamente la temporalidad que constituye el sentido del precursor estado de resuelto, se desemboza con ello él mismo como finito" ${ }^{497}$. El Dasein es un ente que existe finítamente, ya que mientras es la muerte siempre es su posibilidad más peculiar y siempre se mantiene como tal, lo que hace que

\footnotetext{
${ }^{495}$ ST, p. 357.

${ }^{496}$ ST, p. 357.

${ }^{497}$ ST, p. 357.
} 
todas las demás posibilidades sean tales y así se mantengan, como puras posibilidades de ser y nunca realizaciones. "El advenir propio y original es el "a sí”, a sí, existiendo como la irrebasable posibilidad de no-ser. El carácter extático del advenir original reside justamente en que concluye el "poder ser", es decir, es concluso él mismo y en cuanto tal hace posible la comprensión existencial resuelta del "no ser". El "advenir a sí" más propio y original en el sentido de existir en el "no ser" más peculiar"

El advenir propio que despliega la temporalidad original abre al Dasein esencialmente, le abre la peculiaridad de su posibilidad más propia que es la muerte; su finitud como su suprema posibilidad, la que lo constituye radicalmente como posibilidad abierta, que nunca se cierra mientras él existe. La muerte para el Dasein nunca es una realidad porque cuando se realiza el Dasein ya no es más.

Esta primacía del advenir se hará presente también en la exposición de la temporalidad de la cotidianidad, es más, incluso se muestra en la exposición de la historicidad del Dasein y en la apertura historiográfica, de modo que podemos afirmar con seguridad, que no nos referimos a una problemática menor de Ser y tiempo o del trabajo anterior a ella, sino a una cuestión que está en la base misma de la construcción de la analítica y de su proyecto filosófico, el por qué y sus consecuencias es otra cuestión. Puede ser, que tal como dice Löwith: "el punto de partida inmediato del pensamiento prospectivo y retrospectivo de Heidegger es, sin embargo, la experiencia del hoy. El carácter decadente de nuestro tiempo es lo que orienta su pensamiento esencialmente histórico hacia el futuro y a la vez lo motiva, en tanto un pensamiento que desmantela, a descender desde la hegeliana cumbre de la metafísica occidental" ${ }^{\text {499 }}$, o, que en cuanto, "el hombre ex-siste en tanto está en camino hacia algo. Por lo tanto, el pensamiento de Heidegger no es una meditación oriental ni una contemplación griega del ser siempre idéntico, sino un estar-en-camino históricamente condicionado" $" 500$.

Por otra parte, Volpi señala que esta posición de Heidegger se fundamentaría en su crítica a la contemplación puramente teórica como modo privilegiado de conocimiento, que sería superado en este pensamiento gracias a la prioridad de la dimensión práctica, por eso dice:

el privilegio asignado a la theoría dependería de un tácito supuesto metafísico en razón del cual, desde Platón y Aristóteles en adelante, el ser ya no estaría abierto en la extensión plena y originaria del tiempo, sino re(con)ducida a la dimensión de la presencia: la metafísica considera ente en sentido propio sobre todo a lo que está presente y que lo está de manera estable, y la theoría es el comportamiento privilegiado correspondiente a tal comprensión metafísica del ser como presencia. Pero el existir humano, siendo un "tenerque-ser"(Zu-sein) y un "poder ser" (Seinkönnen), se actualiza en una dimensión

\footnotetext{
${ }^{498}$ ST, p. 357.

${ }^{499}$ Löwith, K., Heidegger, pensador de un tiempo indigente, op. cit. , p. 204.

${ }^{500}$ Ibid., p. 203.
} 
eminentemente práctica y es por esencia proyectado y expuesto hacia el futuro. En cuanto tal, no se deja captar y fijar sobre la base de categorías reificantes y constatativas, como algo que estuviera simplemente ahí delante ${ }^{501}$.

Sin embargo, Gadamer sostiene que esta tesis de Heidegger tendría su punto de partida en la lectura que filósofo alemán hace de las epístolas paulinas, según lo cual, "la experiencia del tiempo que Heidegger había encontrado en Pablo era la del retorno de Cristo, que no es un retorno que se pueda esperar, y que significa una parusía, es decir, un advenir y no una presencia" $" 502$.

Esta tesis del autor de Verdad y método iría por una linea distinta a la de Volpi, quien sostiene que la idea de la primacía del futuro por sobre el presente y la presencia habría surgido en el seno de la reapropiación de la filosofía práctica de Aristóteles que Heidegger llevó a cabo a principios de los años veinte ${ }^{503}$. Podemos ver que hay distintas interpretaciones que intentan dar cuenta de la proveniencia de esta primacía del futuro en la concepción del tiempo en Heidegger, que como hemos podido verificar tiene una importancia señalada en su filosofía, tanto en el camino a Ser y tiempo, como en el mismo tratado de 1927, en cuanto sirve de articulador de la analítica existenciaria, y que se manifiesta en la determinación del Dasein como posibilidad, como un poder ser, como un ente que es esencialmente comprensión del ser y de los entes que nos hacen frente en el mundo. Pero también esta primacía y determinación del futuro como modo temporal prioritario y fundamental del tiempo, de la temporalidad, ha servido para contraponer y revertir la idea del tiempo que subyace en la interpretación del ser que nos ha legado la filosofía griega, y que según él ha dominado sin contrapeso la historia de la metafísica tradicional, en otras palabras, este interpretación del ser como presencia, como presente, ha influenciado largamente la historia del pensamiento occidental, extendiendo su rango de penetración en amplios ámbitos de ese mismo pensamiento, como por ejemplo en la filosofía o en la teología.

\section{Capítulo VIII: Desde la temporalidad originaria al tiempo de la cotidianidad}

A juicio de Heidegger, aunque los resultados obtenidos por la analítica hasta el momento nos han iluminado las determinaciones fundamentales de la constitución del Dasein, no puede aún la investigación presumir de una absoluta comprensión de la problemática inherente a ella. Persisten en la investigación ciertos vacíos que han de ser llenados, falta profundizar aun más en la problemática que se ha expuesto, pero no solo se trata de una profundización, se presentan también nuevos horizontes de problematicidad

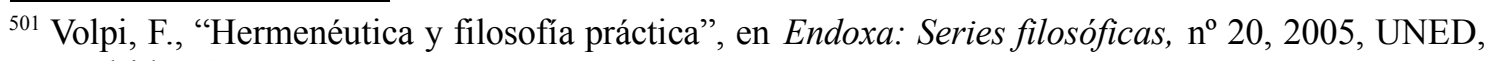
Madrid, p.270.

${ }^{502}$ Gadamer, H., "La dimensión religiosa” en Los caminos de Heidegger, op. cit., p. 158.

${ }^{503}$ Cf, Volpi, F., "Ser y tiempo: Semejanzas con la Ética Nicomaquea”, op. cit., p. 138.
} 
que hasta el momento no se habían manifestado con claridad, presentar esos problemas y su desarrollo es lo que realizaremos ahora, llevando nuestra investigación hasta las determinaciones últimas del proyecto de Heidegger, pero con el objetivo último de que nos permitan destacar cómo aparece en ellas el problema ontológico del advenir.

Una vez expuesta y desarrollada la concepción de la temporalidad originaria, Heidegger entiende como imperativo para el buen resultado y coherencia de la investigación, que esta sea realizada de forma cabal, logrando que los fenómenos obtengan su más rigurosa fundamentación. Se ha de volver sobre los fenómenos ya interpretados, pero no por medio de una simple repetición de lo ganado hasta ahora, sino a través de una revisión de lo realizado, que permita incluir en lo fenómenos toda la riqueza y profundidad de lo conseguido en el desarrollo de la investigación. De forma tal, que sea posible penetrar todavía más en los fenómenos y en las estructuras que se han expuesto, para además determinar qué problemas permanecen todavía ocultos para la analítica existenciaria.

Por lo tanto, una vez desarrollado el sentido del cuidado en la propiedad, urge el análisis de la cotidianidad en su sentido temporal. Esta exigencia metodológica Heidegger la plantea como sigue: "Hecho el análisis temporal del "poder ser total" propio del "ser ahí" y habiendo caracterizado en general la temporalidad del cuidado, es tarea inmediata hacer visible la impropiedad del "ser- ahí" en su específica temporalidad"504, es en cierta forma una repetición del análisis anterior de la temporalidad originaria pero ahora referido a la cotidianidad, aquella modalidad de la existencia en la que nos encontramos la mayor cantidad de las veces, sumidos en la impropiedad. Ahora, es la temporalidad de la cotidianidad la que será escrutada en nuestra investigación, siguiendo de cerca la analítica heideggeriana. Pero no se debe entender este proceder como un intento de realizar una investigación más acuciosa o rigurosa del ser del Dasein y nada más, por el contrario, el pensador de la Selva Negra, sostiene, que "la temporalidad debe verificarse, sin duda, en todas las estructuras esenciales de la constitución fundamental del "ser ahí" Co5 . Con lo cual se alude al carácter propio de esta investigación, que debe ser llevada hasta sus últimas consecuencias, fundamentalmente la de develar el sentido temporal de cada fenómeno de los investigados en la analítica heideggeriana.

En la investigación desplegada en Ser y tiempo, el camino nos conducía desde el cuidado en la impropiedad hasta su determinación como cuidado propio. Sin embargo, nos encontramos ahora con una forma de proceder inversa, que va desde la temporalidad originaria hasta el sentido temporal de la cotidianeidad. De manera, que en "la reiteración de los análisis anteriores tiene que desembozarse la cotidianidad en su sentido temporal, para que salgan a luz los problemas encerrados en la temporalidad y se desvanezca por

\footnotetext{
${ }^{504}$ ST, p. 359.

${ }^{505}$ ST, p. 359.
} 
completo el aparente carácter de "comprensibles de suyo" de los análisis preparatorios" Esta orientación de la analítica no es azarosa o accidental, sino que tiene principalmente un sentido metodológico, más que completar simplemente el análisis precedente, se pretende mostrar como a medida que se avanza en la investigación van apareciendo nuevos problemas. En esta marcha filosofante que Heidegger desarrolla en Ser y tiempo, en el momento en que se avanza en la develación de los fenómenos y de sus estructuras esenciales van apareciendo nuevas y complejas interrogantes propias de la estructura interna de la totalidad de la obra.

La problemática ontológica propia del advenir sigue siendo, como es de esperar, una pieza fundamental de la estructura esencial del Dasein, es aquello lo que principalmente nos interesa dejar establecido de forma precisa. Horizonte problemático, que lejos de desaparecer, sigue jugando un papel fundamental en la estructura de la analítica heideggeriana, incluso en aquellos fenómenos,-la historicidad del Dasein-, que aparentemente presuponen un cuestionamiento a la legitimidad ontológica de lo planteado por Heidegger en relación al advenir. Por lo tanto, es imposible alcanzar completamente los objetivos de nuestra investigación, sino reconocemos la forma en que se inserta dicha problemática en la totalidad de los problemas fundamentales de la obra de 1927, de no ser así, nuestro trabajo quedaría sesgado en su intención de exponer de forma acabada la importancia del advenir y el papel que juega en la unidad de la temporalidad, que se ha revelado como el sentido del ser del Dasein, cuestión que se presenta en cada uno de los momentos decisivos de Ser y tiempo.

Una de las razones que se podría aducir para validar la necesidad de la revisión del sentido temporal de la cotidianidad, sería afirmar que dicho análisis nos evita de manera absoluta las confusiones y las preguntas ontológicamente erróneas acerca del ser del yo en general. Sin embargo, para Heidegger es aún más importante y fundamental que ella, "al par proporciona, de acuerdo con su función central, una visión más original de la estructura de la temporación de la temporalidad. Esta se desemboza como la historicidad del "ser ahí". La proposición "el "ser ahí" es histórico" se revela una proposición ontológico-existenciaria fundamental" $"$. Adquiere así una relevancia peculiar el estudio del sentido temporal de la cotidianidad, que en primer lugar nos brinda una visión aún más original de la temporalización de la temporalidad, y por otra parte, nos permite, gracias a un análisis detenido de la cotidianidad en su sentido temporal, reconocer cierta complejidad inherente a los fenómenos estudiados, complejidades que se habían pasado por alto en un principio, en este caso nos referimos a la historicidad del Dasein, asunto fundamental que no se puede soslayar. Pero por ahora estas impresiones son solo algunos avances de lo que trataremos con mayor profundidad más adelante.

\footnotetext{
${ }^{506}$ ST, p. 359.

${ }^{507}$ ST, p. 360.
} 
Heidegger analiza ahora los elementos que constituyen la temporalidad, en el modo de la impropiedad, pero dicha tarea no es algo completamente nuevo, ya que, "la caracterización de la temporalidad del "estado de abierto" en general conduce a la comprensión del inmediato ser en el mundo ocupándose y con ello de la "indiferencia media" del "ser ahí" por la que empezó la analítica existenciaria" ${ }^{508}$. Con esto, Heidegger nos remite al principio de la investigación, que toma como punto de apoyo el estudio de la temporalidad en la que estamos inmediata y regularmente, es decir, en la cotidianidad.

Antes de realizar el análisis del sentido temporal de la cotidianidad, recordamos lo que se dijo en relación con la temporalidad. La temporalidad no es algo que transcurre en el tiempo, ella esencia de distintos modos, la temporalidad temporaliza posibles modalidades de ella misma y es el esenciar mismo de la temporalidad el que posibilita las modalidades de ser del Dasein, tanto la propiedad como la impropiedad. Es en el temporalizar de la temporalidad en el que se juega la posibilidad de la propiedad como de la impropiedad del Dasein. Este temporalizar de la temporalidad en su sentido cotidiano es lo que analizaremos.

\section{A. El FUtURo DE LA COTIDIANIDAD COMO ESTAR A LA EXPECTATIVA}

Al retomar al análisis de los ingredientes de la unidad que es el cuidado, Heidegger inicia la exposición partiendo de la comprensión, que tomando en cuenta los resultados obtenidos hasta el momento se presenta como uno de los existenciarios más positivamente reveladores e iluminadores de las estructuras esenciales del Dasein. Además, es aquella determinación del estado de abierto del ser ahí, la comprensión, la que funciona generalmente como hilo conductor de la analítica. Lo que queremos destacar que a ella le es propia una peculiar primacía, además de poseer una importancia señalada a lo largo de la investigación. No por casualidad, Heidegger comienza tratando el sentido temporal de la cotidianidad con la exposición de la comprensión. Sin embargo, no se pretende de ninguna manera restarle importancia a los otros existenciarios, dado que poseen el mismo grado de originalidad que la comprensión, nuestro objetivo es una vez más, destacar el papel que desempeña la comprensión en el todo de la obra, su función central en ella. Como dice Peñalver, "si ya el análisis pretemporal fijaba lo esencial de la comprensión en un proyectar una posibilidad de existencia, ahora la revelación del como futuro como condición de posibilidad ontológica del poder eleva a un nuevo nivel la comprensión de la comprensión" 509 .

No es necesario volver una vez más a exponer los caracteres fundamentales de la comprensión que se habían expuesto con anterioridad. Nos basta con recordar que:

\footnotetext{
${ }^{508}$ ST, p. 359.

${ }^{509}$ Peñalver, P., Del espíritu al tiempo, op. cit., p. 206.
} 
el comprenderse, proyectando, (entwerfenden Sichverstehen) en una posibilidad existencial tiene por base el advenir como "advenir sobre sí" (Auf-sich-zukommen) desde la posibilidad bajo la forma de la cual existe el "ser ahí" en cada caso. El advenir hace posible (Zukunft ermöglicht) ontológicamente un ente que es de tal manera que comprendiendo existe en su "poder ser" (verstehend in seinem Seinkönnen existiert) ${ }^{510}$.

Comprendiendo el Dasein es lo que puede ser, en la comprensión se juega su poder ser, él es su poder ser, su posibilidad. Pero en tanto es su posibilidad, ello no significa que conozca explícitamente esas posibilidades, ni tampoco que aprehenda de manera racional o teórica la posibilidad proyectada. De forma, que se arroja constantemente a ella en cuanto posibilidad. En la comprensión que le es propia el Dasein abre su poder-ser, le permite saber siempre de una manera u otra lo que pasa con él, y esto lo puede comprender de manera propia o impropia. En la interpretación de Peñalver, esta comprensión de la comprensión tiene una señalada importancia arquitectónica en la elaboración de la ontología fundamental, cuestión que Heidegger hará notar continuamente, si es que ella no es más que una interpretación de la comprensión del ser en la que se sostiene, y se sostiene el Dasein. Esto es perfectamente concordante con lo expuesto por Heidegger, en cuanto a que el futuro, la futuridad se constituye como el modo temporal que posibilita concretamente la comprensión, en otras palabras, es coherente y consecuente, con la tesis de Heidegger de que el futuro posee una peculiar primacía en la unidad de la temporalidad extática ${ }^{511}$. Además, teniendo presente que en la analítica heideggeriana:
como existir original y propio se manifestó el "estado de resuelto". Inmediata y regularmente (zunächst und zumeist) permanece sin duda el "ser ahí" "no resuelto" (unentschlossen), es decir, cerrado (verschlossen) en punto a su más peculiar "poder ser", al cual solo se transporta en cada caso en la singularización (Vereinzelung). Esto implica: la temporalidad no se temporacía desde el advenir propio (eigentlichen Zukunft $)^{512}$.

Considerando entonces, que no siempre la temporalidad se temporaliza de modo propio, el objetivo que Heidegger se propone es exponer el fenómeno de la temporalidad en el modo de la impropiedad. Modalidad en la que el hombre temporaliza la temporalidad inmediata y regularmente, es decir, la manera como el Dasein se muestra por regla general, inmediata y regularmente, en la medianía. Entregado a las cosas que son objeto de su ocupación, en medio de los entes, de lo a la mano. El Dasein se encuentra la mayor de las veces irresoluto, inmediata y regularmente cerrado a su ser más propio y a sus posibilidades existenciales más auténticas, que las puede ser y proyectar por medio del aislamiento, de la singularización de su ser.

Al afirmar que en ciertos modos de la temporalidad ella no se temporaliza desde el advenir, desde el futuro propio, eso no implica, que en esas circunstancias la temporalidad

\footnotetext{
${ }^{510}$ ST, p. 364.

${ }^{511}$ Cf. Peñalver, P., Del espíritu al tiempo, op. cit., p. 206.

${ }^{512}$ ST, p. 364.
} 
carezca de futuro. Que en la cotidianidad el Dasein no se temporalice desde el advenir es consecuencia de la constitución de la temporalidad originaria, ya que ella es modificable y depende exclusivamente de la modalidad de temporalizar la temporalidad en cada caso, depende de la modalidad de esenciar que le es propia en cada situación.

Para distinguir con claridad el futuro propio del impropio, Heidegger denomina al advenir propio con el término adelantarse (Vorlaufen):

esta expresión indica que el "ser ahí", existiendo propiamente, adviene (sobre sí) (Auf sich zukommen lä $(t)$, en cuanto más peculiar "poder ser", sobre sí; que el advenir tiene que ganarse primero a sí mismo, no desde un presente (Gegenwart), sino desde el advenir impropio (uneigentlichen Zukunft). El término formalmente indiferente para el advenir se halla en la denominación del primer elemento estructural del cuidado en el "preserse". El ser ahí "se prees" fáctica y constantemente, pero no constantemente en cuanto a la posibilidad existencial, "precursando"',513.

El filósofo alemán da así las primeras indicaciones que permitirán precisar la posibilidad del Dasein de ganar para sí la propiedad de su ser, y ello desde la cotidianidad en la que se encuentra sumergido. Como se ha indicado anteriormente, esa posibilidad de ser en la propiedad no la puede ganar desde el presente, desde aquello que es objeto de ocupación. Menos aún la puede obtener desde el advenir propio, lo que no significa que el Dasein en cuanto cuidado carezca de futuro en la cotidianidad. Por el contrario, el Dasein es esencialmente futuridad, incluso en la forma de temporalizar la temporalidad en la cotidianidad. El Dasein para ganarse a sí mismo, para recuperarse desde la cotidianidad tiene que hacerlo desde el futuro impropio. Por lo pronto, permanece en la oscuridad la caracterización de este futuro impropio. Sin embargo, queda claro que la única manera de lograr desvelar su sentido, de alcanzar su determinación esencial es, si desde la cotidianidad, desde la impropiedad del Dasein volvemos sobre su sentido existenciario temporal.

Inmediata y regularmente el Dasein se comprende a sí mismo y a sus posibilidades desde aquello que es objeto de su ocupación más inmediata. Esa comprensión de la medianía, es un comprender impropio, que se conduce según lo factible, lo apremiante del quehacer cotidiano. Regularmente:

el "ser ahí" no adviene sobre sí primariamente en su más peculiar e irreferente "poder ser", sino que, ocupándose de, es expectante (besorgend seiner gewärtig) de sí desde lo que da o rehúsa aquello de que se ocupa. Es desde aquello de que se ocupa desde donde adviene el "ser ahí" sobre sí (Aus dem Besorgten her kommt das Dasein auf sich zu). El advenir impropio (uneigentlich Zukunft) tiene el carácter del "estar a la expectativa"

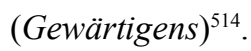

La caracterización más clara del comprender impropio se obtiene desde su proyección, desde su poder ser. Por una parte, en la comprensión propia se alcanza la determinación

\footnotetext{
${ }^{513}$ ST, p. 365.

${ }^{514}$ ST, p. 365.
} 
de sus posibles, desde su poder ser más propio y originario. Por el contrario, en el comprender impropio su proyección al futuro esta sustentada en razón de la esfera de su ocupación inmediata, desde lo pragmático, lo factible en cada caso, de lo urgente en cada momento para él, esto es caracterizado como estar a la expectativa (Gewärtigens) ${ }^{515}$.

El futuro impropio es un estar a la expectativa, de tal forma que ocupándose está expectante de sí mismo, pero no desde su posibilidad más originaria y propia, sino que está a la expectativa, de su poder ser desde el objeto que le ocupa, que le hace frente, solo por eso puede esperar algo, estarlo esperando. Es precisamente ese estar a la expectativa, el que abre cada vez el horizonte desde el cual algo determinado puede ser esperado. Heidegger expresa esto de la siguiente forma:"el esperar (Erwarten) es un modo, fundado en el estar a la expectativa (Gewärtigens), del advenir, que se temporacía propiamente como adelantarse (eigentlich zeitigt als Vorlaufen). Por eso en el adelantarse hay un "ser relativamente a la muerte" más original que en el esperarla de que se preocupa (besorgten Erwarten)" ${ }^{\prime 516}$.

Como sabemos, la temporalidad no es algo que pasa en el tiempo al modo de un ente, no es una cosa que es de una manera u otra, sino que la temporalidad temporaliza distintas modalidades de ella misma, esencia de distintas maneras, y -esto es lo fundamental- según la modalidad de ese esenciar de la temporalidad se abren las posibilidades de la propiedad e impropiedad, como modos de temporalizar la temporalidad del Dasein. El comprender impropio, en el cual el presente se determina en función de la constitución de la cotidianidad, que se comprende a sí misma desde la perspectiva de un poder ser que le adviene en virtud de las respectivas posibilidades de un éxito o de un fracaso en aquellas tareas inmediatas que la cotidianidad le impone, que son cada vez objeto de sus quehaceres. Al estar a la expectativa, al futuro impropio, le corresponde la modalidad de un estar en medio de lo que es objeto de ocupación (Besorgen); como un impropio estar a la expectativa de posibilidades pragmáticas surgidas desde el tráfago de sus ocupaciones inmediatas. Estar a la espera de posibilidades extraídas desde aquellos asuntos que diariamente, a cada momento le competen por todas partes, en el ir y venir cotidiano.

\section{B. EL PRESENTE DE LA COTIDIANIDAD}

El comprender en tanto es un poder ser, es esencial y primariamente advenidero desde el fondo de su ser, por lo que siempre se temporaliza a una con el haber sido y el presente. La caracterización de aquel presente se determinó en sus rasgos generales, pero

\footnotetext{
${ }^{515}$ Rivera traduce Gegenwärtigen como "estar a la espera", dado que ambas traducciones expresan lo mismo, las utilizaremos indistintamente en este sentido.

${ }^{516}$ ST, p. 365.
} 
cabe decir que al futuro impropio, al estar a la expectativa, le corresponde un específico estar en medio de lo que es objeto de ocupación. La modalidad de este éxtasis, el presente, se puede obtener por medio de una comparación con el fenómeno del presente de la temporalidad propia. Puesto que, como bien indica Heidegger:

\begin{abstract}
al adelantarse del "estado de resuelto" en inherente un presente conforme al cual abre una resolución la situación. En el "estado de resuelto" no solo es el presente recobrado de la disipación (Zerstreuung) en aquello de que se ocupa inmediatamente, sino que resulta mantenido en el advenir y el sido (Zukunft und Gewesenheit gehalten). El presente mantenido en la temporalidad propia o presente propio lo llamamos la mirada (eigentlichen Zeitlichkeit gehaltene, mithin eigentliche Gegenwart nennen wir den Augenblick $)^{517}$.
\end{abstract}

El sentido preciso de éxtasis se entiende como la salida fuera de sí que opera en el acto resolutorio, salida fuera de sí que está resuelta, resuelta pero retenida en la resolución, en virtud de la cual el Dasein sale de sí, hacia lo que le hace frente, en dirección de lo que es objeto de su ocupación inmediata, le hace frente en forma de posibilidades $\mathrm{y}$ circunstancias de las que puede ocuparse. "Para el presente propio que surge del propio precursar la finitud resueltamente, Heidegger reserva el término de resonancia kierkegaardiana Augenblick, que significa el sostenido arrobamiento (gehaltene Entrückung) del ser ahí ante las posibilidades y circunstancias de la situación singular: un sostener o mantener el éxtasis del presente, en lugar del habitual dejarlo ir como punto efímero, como ahora de una secuencia homogénea" ${ }^{518}$. Sin embargo, en ese instante nada acontece u ocurre, dado que, "en cuanto presente propio (Gegen-wart eigentliche) permite únicamente que haga frente lo que como "a la mano" o "ante los ojos" puede ser "en un tiempo" (in einer Zeit)" "519. con base a la comparación con el presente propio se puede obtener la caracterización del presente impropio que Heidegger denomina presentación (Gegenwärtigen).

Una vez que Heidegger ha delimitado formalmente el presente propio como instante (mirada), y el presente impropio como presentación, considera necesario destacar, que "en la medida que el comprender impropio proyecta el "poder ser" desde lo susceptible de que se ocupe de ello, se temporacía desde el "presentar". En cambio, se temporacía (zeitigt) la "mirada" (Augenblick) inversamente (umgekehrt), desde el advenir propio" (eigentlichen zukunft)" 520 , con lo cual queda claro, que el presente propio, surge desde el precursor estado de resuelto, cuyo carácter es el de un esencial asumir la finitud, que es una salida fuera de sí, salida pero retenida en la resolución.

Es un sostener fuera de sí la situación abierta, frente a posibilidades y circunstancias de la situación peculiar del Dasein. Sostener el éxtasis del presente, como

\footnotetext{
${ }^{517}$ ST, p. 366.

${ }^{518}$ Peñalver, P., Del espiritu al tiempo, op. cit., p. 207.

${ }^{519}$ ST, p. 366.

${ }^{520}$ ST, p. 367.
} 
un hacerlo permanecer, por contraposición, a un simple dejarlo ir como un ahora de una secuencia prolongada, en cual el presente posee solamente el carácter de un ahora, en el que algo llega a ser o deja de serlo. Esta mirada no puede ser comprendida desde el ahora.

\section{El PASADO COMO OLVIDO}

Por último se ha de precisar el pasado que le corresponde a la cotidianidad, en tanto que, "el comprender impropio se temporacía como un estar a la expectativa presentando (gegenwärtigendes Gewärtigen) a cuya unidad extática tiene que corresponder un correlativo sido (Gewesenheit)" ${ }^{\text {"521 }}$.

Heidegger llama al (haber) sido en su modo propio reiteración. Si el porvenir peculiar a la comprensión propia se vincula a una repetición de la facticidad como destino, el impropio estar a la expectativa de posibilidades extraídas desde lo que es objeto de ocupación es esencialmente solidario con el olvido, en cuanto impropio haber $\operatorname{sido}^{522}$. El pensador nativo de Messkirch explica esto de la siguiente forma:

\footnotetext{
el "advenir sobre sí" propio del "precursor estado de resuelto", es ante todo un retroceder hasta el "sí mismo" más peculiar, arrojado en su singularidad. Este éxtasis hace posible que el "ser ahí", resuelto tome sobre sí el ente que él ya es. En el adelantarse, el "ser ahí" camina de nuevo al encuentro de su más peculiar "poder ser". Al ser sido (Gewesen-sein) propio lo llamamos por ello la reiteración" (Wiederholung) ${ }^{523}$.
}

En aquel proyectarse que no está enraizado en las posibilidades propias y auténticas del Dasein, sino que por el contrario, extrae sus posibilidades desde lo que es objeto de sus quehaceres más inmediatos, es posible si el Dasein ha olvidado su más propio y arrojado poder ser, si ha olvidado su constitución en cuanto condición de arrojado, en su arrojado poder ser. De tal forma, que sus posibilidades más propias han quedado oscurecidas, han caído en el olvido. Pero este no es un olvido cualquiera, tal como dice Heidegger, "este olvidar no es una nada (Vergessen ist nicht nichts) o simplemente la falta de recuerdo, sino un peculiar modo extático "positivo" del sido. El éxtasis del olvidar tiene el carácter del sustraerse, cerrado para sí mismo, ante el más peculiar sido, de tal suerte que este "sustraerse ante.... (Aüsruckens vor) "cierra extáticamente el "ante qué" y a una con esto se cierra para sí mismo" 524 . Es evidente entonces, de qué forma se relaciona el olvido con la condición de arrojado. El olvido como modo impropio del haber-sido, se determina como un yo he sido inmediata y regularmente, recogiendo mis posibilidades desde la ocupación inmediata en medio de los entes presentando. Es sobre la base de ese olvido peculiar al haber sido impropio que se puede conservar algo, como un ente que es distinto al Dasein.

\footnotetext{
${ }^{521}$ ST, p. 367. Rivera traduce Gewesenheit como "haber sido".

${ }^{522}$ Cf. Peñalver, P., Del espiritu al tiempo, op. cit., p. 207.

${ }^{523}$ ST, p. 367.

${ }^{524}$ ST, p. 367.
} 
Del mismo modo, que solo es posible la espera de algo sobre la base del estar a la espera, el recuerdo solo es posible sobre la base del olvido. Y no a la inversa, como se piensa comúnmente, "en cierto modo es el recuerdo el que tiene como base el olvido, el olvido es la condición de posibilidad del recuerdo: afirmación que adquiere por otra parte una importancia ontológica fundamental si se sitúa en la perspectiva de la historia de la metafísica como olvido del ser" ${ }^{\prime 25}$.

En la forma del olvido, es el haber sido el que primariamente abre algo así como el horizonte en el cual el Dasein sumido y en medio de lo que se ocupa y le ocupa puede hacer algo así como recordar. "El estar a la expectativa presentando y olvidando (vergessend-gegenwärtigende Gewärtigen) es una unidad extática peculiar, conforme a la cual se temporacía el comprender impropio en lo que respecta a su temporalidad. La unidad de estos éxtasis cierra el poder-ser propio, y es según esto la condición existenciaria de posibilidad del "estado de no resuelto" (Unentschlossenheit)." ${ }^{26}$. En efecto, es desde la temporalidad originaria, sobre su base como temporalización, que se pueden determinar las distintas modalidades de la temporalidad misma, ella misma se articula de distintas maneras, ya sea desde la propiedad o desde la impropiedad. Pero siempre como un fenómeno unitario de una estructura trimembre. Pero no deja de ser cierto, como dice Heidegger: "si bien el comprender ocupándose (besorgende), impropio, se define por el representar aquello de que se ocupa (Gegenwärtigen des Besorgten), la temporación del comprender (Zeitigung des Verstehen) se lleva a cabo primariamente en el advenir"',527.

El comprender se funda primordialmente en el futuro, por otro lado el encontrarse se temporaliza primariamente desde el haber sido, el estado de ánimo se temporaliza, significa entonces, que su éxtasis peculiar pertenece a un futuro y a un presente, de manera tal, que la forma de temporalizar el haber sido modifica los otros éxtasis cooriginarios. Esta complejidad y articulación es inherente a todas las modalidades de temporalizar la temporalidad.

\section{Capítulo IX: El advenir, el fundamento oculto de la historicidad}

Como a la largo de todo Ser y tiempo, Heidegger insiste en hacernos ver que la única forma de asegurar la validez ontológica de lo alcanzado hasta el momento, la forma de avanzar seguro en pos de una analítica originaria y fundamental del Dasein es realizando una comprensora vuelta atrás sobre aquello que hemos ganado, sobre lo que se ha alcanzado en esta marcha especulativa. Pero es fundamental al mismo tiempo, no

\footnotetext{
${ }^{525}$ Peñalver, P., Del espiritu al tiempo, op. cit., p. 207.

${ }^{526}$ ST, p. 367.

${ }^{527}$ ST, p. 368.
} 
olvidar cuales son las motivaciones ontológico fundamentales que guían la meditación, tal como sostiene Heidegger:

Todos los esfuerzos de la analítica existenciaria se dirigen a una meta: encontrar una posibilidad de responder a la pregunta que interroga por el sentido del ser en general. El hacer esta pregunta en forma requiere que se acote tal fenómeno en que resulta accesible lo que se dice "ser": la comprensión del ser. Mas ésta es inherente a la constitución del ser del "ser ahí". Tan solo, pues, cuando se ha hecho ya una exégesis suficientemente original de este ente, cabe formarse un concepto de la comprensión misma del ser encerrada en la constitución de su $\operatorname{ser}^{528}$.

Por lo tanto, para alcanzar la posibilidad de responder a la pregunta que interroga por el ser es fundamental que este fenómeno, que es comprensión del ser, sea determinado de la manera más precisa posible, revelando las estructuras fundamentales que nos muestren su ser. Así lo entiende Heidegger, que señala que se debe exponer claramente toda aquella problemática que no ha quedado suficientemente determinada a lo largo de exposición.

De alguna forma, en el hecho de reconocer que falta camino por recorrer, que aquello que se ha ganado a pesar de ser aparentemente comprensible de suyo, esconde tras de sí muchas oscuridades y una problemática que permanece aún sin ser determinada de manera cabal. Aún se oculta una íntima conexión entre las estructuras y fenómenos de la analítica del Dasein. "La propia dinámica de la investigación obligó a pasar del ser ahí cotidiano al ser ahí propio dado en la muerte y en la culpa, así, es también aquí la problematicidad interna de la temporalidad cotidiana lo que pide la tematización de la historicidad (...) no es simple, desde luego no es fácil "situar"el tema de la historicidad en el marco de la analítica del Dasein o en la progresión de la búsqueda del sentido de ese ser" ${ }^{\prime 529}$.

\section{A. El SER DEl DASEIN COMO PROLONGACIÓN DEL ENTRE El NACIMIENTO Y LA MUERTE}

Ahora cabe precisar el siguiente paso que se debe dar para descubrir las carencias propias a la analítica en esta fase de su desarrollo, que por el momento no le permiten a Heidegger seguir avanzando hacia un análisis radical y esencial de las estructuras y fenómenos esenciales del Dasein, se pregunta por aquello que ha quedado oculto hasta ahora en la analítica del Dasein, que no ha sido aclarado de manera suficiente, aparece en su horizonte especulativo, que:

el hacer la pregunta referente a la totalidad del "ser ahí" bien puede poseer una genuina precisión ontológica. La pregunta misma puede haber encontrado incluso su respuesta en el "ser relativamente al fin" (Sein zum Ende). Pero la muerte solo es el "fin" del "ser ahí" formalmente tomada, solo es uno de los fines que encierran la totalidad del "ser ahí". El

\footnotetext{
${ }^{528}$ ST, p. 403.

${ }^{529}$ Peñalver, P., Del espíritu al tiempo, op. cit., p. 212.
} 
otro "fin" es el "comienzo", el "nacimiento". Únicamente el ente que es "entre" (zwischen) el nacimiento y la muerte representa el todo buscado ${ }^{530}$.

En una primera aproximación puede haber dado la impresión que la analítica del Dasein, su ser total y propio estaba lo suficientemente elaborada y expuesta con el ser relativamente al fin, sin embargo, esto no es suficiente para dar con la totalidad originaria del Dasein.

En el análisis del ser para la muerte, este ente ha sido expuesto en su carácter originario, tanto en la propiedad como en la impropiedad. Heidegger abre ahora una nueva vía de investigación, que no puede contentarse con la aparente totalidad brindada con la determinación del Dasein exclusivamente como ser relativamente a la muerte, esto le lleva a preguntarse si esta determinación del ser del Dasein como ser relativamente al fin, no posee un carácter definitivamente unidireccional.

El Dasein solamente se ha determinando en su carácter de ir hacia adelante, ha sido caracterizado en un único sentido, en su ser hacia la muerte. Mas, permanece sin ser cuestionado todavía un carácter fundamental del Dasein, no se ha preguntado, ¿qué es lo que pasa con lo que deja tras de sí, con lo que queda a su zaga a lo largo de su existencia? Por una parte, la muerte es solo un término, uno de los límites del Dasein, pero qué es lo que sucede con el otro término o límite, con el comienzo. ¿Acaso no es importante de determinar ese comienzo? o ¿Carece dicha precisión acerca del comienzo de importancia para la analítica? Por el contrario, una vez avanzada la analítica se advierte la importancia, por lo demás obvia, de que el Dasein anteriormente ha nacido. Comenta Peñalver: "el análisis ha insistido-desde luego no arbitrariamente, sino fundándose en un cierto primado de la futuridad en la existencia, que se justificó-en el ir "hacia delante" de la existencia, que deja atrás su haber sido. Hay que recuperar el sentido ontológico de tal haber sido, así como su mismo extenderse, prolongarse (Sicherstrecken), ente el nacimiento y la muerte" ${ }^{\circ 31}$.

Ha llegado el momento de analizar ese comienzo, ese otro límite, el nacimiento. Heidegger nos plantea que, "no solo no se ha fijado la atención en el "ser relativamente al comienzo" (Sein zum Anfang), sino que ante todo no se la ha fijado en el prolongarse (Erstreckung) el "ser ahí" entre el nacimiento y la muerte. En el análisis del ser total se ha pasado por alto justamente el "continuo de la vida" (Zusammenhang des lebens), en el que, sin embargo, se mantiene constantemente de alguna manera el "ser ahí" "'532. Es evidente entonces, que se ha de volver sobre aquello que se deja atrás, de lo sido, el nacimiento. Esto es lo que debemos cuestionar en su pleno sentido ontológico. Pero también, se ha de interrogar por ese entre, que Heidegger llama el prolongarse

\footnotetext{
${ }^{530}$ ST, p. 403.

${ }^{531}$ Peñalver, P., Del espiritu al tiempo, op. cit., p. 215.

${ }^{532}$ ST, p. 403.
} 
(extenderse) del Dasein entre el nacimiento y la muerte. Es lo que comúnmente se denomina el continuo de la vida, que no puede ser entendido como un concepto meramente abstracto, con él se quiere nombrar aquella dimensión en la que el Dasein está inmerso constantemente. A juicio de Peñalver, la elección del fenómeno del continuo de la vida, tendría un valor estratégico para Heidegger, dado que le permitiría, señalar lo incompleto y unilateral de la analítica, utilizando una expresión de uso común y corriente, que luego será deslegitimada ${ }^{533}$.

Parecería sencillo caracterizar el fenómeno denominado como continuo de la vida o trama de la vida. Bastaría con definirla como una sucesión de vivencias que nos suceden a lo largo del día o de la vida, acumulándose una tras otra en un orden cronológico. Desde esta perspectiva, solo la vivencia que es presente es real, el ahora de cada momento es lo real en grado sumo. Lo que significaría que las vivencias pasadas ya no son consideradas como reales, dado que se entiende que ya pasaron. Y las vivencias que puedan venir, aún no son reales, no tienen por el momento ningún grado de realidad. Según el filósofo de la Selva Negra en esta interpretación propia de la cotidianidad, "el "ser ahí" recorre el espacio de tiempo que le es concedido entre los dos límites de tal forma que, siendo "real" solo el ahora, salta, por decirlo así, de uno a otro de los ahoras que integran la secuencia de su "tiempo". Por eso se dice que el "ser ahí" es temporal" 534 . Sucede que bajo la influencia de esta idea, se sigue pensando desde el horizonte conceptual de la tradición metafísica, según la cual el continuo de la vida está constituido por una serie de vivencias, con su particular cronología, en la cual se produce y registra una serie de cambios y variaciones, pero el sí-mismo conserva una cierta identidad a pesar del cambio. Subyace en ella la idea de algo así como una conciencia que es idéntica a sí misma y sujeto de las vivencias. Desde esta óptica, "se asienta en esta caracterización del continuo de la vida, quiérase percibirlo o no, algo "ante los ojos" "en el tiempo" (ein "in der Zeit" Vorhandenes), aunque, como de suyo se comprende, no una cosa (Undingliches)" "535.

En esta interpretación del continuo de la vida Heidegger advierte la influencia del concepto vulgar del tiempo. Esta interpretación vulgar de la temporalidad, peculiar a la cotidianidad, si bien dista radicalmente de lo que entendemos como temporalidad original y propia, en tanto sentido del ser del Dasein, no podemos dejar de reconocerle su propia y original justificación, pero siempre considerando sus propias limitaciones. Queda claro que ella no nos brinda un análisis ontológico fundamental del prolongarse del Dasein entre el nacimiento y la muerte, más aún, ni siquiera es posible el planteamiento originario del problema dentro de sus marcos interpretativos. Un ente que es existencia no puede existir como una simple suma de vivencias que se suceden una tras otra $y$, que van desapareciendo, quedando atrás ya inexistentes. Bajo esta interpretación se entiende al

\footnotetext{
${ }^{533}$ Cf. Peñalver, P., Del espiritu al tiempo, op. cit., p. 216.

${ }^{534}$ ST, p. 404.

${ }^{535}$ ST, p. 404.
} 
Dasein como un ente ante los ojos, que está ahí en el tiempo, ente para el que solo tiene realidad aquello que es siempre presente en el continuo de la vida; esta perspectiva interpretativa, anula cualquier intento para obtener la claridad ontológica del entre el nacimiento y la muerte.

Para aclarar ontológicamente esta cuestión, lo primero que se debe considerar es el mismo prolongarse (Erstreckung) del Dasein, su propio ser está determinado como prolongación, y ello, desde su nacimiento, lo que implica que el ser del Dasein se encuentra desde siempre entre el nacimiento y la muerte. Decir esto, es algo muy distinto a sostener que el Dasein es real en un punto del continuo de la vida, en un punto del tiempo $\mathrm{y}$, que por añadidura esté cercado por lo no real, lo que ya pasó -su nacimiento-, y de lo que tiene hacia delante-la muerte.

Aunque, aquello que deja tras de sí, su nacimiento, no puede ser considerado como un pasado que ya pasó y quedo atrás sin más, al modo de una cosa que ya no está más ante los ojos, como una realidad ya olvidada en el pasado. En el mismo sentido, no se puede considerar o comprender existenciariamente a la muerte como algo que aún no es el tiempo pero que vendrá, que tarde o temprano se hará real. Si así lo interpretáramos, estaríamos comprendiendo al Dasein como un ente que pasa en el tiempo al modo de lo ante lo ojos, de tal suerte que no sería posible acercarse a una determinación originaria y esencial del Dasein. Dice Heidegger: "el "ser ahí" fáctico existe naciendo, y naciendo muere en el acto, en el sentido del "ser relativamente a la muerte". Ambos "fines" y el "entre" ellos son, mientras existe fácticamente el "ser ahí", y son como únicamente es posible sobre la base de ser el ser del "ser ahí" el cuidado"536. En consecuencia, el Dasein siempre es ese entre el nacimiento y la muerte, que no anula o cierra ninguno de sus límites o fines. Por el contrario, mientras existe es siempre ese ser naciendo y muriendo, al momento de nacer ya estoy muriendo, lo que nombra a un ente en cuya constitución ontológica se incluyen ambos fenómenos como partes inseparables de él. El Dasein en tanto existencia, en cuanto cuidado, es el entre. Solo existe el Dasein en cuanto tal, si es a la vez naciendo y muriendo. Este ente que es existencia, es propiamente ese entre, él es ese extensión misma, el prolongarse entre un fin y otro. Con esta caracterización originaria del entre Heidegger pretende superar las interpretaciones clásicas que sostienen que al continuo de la vida le es peculiar una dualidad problemática, en virtud del cambio constante a la que se ve sometida, por una parte está aquello que se va modificando, y por otra, aquello que permanece idéntico, como la conciencia y el sujeto.

Para alcanzar la verdad ontológica acerca del continuo de la vida, Heidegger reconduce su meditación hacia el horizonte propio de la temporalidad del Dasein. De esa forma, se podrá comprender la específica movilidad, prolongación y persistencia propia del continuo de la vida. En primer lugar, al hacer referencia a la movilidad del Dasein se ha de tener en cuenta, que:

${ }^{536}$ ST, p. 405. 
la movilidad (Bewegtheit) de la existencia no es el movimiento de algo "ante los ojos". Se define por el prolongarse (Erstreckung) del "ser ahí". La especifica movilidad del prolongado prolongarse (erstreckten Sicherstreckens) 537 la llamamos el "gestarse histórico" (Geschehen) del "ser ahí". La cuestión del "continuo" del "ser ahí" es el problema de su gestarse histórico. El dejar en franquía la estructura del gestarse histórico $\mathrm{y}$ sus condiciones existenciario-temporales de posibilidad, significa el adquirir una comprensión "ontológica" de la historicidad (Geschichtlichkeit) ${ }^{538}$.

El Dasein no es un ente ante los ojos o que simplemente está ahí, en tal sentido, difícilmente se podrá alcanzar una comprensión originaria de él, si se pregunta por el continuo de la vida desde la perspectiva peculiar a la comprensión cotidiana del Dasein, que entiende el continuo de la vida desde los parámetros de la alteridad e identidad propia de los cambios, inherentes a una conciencia como sujeto de las vivencias. Sin embargo, si nuestra intención última es obtener una determinación originaria de este ente, no se puede conceptualizar el continuo de la vida con categorías que le son propias a la comprensión de la cotidianidad, que se encuentra largamente influenciada por la interpretación del ser de la tradición metafísica, que no hace más que lastrar conceptualmente a los fenómenos. En conclusión: "a la vida como continuidad de vivencias se le atribuye característicamente una ambigüedad "problemática": cambio y permanencia, mismidad idéntica y dispersión en el tiempo. El fenómeno del "entre" el nacimiento y la muerte interpretado existenciariamente desvelará el origen de ilegítimo de aquella "problemática clásica"; y aparecerá él mismo, como una específica, peculiar movilidad (Bewegtheit), la de la historicidad" ${ }^{\prime 539}$.

Heidegger señala que la movilidad peculiar al Dasein se caracteriza esencialmente como gestarse, como acontecer, determinaciones propias del prolongarse peculiar al Dasein, a su extenderse entre un límite y otro, entre el nacimiento y la muerte. El prolongado prolongarse entre el nacimiento y la muerte es a lo que el filósofo alemán denomina el gestarse histórico del Dasein.

Se jugaría aquí una especie de desplazamiento de lo cuestionado. La pregunta que se refiere al continuo de la vida, se transforma, y ahora nos remite, al cuestionamiento del gestarse histórico del Dasein, por su acontecer; por sus estructuras fundamentales, y por sus propias condiciones de posibilidad más originarias, por su condición de posibilidad existenciaria-temporal. De forma tal, que somos conducidos aún más allá por Heidegger, la analítica existenciaria abre la posibilidad de determinar el concepto ontológico de la historicidad, y esto desde la temporalidad originaria.

\footnotetext{
${ }^{537}$ Rivera traduce erstreckten Sicherstreckens como "extenderse extendido".

${ }^{538}$ ST, p. 405. Rivera traduce Geschehen como "acontecer".

${ }^{539}$ Peñalver, P., Del espiritu al tiempo, op. cit., p. 217.
} 


\section{B. LA CONCEPCIÓN VULGAR DE LA HISTORIA COMO PURO PASADO}

El filósofo alemán nos lleva desde la comprensión de la cotidianidad hacia la pregunta por la totalidad de este ente llamado Dasein. No se puede desconocer la importancia, la valía de esta comprensión de la cotidianidad en su trato con los fenómenos, en la interpretación que comúnmente hace de ellos, pero siempre ha de ser considerada como un ámbito limitado de despejamiento. Estas interpretaciones nos han llevado, desde la pregunta por el continuo de la vida, por el entre el nacimiento y la muerte, hasta la posibilidad de una comprensión ontológica de la historicidad del Dasein. Heidegger sintetiza esto diciendo, que "la constitución ontológico-existenciaria de la historicidad tiene que conquistarse en contra de la encubridora interpretación de vulgar de la historia del "ser ahí". La construcción existenciaria de la historicidad tiene sus precisos puntos de apoyo en la comprensión vulgar del "ser ahí" y conduce a través de las estructuras existenciarias ganadas hasta aquí' ${ }^{540}$.

En primer término, Heidegger hace alusión a una problemática adyacente al de la vertiente fundamental de la investigación, que tiene que ver con la historiografía como ciencia de la historia. El problema radica en la determinación del lugar que le es propio a la historia y a su propia fundamentación. Si la historicidad del Dasein tiene su fundamentación en la constitución misma del gestarse histórico del Dasein, ello en virtud de la temporalidad propia, ¿cómo podría ser buscado el lugar de la historia en el saber histórico en tanto ciencia de la historia?

Pareciera ser que el fenómeno originario de la historia queda en la absoluta orfandad, en relación a su posible fundamentación, dado que al no poder obtenerla desde el saber histórico (Historie), menos puede hacerlo desde ninguna ciencia que lo tematice. Para Heidegger, el fenómeno de la historia solamente puede ser objeto de una ciencia historiográfica, de un saber histórico, si es conseguido, desde "la forma de ser de lo histórico (Geschichtlichen), de la historicidad (Geschichtlichkeit), en cuanto arraigada en la temporalidad" ${ }^{541}$, queda así completamente descartado cualquier tipo de reinterpretación que pretenda explicar la historia (Geschichte) desde el ámbito de la historiografía, del saber histórico. Por el contrario, sería más bien factible, explicar la historiografía desde el gestarse histórico que le es propio al Dasein, desde la temporalización de la temporalidad en el acontecer alcanzada desde la temporalidad propia. Rodríguez resume todo esto, de la siguiente forma:

a partir de la temporalidad intrínseca de la existencia humana, de lo que podríamos llamar su textura temporal, Heidegger puede dar un contenido concreto al concepto de historicidad. A la luz de la temporalidad, la historicidad no puede concebirse, en su sentido primario como propiedad de los "hechos" que llamamos históricos, sino como una estructura de la existencia, a saber, la de su interna gestación, la de su propio ir haciéndose

\footnotetext{
${ }^{540}$ ST, p. 406.

${ }^{541}$ ST, p. 406.
} 
en la temporalización de pasado, presente y futuro, única forma de unificación de sí mismo que la analítica existencial conoce. Esta autogestación temporal es el modo propio del acontecer (Geschehen) de la existencia humana, su radical historicidad. Todo sentido posible del término "historia" surge de esta elemental historicidad de la existencia, que descansa en la temporalidad ${ }^{542}$.

En esta investigación Heidegger ha expuesto la posibilidad de un poder ser total (Ganzseinkönnen), la temporalidad originaria, el cuidado como sentido del ser del Dasein, este camino nos ha llevado desde la interpretación vulgar de la historia del Dasein hasta la historicidad, de forma que, "respondiendo al enraizamiento de la historicidad en el cuidado, existe el "ser ahí" en cada caso propia o impropiamente histórico. Lo que bajo el nombre de cotidianidad (Alltäglichkeit) se alzó a la vista de la analítica existenciaria del "ser ahí"como horizonte inmediato, se revela como la historicidad impropia (uneigentlich geschichtliches) del "ser ahí" ${ }^{43}$. Esto significa, que lo aquí tematizado no es algo nuevo o ajeno al contendido de la analítica existenciaria, por el contrario, estaba ya presente en el análisis mismo de la temporalidad originaria.

Heidegger entiende que la interpretación vulgar de la historia es una base sólida para el progreso del análisis, la historicidad impropia del Dasein aparece como punto de referencia fundamental para el avance de la investigación. Una vez más, podemos ver claramente reflejada, esa tensión presente en la estructura del Dasein, la tensión entre propiedad e impropiedad, tensión que no se anula jamás mientras él existe, y que podemos verificar en los distintos niveles de la analítica.

Pero no olvidemos que esta marcha meditativa no determina su andar de manera azarosa, de suerte que solo es accidental que desde la temporalidad de la cotidianidad podamos acceder a la historicidad propia, lo que mueve a Heidegger en esta dirección está exigido por las cosas mismas, en este caso por la misma constitución de este ente llamado Dasein, que nos lleva desde un problemática a otra. Pero siempre cuidando fielmente la coherencia plena de los fenómenos en su estructura interna. Desde el análisis del sentido temporal de la cotidianidad nos acercamos al estudio de la historicidad. Desde la comprensión de la cotidianidad se puede entender la comprensión vulgar de la historia, y a través de ella es posible acceder a un análisis de la historicidad propia.

Empero, la determinación plena de la historicidad propia solo se puede alcanzar, dirigiéndose contra el encubrimiento en el que se sostiene la interpretación vulgar de la historia. En lo fundamental, "el análisis de la historicidad del "ser ahí" trata de mostrar que este ente no es "temporal" por "estar dentro de la historia" (in der Geschichte steht), sino que, a la inversa, solo existe y puede existir históricamente (Geschichtlich) por ser temporal en el fondo de su ser" 544 . En otras palabras, el Dasein no es temporal por ser histórico, como comúnmente se piensa, sino que es histórico por ser en esencia temporal.

\footnotetext{
${ }^{542}$ Rodríguez, R.,Hermenéutica y subjetividad. Ensayos sobre Heidegger, op. cit., p. 37.

${ }^{543}$ ST, p. 406.

${ }^{544}$ ST, p. 407.
} 
El camino que sigue Heidegger le lleva necesariamente a detenerse en la comprensión vulgar de la historia, interpretación que está dominada de punta a cabo por el privilegio del pasado. Al entender la historia como aquello que es primordialmente pasado, se dice que lo histórico es lo que ya pasó y quedó atrás. Las distintas interpretaciones de la concepción vulgar de la historia, según Heidegger, coinciden en entender, "lo histórico en el sentido de lo pasado (Vergangene) se comprende en una relación de acción (Wirkungsbezung) positiva o privativa sobre el "presente" (Gegenwart) en el sentido de lo real "ahora" y "hoy" 545 . Lo que el filósofo alemán quiere decir con esto, es que a pesar de que se puedan recoger múltiples significaciones de la historia, prevalece en todas ellas la significación fundamental de la historia como principalmente determinada por el pasado.

De la misma manera, la realidad, lo real, está principalmente entendido según la especifica relación negativa o positiva respecto al presente, a la ausencia o presencia de lo real en lo presente. Lo pasado ya es parte de nuestra historia. Dicha comprensión vulgar que comprende la historia fundamentalmente como algo ya pasado, adquiere su significación desde aquellas formas de hablar propias de la cotidianidad que entienden lo histórico primordialmente como lo que ya pasó. Esta forma de hablar del pasado se relaciona con la idea de algo que ya no está ahí, que ya no es ante los ojos. Por otra parte, si aún está ante los ojos no actúa sobre el presente, no tiene eficacia sobre él. Otra concepción es la que sostiene que no se puede escapar a la historia, de modo que la historia, lo pasado, puede seguir actuando en el presente, tiene efectividad en él. Según esto, "la historia (Geschichte) es aquel específico gestarse (Geschehen) del "ser ahí" existente que acontece en el tiempo, pero de tal suerte que como historia vale en sentido preferente el gestarse "pasado" (vergangene) y al par "tradicional" (überlieferte) y aún actuante (fortwirkende), todo en el "ser uno con otro" 546 , porque todas ella entienden al hombre como sujeto de los acontecimientos ${ }^{547}$.

Podemos concluir entonces, que lo peculiar y característico de la comprensión vulgar de la historia, es su caracterización de lo histórico como lo pasado. Se fija el fundamento u origen de la historia en el pasado. En tanto, que se la entienda como lo ya pasado y dejado atrás, como si se la comprende como aquello que es particularmente transmitido desde el pasado hacia el presente, pero que en términos generales no tiene mayor relevancia ni peso en el presente. Esta interpretación está sustentada fundamentalmente en una marcada subjetivización del hombre y de la historia, de forma que el hombre aparece como sujeto de los acontecimientos y de la historia. "Esta fijación de lo histórico en lo pasado no resiste la prueba del análisis existenciario porque implica

\footnotetext{
${ }^{545}$ ST, p. 409.

${ }^{546}$ ST, p. 409.

${ }^{547}$ Cf. ST, p. 409.
} 
una objetivación de la historicidad una conversión de lo histórico en Vorhandensein" ${ }^{448}$. Lo histórico, sería entendido como algo que pasa en el tiempo al modo de lo Vorhandenheit. Por lo tanto, el pasado poseería una marcada prioridad, una primacía absoluta en relación a lo peculiarmente histórico, comprendiéndose el pasado como lo fundamental y decisivo de la historia. Lo pasado que ya no está ante los ojos, que ya pasó y quedó atrás.

El Dasein comprendido existenciariamente tiene un pasado caracterizado como un ser sido, que no es un pasado que queda atrás sin más, relegado en lo que ya fue, no es un pasado inerte por así decirlo. Esto porque no es un ente que pasa en el tiempo. "Patentemente no puede el "ser ahí" ser nunca pasado (vergangen), no porque no pueda pasar (unvergänglich), sino porque por su esencia no puede ser nunca "ante los ojos", antes bien, si es existe. Mas un "ser ahí" ya no existente no es en riguroso sentido ontológico pasado, sino "sido ahi" (da-gewesen)" 549 . En este estado de cosas, difícilmente podrán las concepciones vulgares de la historia dar cuenta de la historicidad del Dasein en el modo de la propiedad. Siguiendo los lineamientos de esta interpretación de la historia, se hace más bien problemática una caracterización del Dasein según estos preceptos, o por decirlo menos, se hace confusa, porque el Dasein no es un sujeto o un ente que pasa en el tiempo, no es sustancia, su determinación primera es la existencia.

Por otra parte, permanece aún sin su determinación precisa el lugar específico desde dónde cabe plantearse la pregunta por la historicidad del Dasein. Esto porque este ente, "existe temporalmente en grado tan original como no puede serlo nunca por su propia esencia ontológica nada "ante los ojos" y que pasa (Vergehendes) o sobreviene (Ankommendes) "en el tiempo"" 550 . La meditación heideggeriana, exigida por las cosas mismas, ha de tomar necesariamente otro rumbo, si pretende definir originariamente al Dasein en su historicidad, un ente que es su misma historicidad. Esto significa, que el Dasein no se vuelve o se hace histórico, porque fáctica y concretamente vaya haciendo su pasado, ni porque objetivamente sea determinado por un mundo histórico, sino que más bien es histórico en virtud de su gestarse, de su acontecer ${ }^{551}$.

Por ello, Heidegger sostiene: "el "ser ahí" tiene fácticamente en cada caso su "historia" y puede tenerla porque el ser de este ente está constituido por la historicidad (Geschichtlichkeit)" ${ }^{552}$. Esta es una tesis fundamental para el todo de la investigación, el Dasein está constituido esencialmente por la historicidad y no como un ente que está en la historia o que pasa por ella, al modo de una cosa u objeto al modo de lo vorhanden. Esto traza el camino que permitirá alcanzar teóricamente una comprensión ontológica y

\footnotetext{
${ }^{548}$ Peñalver, P., Del espíritu al tiempo, op. cit., p. 219.

${ }^{549}$ ST, p. 411.

${ }^{550} \mathrm{ST}, \mathrm{p} .412$.

${ }^{551}$ Cf., Peñalver, P., Del espiritu al tiempo, op. cit., p. 219.

${ }^{552}$ ST, p. 412.
} 
existenciaria de la historicidad. Se ha de buscar en la temporalidad los indicios que nos permitan identificar un gestarse que nos lleve a una comprensión de la existencia como histórica.

La historicidad para Heidegger es en lo fundamental una determinación más plena y acabada de la temporalidad. Es menester llevar a cabo una exposición y desarrollo más concreto de la temporalidad. Pero, no con la intención de elaborar simplemente una ontología completa y temática del Dasein. Aquello que en una primera aproximación nos pareció suficiente para la caracterización de la temporalidad, ahora al tenor y exigencia de la investigación, se nos muestra como inacabado e incompleto. Se ha de volver entonces sobre aquello que se había ganado en el análisis de la temporalidad propia, en especial, sobre el precursor estado de resuelto, en el que se alcanza la propiedad del Dasein. Según Álvarez Gómez, esto significaría que:

entonces pudiera percibirse el presente histórico como dependiente de algo que aún no es, no existe pero está llamado a existir. Ésta puede ser la razón por la que Heidegger, considera que la temporalidad es "la condición de posibilidad de la historicidad" y que a su vez se caracteriza ella misma como esencial proyección, de forma que el eje del tiempo según esto no es el presente sino el porvenir: "volviendo "porvenideramente a sí", la resolución se pone en la situación presencializando" ${ }^{" 53}$.

\section{HeRENCIA, TRADICIÓN Y DESTINO}

Con el objetivo de caracterizar la historicidad en el modo de la propiedad, se ha de interrogar de qué forma se vinculan el precursor estado de resuelto con el gestarse del Dasein, ¿en qué sentido se constituye el precursor estado de resuelto como un modo propio del gestarse del Dasein? El precursor estado de resuelto, en el cual el Dasein comprende de forma propia su sí mismo y su poder ser, comprende la muerte como su posibilidad más propia y original. Carga sobre sí su condición de arrojado como el ente que es él mismo. De forma, que "el resuelto tomar sobre sí el peculiar "ahí" fáctico significa al par la resolución de ponerse en la situación. A qué se resuelve en cada caso fácticamente el "ser ahí", no puede por principio, dilucidarlo el análisis existenciario. Pero la presente investigación excluye además toda proyección existenciaria de posibilidades fácticas de la existencia" ${ }^{554}$. Heidegger caracteriza así el precursor estado de resuelto, en el que el Dasein se hace propio en la situación abierta en el ahí, y toma sobre sí su poder ser total y propio, sin embargo, con esta caracterización no se resuelven todos los enigmas. E1 pensador alemán estima que aún subyacen en la analítica una serie de enigmas, cuya presencia en principio fue apenas perceptible, porque se entendió a los fenómenos como absolutamente comprensibles de suyo.

\footnotetext{
$\overline{553}$ Álvarez, M., Teoría de la historicidad, op. cit., p. 184.

${ }^{554}$ ST, p. 413.
} 
En la analítica no se aclara ni se establece a qué se resuelve el Dasein en la situación, a qué es a lo que se resuelve fácticamente. Tampoco se puede obtener de ella un proyecto existenciario de posibilidades concretas de la existencia. Una crítica posible a la analítica podría argüir que dichos reparos se sustentan principalmente por la falta de concreción fáctica de la analítica en su relación con la vida real, lo que no sería más que un indicio de la falta de concreción mencionada, de lo ajeno que está de la vida concreta esta analítica existenciaria, consecuente con esto, dichos cuestionamientos solo serían un síntoma de la distancia absoluta entre la vida concreta y el análisis existenciario.

Sin embargo, hay que decir con claridad, que la investigación que Heidegger lleva a cabo, cuyo carácter ontológico fundamental, no puede pretender dar indicaciones o formulas mágicas de cómo llevar la propia existencia, o cómo proyectarse en un ideal de existencia, por el contrario, su intención es la de analizar el modo en que la existencia se da, su constitución ontológica, cómo se manifiesta en su carácter de ser en el mundo y las posibilidades de ella misma. Respecto a esto, Heidegger comenta que cabe preguntarse, "de dónde pueden sacarse en general las posibilidades sobre las que se proyecta fácticamente el "ser ahí". El adelantarse que se proyecta sobre la posibilidad irrebasable de la existencia, la muerte, solo garantiza la totalidad y propiedad del "estado de resuelto". Mas las posibilidades de la existencia fácticamente abiertas no pueden tomarse a la muerte" ${ }^{555}$. Esto significa, que el precursor estado de resuelto solo se ha determinado en relación al proyectarse sobre la posibilidad límite, la posibilidad de la imposibilidad de la existencia. Lo que Heidegger tematiza es solamente esa totalidad y propiedad que nos brinda la resolución. Pero deja en la más absoluta incógnita, desde dónde podemos obtener las posibilidades concretas de la existencia, en su facticidad y concreción. Por consiguiente, estas posibilidades señaladas no pueden ser alcanzadas desde la muerte, deben ser posibilidades efectivas y concretas. Las posibilidades en cuanto tales, no pueden ser posibilidades fantásticas, mágicas, extraídas de la nada, por el contrario, deben ser cogidas desde alguna parte.

El precursor estado de resuelto, es un adelantarse hacia la posibilidad más propia y peculiar del Dasein, la muerte. Pero esto no se debe entender, como una simple y vacía especulación acerca de la muerte, no es una mera meditación mortis, por el contrario, el precursor estado de resuelto es al mismo tiempo, un retorno al ahí fáctico. El toma sobre sí la carga de su propio y esencial condición de arrojado, asumiéndola (del sí mismo a su propio mundo), de forma que el Dasein retrocede hacia su sí mismo, retorna esencialmente hacia su condición de arrojado. Y de esta forma:

abre las posibilidades fácticas del existir propio en el caso partiendo de la "herencia" (Erbe) que toma sobre sí en cuanto arrojado. El resuelto retroceder (entschlossene Zurückkommen) hacia la condición de arrojado entraña una "tradición" (Sichüberliefern) de posibilidades transmitidas (...) cuanto más propiamente se resuelva el "ser ahí", es

${ }^{555}$ ST, p. 413. 
decir, se comprende sin ambigüedades partiendo de su más peculiar y señalada posibilidad, en el adelantarse hacia la muerte (Vorlaufen in den Tod), tanto menos equívoco y accidental es el encuentro electivo de la posibilidad de su existencia ${ }^{556}$.

Heidegger avanza en una caracterización más plena y originaria del precursor estado de resuelto, que se muestra también como un retroceder que abre las posibilidades fácticas de existencia, abre posibilidades concretas. Por lo tanto, "para que las posibilidades lo sean efectivamente, y no intenciones fantásticas, el ser ahí las tiene que tomar de alguna parte: precisamente de lo que encuentra dado en su facticidad, de su herencia" ${ }^{\text {"55. Las }}$ posibilidades no flotan en el vacío de manera mágica, se enraízan en la propia herencia (Erbe), a partir del propio legado. Ese retroceder resuelto es un retorno a la condición de arrojado, constituyéndose así como un cúmulo de posibilidades que son recibidas, extraídas a partir de la tradición. Toma sobre sí su ser sido, su pasado. Recupera y carga sobre sí todo su haber sido, lo que ya era. Y esto es de tal forma, que mientras más auténtica y propia sea la resolución del Dasein, este comprende la muerte como su posibilidad más propia y original:

al proyectarse en la asunción de su pasado, la existencia es absolutamente heredera de sí misma, se autotransmite, es decir, se hace cargo de sus opciones pasadas, es tradición viva. En virtud de esta estructura de transmisión que la inmersión del pasado en el futuro permite, puede Heidegger decir que "su propio pasado- lo cual significa siempre el de su generación - no sigue al Dasein, sino que le precede siempre". No es el rastro que dejamos tras nosotros, sino nuestro propio horizonte. En cuanto heredera de sí misma, la existencia humana solo puede ser lo que ya $\mathrm{es}^{558}$.

Lo que conllevaría que la elección y comprensión de sus posibilidades fácticas de existencia sean las apropiadas, en cuanto le son las propias, por tanto, le sobrevendrán en menor numero equívocas o engañosas posibilidades de existir extraídas siempre desde sus quehaceres inmediatos.

El adelantarse hacia la muerte, es el que desautoriza toda posibilidad de aparente bienestar o éxito, que se obtiene desde la posibilidad azarosa que nos brinda la comprensión que le es peculiar de la cotidianidad. Como sostiene Heidegger:

La bien asida finitud de la existencia arranca a la multiplicidad sin fin de las primeras posibilidades que se ofrecen, las posibilidades de darse por satisfecho, tomar las cosas a la ligera, rehuir los compromisos, y trae al "ser-ahí" a la simplicidad (Einfachheit) de su "destino individual" (Schicksals). Con esta expresión designamos el gestarse original (ursprüngliche Geschehen) del "ser-ahí, gestarse implícito, en el "estado de resuelto" propio y en el que el "ser-ahí" se hace tradición de sí mismo, libre para la muerte, a sí mismo, es una posibilidad heredada (überliefert) pero sin embargo elegida ${ }^{559}$.

\footnotetext{
${ }^{556} \mathrm{ST}, \mathrm{p} .414$.

${ }^{557}$ Peñalver, P., Del espíritu al tiempo, op. cit., p. 219.

${ }_{558}$ Rodríguez, R., Hermenéutica y subjetividad. Ensayos sobre Heidegger, op. cit. , p. 38.

${ }^{559}$ ST, p. 414.
} 
En esta posibilidad de asumir la finitud propiamente, descansa también la posibilidad de apartar de nuestra existencia esa multiplicidad de posibilidades que señorean bajo la comprensión de la cotidianidad, que principalmente son una huida de responsabilidades, hacia posibilidades de un supuesto bienestar, éxito y tranquilidad, que son las que inmediatamente se nos ofrecen por todas partes y en todos lados. "En el Geschehen propio, el haber sido tiene también una peculiar primacía, pero que solo tiene sentido sobre el fundamento de que la existencia "advenga" sobre sí, proyecte su porvenir o futuro al abrirse a ciertas posibilidades" $"$. Álvarez Gómez interpreta esto de la siguiente forma:
el hombre está destinado a la muerte. Este es su futuro ineludible que le confronta con su propio origen, consistente en la condición de está fácticamente arrojado a la existencia. Esto, el tener que asumir su origen, es lo que fuerza al hombre a contar con su haber-sido y a otorgar a esta dimensión "su peculiar primacía en lo histórico". La apertura hacia el futuro bajo la forma de ser para la muerte le lleva a Heidegger a clausurar en los límites de esos dos acontecimientos existenciales: condición de arrojado a la existencia y ser para la muerte, el significado profundo de la historicidad ${ }^{561}$.

En la posibilidad de asumir la finitud propiamente, nos llevamos sin más a encontrarnos con la simplicidad del propio y singular destino (Schicksal), que nombra aquel ámbito propio y auténtico del Dasein que es el gestarse originario, que pertenece de manera esencial al precursor estado de resuelto, que hace libre al Dasein para su propia muerte. Por eso, "en este retroceso fiel a la facticidad, que es así facticidad histórica, es este hacerse tradición de sí mismo de acuerdo con las posibilidades heredadas-elegidas, recibe el Dasein el don del destino singular" ${ }^{562}$. Se hace entrega a sí mismo de una posibilidad que es legado (Erbe), tradición (überliefert), que ha heredado en su haber sido. Pero, que es al mismo tiempo su propia y singular elección. Un destino que no queda cercenado, ni se reduce a una simple elección o a ser una pura tradición heredada, sino que constituyen una unidad. Se puede tener un destino, ser destino, aceptando las circunstancias adversas y felices. Solo puede ser tal: "cuando el "ser-ahí", adelantándose hasta la muerte permite que ésta se "apodere" (mächtig) de él, se comprende, libre para ella, en la peculiar superpotencia (Übermacht)de su libertad finita, para tomar sobre sí en ésta, que solo "es" en el haber hecho la elección del caso, la impotencia del "estado de abandonado" (Ohnmacht der Überlassenheit) a sí mismo, y para volverse, en esa misma libertad, clarividente para los accidentes de la situación abierta" ${ }^{963}$.

\footnotetext{
${ }^{560}$ Peñalver, P., Del espiritu al tiempo, op. cit., p. 219.

${ }^{561}$ Álvarez, M., Teoría de la historicidad, op. cit., p. 279.

${ }^{562}$ Peñalver, P., Del espíritu al tiempo, op. cit., p. 219.

${ }^{563}$ ST, p. 415.
} 


\section{EL ADVENIR COMO FUNDAMENTO OCULTO DE LA HISTORICIDAD}

Debemos entender el destino como el modo de ser de un ente, en el cual la conciencia, la culpa, la finitud, se copertenecen esencialmente, constituyendo una unidad indisoluble y originaria como cuidado, como un ente que es histórico, que es existencia, cuya condición ontológica de posibilidad es la temporalidad. Solamente un ente que es temporalidad puede ser histórico en el fondo de su ser, puede tener un destino, ser su propio destino. Por esto dice Heidegger:

Solo un ente que en su ser es esencialmente advenidero de tal manera que, libre para su muerte (frei für seinem Tod), y estrellándose contra ella, puede arrojarse retroactivamente (züruckwerfen)sobre su "ahi" fáctico, es decir, solo un ente que en cuanto advenidero (zukünftiges) es con igual originalidad siendo sido(gewesend ist), puede, haciéndose "tradición" de la posibilidad heredada (ererbte Möglichkeit überliefernd), tomar sobre sí su peculiar condición de arrojado y ser, en el modo de la mirada (augenblicklich), para su "tiempo". Solo la temporalidad propia, que es al par finita, hace posible lo que se dice un "destino individual" (Schicksal) es decir, una historicidad propia (eigentliche Geschichtlichkeit) ${ }^{564}$.

Esto significa, que en virtud de la temporalización de la temporalidad es posible que un ente sea propiamente histórico, de modo que asumiendo su esencial finitud retorna hacia su condición de arrojado, hacia su propio ahí. Entregándose a sí mismo su propia posibilidad que ha heredado, y puede hacerse instantáneo para su propio ahí, para su propio tiempo. "En cuanto maduración de la temporalidad, en cuanto dar tiempo al tiempo, la temporalidad es historicidad. Ser acontecido históricamente quiere decir tener destino: precursar a la muerte, dejarse arrojar de rechazo en el "ahí" fáctico y su finitud, transmitirse las posibilidades heredadas y el estar de este modo al "instante" por lo que hace al tiempo propio" 565 , y así ver la apertura de sus posibilidades más propias

Es gracias a la temporalidad originaria y propia que un ente puede ser existencia, puede ser su propio destino, ésta es la constitución peculiar de la historicidad propia. Esto significa, que:

lo realmente histórico es el Dasein. Y lo es precisamente como existente. Existente es entendido aquí en sentido estricto y pleno, en relación con el poder ser total (Ganzseinkönnen) y con la decisión (Entschlossenheit). Esto, como hemos visto, presupone que el Dasein es en sí temporal. En segundo lugar, es histórico el mundo del Dasein, entendiendo por mundo no el conjunto de objetos, sino el conjunto de relaciones donde el Dasein "es", como ser-en-el-mundo. Este mundo va pasando, precisamente porque el Dasein tiene una estructura temporal ${ }^{566}$.

Por lo tanto, solamente un ente que esencia como temporalidad, y en cuanto es advenidero, es a la par un ente que está siendo sido, puede hacerse tradición de la

\footnotetext{
${ }^{564}$ ST, p. 416.

${ }^{565}$ Pöggeler, O., El camino del pensar de Martin Heidegger, op. cit., p. 73.

${ }^{566}$ Berciano, M., Superación de la metafisica en Martin Heidegger, op. cit., p. 79.
} 
posibilidad heredada, asumiendo su estado de condición de arrojado puede ser instantáneo (Augenblick) para su tiempo, posibilitando su destino singular. Como dice Pöggeler:

El ser-ahí es esencialmente "temporal", es decir, temporalización del tiempo. Él puede asumir la temporalización del tiempo por sí mismo; con esto, asume su "historicidad", su destino, en el sentido de tener que temporalizar su tiempo como persona mortal y finita; por sí misma; existe entonces de manera auténtica. Pero el ser-ahí puede olvidar que él mismo temporaliza el tiempo cuando como "algo" temporal se encuentra en el horizonte del tiempo ${ }^{567}$.

Podemos advertir también de qué manera en la temporalización de la temporalidad se experimenta la unidad intrínseca de la estructura que el Dasein es. En la cual todos y cada uno de lo fenómenos esencian como totalidad, con un mismo grado de originalidad, ensamblándose cada uno de los fenómenos de manera precisa y originaria, ajustándose con precisión en el todo estructural de la existencia. Esto lo interpreta el profesor Álvarez de la siguiente forma :

Como ser temporal el hombre ya no camina simplemente hacia su futuro, sino que tiene que proyectar ese futuro, que se convierte así en porvenir, en cuanto que es lo que el hombre tiene que labrar o esculpir para sí. Es así como el simple tiempo es temporalidad y ésta se convierte en el elemento básico de la historia, sobre el que se construye la historicidad, o sea se establece aquello que le impulsa al hombre a hacer una historia(...) lo que representa la temporalidad como un elemento básico de la historicidad ${ }^{568}$

Si bien, no es absolutamente necesario que el estado de resuelto reconozca abiertamente el origen de las posibilidades en la que se proyecta, sí es importante precisar, que en la temporalización de la temporalidad subyace la posibilidad última del Dasein de poder obtener desde la comprensión cotidiana del Dasein, las posibilidades concretas de un poder ser existencial en el cual se proyecte.

Para comprender de forma precisa cómo se vinculan los éxtasis de la temporalidad en todos los estadios de la investigación heideggeriana, es menester volver ahora sobre el éxtasis del advenir. En esta fase de la investigación, y a pesar de que lo tratado sea la historicidad, que comúnmente aparece vinculada de forma determinante con el pasado, Heidegger se esmera en reafirmar una vez más, que el advenir ostenta una peculiar primacía al interior de la analítica propia a Ser y tiempo, en este caso como fundamento oculto de la historicidad, esto en contra de lo que comúnmente podría pensarse, dado que por la influencia de la concepción vulgar de la historicidad y de la tradición filosófica se asigna una prioridad indiscutible al pasado, en cuanto es la instancia temporal decisiva si nos referimos a la historicidad. No obstante, Heidegger le asigna al advenir una peculiar primacía. En el marco de esta problemática, Heidegger habla de la reiteración (Wiederholung):

\footnotetext{
${ }_{567}$ Pöggeler, O., Filosofia y política en Martin Heidegger, op. cit., p. 64.

568 Álvarez, M., Teoría de la historicidad, op. cit., p. 165.
} 
como aquel modo del "estado de resuelto" que se hace "tradición" (überliefernden) de sí y por obra del cual el "ser-ahí" existe expresamente como "destino individual". Pero si el "destino individual" constituye la historicidad original (ursprüngliche Geschichtlichkeit) del "ser ahí", entonces no tiene la historia su centro de gravedad esencial ni en lo pasado (Vergangenen), ni en el hoy y su "conexión" con lo pasado, sino en el gestarse histórico propio de la existencia, el cual brota (entspringt)del advenir del Dasein ${ }^{569}$.

Aún más explicito se manifiesta el filósofo de la Selva Negra, cuando dice que la historia como modo de ser del Dasein:

tiene su raíz tan esencialmente en el advenir, que la muerte, en el sentido de la caracterizada posibilidad del "ser ahí", rechaza a la existencia que la adelanta contra su fáctica condición de arrojada, y así es como presta al "sido"(Gewesenheit) su peculiar primacía en el dominio de lo histórico. El "ser relativamente a la muerte" propio, es decir, la finitud de la temporalidad, es el oculto fundamento (verborgene Grund) de la historicidad del "ser ahí" 570 .

Podemos concluir entonces, que Heidegger comprende al advenir como el fundamento oculto de la historia, de la historicidad, pero no entendiendo el futuro desde una perspectiva puramente cronológica, sino que debe ser comprendido en su sentido existenciario, ha de ser considerado desde su peculiar relación con el proyecto, con el estado de resuelto, desde el cual puede hacerse tradición heredada, y recuperar su más original posibilidad de ser desde lo ya sido.

Para profundizar en esto, hay que señalar que la compresión particular a la cotidianidad ha entendido lo histórico fundamentalmente como lo pasado, dicha visión ha sido la dominante en la interpretación de lo histórico. En Ser y tiempo esta interpretación adquiere una particular perspectiva, que interroga por su sentido primigenio, abriendo una nueva perspectiva para entender lo histórico, la temporalidad, la historicidad. Asimismo,"pudiera percibirse el presente histórico como dependiente de algo que aún no es, no existe pero está llamado a existir. Ésta puede ser la razón por la que Heidegger considera que la temporalidad es "la condición de posibilidad de la historicidad" (...) y que a su vez se caracteriza ella misma como esencial proyección, de forma que el eje del tiempo según esto no es el presente sino el porvenir" ${ }^{271}$

Heidegger entiende la reiteración, como una modalidad del estado de resuelto, en la que el Dasein se entrega a sí mismo una posibilidad heredada, gracias a ella existe como destino singular. Es la reiteración de una posibilidad de existencia que llega a él desde la tradición, pero en ella es la tradición la que se hace concreta, y se manifiesta en un retroceder a la posibilidades que el ya ha sido (Gewesenen). La forma auténtica de corresponder a esa posibilidad en el estado de resuelto, es al mismo tiempo en su carácter de instantánea, una clausura de aquello que en el presente sigue actuando, entendiéndose

\footnotetext{
${ }^{569}$ ST, p. 416. Rivera traduce Wiederholung como "repetición".

${ }^{570}$ ST, p. 417.

${ }^{571}$ Álvarez, M., Teoría de la historicidad, op. cit., p. 184.
} 
esto como un pasado en sentido clásico. "Esa "presencia" del pasado en el futuro no lo es a modo de lastre o peso que permanece, sino como algo envuelto en el propio proyecto hacia lo posible. Este se hace cargo, acoge constantemente, como su posibilidad propia, lo que ya es. Solo un ser que constantemente se asume a sí mismo, que puede por tanto, ser su pasado tiene historia" 572 . Esta es la forma en la cual el Dasein puede existir propiamente en tanto destino. Como puede observarse, el peso esencial de dicha estructura no recae en el pasado ni el presente, sino que el gestarse propio se articula a partir del advenir. En efecto, solo desde la resolución que es el asumir la esencial finitud de la existencia, puede el Dasein entregarse a una posibilidad heredada por tradición y gracias a la cual puede él ser ese mismo destino, puede ser su destino. Por esto, es que el advenir se considera como el fundamento oculto de la historicidad.

\section{E. EL ENTE HISTÓRICO MUNDANO Y LA INTERPRETACIÓN DEL SER COMO PRESENCIA}

Solo puede el pasado, el haber sido, alcanzar su prioridad dentro de lo histórico, si antes el Dasein en su adelantarse hacia la muerte retrocede hacia su condición de arrojado, solo sí este en esencia es propiamente advenidero. Singular interpretación, que plantea que la modalidad propia del Dasein, su ser relativamente a la muerte propiamente, (en que asume su finitud esencial), es él fundamento oculto de la historicidad propia del Dasein. Heidegger por una parte, habla de una particular y manifiesta primacía de lo pasado en la historicidad del Dasein, pero aclarando luego que esto es posible gracias a que se sustenta en un fundamento oculto: el advenir. Según Berciano, esto:

podemos sintetizarlo diciendo que historicidad significa existir como destino, en el modo de destino. Como hemos visto el ser-en-el-mundo, es arrojado y está perdido en el "Man". Como tal, el Dasein recibe una herencia (Erbe). Su apertura como decisión (Entschlossenheit) tiene que aceptar esa herencia. Solo a partir de ella puede decidir, proyectar, realizar sus posibilidades y su existencia auténtica. Existe partiendo de la herencia. (Existieren aus dem Erbe)" ${ }^{973}$.

El Dasein no es histórico o no se hace histórico por la reiteración, sino que es histórico por ser en su esencia temporalidad. Esta reiteración le hace manifiesto al Dasein por vez primera su propia historia, al tiempo que el gestarse histórico y su estado de abierto se basan existenciariamente en la constitución que es propia al Dasein y a su peculiar abertura extática, en cuanto éxtasis de la temporalidad. Heidegger a modo de recapitulación, señala: "lo que hasta aquí hemos descrito como historicidad, ajustándose al carácter implícito en el "precursor estado de resuelto", es lo que llamamos la historicidad propia del "ser ahí". De los fenómenos de la tradición y la reiteración, enraizados en el advenir, resulto claro por qué el gestarse de la historia propia tiene su centro de gravedad

\footnotetext{
${ }^{572}$ Rodríguez, R., Hermenéutica y subjetividad. Ensayos sobre Heidegger, op. cit., p. 38.

${ }^{573}$ Berciano, M., Superación de la metafísica en Martin Heidegger, op. cit., p. 80.
} 
en el "sido"" 574 . Pero esto hemos de entenderlo de acuerdo con las indicaciones anteriores, puesto que, el advenir como fundamento oculto de la historicidad, es desde dónde puede el haber sido constituirse en el centro de gravedad del gestarse histórico. A medida que progresamos en el desarrollo de la analítica, se van haciendo más claras una serie de vínculos esenciales entre los fenómenos que constituyen al Dasein, que dan cuenta de las internas conexiones entre el haber sido, el advenir y el Augenblick, (instante), como temporalización de la temporalidad.

Sin embargo, persiste la incógnita sobre la forma de cómo ese gestarse histórico puede, en tanto destino, constituirse como el continuo total desde el nacimiento hasta la muerte. Queda todavía sin resolver el tema de la posible unidad del continuo de la vida, de la trama de la vida entre el nacimiento y la muerte.

Si bien en el estado de resuelto se muestra de modo originario la constitución del Dasein hacia el otro límite, que recoge para sí el carácter de haber sido, que se proyecta en posibilidades propias. A pesar de que ahora se tematiza aquello que había quedado a espaldas en las primera determinación del ser total y propio, queda aún por resolver: "¿En que estriba el que la cuestión de la constitución del "continuo de la vida" (Lebenszusammenhangs) no encuentre una respuesta satisfactoria?"575. Y ante esta interrogante que queda abierta, Heidegger con otra pregunta nos abre el horizonte que debe reconducir nuestra meditación, lo hace cuestionando la formulación inicial de la pregunta misma por el continuo de la vida: “ ¿y si fuera la historicidad impropia del "ser ahí" lo que impeliese a hacerse cuestión del "continuo de la vida", impidiendo el acceso a la historicidad propia y al "continuo" peculiar a ella?" 576 . Es evidente que Heidegger entiende que la forma de dotar a su investigación de un carácter originario, es dirigiéndola hacia el origen mismo de la pregunta por el continuo de la vida, se debe determinar el específico ámbito ontológico desde dónde ella surge, desde dónde se plantea.

El Dasein se comprende inmediata y regularmente a partir de lo que es objeto de ocupación, de lo que comparece en el mundo circundante. Esta interpretación es la que constituye fundamentalmente el modo de la impropiedad del Dasein. Extrae sus posibilidades desde lo que es objeto de ocupación, todo se mide o calcula en razón del resultado o progreso en nuestra relación con nuestros quehaceres inmediatos, parecería lógico entonces, caracterizar el continuo del Dasein en esta dirección.

Consecuente con esto, serían parte de la historia también todas las cosas con las que el Dasein se encuentra a lo largo de su vida. Por lo tanto, no sería el gestarse histórico más que el aislado transcurrir de vivencias de sujetos diversos. Sin embargo, tal como Heidegger ha señalado, la historia no puede ser interpretada como un simple ir y venir de

\footnotetext{
${ }^{574}$ ST, p. 417.

${ }^{575}$ ST, p. 417.

${ }^{576}$ ST, p. 418.
} 
objetos y sujetos en un tiempo determinado, ella no es "el continuo en movimiento de las alteraciones de los objetos, ni la serie, flotante en el vacío, de las vivencias de los "sujetos"", ya que, "el gestarse de la historia es el gestarse del ser-en-el mundo" 577 . La constitución del Dasein como ser-en-el-mundo histórico implica que todo aquello que le hace frente al Dasein -(lo que es objeto de ocupación, lo ante los ojos, lo a la mano),queda siempre incluido en la historia del mundo. A estos entes se les denomina lo histórico-mundano (das Welt-Geschichtliche). Como dice Heidegger:

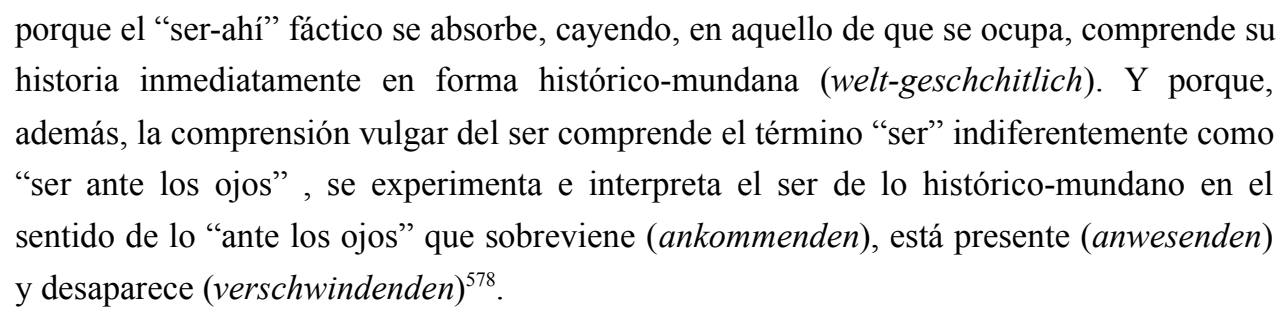

La interpretación clásica del ser como substancia, como lo simplemente presente, nos indica que la idea de lo histórico-mundano está fundamentada principalmente en lo vorhanden, en lo ante los ojos. El Dasein mismo en cuanto caído, comprende primordialmente su historia a partir de los histórico-mundano, aún más, comprende su historia histórico-mundanamente, a partir de la ocupación, se comprende a sí mismo como vorhanden, se concibe como substancia, como un ente más en el mundo. El Dasein con base a la interpretación tradicional del ser, comprender su ser, su propia historia desde lo histórico mundano, desde los entes que comparecen en el mundo

A partir de esta comprensión dominante, que entiende al ser como Anwesenheit, como presente, el sentido del ser aparece como lo comprensible de suyo, de tal forma, que la pregunta por lo histórico mundano y la movilidad del gestarse parece ser inocua y sin mayor importancia. En efecto, inmediata y regularmente el Dasein comprende su historia a partir de lo histórico mundano, la considera solo a partir de lo que es objeto de sus quehaceres, de lo que le hace frente en la inmediatez. Es llevado desde un lado a otro por las posibilidades que recoge desde lo que le ocupa, por tanto: " tiene primero que recogerse de la disipación y la falta de recogimiento y continuidad de lo que ha "pasado"(Passierten), justamente, si es que quiere llegar a sí mismo, brota del horizonte de comprensión de la historicidad impropia, y solo de él, la cuestión de fundar un "continuo" del "ser ahí", en el sentido de las vivencias del sujeto que también son "ante los ojos"',579.

Subyace en esta interpretación, una idea del Dasein que lo entiende como sujeto de las vivencias, que también tiene el modo de lo ante los ojos, de una cosa. Que sea esta la perspectiva interpretativa dominante, se puede comprender desde el irresoluto ser del

\footnotetext{
${ }^{577}$ ST, p. 418.

${ }^{578}$ ST, p. 420.

${ }^{579}$ ST, p. 420.
} 
Dasein que la mayor de las veces y del tiempo está inmerso en la cotidianidad, en la inmediatez, que es precisamente desde donde extrae sus posibilidades de existencia y sus interpretaciones de la historia y del tiempo, así absorto en la impropiedad es irresoluto. Desde ella se manifiesta una interpretación del ser como Anwesenheit y del tiempo como simple presente.

La tarea de indagar en el origen de la pregunta por el continuo del Dasein, que es comprendido por la cotidianidad como una unidad propia a la diversidad de las vivencias entre el nacimiento y la muerte, en un análisis originario se presenta como absolutamente inapropiado, si lo que pretende es una comprensión originaria y fundamental de la totalidad del gestarse histórico del Dasein. Se ha vuelto ahora compresible, por que la historicidad propia del Dasein no es el terreno propicio para preguntar ontológicamente por el continuo de la vida, esto porque, "la clave del encadenamiento de las vivencias entre el nacimiento y la muerte, solo tiene sentido para un ser ahí previamente perdido en la exterioridad de lo que "pasa", perdido en la disipación (...) el problema del asunto no está, pues, tanto en pretender recuperar una unidad como identidad del "sujeto" como en sostener el propio prolongarse, extenderse (Sicherstrecken) o una constancia prolongada" 580 .

Ahora, Heidegger puede decir con seguridad, que no era la pregunta por el continuo de la vida la que es menester realizar, sino que se debe preguntar primeramente: “¿en que forma de ser de sí mismo no se pierde de tal manera que tiene que acabar por empezar, digámoslo así, recogiéndose de la disipación e imaginándose para el recoger una unidad que lo abarque?" 581 . Al analizar esta pregunta, podemos destacar que lo fundamental del problema no está en dotar o reconocer una posible unidad en el continuo de la vida, ni tampoco reconocer una unidad de vivencias entre el nacimiento y la muerte que se dan para un sujeto que las vive. Comprendemos ahora algo que antes solo se había supuesto, el problema de la unidad del continuo de la vida es una fundamentación inadecuada si se pretende obtener una interpretación originaria del ser del Dasein. La anhelada unidad del continuo de la vida, la unidad de vivencias entre el nacimiento y la muerte como cuestionamiento tiene sentido para un Dasein que se encuentra perdido en la cotidianidad, extraviado en sus múltiples quehaceres, perdido en la disipación (Zerstreuung).

La pregunta ha de ser formulada desde otra perspectiva, se ha de indagar en la posibilidad de una modalidad del Dasein, en la que sea capaz de poder recuperarse desde el estado de perdido, ganarse a sí mismo desde la disipación en la está sumergido. Logrando abarcar para sí una unidad coherente y que lo abarque en esa misma unidad, pero sin la necesidad de considerar como fundamental esa concatenación de vivencias propias del continuo de la vida. Heidegger sostiene que esta modalidad, es:

\footnotetext{
$\overline{{ }^{580} \text { Peñalver, P., Del espíritu al tiempo, op. cit., p. } 221 .}$

${ }^{581}$ ST, p. 421.
} 
"el estado de resuelto" del "mismo" contra la inconstancia (Unständigkeit) de la disipación es en sí mismo prolongada constancia (erstreckte Ständigkeit) en que el "ser ahí" en cuanto destino individual mantiene "inclusos" (einbezogen) en su existencia el nacimiento y la muerte y el "entre" ellos, de tal suerte que en semejante constancia el "ser ahí" es en el modo de la mirada (Ständigkeit augenblicklich) para lo histórico-mundano de su situación en el caso ${ }^{582}$.

En consecuencia, el estado de resuelto se erige como esa posibilidad del Dasein en la que este puede recuperarse a sí mismo desde la dispersión en la que se encuentra, y se puede constituir en una prolongada constancia, que es aquella instancia en la cual el Dasein es su propio destino, manteniéndose en la constancia, en la estabilidad, en otras palabras, manteniendo asumido e incorporado en él el nacimiento y la muerte es propiamente su entre. De esta forma, el Dasein se vuelve instantáneo para su situación abierta, para su ahí fáctico, para lo histórico-mundano que le hace frente, se vuelve instantáneo frente a los hechos o acontecimientos que le tocan enfrentar. Heidegger ha determinado al estado de resuelto como aquel modo de ser del Dasein en el que se mantiene el propio prolongarse, el extenderse de este ente, en el que se incluye en tanto destino (propio), el nacimiento y la muerte, un ente que es su entre (zwischen). El pensador de la Selva Negra, resume esto como sigue:

en la reiteración, bajo la forma de destino individual, de posibilidades sidas (gewesener), se retrotrae el "ser ahí" directamente, es decir, como temporalmente extático, a lo ya sido ante de él. Pero con este hacerse tradición (Sichüberliefern) de la herencia, y en el retroceder desde la posibilidad irrebasable de la muerte, es el "nacimiento" "alcanzado en el camino" e incluido en la "existencia", aunque solo por que ésta acepte libre de ilusiones la condición de arrojado de su peculiar "ahí"s83.

En el estado de resuelto la existencia es fiel a su propiedad, a su sí mismo, que consigue en esa vuelta atrás desde la posibilidad insuperable que es la muerte, para que lejos de encubrimientos tome sobre sí su condición de arrojado, su ahí más propio. Es una vuelta atrás desde el futuro hacia su propia condición de arrojado. En esta vuelta hacia atrás se hace tradición de su herencia, en una destinal reiteración de posibilidades sidas.

De tal forma, que el nacimiento, el comienzo, también queda incluido en la existencia:

en el "estado de resuelto" estriba la constancia existencial (existenzielle Ständigkeit) que por su esencia se ha anticipado ya a toda posible "mirada" surgente de ella. El "estado de resuelto" como destino individual es la libertad para el abandono de una determinada resolución requerido posiblemente por la situación. Por ello no queda interrumpida la constancia de la existencia, sino justo ratificada en la "mirada". La constancia ni siquiera se forma por medio ni partiendo de la agregación de los “instantes" (Augenblicken), sino

\footnotetext{
${ }^{582}$ ST, p. 421. Rivera traduce erstreckte Ständigkeit como "continuidad extensa", y Ständigkeit como "estabilidad".

${ }^{583}$ ST, p. 421.
} 
que éstos brotan de la temporalidad ya prolongada (erstreckten) de la reiteración que es siendo sida advenideramente (zukünftig gewesenden Wiederholung) ${ }^{584}$.

A juicio de Heidegger, sería ontológicamente mal comprendido el estado de resuelto, si lo entendiéramos como real, en cuanto vivencia, que dura lo mismo que el acto de resolución, dura lo mismo que el resolverse a la situación, si se lo entendiera como momentáneo, que solamente dura el instante mismo que el acto de resolverse a la situación y nada más. En el estado de resuelto subyace la posibilidad de la constancia existencial, que siempre ha anticipado ya todo posible instante que brote de la temporalidad. Es en cuanto destino individual la propia libertad para poder renunciar a una determinada decisión si es requerido por ésta. Si es exigido por la situación puede dejar de lado la determinada resolución del caso, que no significa, que con ello rompa la constancia propia de la existencia, en tanto, que la constitución propia a la constancia existencial no se articula en virtud de una reunión o acoplamiento de instantes, al modo de una siempre acumulación de ellas. Los instantes brotan, emergen desde la temporalidad ya extendida, prolongada, propia de la reiteración que advenideramente esta siendo sida. Toda vez, que es en el instante mismo en el que se reafirma la constancia propia de la existencia. Se pregunta Álvarez Gómez:

¿en qué se traduce que el presente se convierta en instante? Desde el punto de vista de la negación, en el que el ser ahí no se deje simplemente llevar, en que no se atenga sin criterio propio, a las posibilidades que le viene presentadas en su entorno, en que no se oriente primariamente por lo que piensan y hacen los demás (...) el instante implica que el ser ahí se levanta de su caída en el mundo inauténtico del se (man), de lo que se habla, se piensa y comienza a realizar su propia finitud y, en definitiva, a tomar en serio, a la vista de la muerte, que es posible en cada caso y en cada momento, meditar sobre sus posibilidades más propias ${ }^{585}$.

Por otra parte, en la historicidad impropia, el prolongarse original del destino queda cerrado, se oculta. En ella el Dasein en tanto inconstante va presentando su hoy en la inconstancia del uno mismo. El uno mismo va presentando todo lo novedoso, lo nuevo, de tal forma, que siempre ya ha olvidado lo antiguo. Va de una novedad a otra, siempre huye de una posible elección, como ya siempre ha olvidado lo antiguo, lo heredado, se le cierran las posibilidades y se le hace imposible reiterar lo sido. Solamente puede retener como lo real, como realidad de lo histórico mundano ya sido, los restos e informaciones ante los ojos de aquello que ya ha pasado. Estando sumergido en la presentación del hoy, comprende el pasado desde el presente. Por lo tanto, se cierra a una comprensión originaria y esencial de la historicidad. Solamente con base a la temporalidad originaria y a su peculiar temporalización de la temporalidad en la propiedad, se puede entender la historicidad propia, su peculiar constitución. "la temporalidad de la historicidad propia, por lo contrario, es, en cuanto "mirada" que reitera adelantando (vorlaufend-

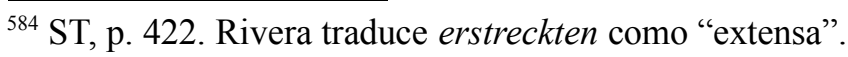

${ }^{585}$ Álvarez, M., Teoría de la historicidad, op. cit., p. 223.
} 
wiederholender Augenblick), una "despresentación" (Entgegenwärtigung) del hoy y una deshabituación de las "usualidades" del uno"

La existencia históricamente impropia, no reconoce la herencia de lo pasado, por lo que busca incesantemente lo nuevo, lo novedoso, lo moderno. Saltando de novedad en novedad. Por el contrario, "la historicidad propia comprende la historia como el "retorno" (Wiederkehr) de lo posible, y sabe de que la posibilidad solo retorna cuando la existencia es en franquía para ella en la reiteración resuelta (entschlossenen Wiederholung), en el modo de la "mirada" y bajo la forma de destino individual" 587.

\section{F. LA HISTORIOGRAFÍA Y SU FUNDAMENTO DESDE EL ADVENIR}

Por último analizaremos brevemente el origen existenciario de la historiografía que Heidegger lleva a cabo, pero solo en tanto se logre con ello, profundizar en la historicidad del Dasein y en su fundamentación propiamente temporal. Señalando además, esa prioridad o primacía, que incluso en el abrir historiográfico posee el advenir. En principio, hay que señalar que el abrir historiográficamente la historia por esencia, por su propia estructura ontológica, está fundamentado en la historicidad del Dasein y esto independiente de si se realiza fácticamente o no. Es al carácter propio de esta vinculación, al que se refiere el problema del origen existenciario de la historiografía en la historicidad del Dasein. Heidegger considera que es menester aclarar esta conexión, y proyectar ontológicamente desde la historicidad del Dasein la idea de la historiografía.

El Dasein en su ser es histórico, en razón de su constitución como temporalidad extático horizontal, está abierto en su respectivo haber sido, por lo cual la tematización del pasado puede realizarse efectivamente en la existencia. En razón de la constitución originaria del Dasein como histórico, la interpretación historiográfica ha de presentar como posible objeto del análisis a un ente que necesariamente deberá tener la forma de ser de un Dasein que ha existido, que es sido ahí. El Dasein en tanto es ser en el mundo, le es inherente en cada caso la historia del mundo, sin él no hay historia del mundo. Cuando el Dasein ya no existe más, el mundo mismo es algo que ha existido. De modo, que la historiografía se funda esencialmente en la historicidad del Dasein, por lo tanto, debe ser posible determinar de manera propia cuál es el objeto de la historia.

Con el afán de lograr delimitar y acotar el tema original de la historiografía, es necesario considerar la historicidad propia y su peculiar modalidad de apertura de lo sido ahí, el abrir del haber existido, esto gracias a la reiteración, que "comprende el "ser ahí" "sido ahí" (dagewesenes) en su posibilidad propia y sida (gewesenen). El "nacer" la historiografía de la historicidad propia significa: la primaria tematización del objeto historiográfico proyecta el "ser ahí sido ahí" sobre su más peculiar posibilidad de

\footnotetext{
${ }^{586}$ ST, p. 422.

${ }^{587}$ ST, p. 422.
} 
existencia del historiógrafo. Ésta es el fundamento existenciario de la historiografía como ciencia hasta en su operaciones "técnicas" más insignificantes" 588 . Según esto, la historicidad de la existencia del historiógrafo es el fundamento de la historiografía como ciencia.

El Dasein solo es real, es efectivo (tatsächlich) de modo propio en la existencia, su carácter de efectivo solo lo puede obtener a partir del abierto proyectarse resuelto hacia un determinado poder ser que se ha elegido, proyectarse hacia una posibilidad que se ha escogido. De forma, que el real sido ahí o haber existido, será la posibilidad existencial en la que concretamente se ha determinado el destino, ya sea, en su carácter individual, colectivo o como historia del mundo. La existencia solo puede ser lo que es, en cuanto, fácticamente arrojada.

Concretamente, el objeto propio de la historiografía es la posibilidad que ha sido fácticamente existente, y no el conjunto de acontecimientos que alguna vez ocurrieron. Su tema tampoco es un universal que se situara sobre lo singular y que lo incluyera en su apertura historiográfica. Si se interpretara de este modo, la posibilidad no podría ser reiterada ni comprendida esencialmente en su apertura propiamente historiográfica, solo se la tergiversaría, proyectándola en un "pálido modelo supratemporal" 589 . Solo la historicidad propia, en su facticidad, en tanto destino resuelto, puede:

abrir la historia "sida ahí" de tal manera que en la reiteración la "fuerza" de lo posible irrumpa en la existencia fáctica, es decir, en su "condición de advenidera" (Zukünftigkeit) advenga a ella. La historiografía no toma por tanto en manera alguna su punto de partida como tampoco la historicidad del "ser ahí" ahistoriográfico- del "presente" (Gegenwart) ni de lo real (Wirklichen) simplemente hoy, para retroceder tanteando desde ahí hacia algo pasado (Vergangenen), sino que también el abrir historiográfico se temporacía desde el advenir. La "selección" de lo que haya de resultar objeto posible para la historiografía es ya hecha en la elección existencial fáctica de la historicidad del "ser ahí" en que radicalmente surge y únicamente es la historiografía ${ }^{590}$.

Como podemos ver, ahora en el análisis de la apertura historiográfica, nuevamente Heidegger manifiesta de manera taxativa la importancia y una cierta prioridad del advenir en la estructura de la temporalidad. Si bien siempre se temporaliza a una con el ser sido y el instante, la historiografía se temporaliza primariamente desde el futuro. Por ello, "la historicidad es, pues, primariamente el modo de ser de la propia existencia humana y solo en virtud de ella lo son las cosas del mundo, los hechos y las gestas, los monumentos y los libros de los filósofos. Y solo por ella hay historiografía (Historie), el intento explícito de acercarse al propio pasado y de hacerse problema de la transmisión histórica" ${ }^{991}$.

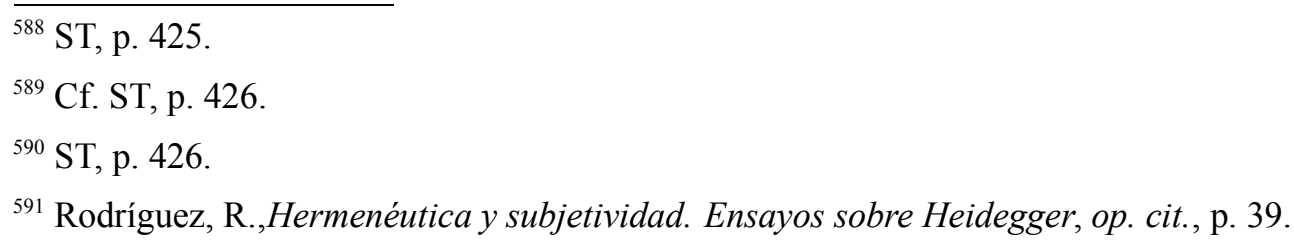


Solamente en la historicidad propia como destino individual resuelto, puede abrir la historia que ya existió, y esto lo puede hacer de tal modo, que en la reiteración lo posible surja en la existencia concreta, que advenga a ella desde la futuridad la fuerza de lo posible. Esto es así, ya que, "la base de este mismo fundamento de la historiografía propia es la temporalidad en cuanto sentido existenciario del ser del cuidado" ${ }^{, 592}$.

Mal puede la historiografía enraizarse esencialmente en el presente, en lo que hoy es efectivo, para desde allí ir retrocediendo a un pasado. También la historiografía, el saber histórico, se temporaliza fundamentalmente desde el futuro. En ésta unidad del advenir y el haber sido, el Dasein se temporaliza como presente, pero al modo de instante, posibilitando la apertura del hoy en el modo de la propiedad. Haciéndolo de tal forma, que el hoy viene a ser interpretado desde un comprender venidero, advenidero- reiterante de una posibilidad de ser del Dasein, en la que se ha tomado sobre sí, que ha asumido, que carga sobre él. El modo propio de la historiografía se transforma en una despresentación del hoy, que en lo fundamental es un desligarse, un abandonar la cadente publicidad, las novedades de lo nuevo, las habladurías propias del carácter público del hoy ${ }^{593}$.

Es importante tener muy claro, que en esta concepción de la historicidad elaborada por Heidegger, el Dasein es propiamente histórico porque es un ente temporal, su esencia es temporal, por consiguiente no es un ente que pase en el tiempo. La historicidad del Dasein se funda en la temporalidad, cuestión que tiene un peso relevante en la reformulación de pregunta por el ser que Heidegger intenta llevar a cabo.

\section{Capítulo X: El fundamento del tiempo vulgar, la concepción del tiempo como simple presente}

En el análisis y exposición de la historicidad del Dasein, se confirma que la temporalidad constituye el ser del Dasein, la existencia se determina en último término como temporal. No obstante, Heidegger señala, que "la exégesis del carácter temporal de la historia se llevo a cabo sin tomar en cuenta el "hecho" de que todo gestarse histórico transcurre en el tiempo. En el curso del análisis temporal-existenciario de la historicidad no se le concedió la palabra a la comprensión cotidiana del "ser ahí", que fácticamente solo tiene noción de la historia como un gestarse histórico “intratemporacial"(innerzeitiges) ${ }^{594}$. En este momento es de suma importancia saber qué significa aquello de que la temporalidad transcurre en el tiempo, dentro del tiempo. Por otra parte, en el análisis temporal existenciario no se consideró que la compresión peculiar a la cotidianidad solamente entiende la historia como un gestarse intratemporal,

\footnotetext{
${ }^{592}$ ST, p. 428.

${ }^{593}$ Cf. ST, p. 428.

${ }^{594}$ ST, p. 435. Rivera traduce innerzeitiges como "intratempóreo".
} 
que está dentro del tiempo, que transcurre en él. Para Heidegger, serían estas las principales carencias que no le permiten dar por suficientes los resultados obtenidos hasta ahora:

Junto a la historicidad se alza la intratemporeidad (Innerzeitigkeit), la cual no se entiende a sí misma como maduración (zeitigung) que da tiempo al tiempo mismo, sino que se orienta a lo ente en el tiempo, con lo que desde luego echa a perder el tiempo en su originariedad. La intratemporeidad no es maduración que adviniendo, esenciando y siendo en el instante de tiempo al tiempo, sino un tener presente al ente pendiente de venir con el tiempo, retener al que se ha ido hace tiempo, presenciar el ente presente ${ }^{595}$.

Dado que el tiempo originario no puede ser concebido como un hecho, como un ente más que está dentro del mundo, el filósofo nativo de Messkirch abre una nueva vía de cuestionamiento que nos lleva al fondo de la cuestión que ha guiado el tratado, y tiene que ver con la comprensión del tiempo que ha influenciado la interpretación del ser y la vida humana, que sigue los cánones de la tradición metafísica. Heidegger afirma: "toda conducta del Dasein debería ser explicada a partir de su ser, esto es, a partir de la temporalidad. Desde ahí habría que explicar el hecho fenoménico de que el Dasein cuente con el tiempo, y, en general, su comprensión vulgar del tiempo"596. Con lo cual quiere decir, que deber ser reconocida de manera expresa la importancia y el derecho propio de está fáctica interpretación óntico temporal de la historia, en otras palabras, que deben ser reconocidos los derechos de la interpretación de la cotidianidad, de la comprensión vulgar del tiempo. Por tanto, ahora se torna como problema de la mayor trascendencia la determinación precisa del sentido ontológico de dicha interpretación, y desde qué ámbito ontológico ha sido extraída dicha exégesis.

\footnotetext{
${ }^{595}$ Pöggeler, O., El camino del pensar de Martin Heidegger, op. cit., p. 74.

${ }^{596}$ Berciano, M., Superación de la metafísica en Martin Heidegger, op. cit. , p. 81.
} 


\section{A. El CONTAR CON EL TIEMPO Y EL TIEMPO DEL MUNDO}

La primera característica a la que alude Heidegger, en cuanto a la relación que el Dasein mantiene con el tiempo, en su comprensión común y corriente, es que siempre cuenta con él. El Dasein antes de realizar una conceptualización o teorización acerca del tiempo, siempre cuenta con el tiempo, se ordena y maneja en torno a esa idea que es contar con el tiempo. Más aún, ese contar con el tiempo, medir su tiempo, es anterior a todo uso de algún instrumento de medición o cálculo del tiempo, que han sido construidos específicamente para esa función. Como dice Peñalver, "el signo más claro de la imposibilidad de marginar este tiempo que no es el tiempo original o temporalidad, es que el ser ahí fácticamente siempre lo tiene en cuenta, y con mayor o menor precisión, lo cuenta, lo mide" $" 597$. Ésta es una de las primeras características de la comprensión cotidiana de tiempo, que muestra por qué es imposible desechar la comprensión vulgar del tiempo, ya que de alguna manera el contar con el tiempo está siempre presente al hablar cotidianamente del tiempo.

El Dasein cuenta siempre con el tiempo, se maneja en la cotidianidad constantemente con esta idea de tiempo que es el contar con él. Además: "existiendo fácticamente, "tiene" el "ser ahí"en cada caso "tiempo" o "no lo tiene". "Se toma tiempo" o "no puede perder tiempo". ¿Por qué se toma el "ser ahí" "tiempo” y por qué puede "perderlo"? ¿De dónde toma el tiempo? ¿Que relación tiene este tiempo con la temporalidad del "ser ahí"?"598. Estas interrogantes aquí planteadas nos sitúan en un nivel clave de la investigación que se lleva a cabo en Ser y tiempo, en el sentido de que preguntan por la procedencia interpretativa de esta idea del tiempo, desde dónde proviene esta idea de tiempo propia de la cotidianidad. Se pregunta también por la posible relación que pueda existir entre ese tiempo vulgar y la temporalidad originaria y propia, entre la concepción del tiempo como presente y como temporalidad originaria.

El Dasein anterior a cualquier teoría o concepto acerca del tiempo cuenta con el tiempo, aunque sin comprender existenciariamente la temporalidad. Sin embargo, toda esta consideración necesita una aclaración previa, puesto que todo comportamiento del Dasein debe ser interpretado esencialmente, es decir, a partir de su temporalidad. Y más específicamente, lo que Heidegger pretende es: "mostrar cómo temporacía el "ser ahí" en cuanto temporalidad una conducta que se conduce con el tiempo de aquel modo que consiste en dar cuenta de él (Rechnung trägt)" "599. Lo incompleto del análisis anterior, radica en que no se han considerado todas las perspectivas del fenómeno temporal, y esa carencia se fundamenta en que a la temporalidad le es propia algo así como un tiempo del

\footnotetext{
${ }^{597}$ Peñalver, P., Del espiritu al tiempo, op. cit., p. 223.

${ }^{598}$ ST, p. 436.

${ }^{599}$ ST, p. 436. Rivera traduce Rechnung trägt como "tomarlo en cuenta".
} 
mundo (Weltzeit), cuestión que no ha sido tematizado de forma suficiente desde la perspectiva del estricto sentido del concepto temporal existenciario de mundo.

Con el objetivo de obtener una caracterización del tiempo del Dasein en la cotidianidad, lo primero que se debe señalar, es que este ente cuenta con su tiempo, lo encuentra primordialmente en lo ente a la mano, en lo ante los ojos, y desde los entes que le hacen frente dentro del mundo. En consecuencia, el tiempo comprendido y experimentado por el Dasein desde el ámbito peculiar a la comprensión inmediata y regular del ser, lo considera como algo ante los ojos, como Vorhandensein. Debido a esto se le asigna primordialmente un carácter entitativo. Con esto queda determinada y encaminada la última fase de nuestro recorrido, que nos llevará a comprender:

cómo y por qué llega el "ser ahí" a desarrollar el concepto vulgar del tiempo" esto "pide una explicación por la constitución, temporalmente fundada, del ser del "ser ahí" que se ocupa del tiempo (zeitbesorgenden). El concepto vulgar del tiempo debe su nacimiento a una nivelación del tiempo original. La demostración de este origen del concepto vulgar del tiempo aportará la justificación de la exégesis anteriormente llevada a cabo de la temporalidad como tiempo original ${ }^{600}$.

Heidegger puntualiza de este modo las consideraciones que nos permitirán verificar de qué forma se relacionan la temporalidad originaria y la concepción vulgar del tiempo, y específicamente, desde qué suelo ontológico se origina esta idea del tiempo de la cotidianidad.

Ahora deberá quedar plenamente expuesta y justificada la temporalidad originaria en su papel de fundamento, de origen de la concepción vulgar del tiempo. Además, se ha de mostrar, la forma en que el concepto de tiempo de la cotidianidad, -en cuanto tiempo del mundo-, con el que cuenta el Dasein, tiene su origen en una nivelación de la temporalidad originaria. Esto es para Heidegger una justificación y exposición suficiente de la interpretación de la temporalidad, demostrando con ello el origen y la fundamentación de la concepción vulgar de tiempo a partir de la temporalidad originaria. Haciendo ver justamente, desde la propia legitimidad del concepto vulgar del tiempo su procedencia esencial desde la temporalidad originaria. Sí es importante destacar que esta legitimidad o derecho de la concepción vulgar del tiempo, solo tiene validez hasta el momento en que esta pretende erigirse como la única y excluyente interpretación del tiempo.

Heidegger también considera relevante explicar en qué sentido el tiempo es tiempo del mundo, y que este tiempo propio surge de esa relación que mantenemos con el mundo, en tanto entes constituidos como ser en el mundo, que nos convierte en inseparables, no hay mundo sin Dasein ni Dasein sin mundo A la constitución misma de la temporalidad le es inherente un tiempo del mundo. No obstante: "la pregunta por el estatuto "legal" del Weltzeit se prolonga naturalmente y se complica con el problema de cómo se traduce a

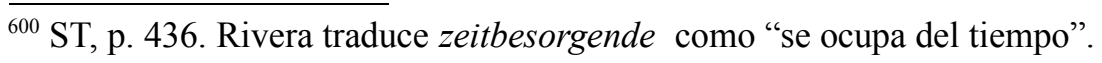


concepto aquella experiencia del tiempo. De Aristóteles a Hegel, y Bergson y a Husserl, a través de lenguajes tan diversos, la historia de la filosofía habrían enseñado siempre la misma idea de tiempo, esto es, como secuencia homogénea de ahoras" ${ }^{601}$. A juicio de Heidegger, para exponer el tiempo del mundo, es menester una determinación más concreta de aquella dualidad presente en la interpretación del concepto del tiempo, que según su determinación histórica, se debate entre una interpretación objetiva o subjetiva, estas últimas interpretaciones son las dominantes a lo largo de la historia de la filosofía. Es menester tener presente que el Dasein, su tiempo originario, no puede ser entendido bajo las categorías de sujeto objeto, substancia, pues este ente es existencia. Tampoco se ha de concebir el tiempo según la imagen de la eternidad, como un tiempo infinito, que pasa y se proyecta hacia la infinitud.

\section{B. TIEMPO DEL AHORA, COMO TIEMPO DE LA OCUPACIÓN DE LO QUE HACE FRENTE EN EL MUNDO}

En la historia del concepto del tiempo, tal como hemos visto en la primera parte de nuestro trabajo, hay una idea que ha dominado sin contrapeso todas las interpretaciones que ha elaborado la tradición filosófica, en las que se comprende al tiempo como una secuencia homogénea de ahoras. Desde esta perspectiva el ahora presente poseería una destacada primacía. El filósofo alemán comenta que esta concepción, en la cual:

el ocuparse de (Besorgen) comprensor en el sentido del "ver en torno" (Umsichtig) se funda en la temporalidad en el modo del presentar reteniendo y estando a la expectativa (gewärtigend-behaltenden Gegenwärtigens). Como calcular, planear, tomar providencias y precauciones ocupándose de, dice siempre ya, lo mismo si es fonéticamente perceptible que si no: "luego" (dann)-debe suceder tal cosa, "antes" (zuvor)-despacharse tal otra, "ahora" (jetzt)-intentarse de nuevo aquella que "entonces" (damals) falló, pasando la ocasión ${ }^{602}$.

Consecuente con esto, la perspectiva de interpretación del tiempo de la cotidianidad, en la cual le es dado un tiempo al Dasein, el luego manifiesta siempre, explícitamente o no, una referencia a un ahora todavía no. Por otra parte, el entonces se refiere a un ahora ya no más. No es difícil concluir que el luego y el entonces se comprendan y entiendan desde su específica relación al ahora, qué es el que los determina primariamente.

El ahora todavía no propio del luego, del posteriormente, se expresa por medio de la presentación que está a la expectativa y retiene, el ahora ya no más peculiar al entonces nombra al retener (Behalten) en tanto presente (Gegenwärtigen) que está a la expectativa (gewärtigendes). El ahora se demuestra como decisivo y determinante al momento de hablar del tiempo en la cotidianidad. El entonces y el luego solo se constituyen como tales, sino en la específica relación que mantengan con el ahora. Lo que significa que la presentación, el presente, tiene una prioridad, una primacía absoluta sobre las demás

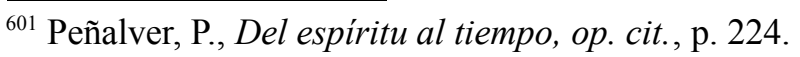

${ }^{602}$ ST, p. 438. 
instancias temporales. En esta interpretación del tiempo (que prioriza al presentar y que se temporiza de modo determinado), el Dasein se enreda, se pierde en el puro presente, que va constantemente presentando y repitiendo a cada momento ahora, ahora, ahora.

Al Dasein se le da, se le asigna un tiempo, cuenta con un tiempo, como un presente que retiene a un antes y que está a la expectativa, a la espera de un después, pero siempre bajo la primacía y tutela de un ahora. Es un ahora que ya pasó, que fue antes y un ahora que será posteriormente, más tarde, después: "Pero todo "luego" es en cuanto tal un "luego cuando...", todo "entonces" un "entonces cuando....", todo "ahora" un "ahora que...". Llamamos a esta estructura relacional de los "ahoras", "entonces" y "luegos", aparentemente comprensibles de suyo, la "fechabilidad" (Datierbarkeit)" indica así la primera característica del tiempo del ocuparse; la fechabilidad. El ahora es una ahora en el que pasa una cosa u otra, el luego es un luego cuando, y de la misma forma, el entonces es un entonces cuando, ésta especifica modalidad de relacionarse de las instancias temporales así tematizadas, es el fundamento de esa fechabilidad. Fechabilidad establecida en virtud de la ausencia o presencia de lo real en el ahora presente.

No obstante, surge la pregunta, ¿de qué cosa forma parte esencialmente esta fechabilidad y en qué se funda? Heidegger sugiere que esa pregunta es de algún modo superflua y sin sentido. La razón es que comprendemos de manera indudable y sin mayor dificultad, el ahora que, el luego cuando, y el entonces cuando, en conexión o vinculado con el tiempo. Sin embargo, que comprendamos esa vinculación con el tiempo, no significa que también conozcamos el tiempo mismo, ni menos su ser. Tampoco nos lleva a entender qué pueda significar el tiempo ni como es posible ese tiempo en su proveniencia original. De tal forma, que si bien utilizamos constantemente conceptos, ideas, palabras, relacionadas con el tiempo, no sabemos qué significa tiempo, de dónde procede el tiempo, menos podemos saber qué pueda ser el tiempo.

Heidegger plantea la pregunta: “¿Por qué el "ser ahí”, al decir algo de aquello de que se ocupa, da simultánea expresión, si bien por lo regular sin fonación, a un "ahora, que...", "luego, cuando...", “entonces, cuando...?"604. Esto sucede porque cuando el Dasein se refiere a algo, se interpreta y expresa también a sí mismo. Al referirse a las cosas, a lo a la mano, a lo ante los ojos, al mismo tiempo se interpreta a sí mismo a partir de ellas, lo que se funda en una presentación y solo es posible como tal.

La comprensión propia a la cotidianidad no posee en modo alguno un conocimiento o comprensión de la temporalidad originaria propiamente tal, ni menos puede esta interpretación de la inmediatez reconocer el origen del tiempo, respecto a esto Heidegger señala:

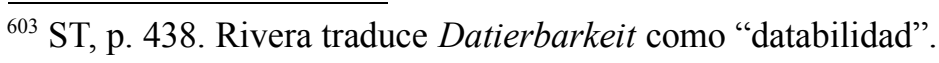
${ }^{604}$ ST, p. 439.
} 
Por constituir horizontal-extáticamente la temporalidad el "estado de iluminado" del "ahí", es por lo que es ella originalmente interpretable ya siempre en el "ahí", con lo que se tiene noción de ella. El presentar que se interpreta a sí mismo, es decir, lo interpretado que se expresa en el "ahora", es lo que llamamos "tiempo". En ello se da a conocer simplemente que de la temporalidad cabe tener noción en cuanto extáticamente patente, más aún, inmediata y regularmente (zunächst und zumeist) solo se tiene noción de ella en este "estado de interpretada" de la ocupación (besorgenden) ${ }^{605}$.

Se reafirma así lo planteado anteriormente, en cuanto a que la comprensión del tiempo como presente, primordialmente como ahora, es lo que domina la comprensión de la cotidianidad. Toda posible determinación del tiempo desde la cotidianidad se hace en referencia a una relación positiva o negativa con el presente, con el ahora. Es una temporalidad que se interpreta a sí misma desde lo que es objeto de ocupación.

La comprensión guiada por el ahora, luego y entonces, determina la estructura de relación que llamamos fechabilidad, esta es una prueba decisiva de que esta interpretación se enraíza en la temporalidad que se comprende a sí misma desde lo que es objeto de ocupación, de las cosas del mundo:

El "ahora" interpreta un presentar (Gegenwärtigen) entes. En el "ahora, que..." está implícito el carácter extático del presente (Gegenwart). La fechabilidad (Datierbarkeit) de los "ahoras", "luegos" y "entonces" es el reflejo de la constitución extática de la temporalidad y por tanto esencial al tiempo mismo. La estructura de la fechabilidad de los "ahoras", "luegos" y "entonces" es la prueba de que ellos, nacidos del tronco de la temporalidad, son ellos mismos tiempo. El expresar, interpretando, los "ahoras", "luegos" y "entonces" es la más original indicación del tiempo ${ }^{606}$.

En esta perspectiva, el tiempo es interpretado en relación a lo que es objeto de ocupación, le es inherente en todo momento una fechabilidad basada en los entes que le hacen frente en el estado de abierto del ahí. En la fechabilidad no es comprendida de forma originaria la unidad extática de la temporalidad ni menos aún es conocida. Sin embargo, ella es el origen o fundamento de la comprensión de la cotidianidad. En esta unidad extática el Dasein es siempre ya su estado de abierto, su aperturidad para sí mismo, en tanto ser-enel-mundo ya siempre le están descubiertos los entes intramundanos.

Desde aquel ámbito interpretativo que abre el ahora, luego y entonces, Heidegger reconoce que aquellos fenómenos son la más inmediata y perceptible indicación del tiempo, por tanto, se les debe reconocer su propio derecho, en razón de su origen a partir de la temporalidad extática. Pero además, son la indicación más cierta de la idea de tiempo que obtenemos desde la inmediatez:

la ocupación presentando, reteniendo y estando a la expectativa (gewärtigend-behaltendgegenwärtigende Besorgen) "se da" de una u otra forma tiempo y se indica éste ocupándose de él, aun sin ninguna determinación del tiempo y antes de toda determinación de éste que específicamente "cuente" (rechnenden). El tiempo se fecha

\footnotetext{
${ }^{605}$ ST, p. 440.

${ }^{606}$ ST, p. 440.
} 
(datiert) aquí, en el modo del caso del darse tiempo (Sich-Zeit-lassens) de la ocupación, por aquello de que en cada caso justamente es objeto de ocupación en el mundo circundante, por lo abierto en el comprender encontrándose (befindlichen Vestehen Erschlossenen), o por lo que uno va haciendo "a lo largo del día"

Esto significa que en el estar a la expectativa inherente a la ocupación, el Dasein queda absorto en sus quehaceres inmediatos, se sumerge en ellos, no se ocupa de sí mismo, sino que se desentiende y desatiende a sí mismo, lo que trae como consecuencia que se olvida de sí mismo, se pierde.

Junto con quedar absorto en los entes que son objeto de ocupación, el tiempo que se da a sí mismo le queda oculto, precisamente por esa misma forma de dar, que viene justamente desde el ocuparse. Sin embargo, en el vivir cotidiano el Dasein nunca comprende su existencia como si ella se sucediera como un conjunto de simples ahoras, como si transcurriera en un continuo constituido por una serie de ahoras. En razón de este mismo ocultamiento, el tiempo que el Dasein se da tiene múltiples fallos e inexactitudes. Muchas veces no somos ni siquiera capaces de reconstruir un día completo de nuestros múltiples quehaceres y ocupaciones, de tal forma, que si nos volvemos sobre el tiempo que hemos usado, podemos reconocer una carencia o falta de constancia, de integridad del tiempo transcurrido, lo que no significa una discontinuidad o despedazamiento del tiempo, sino que es un modo de la temporalidad y de su apertura extática, en cuanto prolongada, extendida.

La forma en que transcurre (verläuft) el tiempo que nos damos y la manera como la ocupación lo determina para sí, solo se podrá reconocer si determinamos su proveniencia esencial, si nos distanciamos de la interpretación del tiempo como un flujo continúo de ahoras, en cuanto puro presente. Es menester, comprender las formas posibles en que el Dasein se da y deja tiempo, que deben ser interpretadas esencialmente desde la modalidad del Dasein que acorde al modo fáctico y concreto de su existencia, tiene tiempo, se da tiempo. Heidegger precisa en relación a esto:

resulta la señal distintiva de la temporalidad de la existencia propia en el que "el estado de resuelto" no pierde tiempo nunca, sino que "siempre tiene tiempo"(immer Zeit hat). Pues la temporalidad del "estado de resuelto" tiene, en lo que se refiere a su presente (Gegenwart), el carácter de la "mirada", cuyo presentar (Gegenwärtigen) la situación, que es el presentar propio, no tiene él mismo la dirección, sino que es tenido en el advenir que va siendo sido (gewesenden Zukunft). La existencia de la mirada se temporacía como prolongación total (ganze Erstrecktheit) del destino individual, en el sentido de la "constancia" histórica, y propia, del "mismo". La existencia temporal de esta forma tiene "constantemente" tiempo para lo que la situación pide de ella. Pero el "estado de resuelto" abre el "ahí", de esta forma, solo como situación. De donde el resuelto nunca pueda lo abierto hacerle frente de tal manera, que no resuelto, pueda perder su tiempo ${ }^{608}$.

\footnotetext{
${ }^{607}$ ST, p. 441.

${ }^{608}$ ST, p. 442.
} 
El filósofo de la Selva Negra retoma también en esta parte de su trabajo el análisis sobre la posibilidad de la propiedad e impropiedad de la existencia fundado en las distintas modalidades de temporalización de la temporalidad. La impropiedad del Dasein, en tanto irresolución, se temporaliza en la forma de una presentación que no está a la expectativa y olvida (ungewärtigend-vergessend Gegenwärtigens), así el Dasein se comprende a partir de lo que es objeto de ocupación, desde los acontecimientos y azares propios a la inmediatez, que por varias direcciones le aparecen y le hacen frente, que le oprimen en la presentación de la irresolución. Es la raíz de aquella expresión característica de la cotidianidad no tengo tiempo para nada (Ich habe keine Zeit). El que existe irresoluto, en la impropiedad de la existencia, pierde, extravía constantemente el tiempo y nunca tiene tiempo ${ }^{609}$.

La posibilidad del Dasein de perder el tiempo, de dejar pasar el tiempo se fundamenta en la constitución ontológica de este ente, tal como dice Heidegger:

"el "ser ahi" fácticamente arrojado (geworfene) solo puede "tomarse" tiempo y

perderlo, porque en cuanto temporalidad extáticamente prolongada le es concedido con

el "estado de abierto" del "ahi", estado fundado en tal temporalidad, un "tiempo"610.

Falta por determinar desde qué perspectiva interpretativa se puede sostener que el tiempo que hemos analizado es, más aún, si cabe la posibilidad de hablar del tiempo como ente. Debemos preguntarnos en qué sentido el tiempo público es, en otras palabras, se debe determinar el carácter fenoménico del tiempo público (öffentlichen Zeit). Heidegger considera oportuno advertir, que este tiempo público alcanza a la totalidad del mundo, y no solo a unos pocos Dasein que hayan elegido regirse según él, por el contrario, le es peculiar a todo Dasein, por lo que debiera ser encontrado por cualquiera que lo quisiera hallar. Si bien, el ocuparse del tiempo puede darse en forma de una fechabilidad, establecida con base a los hechos que acontecen en el mundo circundante, eso siempre ocurre en el ámbito de un ocuparse del tiempo que Heidegger llama cómputo astronómico del tiempo especificado por el calendario. Y esto es de tal manera, que: "por existir esencialmente el "ser ahí", en cuanto arrojado, cayendo, interpreta su tiempo, en la ocupación, en el modo de un contar el tiempo (Zeitrechnung). En este modo se temporacía el "hacerse público" "propio" del tiempo, de tal manera que hay que decir que la condición de arrojado del "ser ahí" es el fundamento de que "se dé" públicamente un tiempo (öffentlich Zeit)" ${ }^{\prime \prime 11}$.

\footnotetext{
${ }^{609}$ Cf. ST, p. 442.

${ }^{610} \mathrm{ST}$, p. 442

${ }^{611}$ ST, p. 444.
} 


\section{LA INTRATEMPORALIDAD COMO TIEMPO PÚBLICO}

Una vez expuesta la fechabilidad y su específica estructura de relación con las instancias del tiempo, que en un primer momento se reveló como vinculada con los hechos o acontecimientos del mundo, Heidegger señala que esa conexión se origina en el horizonte de un contar con el tiempo propia a un cómputo astronómico del tiempo. De forma, que el tiempo entendido como una simple secuencia de ahoras, se transforma ahora en tiempo público: "el tiempo patente (öffentliche Zeit) aparece como aquel tiempo en el que se encuentra el ente intramundano que está a la mano o ante la vista. Esto hace que a estos entes, diferentes del Dasein, haya que considerarlos como intratemporales (innerzeitiges) ${ }^{\prime 612}$. En consecuencia, si el Dasein existe fácticamente, en cuanto caído, en el inmediato ocuparse de lo que le hace frente, interpreta el tiempo en forma de cálculo del tiempo, lo concibe como un ente del cual puede hacer un determinado cálculo, una medición. En esta interpretación fáctica del tiempo es en la que se origina el tiempo público, que se caracteriza como el tiempo en el que comparecen los entes que hacen frente dentro del mundo, los entes con la forma de lo a la mano, de lo ante los ojos, los llamados entes intratemporales; denominación que Heidegger les da a todos los entes que no son al modo de la existencia, que no tiene la constitución propia del Dasein. Este ente en la inmediatez se absorbe de forma constante en una comprensión pragmática de todo lo que le hace frente en el mundo, de lo que rodea, del tiempo, incluso de su propio ser. Entiende el tiempo exclusivamente desde el horizonte del tiempo público, del tiempo del mundo.

Los entes intratemporales para poder relacionarse necesitan poder ver, necesitan claridad. En razón de su condición de arrojado, el Dasein está siempre entre el día y la noche, entre ese constante ir y venir de la oscuridad y la luz, por una parte, el día hace posible la claridad, y por otra, la noche posibilita la oscuridad. Dice Heidegger: " la ocupación hace uso del "ser a la mano" del Sol, que dispensa luz y calor. El Sol es lo que fecha el tiempo interpretado en el ocuparse. De este fechar brota la medida "más natural" del tiempo, el día"613. Según esto, el Dasein fecha el tiempo que tiene que tomar para sí y lo realiza teniendo como referencia al Sol, que es aquel ente que le brinda la claridad para poder ver, para poder ocuparse de lo a la mano. Por ser la medida natural, el Sol puede ser la referencia para fechar el tiempo de la ocupación, de la cotidianidad. Entendido de este modo, sería el Sol como el eterno peregrinante, el instrumento de medida para fechar el tiempo propio de la cotidianidad.

Desde esta particular fechabilidad podemos ver cómo surge la medida más natural del tiempo, el día. El tiempo es medido con base a la referencia más elemental y básica que nos entrega la naturaleza para medir el tiempo, el incesante transcurrir del día y la

\footnotetext{
${ }^{612}$ Berciano, M., Superación de la metafisica en Martin Heidegger, op. cit., p. 82.

${ }^{613}$ ST, p. 445.
} 
noche. El continuo transitar del Sol peregrinante es lo que toma en cuenta el Dasein, en tanto arrojado en el mundo, dándose tiempo a sí mismo. Justamente, “el gestarse histórico del "ser ahí" es, sobre la base de la interpretación del tiempo que fecha y que se haya trazada por anticipado en la condición de arrojado en el ahí, un gestarse "día a día"" Esto supone, que en la raíz de la interpretación propia de la cotidianidad, de la impropiedad del Dasein, está la idea del tiempo como fechable. Por tanto, el gestarse del Dasein, sería un gestarse cotidiano. En este continuo fechar y datar propio de la interpretación bosquejada desde la condición de arrojado, se constituye el gestarse de la cotidianidad, "esta estructura relacional de los instantes del tiempo es la base de la fechabilidad. Esta se constituye en principio en conexión con los acontecimientos del mundo, pero esa conexión se gesta en el horizonte más o menos expresado de un contar con el tiempo por medio de los astros. Así el tiempo, secuencia de ahoras, se convierte en público" $" 15$

Ese tiempo público, fechado en referencia al Sol, a la claridad que este posee y dona con base a sus distintas posiciones en el cielo, es una modalidad de indicar el tiempo al que cualquiera y en cualquier lugar puede acceder. Todos pueden llevar a cabo esta fechabilidad y además pueden entender esta indicación del tiempo. Esto porque en la coexistencia, en nuestro ser con otros, en cuanto ser en el mundo, todos nos encontramos bajo el mismo cielo. En esta fechabilidad de alguna manera todos concuerdan:

Mi comportamiento natural con el tiempo se sostiene ya siempre en un convivir con otro Dasein. En este convivir comparto con los otros no solo la comprensión, la develación de las maneras de comportarse con el ente intramundano, sino con éste, sobre todo la comprensibilidad del correspondiente ahora, luego, entonces. El tiempo del ahora, entonces, luego, esencialmente comprensible y compartido en el convivir con otro Dasein, se muestra como (...) momento estructural, la publicidad ${ }^{616}$.

Todos pueden contar con esta fechabilidad propia del tiempo público, en la cual cada uno señala para sí mismo su propio tiempo, en ella se utiliza una medida que es de público conocimiento, y la forma de considerar el tiempo en la fechabilidad tiene el sentido de una medición, de un cálculo, y para ello, se necesita un instrumento que mida el tiempo, se necesita algo como un reloj. Según Heidegger: "Esto implica lo siguiente: con la temporalidad del "ser ahí" arrojado, abandonado(überlassenen) al "mundo" y que se da tiempo (zeitgebenden), es también ya descubierto lo que se dice un "reloj", esto es, algo "a la mano" que en su retorno regular se ha hecho accesible en el presentar estando a la expectativa" $" 617$

\footnotetext{
${ }^{614}$ ST, p. 445.

${ }^{615}$ Peñalver, P., Del espiritu al tiempo, op. cit., p. 225.

${ }^{616}$ Herrmann, F.,"El concepto del tiempo según Heidegger”, op. cit., p. 97.

${ }^{617}$ ST, p. 445.
} 
El pensador alemán alude así al hecho de que en la temporalidad inherente al Dasein arrojado, que se da tiempo a sí mismo, está siempre presente algo así como un instrumento natural de medición y cálculo del tiempo, lo que podríamos denominar como un reloj natural. Es un ente a la mano que en el continuo transcurrir del día y la noche brinda claridad y alternancia entre la luz y la oscuridad. El astro que brinda luz y calor, el Sol peregrinante en distintas posiciones del cielo es el reloj natural, elemental, es además, el fundamento de todo posible reloj.

Por otra parte, la forma de interpretar el tiempo peculiar al ocuparse, siempre es entendida como un tiempo para... (Zeit zu). De tal modo, que el tiempo con el que cuenta el Dasein cotidiano, el tiempo que se da, es siempre apropiado o inapropiado, podemos decir que le es inherente algo así como un carácter de utilidad. Cualquier modalidad de interpretar el tiempo sea el ahora, luego o entonces, en tanto fechable, está determinado esencialmente, por una estructura, la de ser apropiado (geeignet) y la de ser inapropiado (ungeeignet), que revela su carácter utilitario. Como comenta Herrmann: "El tiempo que busco determinar con el vistazo sobre el reloj es, como ahora, se muestra siempre y esencialmente "Tiempo para"; esto quiere decir, tiempo con el fin de hacer esto o aquello en él. Para todas mis relaciones con el ente de mi respectivo mundo circundante me tomo tiempo. El tomarse tiempo que aún precede al ver el reloj es una manera natural de comportamiento con el tiempo" $"$.

El tiempo así entendido tiene un carácter de un tiempo para o de un no tiempo para, por lo que se comprende el tiempo como referido a un para-qué. El tiempo público basado en la fechabilidad, que tiene ese carácter de un para-qué, de un para algo, nos revela la estructura de la significatividad (Bedeutsamkeit), que constituye la mundanidad del mundo. Por lo tanto, "el tiempo hecho publico (veröffentlichende) tiene, en cuanto tiempo de..., esencialmente carácter mundano (Weltcharakter). De aquí que llamemos al tiempo que se hace público en la temporación de la temporalidad el "tiempo mundano" (Weltzeit). Y esto no porque sea "ante los ojos" como un ente intramundano (innerweltliches), lo que no puede ser nunca, sino porque es inherente al mundo en el sentido de la exégesis ontológico existenciaria" ${ }^{\prime 19}$. En decir, a este tiempo que se hace patente en virtud de la temporalización de la temporalidad se llama el tiempo del mundo.

El tiempo publico en cuanto fechabilidad, tiene el carácter de significatividad, en tanto, que el tiempo con el que cuenta, el tiempo que el ser ahí cotidiano se da, resulta ser apropiado o inapropiado para algún u otro quehacer, esto en razón de su significatividad. "El tiempo que me tomo para tratar así o asá con éste o aquel ente ente determinado respectivamente, el tiempo, en el que yo trato con el ente intramundano y en el que se me

\footnotetext{
${ }^{618}$ Herrmann, F., “El concepto del tiempo según Heidegger”, op. cit., p. 94. ${ }^{619}$ ST, p. 447.
} 
muestra este ente como lo que es, está por su parte determinado por las relaciones significativas $"{ }^{20}$, por eso, este tiempo como significativo es tiempo del mundo.

Ahora sí Heidegger se encuentra en posición de dar forma y caracterizar concretamente la estructura del tiempo del que nos ocupamos, este tiempo publico es fechable (datierbar), público (öffentlich) y tenso (gespannt), es inherente y parte del mundo. Pero, como significativo, el tiempo es tiempo del mundo, pero no se quiere decir con esto que sea intramundano, sino inherente al mundo, este tiempo es respecto a la temporalidad originaria lo fundado y delimitado por ella, por eso se dice que es intratemporalidad y coincide con la mundanidad ${ }^{621}$. Berciano expresa esto de la siguiente forma:

el tiempo está, pues relacionado con el Dasein, este es ontológico-existencialmente temporal. Al Dasein le pertenece la temporalidad, la cual temporaliza el tiempo del mundo (Weltzeit). Como puede verse, esta manera de entender el tiempo no es la corriente.El Dasein, en el cuidarse de los entes, o en ocuparse de ellos, entiende el tiempo de modo vulgar, como una sucesión de "ahoras". A esta comprensión vulgar se le escapan tanto la significatividad (Bedeutsamkeit), que pertenece a la estructura del "ahora" y hace que el tiempo sea tiempo del mundo, como la constitución extático temporal de la temporalidad ${ }^{622}$.

El concreto hacerse tiempo público de la ocupación está fundado en la temporalidad del Dasein, específicamente en una determinada modalidad de temporalización. Se ha de dilucidar en un plano ontológico-existenciario el modo de la temporalización de la temporalidad, que se manifiesta en la interpretación inherente al cálculo del tiempo, en este caso específico, en el uso del reloj. Lo que permitirá obtener una comprensión de la proveniencia y validez peculiar a la medición del tiempo. El concreto hacerse público el tiempo, propio de la ocupación, está fundado esencialmente en la temporalidad del Dasein, de forma especifica en un determinada modalidad de temporalización de la temporalidad.

Se ha de mostrar la específica conexión entre el uso del reloj y la temporalidad que se toma tiempo. Al momento de preguntar por la hora del reloj, lo que se hace es preguntar por el tiempo en el que se está. Utilizar el reloj para medir el tiempo, se fundamenta en la temporalidad del Dasein, que es la que hace posible el estado de abierto del Dasein, posibilitando del mismo modo el fechar el tiempo del que nos ocupamos. Al preguntarnos en qué tiempo se está, al mirar el reloj para ver la hora, se reconoce una acción que se origina y se dirige a un tomar tiempo para sí, tomarse tiempo (einem Sich-Zeit-nehmen), y se afirma constantemente: ahora es esta u otra hora, ahora es tiempo para tal o cual quehacer. Ahora no hay tiempo, ahora es esta hora, ahora todavía hay tiempo, ahora ya pasó el tiempo. Tal forma de preguntar por el tiempo en que se está, toda determinación de la hora en esa perspectiva, está fundamentada y referida al ahora, al simple presente.

\footnotetext{
${ }^{620}$ Herrmann, F., "El concepto del tiempo según Heidegger”, op. cit., p. 96.

${ }^{621}$ Cf. Peñalver, P., Del espiritu al tiempo, op. cit., p. 226.

${ }^{622}$ Berciano, M., Superación de la metafisica en Martin Heidegger, op. cit., p. 83.
} 


\section{Medición y CÁlCULO DEL TIEMPO}

Regirse y conducirse por el tiempo propio de la ocupación mirando la hora del reloj es esencialmente un decir ahora, y según Heidegger, este es "un articular con el habla un presentar que se temporacía en su unidad con un estar a la expectativa reteniendo. El fechar que se lleva a cabo en el uso del reloj se revela como señalado presentar algo "ante los ojos". El fechar no hace simple referencia a algo "ante los ojos", sino que el mismo hacer referencia tiene el carácter de medir (Messens)" "623. Este fechar midiendo (messenden Datierung $)^{624}$ perteneciente a la interpretación del tiempo del ocuparse, se considera principalmente en términos de una relación negativa o positiva referida a los ahoras presentes, en otras palabras, se lleva a cabo aludiendo principalmente al presente. Por tanto, se interpreta el tiempo en un presentante observar algo en la forma de lo ante los ojos, que en cuanto medida, calculo, solo puede ser accesible gracias a un determinado presentar. Heidegger explica esto como sigue: "por tener en el fechar midiendo una especial primacía el presentar lo presente (Gegenwärtigen von Anwesendem), es por lo que la lectura métrica del tiempo (Zeitmessung) en el reloj se expresa también en un señalado sentido con el ahora. En la medición del tiempo se lleva a cabo, por ende, un hacerlo público (Veröffentlichung) con arreglo al cual el tiempo hace frente en cada caso y en todo tiempo para todo el mundo como un "ahora y ahora y ahora"" 625 .

El tiempo comprendido de este modo, es exclusivamente pensado en relación a un ahora inmediatamente presente. Y el tiempo en que se está, que es medible en la lectura del reloj, se manifiesta como tiempo público, como una multiplicidad presente de ahoras. El pasado y el futuro solo adquieren sentido en la relación que guarden con el ahora presente. De modo, que no necesariamente la medición del tiempo así determinada, está conducida hacia una comprensión del tiempo en su constitución esencial. "Con una vistazo sobre el uso del reloj, hemos descrito solamente la primera manera en la que nosotros nos comportamos con el tiempo al interior de nuestra comprensión natural del tiempo" ${ }^{926}$.

Esta medición del tiempo enraizada en la interpretación del tiempo de la ocupación, le otorga al tiempo un marcado carácter de público, por tanto, todos podemos de una manera $u$ otra conocer aquello que denominamos tiempo. En los quehaceres cotidianos constantemente le damos a cada ente su tiempo. De forma, que las cosas solo pueden tener tiempo porque están en el tiempo (in der Zeit), incluidos en él, por lo tanto, cualquier ente intramundano tiene tiempo. Al tiempo propio del encontrarse el Dasein con los entes intramundanos, al tiempo en que hacen frente estos entes, Heidegger lo llama el

\footnotetext{
${ }^{623}$ ST, p. 449.

${ }^{624}$ Rivera traduce messenden Datierung como "datación mesurante".

${ }^{625}$ ST, p. 449.

${ }^{626}$ Herrmann, F., “El concepto del tiempo según Heidegger”, op. cit., p. 93.
} 
tiempo del mundano o tiempo del mundo(Weltzeit). Aquello que está en el mundo, está también en el tiempo, dentro del tiempo, de modo que es intratemporal (innerzeitiges), esto es algo muy distinto a decir que su ser es temporal, ya que, solamente el Dasein puede ser, en otras palabras, solo el Dasein es temporal esencial y originariamente.

En cuanto tiempo público del mundo, la perspectiva del ocuparse del tiempo en medio del ente intramundano, comprende a los entes como algo, que comparece en el tiempo, dentro del tiempo, pero este tiempo no es subjetivo ni objetivo, por ello dice Heidegger:

el tiempo "en que" se mueve y reposa lo "ante los ojos" no es "objetivo", si con este
término se mienta el "ser ante los ojos en sí" (An-sich-vorhanden-sein) de los entes que
hacen frente dentro del mundo (innerweltlich). Pero tampoco es el tiempo "subjetivo", si
por este término comprendemos el "ser ante los ojos" (Vorhandensein) y venir a estar
delante en un "sujeto". El tiempo mundano es más "objetivo" que todo posible objeto,
porque, como condición de posibilidad de los entes intramundanos, resulta "objetivado"
horizontal-extáticamente en cada caso ya con el "estado de abierto" del mundo".

Solamente el Dasein es temporal en esencia, él es temporalidad y no puede estar dentro del tiempo a la manera en que está un ente intratemporal. El mundo no es nunca ni objetivo ni subjetivo, estas categorizaciones propias de la filosofía clásica no pueden dar cuenta de forma originaria de la esencia del mundo. Estas categorías, serían por tanto, completamente incapaces de caracterizar la constitución esencial del mundo, por eso, "para superar el doble error de subjetivizar el tiempo o de objetivizarlo, se requiere "una clara visión de ambas posibilidades". Es lo que debe proporcionar el análisis de cómo el ser ahí cotidiano "llega a concebir teóricamente el tiempo" tiempo del mundo con el que cuenta el Dasein cotidiano, tampoco puede llamarse ni objetivo ni subjetivo. Sin embargo, si se trabajara con aquel marco conceptual, habría que afirmar según Heidegger, que el tiempo del mundo es más objetivo que cualquier objeto.

El tiempo del mundo se lo encuentra tan inmediatamente en lo físico, (no solo en lo psíquico), que por ello es posible que se pueda situar un objeto determinado en el mundo. "Pero el tiempo mundano (Weltzeit) es también más "subjetivo" que todo posible sujeto, porque, dado el sentido bien comprendido del cuidado como el ser del "mismo" fácticamente existente, contribuye a hacer radicalmente posible este ser" ${ }^{29}$. Por eso, el filósofo de la Selva Negra sostiene que el tiempo del mundo es más subjetivo que cualquier posible sujeto, porque en él descansa la posibilidad de ser del sí mismo fácticamente existente. El tiempo no es algo al modo de lo ahí delante ante los ojos, no es un objeto, tampoco un sujeto, no es un ente que está ahí en el sujeto ni en el objeto. No está dentro ni tampoco está afuera, ya que, es anterior a cualquier objetividad o subjetividad, representa la condición de posibilidad de la misma anterioridad.

\footnotetext{
${ }^{627}$ ST, p. 452.

${ }^{628}$ Peñalver, P., Del espiritu al tiempo, op. cit., p. 226.

${ }^{629} \mathrm{ST}, \mathrm{p} .452$.
} 
La temporalidad temporaliza el tiempo del mundo que constituye la intratemporalidad de lo a la mano y de lo ante los ojos. Por tanto, si este tiempo del mundo se enraíza en la temporalización de la temporalidad, no podrá comprenderse de un modo subjetivista ni entenderse como cosa a través de una categoría de objeto. Para poder ir más allá de esta categorización del tiempo según el prisma de la subjetividad u objetividad, se debe alcanzar una perspectiva amplia de ambas interpretaciones. "La temporalidad, en cuanto extático horizontal, temporaliza algo así como tiempo del mundo, el cual constituye una intramporeidad de lo real y de lo que está a la mano. Pero este ente nunca se podrá llamar temporal en sentido estricto" ${ }^{630}$, razón por la cual, se ha de analizar la idea que el Dasein cotidiano tiene del tiempo, además queda sin determinar la proveniencia originaria de ésta comprensión del tiempo vulgar desde la temporalidad originaria. "E1 cotidiano ocuparse que se da tiempo encuentra "el tiempo" en los entes intramundanos que hacen frente "en el tiempo". De aquí que el esclarecimiento de la génesis del concepto vulgar del tiempo tenga que tomar como punto de partida en la intratemporalidad (Innerzeitigkeit)" ${ }^{\prime 631}$.

Estudiar y analizar la génesis del concepto vulgar del tiempo, tiene para Heidegger una importancia señalada, en dicha interpretación se fundamenta la imposibilidad del Dasein de la cotidianidad de comprender la temporalidad originaria, la esencia del Dasein como tiempo, es precisamente aquello lo que impide al Dasein una comprensión originaria y esencial de la temporalidad. Ese concepto vulgar del tiempo es lo que lleva al Dasein a una comprensión del tiempo referido fundamentalmente al ámbito de lo intratemporal, lo que le lleva a comprender el tiempo como infinito. Pero vamos por partes, en primer lugar para entender la génesis del concepto vulgar del tiempo, Heidegger analiza lo que concretamente hace el Dasein cotidiano con el tiempo, con el afán de determinar lo que efectivamente hace este ente con el tiempo, cómo se muestra para la ocupación cotidiana el tiempo, cómo se hace accesible ese tiempo. Con la aperturidad del mundo el tiempo se hace público, y en el estar descubierto el ente intramundano siempre el tiempo se ha vuelto objeto de ocupación, el Dasein estando consigo mismo, calcula su tiempo, el comportamiento en el que uno se rige explícitamente por el tiempo consiste en el uso del reloj $^{632}$.

El Dasein se conduce en relación al tiempo rigiéndose principalmente por el uso del reloj, por medio del mirar la hora en el reloj. Debido a esto, preguntar por el tiempo o preguntar qué es el tiempo, es lo mismo que preguntar qué hora es en el reloj, por eso Heidegger sostiene: "el sentido temporal existenciario de este uso revela ser un presentar la manecilla peregrinante. El seguir, presentando, las posiciones de la manecilla numera (zählt). Este presentar se temporacía en la unidad extática de un retener estando a la

\footnotetext{
${ }^{630}$ Berciano, M., Superación de la metafisica en Martin Heidegger, op. cit., p. 83.

${ }^{631}$ ST, p. 453.

${ }^{632}$ Cf. ST, p. 435. Rivera.
} 
expectativa (gewärtigenden Behaltens)"633. En principio el presentar reteniendo el entonces diciendo ahora, alude a la apertura del horizonte del antes, del anteriormente, es decir, del ya no más, que es una forma de pasado. El presentando estar a la expectativa del luego diciendo ahora, significa la apertura del horizonte del después, del posteriormente. Por lo tanto, lo que se expone y expresa en aquella presentación de un retener que está a la expectativa es el tiempo. En consecuencia, la raíz del concepto vulgar del tiempo es la comprensión común de continuar midiendo, calculando, numerando, las posiciones constantemente en movimiento de la manecilla del reloj, que no es más que un reflejo del reloj natural que es el Sol peregrinante.

Resumiendo lo anterior, Heidegger comenta que el tiempo asi entendido es: "lo numerado que se muestra en el seguir, presentando (gegenwärtigenden) y numerando (Gezählte), la manecilla peregrinante, de tal manera que el presentar se temporacía en su unidad extática con el retener y el estar a la expectativa patentes dentro del horizonte del anteriormente (Früher) y el posteriormente (Später)" ${ }^{334}$. Ésta interpretación del tiempo que se fundamenta primordialmente en el uso del reloj, sería según Heidegger, lo mismo que la definición dada por Aristóteles en la Física, libro IV, que como habíamos visto, sería la interpretación ontológico existenciaria del concepto esbozado por Aristóteles. "El tiempo es según Aristóteles, no él mismo movimiento sino algo en el movimiento, en qué, movimiento y reposo, la sucesión en su transcurso ahora, son contados en el horizonte del antes (del no-más) y del después (del aún-no)" ${ }^{935}$

Nos encontraríamos frente a una reinterpretación de aquella definición, que entiende el tiempo como lo numerado en el movimiento dentro del ámbito de lo anterior y lo posterior. Según el pensador alemán, “el tratado aristotélico sobre el tiempo es la primera exégesis detallada de este fenómeno que se nos ha transmitido. Ha determinado toda concepción posterior del tiempo" ${ }^{936}$, no obstante, esta definición del tiempo no significó nunca un problema para Aristóteles, ya que este se mueve dentro de la interpretación clásica del ser y es en ella en la que se fundamenta el ser como presente, como substancia. Ésta concepción aristotélica ha dominado el horizonte interpretativo del tiempo desde antaño hasta nuestros días. Todo discurrir o meditar acerca del concepto del tiempo, está dominado y enraizado en la interpretación aristotélica del tiempo, en tanto, el tiempo siempre es entendido tal y como se manifiesta en la cotidianidad, en la ocupación circunspectiva (mundo en torno). Esto nos ayuda a entender, por qué no es tarea fácil superar estas interpretaciones dominantes, lo que hace más complejo aún pensar el tiempo de forma originaria y esencial. Dado que, todas las definiciones y explicaciones del concepto del tiempo posterior a la aristotélica, se han fundamentado en el análisis del

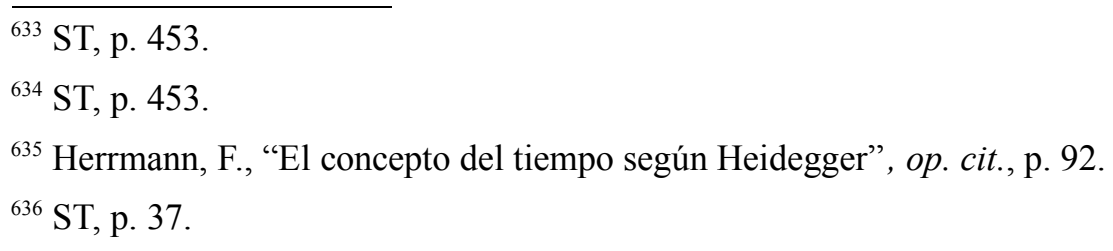


filósofo de Estagira, que es justamente lo que pretende superar esta analítica heideggeriana.

El tiempo se comprende como lo numerado, que se expresa en la presentación (Gegenwärtigen) del puntero en movimiento. En la propia presentación del reloj (móvil) en su específico movimiento se dice siempre ahora aquí, ahora aquí y así continuamente. En conclusión, aquello que se numera es el ahora, el tiempo es considerado fundamentalmente desde esa perspectiva. En consecuencia, "aquello que Aristóteles define como la esencia del tiempo corresponda a la comprensión natural y prefilosófica del tiempo se hace evidente con una mirada a un comportamiento determinado y natural del tiempo. Este comportamiento es el uso del reloj que me muestra, en mi comportamiento con el entorno natural, el tiempo en una cierta expresividad" ${ }^{637}$.

Y estos ahoras, se manifiestan en cada ahora, y puede ser en forma de en seguida ya no, justo ahora aún no, precisamente todavía no. Este tiempo así caracterizado, fundamentado en una dependencia absoluta del ahora presente, reconocido por medio de la utilización del reloj, se denomina el tiempo del ahora (Jetzt Zeit). Tal como Heidegger sostiene: "así es como se muestra para la comprensión vulgar del tiempo éste como una secuencia de ahoras constantemente "ante los ojos", que al par pasan (vergehenden) y vienen (ankommenden). El tiempo resulta comprendido como un "uno tras otro", como "flujo" de los ahoras, como "curso del tiempo" (Lauf derZeit)" "638. Cabe preguntarse ahora, qué hay detrás de esta interpretación del tiempo del mundo, que se oculta tras el tiempo que es objeto de la ocupación.

\section{E. NiVELACIÓN DEL TIEMPO ORIGINARIO}

En esta concepción vulgar del tiempo, en el que la ocupación se da tiempo, cuenta con él, el Dasein no se detiene en una comprensión esencial de este fenómeno expresado, sino que más bien, se pierde, se extravía en lo ante los ojos, en lo a la mano, en lo que es objeto de ocupación. En cuanto, está sometido a la influencia de esta exégesis dominante, no se detiene en una meditación sobre el tiempo, no determina el tiempo en cuanto tal. Todo esto, tiene como consecuencia, según Berciano, que "a la comprensión vulgar se le escapa el horizonte, y por lo tanto también los conceptos como mundo, significatividad, etc. El Dasein como decaído y arrojado se encuentra perdido en "lo cuidado" (das Besorgte), y así, en una temporalidad inauténtica (uneigentliche Zeitlichkeit), en la intratemporalidad. Esto hace que también la historia sea considerada como una acontecer intratemporal (als innerzeitiges Geschehen)" ${ }^{\$ 39}$. Significa entonces, que el Dasein se

\footnotetext{
${ }^{637}$ Herrmann, F., "El concepto del tiempo según Heidegger", op. cit., p. 92.

${ }^{638}$ ST, p. 454.

${ }^{639}$ Berciano, M., Superación de la metafisica en Martin Heidegger, op. cit., p. 83.
} 
absorbe en un presentar caído en medio de lo que es objeto de ocupación, de los entes del mundo, por lo que repite sin cesar: ahora, después, entonces. Así entendido el tiempo, queda sometido a una peculiar nivelación, que lo reduce y simplifica como una serie homogénea de ahoras, queda definido el tiempo como una mera secuencia de ahoras presentes:

En cada respectivo decir-ahora estoy completamente abierto para el horizonte del ahorano-más, es decir, del antes y para el horizonte del ahora-aún-no, eso quiere decir, del después. Justo esto es el contenido de la determinación aristotélica del tiempo. Cuando me concentro temáticamente en el tiempo contado en el uso del reloj, entonces se me muestra éste como el ahora, no-más-ahora y aún-no-ahora. A este tiempo que se muestra en el ahora contado y en el cual me concentro temáticamente lo llama Heidegger el tiempoahora $^{640}$.

Anteriormente se había caracterizado al tiempo de la ocupación en dos de sus principales expresiones. En primer término, se consideró la fechabilidad que se funda en la constitución extática de la temporalidad, el ahora es comprendido como un ahora que, el ahora fechable, datable. Por otra parte, siempre se considera el ahora como apropiado o inapropiado. A esa estructura del ahora le pertenece el carácter de significatividad. La interpretación vulgar del tiempo como secuencia de ahoras, no considera ni tiene en cuenta los fenómenos de la fechabilidad y la significatividad del tiempo, inherentes al tiempo de la ocupación. La constitución del tiempo vulgar encubre esos fenómenos. Este encubrimiento nivela la constitución extático horizontal de la temporalidad, en que se fundamentan la fechabilidad y significatividad. Los ahoras quedan encubiertos en cuanto a su específica relación con la fechabilidad y la significatividad. Por tanto, quedan alineados, formados en un ahora junto a otro ahora, conformándose como una simple sucesión de ahoras. Tal como comenta Herrmann: "La alusión a la estructura de la databilidad (fechabilidad) quiere dejar ver, del mismo modo que la alusión a la estructura de la significatividad, que el tiempo de nuestra comprensión de natural ejecutante del tiempo no es primero una pura desnuda secuencia de ahoras. La concepción vulgar del tiempo como secuencia de ahoras pasa por alto tanto la significatividad como la databilidad del tiempo como caracteres esenciales primarios" ${ }^{941}$. En este estado de cosas, el presente sería el fenómeno temporal decisivo al momento de preguntar y responder por el tiempo en el que se está. De forma, que lo que se expuso en un primer momento como el más básico cálculo del tiempo o medición de él, queda así reafirmado, concibiéndose el tiempo como ahora, como simple presente.

El encubrimiento nivelador del tiempo del mundo que es realizado por la interpretación vulgar del tiempo, no es algo casual o accidental, es un encubrimiento consecuencia de la comprensión del tiempo elaborada exclusivamente desde el ámbito del tiempo del mundo, no considerando el tiempo en su vertiente originaria. Heidegger

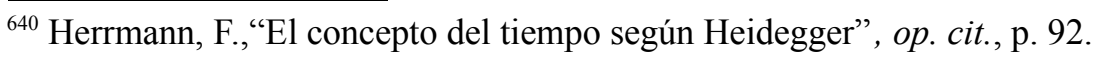

${ }^{641}$ Ibíd., p. 96
} 
comenta: "en lo numerado (Gezählte) en la medición del tiempo ocupándose , el ahora, resulta comprendido implícitamente en el ocuparse de lo "a la mano" y lo "ante los ojos" "642. Por tanto, el ahora se comprende como algo presente al modo de lo ante los ojos, de forma que el ocuparse del tiempo retorna sobre el propio tiempo ya comprendido y ve los ahoras exclusivamente en el ámbito de la comprensión del ser, por la que el mismo ocuparse está conducida, según la interpretación del ser como substancia, como lo simplemente presente, significa entonces, que "la manera ejecutante de mi comportamiento-para en mi tomarme tiempo se define a partir de mi manera de ser, a partir de mi existencia, según la cual a mí en mi ser me va mi ser, mi ser comprendedor de ser en medio de los entes intramundanos" ${ }^{\prime 43}$. Heidegger resume todo lo anterior como sigue:
Aun cuando no se dice expresamente que los ahoras sean "ante los ojos", como las cosas, se lo "ve" ontológicamente, sin embargo, dentro del horizonte de la idea del "ser ante los ojos". Los ahoras van pasando (vergehen) y los que han pasado constituyen el pasado (vergangenen). Los ahoras van viniendo (kommen an) y los que han de venir (ankünftigen) acotan el "porvenir" (Zukunft)" ${ }^{644}$.

Así comprendido y caracterizado el tiempo, se lo entiende como Vorhandenheit, como algo ante los ojos, dado con independencia al Dasein mismo, de forma que se le asigna al tiempo cierta entidad al modo de una cosa que está ahí, considerándolo como un ente más entre otros, con mayor dignidad ontológica, de mayor importancia, pero al fin entendido como ente. Lo que termina por ocultar, encubrir, la constitución extático horizontal de la temporalidad. De modo, que siendo consecuente con aquello, la secuencia homogénea de ahoras, se entiende también como algo ahí delante ante los ojos, como Vorhandenheit, pasando ella misma a estar dentro del tiempo. Heidegger afirma: "en cada ahora es ahora, y en cada ahora ya se ha desvanecido (verschwindet) el ahora. En cada ahora el ahora es ahora, y está, por ende, constantemente presente (anwesend) como él mismo, aunque también en cada ahora advenga (ankommend) y desaparezca cada vez un nuevo ahora. Aunque cambiante de este modo, del ahora da muestras, a la vez, de una constante presencia (Anwesenheit) de sí mismo" ${ }^{645}$.

En dicha secuencia de ahoras no hay interrupciones, y ello a pesar de la continua división de los ahoras, estos seguirán siendo un determinado ahora, y ello porque la duración del tiempo se entiende desde el prisma de algo que siempre está ante los ojos como presencia constante. A juicio de Heidegger, es en esta perspectiva ontológica que se rige por el ente que está ahí presente es el lugar donde se pretende solucionar el problema de la continuidad del tiempo. No obstante, considerado el problema desde este horizonte, queda oculta la estructura del tiempo del mundo, según la cual el tiempo es distendido

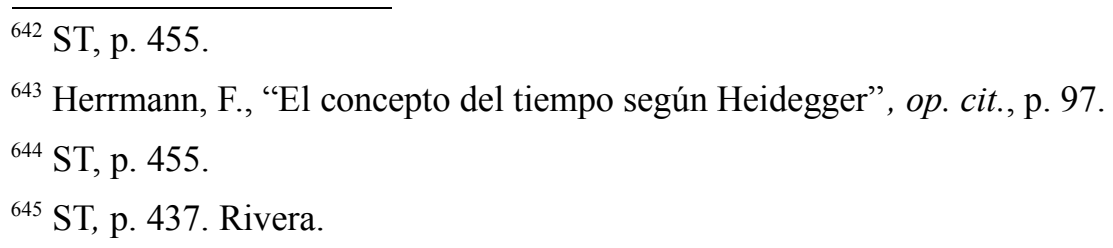


(gespannt), por ello, esta distensión del tiempo no se comprende desde la prolongación horizontal de la unidad extática de la temporalidad que se vuelve pública en el ocuparse del tiempo. Todo ahora, por momentáneo que sea, es ya un ahora, pero esto tiene que concebirse desde aquella cuestión todavía anterior de que proviene todo ahora. Según Heidegger tiene que concebirse, "por la prolongación extática de la temporalidad (exstatischen Erstrecktheit der Zeitlichkeit), que es extraña a toda continuidad de lo "ante los ojos", mas por su parte representa la condición de posibilidad de acceso a todo continuo "ante los ojos"" 646.

En esta exégesis proveniente de la influencia de la tradición filosófica, subyace una idea del tiempo que lo considera como eterno, infinito, y queda así incluido el tiempo en el horizonte de la infinitud, ya que, a cada momento emerge un nuevo ahora, que de cierta manera es siempre el mismo ahora. Esta determinación del tiempo es característica en la concepción del tiempo de la tradición filosófica, que ahora se hace manifiesta en el concepto vulgar del tiempo: el tiempo como infinito, el tiempo como eterno. Nos indica Heidegger, que es el mismo Platón, el que a partir de la comprensión del tiempo como secuencia de ahoras que llegan y se van, se sintió interpelado a nombrar al tiempo como imagen de la eternidad ${ }^{647}$. Esta es un cuestión fundamental y decisiva de la problemática que envuelve a la temporalidad, es donde Heidegger ve uno de los ocultamientos decisivos que surgen desde el concepto vulgar del tiempo, no referimos a la infinitud del tiempo. Por eso, el pensador de la Selva Negra sostiene:

Es la tesis capital de la exégesis vulgar del tiempo, la tesis de que el tiempo es "infinito", lo que hace patente de la manera más perentoria la nivelación y el encubrimiento del tiempo del mundo, y con él de la temporalidad en general, que entraña semejante interpretación. El tiempo se da inmediatamente como ininterrumpida secuencia de ahoras. Todo ahora es también ya un "hace un instante" o "dentro de un instante". Si la caracterización del tiempo se atiene primaria y exclusivamente a esta secuencia, no cabe, radicalmente, encontrar en ella en cuanto tal ningún principio ni fin ${ }^{648}$.

Esto quiere decir, que cuando consideramos el último ahora, es siempre en tanto ahora, un dentro de un instante ya no o de un enseguida ya no más, el tiempo en el sentido de un ahora ya no, una forma de pasado. Por otra parte, todo primer ahora es siempre hace un instante aun no o denantes todavía no, por tanto, es tiempo en el sentido de aun no ahora o ahora todavía no, tiene sentido de futuro. Lo que significa, que estamos frente a una perspectiva del tiempo, que es infinita en las dos dimensiones, hacia el pasado y hacia el futuro.

Esta interpretación del tiempo infinito solo puede ser tal si está constantemente referida al flotante en sí de un transcurrir continuo de ahoras simplemente presentes. Estas concepciones conciben la secuencia de ahoras a partir del ser ante los ojos, desde lo

\footnotetext{
${ }^{646} \mathrm{ST}$, p. 456.

${ }^{647}$ Cf, ST, p. 437. Rivera

${ }^{648}$ ST, p. 457.
} 
vorhanden, por lo tanto nunca se podrá encontrar un fin, una finitud. Esto porque, "la secuencia de los ahoras es ininterrumpida y sin agujeros. Por "mucho" que avancemos en el "dividir" el ahora, sigue siendo siempre ahora. Se ve la continuidad del tiempo dentro del horizonte de algo "ante los ojos" " 649 .

Pero cabe preguntarse ahora, desde dónde surge la nivelación del tiempo del mundo y el ocultamiento de la temporalidad originaria. Entonces, "Si el carácter de impropio del estar es entendido como intratemporeidad irrenunciablemente perteneciente al estar, cabe entonces responder también a la pregunta de por qué la tradición metafísica no ha pensado el tiempo en su originariedad" ${ }^{650}$. Como sostiene Pöggeler hay que ir al fundamento mismo de dicho encubrimiento. Esta nivelación se fundamenta en la constitución misma del Dasein en cuanto cuidado. El Dasein inmediata y regularmente, en medio del ente que le hace frente, se encuentra en un estado de perdido, en tal sentido, existe en el encubrimiento, en el ocultamiento de la propiedad de su ser sí mismo, se encuentra alejado de su ser más propio.

Este encubrimiento tiene un carácter de fuga, de huida ante la muerte, huye de su posibilidad más propia de existencia, huye de su esencial finitud, teniendo en cuenta esto, Heidegger sostiene:

en cuanto es semejante apartar la vista de la finitud, la temporalidad impropia del "ser ahí" cadentemente cotidiano (verfallend-alltäglichen) tiene que desconocer el advenir propio (eigentliche Zukünftigkeit) y con él la temporalidad en general. Y si encima es el uno quien guía la comprensión vulgar del "ser ahí" no puede sino consolidarse la "representación”, olvidada de sí misma, de la "infinitud” del tiempo público (öffentlichen Zeit $)^{651}$

Lo que significa que el Dasein desconoce su ser como advenidero, como finito, por lo tanto, no reconoce la constitución de su ser como temporal.

Podemos concluir, que para Heidegger esta nivelación del tiempo originario, su ocultamiento, se origina en la huida del Dasein frente a su propia finitud esencial, al desconocimiento de su ser como primariamente advenidero. Se concibe el tiempo como lo simplemente presente, como sucesión de ahoras, de forma que se cierra a la comprensión de éste como esencialmente finito, (en tanto advenidero). Esto solo puede comprenderse existencialmente de modo propio en el precursor estado de resuelto. En otras palabras, "Heidegger dice que este ocultamiento no es casual, sino que está radicado en la misma constitución del Dasein, esto es, en la estructura del cuidado, que se ocupa con los objetos, con las cosas, con lo que está a la mano. De ahí que también los "ahoras" sean vistos como cosas; como cosas que pasan (pasado), o como cosas que llegan (futuro)" ${ }^{9652}$.

\footnotetext{
${ }^{649}$ ST, p. 456.

${ }^{650}$ Pöggeler, O., El camino del pensar de Martin Heidegger, op. cit., p. 74.

${ }^{651}$ ST, p. 457.

${ }^{652}$ Berciano, M., Superación de la metafisica en Martin Heidegger, op. cit., p. 83.
} 
Lo que pretende Heidegger con su exégesis, es ir más allá de estas interpretaciones, pero en una forma de retroceso, hacia el propio fundamento de esta compresión del tiempo de los ahoras, por ello dice: "el que en cada ahora, por momentáneo que sea, es ya un ahora, es cosa que tiene que concebirse por aquello aún "anterior"de que procede todo ahora: por la prolongación extática de la temporalidad (ekstatischen Erstrecktheit der Zeitlichkeit), que es extraña a toda continuidad de lo "ante los ojos", mas por su parte representa la condición de posibilidad del acceso a todo lo continuo "ante los ojos"" 653 .

Por tanto, esta fuga ante su propia finitud, se enraíza en la constitución del Dasein en cuanto está inmediata y regularmente caído, sumergido en la cotidianidad, cuyo carácter fundamental es la relación pragmática del ocuparse de lo a la mano, con lo que le hace frente en el mundo. La concepción vulgar del tiempo que lo entiende como secuencia infinita de ahoras, tiene su origen en la temporalidad del Dasein en cuanto caído. Esto reafirma lo que ya se había expuesto, "el ser ahí inmediata y regularmente "cae" en una relación pragmática con lo dado en el mundo y, correlativamente a esta caída, "huye" de su finitud, del carácter irreductible de esa caída y de ese ser fugitivo se deriva lo que tiene de "derecho natural" el concepto vulgar del tiempo"654. Heidegger con esto, le reconoce al concepto vulgar del tiempo sus propios derechos, ya que es propia de la cotidianidad del Dasein, y por lo tanto, expresa la comprensión del ser dominante, en cuanto se encuentra inmediata y regularmente en la cotidianidad. En otras palabras, nuestra vivencia cotidiana del tiempo,-el concepto vulgar del tiempo, la intratemporalidad-, no solamente tienen una señalada importancia, por servir de base fenoménica para la investigación del pensador alemán, sino que también poseen sus propios derechos interpretativos.

Sin embargo, esta interpretación puede perder este reconocimiento y sus derechos, si pretendiese establecerse como la única y dominante concepción del tiempo, como la verdadera y original idea de la temporalidad. Por eso afirma Pöggeler:

la cotidianidad y el carácter impropio del estar tienen que ser entendidos como intratemporeidad, en la cual el estar cae en aquello que está en el tiempo, olvidando de esta manera la maduración que da el tiempo al tiempo mismo (und vergibt so die Zeitigung der Zeit selbst). La intratemporeidad es la temporalidad de la cotidianidad, la temporalidad del concepto "vulgar" del tiempo. Dado que la intratemporeidad "se entronca" en la temporalidad del estar y es "igual de originaria" que la historicidad también el carácter de impropio del estar alcanza una cierta justificación ${ }^{655}$.

A partir de la temporalidad originaria y de su temporalización, es posible hacer comprensible por qué y cómo, el tiempo del mundo se fundamenta y se origina en ella. Tal como dice Heidegger:

\footnotetext{
${ }^{653}$ ST, p. 456.

${ }^{654}$ Peñalver, P., Del espiritu al tiempo, op. cit., p. 228.

${ }^{655}$ Pöggeler, O., El camino del pensar de Martin Heidegger, op. cit., p. 74.
} 
la exégesis de la plena estructura del tiempo mundano sacada de la temporalidad es lo único que da el hilo conductor para "ver" el encubrimiento entrañado en el concepto vulgar del tiempo y apreciar la nivelación de la constitución horizontal-extática de la temporalidad. Pero el buscar la orientación en la temporalidad del "ser ahí" hace posible al par señalar la procedencia y la necesidad fáctica de este encubrimiento nivelador y el poner a prueba la legitimidad de las tesis vulgares sobre el tiempo ${ }^{656}$.

El camino que recorre el pensador de la Selva Negra lo lleva desde el análisis y exposición de la temporalidad originaria y propia a una determinación del tiempo del mundo, desde la temporalidad originaria a la comprensión vulgar del tiempo, y ello para cuestionar la legitimidad y derechos de la interpretación vulgar del tiempo. "El estar puede ser de propio solo si se arranca siempre de nuevo de su carácter de impropio- que permanece presupuesto- si siempre de nuevo se eleva desde la intratemporalidad a la maduración que da tiempo al tiempo mismo" ${ }^{657}$. El acceso a una comprensión propia de la temporalidad es completamente inalcanzable, mientras la interpretación del tiempo se conduzca exclusivamente en el ámbito del tiempo del mundo. Y esto queda así fundamentado, en tanto, "la temporalidad horizontal-extática se temporacía primariamente desde el advenir. La comprensión vulgar del tiempo en el ahora, y en el puro ahora mutilado en su plena estructura que se llama el "presente"" ${ }^{658}$. Se puede ver como en este tratado de 1927, se lleva a cabo una transición, una superación de la concepción clásica del tiempo como ahora, como mera secuencia de ahoras inmediatamente presentes, hacia una concepción unitaria y esencial del tiempo, como una estructura trimembre, en la cual el futuro, el advenir adquiere un especial protagonismo, como aquel éxtasis que abre esencialmente la posibilidad de la temporalización de la temporalidad de forma originaria y propia, como fundamento de ella.

Como señalábamos anteriormente, la concepción vulgar del tiempo ha sido la interpretación dominante a lo largo de la historia de la filosofía para comprender el tiempo, siempre entendiéndolo como lo presente, lo vorhanden, en la que subyace una perspectiva interpretativa del ser mismo como substancia, incluyendo en ella también el ser del hombre, como ser ante los ojos. "Según la tendencia fundamental del estar, la ontología tradicional cae en lo ente que sale al encuentro en el tiempo; falta, así, la maduración que da tiempo al tiempo mismo. La ontología tradicional piensa el ser del ente a partir de lo ente en el tiempo, y luego se hace la idea del tiempo a partir igualmente de la comprensión del ser así adquirida" ${ }^{659}$.

Gracias a esta interpretación heideggeriana, esa postura clásica del tiempo, si no es superada en este análisis, sí por lo menos es sometida a un fuerte cuestionamiento de sus más sólidos cimientos. Abriéndose de este modo, una nueva perspectiva meditativa, quizás

\footnotetext{
${ }^{656}$ ST, p. 459.

${ }^{657}$ Pöggeler, O., El camino del pensar de Martin Heidegger, op. cit., p. 74.

${ }^{658}$ ST, p. 460.

${ }^{659}$ Pöggeler, O., El camino del pensar de Martin Heidegger, op. cit., p. 75.
} 
la más nueva en su arraigo en la tradición, capaz de iluminar nuevos caminos para poder recorrer comprensivamente una meditación que sea conducida por el ser mismo. De forma, que pueda comprender el ser y al Dasein en términos absolutamente distintos a los de la tradición metafísica. Tomando como punto de partida la propia fundamentación en la temporalidad originaria, un cierto privilegio al futuro, al advenir, al hombre como esencialmente finito. 


\section{CONCLUSIONES}

Este trabajo se inició con la premisa de que la originalidad y radicalidad del pensamiento de Heidegger descansa principalmente en su determinación del carácter temporal que permanecía oculto en la concepción del ser de la filosofía griega, que desde sus primeros pasos ha interpretado el ser como ousía, como substancia, como presencia, en último término, como aquello que tiene el carácter de ser siempre. El ser es concebido desde el horizonte del tiempo, específicamente desde una dimensión del tiempo: el presente. Interpretación que tiene su primer momento en la filosofía griega, que no fue capaz de comprender que detrás de su interpretación del ser como ousía, como presencia, se piensa el ser desde el tiempo, entendido como simple presente. Así, nuestro trabajo ha terminado por perfilarse desde las siguientes coordenadas interpretativas: el ser ( Sein), el tiempo (Zeit), la presencia (Anwesenheit), el presente (Gegenwart) y el advenir (Zukunft). Esto nos ha permitido obtener un panorama claro de la forma en que llegan a ensamblarse estas cuestiones en la obra temprana del filósofo alemán y poder destacar el rol que cumple en esto el problema ontológico del advenir, que como se ha mostrado en la presente investigación posee una importancia manifiesta en el proyecto filosófico de Heidegger.

En la conferencia que Heidegger dictó ante la Sociedad Teológica de Marburgo el 25 de julio de 1924 comentó que "El ser futuro da tiempo, forma el presente y permite reiterar el pasado. Visto desde la cuestión del tiempo, esto significa que el fenómeno fundamental del tiempo es el futuro" ${ }^{\text {"60 }}$. Con estas palabras el filósofo alemán resumiría la forma en que entendía el tiempo por aquellos años, a saber, como una triple articulación de presente, pasado y futuro, cuyo fenómeno fundamental es el futuro. Como podemos ver a simple vista, en esta conferencia de 1924 que media entre los cursos de la fenomenología de la religión y Ser y tiempo, Heidegger presenta de forma concreta su interpretación del tiempo y el papel que cumple el futuro en dicha exégesis. Teniendo en cuenta esto, la interpretación del ser como presencia, como simple presente, queda cuestionada de plano.

Por otra parte, Heidegger habla ahí del tiempo sin más, no de la temporalidad, detalle importante si consideramos que esta formulación será matizada, cuando en 1927 señala que "el fenómeno originario de la temporalidad originaria y propia es el advenir" ${ }^{661}$, y, algo aún más importante, que por aquel entonces todavía no había sido planteada rigurosamente la relación existente entre la concepción del ser como presencia y el presente, con lo cual quedaba establecido el vínculo entre ser y tiempo. Cuestión que ya se había perfilado en las lecciones de Marburgo del semestre de verano de 1924, denominadas Grundbegriffe der aristotelischen Philosophie, y que luego será formulada

\footnotetext{
${ }^{660}$ Heidegger, M., El concepto del tiempo, Trotta, Madrid, 2006, p. 47.

${ }^{661}$ Heidegger, M., Ser y tiempo, FCE, Argentina, 1991, p. 357.
} 
expresamente en el tratado El concepto del tiempo que habría sido escrito en noviembre del mismo año, en el cual todas las coordenadas interpretativas mencionadas anteriormente entran a tallar en un mismo proyecto filosófico de cuestionamiento y destrucción de la tradición metafísica que se mantendrán más o menos en la misma dirección hasta Ser y tiempo.

En la filosofía de Heidegger, en sus comienzos como docente universitario, se establecían dos vías de investigación aparentemente cercanas, que caminaban de forma paralela en sus primeras lecciones, una era la pregunta por las categorías fundamentales de la vida fáctica y otra era la crítica a la conceptualidad de la tradición metafísica. En ellas se manifestaba de forma implícita la meditación acerca del tiempo y la pregunta por el ser, sin embargo no quedaba claramente establecida la pertenencia esencial entre un interrogante y otro.

- El primer lugar donde se pueden reconocer estas vías de problematicidad es en los cursos de Fenomenología de la vida religiosa, ahí Heidegger considera que lo más importante de esta experiencia del cristianismo primitivo tiene que ver con el fenómeno de la anunciación, de la proclamación evangélica. En la carta a los tesalonicenses se mostraría lo más propio de la experiencia fáctica de la vida del cristianismo primitivo, que se entiende como un haber llegado a ser cristiano, como un haber devenido a ser en Cristo, y el tener conciencia de esto constituye la unidad de la experiencia fáctica de la vida de las primeras comunidades. Heidegger plantea que la instancia decisiva que define la temporalidad de las comunidades cristianas primitivas es la expectativa de la parousía, la espera de la segunda venida del Mesías. Y es una expectativa de la venida, que no puede ser un simple esperar, por decirlo así, inmóvil, quieto, o un esperar de brazos cruzados a que llegue un acontecimiento que vendrá en el futuro, que aún no es pero luego se hará efectivo. Por el contrario, ha de ser una espera vigilante, tensa y atribulada, que se lleva a sí misma como tribulación, es una expectativa preocupada de la venida del Mesías.

En la expectativa de la parousía se manifiesta una idea de tiempo que sería la propia de la vida humana en su experiencia fáctica, pero no para cualquiera, porque es esencial entender el mensaje y atender la experiencia originaria. El cuándo de la venida no puede ser una fecha disponible $\mathrm{u}$ objetivable, los cristianos no esperan sabiendo con certeza el momento en que se producirá la llegada del Mesías, ni tampoco quieren saberlo. Para San Pablo no es una pregunta de conocimiento o algo de este tipo. Es una seña característica de su temporalidad, la indisponibilidad del cuándo, puesto que no es importante para ellos saber si la segunda venida se concretará más temprano o más tarde.

La expectativa de la parousía no supone una espera sumida en el quietismo, sino que tiene que ver con la ejecución y movilidad constante propia de la vida humana. Por eso esta expectativa no está caracterizada como un esperar sin más a que algo en el futuro 
sobrevenga, sino que la vida fáctica ha de participar de forma activa en esa venida de la parousía, - pero no haciéndola disponible o cosificándola- si se la comprende como decisiva, debe ser una expectativa activa, se debe participar de ella. Por lo tanto, es una expectativa que no se caracteriza en una modalidad de espera quieta de un acontecimiento que viene desde el futuro y frente al cual no cabe hacer nada, si así lo entendiéramos, pensaríamos que la temporalidad de la vida humana de la que Heidegger nos habla, adquiere su sentido desde un acontecimiento que luego llegará y se hará presente, dicho de otra forma, que obtiene su significado desde un hecho que aún no es, pero luego será. La vida se ejecuta aquí y ahora, su carácter temporal se manifiesta en su misma ejecución, en su experiencia fáctica de la vida, claramente determinada por la seguridad de la segunda venida, que se sustenta en una relación peculiar con Dios. Por una parte, seguridad en la venida, pero por otra, indisponible y sin posibilidad de objetivación alguna, por ello dice el autor de Ser y tiempo que "De aquella conexión ejecutiva con Dios nace algo así como la temporalidad" (GA 60, 114/143), en la relación que mantenga el cristiano converso con Dios se juega la posibilidad de una expectativa auténtica de la parousía y surge la temporalidad genuina de la vida fáctica.

El vivir vigilante y despierto, se contrapone a una objetivación de ese futuro, de esa segunda venida y no la calcula como algo disponible. Esta caracterización del tiempo como imprevisto e incalculable nos acerca a esa idea del tiempo propiamente humano, distanciándose del llamado tiempo de la naturaleza, del mundo; de forma tal, que la vivencia de la temporalidad del cristianismo primitivo, que está dirigida primordialmente hacia el advenir, hacia la segunda venida del Mesías, abre una nueva y original vía de interpretación del tiempo. En este sentido de referencia de la vida cristiana, en la expectativa de la segunda venida de Cristo surge el nexo con Dios y propiamente la temporalidad. Dios no se nos hace manifiesto como algo eterno, sino que por el contrario, se nos hace patente en la expectativa atenta de un acontecimiento futuro que se define en la autenticidad de su experiencia religiosa. Heidegger comenta sobre esto que viven la vida como un aún no, como un estar primordialmente abiertos hacia el advenir de la parousía, vueltos hacia un futuro inobjetivable, que no puede ser calculado y determinado en términos cronológicos.

La experiencia fáctica del cristianismo primitivo nos hace visible su sentido temporal como primordialmente futuro, en la expectativa del advenimiento de la parousía, que tendrá lugar como la llegada de un ladrón por la noche; así puede aprehenderse la experiencia originaria del tiempo y tomar sobre sí la facticidad y la historicidad de la vida. La experiencia fáctica de la vida se despliega en el horizonte de la temporalidad, se abre entonces una original vía de cuestionamiento filosófico, poniendo en duda principalmente el concepto del tiempo como simple presente, o como sucesión de ahoras siempre presentes. 
Esto lo resume Gadamer de la siguiente forma: "la experiencia del tiempo que Heidegger había encontrado en Pablo era la del retorno de Cristo, que no es un retorno que se pueda esperar, y que significa un parusía, es decir, un advenir y no una presencia" ${ }^{\$ 662}$.

- Otra instancia clave para nuestra investigación es el Informe Natorp, que es uno de los primeros escritos en los que Heidegger fija con claridad un determinado proyecto de trabajo, y esto a largo plazo, en lo que será un marco programático de su filosofía, cuyas directrices fundamentales son la pregunta por la temporalidad peculiar a la vida fáctica y la pregunta por el sentido directivo del ser. Esto mediante una interpretación ontológicofenomenológica de la existencia. La vida fáctica en su esencial sentido ontológico tiene que ser explicitada de modo genuino, sin encubrimientos, tiene que revelarse en su estructura ontológica. Ha de comprenderse en su dinamismo, en su movilidad fundamental, la temporalidad peculiar a la vida fáctica ha de someterse a una interpretación originaria de modo que se nos haga accesible su ser. Esta interpretación ha de expresar el carácter eminentemente temporal e histórico de la vida humana que nada tiene que ver con la movilidad y el tiempo de la naturaleza, de las cosas.

La caída aparece como un elemento decisivo en la estructura de la vida humana, que muestra el carácter huidizo de vida, ese querer desentenderse de sí mismo que le tranquiliza, le brinda una aparente sosiego, en ese dejarse absorber por el mundo deja de lado la posibilidad de apropiarse originariamente de la vida fáctica, se abandona en los entes del mundo del que se ocupa. Luego de presentar algunos rasgos ontológicos fundamentales del Dasein, Heidegger expone el fenómeno de la muerte. En la forma de abordar este fenómeno por el estado de interpretado localiza un síntoma evidente de esta tendencia a la caída, que es la forma cotidiana en que se comporta la vida fáctica y en cómo se enfrenta el uno a la muerte. Este es el fenómeno que permite a Heidegger articular la totalidad de elementos que constituyen la vida fáctica. He aquí lo novedoso de esta consideración iniciada por el pensador alemán y presentada en este informe. La muerte es el fenómeno en el que descansa la posibilidad de hacer frente a esta tendencia a la caída y permite además apropiarse de la propia existencia, pero lo que es aún más importante, es que abre la posibilidad de comprender la vida en su esencial carácter temporal(uno de los objetivos fundamentales de la filosofía heideggeriana en esta etapa de su pensamiento), lejos de interpretaciones del tiempo surgidas desde los conceptos y exégesis extraídas desde los dominios de las ciencias naturales. La cuestión de la muerte tiene una relevancia señalada, en cuanto suministra el hilo conductor de la problemática ontológica de la vida fáctica.

Heidegger considera como cuestión indispensable para su investigación un diálogo con la tradición metafísica. Es Aristóteles la figura emblemática, en la cual se manifiesta el cumplimiento y concreción de las filosofías anteriores, en él se cristalizan las concepciones del ser que le preceden. Particularmente la Física aristotélica marca un

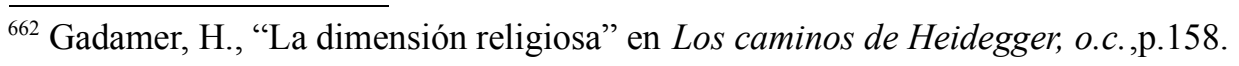


punto de inflexión. Este es un nuevo comienzo sobre el que Aristóteles edificó su constructo filosófico: la experiencia del movimiento. Sin embargo, para Heidegger esta experiencia tal como la entiende el Estagirita no es una determinación propia de la vida fáctica ni tampoco originada desde ella, esto le lleva a preguntarse si la interpretación de la vida humana, como hombre, como animal racional o compuesto de cuerpo y alma, corresponde a una interpretación ontológica genuina obtenida desde la vida fáctica, o si por el contrario, dicha consideración es realizada desde una interpretación ontológica dominante a la cual todos los entes se deben ajustar; y si responden dichas interpretaciones a una consideración metafísica dominante. Heidegger responde a todo esto señalando que esta determinación del ser desde el cual se han de considerar todos los entes obtiene su sentido desde los objetos producidos, desde los útiles empleados en el trato cotidiano con el mundo.

Heidegger concluye que ser significa para Aristóteles ser-producido (Hergestelltsein) y también ser-disponible (Verfügbarsein), en cuanto es aquello que ha sido producido, finalizado, en tanto actividad del trato productivo, la poiesis. Aristóteles obtiene el sentido del ser desde el ámbito de los objetos, de las cosas, de la realidad efectiva. Por lo tanto, el horizonte al que se dirige la experiencia originaria del ser no se sustenta en el horizonte ontológico de las cosas entendidas desde el modo de ser de un objeto que se aprehende teóricamente en su contenido quiditativo; sino, por el contrario, se remite al mundo que comparece en el trato de la producción, de la ejecución y del uso de los objetos producidos. Esta comprensión del ser se obtiene principalmente desde el ámbito del trato práctico con las cosas en cuanto finalizadas, disponibles para su utilización, y no desde una exégesis que considera primeramente a las cosas al modo de un ente que se comprende teóricamente, contemplativamente

En su intento de responder a las preguntas respecto a desde dónde se obtiene este sentido directivo y dominante del ser, Heidegger entiende que es imprescindible una vuelta a Aristóteles, puesto que la crítica heideggeriana intenta conocer los motivos ocultos que guían las concepciones anteriormente señaladas sobre el ser. Para ello es necesario pensar lo no pensado por el Estagirita. En primer término, la exégesis que lleva a cabo el filósofo alemán se remite a la Ética a Nicómaco, libro VI. La custodia del ser en la verdad solo es posible gracias al nous. El nous permite que una determinada región de objetos sea accesible. La sophía y la phrónesis son los modos concretos de realización del nous. La pregunta que sobrevuela es si la constitución ontológica de la vida fáctica se puede leer con mayor claridad en la phrónesis o más bien en la sophía. La sophía custodia el ser de un ente que posee una constitución ontológica de ser siempre necesariamente lo que es, de un ente que se conserva siempre de la misma forma y así se define ontológicamente. Para Aristóteles, la sophía que tiene como objeto de consideración aquello que es siempre de la misma forma, que no cambia, que es inmutable, sería la actividad más pura de la vida humana, por eso es lo más elevado, lo que tiene mayor 
dignidad ontológica, la actividad que posee la mayor excelencia. Dios representa justamente su máxima manifestación, dado que es pensamiento de pensamientos, y resulta de la radicalización ontológica del ente en movimiento, solamente en este inteligir se manifiesta la forma más pura del ente en movimiento. $\mathrm{Y}$ esto no tiene ninguna relación con algún tipo de quehacer práctico, ni de preocupaciones mundanas.

No obstante, la phrónesis, que según Heidegger es la circunspección solícitodiscursiva, custodia un ente que según su carácter ontológico puede ser de otra manera, que no es fijo ni determinado, esto en su archaí, en su a-partir-de-dónde. En la phrónesis se juega de algún modo la vida fáctica, en tanto que ilumina el trato que esta mantiene con el mundo, aquello hacia lo que se dirige es el ser que puede ser de otra manera, es una conducta eminentemente práctica, la phrónesis por tanto hace posible, permite el desarrollo temporal de la vida fáctica en su ser, teniendo un sentido eminentemente práctico. En la phrónesis es posible leer el carácter ontológico genuino de este ente, su determinación temporal e histórica, ella desvela el pleno momento del cómo singularísimo y peculiar de la vida fáctica. En otras palabras, es la apertura del horizonte de la situación y el motivo por el que actúa. Es así como la phrónesis se proyecta en dirección de la meta última hacia la que se dirige cada situación, hace manifiesto el momento, el pleno instante de la vida fáctica que es trato consigo misma, es acto, es eminentemente práctica. En cuanto que la phrónesis custodia un ente que puede ser de otra manera, como objeto del trato que se ocupa es un todavía no que pronto llegará a ser, el ya que hace comparecer el instante, el kairós.

Heidegger poco a poco va concretando su crítica a la filosofía griega, su tarea destructiva de la tradición y reconoce a Aristóteles como el interlocutor que le permite fijar, gracias a sus interpretaciones, el punto de partida de la determinación dominante del ser, aquel horizonte desde dónde parte la pregunta por el ser del ente, punto de partida que jamás fue abandonado; la consideración del ser-objeto como el ser que realmente es. Interpretación que por lo demás, alcanza al mismo ser de la vida fáctica y de los demás entes de la naturaleza y del mundo. El ser del ente se obtiene a partir de la determinación y explicitación de la quiddidad de su objeto, de la quiddidad de su contenido ontológico. Cualquier otra determinación del objeto en cuestión, como por ejemplo la dimensión práctica y ejecutiva de la vida fáctica, se descarta y se comprende negativamente. En la forma en que la vida fáctica se considera a sí misma, está presente el modo en que los primeros filósofos griegos interpretaron lo que les rodeaba. Con esto se expresa de qué forma se hace sentir todo el peso y el influjo de la tradición filosófica en toda meditación actual acerca de cualquier asunto, allí ya está presente y actuando la forma en que los primeros filósofos vieron y entendieron la naturaleza, que les brindó el modelo ontológico desde el cual construyeron sus categorías.

El joven profesor, en esta interpretación directiva del ser, que considera como una radicalización ontológica de la idea del ente en movimiento, -que utiliza como ejemplo 
para su explicación el producir que a llegado a su fin, en consecuencia, ser significa ser producido o estar finalizado-, se encontraría cerca a la identificación que hace por esos años de la concepción del ser que ha dominado la historia de la metafísica: ser como presencia.

Por último, Volpi comenta que esta interpretación del libro VI de la Ética Nicomaquea, le habría permitido a Heidegger dar con la prioridad del advenir. La ontologizacion de la praxis y la determinación práctica de la forma de ser del Dasein, le habrían permitido sostener contra el primado metafísico del presente y la presencia, la manifiesta prioridad del advenir ${ }^{663}$.

- En la conferencia y en el tratado El concepto del tiempo de 1924, Heidegger destaca como un rasgo ontológico esencial del Dasein, que en su condición de ente abierto originariamente hacia algo que todavía no es pero puede ser, es una posibilidad de ser. Para que este ente pueda proporcionar una base suficiente debe hacerse explícito como una totalidad, lo que le permitirá servir de guía para el análisis. Por consiguiente, solo cuando el Dasein es lo que puede ser resulta aprehensible como esa totalidad, cuestión que se logra solamente en su haber llegado al fin que el entrega la muerte, de esta forma está completamente ahí. Pero paradójicamente, este ente en su estar finalizado ya no es más. Este fenómeno señalado, la muerte, es la posibilidad suprema del Dasein porque en cuanto posibilidad ha de mantenerse siempre como posibilidad. La posibilidad de la muerte es indeterminada en su cuándo, pero cierta en su venida. Así entendida, la facticidad del Dasein está determinada esencialmente por esta posibilidad insuperable que es la muerte. Por ello, la exégesis ontológica de este ente, se logrará llevar a cabo según la forma de acceso que resulte la más originaria de acuerdo al propio ente que se investiga, en este caso desde la posibilidad más extrema y propia de este ente. El carácter de inconcluso que constituye a este ente guarda en sí mismo la indicación de la forma correcta de acceder a él, para poder llegar a su constitución estructural esencial. Esta constitución ontológica del Dasein, por ser la originaria, en cuanto posibilidad más extrema, es la que permite asegurar un terreno fenoménico para preguntar por el tiempo de forma genuina. Este ente que se adelanta hasta su ser más propio ha de tener la certeza de su propio haber pasado. De esta forma, el adelantarse se convierte en un estar cierto propio, que en su elección, en el haber elegido el cómo propio determina el adelantarse en términos de un estar resuelto (Entschlossensein). Se obtiene así una caracterización de una forma de ser del Dasein en el modo propio de su ser, que en cuanto adelantarse le abre la posibilidad de su propiedad.

En la consideración ontológica del Dasein en cuanto adelantarse que descubre, ya se hizo manifiesto el tiempo. El Dasein no es un ente que pasa en el tiempo, ni el tiempo es algo ajeno o añadido a él. Según Heidegger, este adelantarse es la forma esencial de la

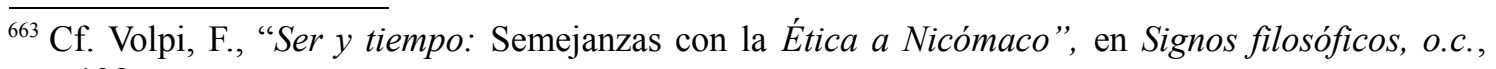
p.138. 
temporalidad del Dasein, gracias a la cual es en la propiedad de su ser, lo que no significa que sea un ente que es en el futuro, sino que es el futuro mismo del ser que este ente es. El sentido de este ser-futuro es el ser temporal, el futuro es el tiempo mismo ${ }^{664}$. Pero, este carácter temporal del que habla Heidegger, no puede ser entendido como algo que tiene el carácter de estar o pasar en el tiempo, sino que es el tiempo mismo y ahí está implícito el ser pasado y el ser presente. Si comprendemos el tiempo como algo que es, o las dimensiones temporales como algo que pasa en el tiempo, el futuro como algo que todavía no es pero luego será y el pasado como lo que ha sido pero dejo de ser estamos entendiendo el tiempo de forma tradicional. El Dasein es el tiempo y no un ente que pasa en el tiempo. Gracias a este análisis se hace comprensible y manifiesto que la dimensión privilegiada del tiempo es el futuro.

En la determinación ontológica del Dasein como ser posible resplandece ese carácter de ser futuro, incluso se indica que este ser futuro significa de modo primordial el ser temporal y este ser temporal significa el tiempo mismo y solo en virtud de esta determinación aparecen señalados el ser presente y el ser pasado, desde ahí adquieren su sentido. Es en el adelantarse hacia su posibilidad más extrema que el Dasein puede ser futuro de modo propio y desde allí pueden ser de forma propia el pasado y el presente, y solo en esta posibilidad de ser auténticamente su futuro este ente es el tiempo mismo.

Heidegger ha concluido, en la conferencia y en el tratado mencionados, que el carácter fundamental del tiempo es el futuro y con ello se le hace visible también, gracias a los trabajos sobre Aristóteles que llevaba a cabo por aquel entonces, que el sentido temporal que se ocultaba en la concepción del ser dominante de la tradición metafísica, lo entendía como ousía, como presencia constante (Anwesenheit). Esto supone un punto de inflexión en la filosofía de Heidegger, en relación a que la reformulación de la pregunta por el ser pasa necesariamente por el análisis de esa conexión indisoluble entre el ser y el tiempo. En el mismo periodo en el que el pensador alemán presenta una elaboración más precisa de la estructura ontológica del Dasein, llega también a la conclusión de que la comprensión griega del ser como presencia oculta una determinación temporal del ser como presente, es decir, llega a esta tesis precisamente a la luz de la exposición del tiempo del Dasein, que se muestra como el contrapuesto al de la tradición filosófica. El pensador de la Selva Negra lleva a cabo una contraposición entre el tiempo de la metafísica y el tiempo del Dasein, con lo que encuentra una forma contundente de expresar esa dimensión temporal inherente a la vida fáctica, que está lejos de la disponibilidad y de la presencia constante para una mirada teórico cognoscitiva de objetos. Como vemos en esta instancia del pensamiento de Heidegger se vincula directamente al advenir (Zukunft) como carácter fundamental del tiempo (Zeit), lo que le permite deducir que en la comprensión griega del

${ }^{664}$ En una de las llamadas notas marginales, que según el editor presumiblemente se habrían escrito entre el año 1925 y 1926, Heidegger dice: "el tiempo, empero, es el futuro" ( Zeit aber ist Zukunft) (GA64,51/69) 
ser (Sein) como presencia (Anwesenheit) se oculta un modo del tiempo, el presente (Gegenwart), quedando así definitivamente perfilado el vínculo entre el ser y el tiempo.

El análisis de las lecciones y trabajos de principios de los años veinte que hemos revisado en la primera parte de nuestra investigación, nos sugieren que no es la cuestión del ser la preocupación fundamental que motiva esas primeras lecciones. Además, es bastante significativo que el punto de partida de la problemática haya sido siempre el análisis de la vida fáctica, el tiempo peculiar a ella como el fenómeno que le permite revelar las insuficiencias de la tradición metafísica para preguntar por el ser de la vida humana, y a partir de ahí la investigación heideggeriana se dirige hacia la pregunta por el ser. Este sería el esquema que sigue la meditación del pensador de la Selva Negra; desde la consideración del tiempo como esencialmente advenidero hacia la pregunta por el ser, a la cual llega una vez que reconoce la insuficiencia de la interpretación de la tradición metafísica en relación a la pregunta por el ser de la vida fáctica. Esto se ha hecho completamente evidente en el tratado El concepto del tiempo, donde ha desarrollado un análisis acabado de la estructura ontológica del Dasein y ha señalado que "el fenómeno fundamental del tiempo es el futuro". Heidegger concluye ahí que la interpretación del ser de la filosofía griega es entendida como presencia, como presente, y llega a la conclusión de que ser para los griegos significa disponibilidad (Verfügbarkeit), estar finalizado, presencia (Anwesenheit), y para Aristóteles, quien fue el primero que interpretó el tiempo, ser significa presencia, presente. Quedando así plenamente vinculada la cuestión del ser y el tiempo como una y la misma pregunta. Todo esto significa, que en última instancia, la filosofía griega ha comprendido el ser como disponibilidad, como presencia, prevaleciendo esta consideración por sobre el sentido originario de ousía, que en su acepción originaria se refería a la posesión o propiedad de algo. Sentido que queda desplazado con la interpretación que lo piensa como presencia constante, con lo cual queda vinculado a un modo del tiempo, el presente. Esta interpretación adquiere sus presupuestos ontológicos desde la filosofía de Parménides y su máximo exponente sería Aristóteles, legado frente al cual, la filosofía posterior no haría más que seguir sus pasos. Además, el propio mundo peculiar al trato es interpretado como presencia, teniendo como modelo la imagen del cielo, de la naturaleza, de lo que está ahí siempre presente; solo lo que comparece de forma permanente y constante es la auténtica realidad y la presencia por definición, la presencia constante del ser siempre. El modelo perfecto de esta presencia, el ente auténtico por antonomasia es el cielo, pues su presencia y permanencia es indubitable e imperecedera. De esta forma, el Dasein mismo interpreta su propio ser desde el mundo, pero entendiendo el mundo como naturaleza, como mundo de su ocupación más inmediata, dicho de otra forma: comprende su ser desde los entes del mundo, que en cuanto ocuparse en el presente deja comparecer el mundo, ese mundo se interpreta como simple presencia, como presente. 
Heidegger establece claramente la distinción y al mismo tiempo conexión entre la presencia (Anwesenheit) y el presente (Gegenwart) como modo del tiempo. Lo que significa que el ser es pensado y concebido por la filosofía griega desde el tiempo. Paradójicamente, la interpretación del tiempo que hace Heidegger es la opuesta a la tradición metafísica. El pasado puede ser de algún modo sometido al escrutinio objetivador, como algo que ya se ha tenido frente a los ojos pero que ya ha pasado; qué decir del presente, es aquello que tenemos frente a los ojos como la presencia inmediata que se puede contemplar y objetivar, sin embargo, el futuro es aquello que no podemos hacer disponible, que no es posible objetivar ni calcular. Este carácter temporal, en cuanto fenómeno, tal como lo comprende Heidegger, posee todas aquellas características del ser o de este ente privilegiado, con la cuales la tradición metafísica no ha contado, que no ha tomado en cuenta, en otras palabras, la constitución esencialmente advenidera mienta a un ente cuya constitución ontológica fundamental es ser una posibilidad, tiene una constitución ontológica distinta a los entes de la naturaleza, todo esto, es lo que ha hecho imposible que la tradición filosófica pueda dar cuenta de este ente, esta tradición todo lo piensa en términos de presencia constante, desde un modo del tiempo, el presente, ocultándose bajo esta consideración del ser la constitución originaria del Dasein, lo que ha derivado en que la pregunta por el ser haya terminado por quedar completamente oscurecida, según los cánones de la tradición.

En esto radica la importancia de esta interpretación del tiempo que Heidegger elabora en esta estancia de su pensamiento, donde no habla de temporalidad sino que se refiere al tiempo mismo. Por lo que cabría pensar, que estamos frente a lo que podríamos llamar una ambivalencia ontológica respecto a la cuestión del tiempo y del ser, no sabemos con seguridad si Heidegger cuando afirma que el fenómeno fundamental del tiempo es el futuro se refiere al tiempo del Dasein o al tiempo sin más, es decir, si por aquel entonces piensa el tiempo del ser mismo desde esta dimensión temporal que ha quedado oculta a la tradición metafísica en virtud de su manifiesta prioridad al simple presente. Estas son cuestiones que consideramos importantes, porque hasta antes de la publicación del tratado el concepto del tiempo y Conceptos fundamentales de la filosofía aristotélica, publicados en 2004 y 2002 respectivamente, quedaba de cierta forma indeterminado en qué momento y de qué modo en la filosofía de Heidegger se plasmó con tintes más definidos el vínculo indisoluble entre la cuestión del ser y del tiempo, lo que impedía determinar el papel que le correspondía al problema ontológico del advenir en esta conjunción del ser y del tiempo que Heidegger interpreta como la cuestión verdaderamente decisiva en la historia de la filosofía, que determinaría su camino posterior.

Es menester hacer una puntualización importante, no pretendemos con esta interpretación restar validez a las otras dimensiones del tiempo, puesto que ha de ser entendido como unidad indisoluble entre pasado, presente y futuro. Lo que se ha hecho es 
exponer la radicalidad del problema ontológico del advenir, que el filósofo alemán afirma de forma concreta y precisa a lo largo de la estructuración de su proyecto filosófico que forja a lo largo de los años 20. Pero que en este periodo de su pensamiento, en el que se está fraguando Ser y tiempo, se esmera en dejar establecido sin ambages que el fenómeno fundamental del tiempo es el futuro, que el carácter fundamental del tiempo es el futuro, esta es la baza fundamental de un pensamiento que pretende enfrentarse con fuerza a la concepción del ser de la metafísica y esto Heidegger lo puntualiza y precisa en el periodo en el cual se le hace plenamente manifiesto el vínculo entre la cuestión del ser y del tiempo, gracias al descubrimiento de que en la interpretación griega del ser como presencia se esconde un modo del tiempo, el presente.

La fuerza con la que el filósofo alemán expresa este problema ontológico del advenir, que luego en Ser y tiempo modificará, pero reafirmará, nos impelen a sostener que esta cuestión es una problemática ontológica de carácter privilegiado, tanto para el análisis de la constitución temporal de la vida fáctica, del Dasein, pero también y fundamentalmente, como aquí afirmamos, en la articulación de la reformulación de la pregunta por el ser desde el tiempo. Esta cuestión a Heidegger le ha venido preocupando desde hace tiempo, por qué la metafísica, la tradición filosófica no ha podido dar cuenta de la vida fáctica desde una perspectiva originaria, que en su genuino carácter temporal es esencialmente advenidera, esta pregunta es la que se escondía en sus primeras formulaciones filosóficas, hasta que por fin llega a la conclusión de que la insuficiencia de la tradición se sustenta en una comprensión del ser desde un modo del tiempo, que ha impedido el acceso al ente hacia el que debe dirigir primordialmente su atención la filosofía. En consecuencia, este problema ontológico del advenir se muestra en lo que hemos denominado su potencial ontológico y esto de forma clara y concreta en el tratamiento y en la progresión del problema del tiempo en los trabajos anteriores a Ser y tiempo.

-El vuelco fundamental a la filosofía que se plantea en Ser y Tiempo se entiende esencialmente a través de la determinación del Dasein como el ente privilegiado al que debemos interrogar antes que a cualquier otro ente, ya que es comprensión del ser, y al estar constituido por esa comprensión del ser le es inherente esa posibilidad de la existencia en la propiedad o en la impropiedad. Lo más propio del Dasein es asumir su ser como esencialmente finito, finitud que solo puede ser asumida en esa radical apertura hacia el advenir, cuestión presente en la estructura de la analítica del Dasein de punta a cabo. Lo que más radical y propiamente somos es lo que aún no somos, posibilidad pura, el hombre comienza por ser su futuro, su porvenir. Tal como hemos señalado, en ningún momento se pretende con esta interpretación restar importancia a los otros éxtasis de la temporalidad, a los otros fenómenos, sino destacar que es el advenir el que sustenta la totalidad unitaria de la temporalidad originaria, además sirve de fundamento a su 
articulación unitaria. Ejemplo de esto es que del mismo modo en que se rescata la idea originaria de futuro se recupera el pasado en su originaria constitución temporal como un pasado con un carácter dinámico que sigue pasando, de igual manera se muestra el presente en medio del que se manifiesta el ente. En la analítica se entiende al Dasein como un ente que debe vivir en lo posible en cuanto posible, un ente que es fundamentalmente una forma de futuro; un adelantarse con el que se nos hace patente de manera invariable la radical y esencial finitud de nuestra existencia. Solamente si el Dasein experimenta o comprende la finitud se le manifiesta la temporalidad originaria. El hombre vive su vida como un advenir a él su posible no seguir viviendo. Solo así le aparece al Dasein el tiempo como horizonte de posibilidad de la comprensión del ser, de su propio ser.

Cuando se hace referencia al Dasein, al cuidado, se está pensando principalmente en un ente que tiene el carácter de estar vuelto hacia lo que adviene, hacia algo futuro, pero al mismo tiempo se alude al pasado que me constituye de modo radical, fui arrojado a la existencia y hacia las cosas que constituyen el mundo. El cuidado es esencialmente un estar abierto hacia lo que adviene. El Dasein como cuidado es un ente que en tanto se proyecta, toma sobre sí su más propia situación y así permite que se haga presente el ente que le hace frente; estas son las tres dimensiones de la temporalidad del Dasein, que constituyen la estructura unitaria del cuidado. La temporalidad revela el sentido del cuidado en la propiedad, si el hombre comprende el sentido de su ser como temporalidad puede entonces en propiedad ser lo que es. La temporalidad así entendida dista mucho de pensarse como algo que pasa en el tiempo, o que trascurre en un antes, un después y un ahora, sino que su ser es la aperturidad de sus tres éxtasis articulados en una íntima unidad. El tiempo es la apertura en la cual estamos, la temporalidad se muestra como el sentido último de todas las determinaciones y estructuras del ser del Dasein, y ahí, se muestra el advenir como el fundamento de la temporalidad humana y de los entes que en ella aparecen.

En esto radica fundamentalmente la diferencia entra la exégesis de la tradición metafísica y la filosofía de Heidegger. Cuando se concibe al hombre como substancia o cosa dicha interpretación es realizada desde un determinado y privilegiado modo temporal, el presente, cuestión que ha terminado por oscurecer el carácter temporal originario de la vida humana. Todo esto acontece porque la interpretaciones provenientes de la ontología clásica, que se sustentan en este privilegio del simple y siempre presente, consideran al hombre como cosa, substancia, sujeto o cógito, como algo presente ante los ojos, lo que constituye la negación de su esencia temporal y su finitud. Según esto, el presente, es lo que fundamenta y determina el pasado y el futuro, es decir, determina la idea del tiempo y del ser. Esta interpretación del tiempo es precisamente el fundamento de la concepción vulgar del tiempo, en la que se sostiene la consideración del tiempo de la cotidianidad. Lo meramente presente como lo primero en la filosofía tradicional para preguntar por el ser, desfigura el carácter originario del ser del Dasein como temporalidad, como tiempo. Lo 
único substante, la única realidad para el Dasein es justamente el tener que hacerse así mismo, su ser como existencia; lo único fijo, acabado, determinado en él, es su apertura, su ser posible, un ser que es dinámico, existe, que es proyecto, posibilidad, radical apertura. Lo estable en él es su ser como advenidero, posee un ser que forzosamente tiene que ser su ahí, en su ser le va su ser mismo, está constantemente en juego su ser.

El Dasein para poder ser su posibilidad más propia, solo lo puede lograr en cuanto precursor estado de resuelto, que es esa apertura a lo más propio que le adviene. El modo propio de la aperturidad del Dasein es el estado de resuelto. Solo en la temporalidad así entendida puede en el Dasein darse el precursor estado de resuelto, que es asumir la posibilidas más originaria de la propia muerte. Fenómeno en el que se abre a la totalidad de su poder ser auténtico y propio.

Dice Heidegger, que "más alta que la realidad está la posibilidad" ${ }^{665}$, de alguna manera esta frase está profundamente influida por esta concepción originaria de la temporalidad. Arrojado sí, pero hacia lo que adviene, como un ser que es primariamente futuro, posibilidad. Se hace patente la primacía de este advenir como un vivir hacia algo, "la posibilidad en cuanto existenciario es (...) la más original y última determinación ontológica positiva del ser-ahí' ${ }^{\prime \prime 666}$, este ente es sus propias posibilidades, se determina radicalmente en función de sus posibilidades, adviniendo desde el futuro. En un sentido el advenir es lo primero que aparece, lo más cercano en las dimensiones temporales. Al preguntar por el ser del Dasein, por el ente que comprende el ser y que guarda una relación originaria con él, se entiende el sentido del ser del Dasein como tiempo, si este despliega su esencia, su ser como temporalidad, aparece el tiempo como horizonte de toda comprensión del ser, es en aquel horizonte en el que debemos fijar nuestra mirada para preguntar por el ser mismo

La tarea que hemos llevado a cabo ha sido sacar a luz la importancia radical y fundamental de un éxtasis de la temporalidad que guarda cierta prioridad sobre los demás, en el cual descansa la posibilidad de la propiedad del Dasein y que lo define primariamente. Ese ente que somos, que soy, está arrojado hacia aquello que adviene inexorablemente, la muerte es la posibilidad más propia, la absoluta imposibilidad de toda otra posibilidad. En tanto asumimos esencialmente la finitud se puede ser en la propiedad de nuestro propio ser, en nuestro radical ser sí mismo, toma sobre sí su propio ser, es su propio destino y lo asume como tal. Es el que es sin más, sin encubrimientos, él es su propio destino. Elige ser sí mismo en su posibilidad más propia.

El comprender, la posibilidad, el poder ser, la existencia, se comprenden esencialmente desde el futuro. En consecuencia, el Dasein se entiende originalmente como posibilidad en su proyección en el advenir a sí de la posibilidad, toda vez que puede ser su

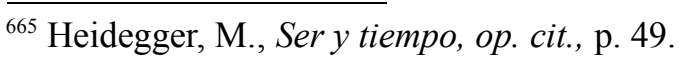

${ }^{666}$ Ibíd., p. 161.
} 
posibilidad más propia si puede advenir a sí. El advenir a sí de la posibilidad en tanto fenómeno originario del futuro, es la condición de posibilidad de la comprensión, del preser-se, del cuidado de la anticipación de la muerte. Podemos decir que el futuro como éxtasis privilegiado es desde dónde se comprende el pasado y el futuro, esto teniendo en cuenta la relación del Dasein con sus propias posibilidades, que es arrojado a sus posibilidades, que siempre es siendo sus posibilidades, de forma que es un ente que es futuro en su más esencial determinación. Este es uno de los planteamientos principales que guían Ser y tiempo en la disputa que Heidegger mantiene con la tradición metafísica, que dicta que el presente es el rasgo fundamental y decisivo de cualquier idea o determinación del concepto del tiempo, siendo el pasado y el futuro, lo ya no real y lo todavía no real, instancias temporales desprovistas de realidad.

Por todas las razones mencionadas, hemos podido verificar que el problema ontológico del advenir se muestra como una cuestión de un carácter verdaderamente fundamental y destacado, tanto en la estructura y desarrollo de la analítica existenciaria, como también en la articulación de la cuestión más puramente ontológica -si es posible decir esto-, por cuanto en la misma clarificación y determinación de esta cuestión, como carácter fundamental del tiempo, Heidegger habría podido concluir que en la concepción del ser como presencia de procedencia griega se ocultaba un modo del tiempo, el presente. 


\section{BIBLIOGRAFÍA}

\section{Bibliografía Primaria: Textos de Heidegger}

\section{HEIDEGGER,}

- Der Zeit Begriff in der Geschichwissenchaft (lección de habilitación docente), en Frühe Schriften (GA1, (ed.) F. v. Herrmann), Vittorio Klostermann, Frankfurt del Meno, 1978, págs. 415-433. Citado de trad.esp. "El concepto del tiempo en la ciencia histórica" en M. Heidegger, Tiempo e historia, Trotta, Madrid, 2009. Trad. Jesús Adrián.

- Die idee der Philosophie und das Weltsanschauungsproblem (lecciones de Friburgo del periodo de posguerra de 1919), en Zur Bestimmung der Philosophie (GA 56/57 (ed.) B. Heimbüchel), Vittorio Klostermann, Frankfurt del Meno, 1987, págs. 3-117. La idea de la filosofía y el problema de la concepción del mundo, Herder, Barcelona, 2005. Trad. Jesús Adrián.

- "Anmerkungen zu Karl Jaspers Psycologie der Weltschauungen" en Wegmarken (GA 9, (ed.) F. v. Herrmann), Vittorio Klostermann, Frankfurt del Meno, 1976, págs. 1-44.

- Observaciones a la Psicología de las concepciones de mundo de Kart Jaspers, en M. Heidegger, Hitos, Alianza, Madrid, 2000, págs. 15-47. Trad. Arturo Leyte y Helena Cortés.

- Einleitung in die Phänomenologie der Religión (lecciones de Friburgo del semestre de invierno de 1920-1921), en Phänomenologie des religiösen Lebens (GA60, (ed.) C. Strube), Vittorio Klostermann, Frankfurt del Meno, 1995, págs. 3-159. Citado de trad. esp. Introducción a la filosofía de la religión, Siruela, Madrid, 2005. Trad. Jorge Uscatescu.

- Augustinus und der Neuplatonismus (lecciones de Friburgo del semestre de verano de 1921), en Phänomenologie des religiösen Lebens (GA60, (ed.) C. Strube), Vittorio Klostermann, Frankfurt del Meno, 1995, págs. 160-302. Citado de trad. esp. Agustin y el Neoplatonismo, en M. Heidegger, Estudios sobre Mística Medieval, Siruela, Madrid, 1997. Trad. Jacobo Muñóz.

- "Phänomenologische Interpretationen zu Aristoteles. Anzeige der Hermeneutischen Situation" (Informe Natorp de 1922), en Dilthey Jahrbuch 6, 1989, págs. 237-274. Citado de trad. esp. Interpretaciones fenomenológicas sobre Aristóteles. Indicación de la situación hermenéutica, Trotta, Madrid, 2002. Trad. Jesús Adrián.

- Ontologíe. Hermeneutik der Faktizität, lecciones de Friburgo del verano de 1923, en (GA63, (ed.) K. Bröcker-Oltmanns), Vittorio Klostermann, Frankfurt del Meno, 1988. Citado de trad. esp. Ontologia. Hermenéutica de la facticidad, Alianza, Madrid, 1999. Trad. Jaime Aspiunza.

- Einführung in die phänomenologische Forschung (lecciones de Marburgo del semestre de verano de invierno de 1923-1924), en (GA17, (ed.) F.v.Herrmann), Vittorio Klostermann, Frankfurt del Meno, 1994. Citado de trad. esp. 
Introducción a la investigación fenomenológica, Síntesis, Madrid, 2008. Trad. Juan José García Norro.

- Grundbegriffe der aristotelischen Philosophie (curso de Marburgo del semestre de verano de 1924), en (GA18, (ed.) M. Michalsky), Vittorio Klostermann, Frankfurt del Meno, 2002.

- Der Begriff der Zeit (conferencia dictada ante la Sociedad Teológica de Marburgo en junio de 1924), en Max Niemeyer, Tubinga, 1989, (reeditada en GA64, (ed.) F.v. Herrmann, Vittorio Klostermann, Frankfurt del Meno, 2004, págs. 105-125). Citado de trad. esp. El concepto del tiempo, Trotta, Madrid, 2006. Trad. Raúl Gabás y Jesús Adrián.

- Der Begriff der Zeit (tratado de 1924), en (GA64, (ed.) F.v. Herrmann), Vittorio Klostermann, Frankfurt del Meno, págs. 1-103). Citado de trad. esp. El concepto del tiempo(el tratado), Herder, Barcelona, 2008. Trad. Jesús Adrián.

- Prolegomena zur Geschichte des Zeitbegriffes (lecciones de Marburgo del semestre de verano de 1925), en (GA 20, (ed.) P. Jaeger), Vittorio Klostermann, Frankfurt del Meno, 1988. Citado de trad. esp. Prolegómenos para una historia del concepto del tiempo, Alianza, Madrid, 2006. Trad. Jorge Aspiunza.

- "Wilhelm Diltheys Forschungarbeit und der gegenwärtige Kampf um eine historische Weltanschauung" (ciclo de diez conferencias dictadas en Kassel desde el día 16 al 21 de abril de 1925), en Diltheys-Jahrbuch 8, 1992-1993, (ed.) E. Rodi, págs. 143-180. Citado de trad. esp. "El trabajo de investigación de Wilhelm Dilthey y la actual lucha por una concepción histórica del mundo" en M. Heidegger, Tiempo e historia, Trotta, Madrid, 2009. Trad. Jesús Adrián.

- Logik. Frage nach der Wahrheit (curso de Marburgo del semestre de invierno de 1925-1926), en (GA21, (ed.) W. Biemel) Vittorio Klostermann, Frankfurt del Meno, 1976. Citado de trad. esp. Lógica: la pregunta por la verdad, Alianza, 2004, Madrid. Trad. Alberto Ciria.

- Sein und Zeit, 1927, Max Niemeyer, Tubinga, ( reeditado con la notas marginales en GA2, (ed.) F.v. Herrmann). Citado de El ser y el tiempo, FCE, Buenos Aires, 1991. Trad. José Gaos. Ser y tiempo, Universitaria, Chile, 1997. Trad. Jorge Eduardo Rivera.

- Die Grundprobleme der Phänomenologie (lecciones de Marburgo del semestre de invierno de verano de 1927), en (GA 22, (ed.) F.v. Herrmann), Vittorio Klostermann, Frankfurt del Meno, 1989. Los problemas fundamentales de la fenomenología, Trotta, Madrid, 2000. Trad. Juan José García Norro.

- "Phänomenologie und Theologie" (conferencia de 1927), en Wegmarken (GA9, (ed.) F.v, Herrmann), Vittorio Klostermann, Frankfurt del Meno, 1978, págs. 45-78. "Fenomenología y teología" en M. Heidegger, Hitos, Alianza, Madrid, 2000, págs. 49-74. Trad. Helena Cortés y Arturo Leyte.

- Metaphysische Anfangsgründe der Logik im Ausgang von Leibniz (lecciones del semestre de verano de 1928) en (GA26, (ed.) K. Held), Vittorio Klostermann, Frankfurt del Meno, 1990. Fundamentos metafísicos de la lógica, Síntesis, Madrid, 2008. Trad. Juan José García Norro.

- Einleitung in die Philosophie (lecciones de Friburgo del semestre de invierno de 1928-1929), en (GA27, (ed.) O. Saame e I. Saame-Speidel) Vittorio 
Klostermann, Frankfurt del Meno, 1996. Introducción a la filosofía, Cátedra, Madrid, 2001. Trad. Manuel Jiménez Redondo.

- Die Grundbegriffe der Metaphysik. Welt-Endlichkeit-Einsamkeit (lecciones de Friburgo del semestre de invierno de 1929-1930), en (GA29/30, (ed.) F.v. Herrmann), Vittorio Klostermann, Frankfurt del Meno, 1983. Los conceptos fundamentales de la metafísica. Mundo-finitud-soledad, Alianza, Madrid, 2007. Trad. Alberto Ciria.

- Kant und das Problem der Metaphysik (1929), Vittorio Klosterman, Frankfurt del Meno, 1991 (reeditado por F.v.Hermmann en GA3). Kant y el problema de la metafisica, FCE, México, 1993. Trad. Gred Ibscher.

- “Was ist Metaphysik?" (conferencia de 1929), en Wegmarken (GA9, (ed.) F.v. Herrmann), Vittorio Klostermann, Frankfurt del Meno, 1978, págs. 103-122. ¿Qué es metafisica?, Siglo Veinte, Buenos Aires, 1992. Trad. Xavier Zubiri.

- “Einleitung zu "Was ist Metaphysik?" (1949), en Wegmarken (GA9, (ed.) F.v. Herrmann), Vittorio Klostermann, Frankfurt del Meno, 1978, págs. 365-383. "Introducción a “¿Qué es metafísica?” en M. Heidegger, Hitos, Alianza, Madrid, 2000, págs. 299-312. Trad. Helena Cortés y Arturo Leyte. "Mein Weg in die Phänomenologie" (1963), en Zur Sache des Denkens, Max Niemeyer, Tubinga, 1976, págs. 81-90 ( reeditado en GA14, por W.v. Herrmann). "Mi camino en la fenomenología" en M. Heidegger, Tiempo y ser, Tecnos, Madrid, 1999. Trad. Manuel Garrido, José Molinuevo y Félix Duque.

\section{Bibliografía Crítica}

\section{J. ACEVEDO,}

- Hombre y mundo, Universitaria, Chile, 1987.

- En torno a Heidegger. Universitaria, Chile, 1990.

- Heidegger y la época de la técnica, Universitaria, Chile, 1999.

\section{J. ADRIÁN,}

- El joven Heidegger. Un estudio interpretativo de su obra temprana al hilo de la pregunta por el ser, Ediciones UAB, Barcelona, 2000.

- "Heidegger y la filosofía práctica de Aristóteles: de la Ética a Nicómaco a la Ontología de la vida humana”, en Taula 33-34, 2000, págs. 91-106.

- "El joven Heidegger. Asimilación y radicalización de la filosofía práctica de Aristóteles", en Logos: Anales del Seminario de Metafísica, nº 34, 2001, págs. 179-221.

- "Prólogo" en M. Heidegger, Interpretaciones fenomenológicas sobre Aristóteles. Indicación de la situación hermenéutica, Trotta, Madrid, 2002, págs. 9-22.

- "Heidegger y la indicación formal: hacia una articulación categorial de la vida humana" en Dianota XLIX/52, 2004, págs. 25-46.

- El programa filosófico del joven Heidegger, Herder, Barcelona, 2008. 
- El lenguaje de Heidegger. Diccionario filosófico(1912-1927), Herder, Barcelona, 2009.

- Heidegger y la genealogía de la pregunta por el ser, Herder, Barcelona, 2010.

G. AGAMBEN,

- "La passion de la facticité", en Heidegger: Questions ouvertes, Paris, Osiris, págs. 63-84.

K. O. APEL,

- Apel, K., La transformación de la filosofía I, Taurus, Madrid,1985. Trad. Adela Cortina. Joaquín Chamorro y Jesús Conill.

H. ARENDT,

- “Martin Heidegger zum 80 Geburtstag”, en Merkur X, 1969, págs. 893-902.

T. AGUILAR-ÁLVAREZ BAY,

- El lenguaje en el primer Heidegger, FCE, México, 1998.

J. ALEMÁN y S. BARRIERA,

- Lacan: Heidegger, un decir menos tonto, Miguel Gómez, Granada, 1998.

M. ÁLVAREZ,

- Pensamiento del ser y espera de Dios, Sígueme, Salamanca, 2004.

- Teorías de la historicidad, Síntesis, Madrid, 2007.

- "Una peculiar vuelta a las cosas" en Acercamiento a la obra de Martin Heidegger, SCLF, nº 5, Salamanca, 1991. págs. 7-26.

- “El problema de Dios en Wittgenstein y Heidegger” en Revista de Occidente, n ${ }^{\mathrm{o}} 258$, Madrid, 2002, págs. 108-123.

C. ASTRADA,

- Martin Heidegger. De la analítica ontológica a la dimensión dialectica, Juarez, Buenos Aires, 1970.

K. AXELOS,

- El pensamiento planetario. El devenir- pensamiento del mundo y el devenirmundo del pensamiento, Monte Ávila, Barcelona, 1969.

- Introducción a un pensar futuro. Sobre Marx y Heidegger, Amorrortu, Buenos Aires, 1973. 


\section{R. BRAGUE,}

- "La fenomenología como vía de acceso al mundo griego. Notas sobre la crítica a la Vorhandenheit como modelo ontológico en la lectura de Aristoteles" en Revista de Filosofía, no 6, vol.4, Madrid, págs. 401-427. Trad. Rafael Gérez.

\section{J. BEAUFRET,}

- Al encuentro de Heidegger. Conversaciones con F. de Towarnicki, Monte Ávila, Caracas, 1993.

\section{J. BECH,}

- De Husserl a Heidegger. La transformación del pensamiento fenomenológico, Universidad de Barcelona, 2001.

\section{BENEDITO,}

- Heidegger en su lenguaje, Tecnos, Madrid, 1992.

\section{J. BENGOA RUIZ,}

- De Heidegger a Haberlas: hermenéutica y fundamentación última de la filosofia contemporánea, Herder, Barcelona, 1992.

\section{BERCIANO,}

- La crítica de Heidegger al pensar occidental, Universidad Pontificia, Salamanca, 1990.

- "Temporalidad y ontología en el círculo de "Ser y tiempo" en Themata: Revista de Filosofía, nº 7, 1990, Sevilla, págs. 13-50.

- Superación de la metafísica en Martin Heidegger, Universidad de Oviedo, 1990.

- “¿ Qué es realmente el Dasein en la filosofía de Heidegger? en Themata: Revista de Filosofía, no 10, 1992, Sevilla, págs. 435-450.

- La revolución filosófica de Martin Heidegger, Biblioteca nueva, Madrid, 2001.

- "Filosofía Heideggeriana y kairós" en Las razones del corazón, (eds). M. Anxo y D. Castillo, Naturaleza y Gracia, Salamanca, 2007, págs. 117-134.

\section{A. BERTORELLO,}

- El límite del lenguaje: la filosofia de Heidegger, Biblos, 2006, Buenos Aires.

\section{W. BIEMEL,}


- La interpretación del arte en Heidegger, Centro de Semiótica y Teoría del Espectáculo. Universidad de Valencia, 1994.

H. BOEDER,

- El límite de la modernidad y el legado de Heidegger, Quadrata, México, 2003. trad. y notas de Martín Zubiria.

W. BROGAN,

- "Die Frage nach der Zeit in Heideggers Aristoteles-Interpretation. Auf dem Weg zu Sein und Zeit" en (eds) Denker, A., Figal, G., Volpi, F., y Zoborowsky, H., Heidegger Jahrbuch 3: Heidegger und Aristóteles, Karl Alber, Friburgo y Múnich, 2007, págs. 96-108.

P. BOURDIEU,

- La ontología política de Martín Heidegger, Paidós, Barcelona, 1991. trad. César de La Mezsa.

E. CARRASCO,

- Heidegger y la historia del ser, Universitaria, Chile, 2007.

C. CARDONA,

- Olvido y memoria del ser, Universidad de Navarra, Pamplona, 1997.

L. CARDONA,

- Heidegger: el testimonio del pensar, Siglo del Hombre, México, 2010.

A. CARPIO,

- El sentido de la historia de la filosofía, Eudeba, Buenos Aires, 1977.

C. CASALE,

- "La interpretación fenomenológica de Heidegger de la escatología paulina" en Teología y Vida, vol. XLIX, nº 3, PUC, Chile, 2008, págs. 399-429.

P. CEREZO,

- Arte, verdad y ser en Heidegger. Fundación Universitaria Española, Madrid, 1963.

I. CHUECAS, 
- "Heidegger y San Pablo. La interpretación fenomenológica de Martin Heidegger a la carta a los Gálatas desde una perspectiva de exégesis bíblica" en Teología y Vida,vol. XLIX, nº 3, PUC, Chile, 2008, págs.161-167.

A. CONSTANTE,

- El retorno al fundamento del pensar (Martin Heidegger), UNAM, México, 1986.

- "La pregunta que interroga por el sentido del ser" en En-claves del pensamiento, vol.IV, $\mathrm{n}^{\mathrm{0}} 7$, Tecnológico de Monterrey, México, 2010, págs. 79100.

E. COLOMER,

- El pensamiento alemán de Kant a Heidegger III, Herder, Barcelona, 1990.

C. CORDUA,

- Filosofía a destiempo: Seis ensayos sobre Heidegger, Rialp, Santiago, 1999.

- Sloterdijk y Heidegger, Universidad Diego Portales, Santiago, 2008.

M. CORVEZ,

- La filosofía de Heidegger, FCE, México, 1970.

D. CRUZ VÉLEZ,

- Filosofía sin supuestos, Sudamericana, Buenos Aires, 1970.

F. DASTUR,

- Heidegger y la cuestión del tiempo, Signos, Buenos Aires, 2006.

- La muerte: ensayo sobre la finitud, Herder, Barcelona, 2008. Trad. Maria Pons.

J. DERRIDA,

- Del espíritu. Heidegger y la pregunta. Pre-Textos, Valencia, 1989.

L. DE LA MAZA,

- "Fundamentos de la filosofía hermenéutica: Heidegger y Gadamer" en Teología y Vida, vol. XLVI, PUC, Chile, 2005, págs. 122-138.

\section{J. DEL MORAL,}

- "Historicidad y temporalidad en el Ser y el tiempo de M. Heidegger", en Signos filosóficos, no 5, UAM, Iztapalapa, págs. 133-141. 


\section{H. DREYFUS,}

- Ser-en-el-mundo: comentario a la primera división de Ser y tiempo de Martin Heidegger, Cuatro Vientos, Santiago, 1996.

F. DUQUE,

- Los confines de la modernidad, Diez años después de Heidegger, Granica, Granada, 1988.

- En torno al humanismo (Heidegger, Gadamer, Sloterdijk), Tecnos, Madrid, 2002.

- Residuos de lo sagrado; tiempo y escatología,, Abada, Madrid, 2010.

J. ECHARRI,

- Fenómeno y verdad en Heidegger, Universidad de Deusto, Bilbao, 1997.

E. ESCALANTE,

- Heidegger, UAM, Iztapalapa, 2009.

\section{ETTINGER}

- H. Arendt y M. Heidegger, Tusquets, Barcelona, 1996. Trad. Daniel Najmías.

\section{A. FABRIS,}

- “L' ermeneutica della facticità" nei corsi friburghesi dal 1919 al 1923” en Heidegger, ed. F. Volpi, Laterza, Roma, 1997, págs. 57-106.

- "El arte del diálogo en el pensamiento de Martin Heidegger" en Heidegger. Sendas que vienen I, (ed.) Felix Duque, UAM, Madrid, 2008, págs. 229-254.

\section{FARIAS,}

- Heidegger y el nazismo, Muchnik, Barcelona, 1989.

\section{P. FERNÁNDEZ,}

- Tiempo y sujeto: después de Heidegger, Encuentro, Madrid, 2010.

\section{FERRY y A. RENAUD,}

- Heidegger y los modernos, Paidos, Buenos Aires, 2001. Trad. Alcira Bixio.

G. FIGAL, 
- Martin Heidegger. Phänomenologie der Freiheit, Verlag Anton Hain, Frankfurt am Main.

- Indiferenciación vital y distanciamiento: la actitud vital hacia si en relación con Heidegger, Kierkegaard y Hegel, Biblos, Buenos Aires, 2010.

\section{S. FILIPPI,}

- "Cristianismo y neoplatonismo en San Agustin: la crítica heideggeriana" en Enfoques, vol. XXII, $\mathrm{n}^{\circ}$ 1, Universidad Adventista de la Plata, Argentina, 2010, págs.15-29.

\section{R. FLÓREZ,}

- Ser y advenimiento, Fundación Universitaria Española, Madrid, 2003.

\section{R. GABÁS,}

- "La interpretación heideggeriana del tiempo en Hegel" en Liberación y constitución del espíritu. Elementos hegelianos en el pensamiento contemporáneo, (eds.) Maria del Carmen Paredes y Mariano Álvarez, SEEH, Universidad de Salamanca, 2010, págs. 139-146.

\section{J. GAOS}

- Introducción a El ser y el tiempo de M. Heidegger, FCE, México, 1996.

\section{H. GADAMER}

- Verdad y método, Sígueme, Salamanca, 1988. Trad. Ana Agud y Rafael de Agapito.

- El problema de la conciencia histórica, Tecnos, Madrid, 1993.

- Mis años de aprendizaje, Herder, Barcelona, 1996. Trad. Rafael Fernández.

- Los caminos de Heidegger, Herder, Barcelona, 2006.

- "Sobre la filosofía alemana en el siglo XX" en ER. Revista de Filosofía, n" 26, 2000, págs. 189-217.

\section{J. GARCÍA BACCA,}

- Nueve grandes filósofos contemporáneos y sus temas, Anthropos, Barcelona, 1990.

\section{J. GARCÍA GAINZA,}

- Heidegger y la cuestión del valor. Estudio de los escritos de juventud, Newbook, Pamplona, 1997. 
P. GARCÍA,

- “¿Ontología fundamental o teoría del conocimiento? ¿Heidegger crítico del Neokantismo?", en Signos filosóficos, nº 7, UAM, Iztapalapa.

H. GANDER,

- "La fenomenología hermenéutica del vivir fáctico en Heidegger", en Heidegger. Sendas que vienen I, (ed.) Felix Duque, UAM, Madrid, 2008, págs. 141-171.

P. GAY,

- La cultura de Weimar. La inclusión de lo excluido, Argos, Barcelona, 1984.

C. GETHMANN,

- Verstehen und Auslegung. Das methodenproblem in der Philosophie Martin Heideggers, Bouvier, Bonn, 1974.

- "Heidegger un die Phänomenologie" en Dasein uns Erkennen. Heidegger im phänomenologisches Kontext, Walter de Gruyter, Berlín, 1993. págs. 3-48.

F. GIL VILLEGAS,

- Los profetas y el Mesías: Lukacs y Ortega como precursores de Heidegger en el Zeitgeist de la modernidad, Centro de Estudios Internacionales, México, 1996.

E. GRASSI,

- La filosofía del humanismo, Anthropos, Barcelona, 1993.

H. GREISH,

- Ontologie et temporalité. Esquisse d'une inteprétation intégrale de Sein und Zeit, PUF, París, 1994.

- La invención de la diferencia ontológica, Las cuarenta, Buenos Aires, 2010. Trad. Julio Fava.

\section{J. GONZÁLEZ,}

- Heidegger y los relojes, Encuentro, Madrid, 2008.

\section{J. GRONDIN,}

- Hans-Georg Gadamer: una biografía, Herder, Barcelona, 2000. Trad. Angela Ackermann. 
- Introducción a la hermenéutica filosófica, Herder, Barcelona, 2002. Trad. Angela Ackermann.

- Introducción a Gadamer, Herder, Barcelona, 2003. Trad. Constantino Ruiz..

- Introducción a la metafísica, Herder, Barcelona, 2006. Trad. Antoni Martínez.

M. HAAR,

- "Le moment (kairós), l' instant (Augenblick) et le temps-du-monde (Weltzeit)" en Heidegger 1919-1929. De l' hermeneutique de la facticité à la métaphysique du Dasein, ed. J. Courtine, París, Jean Vrin, 1996, págs. 67-90.

\section{J. HABERMAS,}

- El discurso filosófico de la modernidad, Taurus, Madrid, 1989.

K. HELD,

- "Fenomenología del "tiempo propio" en Husserl y Heidegger" en La Lámpara de Diógenes, vol. 10, n 18-19, BUAP, México, 2009, págs. 9-29.

\section{F. HERRMANN,}

- Hermeneutische Phänomenologie des Daseins. Eine Erläuterung von Sein und Zeit (vol.1), Vittorio Klostermann, Frankfurt de Meno, 1990.

- "Lógica y verdad en la fenomenología de Heidegger y Husserl" en Anales del Seminario de Historia de la Filosofía, no 13, UCM, Madrid, 1996, págs. 39-55.

- La segunda mitad de Ser y tiempo, Trotta, Madrid, 1997. Trad. Irene BorgesDuarte.

- "El concepto del tiempo según Heidegger" en Revista de Filosofía, vol. 35, no 107, Universidad Iberoamericana, México, 2003. págs. 85-106. Trad. Oscar Espinoza.

M. INWOOD,

- Heidegger, Oxford University Press, Oxford, 1997.

\section{K. JASPERS,}

- Notas sobre Heidegger, Mondadori, Madrid, 1990.

\section{G. JIMÉNEZ,}

- "La noción hermenéutica de indicación formal en el Heidegger temprano" en Escritos de Filosofía, 39/40, 2001, Academia Nacional de Ciencias, Buenos Aires, 2001, págs. 187-196. 


\section{T. KALARIPARAMBIL,}

- "Towards Sketching the "Genesis" of Being and Time" en Heidegger Studien 16, Berlin, 2000, págs.189-220.

Th. KISIEL,

- The Genesis of Heidegger's Bein and Time, University of California Press, Berkeley, y Los Angeles, 1993.

- "Das Entstehen des Begriffsfeldes "Faktizität" im Frühwerk Heideggers" en Dilthey-Jahrbuch, nº 4, 1986-1987, págs. 91-120.

- "Heidegger Gesamstausbage: An international Scandal of Scolarschip" Philosophy Today, no 39, 1995, págs. 3-15.

\section{P. LACOUE-LABARTHE,}

- La ficción de lo político. Heidegger, el arte y la política, Arena, Madrid, 2002. trad. Miguel Lancho.

C. LAFONT,

- Lenguaje y apertura de mundo: el giro lingüístico de la hermenéutica de Heidegger, Alianza, Madrid, 1997.

C. LAMBERT,

- "Consideraciones sobre la religión en la fenomenología del joven Heidegger" en Teología y vida, vol. XLIX, nº 3, PUC, Chile, 2008, págs. 305-314.

- Mundo y existencia: consideraciones fenomenológicas desde la perspectiva de Heidegger y Welte, Brickle, Chile, 2007.

F. LARA,

- "Heidegger y el cristianismo de San Pablo y San Agustín"en Eidos, vol. 7, 2007, Uninorte, Colombia, págs. 28-46.

- "El concepto de fenómeno en el joven Heidegger" en Eidos, vol.8, 2008, Uninorte, Colombia, págs. 234-256

- "Fenomenología y dialéctica. La crítica de Heidegger a la dialéctica" en Martin Heidegger. La experiencia del camino, (ed.) A. Rocha, Uninorte, Colombia, 2009, págs. 95-122.

\section{E. LÉVINAS,}

- Dios, la muerte y el tiempo, Cátedra, Madrid, 1998.

- Descubriendo la existencia con Husserl y Heidegger, Síntesis, Madrid, 2005. 


\section{K. LEHMANN,}

- "Cristliche Geschichtserfahrung und ontologische Frage beim jungen Heidegger" en Heidegger. Perspektiven zur Deutung seines Werker, (ed) O. Pöggeler, Kiepenheur\& Witsch, Colonia y Berlín, 1969, págs. 140-168.

\section{LEYTE COELLO,}

- Heidegger, Alianza, Madrid, 2005.

D. LOSURDO,

- La comunidad, la muerte, Occidente. Heidegger y la ideología de la guerra, Losada, Barcelona, 2003.

K. LÖWITH,

- Mi vida en Alemania antes y después de 1933, Visor, Madrid, 1993. Trad. Ruth Zauner.

- Heidegger. Pensador de un tiempo indigente, FCE, Buenos Aires, 2006. Trad. Roman Setton.

J. MARION,

- Rèduction et donation. Recherches sur Husserl, Heidegger et la phenomenologie, PUF, París, 1989.

F. MARTÍNEZ MARZOA,

- Heidegger y su tiempo, Akal, Madrid, 2000.

C. MÁSMELA,

- Martin Heidegger. El tiempo del ser, Trotta, Madrid, 2000.

R. METCLAFF,

- "Aristoteles und Sein und Zeit" en (eds.)Denker, A., Figal, G., Volpi, F. y Zaborowsky, H., Heideggers Jahrbuch 3: Heidegger und Aristóteles, Karl Alber, Friburgo y Múnich, 2007, págs. 156-170.

\section{J. MOLINUEVO,}

- La ambigüedad de lo originario en Heidegger, Novo Século, Iria Flavia, 1994. Montero, F., Retorno a la fenomenología, Anthropos, Barcelona, 1987. 
- Martin Heidegger: el filósofo del ser, EDAF, Madrid, 2002.

E. MUÑOZ,

- "Hombre y Dios en las interpretaciones de Martin Heidegger sobre San Agustin” en Teología y vida, vol. XLIX, no 3, PUC, Chile, 2008, págs. 447455.

J. NAVARRO CORDÓN y R. RODRÍGUEZ,

- Heidegger y el final de la filosofía, Universidad Complutense, Madrid, 1993.

E. NOLTE,

- Heidegger. Política e historia en su vida y pensamiento, Tecnos, Madrid, 1998. Trad. Elisa Lucena.

M. OLASAGASTI,

- Introducción a Heidegger, Revista de Occidente, Madrid, 1967.

\section{A. ORTIZ-OSSES}

- Heidegger y el ser sentido, Universidad de Deusto, Bilbao, 2009.

H. OTT,

- En camino hacia su biografia, Alianza, Madrid, 1992. Trad. Elena Cortés.

C. OUDEMANS,

- "Heideggers "logische Untersuchungen”, en Heideggers Studien , n 6, 1990, págs. 85-106.

\section{C. PAREDES MARTÍN}

- "Heidegger ante la cuestión de la verdad" en Intencionalidad mundo y sentido. Problemas de fenomenología y metafisica, (ed.) Maria del Carmen Paredes, Universidad de Salamanca, 2003, págs. 39-58.

- "Fenomenología y ontología" en Azalea: Revista de Filosofía, no 6, Salamanca, 2004, págs. 113-138.

- Teorías de la intencionalidad, Síntesis, Madrid, 2007.

M. PECELLÍN y I. REGUERA (Ed.)

- Wittgenstein- Heidegger, Universidad de Badajoz, 1990. 


\section{P. PEÑALVER,}

- Del espíritu al tiempo, Anthropos, Barcelona, 1988.

- “El debate sobre el ser y el tiempo" en La filosofía en el fin de siglo: balances y perspectivas, SCLF, no 15, Salamanca, 2001, págs. 99-112.

O. PÖGGELER,

- Heidegger und die hermeneutische Philosophie, Karl Alber, Friburgo y Múnich, 1983.

- El camino del pensar de Martin Heidegger, Alianza, Madrid, 1993. Trad. Felix Duque.

- Filosofia y politica en Martin Heidegger, Coyoacán, México, 2005. Trad. Ernesto Garzón.

- Neue Wege mit Heidegger, Kart Alber, Friburgo y Múnich, 1992.

\section{S. POGGI,}

- La lógica, la mística, il nulla. Una intepretazione del giovane Heidegger, Edizioni della Normale, Pisa, 2006.

\section{P. REDONDO,}

- "El ateísmo en la filosofía de Heidegger como preparación del lenguaje sobre Dios, en Lenguajes sobre Dios, SCLF, nº13, Salamanca, 1998, págs. 161-175.

- “La presencia de Hegel en el joven Heidegger", en Razón, libertad y estado en Hegel, (eds.) Mariano Álvarez, Maria del Carmen Paredes, SEEH, Universidad de Salamanca, 2000, págs. 313-323.

- Experiencia de la vida y fenomenología en la lecciones de Friburgo de Martin Heidegger, Universidad de Salamanca, 2001.

- Filosofar desde el temple de ánimo, Universidad de Salamanca, 2005.

\section{P. RICOEUR,}

- La metáfora viva, Cristiandad, Madrid, 1980.

\section{A. REGALADO,}

- El laberinto de la razón. Ortega y Heidegger, Alianza, Madrid, 1990.

\section{J. RIVERA,}

- Heidegger y Zubiri, Universitaria, Chile, 2001.

- y M. STUVEN, Comentario a Ser y tiempo de Martin Heidegger, Universidad Católica de Chile, 2008. 
G. RIVERA,

- "Aproximación de la finitud: Heidegger y el ser para la muerte" en En-claves del pensamiento, vol.IV, $\mathrm{n}^{\mathrm{o}}$ 8, Tecnológico de Monterrey, México, 2010, págs. 61-74.

F. RODI,

- "Die Bedeutung Diltheys für Konzeption von Sein und Zeit. Zum Umfeld von Heideggers Kasseler Vorträgen (1925)” en Dilthey Jahrbuch 4, 1986-7, págs. 161-177.

\section{RODRÍGUEZ,}

- Sentido y ser en Heidegger, Prensas Universitarias de Zaragoza, 2004.

\section{R. RODRÍGUEZ,}

- La transformación hermenéutica de la filosofía, Tecnos, Madrid, 1997.

- Del sujeto y la verdad, Síntesis, Madrid, 2004.

- Heidegger y la crisis de la época moderna, Síntesis, Madrid, 2006.

- Hermenéutica y subjetividad, Trotta, Madrid, 2010.

\section{J. L. RODRÍGUEZ MOLINERO,}

- "El "modo de hallarse", en relación con la antropología filosófica de Heidegger" en Acercamiento a la obra de Martin Heidegger, SCLF, $\mathrm{n}^{\mathrm{o}}$ 5, Salamanca, 1991, págs. 67-89.

- "Anticipación de la ontología de Ser y tiempo en los primeros escritos como docente de Martin Heidegger" en Cuadernos Salmantinos de Filosofía, no 24, Salamanca, 1997, págs. 179-208.

- "Desarrollo de la noción de antropología filosófica y de sus tareas fundamentales" en La filosofia en el fin de siglo: balances y perspectivas, SCLF, nº 15, Salamanca, 2001, págs. 289-332.

\section{R. RORTY,}

- Ensayos sobre Heidegger y otros pensadores contemporáneos: Escritos filosóficos 2, Paidós, Barcelona, 1993. Trad. Jorge Virgil.

\section{G. RUFF,}

- Am Ursprung der Zeit. Studie zu Martin Heideggers phänomenologischem Zugang zur christlichen Religion in den ersten "Freiburger Vorlesungen", Duncker\& Humblot, Berlín, 1997.

\section{R. SAFRANSKY,}


- Un maestro de Alemania. M. Heidegger y su tiempo, Tusquets, Barcelona, 1997. Trad. Raul Gabás.

A. SEGURA,

- Heidegger en el contexto “debole” de Vattimo, Universidad de Granada, 1996.

C. SEGURA PERAITA,

- "La vida fáctica en Heidegger" en Themata: Revista de Filosofia, n ${ }^{0}$ 22, Sevilla, 1999, págs. 281-290.

- Hermenéutica de la vida humana, Trotta, Madrid, 2002.

- Heidegger y la metafísica, Publidisa, Madrid, 2007.

\section{J. SERNA,}

- Somos tiempo, Anthropos, Barcelona, 2009.

Th. SHEENAN,

- " The original form of Sein und Zeit: Heidegger's Begriff der Zeit", en Journal of the British Society for Phenomenology, n 10, 1979, págs. 78-83.

- "Heidegger's “ Introduction to the Phenomenology of Religion” (1920-21), en The Personalist, $\mathrm{n}^{\circ}$ 56, 1979-80, págs. 312-324.

\section{P. SLOTERDIJK,}

- Sin salvación: tras la huella de Heidegger, Akal, Madrid, 2011. Trad. Joaquín Chamorro.

F. SOLER,

- Apuntes acerca del pensar de Heidegger, Andres Bello, Santiago, 1983.

E. STEIN,

- La filosofía existencial de Martin Heidegger, Trotta, Madrid, 2010. Trad. Rosa Sala.

G. STEINER,

- Heidegger, FCE, México, 1999. Trad. Jorge Aguilar.

\section{J. TAMINIAUX,}

- Heideggers and the proyect of Fundamental Ontology, State University of New York Press, Albany, 1991. 
E. TUGENDHAT,

- Autoconciencia y autodeterminación, FCE, México, 1993.

- Ser, verdad y acción, Gedisa, Barcelona, 2000.Trad. Rosa Santos-Ihlan.

G. VATTIMO,

- Introducción a Heidegger, Gedisa, Barcelona, 1996. Trad. Alberto Baez.

- El sentido de la existencia. Postmodernidad y nihilismo, Universidad de Deusto, Bilbao, 2007.

B. VEDDER,

- "Die Faktizität der Hermeneutik", en Heidegger Studien 12, Berlin, 1996, págs. 95-108.

G. VELEZ,

- "Peso de la existencia y dificultad hermenéutica en la génesis del pensamiento de Heidegger" en Coherencia, vol.6, $\mathrm{n}^{\mathrm{0}}$ 10, Universidad EAFIT, Colombia, 2009, págs. 113-124.

A. VIGO,

- "Ser, significado y mundo" en Seminarios de Filosofia, no 9, PUC, Chile, 1996. págs. 93-122.

- "Verdad, libertad y trascendencia en Heidegger" en La filosofía como pasión, (coord.) Patricio Brickle, Trotta, Madrid, 2003, págs. 143-190.

- "La recuperación crítica de la pregunta por el ser en Heidegger" en Signos filosóficos, vol. VIII, n 15, UAM, Iztapalapa, 2008, págs. 65-104.

- Arqueología, aleteología y otros estudios heideggerianos, Biblos, Buenos Aires, 2008.

F. VOLPI,

- "La existencia como praxis. Las raíces aristotélicas de la terminología de Ser y tiempo" en Vattimo, G. (ed.), 1994, págs. 327-383.

- "Heidegger, Aristotele, i Greci" en Enrahonar: Quaderns de Filosofía, no 34, UAB, Barcelona, 2002. págs. 73-92.

- "Hermenéutica y filosofía práctica" en Endoxa: Series filosóficas, n 20, UNED, Madrid, 2005, págs. 265-294.

- "Ser y tiempo: Semejanzas con la Ética Nicomaquea" en Signos filosóficos, vol. VIII, nº 16, UAM, Iztapalapa, 2006, págs. 127-147. 
- "Ser y tiempo: ¿una inversión moderna de la Ética nicomaquea?, en Revista de Filosofía, vol. 39, n 120, Universidad Iberoamericana, México, 2007, págs. 149-172.

A. WAELHENS,

- Heidegger, Losange, Buenos Aires, 1954.

\section{A. WAGNER DE REYNA,}

- La ontología fundamental de Heidegger. Su motivo y significaciones, Losada, Buenos Aires, 1939

WOLIN,

- Los hijos de Heidegger( Arendt, Löwith, Jonas, Marcase), Cátedra, Madrid, 2003.

A. XOLOCOTZI,

- "En torno a Heidegger" Diálogo con Friedrich-Wilhelm von Herrmann" en Revista de Filosofía, vol.35, n ${ }^{\mathrm{o}}$ 108, Universidad Iberoamericana, México, 2003, págs. 35-46.

- "Los prejuicios del ser. Reflexiones entorno al inicio de Ser y tiempo", en La Lámpara de Diógenes, vol.6, n 10-11, BUAP, México, págs. 119-126.

- Fenomenología de la vida fáctica y su camino a Ser y tiempo, Plaza y Valdés, México, 2004.

- Subjetividad radical y comprensión afectiva. El rompimiento de la representación en Rickert, Dilthey, Husserl y Heidegger, Plaza y Valdés, México, 2007.

- Facetas heideggerianas, Los libros de Homero, México, 2009.

- Una crónica de Ser y tiempo de Martin Heidegger, BUAP, México, 2011.

\section{H. ZABOROWSKY,}

- "Herkunft aber bleibt stets Zukunft". Anmerkungen zur religiösen und theologischen Dimension des Denkweges Martin Heidegges bis 1919”, en A. Denker, H.-H. Gander, H. Zaborowsky(Ed.) Heidegger-Jahrbuch 1: Heidegger und die Anfänge seines Denkens, Karl Alber, Friburgo y Múnich, 2004, págs. 123-158. 